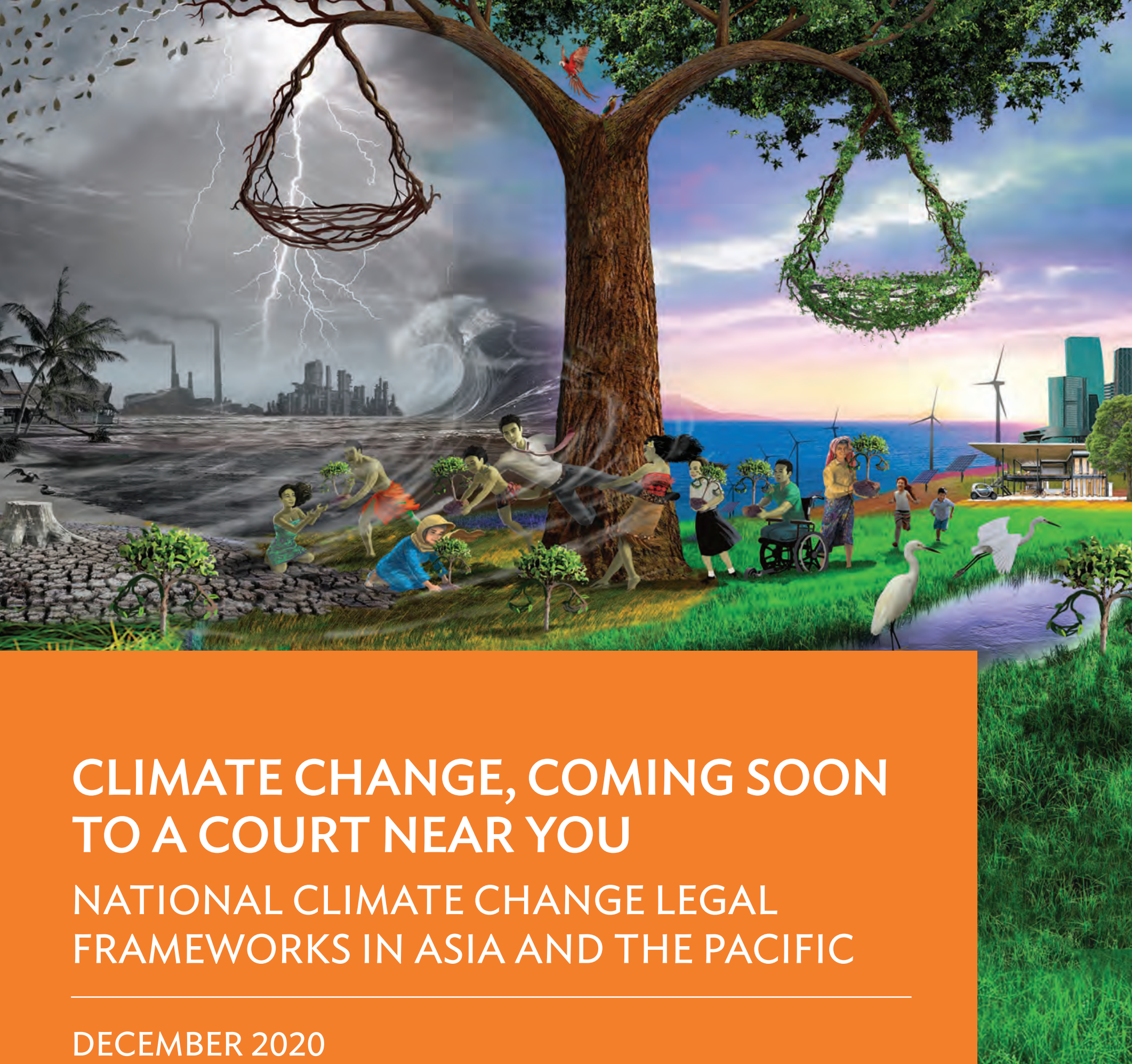

DECEMBER 2020 


\section{CLIMATE CHANGE, COMING SOON TO A COURT NEAR YOU}

NATIONAL CLIMATE CHANGE LEGAL FRAMEWORKS IN ASIA AND THE PACIFIC

DECEMBER 2020 
(C) 2020 Asian Development Bank 6 ADB Avenue, Mandaluyong City, 1550 Metro Manila, Philippines

Tel +632 8632 4444; Fax +63286362444

www.adb.org

Some rights reserved. Published in 2020.

ISBN 978-92-9262-547-4 (print); 978-92-9262-548-1 (electronic); 978-92-9262-549-8 (ebook)

Publication Stock No. TCS200364-2

DOI: http://dx.doi.org/10.22617/TCS200364-2

The views expressed in this publication are those of the authors and do not necessarily reflect the views and policies of the Asian Development Bank (ADB) or its Board of Governors or the governments they represent.

ADB does not guarantee the accuracy of the data included in this publication and accepts no responsibility for any consequence of their use. The mention of specific companies or products of manufacturers does not imply that they are endorsed or recommended by ADB in preference to others of a similar nature that are not mentioned.

By making any designation of or reference to a particular territory or geographic area, or by using the term "country" in this document, $A D B$ does not intend to make any judgments as to the legal or other status of any territory or area.

This work is available under the Creative Commons Attribution 3.0 IGO license (CC BY 3.0 IGO)

https://creativecommons.org/licenses/by/3.0/igo/. By using the content of this publication, you agree to be bound by the terms of this license. For attribution, translations, adaptations, and permissions, please read the provisions and terms of use at https://www.adb.org/terms-use\#openaccess.

This CC license does not apply to non-ADB copyright materials in this publication. If the material is attributed to another source, please contact the copyright owner or publisher of that source for permission to reproduce it. $\mathrm{ADB}$ cannot be held liable for any claims that arise as a result of your use of the material.

Please contact pubsmarketing@adb.org if you have questions or comments with respect to content, or if you wish to obtain copyright permission for your intended use that does not fall within these terms, or for permission to use the ADB logo.

Corrigenda to ADB publications may be found at http://www.adb.org/publications/corrigenda.

Notes:

In this publication, “\$” refers to United States dollars, unless otherwise stated.

ADB recognizes "China" as the People's Republic of China, "Independent State of Papua New Guinea" as Papua New Guinea, "Laos" as the Lao People's Democratic Republic, "Micronesia" as the Federated States of Micronesia, "Vietnam" as Viet Nam, "Bombay" as Mumbai, and "Hanoi" as Ha Noi.

All photos are by ADB.

Cover design by Gayle Certeza, Daniel Desembrana, and John Michael Casipe.

Printed on recycled paper 


\section{CONTENTS}

Tables and Figures

xii

Forewords

Justice Antonio Herman Benjamin $\quad$ xv

Lord Robert Carnwath xix

Justice Syed Mansoor Ali Shah xxi

Preface $x x v$

Acknowledgments $\quad$ xxvii

Abbreviations xxix

Executive Summary xxxiii

Climate Change: A Clarion Call for Judges xxxiii

Why These Reports? xxxiii

Report Series Structure $\quad x x x v$

Key Takeaways $\quad$ xxxv

Moving Forward xxxviii

PART ONE. INTRODUCTION 1

I. Judiciaries Play a Role in Domestic Climate Action and 1 Need Resources

II. Report Structure and Scope 3

III. Report Methodology and Preparation 5

IV. Looking Forward 6

PART TWO. TRENDS IN CLIMATE LAWS AND POLICIES IN ASIA 11 AND THE PACIFIC

I. The Paris Agreement and National Laws and Policies 11 Are Mutually Reinforcing

II. National Preferences Guide Climate Change Legal and 12 Policy Frameworks

III. Framework Climate Laws Are Growing and Have Benefits 13 for Propelling Coordinated Action

IV. Data and Reporting Requirements Are Influencing Legal 14 Frameworks

V. Climate Litigation Is Shaping Climate Law Globally 14 
VI. Science Is Evolving Responses to Climate Change 16

VII. Courts Are Integrating Scientific Consensus into National Law 17

VIII. Adaptation Legal Frameworks Need Strengthening 18

IX. Environmental Impact Assessments Should Consider 18 Climate Change

X. Legal Frameworks on Oceans Need Strengthening 19

XI. Technology and Markets Need Responsive Legal and Regulatory 20 Frameworks

XII. Carbon Pricing Laws and Policies Remain in the Minority 21 Across the Region

PART THREE。COMPARATIVE CONSTITUTIONAL SURVEY 25

I. Constitutional Rights Litigation in Asia and the Pacific 25

II. Constitutional Climate Litigation Is More Common in South Asia 26

III. Rights-Based Climate Litigation Is Less Frequent in Southeast Asia 28 and the Pacific

IV. Rights-Based Litigation Applies Universal Principles, Making It 31 Readily Transferable

V. Using Tables 3.1-3.3 31

PART FOUR. SOUTH ASIA LEGAL FRAMEWORKS 45

I. AFGHANISTAN 45

A. Country Snapshot: Climate and Environmental Challenges $\quad 45$

B. Overarching Climate Change Legal and Policy Framework 45

C. Energy Supply 47

D. LULUCF and REDD+ 50

E. Disaster Risk Management 51

II. BANGLADESH 52

A. Country Snapshot: Climate and Environmental Challenges 52

B. Overarching Climate Change Legal and Policy Framework 52

C. Energy Supply 54

D. Energy Demand 57

E. Climate Finance 58

F. LULUCF and REDD+ 58

G. Transportation $\quad 59$

H. Adaptation 59

I. Disaster Risk Management 60

III. BHUTAN 61

A. Country Snapshot: Climate and Environmental Challenges 61

B. Overarching Climate Change Legal and Policy Framework 61

C. Energy Supply 63

D. Energy Demand 66 
E. LULUCF and REDD+ 66

F. Adaptation 67

G. Disaster Risk Management 68

IV. INDIA 68

A. Country Snapshot: Climate and Environmental Challenges 68

B. Overarching Climate Change Legal and Policy Framework 69

C. Energy Supply 72

D. Energy Demand 74

E. Carbon Pricing $\quad 75$

F. LULUCF and REDD+ 75

G. Cities and Buildings $\quad 75$

H. Adaptation $\quad 76$

I. Subnational Activities 76

$\begin{array}{ll}\text { V. MALDIVES } & 76\end{array}$

A. Country Snapshot: Climate and Environmental Challenges $\quad 76$

B. Overarching Climate Change Legal and Policy Framework 77

C. Energy Supply 78

D. Energy Demand $\quad 81$

E. Transportation $\quad 81$

F. Adaptation 81

G. Disaster Risk Management 82

VI. NEPAL $\quad 83$

A. Country Snapshot: Climate and Environmental Challenges 83

B. Overarching Climate Change Legal and Policy Framework 83

C. Energy Supply $\quad 84$

D. LULUCF and REDD+ 87

E. Agriculture 88

F. Water $\quad 89$

G. Adaptation 89

H. Disaster Risk Management 90

VII. PAKISTAN 90

A. Country Snapshot: Climate and Environmental Challenges 90

B. Overarching Climate Change Legal and Policy Framework 91

C. Energy Supply 94

D. Energy Demand 96

E. LULUCF and REDD+ 96

F. Transportation $\quad 96$

G. Adaptation 97

H. Disaster Risk Management 97

$\begin{array}{ll}\text { VIII. SRI LANKA } & 98\end{array}$

A. Country Snapshot: Climate and Environmental Challenges 98

B. Overarching Climate Change Legal and Policy Framework 99 
C. Energy Supply 100

D. Energy Demand 103

E. Adaptation 103

F. Disaster Risk Management 104

PART FIVE. SOUTHEAST ASIA AND PEOPLE'S REPUBLIC OF CHINA 107 LEGAL FRAMEWORKS

$\begin{array}{ll}\text { I. CAMBODIA } & 107\end{array}$

A. Country Snapshot: Climate and Environmental Challenges 107

B. Overarching Climate Change Legal and Policy Framework 107

C. Energy Supply 112

D. Energy Demand 113

E. Climate Finance 114

F. LULUCF and REDD+ 114

G. Transportation 114

H. Adaptation 115

I. Disaster Risk Management 115

II. INDONESIA 116

A. Country Snapshot: Climate and Environmental Challenges 116

B. Overarching Climate Change Legal and Policy Framework 116

C. Energy Supply 122

D. Energy Demand 123

E. LULUCF and REDD+ 124

F. Transportation 125

G. Adaptation 126

III. LAO PEOPLE'S DEMOCRATIC REPUBLIC 126

A. Country Snapshot: Climate and Environmental Challenges 126

B. Overarching Climate Change Legal and Policy Framework 127

C. Energy Supply 130

D. Energy Demand 130

E. LULUCF and REDD+ 131

F. Adaptation 131

G. Disaster Risk Management 132

IV. MALAYSIA 132

A. Country Snapshot: Climate and Environmental Challenges 132

B. Overarching Climate Change Legal and Policy Framework 133

C. Energy Supply 135

D. Energy Demand 137

E. LULUCF and REDD+ 138

F. Transportation 138

G. Adaptation 139

H. Disaster Risk Management 139 
V. MYANMAR 140

A. Country Snapshot: Climate and Environmental Challenges 140

B. Overarching Climate Change Legal and Policy Framework $\quad 140$

C. Energy Supply 142

D. Energy Demand 145

E. LULUCF and REDD+ 145

F. Transportation 146

G. Adaptation 146

H. Disaster Risk Management 147

VI. PEOPLE'S REPUBLIC OF CHINA 148

A. Country Snapshot: Climate and Environmental Challenges 148

B. Overarching Climate Change Legal and Policy Framework 148

C. Energy Supply 152

D. Energy Demand 153

E. Carbon Pricing 154

F. LULUCF and REDD+ 154

G. Adaptation $\quad 155$

H. Managing Water Resources 155

VII. PHILIPPINES 156

A. Country Snapshot: Climate and Environmental Challenges 156

B. Overarching Climate Change Legal and Policy Framework 156

C. Energy Supply 163

D. Energy Demand 164

E. LULUCF and REDD+ 165

F. Transportation 166

G. Adaptation 167

H. Disaster Risk Management 168

$\begin{array}{ll}\text { VIII. SINGAPORE } & 168\end{array}$

A. Country Snapshot: Climate and Environmental Challenges 168

B. Overarching Climate Change Legal and Policy Framework 168

C. Energy Supply 170

D. Energy Demand 172

$\begin{array}{ll}\text { E. Transportation } & 174\end{array}$

F. Adaptation 174

IX. THAILAND 175

A. Country Snapshot: Climate and Environmental Challenges 175

B. Overarching Climate Change Legal and Policy Framework 175

C. Energy Supply 179

D. Energy Demand 180

E. LULUCF and REDD+ 181

F. Transportation 182 
G. Adaptation 183

H. Disaster Risk Management 183

$\begin{array}{ll}X . & 184\end{array}$

A. Country Snapshot: Climate and Environmental Challenges 184

B. Overarching Climate Change Legal and Policy Framework 184

C. Energy Supply 187

D. Energy Demand 194

E. LULUCF and REDD+ 195

F. Transportation 195

G. Adaptation 196

H. Disaster Risk Management 197

I. Vulnerable Groups 198

PART SIX.THE PACIFIC COUNTRIES LEGAL FRAMEWORKS 201

I. COOKISLANDS 201

A. Country Snapshot: Climate and Environmental Challenges 201

B. Overarching Climate Change Legal and Policy Framework 202

C. Energy Supply 203

D. Energy Demand 205

E. Adaptation 205

F. Disaster Risk Management 205

II. FEDERATED STATES OF MICRONESIA 206

A. Country Snapshot: Climate and Environmental Challenges 206

B. Overarching Climate Change Legal and Policy Framework 206

C. Energy Supply 208

D. Energy Demand 209

E. Adaptation 210

F. Disaster Risk Management 210

III. FIJI 210

A. Country Snapshot: Climate and Environmental Challenges 210

B. Overarching Climate Change Legal and Policy Framework 211

C. Energy Supply 214

D. Energy Demand 216

E. Adaptation 217

IV. KIRIBATI 218

A. Country Snapshot: Climate and Environmental Challenges 218

B. Overarching Climate Change Legal and Policy Framework 219

C. Energy Supply 221

D. Energy Demand 223

E. Adaptation 224 
V. MARSHALL ISLANDS

224

A. Country Snapshot: Climate and Environmental Challenges 224

B. Overarching Climate Change Legal and Policy Framework 225

C. Energy Supply 227

D. Energy Demand 229

E. Adaptation 229

VI. NAURU 230

A. Country Snapshot: Climate and Environmental Challenges 230

B. Overarching Climate Change Legal and Policy Framework 231

C. Energy Supply and Demand 232

D. Adaptation 233

VII. PALAU 234

A. Country Snapshot: Climate and Environmental Challenges 234

B. Overarching Climate Change Legal and Policy Framework 235

C. Energy Supply 236

D. Energy Demand 237

E. Adaptation 238

VIII. PAPUA NEW GUINEA 238

A. Country Snapshot: Climate and Environmental Challenges 238

B. Overarching Climate Change Legal and Policy Framework 239

C. Energy Supply 242

D. LULUCF and REDD+ 245

E. Adaptation 246

F. Disaster Risk Management 247

$\begin{array}{ll}\text { IX. SAMOA } & 247\end{array}$

A. Country Snapshot: Climate and Environmental Challenges 247

B. Overarching Climate Change Legal and Policy Framework 248

C. Energy Supply 249

D. LULUCF and REDD+ 252

E. Adaptation 253

X. SOLOMONISLANDS 253

A. Country Snapshot: Climate and Environmental Challenges 253

B. Overarching Climate Change Legal and Policy Framework 254

C. Energy Supply 255

D. Energy Demand 256

E. LULUCF and REDD+ 257

F. Adaptation 257

G. Disaster Risk Management 258

XI. TIMOR-LESTE 258

A. Country Snapshot: Climate and Environmental Challenges 258

B. Overarching Climate Change Legal and Policy Framework 259 
C. Energy Supply 260

D. LULUCF and REDD+ 262

E. Adaptation 262

XII. TONGA 262

A. Country Snapshot: Climate and Environmental Challenges 262

B. Overarching Climate Change Legal and Policy Framework 263

C. Energy Supply 265

D. LULUCF and REDD+ 265

E. Transportation 266

F. Adaptation 266

G. Disaster Risk Management 266

$\begin{array}{ll}\text { XIII. TUVALU } & 267\end{array}$

A. Country Snapshot: Climate and Environmental Challenges 267

B. Overarching Climate Change Legal and Policy Framework 267

C. Energy Supply 269

D. Energy Demand 271

E. Disaster Risk Management 271

XIV. VANUATU 272

A. Country Snapshot: Climate and Environmental Challenges $\quad 272$

B. Overarching Climate Change Legal and Policy Framework 272

C. Energy Supply 274

D. LULUCF and REDD+ 278

E. Adaptation 278

F. Disaster Risk Management 279

PART SEVEN. CONCLUSION 283

I. Key Takeaways 284

A. National Climate Change Laws and Policies Reveal 284 Likely Future Litigation Trends

B. Constitutional Rights Litigation Is Growing-Information 285 about Constitutional Rights Is Valuable

C. Climate Change Legal and Policy Frameworks Can Be Fragmented 285

II. Looking Forward 286

A. ADB and Judiciaries 286

B. COVID-19 Is Slowing International and National Climate 286 Commitments

C. But We Have a Choice to Build New Social Contracts 287

D. Climate Justice and Legal and Policy Frameworks in the 288 Time of COVID-19 and Beyond 
- noming

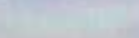

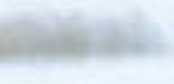

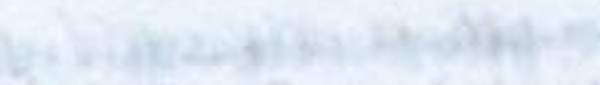
Whowitions

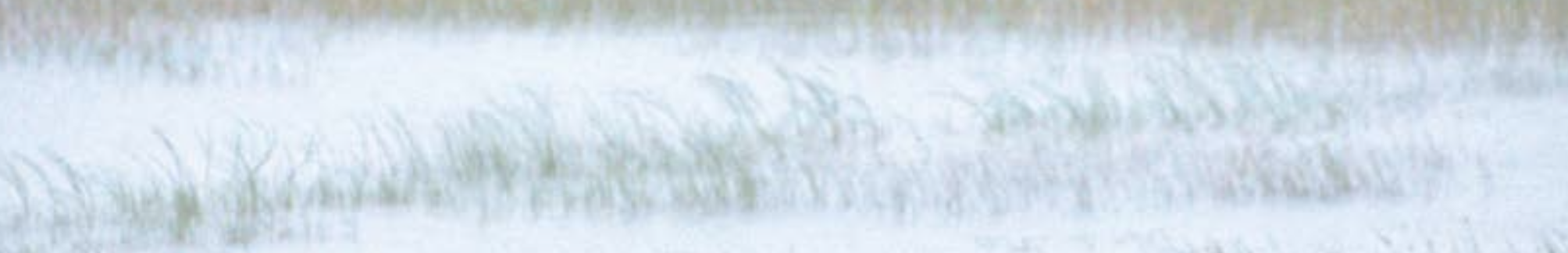

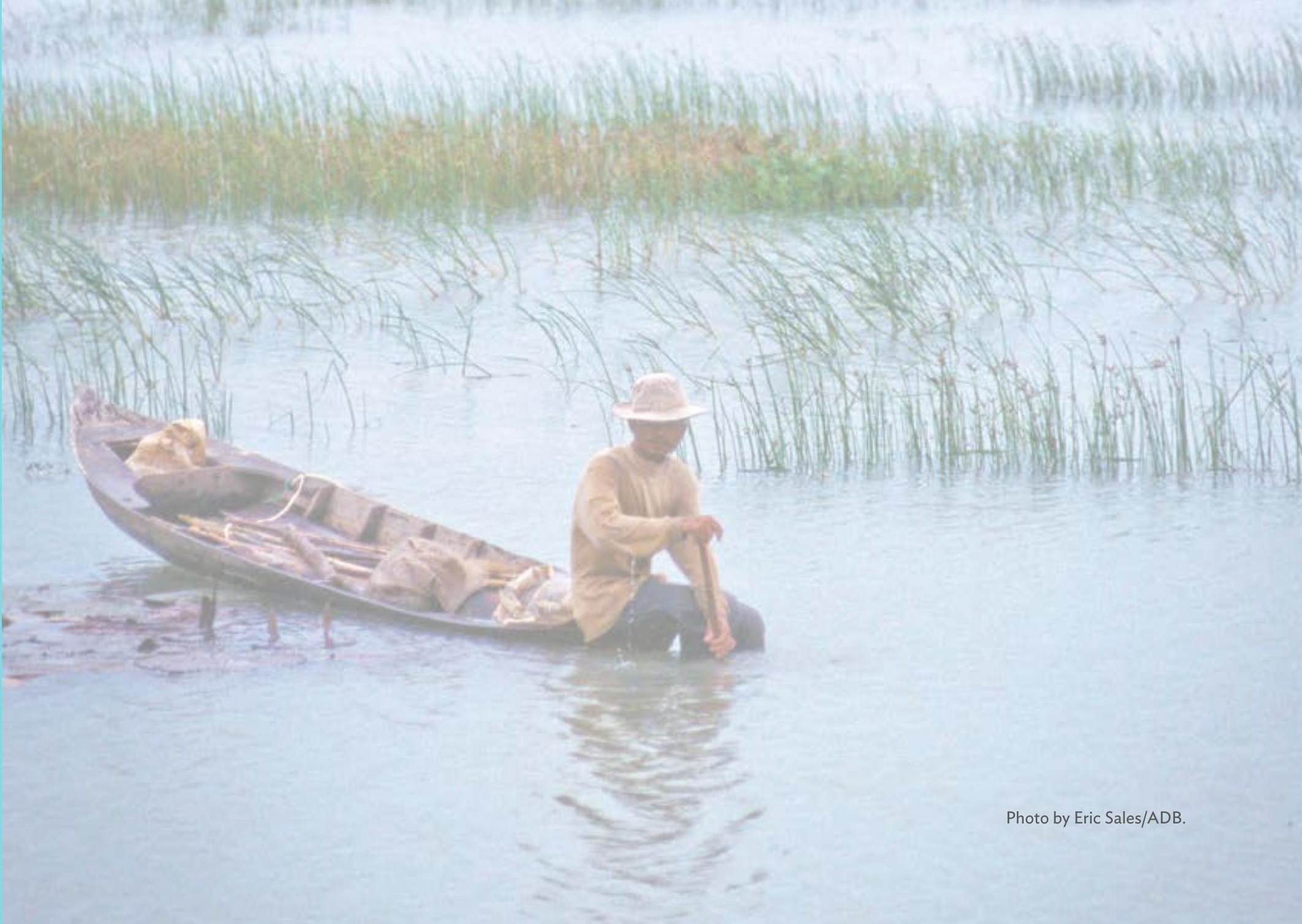




\section{TABLES AND FIGURES}

\section{TABLES}

1 Regions and Countries Covered by the Report 3

3.1 Constitutional Rights, Obligations, and State Directives in South Asia 32

3.2 Constitutional Rights, Obligations, and State Directives in 36

Southeast Asia and the People's Republic of China

3.3 Constitutional Rights, Obligations, and State Directives in the Pacific 40

4.1 Climate Change Legal and Policy Framework of Afghanistan 48

4.2 Climate Change Legal and Policy Framework of Bangladesh 55

4.3 Climate Change Legal and Policy Framework of Bhutan 64

4.4 Climate Change Legal and Policy Framework of India 71

4.5 Climate Change Legal and Policy Framework of Maldives 79

4.6 Climate Change Legal and Policy Framework of Nepal 85

4.7 Climate Change Legal and Policy Framework of Pakistan 93

4.8 Climate Change Legal and Policy Framework of Sri Lanka 101

5.1 Climate Change Legal and Policy Framework of Cambodia 110

5.2 Climate Change Legal and Policy Framework of Indonesia 119

5.3 Climate Change Legal and Policy Framework of the Lao People's 129 Democratic Republic

5.4 Climate Change Legal and Policy Framework of Malaysia 134

5.5 Climate Change Legal and Policy Framework of Myanmar 143

5.6 Climate Change Legal and Policy Framework of the 151 People's Republic of China

5.7 Climate Change Legal and Policy Framework of the Philippines 159

5.8 Climate Change Legal and Policy Framework of Singapore 171

5.9 Climate Change Legal and Policy Framework of Thailand 177

5.10 Renewable Energy Production Targets 181

5.11 Climate Change Legal and Policy Framework of Viet Nam 188

6.1 Climate Change Legal and Policy Framework of the Cook Islands 204

6.2 Climate Change Legal and Policy Framework of the Federated States 208 of Micronesia

6.3 Climate Change Legal and Policy Framework of Fiji 215

6.4 Emission Targets for Energy, Transport, and Forestry Sectors in Fiji, 216 2021-2036 
6.5 Kiribati's Planned Increase in Renewable Energy and Energy Efficiency 219 by 2025

6.6 Climate Change Legal and Policy Framework of Kiribati 222

6.7 Climate Change Legal and Policy Framework of the Republic of the 228 Marshall Islands

6.8 Climate Change Legal and Policy Framework of Nauru 232

6.9 Climate Change Legal and Policy Framework of Palau 236

6.10 Climate Change Legal and Policy Framework of Papua New Guinea 243

6.11 Climate Change Legal and Policy Framework of Samoa 250

6.12 Climate Change Legal and Policy Framework of Solomon Islands 255

6.13 Climate Change Legal and Policy Framework of Timor-Leste 261

6.14 Climate Change Legal and Policy Framework of Tonga 264

6.15 Climate Change Legal and Policy Framework of Tuvalu 270

6.16 Climate Change Legal and Policy Framework of Vanuatu 275

\section{FIGURES}

1 Papua New Guinea's Total Primary Energy Supply, 2014

2 Electricity Consumption in Samoa by Sector, 2016 
We should include courts in the climate change picture because we have no other option. No substitute exists for the court system. If judges are in charge of deciding all sorts of conflicts about life, death, love, human rights, and national security, it makes no sense to leave climate change outside the courtroom.

-Justice Antonio Herman Benjamin 


\section{FOREWORD}

\section{CLIMATE CHANGE AND JUDGES}

limate change poses the most urgent existential challenge of our lifetime-not only for humanity's survival and protection of the planet's biodiversity, but also for the proper functioning of the Environmental Rule of Law. Our global climate's accelerating volatility - with its adverse impacts on ecosystems, vast landscapes, and human health and dignity - is transforming how lawyers and judges address Environmental Law's traditional principles, objectives, instruments, and institutions. From an institutional point of view, the climate crisis fundamentally affects the way we perceive the role of courts in natural resource disputes.

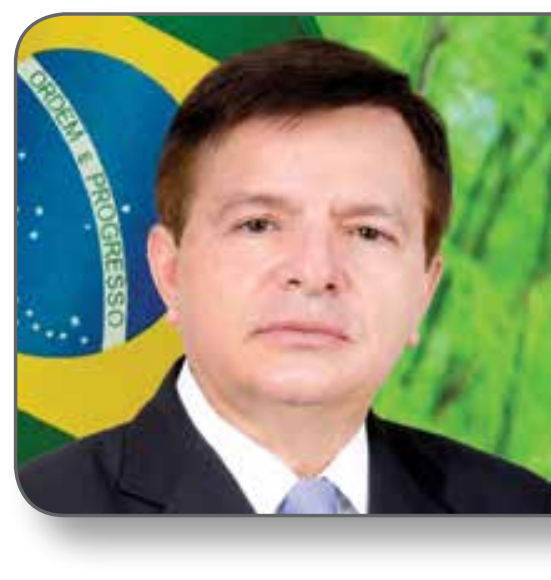

Judges are trained and work in boxes of legal knowledge, practical expertise, and jurisdiction. The "little world" of a judge is one of unavoidable boundaries: political and judicial arenas that fragment ecological spaces instead of respecting them.

Climate change profoundly modifies these ancient premises and rattles judges' comfort zones. Some perceive the subject matter of climate protection-the atmospheric common good, ecosystem services, and intergenerational values - as extending beyond the jurisdiction of local courts. In fact, judges may feel that climate issues reside outside the sovereign borders of national courts. Particularly in respect to the planet's climate, the material good - the atmosphere as a whole-is one that just a few decades ago, following the lessons of Roman law, was considered alien to the categories addressed by domestic legislation.

It is also disturbing to judges that, while those who need protection and would benefit from judicial measures taken to address climate change are spread across the world, only a fraction might live within their jurisdiction. The same applies to the causes of climate change-perpetrated in large part by seemingly faraway activities and actors. Even more complicated for the generalist judge is the inability to see, touch, hear, or directly know the subject of the case. Although intangible categories are not unknown in the judicial context, the more this "physicality" is weakened or dissipated, the more ordinary judges begin to think that the conflict should be decided by someone else or somewhere else.

The climate crisis poses even greater judicial complication when we realize that many countries still do not have comprehensive or effective environmental laws. In others, judges may lack jurisdiction over the whole spectrum of environmental matters. Or, worse, when they can exercise authority, judges may lack the independence, knowledge, or integrity to discharge their responsibilities properly. In other words, although the biodiversity and climate change crises are universal, environmental law and adequate access to courts and justice are not. People in developed countries with robust democratic systems take fair and effective environmental adjudication for granted. For a large portion of the world, however, fundamental access to justice cannot be assumed. Sadly, those large areas are frequently home to rich biodiversity hot spots and tropical forests in desperate need of judicial enforcement. 
Therefore, we may fairly raise the question: should we expect—and trust-courts to address climate change? Despite the above difficulties, my qualified answer is yes, for at least four pragmatic, legal, ethical, and policy and/or institutional reasons.

First, the pragmatic argument. We should include courts in the climate change picture because we have no other option. No substitute exists for the court system. If judges are in charge of deciding all sorts of conflicts about life, death, love, human rights, and national security, it makes no sense to leave climate change outside the courtroom. This assumption does not mean that we do not recognize the enormous differences between climate and "regular" environmental cases. However, the lack of other or better alternatives makes courts an inevitable choice.

Second, it would not be reasonable to entrust Environmental Law to judges, as we already do globally, without including climate change. At the end of the day, many key parts of nature-biomes, ecosystems, species, and genetic diversity - and the human environment will be directly and perhaps irreversibly affected by climate change. For obvious reasons, the exclusion of climate cases would handicap and ossify environmental jurisdiction, transforming it into a body without its heart and preventing the legal system's evolution in a world of rapid transformations. Climate change is already affecting and will continue to affect not just Environmental Law. It will also impact most, if not all, legal disciplines that compose the conventional field of judicial intervention - from constitutional to tax and insurance law, from civil and administrative liability to criminal law, and from family to international and civil procedure law. In other words, if climate change is not allowed to enter the courtroom through the front door (Environmental Law), it will undoubtedly invade the judicial sanctum through the back door.

Third, except for a few areas of law (contracts, for example), judges are merely part of the solution for social problems; even then, they are not the only or even the best option. Courts do not replace the constellation of actors and measures in the climate change domain-both national and international. They complement whatever is in place. Some judges may see this role as a second-class type of judicial intervention, one filled with humility (not a widespread characteristic in the profession) as opposed to the ordinary exercise of jurisdiction in which judges have the final and most authoritative word on any complaint brought before them. That misguided but understandable sentiment fails to grasp judges' role in contemporary society as one that is not uniform for all aspects of human conflicts.

Fourth, the position of judges in climate adaptation is much less daunting than in climate mitigation. Take, for instance, the thousands of cases around the world where judges are already dealing with permits, environmental impact assessments, protected areas, deforestation, water resources, wetlands, and desertification. Is it really defensible to keep addressing those legal issues without taking into account the impacts of climate change? Can a judge decide an objection to a permit for building a hotel resort in the middle of endangered mangroves without considering sea level rise due to climate change? Or adjudicate a case of significant deforestation in a region that is already suffering from growing water stress?

None of these reasons ignore or reduce the relevance of legitimate counterarguments that advocate that climate change policy issues should be fought outside the courtroom. Climate change is not the only or the first highly technologically or economically complex issue facing the courts. Software and DNA cases are common nowadays in many countries. Climate change is no more politically charged than national security, torture, discrimination, abortion, immigration, corruption, same-sex marriage, or election disputes. Even war and peace are not entirely beyond the judicial realm. 
It is also worthwhile mentioning that, in light of general or specific legislation dealing with the subject, including constitutional provisions, judges do not make climate change law. They apply (within the limits of the separation of powers) norms discussed and approved by legislative bodies or enacted by administrative authorities. Under these circumstances, it is not judicial lawmaking, but rather judicial law implementation. Once clear and detailed policies - that go much further than vague, conditional and noncommittal statements of public intentions - are legislated, they become legal policies that can and should be enforced by judges. Otherwise, what would be the purpose of legislating? Therefore we should here make a distinction between activist environmental judges and activist environmental legislation (or legislators).

Thus, with a qualified yes, I respond to the initial question I have posed. It is qualified because it comes with one major and several secondary requirements, especially if we want to have judges involved in responding to the climate change crisis adequately. Let me focus on the primary requirement only. In general, judges are still not fully aware of the existential threat that the climate crisis poses to humanity as a whole and every person on the planet, in every jurisdiction. Judges tend to ignore that environmental law regimes they use in their daily practice already include contact points that allow for easy connection to the climate change dimension. In other instances, new and specialized laws have been passed, but remain unknown to or insufficiently understood by judges and therefore endure as untouched laws in the books. Finally, bound by their training and jurisdictions, judges are prone to feel isolated as professionals - a state of mind that discourages innovation and the kind of learning from each other that greater interaction and communication could bring. From the judges' perspective, the most effective medicine for this complex set of attributes and attitudes, which impair their ability to confidently manage climate change litigation, is judicial education.

And judicial education has been precisely the road chosen by the Asian Development Bank (ADB) in its work with judges from this immense and diverse part of the world. It has been a most successful journey, one that developed a judicial community around Environmental Law. The present reports are testimony to such an initiative and a component of the broader series of successful ADB endeavors in the Environmental Rule of Law universe. As the first publication of its kind with a focus on judges, this report series will greatly benefit those who already know the subject. It will also particularly serve the many for whom climate change is (until now) a remote area of law.

On behalf of the Global Judicial Institute on the Environment, I offer my effusive congratulations to ADB's extraordinary team and the distinguished coauthors of this innovative report series.

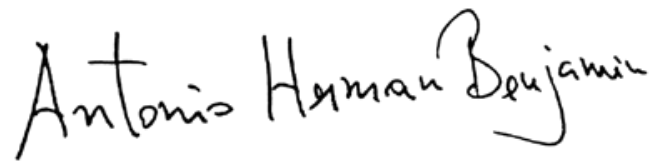

ANTONIO HERMAN BENJAMIN

Justice, National High Court of Brazil

Lead founding member of the Global Judicial Institute on the Environment 6 November 2020 
Climate change is a global challenge.

While the emphasis on the Paris Agreement is on nationally determined contributions, to be enforced by national legal measures, the problems are common to all, and we all have much to learn from each other. 


\section{FOREWORD}

am delighted to welcome this important series of reports on climate litigation and legal frameworks.

It was in 2002 that the Global Judges' Symposium in Johannesburg affirmed the vital role of an independent judiciary and judicial processes in interpreting and enforcing environmental laws, and called for a UNEP-led programme of judicial training and exchange of information on environmental law. Since then, as member of the UNEP judicial advisory group, I have taken part in numerous judicial conferences on environmental law in different parts of the world. Since 2010, the Asian Development Bank has taken a lead in encouraging judicial interchange and training through its Law and Policy Reform Programme, including a series of judicial conferences in the Asia and Pacific region, in which I have been honoured to participate. The cases collected in this study are testament to the richness of the contribution of judges from that part of the world.

Climate change is a global challenge. While the emphasis on the Paris Agreement is on nationally determined contributions, to be enforced by national legal measures, the problems are common to all, and we all have much to learn from each other. Two of the most significant climate change cases in recent years - the Urgenda case in Holland and the Leghari case in Pakistan-came from countries with widely differing legal systems. But the principle they established is universal-that effective action on climate change is a human right and fundamental constitutional responsibility of governments everywhere. As was said in 1993 by the Philippines' Supreme Court in the famous Oposa case, rights to a balanced and healthful ecology are "basic rights" which "predate all governments and constitutions" and "need not be written in the Constitution for they are assumed to exist from the inception of humankind.”

I congratulate the Asian Development Bank team responsible for these remarkable reports. I have no doubt that they will be of immense value to all those involved in giving legal force to the Paris commitments, whether as judges, legislators, or legal professionals.

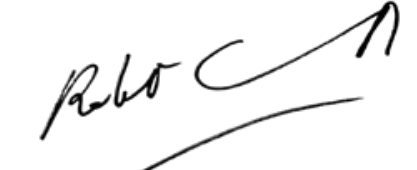

\section{LORD ROBERT CARNWATH}

Commander of the Royal Victorian Order (CVO)

Former Justice of the Supreme Court of the United Kingdom

April 2020

Oposa v. Factoran, G.R. No. 101083, 30 July 1993. 
This report chronicles green and climate jurisprudence that emerged over the years and is a testament to ADB's tireless effort over a decade in building a judicial coalition.

-Justice Syed Mansoor Ali Shah 


\section{FOREWORD}

"I don't want you to be hopeful. I want you to panic... and act as if the house was on fire."

\section{-Greta Thunberg}

U nbridled human desire, supported by unsustainable development over centuries, has disrupted the rhythm of nature. Defiling of the local environment slowly snowballed into a threat for the entire planet as carbon emissions sullied the atmosphere. Humanity's disruption of Earth's system is climate change.

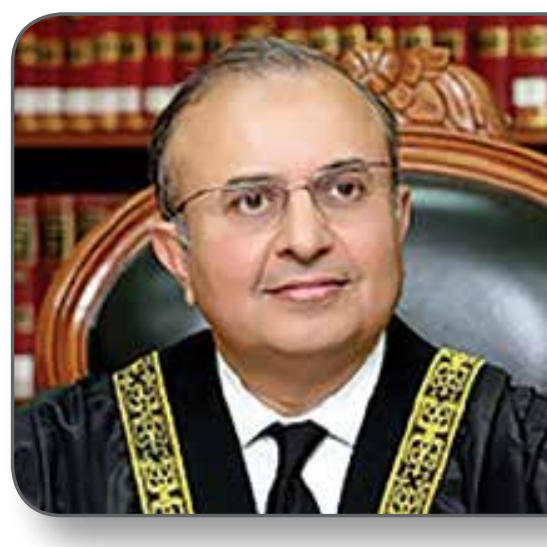

Any remedial response to this global challenge can only be through the collective coordination of humankind. Nationalism needs to give way to global cooperation and solidarity. While nations of the world try to coalesce to combat this challenge, politics and powerful vested interests continue to hamper such a consensus. Nations have been unable to implement their international commitments to meet this most serious existential threat. Dissatisfied citizenry of the world has been compelled to consider other options to combat this challenge. Some of them have knocked at the doors of the courts of justice to fight climate change by making their governments answerable and accountable and by seeking climate justice.

Courts, unlike other limbs of government, are not elected and have no constituencies or voters or political agendas to tow. They are not swayed by politics or other vested or corporate interests, but are guided by ethos of justice and fair play. They function within the frame of constitutionalism and the rule of law. This gives the courts of the world a common language to communicate. It is, therefore, easy to build a global judicial consensus on climate justice. The Asian Development Bank (ADB) realized this and put together a judicial environmental coalition in Asia and the Pacific in 2010. Since then, "green" judges in Asia and the Pacific have met and shared ideas in a series of roundtables and knowledge-sharing events. This unique congress of judges from different jurisdictions debated and dialogued to evolve innovative and avant-garde judicial techniques to safeguard the environment. These judges put these ideas to work and produced far-reaching jurisprudence that has touched the soul of the planet.

Several judiciaries from Asia have a rich tradition in public interest litigation and enforcement of constitutional human rights and, therefore, did not take long to absorb environmentalism in its fold. The jurisprudence that evolved showcased a new judicial technique of forming judicial commissions comprising environmental scientists, experts, and members of the civil society to sit face to face with the government and evolve sustainable solutions. The overarching environmental judicial approach of this period remained inquisitorial and consensus-based.

These judges were ready with their jurisprudence and sharpened tool kit when climate change walked into their courtroom. Climate litigation brought with it a host of new issues that slowly overshadowed the erstwhile environmental litigation. Climate change cut across sectors which were not earlier part of 
the environmental checklist. Climate litigation has to embrace multiple new dimensions like Health Security, Food Security, Energy Security, Water Security, Human Displacement, Human Trafficking, and Disasters Management. Climate Justice covers agriculture, health, food, building approvals, industrial licenses, technology, infrastructural work, human resource, human and climate trafficking, disaster preparedness, health, etc.

Most countries from Asia and the Pacific do not significantly contribute to climate change but suffer at the hands of it. Adaptation, as opposed to mitigation, has a totally different judicial response. Climate change, therefore, has a much broader meaning for the judiciaries of Asia and the Pacific. Adaptation entails issues that, facially, might not appear to be climate related but, upon deeper probe, show a causal link with climate change. The jurisprudence on climate justice emerging from the developed economies is more focused on mitigation and review of governmental decisions to curb emissions. On the whole, jurisprudence evolved by the courts has played a key role in fashioning climate governance and effectively combating climate change.

This report chronicles green and climate jurisprudence that emerged over the years and is a testament to ADB's tireless effort over a decade in building a judicial coalition. The Asian Judges Network on Environment helped the judges meet, discuss, and share ideas, which contributed to developing judicial inventiveness that emerged from Asia and the Pacific. The report is an invaluable exposé of judicial innovation and a valuable source for judiciaries around the world.

As I close this foreword, the coronavirus disease (COVID-19) pandemic has stalled the wheels of human activity and has caged humans with self-isolation and global lockdown. Weeks into it, I see blues skies out of my window, greener pastures, clean air, less noise, singing of the birds, and a general sense of relief on the face of nature. I guess the lesson for humankind is to back up and learn to coexist with nature. A new world is taking shape as I write this. A world that requires us to shed our old ways and move to a new normal. This report and the rich jurisprudence it puts out on display will help us fight and defy going back to the pre-corona world of greed, avarice, mindless consumerism, and unchecked carbon emissions.

I wish this report a huge success.

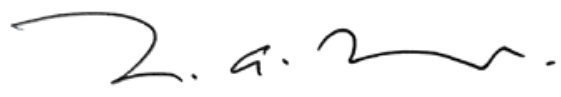

\section{SYED MANSOOR ALI SHAH}

Justice

Supreme Court of Pakistan

Islamabad

20 April 2020 


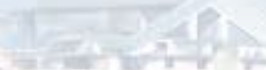

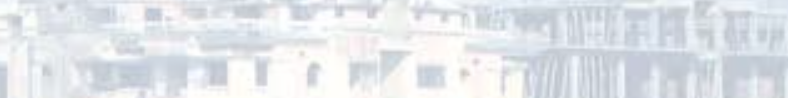

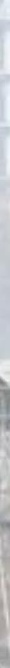
(1) 
ADB is committed to supporting the global climate agenda, including by developing the capacity of judicial systems within Asia and the Pacific to play their vital role.

-Thomas M. Clark

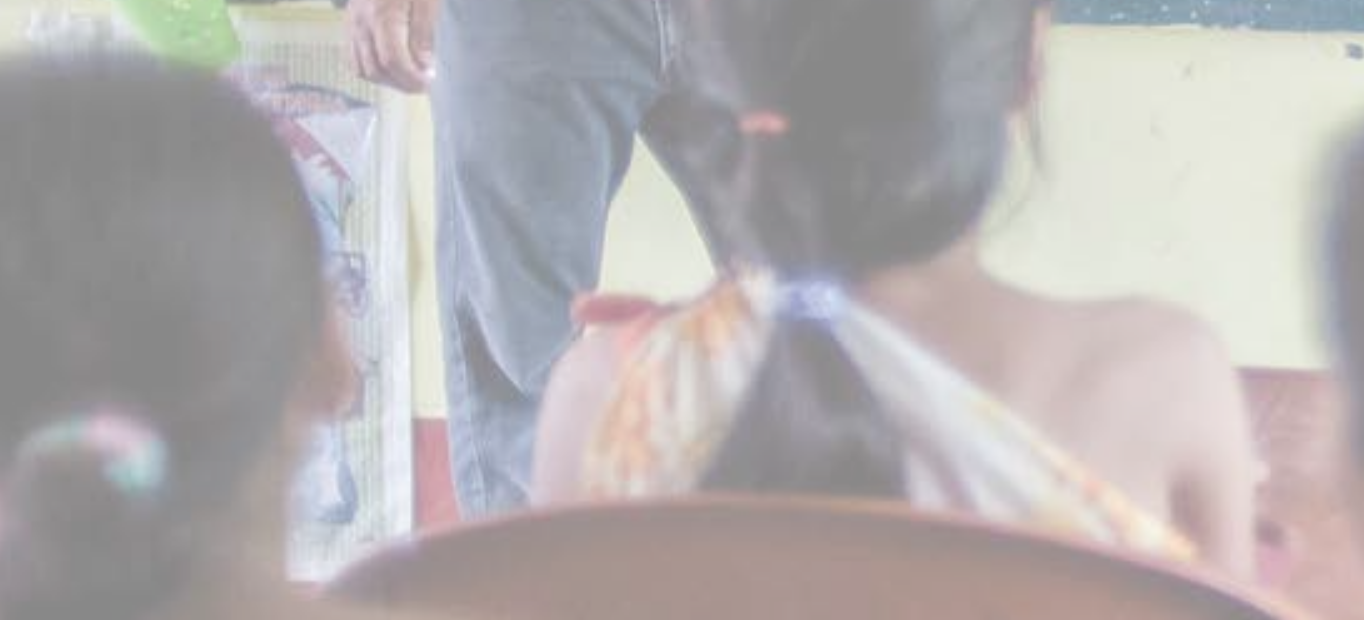




\section{PREFACE}

udges are vital development partners for institutions promoting a sustainable $\checkmark$ and inclusive future, with an indispensable role to play in climate governance in Asia and the Pacific. This work is for them.

The Office of the General Counsel within the Asian Development Bank (ADB) started judicial capacity development on environmental law in 2010 as part of its Law and Policy Reform Program. ADB chose to work with judges for three principal reasons. First, judges form a distinct, independent, and critical branch of government; yet, development partners frequently overlook the benefits of judicial capacity building. Second, judges play a significant role in advancing the rule of law and as guardians of justice in Asia and the Pacific. Third, despite these critical responsibilities, judges need greater resources and opportunities for professional development, information sharing, and judicial networking.

Initially, ADB's program focused on judicial trainings on environmental protection issues, more narrowly, without inclusion of climate mitigation and adaptation. Then, over the past decade, global awareness of climate change and of the need for concerted action to address it surged. Countries expanded their domestic legal and policy frameworks to address climate impacts, and came together in global fora to coordinate this response, most notably by signing the Paris Agreement in 2015. Driven by the need to protect themselves, their children, and their environment from climate change, people turned more to litigation to address climate change, under a variety of theories. With these shifts, ADB expanded the focus of its judicial capacity building program to incorporate climate change and sustainable development.

In our work with judiciaries over the last 10 years, ADB has seen the extraordinary potential of judicial capacity building, along with the huge gaps that remain to be filled.

- Issuing judgments advancing environmental protection can see judges labeled "anti-development." This label isolates and demotivates judges and can hamper them from addressing the serious legal and constitutional issues that may be implicated by climate change. For such judges, we created the Asian Judges Network on Environment (AJNE), a platform to connect judges and legal professionals, facilitate the sharing of knowledge and legal developments on a regional and global level, and boost motivation. ADB also launched annual conferences on environmental and climate law to share best practices. We complemented that work with assisting on targeted national judicial reforms in almost all host countries.

- During the annual judicial conferences, Asian and Pacific judges debated and developed the concepts of environmental and climate justice for the region. These sessions helped develop shared judicial language and frameworks to assess climate issues, and gave impetus to the development of seminal jurisprudence across the region. Despite these successes in the region, broader global audiences are often not aware of the phenomenal work that Asia and Pacific judiciaries do for lack of international reporting. 
The Law and Policy Reform Program realized that ADB could, with these reports, both provide practical support to judges facing complex climate litigation as well as showcase climate jurisprudence from Asia and the Pacific to a broader audience.

In service of these overarching objectives, this report series seeks to (i) share environmental and climate jurisprudence from Asia and the Pacific, contributing to global knowledge on regional climate law and litigation; (ii) provide a comprehensive benchbook and tool kit for judges, especially those from Asia and the Pacific, to facilitate decision-making in this ever-evolving field of law; (iii) capture the results of ADB's judicial capacity development work - the legacy of ADB's work to date; and finally, (iv) acknowledge the prodigious work done by the judiciaries of Asia and the Pacific-ADB applauds their dedication and progress.

ADB was pleased to collaborate with the Sabin Center for Climate Change Law on this project. Michael Burger, Ama Francis, and the team at Sabin provided extraordinary support for ADB, contributing authoritatively on climate litigation around the world in Report Two, supplementing ADB's own research, and drafting the national legal frameworks report.

With pleasure, I acknowledge and introduce ADB's young and extraordinarily smart team of researchers and authors. Seventeen researchers gathered laws and cases from the 32 countries covered by these reports. Gregorio Rafael P. Bueta and Francesse Joy J. Cordon-Navarro contributed to and assisted with reviewing the reports. Maria Cecilia T. Sicangco wrote the report on international climate change legal frameworks and assisted with reviewing and editing these reports.

Many thanks to Irum Ahsan who led this initiative. Irum headed the Law and Policy Reform team between 2017 and 2020, under the guidance of ADB's former Deputy General Counsel Ramit Nagpal. Her energy, drive, and creativity have created a flagship program for ADB. I thank Briony Eales, who steered this initiative tirelessly over the last 3 years, working with researchers and authors, and juggling work with a young child. She worked with the researchers; wrote about climate science, climate litigation, and climate laws; and created a synthesized and cohesive series of reports.

The team diligently works on strengthening the rule of law, a key driver for robust and sustainable economic development. This will be vital work over the coming years. The global efforts to mitigate climate change and address its harmful impacts must only intensify in the near future, especially in Asia and the Pacific. The region is too large, diverse, and globally significant not to be at the center of these efforts. ADB is committed to supporting the global climate agenda, including by developing the capacity of judicial systems within Asia and the Pacific to play their vital role.

We look forward to our continued work with the region's judiciaries to strengthen climate justice and the rule of law.

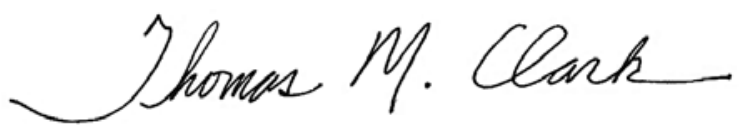

THOMAS M. CLARK

General Counsel

Office of the General Counsel

Asian Development Bank 


\section{ACKNOWLEDGMENTS}

limate Change, Coming Soon to a Court Near You is a flagship publication series of the Law and Policy Reform Program under the Office of the General Counsel of the Asian Development Bank (ADB). The reports would not have been possible without the vision and leadership of Irum Ahsan, project team leader, and currently advisor, Office of the Compliance Review Panel.

Report Three, National Climate Change Legal Frameworks in Asia and the Pacific, was written by Dena Adler, Hillary Aidun, Michael Burger, and Ama Francis of the Sabin Center for Climate Change Law, and Briony Eales and Maria Cecilia T. Sicangco of ADB. Briony Eales also guided the research, editing, and publication of this report. Gregorio Rafael P. Bueta, Francesse Joy J. Cordon-Navarro, and Maria Cecilia T. Sicangco assisted with reviewing and editing.

We thank the team of researchers who made this report possible: Afghanistan, Rohullah Azizi; Bangladesh, Asif Nazrul; Bhutan, Kuenzang Tshering; Cambodia, Phanna Sok; India, Padma Priya; Indonesia, Andri Wibisana; the Lao People's Democratic Republic, Nang Nalinthone; Malaysia, Judge Wan Fadhilah Nor binti Wan Idris; Maldives, Malcolm Simmons; Myanmar, Khin Thandar and Ohnmar Aye; Nepal, Padam Bahadur Shrestha; the Pacific developing member countries, Maria Goreti Muavesi; Pakistan, Angbeen Atif Mirza; the People's Republic of China, Allen Smith; the Philippines, the Supreme Court of the Philippines; Sri Lanka, Wardani Karunaratne; Thailand, Chacrit Sitdhiwej; and Viet Nam, Tran Thi Huong Trang.

We also thank the team of research assistances and interns from the Sabin Center for Climate Change Law who augmented our research: Alexander Fung, Arianna Menzelos, Malia Libby, Alexander Fields, Nina Wolff Landau, Jacob Taylor, Sara Louise Kaufhardt, and Elza Bouhassira, who also assisted with editing.

Tara Mitchell, Frazer Henderson, and Hammed Bolotaolo provided instrumental editorial advice on this report. Judy T. Yñiguez handled typesetting and graphics generation. The cover artwork was designed by Gayle Certeza, Daniel Desembrana, and John Michael Casipe, guided by Anthony Victoria. Monina Gamboa and Marjorie Celis proofed the draft layout.

Support for printing and publishing the report was provided by the Printing Services Unit of the ADB Office of Administrative Services and by the ADB Department of Communications' publications and web teams. We are grateful to Anna Sherwood and colleagues in the Department of Communications for their guidance on design and publishing. Noren Jose advised on ADB style and legal citations.

We express gratitude to former ADB General Counsel Christopher Stephens and former Deputy General Counsel Ramit Nagpal for supporting these reports from their inception. We also thank the present General Counsel Thomas M. Clark for his support in completing this publication. 



\section{ABBREVIATIONS}

ADB

AJNE

APEC

BAU

BCCTF

BERC

CDM

CIA

$\mathrm{CO}_{2}$

COP

COP 23

COP 25

COP 26

COVID-19

DENR

DOE

E2PO

ERIA

ESRL

FAO

GDP

GEF

GHG

GLOF

IEA

IPP

IPCC

IRENA
Asian Development Bank

Asian Judges Network on Environment

Asia-Pacific Economic Cooperation

business as usual

Bangladesh Climate Change Trust Fund

Bangladesh Energy Regulatory Commission

Clean Development Mechanism

Central Intelligence Agency

carbon dioxide

Conference of the Parties

23rd Session of the Conference of the Parties to the United Nations Framework Convention on Climate Change

25th Session of the Conference of the Parties to the United Nations Framework Convention on Climate Change

26th Session of the Conference of the Parties to the

United Nations Framework Convention on Climate Change

coronavirus disease

Department of Environment and Natural Resources

Department of Energy

Energy Efficiency Programme Office

Economic Research Institute for ASEAN and East Asia

Earth System Research Laboratories

Food and Agriculture Organization of the United Nations

gross domestic product

Global Environment Facility

greenhouse gas

glacial lake outburst flood

International Energy Agency

independent power producer

Intergovernmental Panel on Climate Change

International Renewable Energy Agency 
КеTTHA

LDC

LULUCF

MARD

MEC

MOE

MOECAF

MOEF

MOEMR

MONRE

MRV

NAPA

NCCC

NDC

NEPA

NOAA

REDD+

REEEP

SMES

TFEC

TPES

UN

UNDP

UNEP

UNFCCC

WFP
Kementerian Tenaga Teknologi, Hijau Dan Air (Ministry of

Energy, Green Technology and Water)

least developed country

land use, land-use change, and forestry

Ministry of Agriculture and Rural Development

Marshalls Energy Company

Ministry of Energy

Ministry of Environmental Conservation and Forestry

Ministry of Environment and Forestry

Ministry of Energy and Mineral Resources

Ministry of Natural Resources and Environment

measurement, reporting, and verification

National Adaptation Programme of Action

National Climate Change Committee

nationally determined contribution

National Environmental Protection Agency

National Oceanic and Atmospheric Administration

Reducing emissions from deforestation and forest degradation plus the sustainable management of forests, and the conservation and enhancement of forest carbon stocks

Renewable Energy and Energy Efficiency Partnership

small and medium-sized enterprises

total final energy consumption

total primary energy supply

United Nations

United Nations Development Programme

United Nations Environment Programme

United Nations Framework Convention on Climate Change

World Food Programme 


\title{
Weights and Measures
}

\author{
cm \\ centimeter \\ GW \\ gigawatt \\ GWh \\ gigawatt hour \\ km \\ kilometer \\ $\mathbf{k m}^{2}$ \\ square kilometers \\ kt \\ kiloton \\ ktoe \\ kilotonnes of oil equivalent or kilotons of oil equivalent \\ kW \\ kilowatt \\ kWh \\ kilowatt-hours \\ m \\ meter \\ $\mathbf{m}^{3}$ \\ cubic meter \\ $\mathbf{m m}$ \\ millimeter \\ Mtoe \\ million tonnes of oil equivalent or million tons of oil \\ equivalent \\ MW \\ megawatt \\ ppm \\ parts per million \\ $\mathrm{tCO}_{2}$ \\ tonnes of carbon dioxide or tons of carbon dioxide \\ toe \\ tonnes of oil equivalent or tons of oil equivalent
}

Notes: 1. Tonne of oil equivalent (toe) is a unit of energy measuring the amount of energy released by burning one tonne of crude oil. The standard international measure is described as a tonne of oil equivalent, or metric ton of oil equivalent. Countries vary in their reporting, with some reporting on tonne of oil equivalent and others reporting on ton of oil equivalent. This publication uses the term and/or spelling reported by a particular country with a standardized definition (toe) that covers both terms - tonne of oil equivalent and ton of oil equivalent.

2. Tonne of carbon dioxide $\left(\mathrm{tCO}_{2}\right)$ measures the mass of carbon dioxide emissions. The standard international measure is described as tonne of carbon dioxide, or metric ton of carbon dioxide. Countries vary in their reporting, with some reporting on tonne of carbon dioxide and others reporting on ton of carbon dioxide. This publication uses the term and/or spelling reported by a particular country with a standardized definition $\left(\mathrm{tCO}_{2}\right)$ that covers both terms-tonne of carbon dioxide and ton of carbon dioxide. 


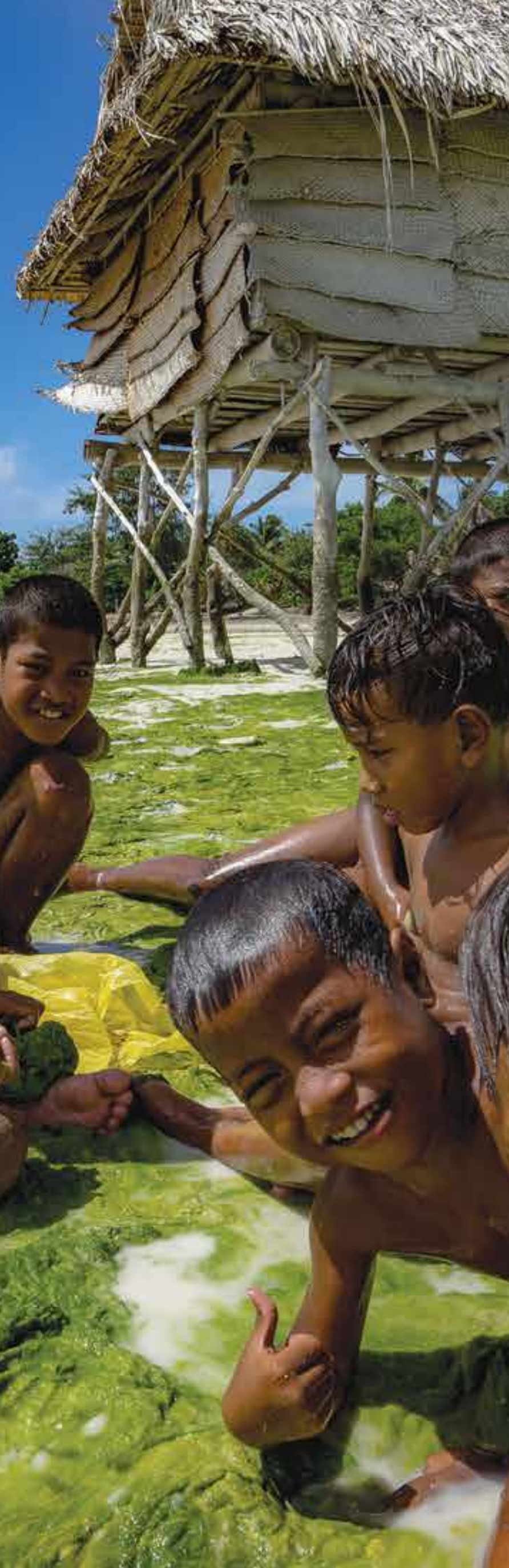



Cases from high-income countries dominate global literature about climate litigation. These countries have different mindsets, legal and policy frameworks, and climate change challenges. Although judges from Asia and the Pacific have much to gain from reading this literature, they also need perspectives and approaches closer to home from peers working with similar challenges.

Most Asia and the Pacific countries have low emissions and are incredibly susceptible to climate change. The region therefore focuses on climate adaptation and resilience-activities supported by ecosystem resilience and biodiversity.

Unfortunately, weak environmental governance is common in Asia and the Pacific, creating cascading effects in this era of climate change. Frail ecosystems and biodiversity offer communities less protection from the impacts of climate change, e.g., healthy mangrove forests protect humans and other species from storm surges. Ecosystems are also more easily damaged by climate change. Unchecked environmental degradation leaves indigenous, agrarian, and island communities even more vulnerable to death, homelessness, and displacement. Judiciaries in the region benefit from understanding the role of ecosystem protection, biodiversity, and sustainable development in boosting local climate resilience. Hence, these reports outline links between environmental protection, biodiversity, and climate change.

Prioritizing environmental protection and low-emission development is challenging in Asia and the Pacific, a region dominated by low to lower middle-income countries with development objectives. Judges who do that are often labeled "anti-development," isolating them from their peers. Judges need access to resources and networks that boost their knowledge, and to information that proves that balanced and appropriate environmental and climate protection makes business sense and aligns with national climate commitments.

Judicial knowledge about climate change, legal frameworks, and relevant legal principles are fundamental to a strong rule of law. Many core principles in climate law stem from environmental law, a field that a few judges in Asia and the Pacific have studied or practiced.

Resource limitations, ad hoc publication of laws, and language barriers in Asia and the Pacific also make it difficult for judges to maintain current knowledge about climate law, climate science, and local climate change impacts, diminishing judicial effectiveness. These reports seek to overcome some of these barriers by synthesizing climate information and achievements and weaving a regional perspective into the global discourse on climate law. 


\section{Report Series Structure}

Within this series are four reports:

- Report Series Purpose and Introduction to Climate Science: a brief introduction to climate change and climate science

- Climate Litigation in Asia and the Pacific and Beyond: a comparative analysis of climate litigation in Asia and the Pacific and the rest of the world

- National Climate Change Legal Frameworks in Asia and the Pacific: analyses of the national climate change policy and legal frameworks in ADB developing member countries in South Asia, Southeast Asia, and the Pacific and the People's Republic of China, with tables to highlight constitutional provisions relevant to climate change and a discussion of trends in climate law

- International Climate Change Legal Frameworks: a ready reference to key international climate change instruments and soft law, with tables showing treaty commitments by country

ADB has specifically designed these reports for judges, quasi-judicial decisionmakers, lawyers from Asia and the Pacific, and those interested in Asian and Pacific climate law.

\section{Key Takeaways}

\section{Litigation}

Climate litigation is growing-in Asia and the Pacific and around the world. Most climate lawsuits in Asia target government respondents, seeking climate action or challenging decisions with climate impacts. The number of cases against governments based on treaty obligations, particularly the Paris Agreement, is increasing, and so is litigation against private entities.

Litigation preferences reflect domestic legal frameworks, with litigants looking for appropriate hooks to support their claims. Of the countries surveyed in this report, $25 \%$ have adopted framework climate legislation-economy-wide framework climate change law. The other states use climate policies and existing laws to achieve their goals. Unclear or incomplete legal and policy frameworks combined with weak enforcement frequently lead litigants to sue for violations of constitutional rights.

Petitioners in Asia favor constitutional litigation because it (i) has been used successfully in environmental litigation, (ii) allows direct access to superior courts, (iii) provides a legal basis for a claim where the existing legal and policy framework is incomplete, and (iv) is easier for petitioners to demonstrate standing where a constitutional right has been breached. The preference for rights-based litigation 
reflects a global trend. Roughly one-third of all climate litigation outside the United States hinges on fundamental, human, and constitutional rights.

Most lawsuits target climate mitigation-the reduction of greenhouse gas emissions. However, litigation seeking climate change adaptation is growing and frequently emerges as a silent issue in Asian environmental lawsuits. In various cases, neither the parties nor the court identified climate change as an issue, but the case outcomes had co-benefits for climate resilience and, therefore, adaptation. These reports treat such cases as climate cases.

Climate litigation in Pacific courts remains rare, which does not reflect the existential nature of the climate threat in the Pacific.

Pacific islanders are more likely to rely on customary dispute resolution to resolve local conflicts, reducing the likelihood of litigation. Pacific nations know that their contribution to climate change is negligible. Lawsuits against national governments are also counterproductive if the state has limited resources to respond. Therefore, Pacific islanders are more likely to pursue human rights petitions in United Nations bodies or engage in transnational litigation, e.g., the climate migration cases filed in Australia and New Zealand.

Women, children, indigenous communities, and older adults-people who are particularly vulnerable to climate change-have also been active in domestic and international climate litigation.

\section{National Legal and Policy Frameworks}

Legal and policy frameworks are growing in Asia and the Pacific as governments plan for low-emission and resilient growth and ramp up climate responses in line with the Paris Agreement.

National legal and policy frameworks help drive global climate action. The period preceding the Paris Agreement (2009-2015) saw the most intense adoption of domestic laws and policies globally. This factor underscores the relationship between bolstering national climate action and driving forward the global agenda. Only collaborative, widespread, and urgent local responses can limit climate change, requiring quality national legal and policy frameworks backed up by well-informed judiciaries supporting implementation.

Legal and policy commitments need strengthening across the region. Most procedures for environmental impact assessments do not expressly require consideration of climate change. Laws requiring proponents to account for climate effects on a project and incorporate climate durability into its design are rare, undermining climate-resilient development. A few laws cover climate change and oceans. 
Climate impacts, the Paris Agreement, technology, and markets will shape domestic climate laws and policies, as governments seek to keep up with changes.

Courts in Asia and the Pacific are shaping national legal and policy frameworks with their decisions. Further, given the existential crisis presented by climate change, courts have been willing to assess whether national laws and policies meet international climate commitments.

\section{International Legal and Policy Frameworks}

COVID-19 put much of 2020 on hold, including meetings central to the Paris Agreement implementation. The 26th Session of the Conference of the Parties to the United Nations Framework Convention on Climate Change was postponed until 2021, delaying agreement on a carbon trading mechanism, common time frames for reporting under the agreement, and ramping up climate finance and technology transfers.

The Paris Agreement is mainly silent on oceans and aviation. However, the adoption of domestic laws and policies in the 6 years leading up to the Paris Agreement showed the power of national legal frameworks to shape global action.

\section{Judges Can Contribute to Better Climate Outcomes}

Judges' role in government makes them gatekeepers, even climate emergency managers. Judges are central to

- holding governments accountable for meeting policy commitments and complying with legal obligations on climate change, the environment, and sustainable development, and thereby shaping legal and policy frameworks;

- admitting relevant and credible scientific evidence for climate change in courtrooms and making judicial findings of fact about climate change, which can elevate the national discourse on climate change (indeed, courts have successfully incorporated international scientific consensus, synthesized by the Intergovernmental Panel on Climate Change, into domestic legal common ground, ensuring that advancements in climate science filter into local law); and

- balancing outcomes and protecting citizens' fundamental, constitutional, and other legal rights, frequently closing the gaps through which people and ecosystems fall.

These functions demonstrate that judges have a vital role in climate governance in Asia and the Pacific. Supporting judges to respond to climate litigation contributes to better quality climate governance. 


\section{Moving Forward}

Today's judges are being asked to decide on the burning issue of our generationclimate change. It is a challenge that threatens to eclipse all others in modern history.

As Albert Einstein once said, "We cannot solve our problems with the same thinking we used when we created them." Significant judicial advancements have often rested on the shoulders of jurists who were willing to apply new consciousness and imagination to existing principles to resolve society's pressing problems. We need new perspectives to create climate justice. Justice will only be fair if it considers diverse perspectives and rights - those of women, children, elders, indigenous peoples, the differently abled, and future generations, as well as those of the traditional power structures.

These reports are for those who must adjudicate climate litigation in Asia and the Pacific. ADB lauds the advancements that Asia and the Pacific judiciaries have made in environmental and climate justice and sustainable development. The authors hope that this jurisprudence brings diversity and a fresh perspective to the global discourse on climate law.

As for climate justice, more work is needed. Emissions continue to rise, and global commitments do not yet have the world on track to limit global warming to well below $2^{\circ} \mathrm{C}$ above preindustrial temperatures. Gaps persist in climate change legal and policy frameworks, allowing action to stagnate. To promote climate justice in Asia and the Pacific, judges can assess these gaps. They can ask, do these frameworks support the overarching $1.5^{\circ} \mathrm{C}-2^{\circ} \mathrm{C}$ temperature goal under the Paris Agreement?

These reports encourage judiciaries to equip themselves with knowledge about climate science and law because litigation demands that judges take part in reckoning climate justice. The future rests heavily on each of us. Those able to make powerful decisions must choose action. This work is in the service of judges and decision-makers. We hope it lights the way, a little. 


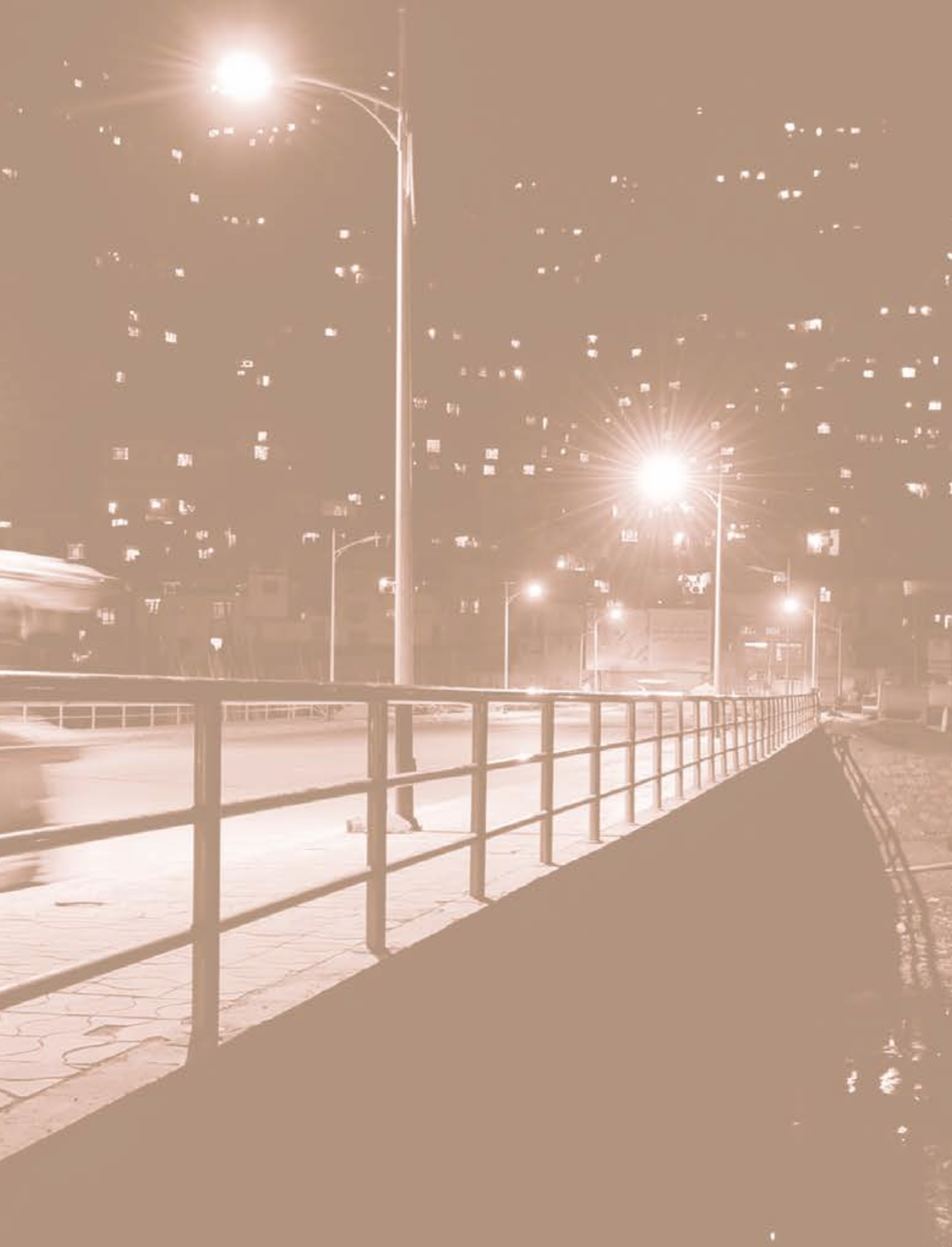




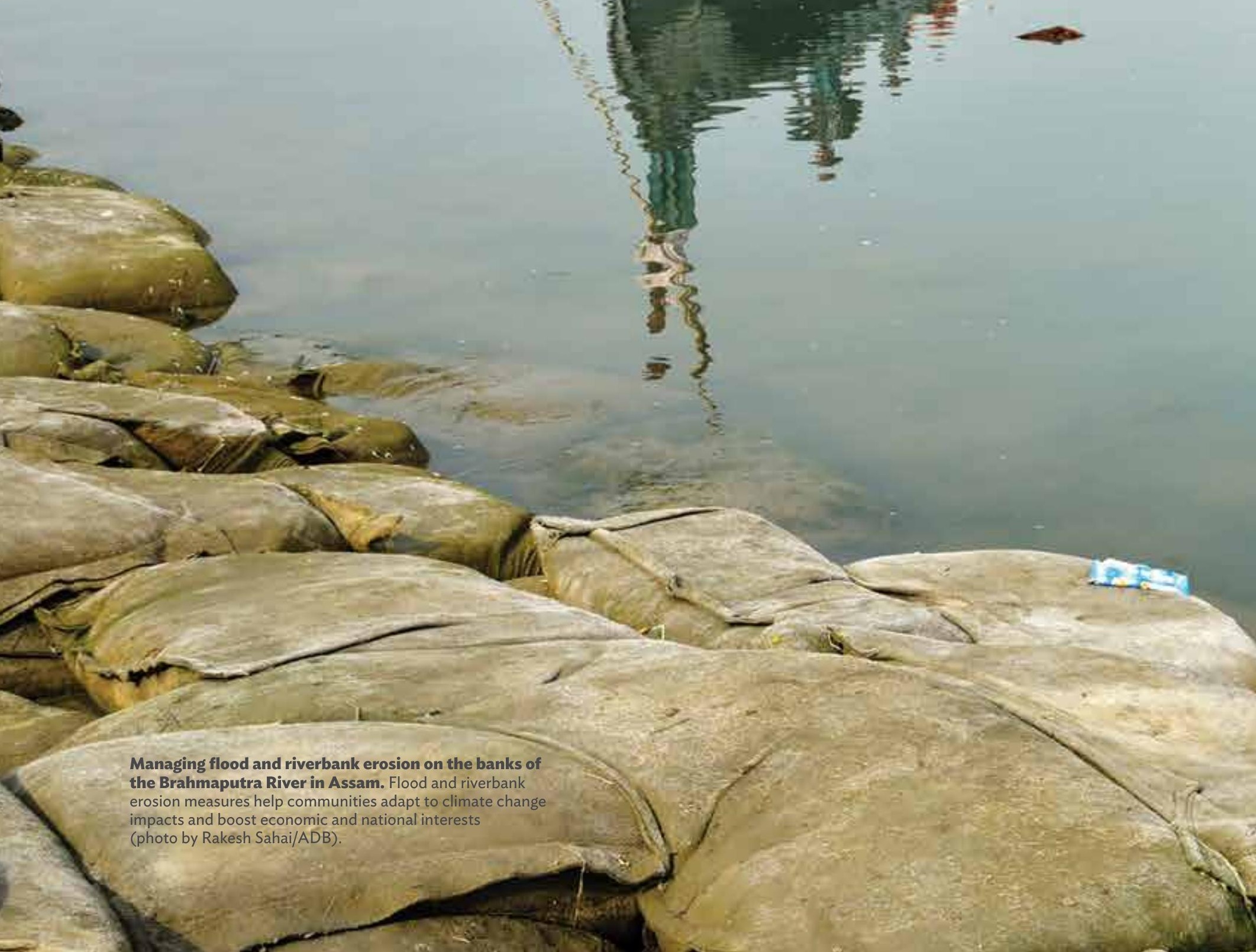




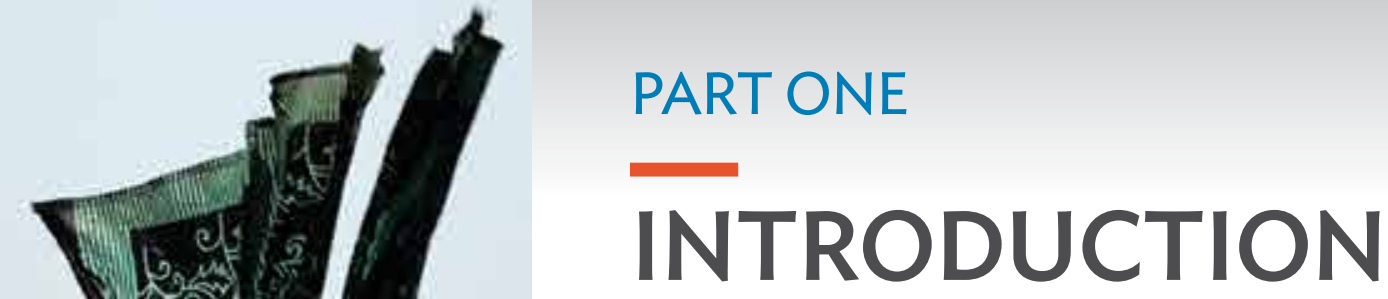

\section{Judiciaries Play a Role in Domestic Climate Action and Need Resources}

The diplomats have done their job: the Paris Agreement points the world in the right direction, and with sophistication and clarity. It does not, however, ensure implementation, which necessarily remains the domain of politicians, businessmen, scientists, engineers, and civil society. ${ }^{1}$

These words reveal a fundamental truth-the Paris Agreement is just the beginning of what needs to be done. How might we ensure that the agreement is implemented? Everyone must "make climate change personal" in their life and contribute to global action. ${ }^{2}$ Only with collective action can humankind limit global warming to well below $2{ }^{\circ} \mathrm{C}$ above preindustrial temperatures, ideally to a maximum of $1.5^{\circ} \mathrm{C} .{ }^{3} \mathrm{Climate}$ change results from emissions all around us, affecting citizens and ecosystems globally. Implementation must, therefore, occur where emissions and impacts arise.

Countries adopt policies and laws consistent with their global commitments to regulate domestic responses to climate change. As of 26 November 2020, there were 2,082 policies and laws globally. ${ }^{4}$ National legal and policy frameworks are vital for low emission and resilient green growth because they integrate international commitments into the national context and ensure domestic implementation.

Despite the global agreement and growth in climate laws, climate change impacts are mounting, and it is apparent that existing climate pledges are insufficient to meet agreed temperature goals. ${ }^{5}$

Faced with devastating impacts on their lives, citizens are suing for climate action. Climate action includes activities to (i) reduce atmospheric greenhouse gas

A. Doyle et al. 2015. Factbox: World Reacts to New Climate Accord. Reuters. 13 December.

2 D. Falvey. 2019. 'Make Climate Change Personal in Your Life', Mary Robinson Urges. The Irish Times. 20 July.

3 Paris Agreement, Paris, 12 December 2015, United Nations Treaty Series, No. 54113. Art. 2(1)(a).

4 Grantham Research Institute on Climate Change and the Environment. Climate Change Laws of the World (accessed 26 November 2020).

5 United Nations Environment Programme (UNEP). 2019. Emissions Gap Report 2019. News release. 26 November. For infographics, see Climate Action Tracker. The World Is Not on Track to Meet $1.5^{\circ} \mathrm{C}$. 
emissions or concentrations (mitigation), (ii) adjust to the impacts of climate change (adaptation), and (iii) boost the capacity of people and ecosystems to recover from climate impacts (resilience). By 26 November 2020, there were more than 1,200 climate suits in the United States alone and at least 400 climate cases in other countries. ${ }^{6}$ Climate litigation is also growing in Asia and the Pacific, requiring judiciaries to interpret or apply their domestic climate change legal frameworks (see Report Two for a discussion about climate litigation in Asia and the Pacific).

The central role of judges -interpreting, upholding, and shaping laws-makes the judiciary integral to domestic climate action. Courts are "increasingly complementing the actions of legislators" by deliberating over climate change court cases worldwide. 7 Patricia Espinosa-Executive Secretary of the United Nations Framework Convention on Climate Change-recently commented, "Relevant legislation, carefully used, supported and backed by an informed judiciary, will also be crucial for realising our shared aspirations for shaping a resilient, low-carbon and truly sustainable future" (footnote 7).

This report-Climate Change, Coming Soon to a Court Near You: National Climate Change Legal Frameworks in Asia and the Pacific-focuses on national climate change legal and policy frameworks in 32 countries in Asia and the Pacific. It belongs to a series of reports on climate law and policy for judges in Asia and the Pacific. Due to the judges' growing concern about climate change and the fact that more people are suing over it, the Asian Development Bank (ADB) prepared these papers to provide more resources about climate change law.

When determining the usefulness of this report to judges in Asia and the Pacific, ADB took into account the resource constraints that prevent many of its developing member countries from publishing their laws and policies online or translating documents into English. These challenges make the records of national climate laws and policies online incomplete. Consequently, judges, lawyers, interested parties, and international development partners are unable to access exhaustive information about various national climate change legal and policy frameworks in the region. Access to laws benefit everyone, and this report seeks to boost accessibility.

Legal and policy frameworks must also facilitate access to climate finance and other resources from international donors. Each country covered by this report has a national designated authority with the Green Climate Fund. ${ }^{8}$ Clear information about national legal and policy frameworks makes it easier for donors to assess sectoral responsibilities and national reporting standards. These factors are vital for the provision of green finance and other resources.

Sabin Center for Climate Change Law. About (accessed 26 November 2020).

7 M. Nachmany et al. 2017. Global Trends in Climate Change Legislation and Litigation. London: Grantham Research Institute on Climate Change and the Environment. p. 4.

8 Green Climate Fund. NDA Directory. 


\section{Report Structure and Scope}

Report Three-National Climate Change Legal Frameworks in Asia and the Pacificreviews climate law and policy frameworks across 32 countries in South Asia, Southeast Asia, and the Pacific (Table 1). ADB collected some 880 laws and policies for this report.

Table 1: Regions and Countries Covered by the Report

\begin{tabular}{|c|c|c|}
\hline South Asia & $\begin{array}{l}\text { Southeast Asia and the } \\
\text { People's Republic of China }\end{array}$ & Pacific \\
\hline Afghanistan & Cambodia & Cook Islands \\
\hline Bangladesh & Indonesia & Federated States of Micronesia \\
\hline Bhutan & Lao People's Democratic Republic & Fiji \\
\hline India & Malaysia & Kiribati \\
\hline Maldives & Myanmar & Marshall Islands \\
\hline Nepal & People's Republic of China & Nauru \\
\hline Pakistan & Philippines & Palau \\
\hline \multirow[t]{7}{*}{ Sri Lanka } & Singapore & Papua New Guinea \\
\hline & Thailand & Samoa \\
\hline & Viet Nam & Solomon Islands \\
\hline & & Timor-Leste \\
\hline & & Tonga \\
\hline & & Tuvalu \\
\hline & & Vanuatu \\
\hline
\end{tabular}

Source: Asian Development Bank.

Report Three contains seven parts, with the body of the report falling within

- Part Two-trends in climate laws and policies in Asia and the Pacific,

- Part Three-constitutional rights survey, and

- Parts Four, Five, and Six-national legal climate change frameworks summaries.

\section{A. Part Two: Trends in Climate Laws and Policies in Asia and the Pacific}

Part Two outlines some key trends relating to climate law and policies. For example, it is clear that (i) climate litigation is shaping domestic legal frameworks, (ii) legal adaptation frameworks across Asia and the Pacific can be strengthened, and (iii) most countries regulate climate change responses with policies and implementation via existing laws. 
The clear preference for defining climate responses via policies, action plans, and existing laws has benefits. It allows countries to roll out policies quickly and update them after testing their usefulness. But without an overarching instrument like a framework climate law to steer the response and ensure that it works cohesively, national collaboration can flounder. Bureaucracy can impede information sharing and reporting, undermining outcomes.

Trends in climate laws and policies are useful predictors of litigation preferences and growth areas within national frameworks. Typically, citizens sue because climate change laws or policies do not or will not achieve the Paris Agreement's goals, or implementation or enforcement is weak. This report does not comment on the adequacy of any country's framework or the application of laws. However, Part Two provides insights into how gaps in legislation and international developments may influence future litigation.

\section{B. Part Three: Constitutional Rights Survey}

Rights-based climate lawsuits are growing in popularity. Outside the United States, they constitute around 35\% of all climate litigation against governments. ${ }^{9}$ Within Asia, rights-based cases typically rely on constitutional rights, particularly the rights to life, environment, and equal protection before the law (see Part II of Report Two for a more detailed discussion of constitutional rights climate litigation).

Given the trend toward rights-based climate litigation, Part Three shows tables identifying constitutions containing the rights to life, environment, food, water, health, housing, self-determination, cultural identity, property, biodiversity, public participation, access to information, and sustainable development. The tables also help judges and practitioners identify which constitutions within South Asia, Southeast Asia, and the Pacific contain related rights, making it easier to determine relevant and comparable climate jurisprudence.

\section{Parts Four, Five, and Six: National Legal Climate Change Frameworks Summaries}

Most countries regulate climate action with a combination of climate policies, plans, and existing laws (see Part Two above for more information about this preference). This approach can make it challenging to gain a holistic perspective on how the entire framework functions.

Parts Four, Five, and Six contains high-level summaries (5-8 pages) of the national climate change legal frameworks for the 32 countries covered by this report. The discussion shows not only the summary of laws, but also how various

9 “The Rights Turn in Climate Litigation,” YouTube video, 43:47, from a presentation given by César Rodríguez-Garavito at the World Commission on Environmental Law Webinar 4: Climate Change in the Courts on 5 June 2020. 
instruments combine to regulate multiple aspects of climate action. Every section (i) begins with a snapshot of the country's climate and environmental challenges; (ii) explains the overarching climate change legal and policy framework, including mitigation and adaptation targets; (iii) lists all relevant climate laws, policies, and instruments in a table; and (iv) enumerates the sector-specific laws, policies, and regulations pertinent to climate action.

Each of the national summaries discusses climate laws, policies, regulations, and instruments that focus on

(i) climate change specifically, such as overarching laws on mitigation or adaptation, or which create institutional frameworks;

(ii) climate finance and carbon financing;

(iii) cities and buildings;

(iv) disaster risk reduction and management;

(v) energy;

(vi) food production and security;

(vii) reducing emissions from deforestation and forest degradation in developing countries, and the role of conservation, sustainable management of forests, and enhancement of forest carbon stocks in developing countries (REDD+) and land use, land-use change, and forestry (LULUCF);

(viii) transportation;

(ix) vulnerable groups;

(x) waste; and

(xi) water resources and coastal zone management.

Not every country has laws or policies regulating these thematic areas, so each summary focuses on the current status of the legal and policy framework in 2019-2020.

\section{Report Methodology and Preparation}

\section{A. Defining Climate Law and Policy in This Report}

This report defines climate laws and policies as any law, policy, regulation, or instrument that contributes to national climate change mitigation and adaptation. In researching for this report, $\mathrm{ADB}$ surveyed laws, policies, regulations, and instruments furthering climate mitigation and adaptation related to

(i) carbon pricing;

(ii) cities and buildings;

(iii) energy;

(iv) environmental impact assessments;

(v) food production and food security; 
(vi) institutional and administrative arrangements;

(vii) materials and manufacturing;

(viii) other relevant laws, such as those targeting pollution or solid waste management;

(ix) LULUCF and REDD+;

(x) refugees, migration, and displacement;

(xi) research and development;

(xii) transportation;

(xiii) water resources and coastal zone management; and

(xiv) women and girls.

\section{B. Report Preparation and Accessing Laws Online}

ADB prepared this report in collaboration with the Sabin Center for Climate Change Law. ${ }^{10} \mathrm{ADB}$ also engaged researchers to collate national laws and policies, especially those not available online and not available in English, to fill the gaps in the information currently available. ADB contributed Parts One, Two, Three, and Seven, while the Sabin Center for Climate Change Law prepared Parts Four, Five, and Six.

To facilitate access to information, this report links with online copies of all laws, policies, regulations, and instruments discussed, where possible. ADB also collaborates with the Grantham Research Institute on Climate Change and the Environment and the Sabin Center for Climate Change Law to upload laws, policies, and other instruments discussed in this report onto the Climate Change Laws of the World database (footnote 4).

\section{Looking Forward}

Uncertainty shrouds global responses to climate change and, therefore, the extent of climactic change. In 2020, there remains a big gap between current global pledges on climate action and the action needed to limit global warming to $1.5^{\circ} \mathrm{C}$ above preindustrial temperatures - the safer option. ${ }^{11}$ The international community is currently on track to exceed $1.5^{\circ} \mathrm{C}$ of warming by $2035,2^{\circ} \mathrm{C}$ by around 2053 , and $3.2^{\circ} \mathrm{C}$ by $2100 .{ }^{12}$

The parties to the Paris Agreement designed the accord to start slowly and improve. The authors recognize that even the countries' imperfect climate action, defined in nationally determined contributions (NDCs), could enhance and reach the net-zero goal by 2050. However, the pledges outlined in the first NDCs were

10 Sabin Center for Climate Change Law.

11 Footnote 5. Additionally, the Intergovernmental Panel on Climate Change (IPCC) acknowledged that $1.5^{\circ} \mathrm{C}$ is a safer limit in IPCC. 2018. Summary for Policymakers. In V. Masson-Delmotte et al., eds. Global Warming of $1.5^{\circ} \mathrm{C}$. An IPCC Special Report. In Press.

12 Climate Analytics and NewClimate Institute. 2019. Climate Action Tracker: Warming Projections Global Update. Berlin. 
low. In 2019, the United Nations Environment Programme (UNEP) reported that "dramatic strengthening of the NDCs is needed in 2020. Countries must increase their NDC ambitions threefold to achieve the well below $2^{\circ} \mathrm{C}$ goal and more than fivefold to achieve the $1.5^{\circ} \mathrm{C}$ goal." ${ }^{\prime 13}$

Unfortunately, the novel coronavirus disease (COVID-19) pandemic is a considerable speed bump for global climate action. Infections in Asia and the Pacific reached 11.37 million by 26 November 2020, with almost 178,000 deaths. ${ }^{14}$ Global deaths were around 1,405,000 (footnote 14).

The widespread shutdown has slowed the passage of laws, the adoption of updated policies and NDCs, and postponed international forums for climate negotiations. ${ }^{15}$ But it has not slowed global warming significantly. ${ }^{16}$ The global monthly mean of atmospheric carbon dioxide $\left(\mathrm{CO}_{2}\right)$ in August 2020 was 409.50 parts per million (ppm), compared with 407.43 ppm in August 2019. ${ }^{17}$ Emissions will also pick up again when economies reopen. Therefore, any emissions reductions must be sustainable and enable economies to function.

Infection control measures that require restricted face-to-face interaction also impact the ability of courts to manage climate litigation. For this reason, in 2020 ADB has supported the Asia-Pacific Judicial Conference on Climate Change: Adjudication in the Time of COVID-19. As its name suggests, the conference (an online forum) explores themes to support judges hearing matters in online courtrooms, a by-product of rolling COVID-19-related shutdowns. Virtual courtrooms might also support judges with climate litigation, particularly matters involving offshore parties.

Climate litigation will not stall for long. Global citizens and businesses are aware of the urgency of improving climate action. Lawsuits will inevitably question the effectiveness of NDC pledges and the legal and policy frameworks that support the international commitments and drive domestic implementation (see Report Two for a more detailed discussion of climate litigation trends.) These cases will ask the courts to intervene.

In the face of climate litigation, judiciaries will need good quality information about national legal and policy frameworks. This report seeks to support judges by providing information about

13 UNEP. 2019. Emissions Gap Report 2019: Executive Summary. Nairobi. p. x.

14 World Health Organization. WHO Coronavirus Disease (COVID-19) Dashboard (accessed 26 November 2020). Countries from Asia and the Pacific fall within the WHO Southeast Asia and Western Pacific regions.

15 The 26th Conference of the Parties to the United Nations Framework Convention on Climate Change (COP 26) has been postponed to 2021.

16 National Oceanic and Atmospheric Administration (NOAA), Earth System Research Laboratories (ESRL). Can We See a Change in the $\mathrm{CO}_{2}$ Record Because of COVID-19?

17 NOAA, ESRL. Trends in Atmospheric Carbon Dioxide: Global Monthly Mean $\mathrm{CO}_{2}$ (accessed 26 November 2020). 
- national legal and policy frameworks for 32 countries in Asia and the Pacific,

- rights and obligations enshrined in the constitutions in Asia and the Pacific, and

- current trends in climate change legal and policy frameworks.

ADB's overarching objective in providing holistic syntheses of national climate change legal and policy frameworks is to aid judges, quasi-judicial decisionmakers, and lawyers involved in climate litigation to do the following:

- Understand the connectedness of issues in this era of anthropogenic climate change, e.g., water, energy, and building permits should now consider climate change. A robust understanding of a country's legal and policy framework makes it easier for decision-makers to apply a climate lens to cases that do not raise climate change as a prima facie issue, where appropriate. Such approaches should result in more just, equitable, and sustainable outcomes.

- Assess the cogency of climate-related laws and policies, particularly when a case argues that a country's national climate laws and policies do not meet international commitments.

- Determine the composition of the legal and policy frameworks of comparative jurisdictions in Asia and the Pacific. Globally, climate litigation results in jurisprudence that cites, adopts, and expands decisions from other jurisdictions. Understanding the nature of another country's national legal and policy framework helps judges discern whether that other jurisdiction's laws and jurisprudence are comparative.

Report Three is just one of many resources that judges can access for relevant and timely information on climate laws and legal frameworks. While this document and the rest of the series focus on Asia and the Pacific, other databases and websites showcase developments in different regions and across the globe:

- Climate Change Laws of the World Database, managed by the Grantham Research Institute on Climate Change and the Environment and the Sabin Center for Climate Change Law, to which ADB is contributing. See https://climate-laws.org/.

- ECOLEX, an information service on environmental law, a joint initiative of the Food and Agriculture Organization of the United Nations (FAO), the International Union for Conservation of Nature (IUCN), and UNEP. See https://www.ecolex.org/.

- FAOLEX, a database maintained by the $\mathrm{FAO}$, which is a comprehensive and up-to-date database of national laws, regulations, and policies on food, agriculture, and natural resources management. See http://www.fao.org/ faolex/country-profiles/en/. 
- Asian Judges Network on Environment, which contains laws, regulations, case laws, and reference materials on environmental and climate laws in Asia and the Pacific. See http://www.ajne.org/.

- Pacific Islands Legal Information Institute, an initiative of the University of the South Pacific School of Law, which collects and publishes legal materials from 20 Pacific island countries, including legislation, subordinate legislation, and cases. See http://www.paclii.org/.

- Asia Pacific Energy Portal, an open-access information platform containing energy statistics, full-text policies, and interactive infrastructure maps maintained by the UN Economic and Social Commission for Asia and the Pacific. See https://asiapacificenergy.org/.

- Climate Change Litigation Databases, two databases of climate change case law maintained by the Sabin Center for Climate Change Law in collaboration with Arnold \& Porter Kaye Scholer LLP. See http://climatecasechart.com/?cn-reloaded=1.

- Global Judicial Portal on Environmental Law, a database supported by the Global Judicial Institute on the Environment and UNEP. The database was created for judges by judges. See https://judicial-portal.edw.ro/.

- InforMEA, a United Nations Information Portal on Multilateral Environmental Agreements. See https://www.informea.org/.

ADB hopes that this report will provide judges, quasi-judicial decision-makers, and climate lawyers across the region with a much-needed reference on climate law and policy. Armed with knowledge about the composition of their country's climate change legal and policy framework, judges will have better capacity to rule on climate-related issues. By shaping the advancement of more dynamic climate legal systems, judges contribute to their country's sustainable future.

During one of the Paris Agreement negotiations, the President of Palau commented, "we need a Paris agreement to include a strong long-term goal and a regular review process ... robust transparency rules and a permanent loss and damage mechanism."18 If national legal frameworks and the Paris Agreement are mutually reinforcing, we need domestic laws and policies that do the same. Citizens and judges can actively participate in this outcome with balanced and intelligent lawsuits and decisions.

18 T. Remengesau, President of Palau, quoted in A. Doyle. 2015. 18 Quotes from World Leaders on Climate Change. World Economic Forum. 1 December. 
Khandke Wind Power Project. The farmers of Khandke

continue with their planting and farming around the wind farm

(photo by lan Taylor/ADB). 


\section{TRENDS IN CLIMATE LAWS AND POLICIES IN ASIA AND THE PACIFIC}

arious trends are emerging in climate law and policy frameworks, providing insight into changes in laws and future litigation, which is relevant information for judiciaries.

\section{The Paris Agreement and National Laws and Policies Are Mutually Reinforcing}

With 189 parties, the Paris Agreement is almost universally ratified. ${ }^{1}$ Unlike its predecessor, the accord does not impose targets on countries. ${ }^{2}$ It shifts responsibility to countries for determining appropriate climate responses. Nations must adopt policies and laws that strive to achieve the Paris Agreement's temperature goal- "holding the increase in the global average temperature to well below $2^{\circ} \mathrm{C}$ above pre-industrial levels and pursuing efforts to limit the temperature increase to $1.5^{\circ} \mathrm{C}$ above pre-industrial levels." ${ }^{3}$

To sustain global commitment and enable scrutiny of governments' progress, the Paris Agreement requires parties to communicate their climate action as nationally determined contributions (NDCs) every 5 years. NDCs must become more ambitious over time, enabling action to ramp up. Greenhouse gas emissions should also peak as soon as possible, rapidly reduce after that, and reach net zero in the second half of this century. ${ }^{4}$

The Paris Agreement and domestic climate law are mutually reinforcing. Its widespread adoption reflected the evolving global consensus on climate change

United Nations Treaty Collection. Paris Agreement (accessed 21 August 2020).

2 The Paris Agreement focuses on action post-2020, succeeding the Kyoto Protocol to the United Nations Framework Convention on Climate Change, which regulated pre-2020 climate action. See Kyoto Protocol to the United Nations Framework Convention on Climate Change, Kyoto, 11 December 1997, United Nations Treaty Series, Vol. 2303, No. 30822. p. 162.

3 Paris Agreement, Paris, 20 May 2020, United Nations Treaty Collection, No. 54113. Art. 2(1)(a).

4 Footnote 3, art. 4. Net-zero emissions means that there is "a balance between anthropogenic emissions by sources and removals by sinks of greenhouse gases." 
during 2009-2015, between the Copenhagen Climate Change Conference and the Paris Agreement. In that time frame, all governments passed 100-143 new climate change laws each year. ${ }^{5}$ In its 2018 assessment of global climate law trends, the Grantham Research Institute on Climate Change and the Environment concluded that the spur of domestic legislation supported and enabled the Paris Agreement (footnote 5). In 2013, Christiana Figueres - former Executive Secretary of the United Nations Framework Convention on Climate Change (UNFCCC)-remarked, "nothing is going to be agreed internationally, until enough is legislated domestically." ${ }^{6}$ Domestic law and policy, therefore, are critical to driving global action on climate change.

The Paris Agreement's defining features-global temperature targets, nonbinding national pledges, improved ambition, transparent reporting, human rights, and participation - are also shaping domestic climate law. During 2016-2020, countries adopted 474 climate laws, policies, and other executive instruments in furtherance of meeting the Paris Agreement goals. ${ }^{7}$ The accord also drives post-2020 global climate action. New reporting requirements, public scrutiny over the adequacy of commitments and financing, and a new carbon trading scheme (yet to be agreed) will likely result in additional domestic regulation. ${ }^{8}$

\section{National Preferences Guide Climate Change Legal and Policy Frameworks}

Each country that adopted the Paris Agreement now has one or more laws or policies governing climate change or the transition to a low-carbon economy (footnote 5). Aside from submitting their NDCs, countries have adopted or plan to adopt policies and strategies for achieving low-emission and climateresilient growth. ${ }^{9}$ These green growth or sustainable development strategies have taken many forms, from dedicated, economy-wide climate change legislation (framework legislation) to broad strategies that allow countries to integrate lowemission and climate-resilient policies into development goals and existing laws.

In Asia and the Pacific, 24 of the 32 countries surveyed in this project (75\%) regulate climate action via national or sectoral policies and existing legal

5 M. Nachmany and J. Setzer. 2018. Policy Brief-Global Trends In Climate Change Legislation And Litigation: 2018 Snapshot. London: Grantham Research Institute on Climate Change and the Environment.

6 C. Figueres. 2013. Speech given at the 1st GLOBE Climate Legislation Summit. London. 14 January.

7 Grantham Research Institute on Climate Change and the Environment and the Sabin Center for Climate Change Law. Climate Change Laws of the World (accessed 7 October 2020).

8 In late 2019, parties to the Paris Agreement deferred reaching agreement about carbon trading under art. 6 of the climate pact. Further negotiations are scheduled for the 26th Conference of the Parties to the United Nations Framework Convention on Climate Change (COP 26), deferred to late 2021.

9 United Nations. 2013. The Role of Legal Instruments to Support Green Low-Emission and ClimateResilient Development: A Guidebook on Assessing, Selecting and Implementing Legal Instruments. Nairobi: UNON Publishing Services Section. p. 1. 
frameworks. ${ }^{10}$ This approach allows for the rapid adoption of short- or long-term climate policies, with existing laws and legal frameworks facilitating implementation, e.g., regulations in forestry or energy. It also enables sectors to devise appropriate goals and actions. However, this approach has drawbacks. It can lead to gaps and inconsistent climate responses, making it challenging for countries to build effective climate responses over the long term.

The Paris Agreement encourages parties to submit a mid-century, long-term development strategy for low greenhouse gas emissions by $2020 .{ }^{11}$ The long-term strategy should lay a path toward decarbonization by 2050. By late November 2020, only 19 parties had filed their long-term strategy, and not all strategies commit to net zero by $2050 .{ }^{12}$ Fiji and the Marshall Islands communicated strategies aiming for carbon neutrality by $2050 .^{13}$ These strategies will shape future domestic climate change policies and laws as countries contemplate and plot out the realities of a net-zero, resilient future.

\section{Framework Climate Laws Are Growing and Have Benefits for Propelling Coordinated Action}

Countries across the region are increasingly adopting framework legislation. The Federated States of Micronesia, Indonesia, the Lao People's Democratic Republic (Lao PDR), Pakistan, Papua New Guinea (PNG), the Philippines, Tuvalu, and Vanuatu have passed dedicated climate framework legislation that establishes institutional frameworks. Fiji and Nepal have climate change bills, and Singapore is the only country in the 32 countries studied across Asia and the Pacific with a specific carbon pricing law. Bangladesh has legislatively created a climate change trust fund.

Framework legislation creates a foundation for unified national climate goals, along with long-term approaches to climate governance. ${ }^{14}$ Clear institutional

10 Afghanistan, Bangladesh, Bhutan, Cambodia, the Cook Islands, Fiji, India, Kiribati, Malaysia, Maldives, the Marshall Islands, Myanmar, Nauru, Nepal, Palau, the People's Republic of China (PRC), Samoa, Singapore, Solomon Islands, Sri Lanka, Thailand, Timor-Leste, Tonga, and Viet Nam do not yet have a framework climate change law, but regulate national climate responses with a combination of national policies and plans and updates to existing legislation.

11 Paris Agreement, Paris, 12 December 2015, United Nations Treaty Series, No. 54113. Art. 4(19); and Conference of the Parties to the Paris Agreement. 2016. Decision 1/CP.21. 12 December. Art. 35.

12 Costa Rica, Fiji, the European Union, France, the Marshall Islands, Portugal, and the United Kingdom's long-term strategies commit to net zero by 2050. See UNFCCC. Communication of Long-Term Strategies (accessed 26 November 2020).

13 See also Government of Fiji. 2018. Fiji Low Emission Development Strategy 2018-2050. Suva; and Government of the Marshall Islands. 2018. Tile Til Eo. 2050 Climate Strategy: "Lighting the Way". Majuro.

14 For a discussion regarding the importance of framework legislation, see M. Nachmany and J. Seltzer, footnote 5 . 
frameworks are critical for enabling cohesive climate responses domestically and establishing transparent channels for the flow of green finance. All of these factors are vital for achieving the Paris Agreement goals.

\section{Data and Reporting Requirements Are Influencing Legal Frameworks}

Data will be central to successful climate action. Countries will need data and information about baselines, impacts, successes, and failures, and for reporting within the Paris Agreement's enhanced transparency framework. ${ }^{15}$ For example, climate risk information is particularly pertinent to adaptation planning. It helps countries identify priorities for adaptive capacity and building resilience. ${ }^{16}$

However, data sharing requires clear frameworks and authorities to enable the communication of information between sectors and government ministries. Further, to optimize data inputs and centralized analysis, governments must facilitate data collection, sharing, and reporting under a measurement, reporting, and verification framework. Framework climate legislation can mandate data sharing and reporting responsibilities, making data sharing easier.

\section{Climate Litigation Is Shaping Climate Law Globally}

Citizens will continue using litigation to hold their government accountable for meeting global climate goals, involving judges in climate governance. Judges are the referees of government, reviewing executive decisions and upholding rights. Jurisprudence from common law countries, where courts may create law, has shaped domestic climate governance, both directly and indirectly.

In December 2019, the Supreme Court of the Netherlands expressly ordered the government to reduce carbon emissions by $25 \%-40 \%$ by $2020 . .^{17}$ The court did not consider that its orders requiring specific reduction targets constituted an impermissible foray into the field of political decision-making. It reasoned that the

15 For information about reporting requirements and the Paris Agreement's enhanced transparency framework, see S. Barakat et al. 2017. A Guide to Transparency under the UNFCCC and the Paris Agreement. London: International Institute of Environment and Development.

16 See M. Nachmany, R. Byrnes, and S. Surminski. 2019. Policy Brief-National Laws and Policies on Climate Change Adaptation: A Global Review. London: Grantham Research Institute on Climate Change and the Environment.

17 The State of the Netherlands (Ministry of Economic Affairs and Climate Policy) v Urgenda Foundation, Case No. 19/00135, ECLI:NL:HR:2019:2007, Supreme Court of the Netherlands, 20 December 2019 (unofficial translation from the court). 
limitation on the political domain prevents courts from issuing an order to create legislation with particular or specific content. Beyond that, courts may "issue a declaratory decision to the effect that the omission of legislation is unlawful." 18 Following the Supreme Court's decision, the government announced measures in April 2020 to cut coal use, reduce cattle and pig herds, subsidize garden greening, and reduce pollution. ${ }^{19}$

Courts in Asia have also issued decisions directing governments to implement or prepare appropriate climate responses. Such outcomes have shaped legal and regulatory responses. In Leghari v. Federation of Pakistan, the High Court of Lahore created the Climate Change Commission to ensure the implementation of the country's climate change policy. ${ }^{20}$ In 2019, the Supreme Court of Nepal directed the national government to enact climate legislation and effectively implement its Climate Change Policy of 2011 in Advocate Padam Bahadur Shrestha vs Prime Minister and Office of Council of Ministers and Others. ${ }^{21}$

Like the Urgenda case, Leghari and Shrestha did not include specific directions about content, but they required the government to make good on its policy and treaty commitments and take appropriate action in the face of an existential threat. ${ }^{22}$ In Shrestha, the court reasoned that it was necessary to enact a climate change law to effectively address climate change.

Rights-based lawsuits are growing in popularity. Outside the United States, rights-based actions constitute around $35 \%$ of all litigation against governments. ${ }^{23}$ About $90 \%$ of these cases were filed after $2015 .{ }^{24}$

Within Asia, litigants have frequently built their cases upon constitutional rights, reflecting a few factors. Asian litigants have long used constitutional rights in environmental public interest litigation, a concept termed environmental constitutionalism. ${ }^{25}$ Applying environmental constitutionalism in the climate change context makes sense because many of the issues overlap. National climate

18 Footnote 17, paras. 8.1-8.4. See also J. Fahner. 2018. Climate Change before the Courts: Urgenda Ruling Redraws the Boundary between Law and Politics. EJIL: Talk. 16 November.

19 J. Watts. 2020. Dutch Officials Reveal Measures to Cut Emissions after Court Ruling. The Guardian. 24 April.

20 Leghari v. Federation of Pakistan, PLD 2018 Lahore 364.

21 Advocate Padam Bahadur Shrestha vs Prime Minister and Office of Council of Ministers and Others, Order No. 074-WO-0283, Supreme Court of Nepal, 25 December 2018 (2075/09/10 BS).

22 The recent case of $R$ (Friends of the Earth) $v$ Secretary of State for Transport \& Others [2020] EWCA Civ 214 is another example of courts requiring governments to take policy commitments into account. In this case, the High Court of Justice required the English government to take into account its climate change policy commitments when preparing the airport national policy statement that allowed the construction of a third runway at Heathrow Airport.

23 "The Rights Turn in Climate Litigation," YouTube video, 45:00, from a presentation given by César Rodríguez-Garavito at the World Commission on Environmental Law Webinar 4: Climate Change in the Courts on 5 June 2020.

24 Footnote 23, at 43:47.

25 See J.R. May and E. Daly. 2017. Judicial Handbook on Environmental Constitutionalism. Nairobi: United Nations Environment Programme. 
change commitments contained within policy documents are harder to challenge, given that the political domain has traditionally been off-limits to the courts. Constitutional rights enable petitioners to remove an issue from the political realm and bring an actionable challenge. The decision in Leghari also demonstrates that Asian courts are willing to hold governments accountable for policy commitments, particularly where implementation failures injure a constitutional right.

Jurisprudence can transcend borders, influencing judicial decisions on laws in other jurisdictions. Rights-based cases transfer easily across jurisdictions because they use common language and principles. Claimants and courts have referred to decisions from other Asian courts. ${ }^{26}$ The comparative nature of rights-based cases makes it useful for judges to have access to the laws cited in such decisions - another benefit of this report.

\section{Science Is Evolving Responses to Climate Change}

Technological advances are improving climate science, which is shaping global responses and, consequently, legal frameworks.

During negotiations for the Paris Agreement, small island developing states pushed hard for the inclusion of the $1.5^{\circ} \mathrm{C}$ temperature goal. Given the lack of scientific knowledge about the new target, the parties to the Paris Agreement invited the Intergovernmental Panel on Climate Change (IPCC) to report on global warming of $1.5^{\circ} \mathrm{C}$. It revealed that $1.5^{\circ} \mathrm{C}$ of warming is far safer for many than $2^{\circ} \mathrm{C} .{ }^{27} \mathrm{It}$ is not safe for everyone, though, especially those living in low-lying coastal areas-around 680 million people globally. ${ }^{28}$

The IPCC report shifted global awareness of emissions cuts needed to meet the climate accord's goals. It stressed that countries must affect widespread and urgent measures before 2030 to limit global warming to $1.5^{\circ} \mathrm{C}$ above preindustrial temperatures. Global greenhouse gas emissions must decrease $7.6 \%$ annually during 2020-2030, and countries must reduce carbon dioxide $\left(\mathrm{CO}_{2}\right)$ emissions to net zero by 2050 - the net-zero target. ${ }^{29}$ The director of the Energy and Climate Intelligence Unit recently observed, "Having a net zero target with a date

26 See for example, Maria Khan et al. v. Pakistan et al., Writ Petition No. 8960 of 2019, High Court of Lahore, in which the petitioners cite decisions on the public trust doctrine on climate change from the United States and India; M. Farooque Vs. Government of Bangladesh 17 BLD (AD) 1 (1997), citing Asian decisions on standing; and Advocate Ramchandra Simkhada and Others vs Office of the Prime Minister and Council of Ministers, Government of Nepal and Others, Writ Petition No. 068-WO-0597 (Supreme Court of Nepal, 13 February 2019), citing Lalit Miglani v. State of Uttarakhand, (2017) SCC Online UTT 392, an Indian decision recognizing nature's right to exist.

27 IPCC. 2018. Summary for Policymakers. In V. Masson-Delmotte et al., eds. Global Warming of $1.5^{\circ} \mathrm{C}$. An IPCC Special Report. In press.

28 IPCC. 2019. Summary for Policymakers. In H.-O. Pörtner et al., eds. IPCC Special Report on the Ocean and Cryosphere in a Changing Climate. In press.

29 United Nations. 2019. Report of the Secretary-General on the 2019 Climate Action Summit and the Way Forward in 2020. New York. p. 9. 
before mid-century is probably the best single indicator of whether a nation is serious about delivering what it promised at the Paris summit." 30

The UN Climate Action Summit 2019 declared $1.5^{\circ} \mathrm{C}$ as the "socially, economically, politically and scientifically safe limit to global warming by the end of this century, and net-zero emissions by 2050 as the global long-term climate objective for all." 31 During the summit, 75 countries committed to creating a 2050 net-zero emissions strategy by 2020 . Bhutan and Suriname have declared themselves carbon negative. ${ }^{32}$ Five states have enacted legislation with 2050 net-zero emissions targets: France, New Zealand, Scotland, Sweden, and the United Kingdom (footnote 32). Chile and Fiji have proposed laws with 2050 net-zero goals, while 10 other countries plus Fiji and the Marshall Islands have outlined their intent to achieve carbon neutrality in policies. ${ }^{33}$

\section{Courts Are Integrating Scientific Consensus into National Law}

Courts have also integrated international scientific consensus on climate change into domestic law. Such integration enables them to assess the viability of national commitments against globally accepted scientific benchmarks.

In Urgenda, the court reasoned that the state was obliged to do its part in responding to climate change because it was a signatory to the UNFCCC and European Convention on Human Rights. As such, the state should act consistently with broadly accepted scientific opinion captured within the UNFCCC and the Paris Agreement.

The Supreme Court of Pakistan is currently hearing a rights-based challenge to the government's decision to mine untapped coal reserves. ${ }^{34}$ The petitioner (a minor) asserts that the government should contribute to global efforts to maintain atmospheric $\mathrm{CO}_{2}$ concentrations within a "safe level" -350 parts per million (ppm) atmospheric $\mathrm{CO}_{2}$ by 2100 . Within its broad scope, this lawsuit tests climate science and energy regulatory frameworks.

Report Two, Climate Change, Coming Soon to a Court Near You: Climate Litigation in Asia and the Pacific and Beyond, provides more information regarding climate litigation.

30 Energy \& Climate Intelligence Unit. 2019. One-Sixth of Global Economy under Net Zero Targets. News release. 25 June.

31 Footnote 29, p. 5.

32 S. Fleming. 2019. These Are the Countries That Have Made Their Climate Commitments Law. World Economic Forum. 13 November.

33 Footnote 32. Austria, Costa Rica, Finland, Germany, Iceland, Ireland, Norway, Portugal, Slovenia, and Switzerland have committed to net zero by 2050. See Energy \& Climate Intelligence Unit. Net Zero Tracker: 2020 Scorecard. For information on Fiji's bill, see Government of Fiji, Ministry of Economy. 2019. Climate Change Bill 2019. Suva.

34 Ali v. Federation of Pakistan \& Another, Constitution Petition in the Supreme Court of Pakistan, 2016. 


\section{Adaptation Legal Frameworks Need Strengthening}

Gaps in laws and policies on adaptation persist in Asia and the Pacific, an undesirable state for a climate-vulnerable region. Five of the 10 countries most affected by climate change globally in 2018 were in Asia and the Pacific. ${ }^{35}$ Further, the Natural Hazards Risk Atlas 2015 reported that 56 of the world's 100 most hazard-prone cities are in Bangladesh (10), Japan (11), the People's Republic of China (PRC) (16), and the Philippines (21). ${ }^{36}$

Domestic law and policy frameworks in Asia and the Pacific tend to focus on early warning systems for disasters. However, few laws and policies work to enhance or require the construction of resilient infrastructure, which mitigates the loss of life and property during disasters. Kiribati's Building Act 2006 stands out because it requires construction projects exceeding $\$ 200,000$ to prepare a sustainability report detailing the effects of climate change on the building. ${ }^{37}$ Policies and laws regulating energy infrastructure also lack adaptation components.

These gaps in adaptation law and policy reflect international trends (footnote 16). Globally, legal frameworks still lack incentives for investment in the physical and social infrastructure needed for climate change adaptation (footnote 16).

\section{Environmental Impact Assessments Should Consider Climate Change}

Explicit language requiring proponents to analyze a project's climate ramifications within an environmental impact assessment (EIA) is not widespread in the legal frameworks of Asia and the Pacific. ${ }^{38}$ More often, the obligation to consider climate change is implicit within EIA procedures.

However, EIAs are fertile ground for climate litigation, and courts will probably see more cases arguing that EIAs should consider a project's climate impact. Litigants in Bali, Indonesia used this ground to challenge a coal-fired power station. ${ }^{39}$ The

35 D. Eckstein et al. 2020. Global Climate Risk Index 2020. Bonn: Germanwatch e.V.

36 Verisk Maplecroft. 2015. Which Cities Are Most Exposed to Natural Hazards? Natural Hazards Risk Atlas 2015.

37 Building Act 2006, s. 19(1)(h).

38 The Lao PDR and Myanmar are examples of jurisdictions that specifically require proponents to account for climate change. See the Lao PDR Environmental Protection Law 2013, art. 22 and Government of Myanmar, Ministry of Environmental Conservation and Forestry. 2015. Notification No. 616 of 2015, Environmental Impact Assessment Procedure. Art. 6.2.1(ii).

39 Administrative Court of Denpasar, Decision No. 2/G/LH/2018/PTUN.DPS, Ketut Mangku Wijana et al. v. Governor of Bali et al. (2018). 
case was unsuccessful because the court held that the petitioners did not have standing and that new technology could mitigate the risk of emissions. ${ }^{40}$

Few jurisdictions in Asia and the Pacific explicitly require reverse EIAs. Reverse ElAs oblige proponents to assess the impact of climate change on a project throughout its life and equip governments to limit approvals to climate-resilient ventures. Myanmar requires proponents to identify the effects of climate change on a project. ${ }^{41}$ Viet Nam's strategic environmental assessments require project planning to evaluate and forecast the impact of climate change..$^{42}$

Some private sector entities grasp the importance of climate change assessments. Equator Principles Financial Institutions now require climate change risk assessments in connection with environmental and social assessments. They impose this requirement on projects with adverse environmental impacts or that emit more than 100,000 tonnes of $\mathrm{CO}_{2}$ equivalent annually (in all project locations). ${ }^{43}$ Borrowers must submit to independent monitoring and reporting during the project life. ${ }^{44}$ The Equator Principles are voluntary, with 111 financial institutions in 37 countries adopting them as of 15 November $2020 .{ }^{45}$ Five financial institutions in the PRC and one financial institution each in South Asia and Southeast Asia have adopted the Equator Principles. ${ }^{46}$

\section{Legal Frameworks on Oceans Need Strengthening}

Around $60 \%-70 \%$ of countries discussed marine environments in their first NDCs, with coastal states focusing more on marine factors than landlocked countries. ${ }^{47}$

40 M. Taylor. 2018. Indonesian Court Rejects Bid to Stop Coal Power Plant Expansion. Reuters. 17 August.

41 Government of Myanmar, Ministry of Environmental Conservation and Forestry. 2015. Notification No. 616 of 2015, Environmental Impact Assessment Procedure. Art. 6.2.1(iii).

42 Government of Viet Nam. 2019. Decree No. 40/2019/ND-CP, amending Decree No. 18/2015/ ND-CP. Hanoi.

43 The Equator Principles Association. 2020. The Equator Principles. Principle 2.

44 Footnote 43, Principle 9.

45 The Equator Principles Association. EP Association Members \& Reporting (accessed 15 November 2020).

46 Within the PRC, Bank of Huzhou, Bank of Jiangsu, Chongqing Rural Commercial Bank, Industrial Bank Co., Ltd, and Mian Yang City Commercial Bank have adopted the Equator Principles. IDFC FIRST Bank in India and DBS Bank in Singapore have also adopted the Equator Principles. See footnote 45.

47 N.D. Gallo, D.G. Victor, and L.A. Levin. 2017. Ocean Commitments Under the Paris Agreement. Nature Climate Change. 7 (11). pp. 833-834, Figure 3 and Table 1. The study found that $70 \%$ of 161 NDCs were ocean inclusive. One hundred and eighty-six countries have now filed their first NDCs. If the additional 25 NDCs did not cover marine environments, only around $60 \%$ of first NDCs would include commitments on this topic. 
Of the countries covered by this report, $55 \%$ of the Asian countries and $64 \%$ of the Pacific countries discussed ocean warming in their first NDCs. ${ }^{48}$ Fewer NDCs from countries in Asia and the Pacific covered ocean acidification, ocean deoxygenation, mangroves, coral reefs, or blue carbon. ${ }^{49}$ Seven of the Asian countries (almost 39\%) and three of the Pacific countries (around 22\%) included in this report series made commitments about mangroves, recognizing their value in carbon sequestration and adaptation (footnote 49). Five Pacific countries (36\%) outlined measures for coral reef protection in their NDCs, typically in the adaptation content (footnote 49). National laws, regulations, and protections for coastal inundation, storm surges, ocean acidification, mangroves, and coral reefs should now be strengthened to accomplish these international pledges.

This report limits its research to laws, regulations, policies, and other instruments issued by the national governments. It might be that many governments treat coastal adaptation as a local measure, explaining why legal and policy frameworks on climate change and oceans are less comprehensive than they are in other sectors.

Legal frameworks on oceans might again reflect and influence international legal frameworks. The Paris Agreement mentions oceans once, potentially taking its lead from national preferences and priorities. Recent scientific developments may help countries determine legal and policy options, particularly the 2019 IPCC report, IPCC Special Report on the Ocean and Cryosphere in a Changing Climate. ${ }^{50}$

\section{Technology and Markets Need Responsive Legal and Regulatory Frameworks}

Markets are responding to climate risk, technological advances (some disruptive), changing preferences, and emerging opportunities. Countries will need legal and policy frameworks that enable the shift to new technology. For example, the International Energy Agency reports that current global policies aim to produce over $50 \%$ of new electricity generation by 2040 from wind, solar photovoltaic, hydro, and nuclear power. ${ }^{51}$ Meeting this target requires policymakers and

48 N.D. Gallo, D.G. Victor, and L.A. Levin. 2017. Ocean Commitments Under the Paris Agreement. Nature Climate Change. 7 (11). p. 835, Table 1 states that NDCs from the following countries cover ocean warming: Bangladesh, Cambodia, Fiji, India, Indonesia, Kiribati, Malaysia, Maldives, the Marshall Islands, Myanmar, Nauru, Palau, Papua New Guinea, the People's Republic of China, Singapore, Solomon Islands, Tonga, Tuvalu, and Viet Nam.

49 N.D. Gallo, D.G. Victor, and L.A. Levin. 2017. Ocean Commitments Under the Paris Agreement. Nature Climate Change. 7 (11). p. 835, Table 1.

50 H.-O. Pörtner et al., eds. IPCC. 2019. IPCC Special Report on the Ocean and Cryosphere in a Changing Climate. In press.

51 International Energy Agency. 2019. World Energy Outlook 2019: Executive Summary. Paris. p. 4. 
regulators "to move fast to keep up with the pace of technological change and the rising need for flexible operation of power systems." ${ }^{2}$

This International Energy Agency report does not assess the efficacy of the region's energy frameworks. Asian energy markets are central to the battle against climate change because they consume $41 \%$ of global energy. ${ }^{53}$ By 2040 , Asia will use around $50 \%$ of the world's energy supply and drive $66 \%$ of growth in energy consumption (footnote 53). Coal remains a primary energy source in Asia. In 2000-2020, Asia built $90 \%$ of global coal-fired capacity, with the average age of coal-fired plants being 12 in its low- to middle-income countries (footnote 51).

Energy policies and laws will be integral to enabling lower-emission energy generation and have featured in regional litigation. Citizens in Bali challenged the government's approval of a coal-fired power station (footnote 39). In Pakistan, six women allege that the government has not approved renewable energy projects or created legal frameworks aiding the uptake of renewable energy. These failures, argue the women, mean that the government will not meet its commitments on renewable energy, undermining its international pledge to support emissions reductions. ${ }^{54}$

\section{Carbon Pricing Laws and Policies Remain in the Minority Across the Region}

Laws and policies to promote carbon pricing are uncommon.

India's 2010 Finance Bill created the National Clean Energy Fund, which invests in research and entrepreneurship in clean energy fields. The PRC launched a national carbon market program in 2017, expecting to establish a nationwide carbon emissions trading scheme by the end of 2020. ${ }^{55}$ Thailand and Viet Nam have launched carbon trading schemes. Bhutan, Nepal, Papua New Guinea, Samoa, and Tonga also have policies that support the creation of carbon trading (see Part Five for more information on country legal and policy frameworks). In 2018, Singapore passed the Carbon Pricing Act (No. 23 of 2018), which requires greenhouse gas emitters to report and pay tax on their emissions.

52 Footnote 51, p. 2.

53 N. Butler. 2018. Of the Two Big Shifts in the Energy Market, One Is a Surprise. Financial Times. 26 November.

54 Maria Khan et al. v. Pakistan et al., Writ Petition No. 8960 of 2019, High Court of Lahore.

55 H. Harvey and M. Hu. 2017. The China Carbon Market Just Launched, And It's the World's Largest. Here's How It Can Succeed. Forbes. 19 December; and M. Xu and D. Stanway. 2020. China to Make National Carbon Trading ‘Breakthrough' by Year-End: Official. Reuters. 14 January. 
The general absence of carbon pricing laws is significant. Economists treat climate change as a market failure because $\mathrm{CO}_{2}$ emissions are a side-effect of economic activities. ${ }^{56}$ Free markets have not priced $\mathrm{CO}_{2}$ emissions, hence not reflecting the external costs of climate change (e.g., droughts, floods, and storms). ${ }^{57}$

"Economists recognize that external costs are a form of market failure," and "the most straightforward way to rectify the market failure is to put a price on carbon emissions" (footnote 57). As future generations from low-income countries will pay the worst of these costs, the market has little incentive to shift without policy and legal intervention.

56 Grantham Research Institute and D. Clark. 2012. Why Do Economists Describe Climate Change as a 'Market Failure'? The Guardian. 21 May.

57 Price on Carbon. 2017. Oreskes Nails It. 1 March. 


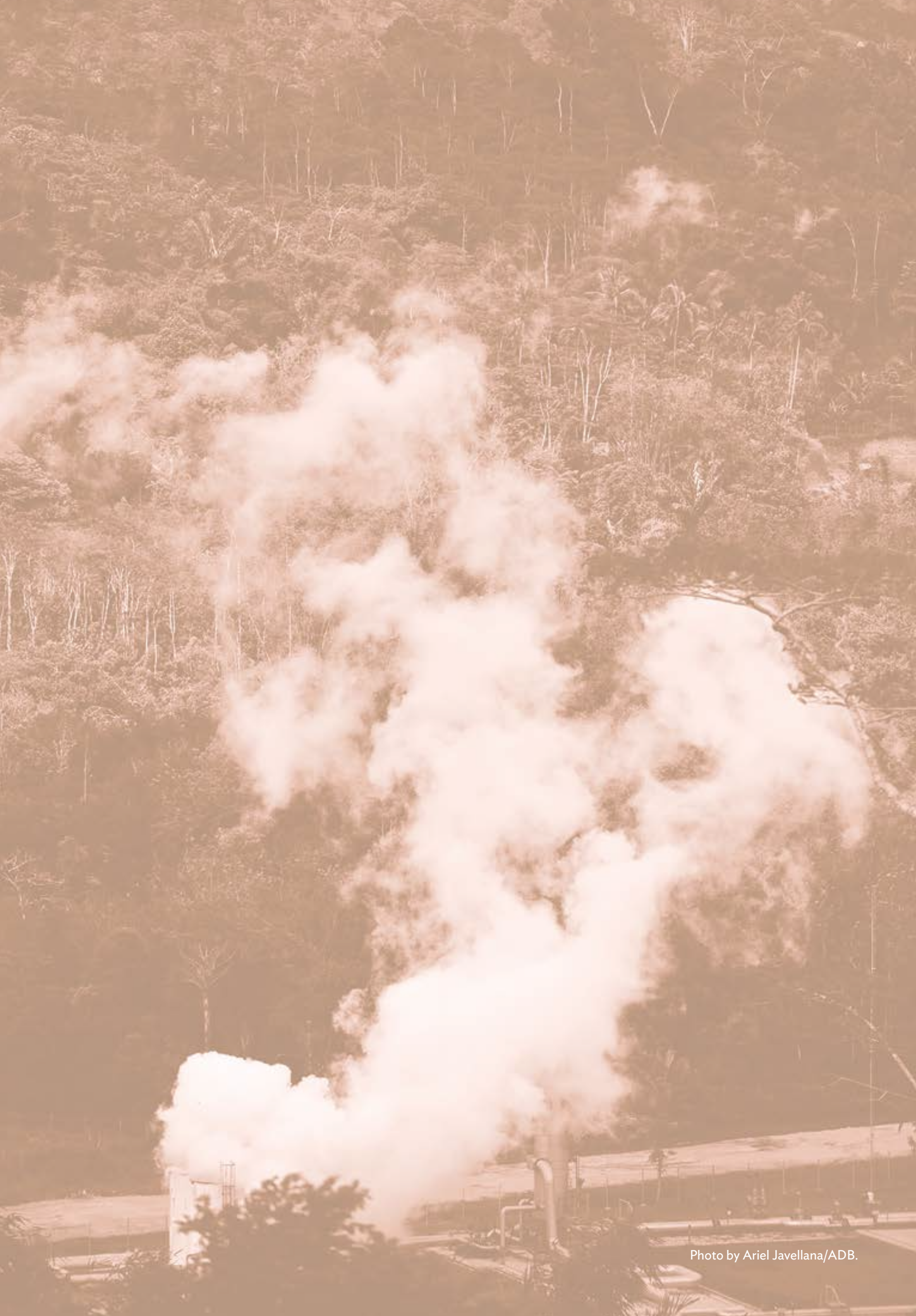




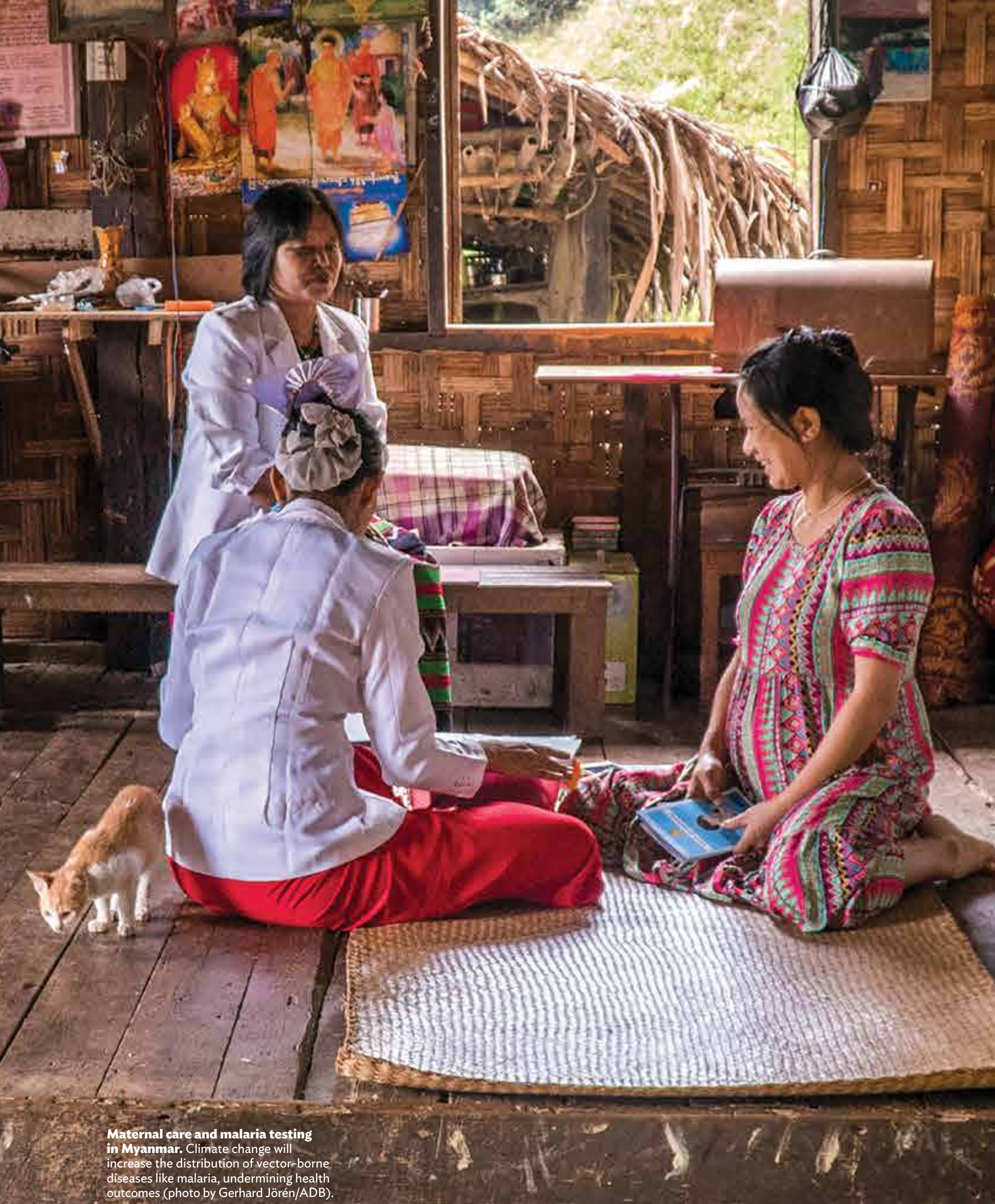




\title{
PART THREE
}

\section{COMPARATIVE CONSTITUTIONAL SURVEY}

\section{Constitutional Rights Litigation in Asia and the Pacific}

\begin{abstract}
itizens are increasingly relying on constitutional rights when suing their governments over climate action. ${ }^{1}$ Rights-based climate litigation constitutes around $35 \%$ of all climate lawsuits outside the United States. ${ }^{2}$ It is growing in Asia, with claimants drawing on their constitutional rights to support their cases. ${ }^{3}$
\end{abstract}

Rights-based lawsuits use fundamental rights expressed in constitutions, international human rights instruments, and universal legal principles. Such cases generally argue that environmental damage and climate change are existential threats undermining the petitioner's fundamental or constitutional rights to life, environment, or equal protection before the law. ${ }^{4}$

Various factors explain why litigants opt for rights-based lawsuits in climate litigation around the world. Modern technology aids access to law, helping litigants recycle successful arguments in receptive jurisdictions. The cases also hinge on human, social, political, and environmental rights, which are enshrined in legal systems globally.

Most of the 32 countries studied in this report series have constitutions that identify and protect fundamental rights. Thirty of the constitutions took effect

See B. Preston. 2018. The Evolving Role of Environmental Rights in Climate Change Litigation. Chinese Journal of Environmental Law. 2 (2). 19 November. pp. 131-164.

2 "The Rights Turn in Climate Litigation," YouTube video, 43:47, from a presentation given by César Rodríguez-Garavito at the World Commission on Environmental Law Webinar 4: Climate Change in the Courts on 5 June 2020.

3 See Report Two in this report series.

4 For regional examples, see Oposa v. Factoran, G.R. No. 101083, 30 July 1993; Leghari v. Federation of Pakistan PLD 2018 Lahore 364; and Advocate Padam Bahadur Shrestha vs Prime Minister and Office of Council of Ministers and Others, Order No. 074-WO-0283, Supreme Court of Nepal, 25 December 2018 (2075/09/10 BS). For global cases, see The State of the Netherlands (Ministry of Economic Affairs and Climate Policy) v Urgenda Foundation, Case No. 19/00135, ECLI:NL:HR:2019:2007, Supreme Court of the Netherlands, 20 December 2019; and Future Generations v. Ministry of the Environment and Others, Corte Suprema de Justicia [C.S.J.] [Supreme Court], Abril 5, 2018, M.P: L. Villabona, Expediente: 11001-22-03-000-2018-00319-01 (Colomb.). 
after the United Nations adopted the Universal Declaration of Human Rights in 1948. ${ }^{5}$ Twenty-five countries promulgated their constitutions after the United Nations adopted the (i) International Covenant on Civil and Political Rights, and (ii) International Covenant on Economic, Social and Cultural Rights in $1966 .{ }^{6}$ Additionally, 19 of these constitutions explicitly contain either a right or a directive principle regarding the environment. ${ }^{7}$

Given the growing preference for rights-based climate lawsuits, it is useful to survey constitutional provisions in South Asia, Southeast Asia, and the Pacific. When courts can access information about constitutional rights, legal arguments, and reasonings applied in complementary jurisdictions, it is easier for judges to discern which climate jurisprudence is comparable.

\section{Constitutional Climate Litigation Is More Common in South Asia}

Using constitutional rights in climate litigation is an extension of environmental constitutionalism, i.e., environmental litigation based on express or implied constitutional rights. ${ }^{8}$ South Asian lawyers and courts have spearheaded environmental constitutionalism in Asia and the Pacific.

Constitutionalizing environmental and climate claims is an efficient way to hurdle procedural challenges, secure relief, and spur governments into action. Constitutional writs in South Asia frequently allow petitioners direct access to superior courts, facilitating faster relief.

Rights-based claims satisfy the standing requirement in many jurisdictions. Historically, environmental and climate change public interest lawsuits struggled to demonstrate that the petitioners had a genuine interest in a case- - common

5 The constitutions of Indonesia (1945) and Tonga (1875) predate the Universal Declaration of Human Rights. See General Assembly Resolution 217 A (III), Universal Declaration of Human Rights, A/RES/217(III) (10 December 1948). The Declaration created the foundation for international human rights law in the 20th century.

6 Except for the following countries that did it before: the Cook Islands (1965), India (1949), Indonesia (1945), Malaysia (1957), Samoa (1960), Singapore (1965), and Tonga (1875). See International Covenant on Civil and Political Rights, New York, 16 December 1966, United Nations Treaty Series, Vol. 999, No. 14668. p. 171; and International Covenant on Economic, Social and Cultural Rights, New York, 16 December 1966, United Nations Treaty Series, Vol. 993, No. 14531. p. 3.

7 The number of Asian and Pacific island states with explicit constitutional provisions increases to 24 if we include non-ADB member countries. See A. Raine and E. Pluchon. 2019.

UN Environment-Advancing the Environmental Rule of Law in the Asia Pacific. Chinese Journal of Environmental Law. 3 (1). pp. 117-126.

8 For a discussion of environmental constitutionalism globally, see J.R. May and E. Daly. 2017. Judicial Handbook on Environmental Constitutionalism. Nairobi: United Nations Environment Programme. 
threshold test for standing. ${ }^{9}$ However, courts in Bangladesh, India, Nepal, Pakistan, and Sri Lanka have relaxed standing to recognize "a form of open standing to vindicate environmental harms on behalf of the public interest." 10 This approach breaks "away from the right-duty pattern of Anglo-Saxon jurisprudence ... broadening the ambit of access to justice by adopting the doctrine of participatory justice with public interest litigation as a prime strategic tool in its hands." 11

In South Asia, only the constitutions of Maldives and Nepal contain an express citizen right to a healthy or clean environment. ${ }^{12}$ Nevertheless, courts in the region have been willing to infer environmental constitutional rights in the absence of express rights. Judicial techniques include (i) drawing inferred rights from within the scope of existing constitutional rights, and (ii) interpreting environmental rights as naturally progressing from constitutional directives on the environment and related state policies (e.g., the public trust doctrine).

For example, in 1995, the Supreme Court of India held that the constitutional rights to life and dignity included the right to a hygienic environment. ${ }^{13}$ The court reasoned that there could be no dignity or quality of life without a clean atmosphere and ecological balance. In addition, the court concluded that a state directive to care for the environment, when combined with the right to life, could amount to an inferred, legally enforceable fundamental environmental right.

The Supreme Court of Sri Lanka also concluded in the Sugathapala Mendis case that a constitutional directive on environmental protection, when combined with the public trust doctrine, obliged the government to protect the environment in furtherance of the people's trust. ${ }^{14}$ Citizens could rightfully seek redress for violations of this obligation because "to hold otherwise would deprive the citizenry from seeking accountability of the institutions to which it has conferred great power and to allow injustice to be left unchecked solely because of technical shortcomings." 15

Courts in Bangladesh, Nepal, Pakistan, and Sri Lanka reached similar conclusions, inferring the right to a clean and healthy environment within the scope of the right to life or equality before the law. ${ }^{16}$ The courts reasoned that environmental

9 In M. Farooque Vs. Government of Bangladesh 17 BLD (AD) 1 (1997). Mustafa Kamal, J. of the Supreme Court of Bangladesh surveyed the various tests for standing for environmental public interest litigation in South Asia.

10 Footnote 8, p. 7.

11 M. Farooque Vs. Government of Bangladesh 17 BLD (AD) 1 (1997). p. 15, para. 35.

12 See Constitution of the Republic of Maldives, 2008, art. 23(d); and Constitution of Nepal, 2015, art. 30.

13 Virender Gaur and Ors. v. State of Haryana and Ors., (1995) 2 SCC 577.

14 Sugathapala Mendis v Chandrika Kumaratunga and Others 20082 Sri LR 339.

15 Footnote 14, p. 17.

16 See M. Farooque Vs. Government of Bangladesh 17 BLD 1 (AD) 1997; Advocate Raju Prasad Chapagain vs Government of Nepal, Ministry of Agriculture and Cooperatives and Others, Nepal Kanoon Patrika (NPK) 2066 (2009), Part 10, Decision No. 8239; Shehla Zia and Others v. WAPDA, PLD 1994 SC 693; and Watte Gedara Wijebanda v Conservator General of Forests 20091 Sri LR 337. 
degradation endangers fundamental rights, like the rights to life; clean environment; and adequate food, water, health, and shelter.

\section{Rights-Based Climate Litigation Is Less Frequent in Southeast Asia and the Pacific}

Indonesia and the Philippines have the largest number of climate lawsuits within Southeast Asia and the Pacific. Otherwise, there are fewer examples of climate and environmental cases across these regions despite the presence of rights to life or a clean environment within various constitutions.

The small number of rights-based climate cases reflects factors that are not unique to climate litigation. The lower litigation rates likely reflect factors such as societal reluctance to take legal action, especially over environmental issues; the dominance of civil law jurisdictions in Southeast Asia; and procedural barriers to suing. ${ }^{17}$ In Southeast Asia, only Indonesia, Malaysia, and the Philippines have relaxed standing requirements in environmental litigation. ${ }^{18}$ Thailand also allows registered environmental nongovernmental organizations to sue for environmental and natural resource protection. ${ }^{19}$

Four of the nine Southeast Asian countries (around 44\%) surveyed have explicit environmental rights or duties under their bill of rights. Indonesians enjoy the right to live in a "good and healthy environment." ${ }^{20}$ Viet Nam's citizens have the right to a clean environment, with a corresponding duty to protect it. ${ }^{21}$ The Constitution of Myanmar obligates citizens to assist the state in environmental conservation. ${ }^{22}$ Thailand's bill of rights grants individuals and communities the right to "manage, maintain and utilize natural resources, environment and biodiversity in a balanced and sustainable manner, in accordance with the procedures as provided by law." 23

17 Cambodia, Indonesia, the Lao People's Democratic Republic (Lao PDR), Thailand, and Viet Nam have civil law systems. The Philippines has a mixed civil and common law system. Malaysia, Myanmar, and Singapore have common law systems.

18 See Oposa v. Factoran, G.R. No. 101083, 30 July 1993; Supreme Court of the Philippines. 2010. A.M. No. 09-6-8-SC, Rules of Procedure for Environmental Cases. Manila; and District Court of Central Jakarta, Decision No. 820/Pdt./G/1988/PN, PT Inti Indorayon Utama (PT IIU) (1988). In Malaysian Trade Union Congress \& Ors v Menteri Tenaga, Air Dan Komunikasi \& Anor [2014] 2 CLJ 525 , the Federal Court of Malaysia relaxed standing requirements for judicial review applications.

19 Enhancement and Conservation of National Environmental Quality Act, 1992 (BE 2535), secs. 7-8; and Central Administrative Court No. 754/2556, Stop Global Warming Association and Others v. Department of Highways (1st Defendant) and Ministry of Transport (2nd Defendant).

20 The 1945 Constitution of the Republic of Indonesia, art. 28H(1).

21 Constitution of the Socialist Republic of Viet Nam, 2013, art. 43.

22 Constitution of the Republic of the Union of Myanmar, 2008, sec. 390

23 Constitution of the Kingdom of Thailand, 2017, sec. 43. 
The placement of these provisions in the bill of rights, alongside other constitutional rights, suggests that they are judicially enforceable, even without implementing legislation. Therefore, constitutionalized climate and environmental cases can directly anchor their causes of action on these provisions and, if warranted, secure relief.

Cambodia's and the Lao PDR's constitutions also articulate duties to protect the environment. In Cambodia, the state is duty-bound to protect the environment and balance natural resources, an obligation in the chapter on the economy. ${ }^{24}$ In the Lao PDR, people and organizations must protect the environment, biodiversity, and natural resources. The state must ensure that socioeconomic development is sustainable by supporting "the protection, restoration, and development of natural resources." 25

As these provisions do not fall under the bill of rights, they are not immediately self-executing. "Policy directives are intended to influence governmental decision-making but are generally not judicially enforceable." 26 Still, they are useful aids to adjudication in a case interpreting related legislation or related constitutional provisions. The Virender Gaur case from India and the Sugathapala Mendis case from Sri Lanka exemplify this judicial technique.

The Philippines has a constitutional right to a clean environment stemming from the basic right to self-preservation and self-perpetuation. ${ }^{27}$

There are no instances of rights-based climate lawsuits in the Pacific.

Only Fiji and Timor-Leste-roughly $14 \%$ of the surveyed Pacific countriesrecognize an explicit right to environment in their bill of rights. ${ }^{28}$ Palau's and Papua New Guinea's constitutions contain directive principles regarding the conservation of the environment. ${ }^{29}$ In particular, Papua New Guinea's constitution expressly references both intergenerational and intragenerational equity and responsibility. Vanuatu's constitution imposes a fundamental duty on each citizen "to safeguard the national wealth, resources and environment in the interests of the present generation and of future generations." ${ }^{30}$ However, this duty is nonjusticiable. ${ }^{31}$

24 The Constitution of the Kingdom of Cambodia, 1993, art. 59.

25 The Constitution of the Lao People's Democratic Republic, 2015, art. 19, which is found within the "Socio-economic Regime" chapter.

26 J. May and E. Daly. 2019. Global Judicial Handbook on Environmental Constitutionalism. 3rd ed. Nairobi: United Nations Environment Programme. p. 24.

27 See Oposa v. Factoran, G.R. No. 101083, 30 July 1993. The Philippine constitution directs the state to ensure a clean and healthful ecology. However, that direction sits within the Declaration of Principles and State Policies and not within the bill of citizens' rights.

28 The Constitution of the Republic of Fiji, 2013, sec. 40; and The Constitution of the Democratic Republic of Timor-Leste, 2002, sec. 61.

29 The Constitution of the Republic of Palau, 1980, art. VI; and The Constitution of the Independent State of Papua New Guinea, 1975. Preamble.

30 The Constitution of the Republic of Vanuatu, 1979, art. 7.

31 Footnote 30, art. 8. 
While the right to a balanced and healthful ecology is to be found under the Declaration of Principles and State Policies and not under the Bill of Rights, it does not follow that it is less important than any of the civil and political rights enumerated in the latter. Such a right belongs to a different category of rights altogether for it concerns nothing less than self-preservation and self-perpetuation-aptly and fittingly stressed by the petitioners-the advancement of which may even be said to predate all governments and constitutions. As a matter of fact, these basic rights need not even be written in the Constitution for they are assumed to exist from the inception of humankind. If they are now explicitly mentioned in the fundamental charter, it is because of the well-founded fear of its framers that unless the rights to a balanced and healthful ecology and to health are mandated as state policies by the Constitution itself, thereby highlighting their continuing importance and imposing upon the state a solemn obligation to preserve the first and protect and advance the second, the day would not be too far when all else would be lost not only for the present generation, but also for those to comegenerations which stand to inherit nothing but parched earth incapable of sustaining life.

Source: Oposa v. Factoran, G.R. No. 101083, per Davide J.

Impediments to standing for public interest litigation, resources (financial and skilled environmental lawyers), and dispute resolution preferences more likely explain why there are fewer rights-based climate cases in the Pacific. Melanesians, Micronesians, and Polynesians have demonstrated a preference for suing parties outside the Pacific, potentially reflecting local perceptions about who should pay for or resolve climate change and who has the resources to do so. ${ }^{32}$

32 See Judgment of 8 May 2019, Carvalho and Others v Parliament and the Council, T-330/18, not published, EU:T:2019:324, litigation in the European Union in which one petitioner was Fijian, and Teitiota $v$ Chief Executive of the Ministry of Business, Innovation and Employment [2014] NZCA 173, in which an i-Kiribati sought refugee status in New Zealand. 


\section{Rights-Based Litigation Applies Universal Principles, Making It Readily Transferable}

Rights-based litigation translates easily across different jurisdictions because it relies on universal rights and principles. Courts acknowledge the universality of rights-based jurisprudence when they cite cases from comparative jurisdictions. ${ }^{33}$

The success of rights-based lawsuits globally means that savvy petitioners may adopt this trend in Southeast Asia and the Pacific. In such cases, judges in Southeast Asia and the Pacific may find it useful to explore the sizeable number of lawsuits on this topic in South Asia. (See Report Two, Climate Change, Coming Soon to a Court Near You: Climate Litigation in Asia and the Pacific and Beyond for a further discussion regarding rights-based climate litigation in Asia and the Pacific.)

\section{Using Tables 3.1-3.3}

This report maps out constitutional provisions to aid judges and decisionmakers in determining which countries have equivalent constitutional rights and potentially comparative constitutional jurisprudence.

Tables 3.1-3.3 highlight explicit and inferred environmental and related rights, obligations, and state directives in the constitutions of South Asia, Southeast Asia (plus the People's Republic of China), and the Pacific. ${ }^{34}$ The tables also make it easier to discern the environmental and climate dimensions of national constitutions.

Furthermore, given the trend toward environmental constitutionalism in the climate change context, understanding the available constitutional rights might hint at trends in future climate lawsuits. These tables complement Report Two of this series, which extensively discusses climate change litigation and dedicates a section to the link between constitutional rights and climate litigation.

33 See M. Farooque Vs. Government of Bangladesh 17 BLD (AD) 1 (1997) (disputing flood plans); BELA Vs. Bangladesh, WP No. 57 of 2010, D-/01-02-2012 (seeking to protect mangroves against shrimp cultivation in Cox's Bazar); Shehla Zia and Others v. WAPDA, PLD 1994 SC 693 (considering various international interpretations of the constitutional right to life); and Watte Gedara Wijebanda v Conservator General of Forests 20091 Sri LR 337 (in finding that the right to a clean environment and the principle of intergenerational equity were intrinsic to the right to equality before the law in Sri Lanka, the court considered jurisprudence from India and the International Court of Justice).

34 In some countries, an environmental or related right may not be enshrined in the constitution but covered by legislation (e.g., Bangladesh's Right to Information Act, 2009). Tables 3.1-3.3 do not cover statutory rights. 
Table 3.1: Constitutional Rights, Obligations, and State Directives in South Asia

\begin{tabular}{|c|c|c|c|c|c|c|}
\hline Country & Life & Environment & Food & Water & Health & Housing \\
\hline Afghanistan & $\checkmark$ 回 $^{\mathrm{b}}$ & 回 & - & - & 回 & 回 \\
\hline Bangladesh & $\checkmark$ 回 & 回 d & 回 & $\mathrm{e}$ & 回 & 回 \\
\hline Bhutan & $\checkmark$ 回 $\triangle^{b}$ & 回 $\Delta^{g}$ & - & - & 回 & - \\
\hline India & $\checkmark$ 回 $^{\mathrm{b}}$ & $\Delta^{h}$ & 回 i & j & 回 k & 1 \\
\hline Maldives & $\checkmark$ & $\checkmark$ 回 & $\checkmark$ & $\checkmark$ & $\checkmark$ & $\checkmark$ \\
\hline Nepal & $\checkmark$ & $\checkmark$ 回 & $\checkmark$ 回 & $\checkmark$ & $\checkmark$ 回 & $\checkmark$ 回 \\
\hline Pakistan & $\checkmark$ 回 $^{b}$ & $r$ & 回 & 5 & 回 t & 回 \\
\hline Sri Lanka & 回 b,v & 回 $\Delta^{w}$ & 回 & - & $x$ & 回 \\
\hline
\end{tabular}

Legend: $\checkmark$ indicates there is an express constitutional right that (i) is found under the bill of rights, and (ii) may not need implementing legislation.

回 indicates there is an express directive principle or state policy.

indicates there has been a court decision inferring the right.

$\triangle$ indicates there is an express citizen obligation that the constitution characterizes as fundamental.

Notes: 1. The entries in this table are based on available information as of 31 August 2020.

2. Art. 7 of the Constitution of the Islamic Republic of Afghanistan declares that the state shall observe the Universal Declaration of Human Rights.

3. Art. 68 of the Constitution of the Republic of Maldives requires courts and tribunals interpreting and applying the rights and freedoms under the bill of rights to "consider international treaties to which the Maldives is a party."

a The right to public participation is broadly construed to include political freedoms (e.g., suffrage, freedom of expression, freedom of association, freedom to form political parties, freedom to form unions).

b The constitution has directive principles on the quality of life and/or standard of living.

c The constitution does not explicitly mention sustainable development but requires the state to foster a society based on "social justice, preservation of human dignity, protection of human rights, realization of democracy, attainment of national unity as well as equality between all peoples and tribes and balance development of all areas of the country" - see art. 6.

d See M. Farooque Vs. Government of Bangladesh 17 BLD (AD) 1 (1997).

e See Rabia Bhuiyan MPv. Ministry of Local Government and Rural Development, et al., 59 DLR (AD) (2007)-the government's noncompliance with its statutory duties to provide access to safe and potable water violated the constitutional right to life. Article 15 also directs the state to provide for the people's necessities.

f See Metro Makers and Developers Ltd Vs. BELA 201265 DLR (AD) 181.

$g$ Bhutan is the only Asian country whose constitution requires the government to maintain at least $60 \%$ forest cover over the kingdom to conserve its natural resources and prevent ecosystem degradation-see art. 5(3). Although the state's obligation to protect the environment does not sit within the citizens' bill of rights, it is one of the main pillars of Bhutan's constitution. See L.S. Tobgye. Undated. The Constitution of Bhutan: Principles and Philosophies. Thimpu: Supreme Court of Bhutan.

h See Bandhua Mukti Morcha v. Union of India, (1984) 3 SCC 161; and Virender Gaur and Ors. v. State of Haryana and Ors., (1995) 2 SCC 577-the constitutional rights to life and dignity include the right to a hygienic environment, including the right to pollution-free air and water.

See People's Union for Civil Liberties v. Union of India \& Ors., Civil Writ Petition No. 196 of 2001 (Supreme Court, 20 August 2001) -the right to life under article 21 includes a right to food. Article 47 of the constitution also directs the state to improve national nutrition, living standards, and public health.

; See Narmada Bachao Andolan v. Union of India, (2000) 10 SCC 664; and AP Pollution Control Board II v. Prof. MV Nayudu, (2001) 2 SCC 62-clean drinking water is an inseparable part of the right to a clean environment and the right to life.

k See Bandhua Mukti Morcha v. Union of India, (1984) 3 SCC 161-the right to live with human dignity under article 21 includes the protection of health. 


\begin{tabular}{|c|c|c|c|c|c|c|}
\hline $\begin{array}{l}\text { Cultural } \\
\text { Identity }\end{array}$ & Property & Biodiversity & $\begin{array}{c}\text { Public } \\
\text { Participation }^{a}\end{array}$ & Information & $\begin{array}{l}\text { Sustainable } \\
\text { Development }\end{array}$ & Country \\
\hline 回 & $\checkmark$ & - & $\checkmark$ & $\checkmark$ & 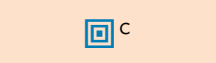 & Afghanistan \\
\hline 回 $\triangle$ & $\checkmark$ & 回 & $\checkmark$ & - & $f$ & Bangladesh \\
\hline 回 $\triangle$ & $\checkmark$ & 回 & $\checkmark$ & $\checkmark$ & 回 & Bhutan \\
\hline$\checkmark \triangle$ & $\checkmark \triangle^{m}$ & n & $\checkmark$ & $* 0$ & 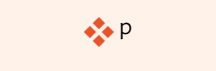 & India \\
\hline$\checkmark \triangle$ & $\checkmark$ & 回 & $\checkmark$ & $\checkmark$ 回 & 回 & Maldives \\
\hline$\checkmark$ 回 & $\checkmark$ 回 $\triangle^{q}$ & 回 & $\checkmark$ & $\checkmark$ & 回 & Nepal \\
\hline$\checkmark$ 回 & $\checkmark$ & - & - & $\checkmark$ & u & Pakistan \\
\hline$\checkmark$ 回 & $\Delta^{y}$ & $\Delta^{z}$ & $\checkmark$ & $\checkmark$ & 回 z & Sri Lanka \\
\hline
\end{tabular}

See Olga Tellis v. Bombay Municipal Corporation, (1985) 3 SCC 545; Shantistar Builders v. Narayan K Totame, (1990) 1 SCC 520 ; and Chameli Singh v. State of UP, (1996) 2 SCC 549. Contrast Narmada Bachao Andolan v. Union of India, (2000) 10 SCC 664, which allowed the resettlement of tribal peoples to construct the Sardar Sarovar Project dam.

m Citizens' obligation to safeguard property is limited to public property-see art. 51A(i).

n Virender Gaur and Ors. v. State of Haryana and Ors., (1995) 2 SCC 577-the State and citizens have a duty to forge an ecological balance and hygienic environment. Article 21 protects the right to life as a fundamental right, encompassing the protection and preservation of environment and ecological balance. "Promoting environmental protection implies maintenance of the environment as a whole comprising the man-made and the natural environment" (p. 581).

- See SP Gupta v. Union of India, AIR 1982 SC 149. The Government of India has since enacted the Right to Information Act, 2005, which grants citizens the right to information under any public authority's control.

p See Vellore Citizen Welfare Forum v. Union of India, AIR 1996 SC 2715; and T.N. Godavaraman Thirumulpad v. Union of India, (2008) 2 SCC 222.

a Citizens' obligation to protect and preserve property is limited to public property-see art. 48(d).

r See Shehla Zia and Others v. WAPDA, PLD 1994 SC 693-the right to life includes a right to environment; and Leghari v. Federation of Pakistan, PLD 2018 Lahore 364-the jurisprudence of Pakistan incorporates environmental justice.

s See General Secretary, West Pakistan Salt Miners Labour Union v. The Director, Industries and Mineral Development, Punjab, 1994 SCMR 2016; and Sindh Institute of Urology and Transplantation v. Nestlé Milkpak Limited, 2005 CLC 424 (Karachi).

t See Messrs Getz Pharma (Pvt) Ltd. through Authorised Person v. Federation of Pakistan, PLD 2017 Sindh 157-article 38(d) of the constitution directs the government to provide necessities of life, such as medical relief.

u See Imrana Tiwana v. Province of Punjab, 2015 CLD 983-Environmental justice blends constitutional principles with the fundamental rights to life, liberty, and human dignity, "which include the international environmental principles of sustainable development, precautionary principle, environmental impact assessment, inter- and intra-generational equity and public trust doctrine" (see p. 37).

$\checkmark$ See Sriyani Silva v Iddamalgoda, Officer-in-Charge, Police Station Paiyagala and Others 20032 Sri LR 6- "Article 11 (read with Article 13(4)), recognises a right not to deprive life whether by way of punishment or otherwise and by necessary implication, recognises a right to life" (p. 77); and Rathnayake Tharanga Lakmali v Niroshan Abeykoon, SC/FR Application No. 577 of 2010 (Supreme Court of Sri Lanka, 17 December 2019) - "The Fundamental Rights Chapter in our Constitution does not expressly refer to a right to life. However, the Constitution, as a living document, should not be construed in a narrow and pedantic sense. I am of the view that constitutional interpretation should be informed by the values embodied in it. The preamble/svasti of the Constitution recognises Dignity and Well-being of the People as a fundamental value that should be furthered by assuring to all People FREEDOM, EQUALITY, JUSTICE, FUNDAMENTAL HUMAN RIGHTS and the INDEPENDENCE OF THE JUDICIARY. In my view, recognition of a right to life is in furtherance of this fundamental value" (p. 13).

w See Watte Gedara Wijebandara v Conservator General of Forests 20091 Sri LR 337; Bulankulama v Secretary, Ministry of Industrial Development 20003 Sri LR 243; and Sugathapala Mendis v Chandrika Kumaratunga and Others 20082 Sri LR 339-the 


\section{NATIONAL CLIMATE CHANGE LEGAL FRAMEWORKS IN ASIA AND THE PACIFIC}

constitutional directive to protect the environment and the public trust doctrine oblige the state to act in furtherance of the trust of the people.

* See Sanjeewa, Attorney-at-Law (on behalf of Gerald Mervin Perera) v Suraweera, Officer-in-Charge, Police Station and Others, SC No. 328 of 2002 (FR), (Supreme Court of Sri Lanka, 27 February 2003)-citizens have the right to choose state or private medical care. The court also recognized everyone's right to enjoy the highest attainable standard of physical and mental health.

y Citizens' obligation to preserve and protect property is limited to public property-see art. 28(d).

z Sri Lanka's constitution does not explicitly mention biodiversity or sustainable development. However, citizens have a constitutional duty to protect nature and conserve its riches: art. 27(f). The state must also establish a just and equitable economic and social order: art. 27(15). In Watte Gedara Wijebandara v Conservator General of Forests 20091 Sri LR 337, the court held that all policy decisions covering the nation's environment and resources must align with the state's obligations under public trust doctrine and seek long-term conservation consistent with the principle of intergenerational equity. "The principle of intergenerational equity and the long-term sustainability of our delicate eco-system and biological diversity vests mainly in the hands of such officials" (p. 362).

Sources:

The Constitution of the Islamic Republic of Afghanistan, 2004;

The Constitution of the People's Republic of Bangladesh, 1972;

The Constitution of the Kingdom of Bhutan, 2008;

The Constitution of India, 1949;

The Constitution of the Republic of Maldives, 2008;

The Constitution of Nepal, 2015;

The Constitution of the Islamic Republic of Pakistan, 1973 and Constitution (Twenty-sixth Amendment) Act, 2019; and

The Constitution of the Democratic Socialist Republic of Sri Lanka, 1978 and Twentieth Amendment to the Constitution, 2020. 


\section{Table 3.2: Constitutional Rights, Obligations, and State Directives in Southeast Asia and the People's Republic of China}

\begin{tabular}{|c|c|c|c|c|c|c|}
\hline Country & Life & Environment & Food & Water & Health & Housing \\
\hline Cambodia & $\checkmark$ 回 $^{\mathrm{b}}$ & 回 & - & - & 回 ${ }^{c}$ & - \\
\hline Indonesia & $\sqrt{ }$ 回 $^{\mathrm{b}}$ & $\checkmark$ & - & $* e$ & $\checkmark$ & $\checkmark^{f}$ \\
\hline Lao PDR & $\checkmark$ 回 $^{b}$ & 回 & - & - & 回 & - \\
\hline Malaysia & $\checkmark$ & $+i$ & - & - & - & - \\
\hline Myanmar & $\sqrt{ }$ 回 $^{\mathrm{b}}$ & 回 $\triangle$ & $O^{k}$ & - & $\checkmark$ 回 & $0^{k}$ \\
\hline PRC & 回 $^{b}$ & 回 & - & - & $\checkmark$ 回 & - \\
\hline Philippines & $\checkmark$ 回 $^{\mathrm{b}}$ & $\checkmark^{\mathrm{p}}$ & q & - & 回 & 回 \\
\hline Singapore & $\checkmark^{\mathrm{u}}$ & - & - & - & - & - \\
\hline Thailand & $\checkmark$ 回 $^{\mathrm{b}}$ & $\checkmark$ 回 $\triangle$ & - & 回 & $\checkmark$ 回 $^{\mathrm{w}}$ & 回 \\
\hline Viet Nam & $\sqrt{ }$ 回 $^{\mathrm{b}}$ & $\checkmark$ 回 $\triangle x$ & - & - & $\checkmark$ 回 & 回 \\
\hline
\end{tabular}

Lao PDR = Lao People's Democratic Republic, PRC = People's Republic of China.

Legend: $\checkmark$ indicates there is an express constitutional right that (i) is found under the bill of rights, and (ii) may not need implementing legislation.

回 indicates there is an express directive principle or state policy.

* indicates there has been a court decision inferring the right.

- indicates that the right or directive applies only to a certain class or subset of the population.

$\triangle$ indicates there is an express citizen obligation that the constitution characterizes as fundamental.

Notes: 1. The entries in this table are based on available information as of 31 August 2020.

2. Art. 31 under the bill of rights (Chapter III: The Rights and Obligations of Khmer Citizens) of the Constitution of the Kingdom of Cambodia declares that the state "recognizes and respects human rights as enshrined in the United Nations Charter, the Universal Declaration of Human Rights and all the treaties and conventions related to human rights, women's rights and children's rights."

3. Art. 28J(1) of the Constitution of the Republic of Indonesia states that each person has the "duty to respect the human rights of others." Sec. 50(6) of the Constitution of the Kingdom of Thailand articulates the duty of every person to "respect and not to violate the rights and liberties of other people." Art. 15 of the Constitution of the Socialist Republic of Viet Nam characterizes the citizen duty to respect the rights of others as "inseparable" from citizens' rights. These provisions may open the door to horizontal application of constitutional rights.

4. The Constitution of the People's Republic of China is not justiciable. See F. Hualing and Z. Xiaobo. 2018. What Makes the Chinese Constitution Socialist? International Journal of Constitutional Law. 16 (2). p. 56.

a The right to public participation is broadly construed to include political freedoms (e.g., suffrage, freedom of expression, freedom of association, freedom to form political parties, freedom to form unions).

b The constitution has directive principles on the quality of life and/or standard of living.

c Children have a right to health-couched as a state duty to protect-under art. 48 of the constitution's bill of rights (Chapter III: The Rights and Obligations of Khmer Citizens). Art. 72 under Chapter VI (Education, Culture and Social Affairs) is a general directive principle "guarantee[ing]" the health of the people.

d The bill of rights protects the fundamental right to property. But art. 60 (under Chapter V: Economy) allows the state to temporarily use private property as authorized by law under special circumstances. Furthermore, the citizens' obligation to respect property is limited to public property and legally acquired private property-see art. 50.

e See Decision 85/PUU-XI/2013 (18 February 2015) of the Constitutional Court of Indonesia, which held that access to water is a basic, fundamental human right that the state has the responsibility to fulfill.

f Art. $28 \mathrm{H}$ (under the bill of rights, Chapter XA: Human Rights) states that every person shall have the right to have a home. However, the constitution is silent on the other elements of the right to housing, e.g., protection against forced evictions and arbitrary demolition of one's home. 


\begin{tabular}{|c|c|c|c|c|c|c|}
\hline $\begin{array}{l}\text { Cultural } \\
\text { Identity }\end{array}$ & Property & Biodiversity & $\begin{array}{c}\text { Public } \\
\text { Participation }^{\mathrm{a}}\end{array}$ & Information & $\begin{array}{c}\text { Sustainable } \\
\text { Development }\end{array}$ & Country \\
\hline 回 & $\checkmark$ 回 $\triangle^{d}$ & - & $\checkmark$ & 回 & - & Cambodia \\
\hline 回○g & $\checkmark$ & - & $\checkmark$ & $\mathrm{h}$ & - & Indonesia \\
\hline 回 & 回 & - & $\checkmark$ & 回 & 回 & Lao PDR \\
\hline$\rho^{j}$ & $\checkmark$ & - & $\checkmark$ & - & - & Malaysia \\
\hline$\checkmark$ 回 $\triangle$ & $\checkmark$ 回 $\triangle^{\prime}$ & - & $\checkmark$ & - & - & Myanmar \\
\hline$\checkmark$ 回 & 回 $\Delta^{m}$ & 回 $^{n}$ & $\checkmark$ & - & 回。 & PRC \\
\hline 回 $^{r}$ & $\checkmark$ 回 & - & $\checkmark$ 回 $^{s}$ & $\checkmark$ 回 & 回 ${ }^{\mathrm{t}}$ & Philippines \\
\hline 回 & ov & - & $\checkmark$ & - & - & Singapore \\
\hline$\checkmark$ 回 $\triangle$ & $\checkmark$ & $\checkmark$ 回 $\triangle$ & $\checkmark$ 回 & $\checkmark$ 回 & $\checkmark$ 回 & Thailand \\
\hline$\checkmark$ 回 & $\checkmark$ 回 & 回 & $\checkmark$ & h & 回y & Viet Nam \\
\hline
\end{tabular}

g Art. 28I(3) under the bill of rights defines the right to cultural identity of traditional communities. A broader state directive to advance the national culture of Indonesia is found under Chapter XIII: Education.

h Art. 28F of the Constitution of the Republic of Indonesia articulates the right "to obtain information for [self] development." Similarly, Art. 25 of the Constitution of the Socialist Republic of Viet Nam states that citizens shall enjoy the right to access information. However, in both cases, there is no constitutional provision that specifically guarantees the right to access information held by public bodies. See Tan Tek Seng v Suruhanjaya Perkhidmatan Pendidikan \& Anor. [1996] 1 MLJ 261_"the expression 'life' appearing in art. 5(1) does not refer to mere existence. It incorporates all those facets that are an integral part of life itself and those matters which go to form the quality of life.... It includes the right to live in a reasonably healthy and pollution free environment" (p. 288).

i Part XIIA of the Constitution of Malaysia provides additional protections specifically for the states of Sabah and Sarawak. These protections include the use of native languages, the reservation of land for "natives" of Sabah and Sarawak, and preferential treatment regarding the alienation of land. List 2A of the Constitution's Ninth Schedule also deals with native law and custom in these two states.

k Sec. 26(b) (under Chapter I: Basic Principles of the Union) indicates that the state shall enact the necessary laws for civil servants to have security and sufficiency of food, clothing, and shelter. There is no corresponding provision for the general population.

' Citizens' obligation to protect and preserve property is limited to public property-see sec. 390.

m Citizens' obligation to protect property is limited to public property-see art. 53.

" See art. 9 (under Chapter I: General Principles); and the Preamble, which references "ecological civilizations."

- The term "sustainable development" does not appear in the constitution. However, there are discrete directive provisions that promote economic development (e.g., art. 14 under Chapter I: General Principles) and environmental objectives (e.g., the Preamble; and arts. 9, 10, and 26 under Chapter I: General Principles).

p Oposa v. Factoran, G.R. No. 101083, 30 July 1993 - the right to a balanced and healthful ecology stated under sec. 16, art. II (Declaration of Principles and State Policies) is a self-executory natural right.

a Children have a "right to proper care and nutrition." However, this right is found under sec. 3 of art. XV (The Family), not the bill of rights (art. III). This provision does not extend to other citizens.

r See sec. 14 (under art. XIV: Education, Science and Technology, Arts, Culture and Sports) on the "Filipino national culture." Other provisions protect the rights of indigenous cultural communities to preserve and develop their cultures, traditions, and institutions.

$s$ Broad participation rights (e.g., freedom of expression and freedom of association, including the right to form unions) are found in the bill of rights (art. III). See also sec. 16, art. XIII. The constitution further states directive principles on the participation rights of (i) workers, farmers, and landowners (secs. 3 and 5, art. XIII [Social Justice and Human Rights]); and (ii) families and family associations (sec. 3, art. XV [The Family]).

t The term "sustainable development" does not appear in the constitution. However, it has directive principles that, taken together, reflect the substance of sustainable development-e.g., sec. 16 (under art. II: Declaration of Principles) and sec. 1 (under art. XII: National Economy and Patrimony). 
u Yong Vui Kong v Public Prosecutor [2010] SGCA 20-art. 9(1) protects the right to life. However, the court declared that it was "not possible" to interpret art. 9(1) of the Constitution of the Republic of Singapore in the expansive way that the Supreme Court of India interpreted art. 21 of the Constitution of the Republic of India.

$\checkmark$ Art. 15 (under Part II: Fundamental Liberties) of the constitution states that religious groups have the right to acquire and own property, and hold and administer it in accordance with law. There is no express reference to a similar right to property for individuals or citizens.

w See sec. 58 (under Chapter V: Duties of the State) on health impact assessments.

* Art. 63 explicitly references the state policy to "respond to climate change."

y The term "sustainable development" does not appear in the constitution. However, it has directive principles that, taken together, reflect the substance of sustainable development-e.g., arts. 50 and 63 (under Chapter III: Economy, Society, Culture, Education, Science, Technology, and Environment).

Sources:

The Constitution of the Kingdom of Cambodia, 1993;

The Constitution of the Republic of Indonesia, 1945;

The Constitution of the Lao People's Democratic Republic, 2015;

The Constitution of Malaysia, 1963 and Constitution (Amendment) Act, 2019;

The Constitution of the Republic of the Union of Myanmar, 2008;

The Constitution of the Republic of Singapore, 1965;

The Constitution of the People's Republic of China, 1982;

The Constitution of the Republic of the Philippines, 1987;

The Constitution of the Kingdom of Thailand, 2017; and

The Constitution of the Socialist Republic of Viet Nam, 2013. 


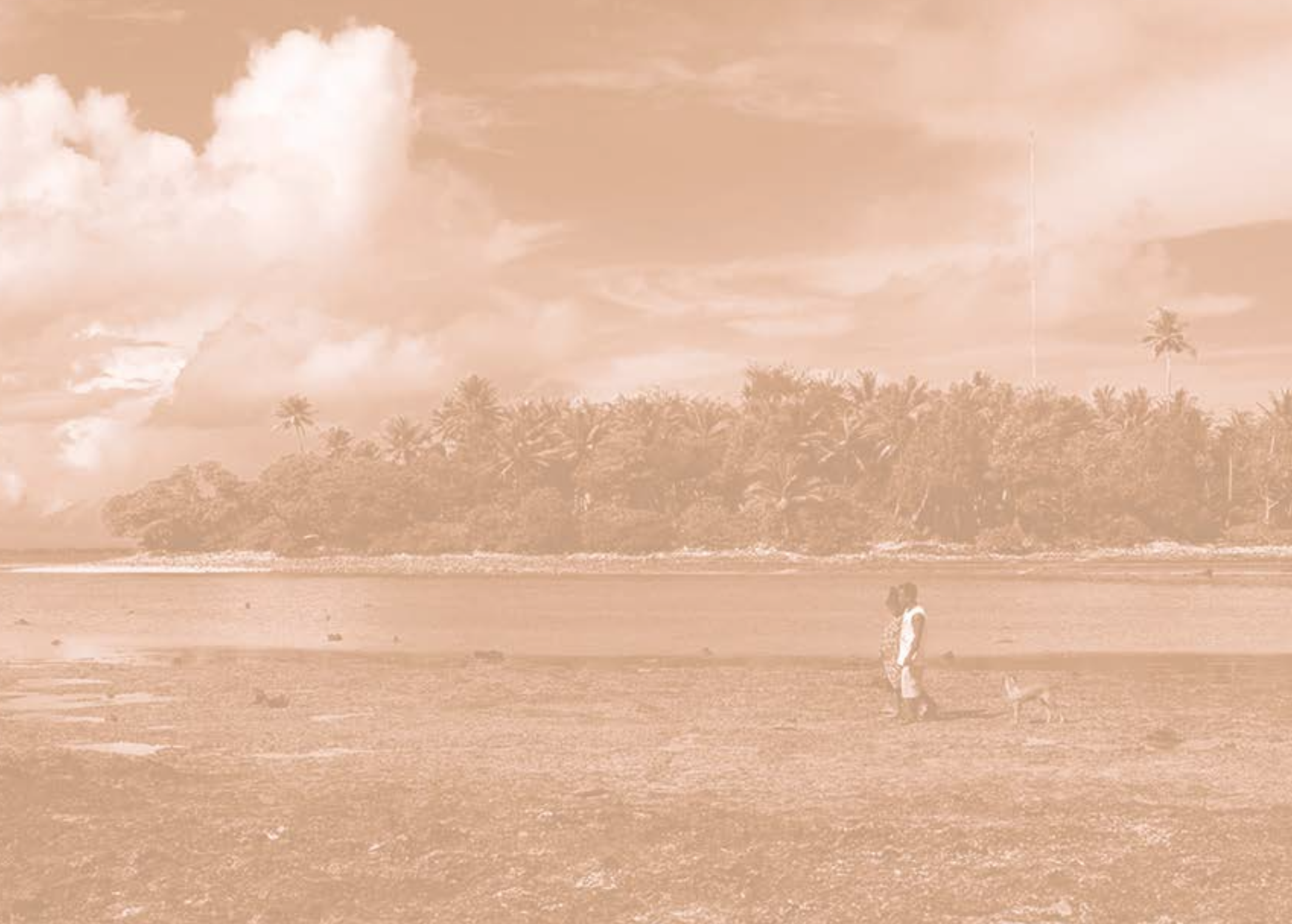

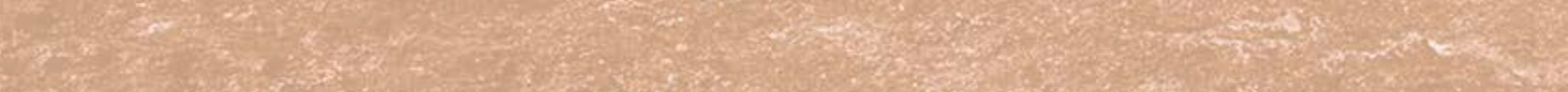

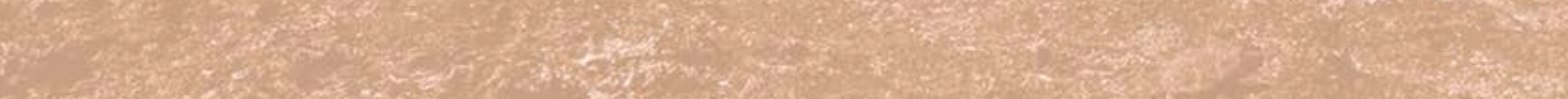
Nand

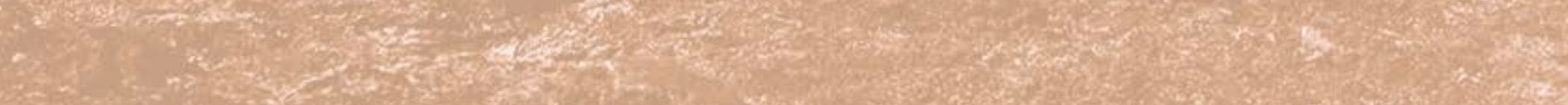

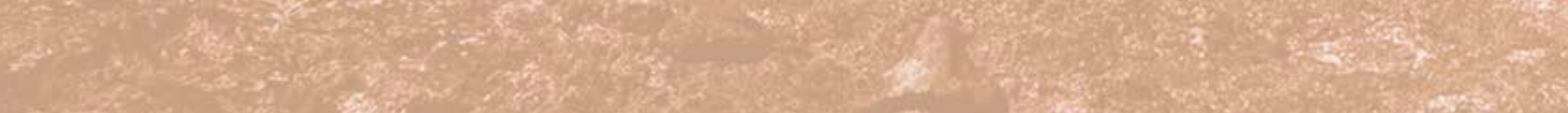
Photoby Eric Sales ADB. Whoto by Eric Sales $A$ ADB.

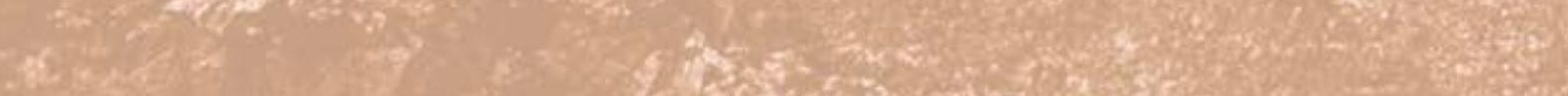




\section{Table 3.3: Constitutional Rights, Obligations, and State Directives in the Pacific}

\begin{tabular}{|c|c|c|c|c|c|c|}
\hline Country & Life & Environment & Food & Water & Health & Housing \\
\hline Cook Islands & $\checkmark$ & - & - & - & - & - \\
\hline FSM & $\checkmark$ & - & - & - & 回 & - \\
\hline Fiji & $\checkmark$ & $\checkmark$ 回 $^{c}$ & $\checkmark^{\mathrm{d}, \mathrm{e}}$ & $\checkmark^{d}$ & $\checkmark^{d}$ & $\checkmark^{\mathrm{d}, \mathrm{f}}$ \\
\hline Kiribati & $\checkmark$ & - & - & - & - & - \\
\hline Marshall Islands & $\checkmark$ & $\mathrm{i}$ & - & - & $\checkmark$ & - \\
\hline Nauru & $\checkmark$ & - & - & - & - & - \\
\hline Palau & $\checkmark$ & 回 & - & - & $\checkmark$ 回 & - \\
\hline PNG & $\checkmark$ & 回 $^{j}$ & 回 $^{k}$ & 1 & 回 & - \\
\hline Samoa & $\checkmark^{\mathrm{m}}$ & - & - & - & - & - \\
\hline Solomon Islands & $\checkmark$ & - & - & - & - & - \\
\hline Timor-Leste & $\checkmark$ & $\checkmark$ 回 $\triangle$ & - & - & $\checkmark$ 回 $\triangle$ & $\checkmark$ \\
\hline Tonga & $\checkmark$ & - & - & - & - & - \\
\hline Tuvalu & $\checkmark$ & - & - & - & - & - \\
\hline Vanuatu & $\checkmark$ & $\Delta^{\circ}$ & - & - & - & - \\
\hline
\end{tabular}

FSM = Federated States of Micronesia, PNG = Papua New Guinea.

Legend: $\checkmark$ indicates there is an express constitutional right that (i) is found under the bill of rights, and (ii) may not need implementing legislation.

回 indicates there is an express directive principle or state policy.

indicates there has been a court decision inferring the right.

$\triangle$ indicates there is an express citizen obligation that the constitution characterizes as fundamental.

Notes: 1. The entries in this table are based on available information as of 31 August 2020.

2. Sec. 7 of the Constitution of the Republic of Fiji expressly allows courts to consider relevant international law when interpreting the rights and freedoms in the bill of rights.

3. See Teriaki v Kauongo [2009] KIHC 27-the High Court of Kiribati ruled that the bill of rights provisions in the constitution can also apply in actions to protect a right between private citizens (i.e., the horizontal application of constitutional rights).

4. Sec. 3 of the Constitution of the Republic of the Marshall Islands states that a court, in interpreting and applying the constitution, "shall look to the decisions of the courts of other countries having constitutions similar, in the relevant respect, to the Constitution of the Republic of the Marshall Islands." Local courts are not bound by foreign decisions. In following any such decision, a court must take into account the constitution as a whole and the circumstances in the country.

5. The Constitution of the Independent State of Papua New Guinea categorizes basic rights into fundamental rights and qualified rights. A law that is "reasonably justifiable in a democratic society having a proper respect for the rights and dignity of mankind" may limit qualified rights. In determining whether a law complies with this standard, sec. 39 of the constitution allows courts to have regard to, among others, (i) the Charter of the United Nations; (ii) the Universal Declaration of Human Rights; and (iii) "any other declaration, recommendation or decision of the General Assembly of the United Nations concerning human rights and fundamental freedoms."

6. The constitutions of the Independent State of Papua New Guinea (sec. 34) and Tuvalu (sec. 12) generally allow the horizontal application of constitutional rights. Bill of rights provisions apply (i) between individuals, and (ii) between governmental bodies and individuals. They also apply, in relation to corporations and associations (other than governmental bodies), in the same way they apply to and in relation to individuals. However, horizontal application may not be applied to the extent that the contrary intention appears in the constitution.

7. Art. 23 of the Constitution of the Democratic Republic of Timor-Leste states that fundamental rights shall be interpreted in accordance with the Universal Declaration of Human Rights.

8. Sec. 15 of the Constitution of Tuvalu states that "all laws, and all acts done under a law, must be reasonably justifiable in a democratic society that has a proper respect for human rights and dignity." In determining whether a law or an act complies 


\begin{tabular}{|c|c|c|c|c|c|c|}
\hline $\begin{array}{l}\text { Cultural } \\
\text { Identity }\end{array}$ & Property & Biodiversity & $\begin{array}{c}\text { Public } \\
\text { Participation }^{\mathrm{a}}\end{array}$ & Information & $\begin{array}{l}\text { Sustainable } \\
\text { Development }\end{array}$ & Country \\
\hline- & $\checkmark$ & - & $\checkmark$ & - & - & Cook Islands \\
\hline 回 & $\checkmark^{\mathrm{b}}$ & - & $\checkmark$ & - & - & FSM \\
\hline 回 & $\checkmark$ & - & $\checkmark$ & $\checkmark$ 回8 & $\checkmark$ 回 $^{c}$ & $\mathrm{Fiji}$ \\
\hline 回 & $\checkmark$ & - & $\checkmark$ & h & - & Kiribati \\
\hline 回 & $\checkmark$ & - & $\checkmark$ & - & - & Marshall Islands \\
\hline- & $\checkmark$ & - & $\checkmark$ & - & - & Nauru \\
\hline- & $\checkmark$ & - & $\checkmark$ & $\checkmark$ & - & Palau \\
\hline 回 & $\checkmark$ & 回 & $\checkmark$ 回 & $\checkmark$ & 回 j & PNG \\
\hline 回 & $\checkmark$ & - & $\checkmark$ & - & - & Samoa \\
\hline 回 & $\checkmark$ & - & $\checkmark$ 回 & h & - & Solomon Islands \\
\hline$\checkmark$ 回 $\triangle$ & $\checkmark$ & 回 & $\checkmark$ & $\checkmark$ & $\checkmark$ 回 $\triangle$ & Timor-Leste \\
\hline- & $\checkmark$ 回 & - & $\checkmark$ & - & - & Tonga \\
\hline 回 $^{n}$ & $\checkmark$ & - & $\checkmark$ & h & - & Tuvalu \\
\hline 回p & $\checkmark$ & - & $\checkmark^{\mathrm{q}}$ & $\mathrm{q}$ & $\Delta^{\circ}$ & Vanuatu \\
\hline
\end{tabular}

with this standard, a court may have regard to, among others, (i) the law, practices, and judicial decisions of other countries that the court reasonably regards as democratic; and (ii) international conventions, declarations, recommendations, and judicial decisions concerning human rights.

a The right to public participation is broadly construed to include political freedoms (e.g., suffrage, freedom of expression, freedom of association, freedom to form political parties, freedom to form unions).

b See Linter v Federated States of Micronesia [2016] FMSC 37-unpaid salary is interest in property, which the government cannot withhold without due process.

c Sec. 40 of the Constitution of the Republic of Fiji incorporates the principle of intergenerational equity-the right to a clean and healthy environment includes the right to have the natural world protected for the benefit of present and future generations. However, a law or an administrative action may limit this right to the extent necessary.

d Secs. 35, 36, and 38 of the Constitution of the Republic of Fiji state that "it is the responsibility of the state to show that the resources are not available," if the state "claims that it does not have the resources to implement the right" to (i) adequate food of acceptable quality; (ii) clean and safe water in adequate quantities; (iii) health, conditions, and facilities necessary to good health and health care services; and (iv) accessible and adequate housing and sanitation.

- See Rarasea $v$ The State [2000] FJHC 146-reducing a prisoner's food rations as a form of punishment (i) violates his constitutional right to be free from "cruel, inhumane, degrading or disproportionately severe treatment or punishment;" and (ii) is not consonant with the state's undertaking under art. 11 of the International Covenant on Economic, Social and Cultural Rights (ICESCR) to provide its people with adequate food.

f See Proceedings Commissioner v Kant [2017] FJHC 407-a private landlord violated his tenants' constitutional right against arbitrary evictions when he (through an agent) locked the house because they were in arrears. This decision is notable because Fijis constitution does not expressly provide for the horizontal application of constitutional rights. The High Court also considered sec. 39 of the constitution (freedom from arbitrary evictions) in relation to (i) its impact upon vulnerable groups (women, children, and the elderly); and (ii) General Comment No. 4 of the Committee on Economic, Social and Cultural Rights (on the scope of the human right to housing in art. 11 of the ICESCR).

$g$ The High Court of Fiji has ruled that members of the public have the right to secure copies of environmental impact assessments without restrictions, pursuant to sec. 17 of the Environment Management Act. The Fiji Times. 2016. Court Rules on EIA Regulations. 25 May.

h The Constitutions of the Republic of Kiribati (sec. 12, under Chapter II: Protection of the Fundamental Rights and Freedoms of the Individual), the Solomon Islands (sec. 12, under Part II: Protection of Fundamental Rights and Freedoms of the Individual), and Tuvalu (sec. 24, under Part II: Bill of Rights) states that the freedom of expression includes the freedom to receive and communicate ideas 
and information without interference. However, there is no constitutional provision that specifically guarantees the right to access information held by public bodies.

i See Kabua, et al. v. M/V Mell Springwood, et al. SCT Civil 2016-001, 22 October 2019-customary and traditional owners of wetos (land running across atolls from the lagoon to the ocean) do not have a legal interest in the coral reef that was damaged by a vessel's grounding, and thus do not have standing to file a civil case for damages for injury allegedly caused to the reef and the associated marine resources.

j The Preamble of the Constitution of the Independent State of Papua New Guinea expressly integrates the principles of intergenerational and intragenerational equity and responsibility. The country's natural resources and environment are "to be conserved and used for the collective benefit of us all and be replenished for the benefit of future generations."

k See Yasause v Keko [2017] PGNC 183-prison food rations that do not conform with the minimum dietary standard imposed by law do not violate the constitutional guarantee against cruel or inhuman treatment. But the court determined that the authorities failed to comply with the minimum standard of food provision, thus failing to afford the detainees equal protection by the law. See Regional Rights Resource Team of the Pacific Community. 2019. Yasause v Keko. In Chris Yuen, ed. Pacific Human Rights Law Digest. 6. p. 24.

1 There is no express right to water in the Constitution of the Independent State of Papua New Guinea. However, in a case involving an asylum seeker, the Supreme Court agreed with the plaintiff that withdrawal of, among others, access to water, amounted to a violation of constitutional rights. Boochani v The Independent State of Papua New Guinea et al. (2017) SC1633.

m See Jackson v Attorney General [2009] WSSC 122-the constitutional guarantee of life only applies to intentional deprivation of life. It does not include an implied right to be free from unintended deprivation of life. Neither does it impose a positive duty on the state to protect life.

$n$ The Preamble of the Constitution of Tuvalu states that the stability of Tuvaluan society and the happiness and welfare of its people depend largely on the maintenance of Tuvaluan values, culture, and tradition. In addition, sec. 29 allows the government to regulate or place some restrictions on the exercise of fundamental rights if their exercise may directly threaten Tuvaluan values or culture.

- Art. 7 of the Constitution of the Republic of Vanuatu states that every person has the fundamental duty to "safeguard the national wealth, resources and environment in the interests of the present generation and of future generations." Art. 8 clarifies that this duty is nonjusticiable. Nevertheless, public authorities have the duty to encourage compliance with it.

p Chapter 5 of the Constitution of the Republic of Vanuatu grants limited rights to the Malvatumauri Council of Chiefs, composed of custom chiefs elected by their peers. The council advises the Parliament on land matters, customs, and traditions and may make recommendations for the preservation and promotion of ni-Vanuatu culture and languages.

q The Republic of Vanuatu's Right to Information Act No. 13 of 2016 became operative on 6 February 2017. Two of the stated purposes of the law are to (i) "give effect to the right to freedom of expression under art. 5(1)(g) of the Constitution," and (ii) "increase public participation in governance."

Sources:

The Constitution of the Cook Islands, 1964;

The Constitution of the Federated States of Micronesia, 1978;

The Constitution of the Republic of Fiji, 2013;

The Constitution of the Republic of Kiribati, 1979 and Constitution (Amendment) Act 2013;

The Constitution of the Republic of the Marshall Islands, 1979;

The Constitution of the Republic of Nauru, 1968 and Constitution (Amendment) Act 2018;

The Constitution of the Republic of Palau, 1980 and Committee on the Rights of the Child, Consideration of Reports Submitted by States Parties under Article 44 of the Convention-Second Periodic Reports of States Parties Due in 2002-Palau (Received 27 July 2016), CRC/C/PLW/2 (15 March 2017);

The Constitution of the Independent State of Papua New Guinea, 1975;

The Constitution of the Independent State of Samoa, 1960, Constitution Amendment Act 2019, Constitution Amendment Act (No. 2)

2019, and Constitution Amendment Act (No. 3) 2019;

The Constitution of the Solomon Islands, 1978;

The Constitution of the Democratic Republic of Timor-Leste, 2002;

The Constitution of the Kingdom of Tonga, 1875;

The Constitution of Tuvalu, 1986; and

The Constitution of the Republic of Vanuatu, 1979. 

Punakha Dzong. In 1994, floods nearly destroyed

Punakha Dzong, also called Pungtang Dechen Photrang

Dzong (the palace of great happiness). Melting and

shrinking glaciers make Bhutan vulnerable to flooding

and water scarcity (photo by Eric Sales/ADB).

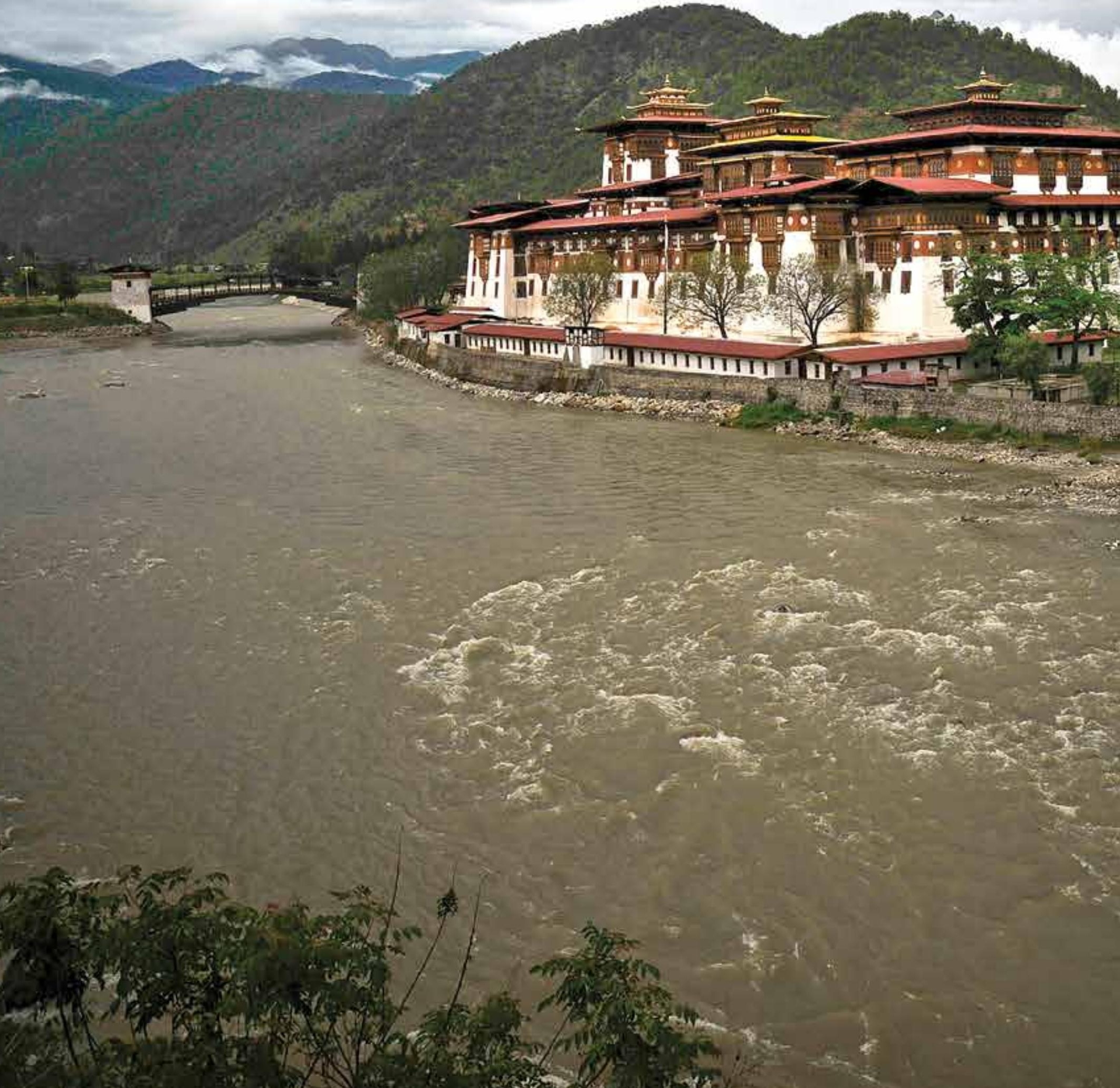




\section{PART FOUR}

\section{SOUTH ASIA \\ LEGAL FRAMEWORKS}

\section{Afghanistan}

\section{A. Country Snapshot: Climate and Environmental Challenges}

Afghanistan is a landlocked country in Central Asia and South Asia, vulnerable to the effects of climate change. Major environmental hazards in the country include droughts and flooding. ${ }^{1}$ For example, Afghanistan experienced a 9-year drought during 1998-2006, its most severe drought on record. ${ }^{2}$ Climate change threatens to undermine agriculture, energy, health care, and infrastructure. ${ }^{3}$ Given that $80 \%$ of Afghans depend on cattle grazing and rain-fed agriculture for their livelihoods, food and income security has become a particular challenge (footnote 2). Since 1978, the area of arable land has decreased by approximately $60 \%$, leaving only $12 \%$ of national land area suitable for agriculture (footnote 2 ). Other challenges include inadequate potable water, overgrazing, soil degradation, desertification, and deforestation (footnote 1).

\section{B. Overarching Climate Change Legal and Policy Framework}

\section{Mitigation and Adaptation Targets}

Afghanistan signed the United Nations Framework Convention on Climate Change (UNFCCC) in June 1992. ${ }^{4}$ In November 2016, Afghanistan submitted its first nationally determined contribution (NDC) to the Paris Agreement, pledging a 13.6\% decrease in greenhouse gas (GHG) emissions by 2030 compared with a business as usual (BAU) 2030 scenario. ${ }^{5}$ This first NDC remains conditional on external support in finance, technology and legal assistance, and capacity building.

United Nations Development Programme (UNDP). Afghanistan.

UNDP. Climate Change Adaptation Afghanistan.

3 United Nations Environment Programme (UNEP). 2015. Climate Change Threats and Vulnerabilities in Afghanistan.

4 United Nations Framework Convention on Climate Change, New York, 21 March 1992, United Nations Treaty Series, Vol. 1771, No. 30822. p. 107.

5 Government of Afghanistan. 2016. Afghanistan First Nationally Determined Contribution. Kabul. 


\section{Overview of Climate Change Laws and Policies}

Although Afghanistan has not yet adopted any laws or policies expressly devoted to climate change mitigation or adaptation, climate change cuts across the country's environmental, development, and energy strategies. The National Environmental Protection Agency (NEPA) coordinates all environmental management activities and is mandated to mainstream environmental and climate change issues into Afghanistan's national development framework. ${ }^{6}$ Various agencies subsidiary to NEPA also deal with environmental management, such as the

(i) Ministry of Agriculture, Irrigation and Livestock;

(ii) Ministry of Energy and Water;

(iii) Ministry of Public Health;

(iv) Ministry of Rural Rehabilitation and Development;

(v) Ministry of Urban Development and Housing;

(vi) Ministry of Public Works;

(vii) Ministry of Mines and Petroleum;

(viii) Ministry of Industry and Commerce;

(ix) Ministry of Finance; and

(x) Afghanistan National Disaster Management Authority (footnote 6).

In 2008, the government launched the 5-year Afghanistan National Development Strategy (ANDS) to outline a vision for "a society of hope and prosperity based on a strong, private sector-led market economy, social equity, and environmental sustainability" by $2020 .^{7}$ The ANDS contains the National Environment Strategy, which seeks to "(i) secure a clean and healthy environment; (ii) attain sustainable economic and social development while protecting the natural resource base and the environment of the country; and (iii) ensure effective management of the country's environment through participation of all stakeholders."

Climate change is not addressed explicitly in the ANDS, but priority program areas include forest restoration and sustainable use, conservation of biodiversity, and pollution control. The ANDS recognizes the importance of integrating environmental challenges into planning processes and requires oversight of the development project's environmental impacts.

Afghanistan, which is in its "Transformation Decade" (2015-2024), strives for self-reliance by $2024 .^{9}$ This self-reliance plan covers Afghanistan's "development

6 Government of Afghanistan. 2015. A Summary of Afghanistan's Progress on Climate Change Adaptation. Kabul.

7 Government of Afghanistan. 2008. Afghanistan National Development Strategy (2008-2013): A Strategy for Security, Governance, Economic Growth \& Poverty Reduction. Kabul. p. i.

8 Footnote 7, p. 151.

9 Asian Development Bank (ADB). 2017. Country Partnership Strategy: Afghanistan, 2017-2021. Afghanistan-Inclusive and Sustainable Growth. Manila. p. 1. 
goals, key reforms, and investment priorities" (footnote 9). The country also drafted the National Peace and Development Framework (2017-2021). ${ }^{10}$

Additionally, the National Environmental Action Plan of 2009-which the United Nations Environment Programme (UNEP) and NEPA drafted-asserts the importance of integrating environmental concerns into national policies to minimize negative environmental impacts and take advantage of environmental opportunities. The National Environmental Action Plan focuses on air, land, biodiversity, and water. It also calls for "a study to determine the likely impacts of climate change on the agricultural and natural resource base of Afghanistan."11 The World Food Programme (WFP), UNEP, and NEPA published a climate change impact study in 2016. ${ }^{12}$ The study assessed livelihood vulnerability to drought and floods over 30 years, allowing the authors to map food security hot spot areas and project future climate impacts to food security.

Afghanistan has also prepared a combined National Adaptation Programme of Action for Climate Change and National Capacity Needs Self-Assessment for Global Environmental Management..$^{13}$ The document allowed the government to determine priority needs for adaptation climate change against the backdrop of desertification and biodiversity loss.

\section{Energy Supply}

The state primarily owns Afghanistan's energy sector. ${ }^{14}$ Reliable or recent data on the mix of Afghanistan's energy sources is sparse. However, the national energy strategy observed that Afghanistan had transitioned from being an energy exporter-natural gas to the Soviet Union before the onset of civil crises in 1978 - to importing over $50 \%$ of the energy consumed in $2005 .{ }^{15}$ The strategy stated that energy imports were necessary due to deteriorating infrastructure, incapable of meeting local energy demand (footnote 15). The failure of electricity utilities to recover sufficient levies to cover operating and capital costs exacerbated infrastructure maintenance issues (footnote 15). However, Afghanistan has a strong potential for renewable energy generation, particularly solar, wind, geothermal, and micro-hydropower (footnote 14).

Table 4.1 summarizes Afghanistan's climate change legal and policy framework.

10 Government of Afghanistan. Afghanistan National Peace and Development Framework (ANDF): 2017 to 2021. Kabul.

11 Government of Afghanistan, National Environmental Protection Agency (NEPA), and UNEP. 2009. National Environmental Action Plan. Kabul. p. 24.

12 WFP, UNEP, and NEPA. 2016. Climate Change in Afghanistan: What Does It Mean for Rural Livelihoods and Food Security: What Does It Mean for Rural Livelihoods and Food Security?

13 UNEP, GEF, and Government of Afghanistan, NEPA. 2009. Afghanistan: National Capacity Needs Self-Assessment for Global Environmental Management (NCSA) and National Adaptation Programme of Action for Climate Change (NAPA). Nairobi: United Nations Environment Programme.

14 R. Rostami et al. 2017. An Overview of Afghanistan's Trends Toward Renewable and Sustainable Energies. Renewable and Sustainable Energy Reviews. 76. pp. 1440-1464.

15 Government of Afghanistan. 2007. Energy Sector Strategy (2007/08-2012/13). Kabul. 


\section{Table 4.1: Climate Change Legal and Policy Framework of Afghanistan}

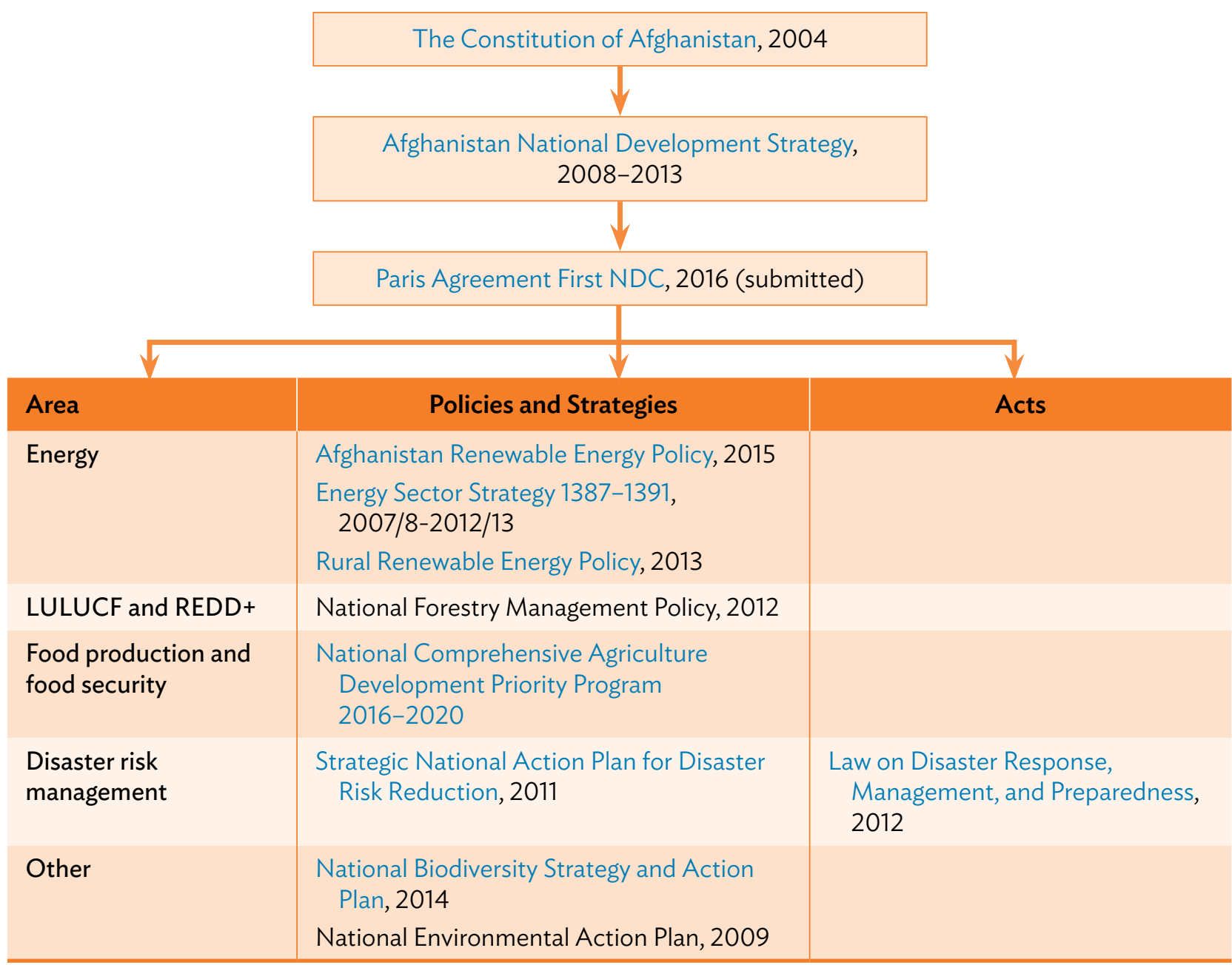

LULUCF = land use, land-use change, and forestry; NDC = nationally determined contribution; REDD + = reducing emissions from deforestation and forest degradation, conservation of existing forest carbon stocks, sustainable forest management, and enhancement of forest carbon stocks.

Source: Authors.

\section{Sector-Wide Energy Strategies}

The Energy Sector Strategy 2007/08-2012/13 establishes Afghanistan's energy sector targets for 2008-2013 as part of the ANDS (footnote 15). Sector-specific goals include electrification of $65 \%$ of households and $90 \%$ of nonresidential buildings, and deploying 10 megawatts (MW) of wind power by 2011 and $50 \mathrm{MW}$ by 2016. It also aims to rehabilitate 94 MW of hydropower capacity by 2008 . The strategy's five primary pillars are (i) increasing the efficiency of existing operations; (ii) promoting public-private partnerships and sector governance; (iii) prioritizing improved capacity development and coordination; (iv) providing rural energy; and ( $v$ ) increasing supply (including wind energy), reducing consumption, and expanding energy and electricity. Poverty reduction is a priority across the five pillars. 
The Energy Sector Strategy also aims to address the environmental impacts of energy and reduce GHG emissions effectively by

(i) focusing on efficiency in energy production and end use,

(ii) moving toward renewable energy production,

(iii) shifting to energy that minimizes indoor air pollution,

(iv) coupling energy supply with activities that generate income to reduce pressure on natural resources,

(v) ensuring that all electricity infrastructure complies with environmental impact assessments (EIAs) and pollution control provisions of the Afghanistan environmental law, and

(vi) promoting coordination between energy sector institutions and NEPA.

\section{Renewable Energy Policies}

Renewable energy has become a significant part of Afghanistan's Energy Sector Strategy. The Ministry of Energy and Water has estimated the national capacity of renewable sources to be at least $800 \mathrm{MW}$, including mini and micro power capacity. This capacity includes wind power of $66,726 \mathrm{MW}$, solar energy of 222 gigawatts (GW), biogas energy from livestock manure of 6,619 gigawattshour (GWh) annually, energy from waste incineration of $134 \mathrm{GWh}$ annually, and a large yet unquantified geothermal potential. ${ }^{16}$

The first major policy on renewables was the Rural Renewable Energy Policy (RREP) of 2013 (footnote 16). A component of the Energy Sector Strategy, the RREP seeks to improve environmental and socioeconomic conditions in rural regions. Recognizing the potential for rural growth, it promotes the development of rural renewable energy technologies by capitalizing on local resources as well as off-grid destinations. The RREP also describes the benefits of renewable energy as (i) providing enhanced energy independence and supply, and greater energy security; and (ii) boosting job creation, social cohesion, rural development, local industries, and environmental benefits.

The RREP explicitly frames energy as a climate challenge. It aims to "alleviate the environmental and health impacts of electricity generated by unsustainable and inefficient traditional biomass fuels and fossil fuels. Displacing GHG emissions will provide significant global climate change benefits." "7 The RREP brings together a range of stakeholders including nonprofits, international donors, the private sector, government agencies, and the rural communities themselves.

In 2015, the Ministry of Energy and Water published the Renewable Energy Policy, which encourages renewable energy use and production to gain a place in the international renewable energy market, meet national energy needs, and achieve

16 Government of Afghanistan, Ministry of Energy and Water and Ministry of Rural Rehabilitation and Development. 2013. Afghanistan Rural Renewable Energy Policy. Kabul.

17 Footnote 16, p. 5. 
sustainable development. ${ }^{18}$ The policy specifically aims for the deployment of 4,500-5,000 MW of renewable energy capacity by 2032 through private investment, on- and off-grid initiatives, utility purchasing rules, net metering programs, the deregulation and delicensing of smaller solar and hydro projects, and the promotion of carbon credits. The policy set up the Renewable Energy Coordination Committee within the Ministry of Energy and Water to supervise the policy implementation for 2015-2020 (first term).

In 2017, the Government of Afghanistan commissioned the Renewable Energy Roadmap or RER2032. ${ }^{19}$ The roadmap was developed to realize the vision and intent of the Renewable Energy Policy (i.e., 4,500-5,000 MW of renewable energy capacity by 2032) and to transition from donor grant-funded renewable energy projects to a fully private sector-led industry by 2032 (footnote 19).

\section{LULUCF and REDD+}

Land use, land-use change, and forestry (LULUCF) is one of the highest-emitting sectors in Afghanistan, alongside energy and agriculture. ${ }^{20}$ Against this backdrop, the National Forestry Management Policy of Afghanistan promotes an integrated and holistic approach to environmental management and conservation, focusing on watersheds and ecosystems. ${ }^{21}$

Acknowledging the country's enormous agricultural potential, the government created the 2016 National Comprehensive Agriculture Development Priority Program, a strategic framework for reforming and developing Afghanistan's agriculture sector in 2016-2020. ${ }^{22}$ These are the seven priority areas:

(i) improving irrigation systems,

(ii) increasing wheat production,

(iii) managing the horticulture value chain,

(iv) developing the livestock sector,

(v) managing climate-sensitive natural resources,

(vi) building nutrition and food security resilience, and

(vii) reforming institutions.

18 Government of Afghanistan, Ministry of Energy and Water. 2015. Renewable Energy Policy. Kabul.

19 IT Power Consulting Private Limited. 2017. Renewable Energy Roadmap for Afghanistan: RER 2032. Bangkok: Asia Pacific Energy Portal.

20 Government of Afghanistan, NEPA. 2017. Second National Communication under the United Nations Framework Convention on Climate Change. Kabul.

21 Government of Afghanistan, Ministry of Agriculture, Irrigation and Livestock. 2012. National Forestry Management Policy of Afghanistan. Kabul.

22 Government Afghanistan, Ministry of Agriculture, Irrigation and Livestock. 2016. National Comprehensive Agriculture Development Priority Program 2016-2021: A Strategic Framework for Agriculture Sector Development and Reform. Kabul. 
Strategic priority five (managing climate-sensitive natural resources) identifies community-based sustainable forest management as essential to developing the economy and building sustainable rural livelihoods. Specific national targets include conserving 210,000 hectares of rangeland. Additionally, the program seeks to increase protected areas from $0.34 \%$ to $2.00 \%$ of Afghanistan's land.

In 2014, NEPA prepared the National Biodiversity Strategy and Action Plan to guide biodiversity management and conservation for the Afghan government to implement the goals of the Convention on Biological Diversity. ${ }^{23}$ The action plan also deals with forest management. According to the action plan, preparing and implementing a program on climate change adaptation is a high-priority strategy. It recommends expanding the network of protected areas, as well as integrating an ecosystem-based approach to biodiversity conservation into climate change mitigation and adaptation.

\section{E. Disaster Risk Management}

The frequent earthquakes, floods, mudslides, droughts, dust storms, and melting glaciers and snowmelt shape Afghanistan's disaster risk management policies. The 2011 Strategic National Action Plan for Disaster Risk Reduction builds on the Hyogo Framework for Action 2005-2015. ${ }^{24}$ The action plan acknowledges that climate change hazards drive poverty and identifies disaster risk reduction as critical in promoting development, security, and peace. It contains six objectives for disaster risk reduction: (i) strengthening the disaster management mechanism, (ii) improving stakeholder knowledge sharing, (iii) enhancing the early warning system, (iv) increasing public awareness of disaster risk reduction, (v) improving community resilience to reduce foundational risk factors, and (vi) strengthening disaster preparedness capacities in the government.

Additionally, the Law on Disaster Response, Management, and Preparedness, 2012 regulates activities related to prevention, mitigation, and the management of both natural and unnatural (human-generated) disasters. It also seeks to manage the post-disaster landscape and protect legal properties. Finally, the law establishes the Office of Disaster Preparedness to coordinate all disaster-related activities including the implementation of the National Disaster Management Commission's decisions and recommendations, with support from multiple levels of government and impacted communities.

23 Government of Afghanistan, NEPA. 2014. National Biodiversity Strategy \& Action Plan. Kabul; Convention on Biological Diversity, Rio de Janeiro, 5 June 1992, United Nations Treaty Series, Vol. 1760, No. 30619. p. 79.

24 Government of Afghanistan, Afghanistan National Disaster Management Authority. 2011. Afghanistan Strategic National Action Plan for Disaster Risk Reduction: Towards Peace and Stable Development. Kabul. 


\section{Bangladesh}

\section{A. Country Snapshot: Climate and Environmental Challenges}

Bangladesh is one of the most vulnerable countries to the adverse impacts of climate change. ${ }^{25}$ It experiences cyclones, floods, and saltwater inundation, and is also vulnerable to storm surges and drought (footnote 25 ). These climate impacts hinder Bangladesh's development and its goal of eliminating poverty and becoming a middle-income country by $2021 .{ }^{26}$ Adverse climate effects also undermine the livelihoods of some of the world's poorest people-one in four Bangladeshis lives in poverty. ${ }^{27}$ The government estimates that it will need $\$ 27$ billion for mitigation and $\$ 42$ billion for adaptation measures during $2015-2030.28$

\section{B. Overarching Climate Change Legal and Policy Framework}

\section{Mitigation and Adaptation Targets}

In its nationally determined contribution (NDC), Bangladesh pledged a $5 \%$ unconditional reduction in GHG emissions by 2030 from business as usual (BAU) levels for its transport, industry, and power sectors (footnote 28). This target is based on goals set out in the 2008 Renewable Energy Policy and the Bangladesh Climate Change Strategy and Action Plan (BCCSAP) 2009. ${ }^{29}$ The NDC, submitted in 2015, also contains a conditional pledge to reduce GHG emissions by 15\% below a BAU scenario by 2030 .

To achieve this conditional reduction, the NDC sets targets for the power, transport, industry, agriculture, waste, household, and commercial sectors. These 2030 targets include (i) reducing the commercial sector's overall energy consumption by $25 \%$ compared with $\mathrm{BAU}$, (ii) increasing rice cultivation using alternate wetting and drying irrigation by $20 \%$, (iii) shifting up to $20 \%$ of passenger traffic from road to rail compared with BAU, and (iv) diverting $50 \%$ of the managed waste fraction from landfill to composting.

25 Displacement Solutions. 2012. Climate Displacement in Bangladesh: The Need for Urgent Housing, Land and Property (HLP) Rights Solutions; World Bank. 2012. Bangladesh Climate Change Resilience Fund. News. 22 May.

26 L. Gimenez, D. Jolliffe, and I. Sharif. 2014. Bangladesh, a Middle Income Country by 2021: What Will It Take in Terms of Poverty Reduction? Washington, DC: World Bank.

27 World Bank. 2017. Bangladesh Continues to Reduce Poverty But at Slower Pace. News. 24 October. Washington, DC.

28 Government of Bangladesh, Ministry of Environment and Forests. 2016. First Nationally Determined Contributions. Dhaka.

29 Government of Bangladesh, Ministry of Power, Energy and Mineral Resources. 2008. Renewable Energy Policy of Bangladesh. Dhaka; Government of Bangladesh, Ministry of Environment and Forests. 2009. Bangladesh Climate Change Strategy and Action Plan 2009. Dhaka. 


\section{Overview of Climate Change Laws and Policies}

Given Bangladesh's high rates of poverty, unemployment, underemployment, and extreme vulnerability to natural disasters and climate change, sustainable development is critical to the country's growth (footnote 25). A key challenge in achieving sustainable development-as identified in the National Sustainable Development Strategy (2010-2021) - is climate change. ${ }^{30}$

Referring to the BCCSAP as a guiding document, the strategy calls for scaling up existing investments in disaster risk reduction. Investments to strengthen disaster resilience include climate proofing coastal polders, afforestation, removing waterlogging, developing crop varieties that can tolerate climate stress, and mainstreaming disaster risk reduction and climate change. The strategy also highlights ways to address mitigation, adaptation, and capacity building across sectors, but particularly within agriculture, transport, energy, utilities, urban housing, and shelter.

The Ministry of Environment and Forests, the key government actor in the climate realm, has developed two critical pieces of domestic strategy-the BCCSAP and the National Adaptation Programme of Action (NAPA). ${ }^{31}$ Launched in 2005, the NAPA was significantly revised in 2009 to meet Bangladesh's extensive adaptation needs. ${ }^{32}$ The revised NAPA outlines 45 adaptation measures across six themes:

(i) food security and pro-poor social safety net,

(ii) comprehensive disaster management,

(iii) climate-resilient infrastructure,

(iv) mainstreaming climate change,

(v) capacity and knowledge enhancement, and

(vi) strategic natural resources management.

The NAPA also calls for the creation of the BCCSAP. Issued in 2009, the BCCSAP seeks to establish a medium- to long-term plan for building resilience and achieving sustainable, low-carbon development over 10 years. ${ }^{33}$ The BCCSAP targets 44 national programs focused on six priority areas:

(i) food security, social protection, and health;

(ii) comprehensive disaster management;

(iii) infrastructure;

(iv) research and knowledge management;

30 Government of Bangladesh, General Economics Division of the Planning Commission. 2013. National Sustainable Development Strategy (2010-2021). Dhaka.

31 Government of Bangladesh, Ministry of Environment and Forests. 2009. Bangladesh Climate Change Strategy and Action Plan 2009. Dhaka; and Government of Bangladesh, Ministry of Environment and Forests. 2005. National Adaptation Programme of Action (NAPA). Dhaka.

32 Government of Bangladesh, Ministry of Environment and Forests. 2009. National Adaptation Programme of Action (NAPA). Dhaka.

33 Government of Bangladesh, Ministry of Environment and Forests. 2009. Bangladesh Climate Change Strategy and Action Plan 2009. Dhaka. 
(v) mitigation and low-carbon development; and

(vi) capacity building and institutional strengthening.

The BCCSAP prioritizes vulnerable populations-women, children, and the poor-across all these areas. Examples of specific programs include river restoration, reforestation, landfill methane capture, improved vehicle fuel efficiency, increased use of public transport, reduced agricultural emissions, and improved energy efficiency in the domestic and commercial sectors. These initiatives were financed in part by the Bangladesh Climate Change Trust Fund (BCCTF) through the Climate Change Trust Fund Act, 2010, and the Bangladesh Climate Change Resilience Fund. ${ }^{34}$

The government's Seventh Five-Year Plan, 2016-2020 outlines goals for supporting the BCCSAP. ${ }^{35}$ It seeks to create a framework for continued high economic growth and hopes to build on the success of earlier five-year plans. It contains a chapter on sustainable development, climate change, and the environment. This chapter articulates a three-pronged sustainable development strategy: environmental management, climate change management and resilience (mitigation and adaptation), and disaster management.

Bangladesh also has over 180 statutory laws relating to environmental management that were developed before climate change became a national and international priority. However, they may still be relevant in a climate context by providing a legal basis for government-led adaptation and mitigation measures. For example, the 1965 Factories Act regulates industrial emissions and can be used to regulate GHG emissions. The Water Act of 2013 governs integrated management of water resources. As climate change affects water availability and sets limits for sustainable water use, this act will likely become relevant for water-related adaptation initiatives.

Table 4.2 summarizes Bangladesh's climate change legal and policy framework.

\section{Energy Supply}

As of 2018, Bangladesh's energy mix comprised 23,011 kilotonnes of oil equivalent (ktoe) of natural gas, 9,628 ktoe of biofuels and waste, 6,504 ktoe of primary and secondary oil, and 2,202 ktoe of coal. ${ }^{36}$ Hydropower and wind and solar made minor contributions to the total energy mix, with hydropower supplying 93 ktoe, and wind and solar supplying 26 ktoe (footnote 36). In 2008, the Power Division of the Ministry of Power, Energy and Mineral Resources published the Renewable Energy Policy in recognition of the scarcity of nonrenewable fuels, the dependence on foreign fuels, and the contribution of fossil fuels to climate change. ${ }^{37}$

34 World Bank. 2012. Bangladesh Climate Change Resilience Fund. News release. 22 May.

35 Government of Bangladesh, General Economics Division of the Planning Commission. 2015. Seventh Five Year Plan: FY2016-FY2020: Accelerating Growth, Empowering Citizens. Dhaka.

36 International Energy Agency. Energy Supply: Bangladesh (accessed 17 September 2020).

37 Government of Bangladesh, Ministry of Power, Energy and Mineral Resources. 2008. Renewable Energy Policy of Bangladesh. Dhaka. 
Table 4.2: Climate Change Legal and Policy Framework of Bangladesh

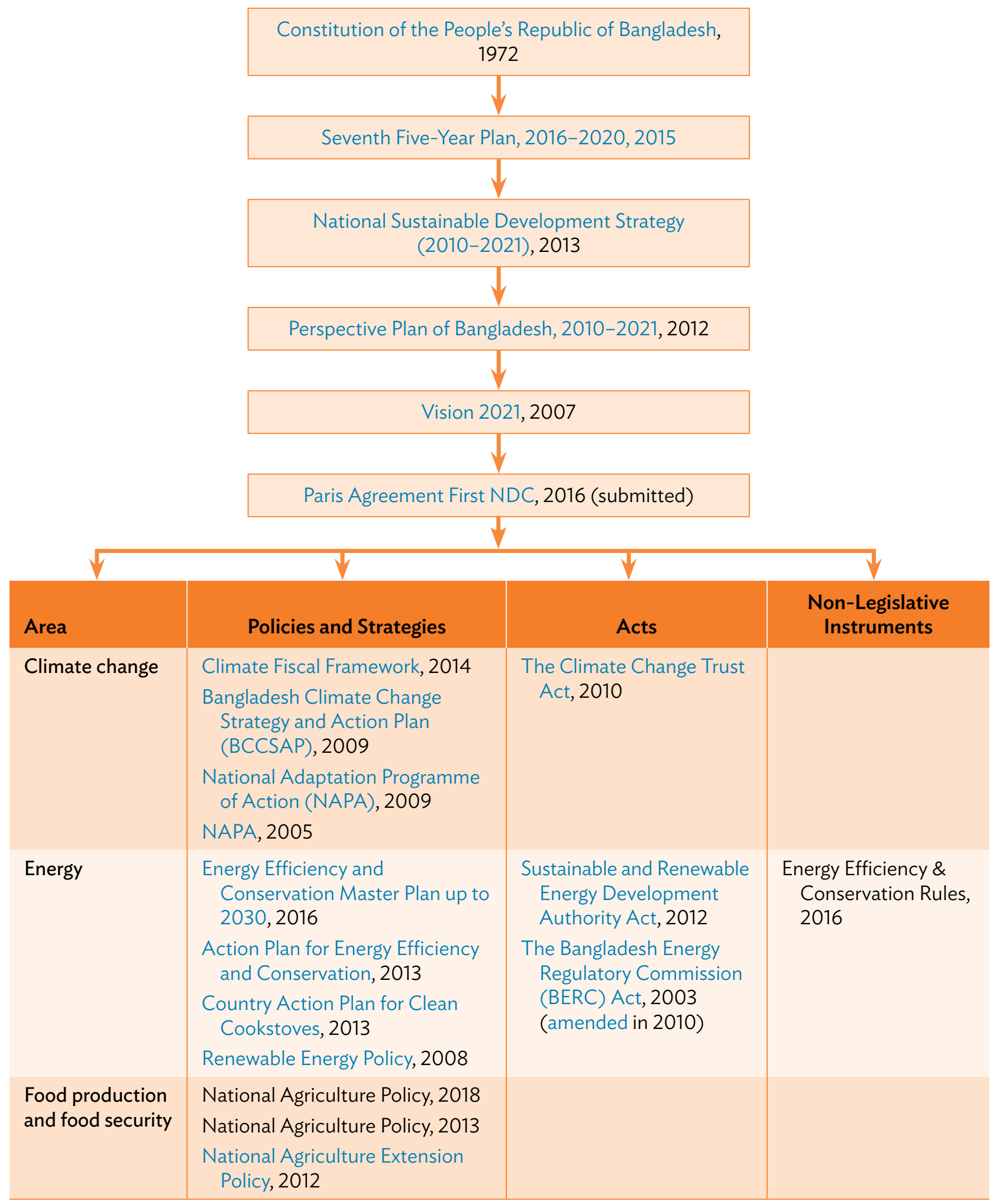


Table 4.2 continued

\begin{tabular}{l|l|l|l} 
Area & \multicolumn{1}{|c|}{ Policies and Strategies } & \multicolumn{1}{c|}{ Acts } & \multicolumn{1}{c}{$\begin{array}{c}\text { Non-Legislative } \\
\text { Instruments }\end{array}$} \\
\hline Waste & $\begin{array}{l}\text { National 3R Strategy for Waste } \\
\text { Management, 2010 }\end{array}$ & \\
$\begin{array}{l}\text { Disaster risk } \\
\text { management }\end{array}$ & $\begin{array}{l}\text { National Disaster Management } \\
\text { Policy, 2015 } \\
\text { National Plan for Disaster } \\
\text { Management (2016-2020), 2017 }\end{array}$ & $\begin{array}{c}\text { Disaster Management Act, } \\
2012\end{array}$ & \\
Other & $\begin{array}{l}\text { National Biodiversity Strategy and } \\
\text { Action Plan, 2016-2021 }\end{array}$ & $\begin{array}{l}\text { Biodiversity Act, 2017 } \\
\text { Environment Court Act, } \\
2000\end{array}$ & \\
\hline
\end{tabular}

NDC = nationally determined contribution .

Source: Authors.

The Renewable Energy Policy sets a goal of 5\% renewable energy by 2015 and $10 \%$ by 2020 (footnote 37). It includes three other key provisions: the development of renewable energy projects, the creation of a national regulatory framework to encourage renewable electricity generation, and the approval by the Bangladesh Energy Regulatory Commission (BERC) of an energy tariff containing an option for green energy tariffs.

On the recommendation of the Renewable Energy Policy, the Sustainable and Renewable Energy Development Authority Act, 2012 was passed. The act establishes the Sustainable and Renewable Energy Development Authority to promote renewable energy use and development, heighten energy security, and mitigate and adapt to climate change. The authority has various responsibilities:

(i) promoting, standardizing, and labeling energy-efficient equipment;

(ii) assisting the government in creating and implementing a building code focused on energy efficiency;

(iii) promoting renewable energy commercialization and private sector energy efficiency;

(iv) providing financial and technical support in research, development, demonstration, and training on renewable energy; and

(v) sending tariff proposals to the BERC.

The Sustainable and Renewable Energy Development Authority also promotes energy conservation and efficiency measures, which help reduce overall use and GHG emissions related to electricity generation. 


\section{Energy Demand}

Demand for electricity in Bangladesh is estimated to reach 34,000 megawatts (MW) by $2030 . .^{38}$ It is growing due to population growth, industrialization, and increasing demand for modern household appliances. ${ }^{39}$ The government plans to expand power generation beyond projected demand to propel economic growth, especially in the export sector. It also aims to meet the demands of the growing middle class (footnote 38).

In 2003, the BERC was established through the Bangladesh Energy Regulatory Commission Act, 2003 to promote the efficient use of energy. It is mandated to (i) determine institutional energy efficiency standards; (ii) monitor institutions through energy audits; and (iii) ensure energy efficiency in generation, transmission, and distribution.

In 2016, the government issued the draft Energy Efficiency \& Conservation Rules to help the Sustainable and Renewable Energy Development Authority to function effectively. ${ }^{40}$ The rules concern

(i) equipment and appliance labeling and standards,

(ii) building energy conservation,

(iii) small and medium-sized enterprises,

(iv) service and industry,

(v) government operations,

(vi) energy conservation and efficiency information,

(vii) policy development and reporting,

(viii) public awareness-raising, and

(ix) additional funding sources (including the Clean Development Mechanism [CDM] and the Bilateral Offset Credit Mechanism).

The rules also detail the equipment and appliances eligible for energy efficiency labeling requirements, the criteria to determine large energy consumers, and a timeline for voluntary and mandatory energy audits for large energy consumers.

In 2016, the Ministry of Power, Energy and Mineral Resources also developed the Energy Efficiency and Conservation Master Plan up to 2030 to expand on a 2013 action plan for energy efficiency and conservation. ${ }^{41}$ Given the predicted increase in energy consumption with the simultaneous decrease in natural gas production,

38 Government of the United States (US), Department of Commerce, SelectUSA. BangladeshPower \& Energy.

39 P. Wester et al. 2019. The Hindu Kush Himalaya Assessment: Mountains, Climate Change, Sustainability and People. Cham, Switzerland: Springer.

40 Government of Bangladesh, Ministry of Power, Energy and Mineral Resources. 2016. Energy Efficiency \& Conservation Rules. Dhaka.

41 Government of Bangladesh, Ministry of Power, Energy and Mineral Resources (Sustainable and Renewable Energy Development Authority). 2016. Energy Efficiency and Conservation Master Plan up to 2030. Dhaka. 
the master plan addresses the need for demand-side energy management. This need is bolstered by the workforce shift from labor- to energy-intensive industries and the desire to prevent further dependency on imported fuels. As a result, the master plan reiterates the national target to improve energy intensity by $20 \%$ compared with the 2013 level by 2030, which would save 95 million tons of oil equivalent (Mtoe).

\section{E. Climate Finance}

After the launch of the BCCSAP, the BCCTF was established under the Climate Change Trust Fund Act, 2009. The act seeks to initiate mitigation, adaptation, and other climate action measures under the BCCSAP. It included a $\$ 100$ million budget annually for $2009-2011$, stipulating that $66 \%$ of this budget be allocated to BCCSAP-related projects. The BCCTF is the first national climate fund established by a least developed country and focuses on supporting adaptation efforts.

In 2014, the Ministry of Finance created the Climate Fiscal Framework to guide climate fiscal policy-making. ${ }^{42}$ The framework helps identify the supply and demand of climate fiscal funds, and prioritizes the sustainability and transparency of climate finance policies. It prepares the public finance system to access and use domestic and international climate finance efficiently and effectively. To this end, it seeks to cost and prioritize climate actions, access domestic and international sources for climate finance, deliver climate finances, track climate expenditures through the Climate Expenditure Tracking Framework, and make climate finance and expenditure more transparent and accountable. The framework also recommends updating the BCCSAP, establishing a climate fiscal cell in the Finance Division of the Ministry of Finance and increasing fund allocations to the BCCTF.

\section{F. LULUCF and REDD+}

Some laws and policies address the connection between forest issues and climate change. For example, the Constitution of Bangladesh recognizes that "the state shall endeavour to protect and improve the environment and to preserve and safeguard the natural resources, bio-diversity, wetlands, forest and wild life for the present and future citizens." 43 This article could support mitigation activities under REDD+ (reducing emissions from deforestation and forest degradation, conservation of existing forest carbon stocks, sustainable forest management, and enhancement of forest carbon stocks).

Furthermore, many local government laws have provisions relating to either afforestation or street planting in urban areas-e.g., the Paurashava Ordinance, 1977; the Union Parishad Act, 2009; and the Laws on Hill Districts. The

42 Government of Bangladesh, Ministry of Finance. 2014. Bangladesh Climate Fiscal Framework. Dhaka.

43 Constitution of the People's Republic of Bangladesh, 1972. art. 18A. 
Acquisition of Waste Land Act, 1950 allows for afforestation of wasteland. The BCCSAP pushes Bangladesh to take both mitigation and adaptation measures, which could include REDD+ activities. The National Forest Policy, $1994,{ }^{44}$ which aimed to raise total forest cover to $20 \%$ by 2015 , preceded the Forestry Master Plan (2017-2036). ${ }^{45}$ Given that reforestation falls under the "plus" components of REDD+, National Forest Policy, 1994 provided a supportive framework for REDD+ activities. The Ministry of Environment and Forests approved the National REDD+ Readiness Roadmap in 2012. ${ }^{46}$

\section{G. Transportation}

GHG emissions from transportation are growing faster than those from any other sectors (footnote 33). Thus, the BCCSAP identifies increasing energy efficiency in the transport sector as a key priority. In particular, the BCCSAP recommends promoting public transport and energy efficiency, improving transport planning, and moving away from fossil fuels where possible and appropriate.

\section{H. Adaptation}

With its key planning document, Vision 2021, Bangladesh aims to eradicate poverty and achieve lower middle-income country status by 2021 , which it did 6 years ahead in 2015. ${ }^{47}$ Although Vision 2021 is primarily a development document, it also guides the country's adaptation strategy. It is implemented in part through the Perspective Plan of Bangladesh (2010-2021), which breaks down the vision into medium- and long-term goals. ${ }^{48}$

One of the perspective plan's goals is "to implement strategies to protect Bangladesh from unpleasant effects of climate change and global warming." ${ }^{49}$ The perspective plan discusses the state of climate change in Bangladesh as well as the strategies to protect the Bangladeshi people, especially the most vulnerable communities. Focus areas include preventing transport- and industry-related air pollution, ensuring scientific waste disposal, and taking all needed actions to protect people from disasters. More specific strategies include afforestation; crop diversification; integrated coastal zone management; and regional cooperation for drought, flood, and river management.

44 Government of Bangladesh, Ministry of Environment and Forests. 1994. National Forest Policy. Dhaka.

45 Government of Bangladesh, Ministry of Environment and Forests. 2016. Bangladesh Forestry Master Plan 2017-2036. Dhaka.

46 United Nations REDD Programme and Government of Bangladesh. 2012. National REDD+ Readiness Roadmap. Geneva: United Nations REDD Programme.

47 Centre for Policy Dialogue. 2007. Bangladesh Vision 2021. Dhaka.

48 Government of Bangladesh, General Economics Division of the Planning Commission. 2012. Perspective Plan of Bangladesh 2010-2021: Making Vision 2021 a Reality. Dhaka.

49 Footnote 48, p. 9. 
Bangladesh has also prioritized water resource management. The Water Act, 2013; the Coastal Zone Policy, 2005; and the Integrated Coastal Zone Management Plan, 2005 set goals and guidelines for managing water. ${ }^{50}$ Both Vision 2021 and the Water Act have supported adaptive measures concerning water management. For example, the Ganges Barrage Project—enabled by Vision 2021 and the Water Act-is a large-scale project to expand irrigation, prevent saltwater intrusion, and increase freshwater availability in the Sundarbans region, a delta mangrove area in the Bay of Bengal.

The government targets food and nutrition security in the National Agriculture Policy and aims to enhance agricultural productivity and diversification. ${ }^{51}$ The National Food Policy, 2013 also supports food security, focusing on food availability and nutrition for women and children by enhancing women's purchasing power. ${ }^{52}$ The National Food Policy Plan of Action (2008-2015) supported implementing the National Food Policy by identifying strategic interventions, responsible actors, and priority targets. ${ }^{53}$

\section{Disaster Risk Management}

In 2016, the updated National Plan for Disaster Management (2016-2020) was promulgated by the Ministry of Disaster Management and Relief based on the previous National Plan for Disaster Management (2010-2015) published by the Ministry of Food and Disaster Management. ${ }^{54}$ The plan builds on the government's success in disaster management and international disaster risk reduction frameworks. It has three core goals: saving lives, protecting investments, and recovering effectively. Adopting a phase-wise approach with 34 core targets to be implemented in partnership with relevant stakeholders in the context of rapid changes in Bangladesh, the plan takes a whole-of-government approach and attaches importance to engaging the private sector.

Parliament passed the Disaster Management Act in 2012, which seeks to substantially reduce disaster risks to a level deemed acceptable through interventions, emergency response implementation, recovery and rehabilitation, humanitarian assistance, institutional capacity improvements, and comprehensive disaster management system.

50 Government of Bangladesh, Ministry of Water Resources. 2005. Coastal Zone Policy, 2005. Dhaka; and Government of Bangladesh, Ministry of Water Resources. 2005. Integrated Coastal Zone Management Plan. Dhaka.

51 Government of Bangladesh, Ministry of Agriculture. 2013. National Agriculture Policy. Dhaka; and Food and Agriculture Organization of the United Nations (FAO). 2016. Bangladesh Country Fact Sheet on Food and Agriculture Policy Trends. Rome.

52 Government of Bangladesh, Ministry of Agriculture. 2013. National Food Policy. Dhaka.

53 Government of Bangladesh, Ministry of Food and Disaster Management, Food Planning and Monitoring Unit. 2008. National Food Policy Plan of Action (2008-2015). Dhaka.

54 Government of Bangladesh, Ministry of Disaster Management and Relief. 2017. National Plan for Disaster Management (2016-2020). Dhaka; and Government of Bangladesh, Ministry of Food and Disaster Management. 2010. National Plan for Disaster Management, 2010-2015. Dhaka. 


\section{\|l\|. Bhutan}

\section{A. Country Snapshot: Climate and Environmental Challenges}

Bhutan is a constitutional monarchy, in which the King serves as Head of State and the Prime Minister leads the executive branch of government. It is the world's only carbon-negative country. ${ }^{55}$ According to its second national GHG inventory, Bhutan's estimated sequestration capacity in 2000 was 6.3 million tons of carbon dioxide $\left(\mathrm{tCO}_{2}\right)$, while emissions were only 1.6 million $\mathrm{tCO}_{2} \cdot{ }^{56}$ Bhutan serves as a net sink for GHGs because it has extensive forest cover, low levels of industrial activity, and almost 100\% electricity generation through hydropower (footnote 56 ).

Nevertheless, Bhutan faces some projected climate-related impacts because of its fragile mountainous ecosystem and economy, including challenges to its water resources, agriculture, forests and biodiversity, and hydropower sectors (footnote 56). Increasingly frequent and extreme weather events also pose a challenge to the landlocked least-developed country (footnote 56).

\section{B. Overarching Climate Change Legal and Policy Framework}

\section{Mitigation and Adaptation Targets}

Committed to remaining carbon neutral when it signed the Paris Agreement, Bhutan has demonstrated significant climate leadership. According to its nationally determined contribution (NDC), Bhutan's GHG emissions will not exceed the sequestration capacity of its forests-estimated at 6.3 million $\mathrm{tCO}_{2}$. The NDC also sets a goal of offsetting $22.4 \mathrm{tCO}_{2}$ equivalent per year by 2025 by exporting hydropower.

\section{Overview of Climate Change Law and Policy}

Bhutan's approach to climate change has been policy-driven and carbon neutrality-focused. In 2019, the National Environment Commission Secretariat issued the Climate Change Policy. ${ }^{57}$ The policy's overarching goal is to ensure that Bhutan remains carbon neutral in its development while adapting to climate change by (i) providing strategic guidance to identify and respond to the challenges and opportunities of climate change, (ii) integrating climate changerelated measures into relevant documents and implementing them appropriately, and (iii) establishing meaningful participation of all stakeholders.

55 M. Tutton and K. Scott. 2018. What Tiny Bhutan Can Teach the World about Being Carbon Negative. CNN. 11 October.

56 Government of Bhutan, National Environment Commission. 2016. Kingdom of Bhutan: First Nationally Determined Contribution. Thimphu.

57 Government of Bhutan, National Environment Commission. 2019. Climate Change Policy of the Kingdom of Bhutan 2019. Thimphu. 
The Climate Change Policy recognizes the constitutional right of citizens-and the responsibility of both citizens and the government-to enjoy and maintain sustainable development and environmental conservation for current and future generations. It also reaffirms several features of the National Environment Protection Act, 2007, such as the (i) polluter-pays principle, (ii) precautionary principle, (iii) payment of ecosystem services, and (iv) right to information and engagement of all stakeholders.

The National Environment Protection Act provides a framework for Bhutan's climate action, although it does not contain any explicit climate-related provisions. The act aims to "provide for the establishment of an effective system to conserve and protect environment..., so as to independently regulate and promote sustainable development in an equitable manner." 58 It incorporates fundamental environmental principles into the law of Bhutan, such as the principles of precaution, polluter pays, and intergenerational equity and responsibility; critical to climate action. The act prescribed emissions standards and empowered the National Environment Commission to impose those standards. The goal is to regulate polluting technologies and products and make producers responsible for their products' full life cycle through reuse, recycling, recovery, or paying for waste management.

Bhutan's commitment to carbon-neutral development is further outlined in its National Strategy and Action Plan for Low Carbon Development. ${ }^{59}$ Launched in 2012, the action plan analyzes sector emissions under a business as usual (BAU) scenario. It models three alternative energy scenarios for 2005-2040: (i) option one-achieving a high degree energy efficiency in the industrial, tertiary, and residential sector; (ii) option two-generating a high degree of electricity from renewable energy; and (iii) option three-combining options one and two.

Under the baseline scenario, emissions in 2009 were around 2.1 million $\mathrm{tCO}_{2}$ equivalent, with half coming from agriculture and a quarter each from energy and industry. Under a BAU scenario, emissions will reach 4.7 million $\mathrm{tCO}_{2}$ equivalent by 2040 , which is still below the national sequestration capacity. However, increased energy efficiency (option one) could reduce Bhutan's emissions by $10 \%$ in 2040 compared with the baseline. Option two-increasing the share of renewable energy - could reduce emissions by $42 \%$, and option three-boosting energy efficiency and renewable energy generation-could reduce emissions by $49 \%$ relative to the baseline level in 2040 .

The Action Plan for Low Carbon Development also explores options for financing its goals, including the CDM and the Nationally Appropriate Mitigation Actions.

58 National Environmental Protection Act, 2007. sec. 3.

59 Government of Bhutan, National Environment Commission. 2012. National Strategy and Action Plan for Low Carbon Development, 2012. Thimphu. 
Bhutan also recognizes climate change as integral to its economic growth in its Economic Development Policy (2016), which focuses on boosting a green and self-reliant economy. ${ }^{60}$ The policy aims to achieve a minimum average economic growth rate of $10 \%$, become a middle-income country by 2020 , achieve economic self-reliance by 2020 , and sustain full employment (97.5\%). It sets out the following strategies:

(i) promote the "five jewels" (hydropower, agriculture, cottage and small industries, tourism, and mining);

(ii) diversify the economic base with minimal ecological footprint;

(iii) harness and add value to natural resources sustainably;

(iv) increase and diversify exports;

(v) promote Bhutan as an organic brand;

(vi) promote industries that build the image of "Brand Bhutan";

(vii) reduce fossil fuel dependency; and

(viii) promote industries through a cluster effect and championing approach.

The Economic Development Policy also outlines strategies the government should promote for sustainable development, such as green and climate-smart agriculture, sustainable tourism, and sustainability in education.

Table 4.3 summarizes Bhutan's climate change legal and policy framework.

\section{Energy Supply}

As a result of privatization in Bhutan's energy sector in 2002, commercial management and ownership is no longer the exclusive purview of the government. ${ }^{61}$ Nevertheless, the Ministry of Economic Affairs serves as the primary policy-making body on energy.

Hydropower from run-of-the-river schemes generates almost $100 \%$ of national electricity supply (footnote 56). Hydroelectricity exports offset 4.4 million $\mathrm{tCO}_{2}$ equivalent per year in 2015, and could offset up to 22.4 million $\mathrm{tCO}_{2}$ equivalent per year by 2025 (footnote 56). Consistent with this goal, the Economic Development Policy seeks to build 5,000 MW of hydropower by 2022 (footnote 60).

The Economic Development Policy also encourages the development of other renewable energy projects (footnote 60). It calls for (i) adopting a feed-in-tariff policy by 2018; (ii) granting incentives to promote rooftop water and space heating systems; (iii) researching and developing renewable energy and efficiency; and (iv) creating the National Energy Efficiency and Conservation Policy, and Energy Efficiency Building Codes and Guidelines. The policy also designates funds to conserve catchment areas and support renewable energy and energy efficiency initiatives.

60 Government of Bhutan. 2016. Economic Development Policy. Thimphu.

61 ADB. 2014. Country Partnership Strategy: Bhutan, 2014-2018. Manila. 


\section{Table 4.3: Climate Change Legal and Policy Framework of Bhutan}

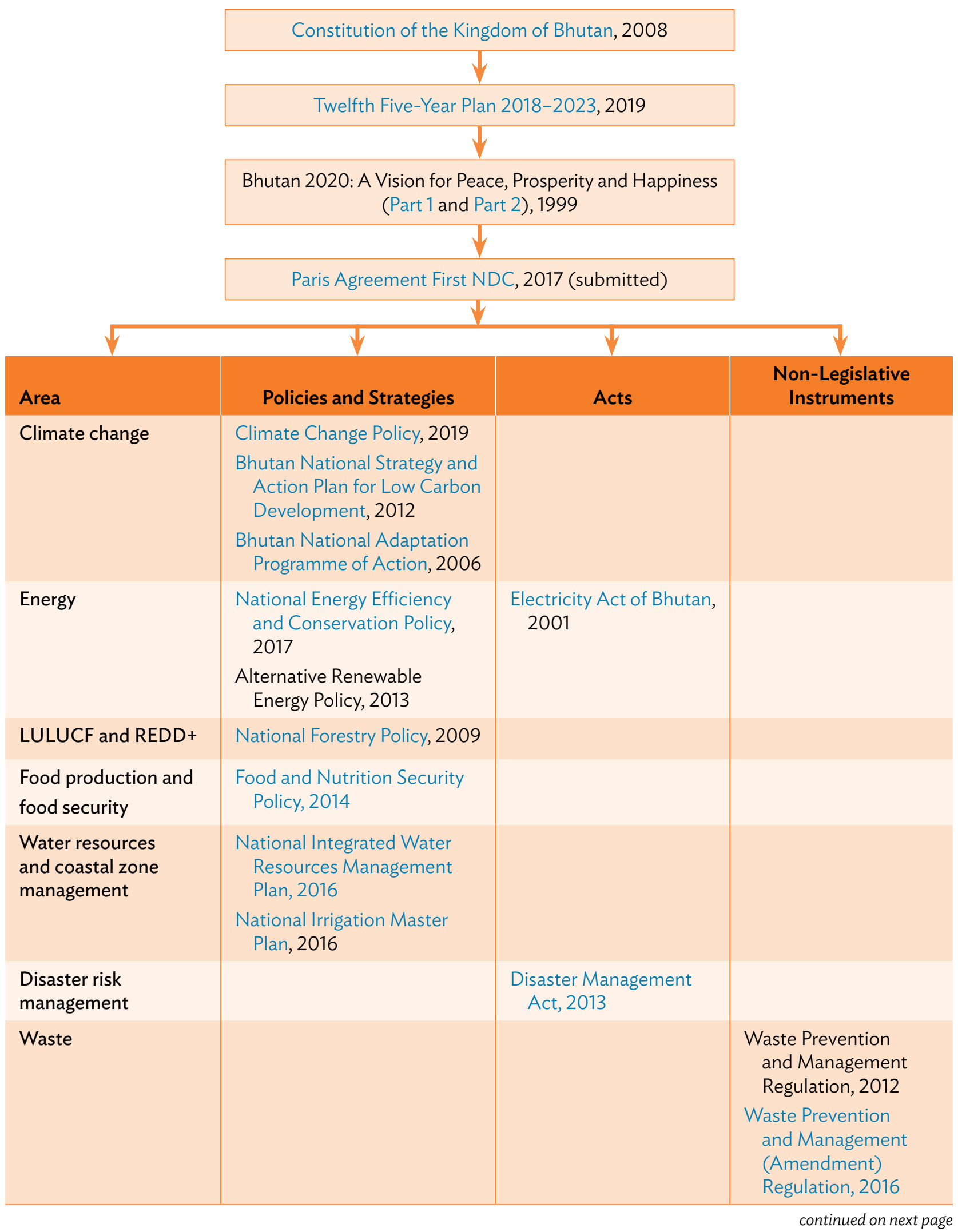




\begin{tabular}{l|l|l|l} 
Area & \multicolumn{1}{|c|}{ Policies and Strategies } & Acts & $\begin{array}{c}\text { Non-Legislative } \\
\text { Instruments }\end{array}$ \\
\hline Other & $\begin{array}{l}\text { Economic Development } \\
\text { Policy, 2016 }\end{array}$ & $\begin{array}{c}\text { National Environment } \\
\text { Protection Act, 2007 } \\
\end{array}$ & \\
& $\begin{array}{l}\text { National Biodiversity } \\
\text { Strategies and Action Plan, } \\
\end{array}$ & \\
& & \\
\hline
\end{tabular}

LULUCF = land use, land-use change, and forestry; NDC = nationally determined contribution; REDD + = reducing emissions from deforestation and forest degradation, conservation of existing forest carbon stocks, sustainable forest management, and enhancement of forest carbon stocks.

Source: Authors.

Bhutan's Electricity Act, 2001 also allows for evolution in the national power supply. Although the act does not mention climate change, three of the seven objectives relate to climate change: (i) promoting renewable energy development, (ii) considering the environment when developing electricity sources, and (iii) promoting efficiency in electricity service delivery and management. The act enables private sector participation and explains the required licenses and regulations for power companies. It also establishes the Bhutan Electricity Authority, an autonomous entity tasked with outlining the specifications, standards, and codes for the industry to "ensure the protection of the natural resources, the environment and other public interests affected by the development of electricity supply." ${ }^{2}$

\section{Renewable Energy Policies}

The Alternative Renewable Energy Policy, 2013 directs the development and promotion of renewable energy through the adoption of solar, bioenergy, wind, geothermal, waste-to-energy, and hydro technologies (pico, micro, mini and small). ${ }^{63}$ The policy acknowledges the importance of diversifying energy production given "rising energy demand, the reliance on a single electricity source, increasing fossil fuel imports, and low hydropower production in winter months." ${ }^{64}$ By diversifying energy production, Bhutan can work toward energy security and mitigate climate change.

The policy sets a preliminary minimum target of $20 \mathrm{MW}$ of renewable energy by 2025 . It hopes to achieve this by promoting green growth and using a mix of renewable energy technologies, including $5 \mathrm{MW}$ each of solar, wind, and biomass energy. Long-term objectives include developing a framework for carbon trading mechanisms.

62 Electricity Act of Bhutan, 2001. sec. 11.2(vi).

63 Government of Bhutan, Ministry of Economic Affairs. 2013. Alternative Renewable Energy Policy 2013. Thimphu.

64 Footnote 63, p. 5. 


\section{Energy Demand}

Total fuel consumption in Bhutan is dominated by traditional sources of fuel, such as biomass (fuelwood, biogas, and briquettes), which accounts for $36 \%$ of consumption. ${ }^{65}$ Electrification since 2005 has resulted in a growing shift from biomass to electricity, with electricity constituting more than a quarter (28\%) of fuel consumption. Other major fuel sources include coal (15\%) and diesel (16\%). ${ }^{66}$ Petrol, kerosene, and liquefied petroleum gas make up the remaining 5\% of the total fuel mix. As of 2015, Bhutan had achieved $100 \%$ access to electricity in urban areas and $94 \%$ in rural areas.

Following the release of Bhutan's Economic Development Policy, the National Energy Efficiency and Conservation Policy (NEECP) was launched in 2017 to promote, incentivize, govern, and monitor energy efficiency and conservation measures. ${ }^{67}$ The NEECP recognizes the economy-wide benefits of energy efficiency and conservation, which include reduced energy intensity, lesser GHG emissions, less pressure on forest resources, and higher revenues as more electricity becomes available for export.

While the NEECP assigns roles and responsibilities to many agencies regarding energy efficiency and conservation, it focuses on the organizational strengthening of the Department of Renewable Energy. The department is responsible for utilizing the Renewable Energy Development Fund to support efficiency and conservation measures. It also develops a monitoring, reporting, and verification mechanism to assess energy efficiency and conservation programs.

The NEECP identifies sectors - such as industry, transport, buildings, and appliances-in which energy performance standards can be improved. These standards are then developed, enforced, and promoted by the Department of Renewable Energy, the Ministry of Works and Human Settlement, and the Ministry of Information and Communications. The average annual savings potential in electricity consumption in the buildings, industry, and appliances sectors is about 300 million kilowatt-hours annually. The NEECP also recognizes that fuel-efficient vehicles, electric vehicles, mass transportation, and nonmotorized transportation can reduce fuel costs, harmful vehicular pollution, and congestion.

\section{E. LULUCF and REDD+}

Bhutan's extensive forest cover serves as a net sink for GHGs (footnote 56). The Constitution of Bhutan requires a minimum of $60 \%$ of forest cover at all times. 68

65 Government of Bhutan, Ministry of Economic Affairs. 2016. Energy Data Directory 2015. Thimphu. pp. 48-49.

66 Footnote 65, p. 48.

67 Government of Bhutan, Ministry of Economic Affairs. 2017. National Energy Efficiency and Conservation Policy. Thimphu.

68 Constitution of the Kingdom of Bhutan, 2008. art. 5(3). 
Currently, $71 \%$ of the total land is under forest cover. ${ }^{69}$ Launched in 2009 , the National Forest Policy provides guidelines for the sustainable use and protection of forests, wild plants, and animals, as well as the conservation of water and soil resources in Bhutan. ${ }^{70}$ The policy outlines six key objectives:

(i) sustainably producing goods and services to meet societal needs through forest management;

(ii) preserving biodiversity, natural habitats, and ecosystem services by maintaining protected areas such as biological corridors, nature reserves, botanical parks, conservation areas, wildlife sanctuaries, and national parks;

(iii) managing forested watersheds to maintain high-quality water supply and sustainable rural livelihoods;

(iv) ensuring that rural communities can meet the majority of their demands for timber as well as benefit economically from the sustainable management of community forests;

(v) preserving an efficient and profitable forest-centered industry; and

(vi) engaging in institutional and organizational reform to meet these objectives.

The National Forest Policy also notes the value of forests in maintaining income from ecotourism and environmental services, and high-quality water supply for hydropower, irrigation, and domestic use.

\section{F. Adaptation}

Bhutan is a small, landlocked, and mountainous country. Its climate vulnerability stems from a heavy dependence on climate-sensitive sectors-such as hydropower and agriculture - and large areas of glacial lakes and glaciers (footnote 56). Bhutan is at risk of glacial lake outburst floods (GLOFs) from rising global temperatures; land degradation from landslides, intense rainfall, cyclones, and erosion from changing weather patterns; and flashfloods from intense rainfall and cyclones (footnote 56).

In 2006, the government launched its National Adaptation Programme of Action (NAPA) to address Bhutan's climate vulnerability. ${ }^{71}$ The NAPA addresses the links between responding to climate change and developing sustainably. It identifies key adaptation needs by sector and by climate hazard. Nine priority adaptation projects are

(i) a disaster management strategy with a pilot implementation of food security and emergency medicine;

(ii) the artificial lowering of Thorthormi Glacier Lake;

69 Government of Bhutan, Department of Forests and Park Services. 2017. National Forest Inventory Report: Stocktaking Nation's Forest Resources: Volume I. Thimphu.

70 Government of Bhutan, Ministry of Agriculture. 2009. National Forest Policy of Bhutan, 2009. Thimphu.

71 Government of Bhutan. 2006. Bhutan National Adaptation Programme of Action. Thimphu. 
(iii) a weather forecasting system to serve farmers and agriculture;

(iv) landslide management and flood prevention, with pilot schemes in critical areas;

(v) the flood protection of downstream industrial and agricultural area;

(vi) rainwater harvesting;

(vii) GLOF Hazard Zoning, with a pilot scheme-Chamkar Chu Basin;

(viii) the installation of Early Warning System on Pho Chu Basin; and

(ix) the promotion of community-based forest fire management and prevention.

The 2012 addendum to the NAPA notes that while the project to address the threat of flooding from Thorthormi Glacier Lake was implemented, a lack of funding has prevented the implementation of further NAPA priority projects. The update also recognizes that cyclones and other new climate hazards have emerged, requiring reassessment of remaining priority projects.

\section{G. Disaster Risk Management}

Seeking to mainstream disaster risk reduction, the Disaster Management Act, 2013 establishes the National Disaster Management Authority as the decisionmaking body for disaster management. The body approves contingency plans, hazard zoning, and national standards for disaster risk management and reduction.

\section{India}

\section{A. Country Snapshot: Climate and Environmental Challenges}

India has a federal system of government and is the world's second most populous country, being home to $17.7 \%$ of the world's population. ${ }^{72}$ Around $42 \%$ of India's workforce works in agriculture, making them susceptible to climate impacts like heat waves, flooding, and drought, and vulnerable to displacement. ${ }^{73}$ During 2004-2014, the Indian economy grew by about $11 \%$ each year. In 2014 , the country was the third-largest economy in the world. ${ }^{74}$

Climate change has already impacted India's climate. India experiences unusual and unprecedented heat waves more frequently and more extensively. ${ }^{75}$ Monsoon patterns are changing. Since the 1950 s, monsoon rainfall has diminished, but India has also experienced more frequent heavy rainfall events (footnote 75). Rising temperatures

72 Worldometer. India Population (live) (accessed 18 September 2020).

73 H. Plecher. 2020. Distribution of the Workforce Across Economic Sectors in India 2019. Hamburg: Statista; and World Bank. 2013. India: Climate Change Impacts. News. 19 June.

74 United States (US) Energy Information Administration. 2016. India: Analysis.

75 World Bank. 2013. India: Climate Change Impacts. News. 19 June. 
and unpredictable rainfall significantly impact the agriculture, forestry, and power sectors, threatening food and energy security. ${ }^{76}$ India's two dominant forms of power generation-hydropower and thermal power-require consistent water supplies.

India has shown strong support for climate action, adopting climate adaptation and awareness strategies early (footnote 75).

\section{B. Overarching Climate Change Legal and Policy Framework}

\section{Mitigation and Adaptation Targets}

In its first nationally determined contribution (NDC) to the Paris Agreement, India committed to both conditional and unconditional GHG emission reductions by $2030 .{ }^{77}$ Unconditionally, India pledges to reduce the emission intensity of its gross domestic product (GDP) by 33\%-35\%. Conditionally, it pledges to meet $40 \%$ of installed power capacity from nonfossil fuel sources. India's conditional target is contingent upon receiving international financing from mechanisms such as the Green Climate Fund as well as technology transfers.

India still actively participates in the Clean Development Mechanism (CDM) established under the Kyoto Protocol. It has hosted 1,748 registered CDM projects as of December 2019. ${ }^{78}$

\section{Overview of Climate Change Law and Policy}

Instead of developing binding climate legislation, India has taken a policy-based approach to tackle climate change. In 2006, India released its National Environment Policy, which guides action on sustainability. ${ }^{79}$ The policy articulates key elements of India's climate response. For example, it notes the principle of common but differentiated responsibilities; recognizes the need for climate change adaptation; and identifies India's vulnerabilities to climate change and the impact on agriculture, health, the coasts, forests, and water resources. Critically, the policy encourages Indian industries to take part in the CDM of the Kyoto Protocol, to which India had no binding emissions targets as a non-Annex I country.

In 2008, India issued its most crucial executive policy on climate change: the National Action Plan on Climate Change (NAPCC)..$^{80}$ The NAPCC provides a framework and guiding principles for sectors creating low-carbon growth

76 Footnote 75; United Nations Development Programme (UNDP). Climate Change Adaptation: India.

77 Government of India. 2016. India's First Nationally Determined Contribution: Working Towards Climate Justice. Delhi.

78 United Nations Framework Convention on Climate Change (UNFCCC). Clean Development Mechanism. Project Search-India (accessed 28 December 2019).

79 Government of India, Ministry of Environment and Forests. 2006. National Environment Policy, 2006. Delhi.

80 Government of India, Prime Minister's Council on Climate Change. 2008. National Action Plan on Climate Change. Delhi. 
strategies. It focuses on improving climate change understanding and initiating action on mitigation, energy efficiency, adaptation, and conservation of natural resources while simultaneously promoting economic growth. It sets a target of $5 \%$ renewable energy in the national grid by 2010 and aims to increase the share of renewable energy by $1 \%$ annually to reach a $15 \%$ share of the grid by 2020 .

The NAPCC's eight strategic missions concern solar, enhanced energy efficiency, sustainable habitat, water, sustaining Himalayan ecosystems, Green India, sustainable agriculture, and strategic knowledge. After the NAPCC was released, states were asked to prepare action plans. All Indian states have completed or are preparing their own State Action Plans on Climate Change. ${ }^{81}$

The government established the Advisory Council on Climate Change alongside the NAPCC and designated the Prime Minister as its chair. Reconstituted in 2014, this council is made up of diverse stakeholders including members of industry, civil society, and the government. The council establishes directives on national climate change action and aids in coordinating the domestic agenda as well as reviewing research and development under the NAPCC. Furthermore, it advises on international negotiations and periodically reviews the progress of the respective missions.

In 2010, the Indian Network for Climate Change Assessment-an organization of research institutions - published Climate Change and India: A 4x4 Assessment. ${ }^{82}$ The assessment details impacts on forests, water resources, human health, and agriculture in the northeast, the coastal areas, the Western Ghats, and the Himalayan region. The Indian government has responded to the threats posed by climate change through its policies, which cover carbon pricing; energy supply and demand; LULUCF and REDD+; cities and buildings; and climate change adaptation.

The government released the last five-year multisector development plan in $2012 .{ }^{83}$ The Twelfth Five-Year Plan for 2012-2017 aimed for 8.2\% growth and prioritized the reduction of energy intensity and the increase in domestic energy supply. The government established the Expert Group on Low Carbon Strategy for Inclusive Growth after this plan to write a low-carbon development road map. ${ }^{84}$ The road map recommended a strategy for low-carbon growth in multiple sectors including electricity, transportation, industry, oil and gas, buildings, and forestry. After the government abolished five-year plans, the National Institution for Transforming India prepared the Three-Year Action Agenda: 2017-2018 to 2019-2020.85 Part VII of the agenda focuses on sustainability, particularly pollution, forests, and water resources.

81 E. Gogoi. 2017. In Depth: India's State Action Plans on Climate Change: towards Meaningful Action. Oxford: Oxford Policy Management.

82 Indian Network for Climate Change Assessment. 2010. Climate Change and India: A 4x4 Assessment: A Sectoral and Regional Analysis for 2030s. Delhi.

83 Government of India, Planning Commission. 2013. Twelfth Five Year Plan (2012-2017): Faster, More Inclusive and Sustainable Growth: Volume I. Delhi.

84 Government of India, Planning Commission. 2014. The Final Report of the Expert Group on Low Carbon Strategies for Inclusive Growth. Delhi.

85 Government of India, National Institution for Transforming India. 2017. Three Year Action Agenda, 2017-18 to 2019-20. Delhi. 
Table 4.4 summarizes India's climate change legal and policy framework.

Table 4.4: Climate Change Legal and Policy Framework of India

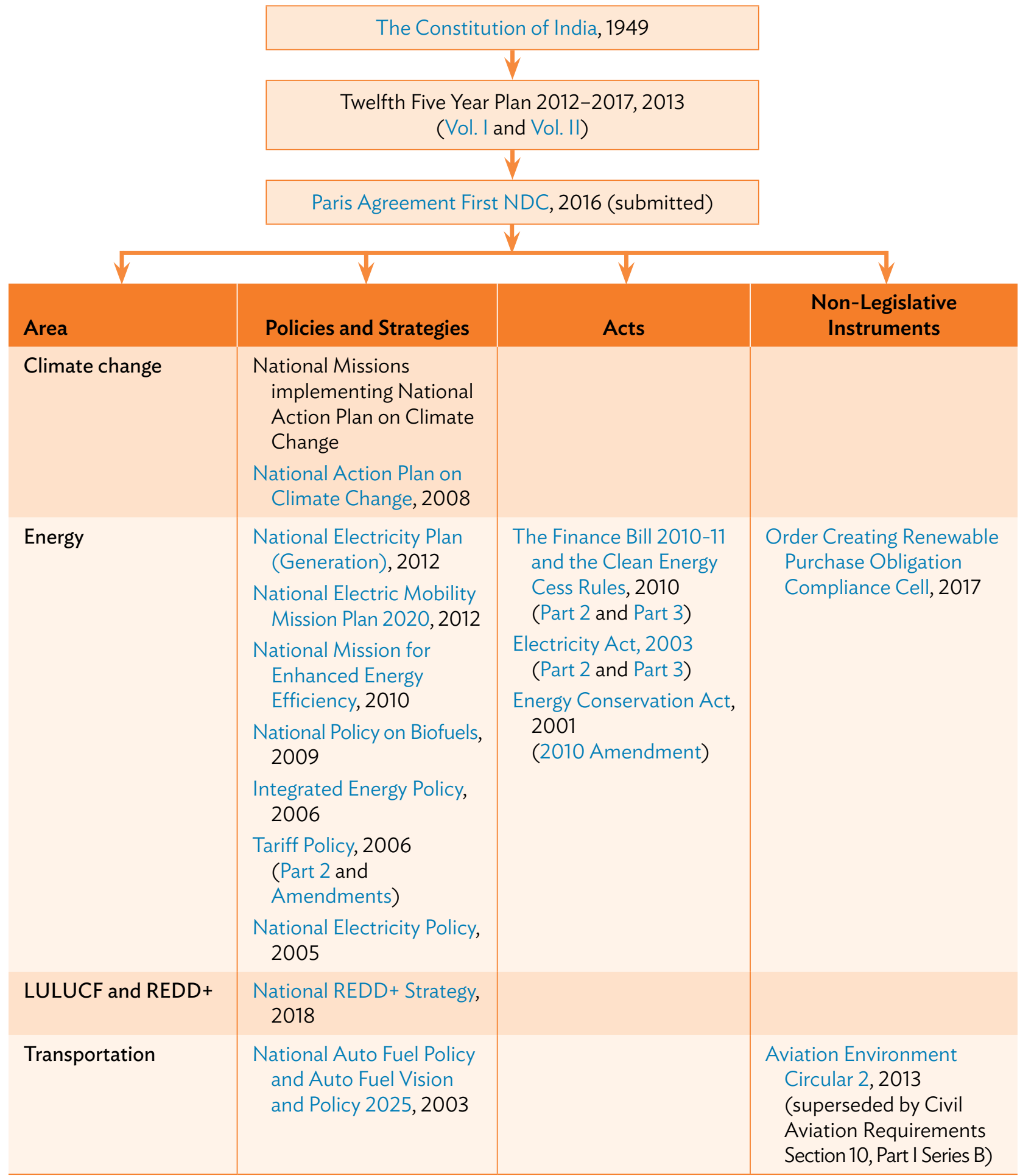


Table 4.4 continued

\begin{tabular}{|c|c|c|c|}
\hline Area & Policies and Strategies & Acts & $\begin{array}{l}\text { Non-Legislative } \\
\text { Instruments }\end{array}$ \\
\hline $\begin{array}{l}\text { Food production and } \\
\text { food security }\end{array}$ & $\begin{array}{l}\text { National Mission for } \\
\text { Sustainable Agriculture, } \\
2014 \text { (2017 Update) } \\
\text { National Food Security } \\
\text { Mission, } 2007 \\
\text { National Initiative on } \\
\text { Climate Resilient } \\
\text { Agriculture }\end{array}$ & & \\
\hline $\begin{array}{l}\text { Water resources } \\
\text { and coastal zone } \\
\text { management }\end{array}$ & $\begin{array}{l}\text { National Water Mission, } \\
2011 \text { (Volumes I and II) }\end{array}$ & & \\
\hline Cities and buildings & $\begin{array}{l}\text { National Mission on } \\
\text { Sustainable Habitat, } \\
2015\end{array}$ & & $\begin{array}{l}\text { Energy Conservation } \\
\text { Building Code, } 2017 \\
\text { National Building Code, } 2016\end{array}$ \\
\hline Industry & & & $\begin{array}{l}\text { Ministry of Communications } \\
\text { and IT: Directions on } \\
\text { Implementing Green } \\
\text { Technologies in Telecom } \\
\text { Sector, } 2012\end{array}$ \\
\hline Other & $\begin{array}{l}\text { National Environment } \\
\text { Policy, } 2006\end{array}$ & $\begin{array}{l}\text { The National Green } \\
\text { Tribunal Act, } 2010\end{array}$ & \\
\hline
\end{tabular}

LULUCF = land use, land-use change, and forestry; NDC = nationally determined contribution; REDD + = reducing emissions from deforestation and forest degradation, conservation of existing forest carbon stocks, sustainable forest management, and enhancement of forest carbon stocks.

Source: Authors.

\section{Energy Supply}

The latest data from India's Ministry of Power note that coal is the country's largest energy source, providing 55.3\% of total energy, followed by renewable energy sources (biomass, wind, waste, solar) at $23.8 \%$, and hydro at $12.3 \%{ }^{86}$ India's renewable power capacity of 118 gigawatts (GW) is the fifth-highest in the world, and the Indian government aims to reach $500 \mathrm{GW}$ by $2030 .{ }^{87}$ In the 2019 United Nations (UN) Climate Action Summit, India announced it would aim for $450 \mathrm{GW}$ of renewable energy capacity. ${ }^{88}$

86 Government of India, Ministry of Power. Power Sector at a Glance (accessed 18 September 2020).

87 S. Bailey and J. Defterios. 2019. ReNew Power: The Indian Unicorn Built on Green Energy. CNN. 15 July.

88 A. Jaiswal and S. Kwatra. 2019. India Announces Stronger Climate Action. Natural Resources Defense Council. Expert blog. 23 September. 


\section{Sector-Wide Energy Strategies}

In 2012, India issued energy-related policies: the National Electricity Plan of 2012 (Electricity Plan) ${ }^{89}$ and the National Electric Mobility Mission Plan 2020.90 The goal of the Electricity Plan was to ensure reliable electricity access nationwide. Recognizing the rapid pace of economic growth, the Electricity Plan sought to expand rural access to electric power and increase total generation while reducing the sector's emissions. The plan's targets included (i) technical modifications of power stations, (ii) thermal power plant renovations and retirements, (iii) hydroelectric power plant renovations, (iv) energy efficiency measures, (v) power distribution, and (vi) the improvement of coal quality.

In 2018, the government issued the new National Electricity Plan. ${ }^{91}$ The plan reinforces the government's commitment to transform the electricity sector and move quickly to address climate change. ${ }^{92}$ It also supports the government's goal of increasing renewable energy, closing coal power plants, and preparing for a low hydropower scenario (footnote 92).

The National Electric Mobility Mission Plan also supports low carbon growth and focuses on the development of domestic manufacturing capabilities and electric mobility in India. It emphasizes that transportation efficiency is intended to mitigate the impacts of transportation on climate change.

Previous energy-related executive policies include the Integrated Energy Policy of 2006 and the National Electricity Policy of 2005. ${ }^{93}$ Earlier, the Indian legislature passed the Electricity Act, 2003, which sought to coordinate power sector development, efficiency, and environmentalism.

\section{Renewable Energy Policies}

The government has promoted renewable and alternative sources of energy through the 2017 Order on Renewable Purchase Compliance and the 2009 Biofuels Policy. ${ }^{94}$ The 2006 Tariff Policy mandates that solar purchase obligation targets reach $3 \%$ by 2022 and that solar power, on the whole, reaches $100 \mathrm{GW}$ by $2022 .{ }^{95}$ The Tariff Policy is aligned with the National Solar Mission, which

89 Government of India, Ministry of Power, Heavy Industries and Public Enterprises. 2012. National Electricity Plan. Delhi.

90 Government of India, Ministry of Heavy Industries and Public Enterprises. 2012. National Electric Mobility Mission Plan 2020. Delhi.

91 Government of India, Ministry of Power. 2018. National Electricity Plan. Delhi.

92 T. Buckley and K. Shah. 2018. IEEFA India: New National Electricity Plan Reinforces Intent Toward 275 Gigawatts of Renewables-Generated Electricity by 2027. Institute for Energy Economics and Financial Analysis (IEEFA). 19 April.

93 Government of India, Planning Commission. 2006. Integrated Energy Policy; and Government of India. 2005. National Electricity Policy. Delhi.

94 Government of India. 2017. Order: Creation of Renewable Purchase Obligation. Delhi; and Government of India, Ministry of New and Renewable Energy. 2007. National Policy on Biofuels. Delhi.

95 Government of India. Ministry of Power. 2016. Tariff Policy. Delhi. 
promotes the generation of solar energy from small and large plants. ${ }^{96}$ Alongside the National Solar Mission are local projects such as the Solar Water Heater Program, Village Electrification Program, and Solar Photovoltaic Program. ${ }^{97}$

\section{Energy Demand}

In total, primary energy consumption in India reached 775 million tons of oil equivalent (Mtoe) in 2013 (footnote 74). The government has implemented legislation to reduce energy consumption. India's Energy Conservation Act, 2001 allows the central government to give certificates for energy savings to consumers who save energy relative to prescribed standards. Through this permitting approach to energy consumption, consumers who exceed standards can purchase such certificates.

Additionally, large consumers must adhere to consumption norms; new buildings must align with the Energy Conservation Building Code, 2017; and appliances must meet standards of energy performance. The Bureau of Energy Efficiency is responsible for enforcing the code. Energy efficiency increases further avoided $15 \%$ of energy demand and 300 tons of carbon dioxide $\left(\mathrm{tCO}_{2}\right)$ emissions over 2000-2018.98

Approved in 2010, the National Mission for Enhanced Energy Efficiency (Mission) aligns with the Energy Conservation Act, 2001 in its mandate to implement energy efficiency measures through the Bureau of Energy Efficiency in India. ${ }^{99}$ This Mission emerged from the responsibilities delegated by the NAPCC. Its major initiatives are enhancing the cost-effectiveness of energy efficiency implementation, increasing energy efficiency in appliances through improving affordability, creating mechanisms to finance demand-side management projects, and heightening energy efficiency through fiscal instruments.

In its 2014 amendment, the Mission emphasizes technology investments, venture capital creation, systems of appliance ratings, and an energy conservation building code. Most significantly, its Perform, Achieve, and Trade mechanism seeks to decrease emissions by 25 million tons annually by 2014-2015. ${ }^{100}$ Energy efficiency is also promoted through the Energy Conservation Building Code, 2017 and the National Mission on Sustainable Habitat. ${ }^{101}$

96 Government of India. 2010. Jawaharlal Nehru National Solar Mission. Delhi.

97 UNFCCC, Clean Development Mechanism (CDM). 2019. PoA 8855: Solar Water Heater Program in India; Government of India, Ministry of New and Renewable Energy. 2013. Remote Village Electrification Program; and UNFCCC, CDM. PoA 8426 : India Small Scale Solar PV Programme of Activities.

98 International Energy Agency. India: Key Energy Statistics, 2018 (accessed 9 July 2020).

99 Government of India. 2010. National Mission for Enhanced Energy Efficiency. Delhi.

100 Government of India, Bureau of Energy Efficiency. Perform, Achieve, and Trade Scheme; and Government of India, Ministry of Power. PAT Cycle. Delhi.

101 V. Shivaranjani. 2015. National Mission on Sustainable Habitat. Chennai, India: Centre for Development Finance. 


\section{E. Carbon Pricing}

The 2010 Finance Bill created the National Clean Energy Fund, a body that invests in research and entrepreneurship in clean energy fields. This fund allows projects from the private and public sectors to receive financing in the form of viability gap funding or loans. It sets a tax on coal at $\$ 0.81$ per ton. This tax was increased to $\$ 3.22$ per ton in 2015 to finance clean energy projects and research, as well as programs for environmental remediation. ${ }^{102}$ The interministerial group comprising heads from different government ministries was created to approve eligible projects.

\section{F. LULUCF and REDD+}

The National Mission for Green India (Green India) is part of the NAPCC. Green India recognizes the impact of forests on biodiversity conservation, food, livelihood and water security, and climate change mitigation. ${ }^{103}$ It models a participatory, decentralized approach to sustainability by involving grassroots organizations and communities in planning, implementing, and monitoring processes. It uses crosscutting interventions such as decentralizing forest governance, adding value through cross-sector program convergence, and bolstering investments to manage tree cover and protect forests. Specific objectives of the mission include increasing forest cover or forest quality in 10 million hectares of forestlands and non-forestlands and achieving enhanced annual $\mathrm{CO}_{2}$ sequestration by 50-60 million tons in the year $2020 .^{104}$

A REDD + national consultation was held in India in 2012, and the government established a technical group for assessing and monitoring REDD+ activities. Released in 2018, the National REDD+ Strategy aims to increase carbon sink up to 3 billion $\mathrm{tCO}_{2}$ equivalent by 2030 in alignment with India's NDC. ${ }^{105}$

\section{G. Cities and Buildings}

The National Building Code, 2016 and the Energy Conservation Building Code, 2017 contribute to India's climate change policy approach. The National Building Code establishes comprehensive guidelines to regulate construction. Specifically, it includes a preference for refrigerants with low global warming potential to decrease overall emissions of GHGs, aligning with the trend of hydrofluorocarbon phaseout.

The Bureau of Indian Standards is making revisions to incorporate sustainability into the National Building Code. The Energy Conservation Building Code helps decrease emissions by establishing the minimum requirements for energy

102 International Institute for Sustainable Development. The Evolution of the Clean Energy Cess on Coal Production in India; and Government of India, Department of Energy. 2017. National Clean Energy and Environment Fund. Delhi.

103 Government of India, Ministry of Environment and Forests. 2014. National Mission for a Green India. Delhi.

104 Footnote 103, p. 8.

105 Government of India, Ministry of Environment, Forest and Climate Change. 2018. National REDD+ Strategy: India. Delhi. 
efficiency in the design and construction of buildings. It also provides two sets of requirements so that enhanced energy efficiency incrementally raises standards beyond minimum regulations.

\section{H. Adaptation}

Receding glaciers, declining rainfall, and increasing flooding pose threats to water and food security in India, especially threatening natural ecosystems, rural households, and the coasts. ${ }^{106}$ In response to these challenges, the government has integrated adaptation efforts into its environmental policies. The National Mission for Sustaining the Himalayan Ecosystem concerns specifically climate change adaptation. It aims to develop management and policy measures to sustain and protect the Himalayan glacier and mountain ecosystem (footnote 106).

In July 2007, the United Nations Framework Convention on Climate Change (UNFCCC) launched the Adaptation Fund to address climate change impacts and develop resilience. The Adaptation Fund is financing six small-scale projects across India, implemented by the National Bank for Agriculture and Rural Development. ${ }^{107}$

\section{Subnational Activities}

All Indian states must prepare State Action Plans on Climate Change in alignment with the goals of the NAPCC. All 7 union territories and 29 states have completed or are currently preparing their plans.

\section{Maldives}

\section{A. Country Snapshot: Climate and Environmental Challenges}

Maldives, a low-lying island nation in the Indian Ocean, is a presidential republic consisting of approximately 1,190 islands, with its population spread over approximately 197 islands. ${ }^{108}$ Its economy relies on two climate-sensitive sectors: tourism and fisheries (footnote 108). It faces climate challenges typical to small island countries, e.g., its low-lying nature makes it vulnerable to climate change impacts (footnote 108). Higher ocean temperatures, increased ocean acidification, and extreme weather events threaten livelihoods and biodiversity. ${ }^{109}$ More than $60 \%$ of its inhabited islands experience severe beach erosion (footnote 109).

106 Government of India, Ministry of Science and Technology. 2010. National Mission for Sustaining the Himalayan Ecosystem. Delhi.

107 National Bank for Agriculture and Rural Development. Adaptation Fund under United Nations Framework Convention on Climate Change (UNFCCC).

108 Government of Maldives, Ministry of Environment and Energy. 2016. Maldives' First Nationally Determined Contribution. Malé.

109 Government of Maldives, Ministry of Environment and Energy. 2016. National Biodiversity Strategy and Action Plan, 2016-2025. Malé. 
Maldives' vulnerability to climate change is heightened by limited socioeconomic and technological capacities (footnote 108).

\section{B. Overarching Climate Change Legal and Policy Framework}

\section{Mitigation and Adaptation Targets}

In its nationally determined contribution (NDC) to the Paris Agreement, Maldives pledges an unconditional 10\% reduction in GHG emissions by 2030 from business as usual (BAU) levels (footnote 108). Maldives pledges as much as a $24 \%$ reduction by 2030 , conditional upon financial support, capacity building, and technology transfer. However, given Maldives' minimal contribution to global emissions, the NDC focuses on adaptation including enhancing food and water security, increasing infrastructure resilience and coastal protection, and addressing climate impacts on public health, tourism, and fisheries.

\section{Overview of Climate Change Law and Policy}

In its climate action, Maldives is prioritizing adaptation and low-emission development (footnote 108). Given Maldives' limited financial resources, capacity, and technology, its climate initiatives also focus on increasing access to support in these areas (footnote 108). In 2015, the Ministry of Environment and Energy launched the Climate Change Policy Framework (Climate Framework) to foster and guide a national climate action. ${ }^{10}$ The Climate Framework seeks to mainstream climate change by integrating the following principles into national lawmaking and development planning: intergenerational equity, climate leadership, international partnership, international commitments, climate resilience, and transfer of technology (footnote 110).

The Climate Framework includes five main policy targets: (i) increasing sustainable financial resources; (ii) cementing a low-emissions development strategy and energy security; (iii) developing stronger adaptation actions and climate resilience in communities and infrastructure; (iv) establishing a lead role in global climate change forums as an advocate for most vulnerable countries and small island developing states; and (v) promoting sustainable development. The Climate Framework identifies broad strategies to achieve each of the policy targets. A progress report in its fourth year and a midterm review in its fifth year are proposed to monitor and evaluate policy targets.

In addition to the Climate Framework, the Climate Change Bill was scheduled for submission to Parliament in 2017. The bill will address the adverse impacts of climate change, provide enforcement mechanisms, and facilitate Maldives' compliance with the international environmental conventions and protocols to which it is a party. The Ministry of Environment and Energy, the body responsible for drafting the Climate Change Bill, had not submitted the document at the time of writing.

110 Government of Maldives, Ministry of Environment and Energy. 2015. Climate Change Policy Framework. Malé. 
In 2009, the Maldives Climate Change Trust Fund was established to support a climate-resilient economy and society. ${ }^{111}$ The fund is managed by the World Bank and supports low-carbon development through mitigation and adaptation activities (footnote 111). The European Union and the Australian government pledged $\$ 10.3$ million to the first phase of the fund (footnote 111). Three projects have been implemented thus far: Wetlands Conservation and Coral Reef Monitoring for Adaptation to Climate Change, Clean Energy for Climate Mitigation, and Ari Atoll Solid Waste Management (a pilot project) (footnote 111).

The wetlands project supports community-based wetland management, rainwater harvesting, coral reef monitoring, and capacity building within local government. ${ }^{112}$ The clean energy project increases solar energy, energy conservation, and technical assistance related to renewable energy uptake. ${ }^{113}$ The waste management project supports the development of an island-level integrated solid waste management system and residual waste transfer system for off-island disposal on Ari Atoll. ${ }^{114}$

In 2015, the government initiated the second phase of the fund to support the Climate Change Adaptation Project, which was funded by the European Union. ${ }^{115}$ The project supports two southernmost atolls in undertaking an integrated approach to responding to climate risks, particularly the measures related to flood management, wetland management, biodiversity conservation, and integrated solid waste management.

Table 4.5 summarizes Maldives' climate change legal and policy framework.

\section{Energy Supply}

Imported petroleum fuels supply most of the energy in Maldives. ${ }^{116}$ In 2017, Maldives imported 561,435 metric tons of fuel (footnote 116). The majority of this fuel was diesel (80\%), with petrol (10\%), aviation gas (7\%), and cooking gas (3\%) also contributing to the energy supply mix (footnote 116). Diesel supports power generation and transportation by both the state power utility and private generators throughout the outer islands. Maldives has 11 megawatts ( $\mathrm{MW}$ ) of the total installed capacity of renewable energy (footnote 116).

111 Government of Maldives, Ministry of Environment and Energy. 2014. Social Assessment and Management Framework (Resettlement Policy Framework): Climate Change Adaptation Project. Malé. 26 November.

112 World Bank. Wetlands Conservation and Coral Reef Monitoring for Adaptation to Climate Change; and World Bank. 2015. Implementation Completion and Results Report: Wetland Conservation and Coral Reef Monitoring for Adaptation to Climate Change Project in Maldives.

113 World Bank. 2015. Implementation Completion and Results Report: Clean Energy for Climate Mitigation Project in Maldives.

114 World Bank. 2012. Integrated Safeguards Data Sheet: Ari Atoll Solid Waste Management Pilot Project in Maldives.

115 World Bank. 2015. International Development Association Project Appraisal Document: Climate Change Adaptation Project (CCAP) in Maldives. 7 May.

116 Government of Maldives, Ministry of Environment and Energy. 2018. Island Electricity Data Book 2018. Malé. 


\section{Table 4.5: Climate Change Legal and Policy Framework of Maldives}

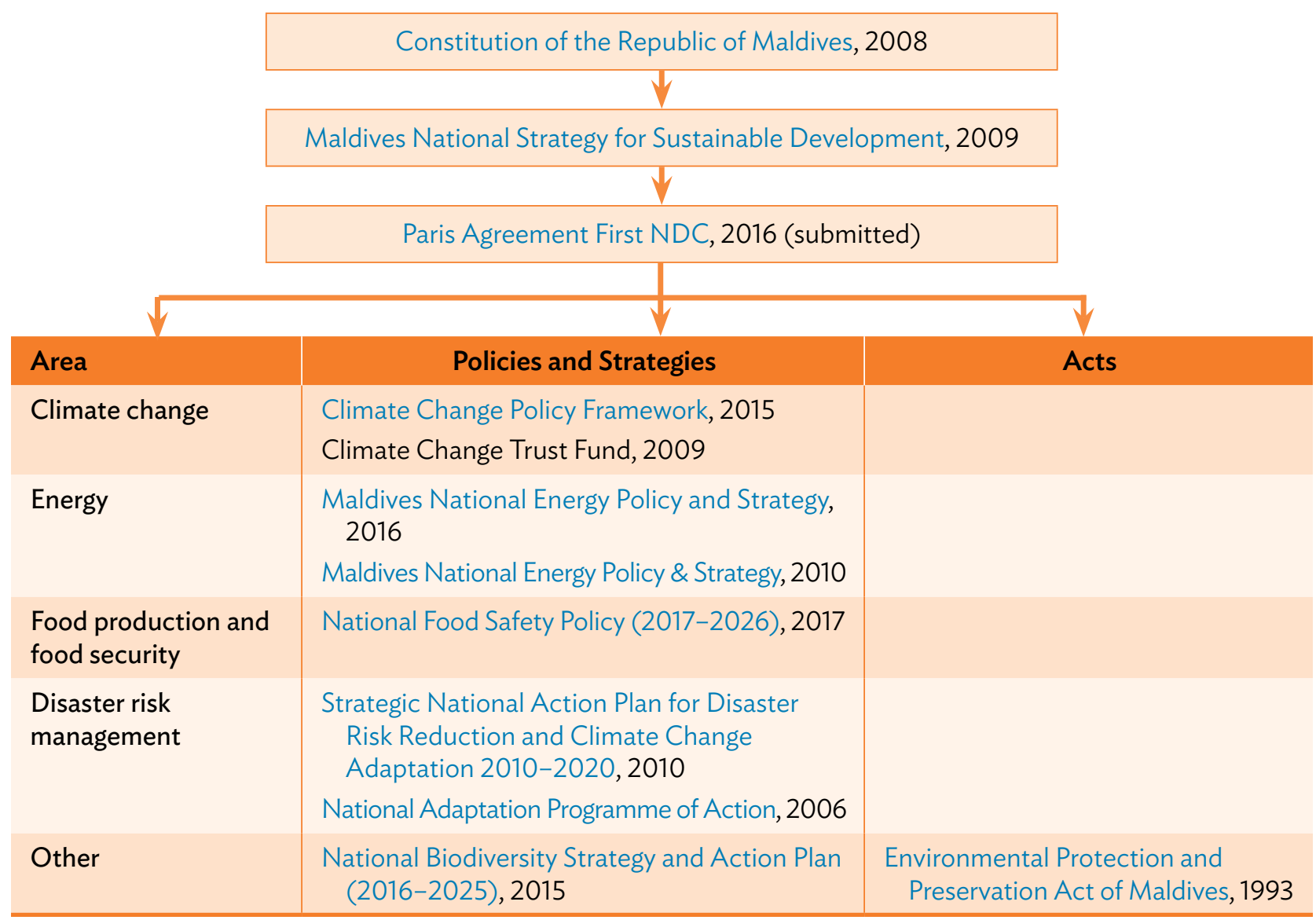

NDC $=$ nationally determined contribution.

Source: Authors.

\section{Sector-Wide Energy Strategies}

In 2010, the Ministry of Housing and Environment launched the National Energy Policy and Strategy (2010 Energy Policy), creating a national policy framework for energy. ${ }^{117}$ The 2010 Energy Policy explains that the goal to become carbon neutral-including in the energy sector-by 2020 depends on three factors: the dependence on foreign fuel; the threat of climate change; and the need to provide reliable, sustainable, and affordable energy to all citizens. It designates (i) the Climate Change and Energy Department within the Ministry of Housing and Environment as the lead agency of the energy sector, and (ii) the Maldives Energy Authority as the regulatory body.

To achieve carbon neutrality in the energy sector by 2020, the 2010 Energy Policy outlines key strategies:

117 Government of Maldives, Ministry of Housing and Environment. 2010. Maldives National Energy Policy and Strategy. Malé. 
(i) develop and implement energy use forecasts;

(ii) create and manage targets to reach carbon neutrality in the energy sector;

(iii) promote research and development of carbon capture and storage;

(iv) prioritize compliance of energy industries with environmental and safety standards;

(v) establish an environmental division in all of the energy sector utilities to facilitate compliance with the Environmental Protection and Preservation Act, 1993;

(vi) use disincentives and incentives to encourage demand- and supply-side energy efficiency;

(vii) use incentives to encourage greater use of electric vehicles and establish renewable charging stations;

(viii) promote indigenous renewable sources of energy through research and development, technology transfer, and concessionary external financing; and

(ix) strengthen the legal and institutional framework of the energy sector.

The 2010 Energy Policy also sets guiding principles that emphasize universal and equitable access to electricity, energy efficiency and conservation, low-carbon technologies and lifestyles, private sector involvement, and renewable technologies and local resources as an alternative to foreign fossil fuel dependence.

\section{Renewable Energy Policies}

The Ministry of Housing and Environment revised the 2010 Energy Policy, launching the 2016 Energy Policy and Strategy (2016 Energy Policy). ${ }^{118}$ The 2016 Energy Policy distills the nine focus areas of the 2010 policy into five: (i) strengthening regulations and institutions in the energy sector, (ii) promoting energy efficiency and conservation, (iii) increasing renewable energy use, (iv) improving the sustainability and reliability of electricity provision and ensuring electricity access, and (v) increasing energy security.

The 2016 Energy Policy acknowledges the challenges of transitioning to renewable energy due to the projected growth of annual electricity demand (8.5\% per year) and the fragmented nature of electricity generation and distribution facilities (each island has its own). In the short term, the 2016 Energy Policy sets a goal to produce at least $30 \%$ of daytime peak-load of electricity from renewable energy sources on all inhabited islands by 2018. One of the Energy Policy's strategies for increasing energy efficiency is the enforcement of emissions standards for point-source polluters. ${ }^{119}$

118 Government of Maldives, Ministry of Environment and Energy. 2016. Maldives Energy Policy and Strategy, 2016. Malé.

119 Footnote 118, p. 19, Strategy 2.07. 


\section{Energy Demand}

Maldives realized universal access to electricity by $2008 .{ }^{120}$ Almost $57 \%$ of all electricity generated supplies the greater Malé region-Malé, Villingili, and Hulhumalé (footnote 120). In 2018, the region had an installed capacity of $101 \mathrm{MW}$ and consumed about 400 gigawatt-hours (GWh), the nation's highest electricity consumption (footnote 120). Electricity consumption in the outer islands was $304 \mathrm{GWh}$ in 2017 (footnote 120). Maldives is experiencing increased electricity demand, with growth projected at $8.5 \%$ per annum (footnote 118 ). The 2016 Energy Policy includes goals to increase energy efficiency and conservation.

\section{E. Transportation}

Transport accounts for approximately a quarter of GHG emissions. ${ }^{121}$ These emissions, however, are rapidly increasing. For example, there was a 295\% increase in vehicle registrations from 2007 to 2014 (footnote 121). Given this context, the government drafted the Low Carbon Strategy for the Transport Sector in 2014 (Transport Strategy) (footnote 121). The Transport Strategy aims to mitigate GHG emissions from transport through various measures including promoting eco-sensitive driving behavior, fostering low-carbon technology for aircraft and other vessels, and establishing energyefficient infrastructure and reengineered roads for low-carbon transport.

The Transport Strategy also recommends that laws and regulations governing low-carbon transport should be implemented in the short term. In the long term, the Transport Strategy recommends establishing a sustainable financing mechanism in conjunction with subsidies or other fiscal mechanisms to support a low-carbon transport sector. The Transport Strategy was also made available for public comment.

\section{F. Adaptation}

Maldives is highly committed to adaptation and dedicated a significant portion of its NDC to adaptation measures (footnote 108). The NDC sets the following adaptation priorities:

(i) enhancing food security through climate risk insurance for farmers, food storage and distribution facilities, and alternative technologies to build more resilient local agriculture;

(ii) building infrastructure resilience through coastal protection for airports, relocating the Malé commercial port to another island, climate proofing all critical infrastructures, and establishing the National Building Code and the National Development Act that integrates climate- and weather-related concerns into relevant planning;

120 Government of Maldives, Ministry of Environment and Energy. 2018. Island Electricity Data Book 2018. Malé. p. 10.

121 Government of Maldives, Ministry of Environment and Energy. 2014. Low Carbon Strategy for the Transport Sector. Malé. 
(iii) protecting public health through vector surveillance and control programs;

(iv) enhancing water security through the Integrated Water Resource Management Schemes, which include rainwater harvesting, desalinization, and groundwater recharging;

(v) enhancing coastal protection through shore protection and reclamation and land elevation;

(vi) safeguarding coral reefs and their biodiversity through an ecosystem approach to conservation and a reduction of local pollution sources;

(vii) protecting tourism through an insurance mechanism and a "green tax" (a tax on environmentally harmful activities) to fund environmental management;

(viii) supporting fisheries through diversification, access to financing for agriculture, and a stronger insurance mechanism;

(ix) improving early warning systems and climate forecasting;

(x) securing sustainable financing; and

(xi) improving climate governance through national adaptation plans, passing a climate change law, and continuing to build domestic capacity.

The government also prepared the National Adaptation Programme of Action (NAPA) to present a comprehensive framework for adaptation. ${ }^{122}$ The NAPA aims to enhance the resilience of natural, human, and social systems in the face of adverse climate impacts. It also acknowledges that adaptation is a priority for Maldives and other low-lying island states.

Recognizing the impact of climate change on national food security, the Ministry of Health prepared the National Food Safety Policy, 2017-2026. ${ }^{123}$ The policy contains four policy goals including strengthening the food chain to ensure the safety, health, and quality of food. In 2016, the government released the National Biodiversity Strategy and Action Plan, 2016-2025 to enhance climate resilience of coral reefs, wetlands, mangroves, and other vulnerable ecosystems (footnote 109).

\section{G. Disaster Risk Management}

The Strategic National Action Plan for Disaster Risk Reduction and Climate Change Adaptation was implemented in 2010, recognizing the severe risk that sea level rise poses to Maldives. ${ }^{124}$ It seeks to create a more integrated approach to disaster risk reduction and management and principally aims to address four strategic areas: good governance, empowering communities, building resilient communities with sufficient access to resources, and risk-sensitive development.

122 Government of Maldives, Ministry of Environment, Energy and Water. 2006. National Adaptation Programme of Action (NAPA). Malé.

123 Government of Maldives, Ministry of Health. 2017. National Food Safety Policy (2017-2026). Malé.

124 Government of Maldives, National Disaster Management Authority. 2010. Strategic National Action Plan for Disaster Risk Reduction and Climate Change Adaptation, 2010-2020. Malé. 


\section{Nepal}

\section{A. Country Snapshot: Climate and Environmental Challenges}

Nepal, a landlocked country in South Asia, is a democratic multiparty federal republic. Its mountainous geography makes it extremely vulnerable to climate change. Rising temperatures in the Himalayas are resulting in higher volumes of meltwater runoff, flooding natural dams and causing glacial lake outburst floods (GLOFs). ${ }^{125}$ GLOFs endanger downstream communities and those who depend on fresh water from rivers and streams. ${ }^{126} \mathrm{Nepal}$ has also experienced deadly and costly landslides and drought. ${ }^{127}$

\section{B. Overarching Climate Change Legal and Policy Framework}

\section{Mitigation and Adaptation Targets}

Nepal has actively participated in climate change negotiations under the UNFCCC and served as chair of the 2013 and 2014 least developed countries coordination group. Nepal's first nationally determined contribution (NDC) to the Paris Agreement includes a commitment to formulating national adaptation plans, improving adaptation strategies, and creating the Low Carbon Economic Development Strategy. ${ }^{128}$ By 2050, Nepal seeks to achieve $80 \%$ renewable electricity and a $50 \%$ reduction in fossil fuel dependence. Additionally, the government commits to clean energy quotas and aims to maintain as forest no less than $40 \%$ of its total land area. Nepal's NDC does not include any economywide emissions reduction targets.

\section{Overview of Climate Change Law and Policy}

Nepal has largely taken a policy-based approach in addressing climate change and has not yet passed any binding climate legislation. ${ }^{129}$ The government has named the Ministry of Forest and Environment as the national authority for implementing and coordinating Climate Change Policy, 2011. ${ }^{130}$ Within this

125 Government of Nepal, Ministry of Population and Environment. 2016. Nationally Determined Contributions. Kathmandu; and K. Cook et al. 2018. Glacial Lake Outburst Floods as Drivers of Fluvial Erosion in the Himalaya. Science. 362 (6410). pp. 53-57.

126 K. Cook et al. 2018. Glacial Lake Outburst Floods as Drivers of Fluvial Erosion in the Himalaya. Science. 362 (6410). pp. 53-57.

127 R. Sapkota and K. Rijal. 2016. Climate Change and Its Impacts in Nepal. Kathmandu: Tribhuvan University.

128 Government of Nepal, Ministry of Population and Environment. 2016. Nationally Determined Contributions. Kathmandu.

129 In 2018, the Supreme Court of Nepal directed the government to pass a national climate law. See Advocate Padam Bahadur Shrestha vs Prime Minister and Office of Council of Ministers and Others, Case No. 074-WO-0283, Supreme Court of Nepal, 25 December 2018 (2075/09/10 BS).

130 Footnote 128. The first NDC named the Ministry of Population and Environment as the responsible ministry, but accountability has since shifted to the Ministry of Forest and Environment. 
ministry, the Climate Change Management Division was established in 2010. ${ }^{131}$ Additionally, there is the Climate Change Council-led by the Prime Ministerand the Climate Change Initiatives Coordination Committee, which seeks to represent national and international nongovernment organizations (NGOs), the private sector, donors, and other institutions (footnote 128). These entities are responsible in part for aligning climate change with development activities (footnote 128).

The Climate Change Policy, 2011 represents Nepal's primary climate change document. ${ }^{132}$ Through sustainable development and environmental conservation, this policy seeks to limit climate change impacts-including those on agriculture, water resources, biodiversity and forests, tourism, human health, quality of life, and infrastructure developments.

The policy's two main goals are (i) enhancing livelihood opportunities through mitigation and adaptation measures, and (ii) adopting low-carbon development while adhering to national and international climate commitments. It also aims to establish a climate change center to conduct research, provide technical and political advice to the government, initiate local adaptation actions, and monitor outcomes. Additionally, the policy provides for the preparation of a strategy for carbon trading to benefit from the Kyoto Protocol's Clean Development Mechanism (CDM) as well as a strategy for low-carbon socioeconomic development. The National Framework on Local Adaptation Plans for Action ${ }^{133}$ and the National Adaptation Programme of Action (NAPA) to Climate Change ${ }^{134}$ support policy implementation.

Nepal has integrated its Climate Change Policy, 2011 into development planning. For example, the Nature Conservation National Strategic Framework for Sustainable Development, 2015-2030 aims to promote climate change awareness, ecosystem services payments, and value additions for renewable energy, and to implement the Climate Change Policy, 2011. ${ }^{135}$

Table 4.6 summarizes Nepal's climate change legal and policy framework.

\section{Energy Supply}

Primary energy supply in Nepal in 2014 includes biomass (80\%), oil products (12\%), coal (4\%), hydro (3\%), and electricity (1\%). ${ }^{136}$

131 Government of Nepal, Ministry of Forests and Environment. Climate Change Management Division.

132 Government of Nepal. 2011. Climate Change Policy, 2011. Kathmandu.

133 Government of Nepal, Ministry of Environment. 2011. National Framework on Local Adaptation Plans for Action. Kathmandu.

134 Government of Nepal, Ministry of Environment. 2010. National Adaptation Programme of Action (NAPA) to Climate Change. Kathmandu.

135 Government of Nepal, National Planning Commission. 2015. Nature Conservation National Strategic Framework for Sustainable Development (2015-2030). Kathmandu.

136 Asian Development Bank. 2017. Nepal Energy Sector Assessment, Strategy, and Road Map. Manila; World Bank. GDP Growth (Annual \%)—Nepal (accessed 19 December 2019). 


\section{Table 4.6: Climate Change Legal and Policy Framework of Nepal}

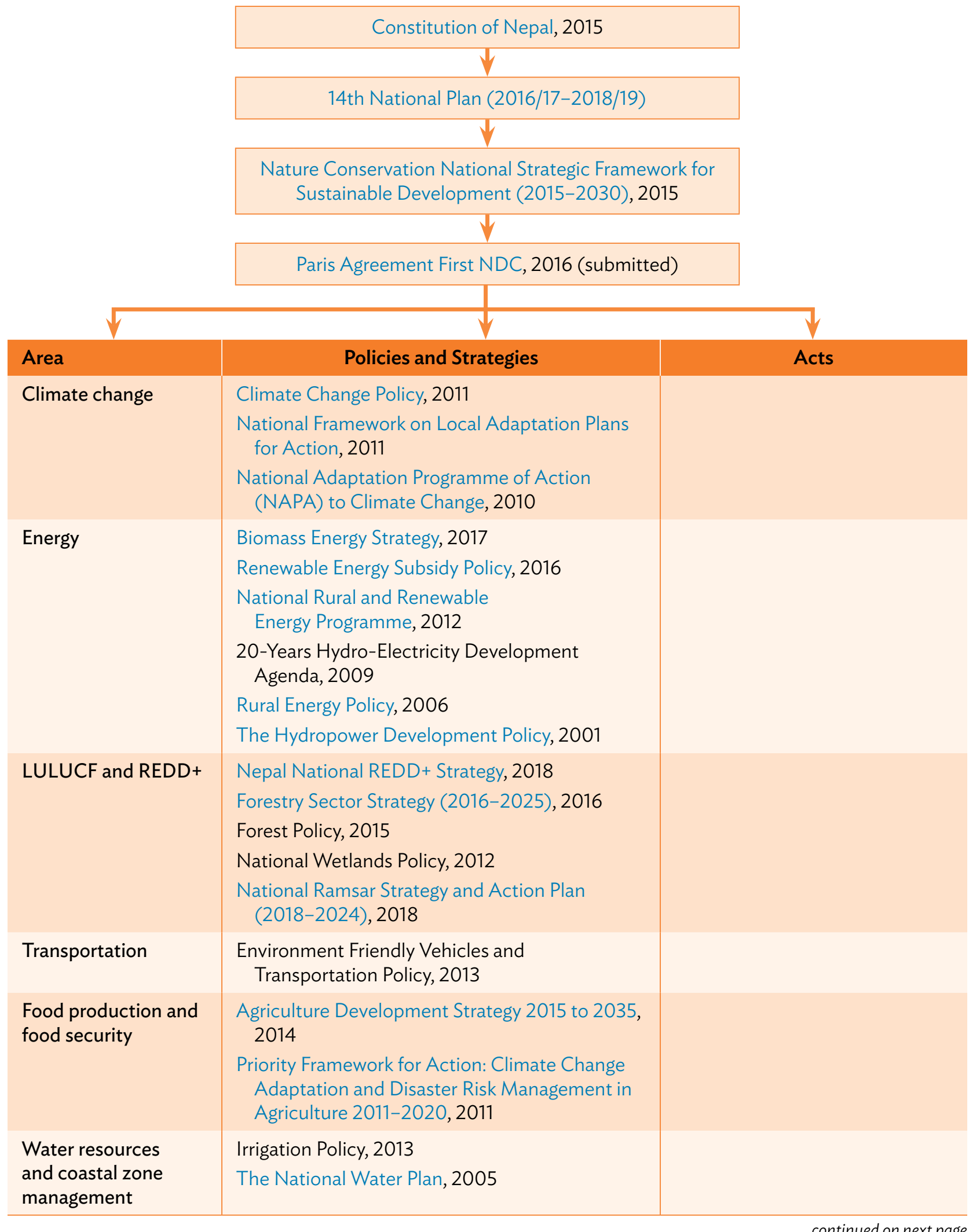


Table 4.6 continued

\begin{tabular}{|c|c|c|}
\hline Area & Policies and Strategies & Acts \\
\hline Cities and buildings & $\begin{array}{l}\text { National Urban Development Strategy, } \\
2017 \text { (Part A, and B) }\end{array}$ & \\
\hline Industry & & $\begin{array}{l}\text { Industrial Enterprises Act, } 2020 \\
\text { (English Summary) }\end{array}$ \\
\hline $\begin{array}{l}\text { Disaster risk } \\
\text { management }\end{array}$ & $\begin{array}{l}\text { National Disaster Response Framework, } 2013 \\
\text { National Strategy for Disaster Risk Management } \\
\text { in Nepal, } 2008 \\
\text { National Disaster Risk Reduction Strategic } \\
\text { Action Plan (2018-2030), } 2018\end{array}$ & $\begin{array}{l}\text { Disaster Risk Mitigation and } \\
\text { Management Act, } 2017\end{array}$ \\
\hline Other & $\begin{array}{l}\text { National Biodiversity Strategy and Action Plan } \\
\text { 2014-2020, } 2014 \\
\text { Environment-Friendly Local Governance } \\
\text { Framework, } 2013\end{array}$ & $\begin{array}{l}\text { Local Government Operation } \\
\text { Act, } 2017\end{array}$ \\
\hline
\end{tabular}

LULUCF = land use, land-use change, and forestry; NDC = nationally determined contribution; REDD+ = reducing emissions from deforestation and forest degradation, conservation of existing forest carbon stocks, sustainable forest management, and enhancement of forest carbon stocks.

Source: Authors.

\section{Renewable Energy Policies}

The current renewable energy capacity in Nepal is high. Solar grid potential has been estimated at 2,100 megawatts (MW), and wind potential at 3,000 MW.137 The government's policy approach encourages the uptake of renewable and alternative energy sources. Specifically, the 20-Years Hydro-Electricity Development Agenda of 2009 aims to develop 10,000 MW of hydropower within 10 years to further diversify energy supply. ${ }^{138}$ This development agenda expressly recognizes that Nepal has experienced the effects of climate change. The Hydropower Development Policy, 2001 outlines hydropower development and export strategies including the provision of rural electricity. ${ }^{139}$ More recent policies include the Biomass Energy Strategy 2017 and the Renewable Energy Subsidy Policy, 2016.140 Ultimately, all policies seek to contribute to environmental protection by increasing alternative and renewable energy sources.

Energy policies also prioritize rural electricity access, as $80 \%$ of Nepal's population is rural. ${ }^{141}$ For example, the National Rural Renewable Energy Program

137 S. Ghimire and Z. Naeen. 2017. Renewable Energy: Huge Potentials. The Himalayan Times. 6 October.

138 Government of Nepal. 2009. 20-Years Hydro-Electricity Development Agenda. Kathmandu.

139 Government of Nepal, Ministry of Water Resources. 2001. The Hydropower Development Policy, 2001. Kathmandu.

140 Government of Nepal, Ministry of Population and Environment. 2017. Biomass Energy Strategy 2017. Kathmandu; Government of Nepal, Ministry of Population and Environment. 2016. Renewable Energy Subsidy Policy, 2073 BS. Kathmandu.

141 World Bank. Rural Population (\% of Total Population)—Nepal (accessed 19 December 2019). 
(NRREP) of 2012 seeks to improve living standards, increase employment and productivity, decrease energy dependency, and attain sustainable development. ${ }^{142}$ The NRREP plans to accomplish these tasks by integrating alternative energy sources into rural communities' socioeconomic activities. It emphasizes poverty reduction as well as enhancing technical support and business development to deploy renewable energy in rural areas. The Central Renewable Energy Fund is the NRREP's main financial institution.

Predating the NRREP, the Rural Energy Policy, 2006 aimed to increase rural energy security and decrease fossil fuel dependence by promoting biogas, solar energy, wind energy, cleaner cookstoves, and better water mill technology. ${ }^{143}$

\section{LULUCF and REDD+}

Forest degradation and deforestation occur at high rates in Nepal due to overharvesting, high forest dependency, poverty, challenges of effective governance, and a desire for agricultural expansion. ${ }^{144}$ The forestry-related policy generally emphasizes community-based, decentralized forest management (footnote 144).

The Ministry of Forests and Environment is responsible for implementing the National REDD+ Strategy of Nepal of 2018. ${ }^{145}$ The ministry established a specific REDD + department, which is responsible for forest conservation efforts, modern farming development, and biodiversity protection. The National REDD+ Strategy of Nepal seeks "to strengthen the resilience of forest ecosystems for emission reductions and [increase] environmental, social, and economic benefits through improved policies, measures and institutions with enhanced stakeholder capacity, capability and inclusiveness." 146

Major activities include the (i) application of community forestry, (ii) increase in in-situ ecosystem conservation, (iii) expansion of watershed management services and soil conservation, and (iv) implementation of awareness campaigns. Community forestry is especially highlighted. The National REDD+ Strategy calls for climate change vulnerability assessments in forest ecosystems as well as linkages between land use planning and climate change. It also provides climate change mitigation actions through payment mechanisms and an emphasis on education.

142 Government of Nepal. 2012. Project Document: Renewable Energy for Rural Livelihoods (RERL). Kathmandu.

143 Government of Nepal, Ministry of Environment. 2006. Rural Energy Policy, 2006. Kathmandu.

144 N. Paudel et al. 2013. The Context of REDD+ in Nepal: Drivers, Agents and Institutions. Occasional Paper. No. 81. Bogor, Indonesia: Center for International Forestry Research.

145 Government of Nepal, Ministry of Forests and Environment. 2018. Nepal National REDD+ Strategy. Kathmandu. REDD+ means reducing emissions from deforestation and forest degradation, conservation of existing forest carbon stocks, sustainable forest management, and enhancement of forest carbon stocks.

146 Government of Nepal, Ministry of Forests and Environment. 2018. Nepal National REDD+ Strategy. Kathmandu. p. 15. 
Additionally, the Forestry Sector Strategy, 2016-2025 outlines forestry sector development in Nepal to sustainably manage biodiversity, forest ecosystems, and watersheds. ${ }^{147}$ Its principles include the promotion of a decentralized, inclusive, well-governed, and competitive forestry sector that provides equitable opportunities for livelihood and income. The strategy's major thematic areas include forest management, ecosystem management and biodiversity conservation, climate change response (through resilience and mitigation), watershed management, economic development, capacity enhancement, and information management.

The government issued the Forest Sector Strategy of 2016-2025 after the Forest Policy of Nepal, 2015, which emphasizes forest protection. ${ }^{148}$ The Forestry Sector Strategy prescribes various policies including plans to increase local capacity to respond to climate change through resilience, adaptation, and mitigation. It prioritizes optimum land use and technology access, and focuses on implementing climate-friendly forest management and improving food security, water disaster control, technological development, agenda creation, and research.

\section{E. Agriculture}

Agriculture and food security represent a major component of Nepal's climate policy. Over half the population directly engages in farming, while agriculture comprises more than one-third of the gross domestic product (GDP). ${ }^{149}$ The Constitution of Nepal, which has provisions for environmental protection, outlines agriculture and land reform mandates.

Most recently, the Agriculture Development Strategy (ADS) of 2015-2035 has sought to shape food-and farming-related decisions in Nepal. ${ }^{150}$ Drafted by the Ministry of Agricultural Development in coordination with the National Peasants' Coalition, the ADS provides an action plan and road map toward achieving four major targets: productivity, good governance, competitiveness, and commercialization. In attaining these goals, the ADS promotes inclusivity, sustainability, economic development, and infrastructure connectivity. Expected results include increases in food security, trade competitiveness, prosperity, and farmers' rights.

The ADS also contains specific provisions on climate change resilience, including (i) researching stress-tolerant crop, fish, and livestock varieties that also have high yields; (ii) developing an early warning system specifically for food security; and (iii) establishing weather indices and climate information systems for farmers.

147 Government of Nepal, Ministry of Forests and Soil Conservation. 2016. Forestry Sector Strategy (2016-2025). Kathmandu.

148 Government of Nepal, Ministry of Forests and Soil Conservation. 2015. Forest Policy of Nepal of 2015. Kathmandu.

149 S. Bhusal. 2019. Agricultural Impacts of Climate Change and the Climate Change Adaptations-A Nepalese Context Review. Acta Scientific Agriculture. 3 (7). pp. 234-238.

150 Government of Nepal, Ministry of Agricultural Development. 2016. Agricultural Development Strategy (ADS) 2015 to 2035. Kathmandu. 
In 2011, the Priority Framework for Action, 2011-2020 set sector-wide goals for agricultural changes in Nepal. ${ }^{151}$

Agricultural concerns are also embedded in prominent multisector policies, including the National Biodiversity Strategy and Action Plan, 2014-2020;152 the National Water Plan, 2005; $; 153$ and the Climate Change Policy, 2011 (footnote 132).

\section{F. Water}

Climate change is exacerbating drought and flooding in Nepal. ${ }^{154}$ The National Water Plan, 2005-a multisector strategic document-covers all major waterrelated sectors such as fisheries, hydroelectric power, tourism, and agriculture. Specific goals of the plan include improving data dissemination, increasing the number of rainfall stations, equipping the stations with telemetry systems to assist in flood and weather forecasting, and expanding the Department of Hydrology and Meteorology station's network to meet the standards of the World Meteorology Organization.

Furthermore, the 2013 Irrigation Policy specifically targets the planning and management of seasonal rain for year-round irrigation. ${ }^{155}$ This policy advocates for measures such as rainwater harvesting and underground water development. It also dictates that climate change and disaster risk management must be integrated for effective climate change adaptation and mitigation, and that all irrigation systems must be sustainable.

\section{G. Adaptation}

Nepal has begun to integrate climate resiliency into development planning. For example, the Climate Change Policy, 2011 and the NAPA highlight climate resiliency as a means to decrease vulnerability to climate change (footnote 134).

The Nepal Climate Change Support Programme focused on climate change adaptation in vulnerable communities. ${ }^{156}$ During its first phase, the program designed local adaptation plans for 100 vulnerable villages in 14 districts and

151 Government of Nepal, Ministry of Agriculture and Cooperatives. 2011. Climate Change Adaptation and Disaster Risk Management in Agriculture: Priority Framework for Action, 2011-2020. Kathmandu.

152 Government of Nepal, Ministry of Forests and Soil Conservation. 2014. Nepal National Biodiversity Strategy and Action Plan, 2014-2020. Kathmandu.

153 Government of Nepal, Water and Energy Commission. 2005. National Water Plan Nepal. Kathmandu.

154 M. Karki, P. Mool, and A. Shrestha. 2009. Climate Change and Its Increasing Impacts in Nepal. The Initiation. 3. pp. 30-37.

155 Government of Nepal, Water and Energy Commission. 2013. Irrigation Policy. Kathmandu.

156 United Nations Development Programme (UNDP) Nepal. Nepal Climate Change Support Programme (NCCSP). 
aimed to implement local action plans in each district. ${ }^{157}$ The government and international donors extended the program, implementing climate resilient development projects with 26 local governments (footnote 157). Of the program's 78 projects, 66 were implemented by local users' committees (footnote 157).

\section{H. Disaster Risk Management}

The Disaster Risk Mitigation and Management Act, 2017 is a climate changerelated piece of legislation that repealed and replaced the Natural Calamity Relief Act, 1982. Specifically, it established the Disaster Risk Reduction and Management Council to increase cooperation among local and national authorities. Priority areas include the protection of both private and public property, public life, cultural and national heritages, and those at risk from disasters such as flooding, earthquakes, and landslides. The act also addresses issues related to land use and river control.

Examples of disaster risk management policies are the National Disaster Response Framework of $2013^{158}$ and the National Strategy for Disaster Risk Management, 2009. ${ }^{159}$ Published by the Ministry of Home Affairs, the framework facilitates efficiency and coordination to improve large-scale disaster response. It addresses actions taken before, during, and after the disasters; the maintenance of law and order; the care for vulnerable people; and the protection of public property (footnote 158). It extends to national, regional, district, and local governments.

\section{Pakistan}

\section{A. Country Snapshot: Climate and Environmental Challenges}

Pakistan is a federal parliamentary republic in South Asia. It has faced extreme weather events, including droughts, floods, cyclones, heat waves, and glacial lake outbursts, weakening property, livelihoods, and economic growth. ${ }^{160}$ Climate change projections predict average temperature warming in the region to exceed the global mean, affecting the timing and strength of monsoon rainfall (footnote 160). As of 2015, Pakistan ranked 135th in the world on per capita greenhouse gas (GHG) emissions and 31st on total GHG emissions (footnote 160). Climate change is expected to significantly impact water-dependent sectors such as agriculture and industry (footnote 160).

157 UNDP. 2019. Nepal Climate Change Support Programme 1-Transition Extension. Kathmandu: UNDP.

158 Government of Nepal, Ministry of Home Affairs. 2013. National Disaster Response Framework (NDRF). Kathmandu.

159 Government of Nepal, Ministry for Home Affairs. 2009. National Strategy for Disaster Risk Management, 2009. Kathmandu.

160 ADB. 2017. Climate Change Profile of Pakistan. Manila. 


\section{B. Overarching Climate Change Legal and Policy Framework}

\section{Mitigation and Adaptation Targets}

Pakistan's first nationally determined contribution arose from its development vision outlined in Pakistan 2025: One Nation, One Vision (Pakistan 2025). ${ }^{161}$ Pakistan pledges to reduce as much as $20 \%$ of its projected GHG emissions by 2030 , conditional upon international grant availability. Pakistan also aims to increase forest cover from $6 \%$ to $10 \%$ by 2030 , including through large-scale tree plantation programs.

\section{Overview of Climate Change Law and Policy}

Pakistan employs a combination of legislation and policies to address climate change. Most recently, the government passed the Climate Change Act, 2017 to meet Pakistan's international climate obligations and ensure the adoption of effective adaptation and mitigation policies and programs. The act created the Pakistan Climate Change Council, led by the Prime Minister, which is responsible for all climate-related tasks. Specifically, the council's roles include

(i) supervising and coordinating enforcement;

(ii) overseeing the implementation of international agreements that concern climate change;

(iii) facilitating the integration of climate change-related concerns into governmental decision-making;

(iv) approving and monitoring the implementation of policies surrounding mitigation and adaptation, including those in relation to the Sustainable Development Goals;

(v) monitoring the implementation of Pakistan's National Adaptation Plan, Nationally Appropriate Mitigation Action Framework, and National Communication to the UNFCCC Secretariat; and

(vi) overseeing guidelines surrounding biodiversity, habitat, and resource protection.

The Climate Change Act, 2017 also established the Pakistan Climate Change Authority to develop climate-related policies and projects and advise the government on how to implement Pakistan's international climate change obligations.

Another cornerstone climate document is the National Climate Change Policy of 2012. ${ }^{162}$ It seeks "to ensure that climate change is mainstreamed in the economically and socially vulnerable sectors of the economy and to steer

161 Government of Pakistan. 2016. Pakistan's First Nationally Determined Contribution. Islamabad; and Government of Pakistan, Ministry of Planning, Development and Reform (Planning Commission). 2014. Pakistan 2025: One Nation - One Vision. Islamabad.

162 Government of Pakistan, Ministry of Environment. 2012. National Climate Change Policy. Islamabad. 
Pakistan towards climate-resilient development." 163 The Ministry of Environment developed the policy in collaboration with various federal institutions, provinces, and civil society.

The policy established climate change policy implementation committees at the federal and provincial levels to build greater cohesion in national climate responses (footnote 160). Chaired by the federal minister of climate change, the national committee meets biannually and is mandated to update the climate change policy every 5 years (although the policy has not been updated since its first iteration in 2012). The national committee reports to the Prime Minister's Committee on Climate Change, the overarching body for climate change monitoring (footnote 160).

Subsequently, the government adopted the Framework for Implementation of Climate Change Policy, 2014-2030 (Implementation Framework) to build on the National Climate Change Policy by establishing and scheduling priority actions in targeted sectors. ${ }^{164}$ Intended to be a catalyst for mainstreaming climate change into government decisions, the Implementation Framework acknowledges that Pakistan is highly vulnerable to the adverse impacts of climate change, especially extreme events. The Implementation Framework thus focuses on adaptation across vulnerable ecosystems and various sectors including water, agriculture, forestry, coastal areas, biodiversity, and health.

Affirming Pakistan's role in limiting average global temperature increase-though its contribution to GHG emissions is small-the Implementation Framework outlines "mitigation efforts in sectors such as energy, forestry, transport, industries, urban planning, agriculture and livestock." 165 Finally, the framework includes actions concerning disaster preparedness.

Development plans also address climate change as a cross-cutting issue. Created in 2014, Pakistan 2025 is a multisector national development plan, recognizing that climate change is a threat to development and that adaptation and mitigation are necessary to sustain growth. ${ }^{166}$ Pakistan 2025 outlines 25 goals to meet the Sustainable Development Goals and the Millennium Development Goals by 2030. Goals related to climate change include doubling the generation of power to exceed 45,000 megawatts (MW), increasing electricity access from $67 \%$ to $90 \%$ of the population, increasing the generation mix to $15 \%$, and decreasing distribution losses to 10\% (footnote 166). Additionally, Pakistan 2025 contains targets for indigenous power generation, increasing energy efficiency in appliances and products, increasing water storage capacity, improving agricultural water use efficiency, providing clean drinking water, and decreasing food insecurity.

163 Footnote 162, p. 1.

164 Government of Pakistan, Climate Change Division. 2013. Framework for Implementation of Climate Change Policy (2014-2030). Islamabad.

165 Footnote 164, p. 1.

166 Government of Pakistan, Ministry of Planning, Development and Reform (Planning Commission). 2014. Pakistan 2025: One Nation - One Vision. Islamabad. 
The National Sustainable Development Strategy of 2012 is another development document that addresses climate change, defining sustainable development and the pathway to a green economy. ${ }^{167}$ It sets an overarching goal of achieving "a vibrant and equitable economic growth" with benefits for all, especially the vulnerable and the poor. ${ }^{168}$ Furthermore, the strategy calls for economic growth that avoids degradation and excessive exploitation of natural resources. Recognizing that climate change may undermine future planning for sustainable development, the strategy created the National Climate Change Policy and the National Climate Change Fund.

Table 4.7 summarizes Pakistan's climate change legal and policy framework.

\section{Table 4.7: Climate Change Legal and Policy Framework of Pakistan}

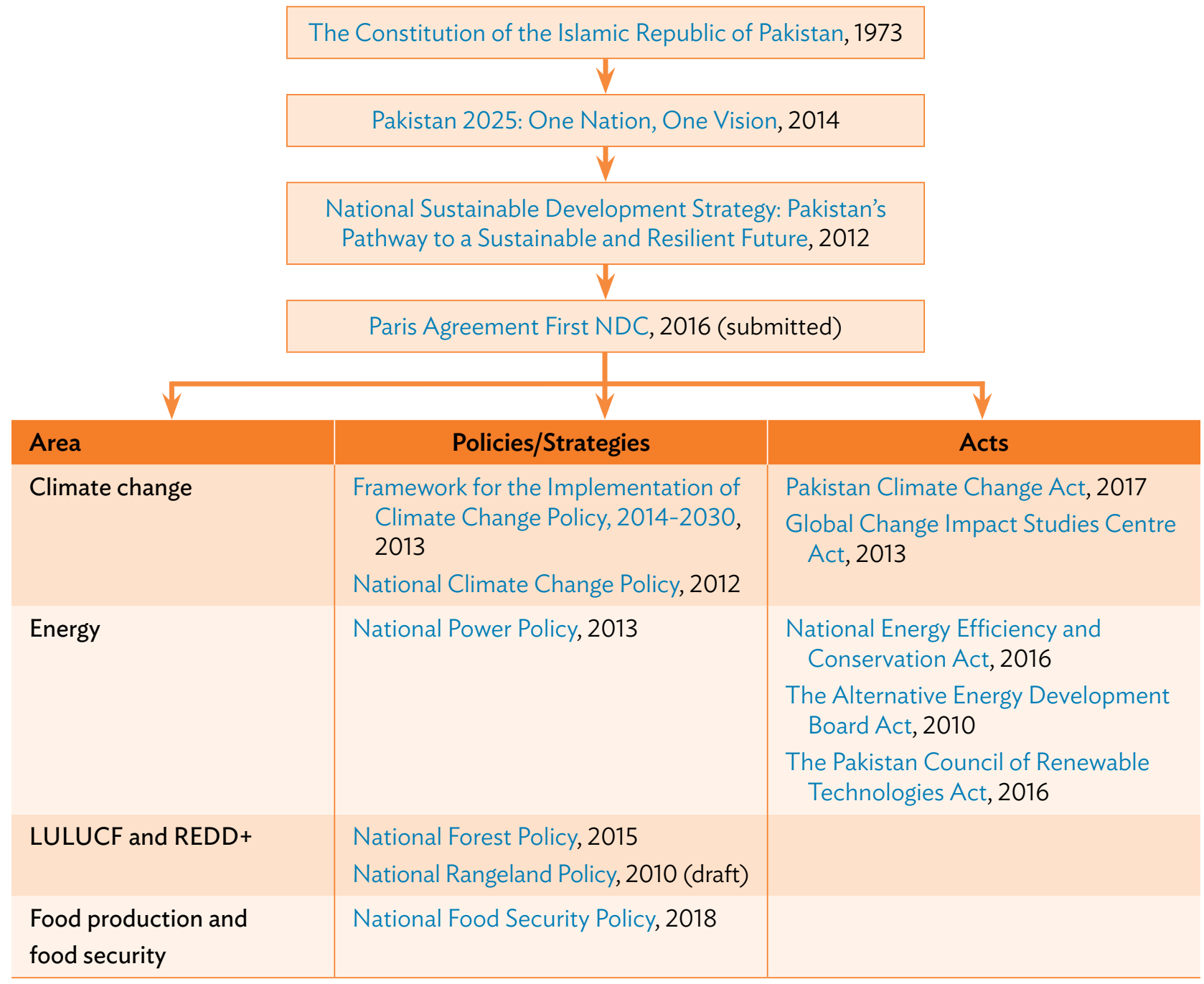

continued on next page

167 M. A. Khan and A. Pervaiz. 2012. National Sustainable Development Strategy: Pakistan's Pathway to a Sustainable and Resilient Future. Islamabad: Government of Pakistan. p. 7.

168 Footnote 167, p. 6. 
Table 4.7 continued

\begin{tabular}{|c|c|c|}
\hline Area & Policies/Strategies & Acts \\
\hline $\begin{array}{l}\text { Water resources and } \\
\text { coastal zone management }\end{array}$ & National Water Policy, 2018 & \\
\hline Vulnerable groups & $\begin{array}{l}\text { National Policy Guidelines on } \\
\text { Vulnerable Groups in Disasters, } 2014\end{array}$ & \\
\hline Disaster risk management & $\begin{array}{l}\text { Disaster Management Strategy, } \\
\text { 2015-2020, } 2015 \\
\text { National Disaster Risk Reduction } \\
\text { Policy, } 2013 \\
\text { National Disaster Risk Management } \\
\text { Framework, } 2007\end{array}$ & $\begin{array}{l}\text { The National Disaster Management } \\
\text { Act, } 2010\end{array}$ \\
\hline Other & $\begin{array}{l}\text { National Biodiversity Strategy and } \\
\text { Action Plan, 2017-2030 }\end{array}$ & \\
\hline
\end{tabular}

LULUCF = land use, land-use change, and forestry; NDC = nationally determined contribution; REDD + = reducing emissions from deforestation and forest degradation, conservation of existing forest carbon stocks, sustainable forest management, and enhancement of forest carbon stocks.

Source: Authors.

\section{Energy Supply}

As of 2018, Pakistan's primary sources of energy were $33 \%$ biofuels and waste, $26 \%$ natural gas, $26 \%$ oil, $10 \%$ coal, $3 \%$ hydropower, and 2\% nuclear energy. ${ }^{169}$ The household sector uses the largest share of electricity in Pakistan, consuming $51 \%$ of all electricity in $2018 .{ }^{170}$ Pakistan is a net energy importer, importing 44.2 megatons of oil equivalent in $2018 .{ }^{171}$

The National Power Policy, 2013 was developed by the Ministry of Water and Power to establish an overarching energy policy. ${ }^{172}$ The policy identifies challenges to power provision, such as the current and increasing gap between demand and supply, the high price of electricity due to reliance on thermal fuel, energy inefficiency attributable to power cuts, circular debt and subsidies caused by energy inefficiency, high generation costs, and energy theft.

The policy aims to increase energy conservation, generate power sustainably, supply energy affordably, and promote good governance. It sets five specific targets: (i) eliminate the gap between demand and supply no later than 2017, (ii) reduce generation costs through the use of indigenous resources, (iii) reduce losses from distribution and transmission, (iv) increase the payment rate of electricity, and $(v)$ reduce the processing time for decision-making. The policy

\footnotetext{
169 International Energy Agency (IEA). 2018. Pakistan: Total Energy Supply by Source (accessed 19 September 2020).

170 IEA. 2018. Pakistan: Electricity Final Consumption By Sector (accessed 19 September 2020).

171 IEA. 2018. Pakistan: Net Energy Imports (accessed 19 September 2020).

172 Government of Pakistan, Ministry of Water and Power. 2013. National Power Policy, 2013. Islamabad.
} 
also aims to cut transmission and distribution losses to $16 \%$ by 2017 from an undated baseline of $23 \%-25 \%$.

To further renewable energy promotion, the Alternative Energy Development Board Act established the Alternative Energy Development Board (board) in 2010. The act recognizes that increasing the adoption of alternative and renewable energy sources will support sustainable economic growth. It also establishes the Alternative Energy Fund to carry out board functions.

The board is an independent body with a mandate to facilitate an increase in alternative or renewable energy by (i) developing national plans, strategies, and policies to promote renewable and other alternative energy sources; (ii) monitoring, certifying, and evaluating renewable and other alternative energy products and projects; (iii) coordinating the commercialization of renewable and other alternative energy technologies; and (iv) facilitating the generation of energy by renewable and other alternative energy technologies.

The board partnered with the World Bank to initiate the Renewable Energy Resource Mapping Project in 2014. ${ }^{173}$ This project contains three phases, ultimately seeking to produce validated wind and solar resource atlases (footnote 173). Atlases are intended to be used for renewable energy development guidance and tariff-setting.

In 2010, the Pakistan Council of Renewable Technologies Act was passed to establish the Pakistan Council of Renewable Energy Technologies, which aims to build an institutional structure for renewable energy use. The act tasks the council with the following functions related to renewable energy:

(i) acquisition, development, and dissemination of processes and techniques that help promote alternative and renewable energy technology, including that of solar, photovoltaic, hydrogen, thermal, biomass, and wind;

(ii) development of technologies needed in renewable and other alternative energy fields;

(iii) facilitation of research and development for renewable and other alternative energy technologies;

(iv) expansion of education and training opportunities for renewable and other alternative energy technologies;

(v) organization of events including workshops and conferences to facilitate renewable energy adoption; and

(vi) coordination with international and national organizations.

173 Government of Pakistan, Alternative Energy Development Board. International Cooperation: World Bank. 


\section{Energy Demand}

The National Energy Efficiency and Conservation Act, 2016 replaces the Pakistan Energy Efficiency and Conservation Act, 2011. The act defines the federal government's role in facilitating energy conservation through measures such as issuing certificates for energy saving, drafting building codes, and establishing the Energy Conservation Fund. The act also establishes other entities: the National Energy Efficiency and Conservation Authority, the National Energy Efficiency and Conservation Board, and the Authority Fund.

Supervised by the National Energy Efficiency and Conservation Board, the National Energy Efficiency and Conservation Authority has various responsibilities: (i) serving as the lead facilitator of energy conservation programs in all economic sectors, (ii) drafting and updating the policy on national energy conservation for the board, (iii) engaging in energy auditing, and (iv) creating research programming and demonstrations.

\section{E. LULUCF and REDD+}

Forest cover in Pakistan is decreasing at $1.66 \%$ per year and currently measures only $2.2 \%$ (or about 4.55 million hectares) of land. ${ }^{174}$ The National Forest Policy of 2010 aims to restore degraded and deforested areas and improve existing forests. ${ }^{175}$ Updated in 2015, the policy seeks to increase public awareness, reduce Pakistan's carbon footprint, establish protected areas, and implement mass afforestation program. ${ }^{176}$ It also guides the implementation of international agreements on biodiversity, climate change, and forestry.

Pakistan 2025 aims to prevent deforestation (footnote 166). Specifically, it aims for a $6 \%$ forest cover increase by 2030 through a combination of heightened awareness, societal pressure on law enforcement, planting campaigns, and improved management of watersheds.

\section{F. Transportation}

Pakistan 2025 estimates that transportation-related inefficiencies have cost $4 \%-6 \%$ of national gross domestic product (GDP). Major initiatives to increase efficiency and integration of the transport system include replacing and doubling railway tracks, constructing major new motorways, implementing new locomotives and railway carriages, increasing efficiency in customs and port handling, increasing the number of functional airports, modernizing truck fleets, and implementing mass transit options in urban areas.

174 C.I. Ali. 2018. Forests (An Assets): Situation in Pakistan. Technology Times. 17 December.

175 Government of Pakistan. 2010. National Forest Policy. Islamabad.

176 Government of Pakistan, Ministry of Climate Change. 2015. National Forest Policy, 2015. Islamabad. 
The National Sustainable Development Strategy also aims to increase sustainability in transportation. The Implementation Framework plans to mitigate transportcaused GHG emissions by increasing the number of vehicle maintenance service centers, establishing vehicle emissions testing, and increasing the use of biofuels.

\section{G. Adaptation}

As water-dependent sectors are expected to become significantly impacted by the effects of climate change, recent sector-specific policies have also prioritized adaptation (footnote 160). The National Food Security Policy of 2018 seeks to adapt to climate change and ensure climate resiliency in food production. ${ }^{177}$ On agriculture, the policy outlines a strategic framework with specific policy imperatives such as promoting alternative crops and developing fortified cultivars.

The National Water Policy of 2018, to make it easier to adapt to climate change, facilitate the expansion of water availability, enhance the quality and availability of fresh water, improve water management in urban areas, address demands for drinking water, advocate for behavioral change, and invest in the development of hydropower to increase renewable energy. ${ }^{178}$

In terms of broader policies and multisector strategies, the National Climate Change Policy maintains a focus on adaptation, with adaptation measures for agriculture, water resources, coastal areas, forestry, and biodiversity (footnote 162). The policy also commits to gender- and poverty-sensitive adaptation. Given climate change vulnerability, the degradation of ecosystems, and high rural poverty levels in Pakistan, adaptation efforts remain a major focus of Pakistan 2025 and the Implementation Framework.

\section{H. Disaster Risk Management}

A major component of Pakistan's approach to climate change adaptation is disaster risk management. The National Disaster Management Act, 2010 sets the groundwork for this approach by establishing the National Disaster Management Commission, the National Disaster Management Authority, and the National Disaster Response Force. The Prime Minister chairs the National Disaster Management Commission, which institutionalizes state response to human-made and natural disasters. The commission's major responsibilities include

(i) establishing disaster management policies,

(ii) approving the national plan,

(iii) approving subsequent plans by government divisions and ministries,

(iv) establishing guidelines for provincial authorities and the federal government,

177 Government of Pakistan, Ministry of National Food Security and Research. 2018. National Food Security Policy. Islamabad.

178 Government of Pakistan, Ministry of Water Resources. 2018. National Water Policy. Islamabad. 
(v) providing funding and facilitating the financing of climate change mitigation and response, and

(vi) taking additional measures deemed necessary for disaster prevention and mitigation.

The National Disaster Management Authority was established to coordinate disaster management, prepare the national plan, implement national policy, and establish guidelines for ministries and provincial authorities.

Subsequently, the National Disaster Risk Reduction Policy was passed in 2013. ${ }^{179}$ Published by the Ministry of Climate Change, this policy seeks to decrease hazard vulnerabilities and increase resilience. It provides guidelines for timely hazard mitigation investment and preparedness in reducing disaster risk and the resulting damages and costs. Additionally, in 2015, a five-year strategy was passed: the Disaster Management Strategy 2015-2020, which builds on the 2007 National Disaster Risk Management Framework. ${ }^{180}$ Its twofold approach to disaster risk management constitutes (i) mitigation, prevention, and preparedness; and (ii) reconstruction, response, and rehabilitation. The disaster management strategy focuses on strengthening community response by recommending the creation of disaster management committees and mapping community hazards and vulnerabilities.

Another key policy is the National Policy Guidelines on Vulnerable Groups in Disasters of 2014, which stresses the importance of linking climate change and disaster preparedness. ${ }^{181}$ The policy ensures that disaster response is nondiscriminatory and caters to the needs of vulnerable groups. Additional goals include increasing participation in disaster management, collecting data on vulnerable populations, improving accessibility to relief distribution, and providing medical care.

\section{Sri Lanka}

\section{A. Country Snapshot: Climate and Environmental Challenges}

Sri Lanka, a small island in the Indian Ocean, is a presidential republic. It is highly vulnerable to a range of adverse climate change effects. Sea level rise threatens Sri Lanka's coastal region, with negative repercussions for tourism and fisheries. ${ }^{182}$ Much of the population and the country's income from foreign sources depends

179 Government of Pakistan, Ministry of Climate Change, National Disaster Management Authority. 2013. National Disaster Risk Reduction Policy. Islamabad.

180 Pakistan Poverty Alleviation Fund. 2015. Disaster Management Strategy 2015-2020. Islamabad; and Government of Pakistan, National Disaster Management Authority. 2007. National Disaster Risk Management Framework. Islamabad.

181 Government of Pakistan, National Disaster Management Authority. 2014. National Policy Guidelines on Vulnerable Groups in Disasters. Islamabad.

182 Government of Sri Lanka, Ministry of Mahaweli Development and Environment. 2016. Nationally Determined Contributions. Colombo. 
on agriculture, which is undermined by extreme weather events like drought and flood. ${ }^{183}$ Climate change could also alter critical ecosystem services. Although Sri Lanka minimally contributes to global GHG emissions, it is committed to both mitigation and adaptation measures (footnote 182).

\section{B. Overarching Climate Change Legal and Policy Framework}

\section{Mitigation and Adaptation Targets}

In 2016, the Ministry of Mahaweli Development and Environment submitted Sri Lanka's first nationally determined contribution (NDC) to the Paris Agreement (footnote 182). Sri Lanka's NDC sets some quantified targets in the energy, transport, industry, forestry, and waste sectors. First, all sectors have targets to decrease GHG emissions by 2030 compared with the 2010 business as usual (BAU) scenario: in the energy sector by $20 \%$ (4\% unconditionally and $16 \%$ conditionally); and in the transport, industry, forest, and waste sectors by $10 \%$ (3\% unconditionally and $7 \%$ conditionally).

Second, there are sector-specific targets. Sri Lanka aims to increase the share of renewable energy from $50 \%$ to $60 \%$ by 2020 by establishing a range of power plants: 176 megawatts (MW) of mini hydro, $105 \mathrm{MW}$ of biomass, $115 \mathrm{MW}$ of solar, and $514 \mathrm{MW}$ of large-scale wind. It also plans to reduce unproductive vehicles by $25 \%$ by 2025 . A $50 \%$ reduction is conditional on support. Furthermore, the country has a series of targets to meet by 2030: (i) increase forest cover from $29 \%$ to $32 \%$, (ii) establish energy-efficient and environmentally sustainable transport systems, and (iii) develop and implement comprehensive waste management strategies for $40 \%-60 \%$ of local authorities.

In 2017, the government released its short-term Readiness Plan for Implementation of Intended Nationally Determined Contributions, 2017-2019 to implement its NDC and meet its emissions targets by $2030 .{ }^{184}$

\section{Overview of Climate Change Law and Policy}

Sri Lanka has taken steps to strengthen its national climate change policy. It established the Climate Change Secretariat in 2008 to institute government action on climate change. In 2012, the government launched the country's key climate policy - the National Climate Change Policy (Climate Policy). ${ }^{185}$ The Climate Policy enacts mitigation and adaptation measures through

183 R. Eeswaran. 2018. Climate Change Impacts and Adaptation in the Agriculture Sector of Sri Lanka: What We Learnt and Way Forward. In W. Leal Filho et al., eds. Handbook of Climate Change Communication: Vol. 2: Practice of Climate Change Communication. Cham, Switzerland: Springer.

184 Government of Sri Lanka, Ministry of Mahaweli Development and Environment, Climate Change Secretariat. 2016. Readiness Plan for Implementation of Intended Nationally Determined Contributions (INDCs), 2017-2019. Colombo.

185 Government of Sri Lanka, Ministry of Environment and Wildlife Resources, Climate Change Secretariat. 2012. The National Climate Change Policy of Sri Lanka. Colombo. 
sustainable development. It includes 25 policy statements to address areas of climate change for Sri Lanka. The core objectives of the Climate Policy are to

(i) raise awareness of Sri Lanka's vulnerability to climate change and build capacity for effective choices;

(ii) improve adaptation measures to minimize adverse impacts on ecosystems, people, and their livelihoods;

(iii) mitigate GHG emissions;

(iv) encourage sustainable production and consumption;

(v) improve domestic capacity to address climate change impacts; and

(vi) mainstream climate change issues into national development.

The Climate Policy also highlights the need to address climate change in disaster management, protect human health, encourage resilient food production technologies, manage water resources effectively, and incorporate low-emission strategies in land use planning and urban development.

Another climate-related policy, the National Action Plan for Haritha (or Green) Lanka Programme, 2015-2020, ultimately aims to ensure clean air. ${ }^{186}$ The program sets out plans for countering the adverse effects of climate change and expanding efficient and sustainable energy and power generation. Other targets include achieving integrated waste management, and water and food security. The program encourages the use of economically viable renewable energy resources, carbon sequestration, and land use zoning practices to reach these goals and reduce vulnerability to climate impacts.

The government has also prepared some documents related to the United Nations Framework Convention on Climate Change (UNFCCC), including the National Adaptation Plan for Climate Change Impacts in Sri Lanka, 2016-2025, ${ }^{187}$ and the Readiness Plan for Implementation of Intended Nationally Determined Contributions, 2017-2019 (footnote 184). In 2010, Sri Lanka also conducted vulnerability assessments on water, health, agriculture, fisheries, urban development, human settlements, and economic structure.

Table 4.8 summarizes Sri Lanka’s climate change legal and policy framework.

\section{Energy Supply}

Sri Lanka relies heavily on imported fossil fuels and seeks to provide electricity to a greater share of its population. ${ }^{188}$ In 2016, Sri Lanka's total primary energy supply

186 Government of Sri Lanka, National Council for Sustainable Development. 2009. National Action Plan for Haritha Lanka Programme. Colombo.

187 Government of Sri Lanka, Ministry of Mahaweli Development and Environment, Climate Change Secretariat. 2016. National Adaptation Plan for Climate Change Impacts in Sri Lanka, 2016-2025. Colombo.

188 Government of Sri Lanka, Ministry of Power and Energy. 2008. National Energy Policy and Strategies of Sri Lanka. Colombo. 


\section{Table 4.8: Climate Change Legal and Policy Framework of Sri Lanka}

\begin{tabular}{|c|c|c|}
\hline & $\begin{array}{l}\text { Constitution of the Democratic Socialist Republic of } \\
\text { Sri Lanka, } 1978\end{array}$ & \\
\hline & $\downarrow$ & \\
\hline & Vision 2025, 2017 & \\
\hline & $\Downarrow$ & \\
\hline & Paris Agreement First NDC, 2016 (submitted) & \\
\hline \multicolumn{3}{|l|}{$y$} \\
\hline Area & Policies and Strategies & Acts \\
\hline Climate change & $\begin{array}{l}\text { Readiness Plan for Implementation of Intended } \\
\text { Nationally Determined Contributions 2017-2019, } \\
2016 \\
\text { Technology Needs Assessment and Technology } \\
\text { Action Plans for Climate Change Mitigation, } 2014 \\
\text { National Climate Change Policy of Sri Lanka, } 2012 \\
\text { National Climate Change Adaptation Strategy for } \\
\text { Sri Lanka, } 2011 \text { to 2016, } 2010 \\
\text { National Action Plan for Haritha Lanka Program, } 2009\end{array}$ & \\
\hline Energy & $\begin{array}{l}\text { Long Term Generation Expansion Plan 2018-2037, } 2018 \\
\text { Sri Lanka Energy Sector Development Plan for a } \\
\text { Knowledge-Based Economy, 2015-2025, } 2015 \\
\text { National Energy Policy and Strategies of Sri Lanka, } 2008\end{array}$ & $\begin{array}{l}\text { Sri Lanka Sustainable Energy } \\
\text { Authority Act, No. } 35 \text { of } \\
2007\end{array}$ \\
\hline $\begin{array}{l}\text { Water resources } \\
\text { and coastal zone } \\
\text { management }\end{array}$ & $\begin{array}{l}\text { Sri Lanka Coastal Zone and Coastal Resource } \\
\text { Management Plan, } 2018 \\
\text { National Rainwater Harvesting Policy and Strategies, } \\
2005 \\
\text { National Wetland Policy and Strategy, } 2005\end{array}$ & \\
\hline $\begin{array}{l}\text { Cities and } \\
\text { buildings }\end{array}$ & $\begin{array}{l}\text { National Physical Planning Policy and Plan 2011-2013, } \\
2010\end{array}$ & $\begin{array}{l}\text { Urban Development Authority } \\
\text { (Amendment) Act No. } 41 \\
\text { of } 1988\end{array}$ \\
\hline Waste & National Policy on Solid Waste Management, 2002 & \\
\hline $\begin{array}{l}\text { Disaster risk } \\
\text { management }\end{array}$ & $\begin{array}{l}\text { Sri Lanka Comprehensive Disaster } \\
\text { Management Programme, 2014-2018, } 2014 \\
\text { National Policy on Disaster Management, } 2010\end{array}$ & $\begin{array}{l}\text { Sri Lanka Disaster } \\
\text { Management Act, No. } 13 \text { of } \\
2005\end{array}$ \\
\hline Other & $\begin{array}{l}\text { Clean Air 2025, } 2016 \\
\text { National Biodiversity Strategic Action Plan 2016-2022, } \\
2016 \\
\text { National Environmental Policy and Strategies, } 2003\end{array}$ & $\begin{array}{l}\text { National Insurance Trust Fund } \\
\text { Act, No. } 28 \text { of } 2006\end{array}$ \\
\hline
\end{tabular}

NDC = nationally determined contribution .

Source: Authors. 
was 11,670 kilotons of oil equivalent (ktoe), consisting of oil (45\%), biofuel and waste (40\%), coal (12\%), and hydro (3\%). ${ }^{189}$ The government has adopted laws and policies to address the key challenges facing the energy sector-reducing reliance on imported fossil fuels and decreasing the cost of electricity.

\section{Sector-Wide Energy Strategies}

In 2007, the Sri Lanka Sustainable Energy Authority Act was passed. It established the Sri Lanka Sustainable Energy Authority to develop renewable energy resources, build energy development areas, advocate for energy security, and improve energy delivery reliability and affordability. It also aims to establish energy efficiency, and conservation programs and measures. The Sustainable Energy Authority is mandated to draft a national energy policy that expands renewable energy use to improve energy security. It must review applications for on- and off-grid renewable energy projects, prepare policies and plans to promote renewable resources, and conduct preliminary investigations and studies to determine renewable potential.

Following the establishment of the energy authority, the government launched the National Energy Policy and Strategies of Sri Lanka (NEPS) in 2008 (footnote 188). NEPS sets a target of sourcing $38 \%$ of electrical energy supply from renewables and hydro by 2015. Its main goal is to achieve the Millennium Development Goals by transforming the energy sector. To that end, NEPS seeks to promote affordable and sustainable renewable energy. Specific initiatives include expanding access to affordable energy, improving planning in the energy sector, carrying out regulation and management tasks, and revitalizing biomass for energy generation. NEPS does not explicitly reference climate change.

The Sri Lanka Energy Sector Development Plan for a Knowledge-Based Economy, 2015-2025 builds on NEPS and recognizes the importance of achieving a cleaner future through green energy. ${ }^{190}$ It aims to achieve energy security and independence by 2030 in a sustainable manner. Accordingly, it aims to produce $60 \%$ of the electricity supply from renewable energy by 2020 and 100\% from renewable and domestic sources by 2030 . It also sets the target to reduce electricity network losses to $8 \%$ by 2020 and reduce the energy sector's carbon footprint by $5 \%$ by 2025 compared with a 2014 baseline. Other energy sector targets include providing affordable electricity coverage to all people in Sri Lanka and producing the total petroleum product demand of the country domestically by 2025 .

Within the plan's eight priority areas, two address climate change and sustainability. First, to expand green energy, the plan highlights (i) maximizing the development of renewable energy, (ii) establishing a competitive bidding process for large-scale wind and solar power, (iii) using net metering to promote small renewables, (iv) integrating climate change and environmental protection into energy

189 International Energy Agency. Total Primary Energy Supply by Source Sri Lanka 1990-2016.

190 Government of Sri Lanka, Ministry of Power and Energy. 2015. Sri Lanka Energy Sector Development Plan for a Knowledge-Based Economy, 2015-2025. Colombo. 
sector development plans, (v) promoting off-grid renewables and biomass, and (vi) reducing the energy sector's carbon footprints. Second, the plan promotes conservation and efficient energy use on demand and supply sides within buildings, transport, and electricity.

\section{Energy Demand}

Sri Lanka's key energy policies also address energy efficiency and conservation. NEPS, for example, called for the establishment of specific benchmarks for energy consumption of domestic, transport, and commercial sectors by the end of 2008. The Sri Lanka Energy Sector Development Plan for a Knowledge-Based Economy, 2015-2025 sets two energy demand goals: (i) reduce petroleum fuel use in transportation by $5 \%$ through efficient modes of transportation and transport electrification by 2020 , and (ii) reduce annual growth in energy demand by $2 \%$ through efficient use and conservation (footnote 190). Clean Air 2025 seeks to minimize the emission of harmful pollutants. ${ }^{191}$ To manage air emissions from the transport sector, the plan creates strategies such as establishing customerfriendly public transport systems, e.g., mass public transportation and green freight transport system.

\section{E. Adaptation}

The National Adaptation Plan for Climate Change Impacts in Sri Lanka, 2016-2025 was created in line with the guidelines for the development of national adaptation plans from the UNFCCC (footnote 187). It describes climate change impacts in Sri Lanka, such as altered rainfall distribution pattern, an increase in severity and frequency of extreme weather events, and sea level rise. Given these impacts, the plan aims to build adaptive capacity and reduce vulnerability to climate change. It addresses the adaptation needs of the following nine important sectors and areas:

(i) water;

(ii) coastal and marine sector;

(iii) health;

(iv) food security in fisheries, agriculture, and livestock;

(v) biodiversity and ecosystems;

(vi) tourism and recreation;

(vii) infrastructure and human settlements;

(viii) export agriculture; and

(ix) industry, energy, and transportation.

Priority actions include developing climate-change-resilient crops and breeds to promote food security, implementing a surveillance program to detect and monitor climate-induced diseases, and conducting trainings on climate-resilient buildings for industry stakeholders.

191 Government of Sri Lanka, Ministry of Mahaweli Development and Environment. 2016. Clean Air 2025: An Action Plan for Air Quality Management. Kotte, Sri Lanka. 
The National Climate Change Adaptation Strategy for Sri Lanka (Adaptation Strategy) serves as an earlier key climate change policy. ${ }^{122}$ Adopted in 2010 and applicable to 2011-2016, it provides a framework "aimed at systematically moving Sri Lanka and its people towards a climate change-resilient future." 193 It recognizes the vulnerability of Sri Lanka to climate change, citing the increases in natural disasters, changes in rainfall, increases in temperature, and rise of sea level.

The Adaptation Strategy contains five strategic goals: (i) mainstreaming climate change adaptation into national planning and development, (ii) enabling climateresilient and healthy human settlements, (iii) minimizing climate change impacts on food security, (iv) improving climate resilience of key economic drivers, and (v) safeguarding natural resources and biodiversity from climate change impacts. It identifies a broad range of interventions across multiple sectors to address these goals, but does not put forward specific action plans or mechanisms to monitor progress. An additional Sri Lanka rupees (SLRs) 47.7 billion is needed to implement its goals over its 6-year duration.

Relevant to adaptation is the National Biodiversity Strategic Action Plan 2016-2022. ${ }^{194}$ Mapping the legislative and policy framework for biodiversity conservation, the plan sets 12 national targets for 2022. Target 2 seeks to conserve habitats and envisages that this action will help manage climate change-driven impacts.

Finally, the Ministry of Environment and Renewable Energy prepared the Technology Needs Assessment and Technology Action Plans for Climate Change Mitigation in 2014 to identify and evaluate technologies that can contribute to climate mitigation and adaptation while advancing national development objectives. ${ }^{195}$

\section{F. Disaster Risk Management}

The government has developed two policies on reducing disaster risk. The National Disaster Management Policy of 2010 calls for integrating adaptation into disaster risk reduction activities. ${ }^{196}$ The Sri Lanka Comprehensive Disaster Management Programme, 2014-2018 focuses on mainstreaming disaster risk reduction and climate change adaptation into the development process. ${ }^{197}$

192 Government of Sri Lanka, Ministry of Environment and Wildlife Resources, Climate Change Secretariat. 2010. National Climate Change Adaptation Strategy for Sri Lanka, 2011-2016. Colombo.

193 Footnote 192, p. 11 (Executive Summary).

194 Government of Sri Lanka, Ministry of Mahaweli Development and Environment. 2016. National Biodiversity Strategic Action Plan 2016-2022. Colombo.

195 Government of Sri Lanka, Ministry of Environment and Renewable Energy, Climate Change Secretariat. 2014. Technology Needs Assessment and Technology Action Plans for Climate Change Mitigation. Colombo.

196 Government of Sri Lanka, National Council for Disaster Management. 2010. National Policy on Disaster Management. Colombo.

197 Government of Sri Lanka, Ministry of Disaster Management. 2014. Sri Lanka Comprehensive Disaster Management Programme, 2014-2018. Colombo. 
c) 6

$\cos ^{2} \mathrm{e}$ 


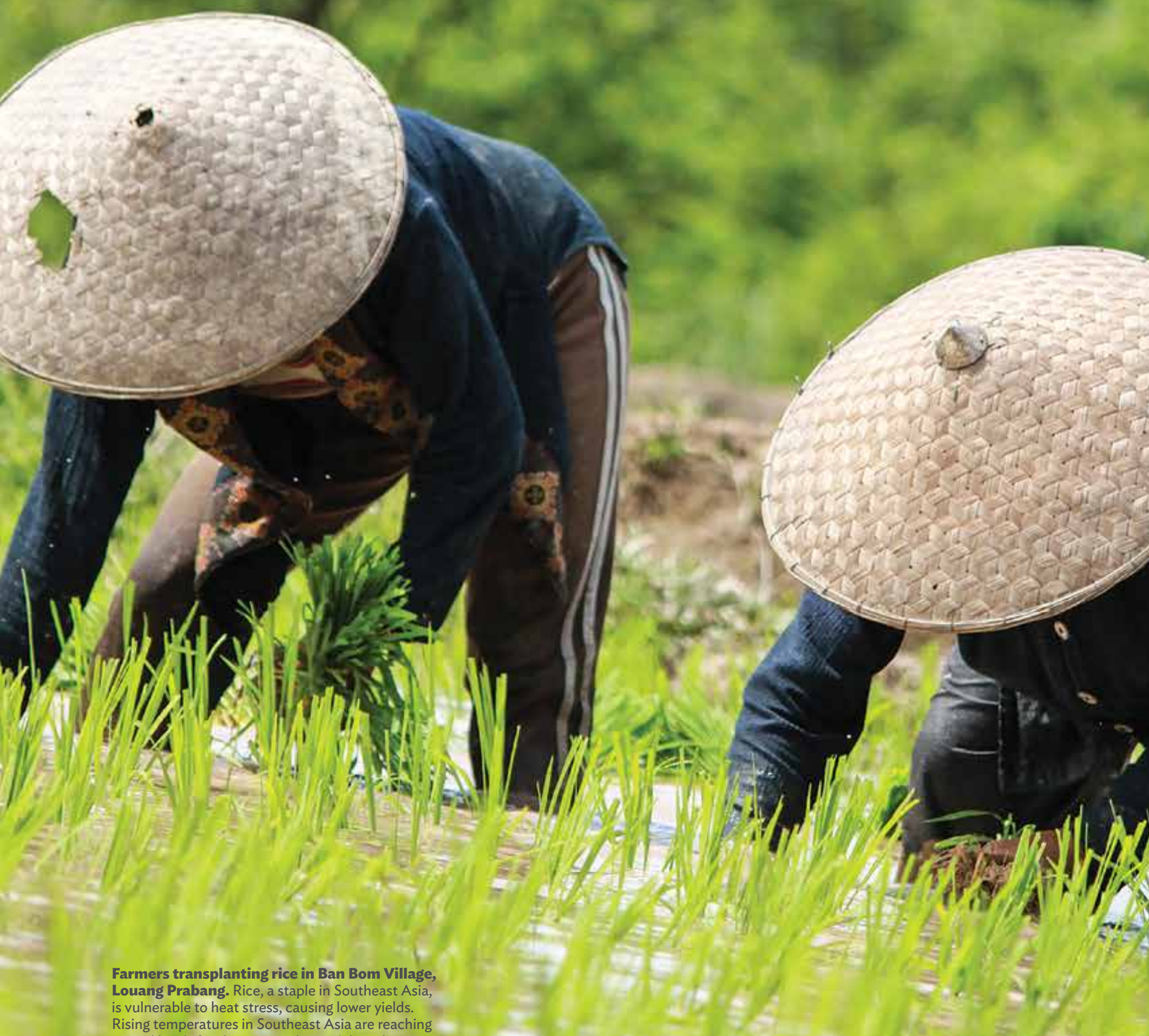
critical levels for this essential crop (photo by

Xaykhame Manilasit/ADB). 


\section{SOUTHEAST ASIA AND PEOPLE'S REPUBLIC OF CHINA LEGAL FRAMEWORK SUMMARIES}

\section{Cambodia}

\section{A. Country Snapshot: Climate and Environmental Challenges}

The Kingdom of Cambodia is a parliamentary constitutional monarchy that has become more vulnerable to climate change impacts such as floods, drought, and saltwater intrusion. ' Significant rainfall results in almost annual floods, particularly in the lower Tonlé Sap basin and the lower Mekong River provinces. ${ }^{2}$ Given that Cambodia faces significant flooding and typhoons, climate change will potentially disrupt infrastructure, including road systems, ports, railways, and oil supply. ${ }^{3}$ Typhoon Ketsana disrupted the oil supply in 2009, causing flooding on underdeveloped road systems (footnote 3). Climate change can also upset the monsoons and the hydrological function of the Mekong-Tonle Sap River drainage system, thereby impacting agriculture, the main livelihood of rural households. ${ }^{4}$

\section{B. Overarching Climate Change Legal and Policy Framework}

\section{Mitigation and Adaptation Targets}

Cambodia's first nationally determined contribution (NDC) sets a target to reduce greenhouse gas ( $\mathrm{GHG}$ ) emissions by $27 \%$ by 2030 compared with the business as usual (BAU) scenario (footnote 1). By signing the Paris Agreement, Cambodia also committed to increasing forest cover to $60 \%$ of its national land

Government of Cambodia. 2017. Cambodia's First Nationally Determined Contribution. Phnom Penh. C. Berdik. 2014. Cambodia: The Giving Flood. Pulitzer Center. 11 June.

Economic Research Institute for ASEAN and East Asia (ERIA). 2019. Cambodia Basic Energy Plan. Jakarta.

4 United Nations Development Programme (UNDP). Reducing the Vulnerability of Cambodian Rural Livelihoods through Enhanced Sub-National Climate Change Planning and Execution of Priority Actions. 
area and maintaining that level from 2030 onward. Its land use, land-use change, and forestry (LULUCF) estimates emission reductions by about 4.7 tons of carbon dioxide $\left(\mathrm{tCO}_{2}\right)$ equivalent per hectare per year (footnote 1).

\section{Overview of Climate Change Law and Policy}

To achieve its climate objectives, Cambodia formed the National Climate Change Committee (NCCC), an interministerial mechanism mandated to prepare, coordinate, and monitor the implementation of policies, strategies, legal instruments, and plans to address climate change issues. ${ }^{5}$ The NCCC secretariat is the Climate Change Department of the Ministry of Environment.

The NCCC was established under Cambodia's National Strategic Development Plan (NSDP) 2014-2018, which outlines Cambodia's plan to become an upper middle-income country and discusses the threats that climate change poses to infrastructure, agriculture, fishing, and other industries (footnote 5). The NSDP was formulated as part of the Rectangular Strategy Phase III (2013-2018), designed to strengthen sustainable development goals such as promoting economic growth, creating jobs, distributing the fruits of growth equitably, and ensuring effective public institutions and management of resources. ${ }^{6}$

The government updated the NSDP 2014-2018 with the NSDP 2019-2023. ${ }^{7}$ The new NSDP reaffirmed the government's plan to become an upper middle-income country by 2030 and a high-income country by 2050, with a sustainable growth of around $7 \%$ per year and a reduction in the poverty rate to below $10 \%$.

Cambodia's Climate Change Strategic Plan 2014-2023 created a national framework for responding to climate change and supporting sustainable development. ${ }^{8}$ It outlined eight strategic objectives:

(i) promoting climate resilience by improving food, water and energy security;

(ii) reducing sectoral, regional, and gender vulnerability to climate change impacts and their associated health risks;

(iii) building the resilience of critical ecosystems, biodiversity, protected areas, and cultural heritage sites to climate change;

(iv) achieving sustainable development by promoting low-carbon planning and technologies;

5 Government of Cambodia, Ministry of Planning. 2014. National Strategic Development Plan 2014-2018. Phnom Penh.

6 Government of Cambodia. 2013. "Rectangular Strategy" for Growth, Employment, Equity and Efficiency Phase III. Phnom Penh.

7 Government of Cambodia, Ministry of Planning. 2019. National Strategic Development Plan 2019-2023. Phnom Penh.

8 Government of Cambodia, National Climate Change Committee. 2013. Cambodia Climate Change Strategic Plan 2014-2023. Phnom Penh. 
(v) improving climate change responses with capacity building and awareness raising;

(vi) enhancing the adaptive capacity of social protection programs and improving participatory approaches to minimize loss and damage resulting from climate change;

(vii) strengthening national institutions and coordination to boost national responses to climate change; and

(viii) participating collaboratively and actively in regional and global climate change processes. ${ }^{9}$

During 2014-2016, Cambodia developed 17 short-term ministry-specific interventions as laid down in the Climate Change Action Plan 2016-2018. ${ }^{10}$ These plans present sector-specific climate-related risks, implementation measures to address those risks, and a budgeting and monitoring plan for the implementation measures. The government has prepared action plans that cover mitigation and climate change adaptation for the following sectors:

(i) environment;

(ii) mining and energy;

(iii) tourism;

(iv) education;

(v) rural development;

(vi) public work and transportation;

(vii) water resources and meteorology;

(viii) land management, urbanization planning, and construction;

(ix) information;

(x) industry and handicraft;

(xi) agriculture, fisheries, and forestry;

(xii) gender;

(xiii) health; and

(xiv) disaster management.

The Gender and Climate Change Action Plan, 2014-2018 seeks to reduce the vulnerability of women and other groups susceptible to climate change. ${ }^{11}$ It aims to increase women's participation in climate change planning and boost the national capacity to plan, implement, and monitor gender-sensitive climate change adaptation and mitigation activities.

Table 5.1 summarizes Cambodia's climate change legal and policy framework.

9 Footnote 8, p. xvii.

10 Government of Cambodia, Ministry of Environment. 2016. Climate Change Action Plan 2016-2018. Phnom Penh.

11 Government of Cambodia, Ministry of Women's Affairs. 2014. Gender and Climate Change Action Plan (GCCAP) 2014-2018. Phnom Penh. 


\section{Table 5.1: Climate Change Legal and Policy Framework of Cambodia}

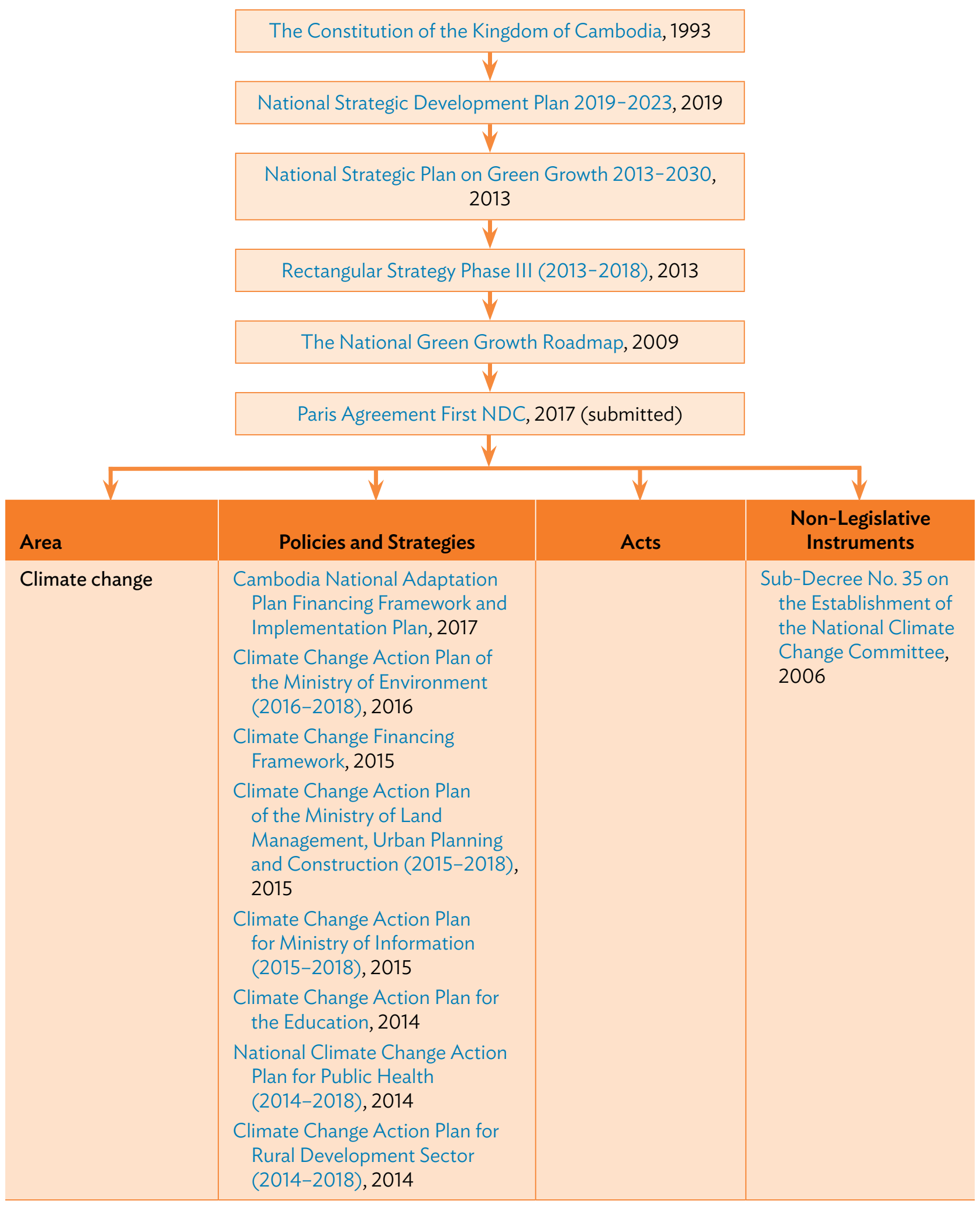


Table 5.1 continued

\begin{tabular}{|c|c|c|c|}
\hline Area & Policies and Strategies & Acts & $\begin{array}{l}\text { Non-Legislative } \\
\text { Instruments }\end{array}$ \\
\hline & $\begin{array}{l}\text { Cambodia Climate Change } \\
\text { Strategic Plan (2014-2023), } 2013 \\
\text { National Policy on Green Growth, } \\
2013 \\
\text { National Adaptation Programme } \\
\text { of Action to Climate Change, } \\
2006\end{array}$ & & \\
\hline Energy & $\begin{array}{l}\text { Cambodia Basic Energy Plan, } 2019 \\
\text { Climate Change Action Plan for } \\
\text { Mines and Energy Sectors, } 2015 \\
\text { Climate Change Strategic Plan } \\
\text { for Manufacturing Industry and } \\
\text { Energy, } 2013\end{array}$ & & $\begin{array}{l}\text { Prakas No. } 470 \text { on } \\
\text { Establishment of } \\
\text { General Requirement } \\
\text { of Electric Power } \\
\text { Technical Standards, } \\
2004\end{array}$ \\
\hline LULUCF and REDD+ & $\begin{array}{l}\text { National REDD+ Strategy } \\
\text { (2017-2026), } 2017 \\
\text { National Protected Area Strategic } \\
\text { Management Plan } \\
\text { (2017-2031), } 2017 \\
\text { National Forest Programme } \\
\text { (2010-2029), } 2010\end{array}$ & & \\
\hline Transportation & $\begin{array}{l}\text { Climate Change Action Plan for } \\
\text { Transport Sector (2014-2018), } \\
2014\end{array}$ & & \\
\hline $\begin{array}{l}\text { Food production and } \\
\text { food security }\end{array}$ & $\begin{array}{l}\text { Climate Change Priorities Action } \\
\text { Plan for Agriculture, Forestry } \\
\text { and Fisheries Sector } \\
\text { (2014-2018), 2014 } \\
\text { The Strategic Planning Framework } \\
\text { for Fisheries (2010-2019), } 2010\end{array}$ & & \\
\hline $\begin{array}{l}\text { Water resources } \\
\text { and coastal zone } \\
\text { management }\end{array}$ & $\begin{array}{l}\text { Climate Change Action Plan } \\
\text { for Water Resources and } \\
\text { Meteorology (2014-2018), } 2014\end{array}$ & & \\
\hline Cities and buildings & & & $\begin{array}{l}\text { Guidelines for } \\
\text { Integrating } \\
\text { Climate Change } \\
\text { Considerations } \\
\text { into Commune } \\
\text { Development } \\
\text { Planning - General, } \\
2014\end{array}$ \\
\hline Vulnerable groups & $\begin{array}{l}\text { Gender and Climate Change } \\
\text { Action Plan (2014-2018), } 2014\end{array}$ & & \\
\hline
\end{tabular}


Table 5.1 continued

\begin{tabular}{|c|c|c|c|}
\hline Area & Policies and Strategies & Acts & $\begin{array}{l}\text { Non-Legislative } \\
\text { Instruments }\end{array}$ \\
\hline Industry & $\begin{array}{l}\text { Climate Change Action Plan in } \\
\text { Tourism Sector (2015-2018), } \\
2015 \\
\text { Climate Change Action Plan for } \\
\text { Industry and Handicraft Sectors } \\
\text { (2015-2018), } 2015\end{array}$ & & \\
\hline $\begin{array}{l}\text { Disaster risk } \\
\text { management }\end{array}$ & $\begin{array}{l}\text { Climate Change Strategic Plan for } \\
\text { Disaster Management Sector, } \\
2013\end{array}$ & $\begin{array}{l}\text { Law on Disaster } \\
\text { Management, } 2015\end{array}$ & $\begin{array}{l}\text { Royal Decree on the } \\
\text { Organization and } \\
\text { Functioning of the } \\
\text { National Committee } \\
\text { for Disaster } \\
\text { Management, } 2015\end{array}$ \\
\hline Other & $\begin{array}{l}\text { National Biodiversity Strategy and } \\
\text { Action Plan, } 2016\end{array}$ & & \\
\hline
\end{tabular}

LULUCF = land use, land-use change, and forestry; NDC = nationally determined contribution; REDD + = reducing emissions from deforestation and forest degradation, conservation of existing forest carbon stocks, sustainable forest management, and enhancement of forest carbon stocks.

Source: Authors.

\section{Energy Supply}

Cambodia's total primary energy supply (TPES) comes mainly from fuelwood and other biomass (44.4\%), followed by oil (38.5\%), coal (10.7\%), hydropower (3.6\%), and electricity imports (2.8\%). ${ }^{12}$ During 2010-2015, Cambodia's energy use grew annually by an average of $6.9 \%$ (footnote 12 ). During this time, the supply of coal increased from $0.7 \%$ to $10.7 \%$, while the supply of hydropower increased from $0.1 \%$ to $3.6 \%$ (footnote 12 ).

The TPES is projected to increase from 7 million tons of oil equivalent (Mtoe) in 2015 to almost 13 Mtoe in 2030 at an average rate of almost 4\% per year (footnote 3). Under the BAU scenario, fossil fuels would represent $60 \%$ of Cambodia's TPES by 2030 due to the rapidly increasing coal consumption for power generation as well as oil consumption for cars and motorbikes (footnote 3 ).

According to the generation development plan for 2017-2030 created by the Ministry of Mines and Energy, Cambodia is projected to have more than 4,700 megawatts (MW) in new total energy capacity by 2030 , with coal (11 coal projects) and gas to make up the largest portion at 2,373 MW (footnote 3).

12 Asian Development Bank (ADB). 2018. Cambodia Energy Sector Assessment, Strategy, and Road Map. Manila. 
Hydropower is slated to reach 1,602 MW, also with 11 planned projects (footnote 3). Solar and wind powers are projected to reach $305 \mathrm{MW}$, oil $251 \mathrm{MW}$, and biomass $185 \mathrm{MW}$ (footnote 3).

The government also plans to expand hydropower and solar electricity generation. In 2006, the Ministry of Mines and Energy and the Cambodian National Mekong Committee identified 60 possible sites for hydropower development in Cambodia with around 10,000 MW of power generation (footnote 3). Furthermore, the 2016 Mekong Strategic Partners report indicates that Cambodia has a solar photovoltaic potential of $700 \mathrm{MW}$ (footnote 3 ).

\section{Sector-Wide Energy Strategies}

To satisfy its growing electricity demand from rapid urbanization, Cambodia can harness non-hydro renewable energy, including biomass, solar power, and wind power. However, the government has not yet set a national target for renewable energy usage (footnote 3 ).

The Climate Change Action Plan for Mines and Energy Sectors (2016-2018) acknowledges that Cambodia's increasing energy demand will contribute to global GHG emissions, thereby outlining measures to increase the efficiency of energy consumption and production. ${ }^{13}$

The Climate Change Strategic Plan for Manufacturing Industry and Energy, released in 2013, states that Cambodia must engage in efficient resource consumption and make use of available environmental technology. ${ }^{14}$ The plan focuses on small and mediumsized enterprises (SMEs), aiming to reduce their GHG emissions and improve their energy efficiency. These measures will produce environmental benefits and allow SMEs to reduce costs and increase their access to international markets. The plan also aims to diversify energy sources to include solar, wind, hydro, biomass, and bioenergy.

\section{Energy Demand}

Energy consumption in Cambodia has grown over time. From 2010 to 2015, total final energy consumption (TFEC) increased from 2.449 Mtoe to 3.413 Mtoe (footnote 3 ). In the same period, total electricity consumption increased from 2,283 gigawatt-hours (GWh) to 5,398 GWh (footnote 3). Demand for petroleum products grew by $7.2 \%$ annually during $2012-2016$ and will continue to grow. ${ }^{15}$ By 2040, the total demand for petroleum products will likely reach 4.65 Mtoe (footnote 3). The upward trend in Cambodia's energy consumption will also continue. According to government projections, TFEC should reach around

13 Government of Cambodia, Ministry of Mines and Energy. 2015. Climate Change Action Plan for Mines and Energy Sectors. Phnom Penh.

14 Government of Cambodia, Ministry of Industry, Mines and Energy (now Ministry of Mines and Energy). 2013. Climate Change Strategic Plan for Manufacturing Industry and Energy. Phnom Penh.

15 Footnote 3, p. 2. 
9 Mtoe by 2030 (footnote 3). Energy consumption in the commercial and residential sectors will likely have the highest growth rate, with strong growth in the transport sector also (footnote 3 ). Electricity consumption is projected to increase by nearly $9 \%$ per year by 2030 (footnote 3 ).

\section{E. Climate Finance}

Following the Cambodia Climate Change Strategic Plan, the government developed its Climate Change Financing Framework in $2015 .^{16}$ This document provides a rationale for taking action against climate change based on its estimated socioeconomic impacts, including (i) less agricultural productivity due to drought and floods, (ii) more climate-sensitive diseases, (iii) rapid degradation of infrastructure, and (iv) flood damage to urban infrastructure. The Climate Change Financing Framework helps in establishing a transparent, reliable, and attractive climate change financing framework.

\section{F. LULUCF and REDD+}

Cambodia's National REDD+ Strategy seeks "to contribute to national and global climate change mitigation by improving the management of its natural resources and forest lands." 17 The REDD + Strategy identifies the threats to forest lands and the drivers of those threats. Its objectives include (i) improving management and monitoring of forest resources and forest land use; (ii) strengthening implementation of sustainable forest management; and (iii) mainstreaming approaches to reduce deforestation, build capacity, and engage stakeholders.

Aimed at promoting sustainable forest management, Cambodia's National Forest Programme 2010-2029 sets a goal of 60\% forest cover by $2015 . .^{18}$ The program acknowledges the threat that climate change poses to sustainable forest management and discusses sustainable forest financing and the need to adapt forestry plans to climate change.

\section{G. Transportation}

Cambodia's Climate Change Action Plan for Transport Sector 2014-2018 recognizes that the transport sector is vulnerable-and a contributor-to climate change. ${ }^{19}$ The action plan identifies measures to promote climate-resilient transport infrastructure and low-carbon consumption. Strategies include developing road construction and maintenance design standards that account for climate change impacts-e.g., when

16 Government of Cambodia, National Council for Sustainable Development. 2015. Climate Change Financing Framework. Phnom Penh.

17 Government of Cambodia. 2017. National REDD+ Strategy 2017-2026. May. Phnom Penh. p. i. REDD+ stands for reducing emissions from deforestation and forest degradation, conservation of existing forest carbon stocks, sustainable forest management, and enhancement of forest carbon stocks.

18 Government of Cambodia. 2010. National Forest Programme 2010-2029. Phnom Penh.

19 Government of Cambodia, Ministry of Public Works and Transport. 2014. Climate Change Action Plan for Transport Sector 2014-2018. Phnom Penh. 
repairing and rehabilitating road infrastructure. The action plan also aims to build capacity and institutional strength to address climate change impacts. Strategies for promoting low-carbon consumption include enhancing the inspection and maintenance of vehicles, promoting integrated public transport in major cities, and establishing green belts along major roads.

\section{H. Adaptation}

Given Cambodia's vulnerability to the impacts of climate change, the government, recognizing that adaptation is important to protect its citizens, submitted its National Adaptation Programme of Action to the United Nations Framework Convention on Climate Change (UNFCCC) Secretariat in 2006. ${ }^{20}$ In 2014, the government released its Climate Change Priorities Action Plan for Agriculture, Forestry and Fisheries Sector 2014-2018, which contains strategies to build the capacity of its agriculture, forestry, and fisheries sectors to adapt to climate change. ${ }^{21}$

In 2017, the government developed the Cambodia National Adaptation Plan Financing Framework and Implementation Plan to bring the National Adaptation Plan closer to execution. ${ }^{22}$ The framework acknowledges that financing is critical to implementing adaptation action. It was developed by analyzing demand and gaps in the climate change action plans and national stakeholder consultations, as well as by evaluating the international climate finance landscape. It also states that the actions identified under the line ministries' climate change action plans are considered key inputs to the National Adaptation Plan. It provides short-term suggestions for 40 priority climate change actions and medium- and long-term recommendations such as pursuing sector-wide approaches; strengthening project and budgeting capabilities; and further developing a national repository on climate science, knowledge, and development.

\section{Disaster Risk Management}

Implemented in 2013, the Climate Change Strategic Plan for Disaster Management Sector seeks to create resilience for Cambodia's large agrarian community. ${ }^{23} \mathrm{It}$ builds on the Hyogo Framework for Action 2005-2015, which emphasizes the interconnected relationship between adaptation and disaster risk reduction. ${ }^{24}$ It also focuses on educating community leaders on disaster risk management and integrating these concerns into school curricula.

20 Government of Cambodia, Ministry of Environment. 2006. National Adaptation Programme of Action to Climate Change (NAPA). Phnom Penh.

21 Government of Cambodia, Ministry of Agriculture, Forestry and Fisheries. 2014. Climate Change Priorities Action Plan for Agriculture, Forestry and Fisheries Sector 2014-2018. Phnom Penh.

22 Government of Cambodia, National Council for Sustainable Development. 2017. Cambodia National Adaptation Plan Financing Framework and Implementation Plan. Phnom Penh.

23 Government of Cambodia, National Committee for Disaster Management. 2013. Climate Change Strategic Plan for Disaster Management Sector. Phnom Penh.

24 World Conference on Disaster Reduction. 2005. Hyogo Framework for Action 2005-2015: Building the Resilience of Nations and Communities to Disasters. Hyogo, Japan. 18-22 January. 
The Royal Decree on the Organization and Functioning of the National Committee for Disaster Management of 2015 defines the scope and function of the National Committee for Disaster Management, which is mandated to meet annually with technical advisers to issue disaster management plans and programs. ${ }^{25}$ The Law on Disaster Management was also passed in 2015 to formally establish the National Committee for Disaster Management. ${ }^{26}$

\section{Indonesia}

\section{A. Country Snapshot: Climate and Environmental Challenges}

Indonesia is a presidential republic that has passed meaningful legislation on climate change, but continues to be vulnerable to its effects. ${ }^{27}$ Sea level rise poses challenges for Indonesia, which has 81,000 kilometers $(\mathrm{km})$ of coastline and 42 million people living on land less than 10 meters above sea level. ${ }^{28}$ Indonesia faces threats from other climate change impacts, including more frequent intense drought, forest fires, landslides, and severe storms (footnote 28).

\section{B. Overarching Climate Change Legal and Policy Framework}

\section{Mitigation and Adaptation Targets}

Indonesia's first nationally determined contribution (NDC) sets a target to reduce GHG emissions by $26 \%$ by 2020 compared with the BAU scenario. ${ }^{29}$ The country sets a $29 \%$ unconditional reduction by 2030 and a $41 \%$ conditional reduction (upon international financing mechanisms) by 2030 (footnote 29). It also aims to reduce deforestation and forest degradation.

\section{Overview of Climate Change Law and Policy}

Indonesia's approach to managing climate change has involved a combination of policy initiatives, and decrees and regulations. In 2007, the Ministry of Environment launched the National Action Plan Addressing Climate Change (Climate Change Action Plan), which guides the approach of the organizations that address climate change, integrating and coordinating multisector efforts. ${ }^{30}$

25 Government of Cambodia. 2015. Royal Decree on the Organization and Functioning of the National Committee for Disaster Management. Phnom Penh.

26 Government of Cambodia. 2015. Law on Disaster Management. Phnom Penh.

27 Grantham Research Institute on Climate Change and the Environment, Climate Change Laws of the World. Indonesia: Overview and Context.

28 United States Agency for International Development. 2017. Climate Risk Profile: Indonesia. Jakarta.

29 Government of Indonesia. 2016. First Nationally Determined Contribution. Jakarta.

30 Government of Indonesia, State Ministry of Environment. 2007. National Action Plan Addressing Climate Change. Jakarta. 
In terms of mitigation, the Climate Change Action Plan includes guidelines to establish sector regulations for LULUCF and energy, including the creation of the National Commission on Clean Development Mechanism (CDM). The Climate Change Action Plan includes a strong focus on the LULUCF sector and seeks to reduce emissions and increase carbon absorption capacity. It also contains targets for policies on spatial planning, poverty reduction, law enforcement, research and development, and engineering.

The planning agency, Badan Perencanaan Pembangunan Nasional (Ministry of National Development Planning), launched Indonesia Climate Change Sectoral Roadmap in 2010. ${ }^{31}$ The Indonesia Climate Change Trust Fund was also established in 2010 to scale up financing by linking international finance and domestic investment. ${ }^{32}$

Presidential Decree No. 61 of 2011 established the National Action Plan for Greenhouse Gas Emission Reduction to implement Indonesia's emissions reduction goals across various sectors, including agriculture, forestry, industry, energy, and infrastructure. A guiding document for developing nationally appropriate mitigation actions, the national action plan works alongside the gubernatorial regulations on provincial action plans to reduce $\mathrm{GHG}$ emissions. ${ }^{33}$

In the National Medium Term Development Plan 2015-2019 (Development Plan), ${ }^{34}$ the green economy is the foundation of the country's development program, emphasizing on "inclusive and sustainable growth, increasing value added of natural resources with the sustainable approach, increasing quality of the environment, disaster mitigation and tackling climate change." 35 The Development Plan further establishes GHG emissions reduction for five priority sectors - forestry and peatlands, agriculture, energy and transportation, industry, and waste - to meet a 26\% reduction in 2019, in line with the National Action Plan for Greenhouse Gas Emission Reduction (footnote 35).

The Development Plan also sets qualitative goals such as (i) supporting the development of green cities; (ii) developing rural and remote areas, with special attention to border areas, disadvantaged regions, transmigration areas, and small islands; (iii) eradicating illegal logging, fishing, and mining; (iv) improving governance in natural resources and increasing community participation in forest management; and ( $v$ ) increasing community resilience to climate change impacts in 15 vulnerable regions defined in the National Action Plan for Climate Change

31 Government of Indonesia. 2009. Indonesia Climate Change Sectoral Roadmap (ICCSR). Jakarta.

32 Climate Funds Update. Indonesia Climate Change Trust Fund.

33 Government of Indonesia. 2013. Indonesia's Framework for Nationally Appropriate Mitigation Actions. Jakarta.

34 Government of Indonesia. 2014. Rencana Pembangunan Jangka Menengah Nasional 2015-2019 (National Medium Term Development Plan 2015-2019). Jakarta.

35 Grantham Research Institute on Climate Change and the Environment, Climate Change Laws of the World. National Medium Term Development Plan 2015-2019 (RPJMN 2015-2019). 
Adaptation. ${ }^{36}$ The Development Plan also contains regional initiatives. The Ministry of Environment and Forestry (MOEF) has promulgated some climate-relevant regulations. For example, MOEF Regulation No. 7 of 2018 guides national assessments of climate risks, vulnerability, and impacts. ${ }^{37}$ It advises the public and the government on how to determine the methodology, analytical scope, data, and indicators for climate change risk, vulnerability, and impact studies. It also provides specific criteria for these studies. Study components include sensitivity, exposure, adaptation capacity, and climate-related harms. The regulation dictates that climate impact analysis should provide impact information such as frequency, location, duration, and extent. It further outlines study indicators based on the type of hazard and socioeconomic circumstances.

MOEF Regulation No. 71 of 2017 provides the legal basis for establishing Indonesia's National Registry System of its GHG inventory. ${ }^{38}$ The registry system was developed to comply with article 13 of the Paris Agreement, which mandates that parties maintain transparency in meeting their GHG emissions reduction targets. It is a web-based inventory of the country's actions and resources relating to adaptation, mitigation, and other activities.

MOEF Regulation No. 72 of 2017 implements a system for measurement, reporting, and verification (MRV) and related resources for managing climate change. ${ }^{39}$ The regulation dictates that individuals, the private sector, local government, and the central government implement resources and establish agencies to address climate change. All actions that mitigate climate change must be carried out through the MRV system for REDD+ and reported to the MOEF. ${ }^{40}$

Table 5.2 summarizes Indonesia's climate change legal and policy framework.

36 Government of Indonesia. 2014. National Action Plan for Climate Change Adaptation (RAN-API). Jakarta. These 15 regions are as follows: Bali Province, Semarang City, Pekalongan City, West Java Province, Blitar City, Bandar Lampung City, East Java Province, Malang District, Batu City, Malang City, West Nusa Tenggara Province, Lombok Island, Tarakan District, South Sumatra Province, and North Sumatra Province.

37 Government of Indonesia, Ministry of Environment and Forestry (MOEF). 2018. Regulation No. 7 of 2018. Jakarta.

38 Government of Indonesia, MOEF. Regulation No. 71 of 2017. Jakarta.

39 Government of Indonesia, MOEF. 2017. Regulation No. 72 of 2017. Jakarta.

40 REDD+ means reducing emissions from deforestation and forest degradation in developing countries, and the role of conservation, sustainable management of forests, and enhancement of forest carbon stocks in developing countries. 


\section{Table 5.2: Climate Change Legal and Policy Framework of Indonesia}

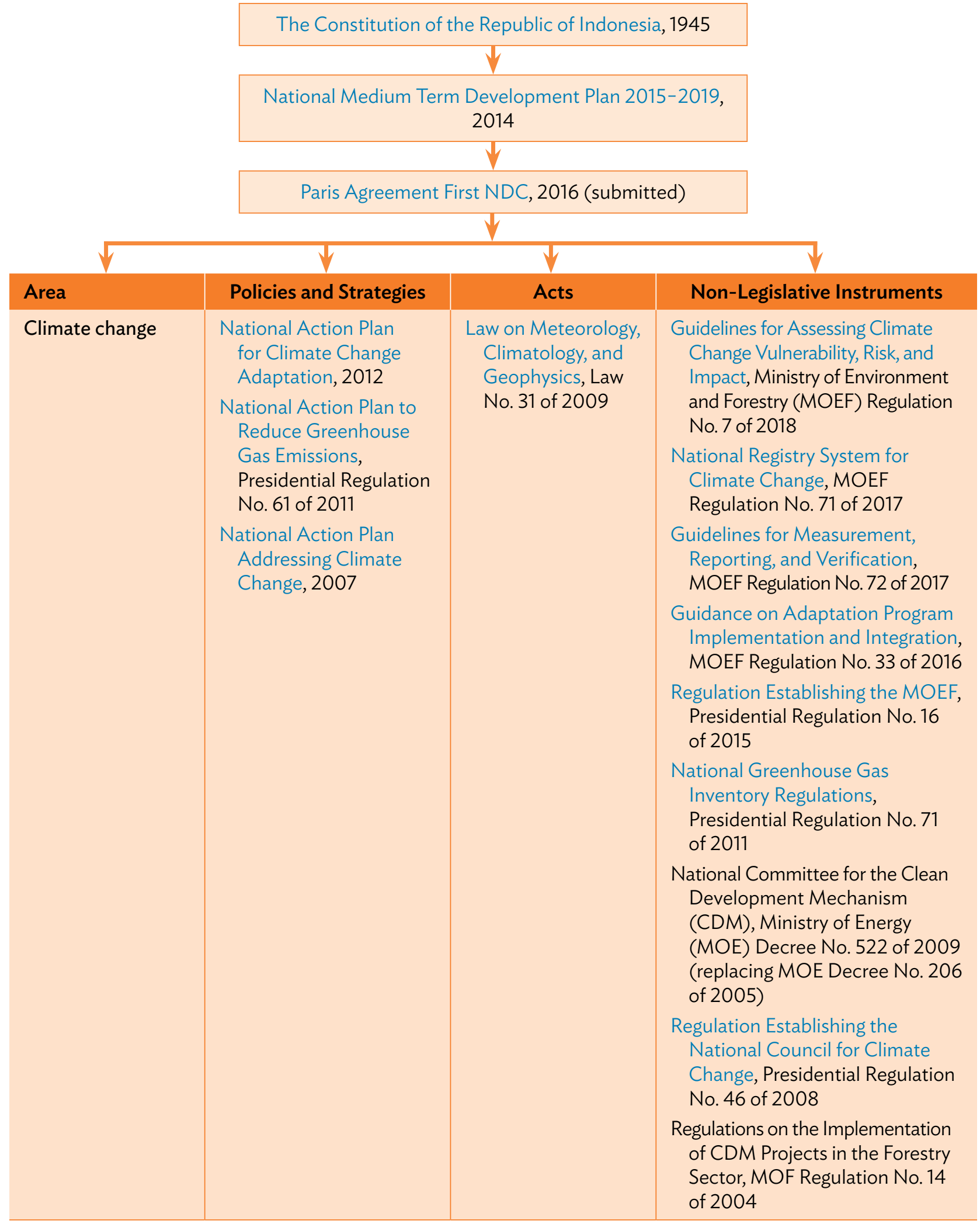


Table 5.2 continued

\begin{tabular}{|c|c|c|c|}
\hline Area & Policies and Strategies & Acts & Non-Legislative Instruments \\
\hline Energy & $\begin{array}{l}\text { National Energy } \\
\text { Policy, Government } \\
\text { Regulation No. } 79 \text { of } \\
2014 \\
\text { Policy on Renewable } \\
\text { Energy Development } \\
\text { and Energy } \\
\text { Conservation, Ministry } \\
\text { of Energy and Mineral } \\
\text { Resources (MOEMR) } \\
\text { Decree No. } 2 \text { of } 2004\end{array}$ & $\begin{array}{l}\text { Geothermal Law, } \\
\text { Law No. } 21 \text { of } \\
2014 \\
\text { Law on Energy, Law } \\
\text { No. } 30 \text { of } 2007\end{array}$ & $\begin{array}{l}\text { Renewable Energy Regulations, } \\
\text { MOEMR Regulation No. } 12 \text { of } \\
2017 \\
\text { Renewable Energy Regulations, } \\
\text { MOEMR Regulation No. } 50 \text { of } \\
2017 \\
\text { List of Projects Under the Fast } \\
\text { Track Program on Renewable } \\
\text { Energy, Coal, and Gas Power, } \\
\text { MOEMR Regulation No. } 40 \\
\text { of } 2014 \text { (amending MOEMR } \\
\text { Regulation No. } 15 \text { of } 2010 \text { ) } \\
\text { Regulations for the Geothermal } \\
\text { Mining Natural Resources } \\
\text { Revenue Sharing Fund, Minister } \\
\text { of Finance Regulation No. } 216 \\
\text { of } 2012 \\
\text { Regulation on Energy Conservation, } \\
\text { Presidential Regulation No. } 70 \text { of } \\
2009 \\
\text { Instruction on Energy and } \\
\text { Water Efficiency, Presidential } \\
\text { Instruction No. } 2 \text { of } 2008 \\
\text { Instruction on Biofuel Production } \\
\text { and Use, Presidential Instruction } \\
\text { No. } 1 \text { of } 2006 \\
\text { Government Energy Efficiency } \\
\text { Obligations, Presidential } \\
\text { Instruction No. } 10 \text { of } 2005\end{array}$ \\
\hline $\begin{array}{l}\text { LULUCF and } \\
\text { REDD+ }\end{array}$ & & $\begin{array}{l}\text { Law on Prevention } \\
\text { and Eradication of } \\
\text { Forest Destruction, } \\
\text { Law No. } 18 \text { of } \\
2013 \\
\text { Law on Plantations, } \\
\text { Law No. } 18 \text { of } \\
2004\end{array}$ & $\begin{array}{l}\text { Extension to the Moratorium on } \\
\text { Issuing New Peatland and Forest } \\
\text { Utilization Licenses, Presidential } \\
\text { Instruction No. } 6 \text { of } 2017 \\
\text { Procedures for Conducting an } \\
\text { Inventory and Determining Peat } \\
\text { Ecosystem Function, MOEF } \\
\text { Regulation No. } 14 \text { of } 2017 \\
\text { Groundwater Measurement } \\
\text { Procedures at Peat Ecosystem } \\
\text { Point, MOEF Regulation No. } 15 \\
\text { of } 2017 \\
\text { Technical Guidelines for Recovery } \\
\text { of Peat Ecosystem Functions, } \\
\text { MOEF Regulation No. } 16 \text { of } 2017\end{array}$ \\
\hline
\end{tabular}


Table 5.2 continued

\begin{tabular}{|c|c|c|c|}
\hline Area & Policies and Strategies & Acts & Non-Legislative Instruments \\
\hline & & & 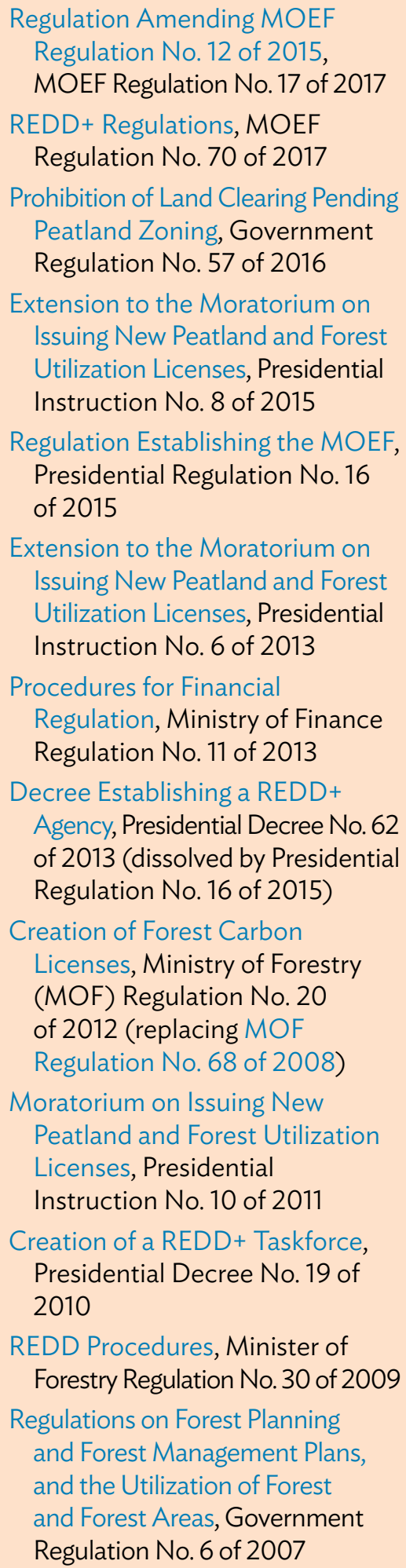 \\
\hline
\end{tabular}


Table 5.2 continued

\begin{tabular}{|c|c|c|c|}
\hline Area & Policies and Strategies & Acts & Non-Legislative Instruments \\
\hline $\begin{array}{l}\text { LULUCF and } \\
\text { REDD }{ }^{a} \\
\text { (continued) }\end{array}$ & & & $\begin{array}{l}\text { Regulations on the Implementation } \\
\text { of CDM Projects in the Forestry } \\
\text { Sector, MOF Regulation No. } 14 \\
\text { of } 2004 \\
\text { Forest Protection Regulations, } \\
\text { Government Regulation No. } 45 \\
\text { of } 2004\end{array}$ \\
\hline $\begin{array}{l}\text { Water resources } \\
\text { and coastal zone } \\
\text { management }\end{array}$ & & & $\begin{array}{l}\text { Instruction on Energy and } \\
\text { Water Efficiency, Presidential } \\
\text { Instruction No. } 2 \text { of } 2008\end{array}$ \\
\hline Waste & & $\begin{array}{l}\text { Law on Waste } \\
\text { Management, Law } \\
\text { No. } 18 \text { of } 2008\end{array}$ & \\
\hline Other & & $\begin{array}{l}\text { Law on Environmental } \\
\text { Protection and } \\
\text { Management, Law } \\
\text { No. } 32 \text { of } 2009\end{array}$ & $\begin{array}{l}\text { Regulation on Damage Control } \\
\text { and Environmental Pollution } \\
\text { from Forest Fires, Government } \\
\text { Regulation No. } 4 \text { of } 2001\end{array}$ \\
\hline
\end{tabular}

LULUCF = land use, land-use change, and forestry; NDC = nationally determined contribution; REDD+ = reducing emissions from deforestation and forest degradation, conservation of existing forest carbon stocks, sustainable forest management, and enhancement of forest carbon stocks.

Source: Authors.

\section{Energy Supply}

Indonesia's total primary energy supply (TPES) is projected to increase to 332 million tons of oil equivalent (Mtoe) by 2025 and to more than 1,041 Mtoe by $2050 .{ }^{41}$ Under the BAU scenario, fossil fuels will drive much of this growth. There were significant increases in the consumption of coal as a percentage of the country's total primary energy consumption-from $24 \%$ in 2008 to $33 \%$ in 2018.42 "Wind and solar power generation remain negligible in Indonesia." ${ }^{43}$

\section{Sector-Wide Energy Strategies}

Indonesia's energy strategy is outlined in the National Energy Policy (NEP), Presidential Regulation No. 5 of 2006, which "emphasizes diversification, environmental sustainability, and maximum use of domestic energy resources." 44 In 2014, the NEP was updated to include new target energy mixes-(i) oil (25\%), natural gas (22\%), coal (30\%), and new and renewable energy (23\%) for 2025;

41 Secretariate General of National Energy Council. 2016. Indonesia Energy Outlook 2016. Jakarta.

42 BP. 2019. BP Statistical Review - 2019. Indonesia's Energy Market in 2018.

43 Footnote 42, p. 1.

44 Government of Indonesia. 2006. Presidential Regulation No. 5 of 2006, National Energy Policy. 25 January. Jakarta; ADB. 2016. Indonesia Energy Sector Assessment, Strategy, and Road Map. Manila. p. 3. 
and (ii) oil (20\%), natural gas (24\%), coal (25\%), and new and renewable energy (31\%) for 2050.45

The NEP also provides for government subsidies. For example, the NEP stipulates that subsidies can be used when renewable energy is more expensive than the energy from nonsubsidized fossil fuel. Electricity and fuel subsidies are also available for certain populations experiencing poverty.

\section{Renewable Energy Policies}

Ministry of Energy and Mineral Resources (MOEMR) Regulation No. 50 of 2017 (Regulation 50) mandates that Perusahaan Listrik Negara, the state-owned electricity company, must buy electricity from power plants that use renewable energy ${ }^{46}$ Regulation 50 defines renewable energy sources as including wind, solar, biogas, biomass, hydropower, geothermal, solid waste incineration, and temperature and motion differences in sea layers. The regulation also specifies that Perusahaan Listrik Negara must purchase electricity through a direct selection mechanism.

Regulation 50 replaced MOEMR Regulation No. 12 of 2017 (Regulation 12), which established electricity tariffs. Regulation 12 imposed caps on tariffs: (i) at $85 \%$ of the region's electricity generation costs for solar photovoltaic, wind, hydro, biomass, and biogas; and (ii) at 100\% of the region's electricity generation costs for city waste-toenergy and geothermal plants, unless agreed upon otherwise. ${ }^{47}$ Regulation 50 increased the tariff for hydropower to $100 \%$ of the region's electricity generation cost and imposed a tariff cap for seawater energy at $100 \%$ of the region's electricity generation cost.

\section{Energy Demand}

Energy consumption in Indonesia has increased over time from 133 Mtoe in 2008 to 186 Mtoe in 2018 (footnote 42). Likewise, total electricity generation increased from 149 terawatt-hours (TWh) in 2008 to 267 TWh in 2018 (footnote 42). During 2007-2017, the demand for coal increased by $4.7 \%$ per year, for oil by $2.1 \%$, and for natural gas by $1.1 \%$ (footnote 42 ). In 2018, primary energy consumption came from oil (45\%), coal (33\%), natural gas (18\%), hydropower (2\%), and biomass and geothermal power (1.8\%) (footnote 42 ).

Indonesia's energy demand is expected to continue to increase. Current projections indicate that total final energy consumption (TFEC) will reach 238.8 Mtoe by 2025 and 682.3 Mtoe by 2050 (footnote 41). Energy demand is projected to grow on average by $4.9 \%$ per year during $2015-2050$ and will be driven by the transportation and industry sectors as well as the commercial and household sectors (footnote 41).

45 Government of Indonesia. 2014. Government Regulation No. 79 of 2014, National Energy Policy. Jakarta.

46 Government of Indonesia, Ministry of Energy and Mineral Resources (MOEMR). 2017. Regulation No. 50 of 2017 on Utilization of Renewable Energy Sources for Power Supply. Jakarta.

47 Government of Indonesia, MOEMR. 2017. Regulation No. 12 of 2017 on Utilization of Renewable Energy Sources for Power Supply. Jakarta. 


\section{Sector-Wide Energy Strategies}

Indonesia is shifting its energy strategy to a focus on demand-side versus supply-side management, indicating that Indonesia is making substantial efforts toward efficient sectoral energy demand (footnote 41). The Energy Law, 2007 primarily regulates energy demand and mandates the establishment of the National Energy Council. The council oversees the development of the Rencana Induk Konservasi Energi Nasional (National Master Plan for Energy Conservation) and other energy management policies. ${ }^{48}$

Indonesia has set three main energy efficiency targets. The first aims to reduce energy intensity by $1 \%$ per year until 2025 , as established by the National Master Plan for Energy Conservation (footnote 48). The second seeks to achieve a $41 \%$ reduction of TPES in 2025 against a BAU scenario by implementing energy efficiency and conservation measures, as established by the Blueprint of National Energy Management (2005-2025)..$^{49}$ The third plans to achieve an energy elasticity of less than 1 in 2025, as established in the 2006 National Energy Policy. ${ }^{50}$

There are also some energy efficiency initiatives, including mandatory energy conservation of government office buildings, a government-funded energy audit program for private sector buildings, and an energy labeling program.

\section{E. LULUCF and REDD+}

Deforestation and forest degradation are critical issues in Indonesia due to significant financial incentives for capitalizing on forest resources. ${ }^{51}$ Forest industries contribute approximately $3.5 \%$ of Indonesia's gross domestic product (GDP) ( $\$ 21$ billion) to the economy (footnote 51). Indonesia has one of the highest rates of deforestation and degradation in the world. During 1990-2005, about 28 million hectares of its forests had been cleared. ${ }^{52}$

Up to $84 \%$ of Indonesia's GHG emissions arise from land-use change and deforestation, and about half of these from carbon-rich peatlands. ${ }^{53}$ Indonesia is the world's fourth-largest GHG emitter due primarily to land-use change and fires on peatland. ${ }^{54}$

48 International Energy Agency. 2017. National Master Plan for Energy Conservation. Paris.

49 Government of Indonesia, Ministry of Energy and Mineral Resources. 2006. Blueprint of National Energy Management (2005-2025). Jakarta.

50 Footnote 49. Energy elasticity is the rate of change in energy consumption over the rate of change in the gross domestic product (GDP). A country's GDP growth should be faster than its increase in energy consumption for the country to achieve an energy elasticity of less than 1 . In other words, its economic activities should not be so heavily dependent on energy consumption.

51 Programme for the Endorsement of Forest Certification. 2014. Indonesian Forests to Benefit from PEFC Certification. PEFC system news. 9 October.

52 World Resources Institute. Forest Cover, 1990-2005, Indonesia (accessed 15 December 2019).

53 World Resources Institute. Forest Cover Loss in Indonesia, 2000-2005: The Starting Point for the Norwegian Billion to Reduce Deforestation (accessed 15 December 2019).

54 D. Dunne. 2019. The Carbon Brief Profile: Indonesia. CarbonBrief. 27 March. 
Presidential Instruction No. 6 of 2013 sets an overall goal to "resolve ongoing various efforts to improve governance of forest and peat land ... to reduce emissions from deforestation and forest degradation." ${ }^{5}$ It seeks to improve the governance of peatland and forest to reduce emissions related to forest degradation and deforestation. To reach this goal, it instructs ministers and other officials to suspend certain licensing activities and improve permitting policies.

Presidential Regulation No. 16 of 2015 integrated the Ministry of Environment with the Ministry of Forestry to create the Ministry of Environment and Forestry (MOEF), which became the sole drafter and implementer of Indonesia's climate change policies. ${ }^{56}$ The regulation also created the Directorate General of Climate Change, responsible for creating and implementing standards, policies, norms, and criteria for the following areas:

(i) adaptation;

(ii) mitigation;

(iii) ozone-depleting substances;

(iv) GHG inventories;

(v) resource mobilization;

(vi) climate change monitoring, reporting, and verification; and

(vii) forest and peatland control.

MOEF Regulation No. 70 of 2017 establishes REDD+ regulations and mandates that REDD+ sites must undergo measurement, reporting, and verification (MRV). ${ }^{57} \mathrm{It}$ establishes MRV as the foundation of a results-based system of payment awarded to achievements in emissions reductions. It dictates that the MOEF's Director General of Climate Change will serve as the national focal point of REDD+ implementation. The director general will also communicate REDD+ activities to the United Nations Framework Convention on Climate Change (UNFCCC) Secretariat. The regulation also addresses results-based payments, Forest Reference Emissions Level/Forest Reference Level, the National Registry System, and the Safeguards Information System.

\section{F. Transportation}

Transportation is expected to drive a significant part of rising energy demand, as Indonesia experiences more urbanization and motorization. ${ }^{58}$ Transportation is the third-largest source of energy-related carbon dioxide $\left(\mathrm{CO}_{2}\right)$ emissions. Road transport emissions are predicted to increase from 105.8 metric tons of $\mathrm{CO}_{2}\left(\mathrm{tCO}_{2}\right)$ in 2010 to $261 \mathrm{tCO}_{2}$ by 2030 under a BAU scenario. ${ }^{59}$

55 Government of Indonesia. 2013. Presidential Instruction No. 6 of 2013. Jakarta. p. 1.

56 Government of Indonesia. 2015. Presidential Regulation No. 16 of 2015. Jakarta.

57 Government of Indonesia, MOEF. 2017. Regulation No. 70 of 2017. Jakarta.

58 M. Nachmany et al. 2015. Climate Change Legislation in Indonesia: An Excerpt from the 2015 Global Climate Legislation Study: A Review of Climate Change Legislation in 99 Countries. London: Grantham Research Institute on Climate Change and the Environment.

59 S. Gota et al. 2015. Emission Reduction Potential in the Transport Sector by 2030: Key Findings. Paris Process on Mobility and Climate. 
In response to these challenges, the Ministry of Transport developed the Sustainable Urban Transport Programme Indonesia in 2012, which is divided into two phases: piloting (2015-2019) and full-scale implementation (2020-2030) (footnote 58). It is expected to mitigate $0.7-1.8 \mathrm{tCO}_{2}$ in 2030 in each city in which the program is piloted, with cumulative reduction until 2030 estimated at $7.2-14.1 \mathrm{tCO}_{2}$.

\section{G. Adaptation}

The Ministry of National Development Planning and the National Development Planning Agency developed the National Action Plan for Climate Change Adaptation in $2012 .{ }^{60}$ The plan seeks to build resilience in three key areas: the economy, livelihoods, and environmental services. These three areas are broken down further into subsectors with an action plan for achieving targets. The plan also identifies climate challenges, including sea level rise, rainfall variability, and changing interannual patterns, and it maps the sectors likely to be affected by these risks. It works together with the National Medium Term Development Plan 2015-2019.

MOEF Regulation No. 33 of 2016 guides climate change adaptation projects and integrates them into development plans. ${ }^{61}$ The regulation specifies a process for adaptation that includes identifying targeted sectors, regions, and impacts; studying climate vulnerability; formulating adaptation opinions; selecting prioritized adaptation action; and integrating adaptation actions into development plans, policies, and programs. The regulation also outlines indicators for studies on climate vulnerability and impacts.

\section{Lao People's Democratic Republic}

\section{A. Country Snapshot: Climate and Environmental Challenges}

The Lao People's Democratic Republic (Lao PDR), which is a one-party socialist republic, faces threats from numerous climate change impacts, especially increasingly frequent and intense floods and droughts, and increased temperatures. ${ }^{62}$ These impacts threaten both agricultural and hydropower production, which are critical to the country's food and energy security. In 2018, the agriculture and industry sectors accounted for $53.2 \%$ of total gross domestic product (GDP), with the industry sector contributing $46.8 \% .{ }^{63}$ While the agriculture sector is shrinking as a percentage of GDP, it employs approximately

60 Government of Indonesia, Ministry of National Development Planning and National Development Planning Agency. 2012. National Action Plan for Climate Change Adaptation (RAN-API): Synthesis Report. Jakarta.

61 Government of Indonesia, MOEF. 2016. Regulation No. 33 of 2016. Jakarta.

62 Food and Agriculture Organization of the United Nations (FAO). Building Resilience to Climate Change in Laos.

63 ADB. Lao People's Democratic Republic, Key Indicators (accessed 26 June 2020). 
$70 \%$ of the population. ${ }^{64}$ Hence, climate change impacts in rural areas have widespread impacts on the Lao people.

Extreme weather events such as typhoons threaten lives and food security. During 2009-2011, the Lao PDR was struck by several typhoons, which resulted in many deaths, rendered thousands of people homeless, and caused major destruction to crops and livestock. ${ }^{65}$ Floods in 2018 affected almost 750,000 people and destroyed over 100,000 hectares of crops. ${ }^{66}$ The Lao PDR's "contribution to global GHG emissions is negligible." ${ }^{67}$ However, the country still plans to take mitigation measures while building resilience to adverse climate impacts, especially in the agriculture sector. ${ }^{68}$

\section{B. Overarching Climate Change Legal and Policy Framework}

\section{Mitigation and Adaptation Targets}

The Lao PDR's first nationally determined contribution (NDC) aims to increase the share of renewable energy to $30 \%$ of total energy consumption by $2025 .{ }^{69}$ Additionally, the NDC targets to increase forest cover to $70 \%$ of total land area by 2020 (footnote 69). In the transport sector, the government aims to increase the share of biofuels to $10 \%$ of total transport fuels by 2025 (footnote 69).

\section{Overview of Climate Change Law and Policy}

In 2010, the Lao PDR published its Strategy on Climate Change (Climate Strategy), which recommends implementing adaptation measures to promote sustainable economic development and increase economic resilience to climate change impacts. $^{70}$ The Climate Strategy sets some goals, including (i) reinforcing the Sustainable Development Goals of Lao PDR, such as actions to achieve low-carbon economic growth; (ii) increasing the resilience of key sectors of the national economy and natural resources; (iii) creating national and international partnerships to achieve national development goals; and (iv) educating the public about climate change impacts to build stakeholder buy-in.

The Climate Strategy sets a quantified target of $65 \%$ reforestation for carbon sequestration by 2015 and $70 \%$ by 2020 (footnote 70). It also details strategic priorities and possible mitigation and adaptation measures by sector, including agriculture, forestry and land use, energy, and transport.

64 ADB. 2020. Asian Development Outlook 2020: What Drives Innovation in Asia? Manila.

65 P. Thevongsa. 2012. Climate Change and Its Impact on the Lao and Cambodian People. Vientiane Times. 3 May.

66 Government of the Lao PDR. 2018. Post-Disaster Needs Assessment: 2018 Floods, Lao PDR. Vientiane.

67 United Nations, Lao PDR. 2017. What Does the international Climate Conference COP 23 Mean for Lao PDR? Press release. 11 December.

68 United Nations Development Programme (UNDP). Lao PDR Project Document. New York.

69 Government of the Lao PDR. 2016. First Nationally Determined Contribution. Vientiane.

70 Government of the Lao PDR. 2010. Strategy on Climate Change of the Lao PDR. Vientiane. 
The Lao PDR has also emphasized the importance of addressing climate change in its development plans. One major directive in the Seventh Five-Year National Socio-Economic Development Plan (2011-2015) is to protect and sustain the environment, as well as pursue climate change mitigation. ${ }^{71}$ Proposals to achieve this directive include water conservation, preservation and enhancement of forest cover, and improvements in evaluating and monitoring environmental impacts arising from new industrial and investment projects.

The Eighth Five-Year National Socio-Economic Development Plan (2016-2020) outlines the Lao PDR's goal to become an upper middle-income country by 2030 and integrates climate concerns into development planning. ${ }^{72}$ The plan discusses climate change's impact on food production, the role of environmental protection in alleviating poverty, the impact of climate change on women, and the importance of resilience initiatives. It also highlights how climate change has increased the frequency and severity of natural disasters.

The Lao PDR is updating its climate change strategy and strategy for disaster risk management.

Outside of the policy realm, the Lao PDR enacted its Environmental Protection Law, 2013, which defines principles, regulations, and measures related to environmental management, and emphasizes mitigating anthropogenic impacts and pollution. The law aims to balance social and natural environments, sustain natural resources and public health, and combat climate change. Article 19 requires strategic environmental assessments that consider climate change effects.

Article 20 stipulates that preventative measures against natural disasters should be undertaken, such as planting trees and constructing dikes and drainage canals. The law also acknowledges the effect of climate change on biodiversity and establishes the Initial Environment Examination. ${ }^{73}$ The Initial Environment Examination analyzes data that anticipate minor environmental impacts from investment projects or activities, including those related to climate change.

In 2019, the Lao PDR enacted its Decree No. 321/Govt, Decree on Climate Change to govern the management, monitoring, and inspection of climate mitigation and adaptation efforts in the country. The decree functions as an umbrella law to build institutional frameworks to enable climate action in the Lao PDR. It seeks to mainstream climate change into the Lao PDR's national and local planning and to promote unified and collaborative government action on climate change.

A central feature of the decree is its creation of a national data and information system on climate change, managed by the Ministry of Natural Resources and Environment. All ministries in the Lao PDR must provide information on sectoral

71 Government of the Lao PDR, Ministry of Planning and Investment. 2011. The Seventh Five-Year National Socio-Economic Development Plan (2011-2015). Vientiane.

72 Government of the Lao PDR, Ministry of Planning and Investment. 2016. 8th Five-Year National Socio-Economic Development Plan (2016-2020). Vientiane.

73 Law No. 29/NA, Environmental Protection Law, 2013, art. 21. 
climate change impacts to the information system. The decree establishes a framework for undertaking climate vulnerability assessments in adaptation planning. It also amends the Environmental Protection Fund, allowing it to receive international climate change funding. Ministerial rights and duties are also set out in the decree to promote greater government collaboration on climate mitigation or adaptation in the Lao PDR.

The Lao PDR also passed the Disaster Management Law in 2019, which creates a risk information system and ensures that all disaster information and data are readily accessible. It also establishes national rights and responsibilities for disaster management in the Lao PDR.

Table 5.3 summarizes the Lao PDR's climate change legal and policy framework.

\section{Table 5.3: Climate Change Legal and Policy Framework of the Lao People’s Democratic Republic}

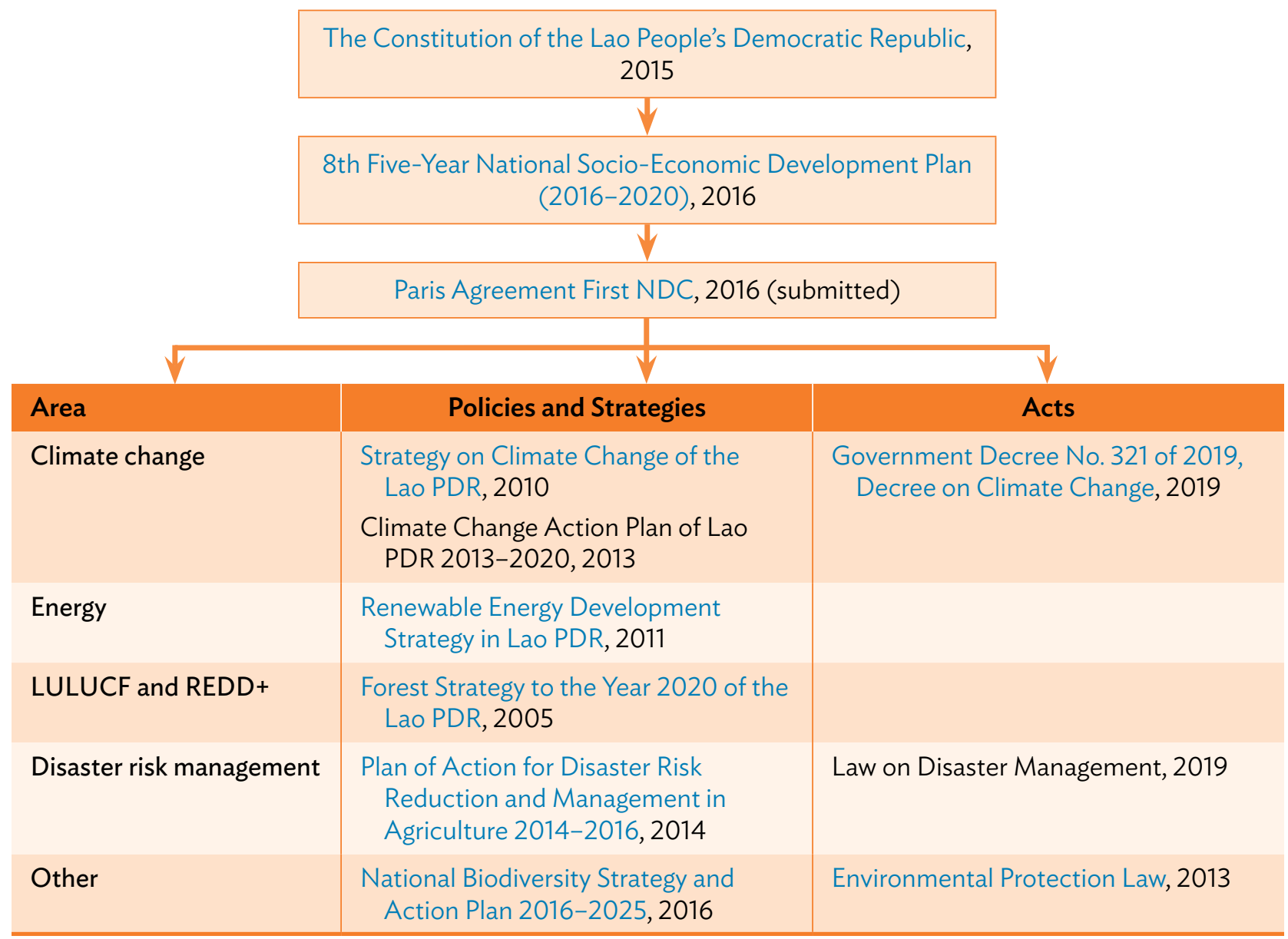

LULUCF = land use, land-use change, and forestry; NDC = nationally determined contribution; REDD + = reducing emissions from deforestation and forest degradation, conservation of existing forest carbon stocks, sustainable forest management, and enhancement of forest carbon stocks.

Source: Authors. 


\section{Energy Supply}

In 2015, the Lao PDR's total primary energy supply (TPES) came from biomass (34\%), coal (33\%), petroleum (20\%), and hydropower (9\%). ${ }^{74}$ The TPES increased from 1.618 million tons of oil equivalent (Mtoe) in 2000 to 4.765 Mtoe in 2015, at an average annual growth rate of 7.5\% (footnote 74). During 2000-2015, coal saw the largest increase at an annual average rate of $42.2 \%$ (footnote 74 ). Hydropower and petroleum also grew rapidly during this period, with average growth rates of $9.8 \%$ for hydropower and $8.5 \%$ for petroleum (footnote 74 ).

The Lao PDR's TPES is projected to annually increase by an average of $5.1 \%$ through 2040. ${ }^{75}$ Coal is projected to grow at the highest rate, representing $38.4 \%$ of energy supply by 2040 (footnote 75). Hydropower production is expected to increase at an annual average of 4.5\%, reaching 4.35 Mtoe by 2040 (footnote 75). Oil is also projected to experience significant growth, comprising $31.7 \%$ of energy supply by 2040 (footnote 75). Biomass is projected to grow at an annual average of only $1.1 \%$ and produce 1.69 Mtoe by 2040 (footnote 75).

\section{Renewable Energy Policies}

In 2011, the Lao PDR released the Renewable Energy Development Strategy, which calls for increasing renewable energy production to maintain consistent energy supply, address climate change, and encourage economic development. ${ }^{76}$ The strategy aims to increase the share of renewable sources to $30 \%$ by 2025 and the share of biofuels to $10 \%$ of total transport energy consumption (footnote 76 ).

\section{Energy Demand}

The Lao PDR's total final energy consumption (TFEC) has grown radically since 2000, when it was 1.509 Mtoe (footnote 74). Before 2013, hydropower was the country's only source of power (footnote 74). In 2015, the Lao PDR's TFEC had grown to approximately 9 Mtoe and the Hongsa thermal power plant started operations. ${ }^{77}$ Coal has grown to dominate the fuel mix, providing $71.1 \%$ of the total final energy demand in 2015 (footnote 77).

The TFEC is expected to continue to increase to just over 15 Mtoe by 2030 and nearly 30 Mtoe by 2040, with coal representing $85.3 \%$ of TFEC in 2040

74 Government of the Lao PDR, Ministry of Energy and Mines. 2018. Lao PDR Energy Statistics 2018. Jakarta: ERIA.

75 K. Kouphokham. 2016. Lao PDR Country Report. In S. Kimura and P. Han, eds. Energy Outlook and Energy Saving Potential in East Asia 2016. ERIA Research Project Report 2015-5. Jakarta: ERIA. pp. 193-213.

76 Government of the Lao PDR, Ministry of Energy and Mines. 2011. Renewable Energy Development Strategy in Lao PDR. October. Vientiane.

77 K. Kouphokham. 2019. Chapter 10. Lao PDR Country Report. In S. Kimura and H. Phoumin, eds. Energy Outlook and Energy Saving Potential in East Asia 2019. Jakarta: ERIA. pp. 185-186 and Figures 10.1, 10.2, and 10.3. 
(footnote 77). The industry sector is projected to have the highest growth rate, consuming over 75\% of TFEC in 2030 and 2040, followed by transport and other sectors-residential, agriculture, services, and commerce (footnote 77). The Lao PDR has not yet issued any energy conservation policies.

\section{E. LULUCF and REDD+}

With $80 \%$ of the population heavily dependent on forest resources, the Lao PDR has encountered problems associated with rapid deforestation. ${ }^{78}$ In 2005 , the Lao PDR released the Forest Strategy to the Year 2020 to preserve its forests, aiming to achieve targets established in the national socioeconomic plans, such as naturally regenerating 6 million hectares of forest and planting 500,000 hectares of trees on highly degraded forestland by $2020 .{ }^{79}$ Protecting forests entails formulating a national tree plantation development plan and forest harvesting management plans, as well as monitoring the effectiveness of these initiatives. Other objectives of the strategy include sustainably managing natural resources and eradicating poverty.

\section{F. Adaptation}

The Lao PDR's Climate Strategy includes recommendations for implementing adaptation measures to promote sustainable economic development and increase economic resilience to climate change (footnote 70 ). The strategy sets goals for

(i) increasing the resilience of strategic economic sectors and natural resources to climate impacts;

(ii) strengthening cooperation with national stakeholders and international partners to achieve Lao PDR's national development goals; and

(iii) raising awareness about climate change, vulnerability, and impacts to improve the public's and stakeholder readiness to act.

In 2009, the Lao PDR issued its National Adaptation Programme of Action, which outlines the country's plan to undertake adaptation measures focused on agriculture, forestry, water resources, and public health..$^{80}$ The program was expanded within the Climate Strategy to target the main sectors of the economyagriculture and food security, land-use change and forestry, water, energy and transport, urban development, industry, and public health. The Lao PDR aims to promote climate resilience in farming systems and agricultural infrastructure and increase the resilience of urban development and infrastructure. These adaptation measures are scheduled to be implemented by 2020 .

78 World Bank. 2011. Government of Lao PDR Makes Progress in Combating Illegal Logging and Corruption in the Forestry Sector. Press release. 24 March.

79 Government of the Lao PDR. 2005. Forest Strategy to the Year 2020 of the Lao PDR. Vientiane.

80 Government of the Lao PDR. 2009. National Adaptation Programme of Action to Climate Change. Vientiane. 


\section{G. Disaster Risk Management}

The Plan of Action for Disaster Risk Reduction and Management in Agriculture (2014-2016) is a key adaptation-related policy, recommending that the Ministry of Agriculture and Forestry integrate risk prevention and mitigation into agricultural activities. ${ }^{81}$ It seeks to promote quicker agricultural recovery for fisheries, livestock, forests, and crops after natural disasters. It has five priority areas such as adapting to climate change in agriculture; monitoring and assessing risks and vulnerabilities posed by climate change; and raising awareness on climate change-related impacts, disaster risk reduction and management, and adaptation to climate change.

The Law on Disaster Management establishes an institutional framework for disaster prevention in the Lao PDR. It enables the government to collect data about disaster risk and populate a risk information system. Each sector within the Lao PDR is responsible for evaluating potential risks and reporting to the National Disaster Management Committee. The law incorporates measures for disaster risk reduction and early warning. The act defines the national and subnational responsibilities for disaster management and outlines the rights of disaster victims. The newly established Disaster Management Fund should finance emergency aid, repair of necessary infrastructure, and search and rescue.

\section{Mallaysia}

\section{A. Country Snapshot: Climate and Environmental Challenges}

Malaysia is a federal constitutional monarchy at risk from climate change impacts, including sea level rise, severe floods, and water shortages due to extreme rainfall variability. ${ }^{82}$ Increasingly unpredictable weather has led to a 10\%-15\% decrease in annual farming yields, undermining food security (footnote 82 ). Greater rainfall intensity has led to severe monsoonal floods. ${ }^{83}$ Seasonal monsoon floods result in an annual direct loss of Malaysian ringgit (RM)915 million (about $\$ 220$ million in late 2020) (footnote 83). Extreme floods in 2014 caused RM2.9 billion (about $\$ 701$ million in late 2020) in damages to public infrastructure (footnote 83). Malaysia has also recorded higher surface temperatures over the past 5 decades (footnote 83). In 2011, its total GHG emissions represented approximately $0.6 \%$ of global emissions (footnote 83 ). Nevertheless, Malaysia has undertaken mitigation measures. Climate change mitigation and adaptation remain a priority, alongside poverty eradication and development (footnote 83).

81 Government of the Lao PDR, Ministry of Agriculture and Forestry. 2014. Plan of Action for Disaster Risk Reduction and Management in Agriculture (2014-2016). Vientiane.

82 S. Norshidi. 2018. Climate Change in Malaysia: Floods, Less Food, and Water Shortages - Yet Its People Are Complacent. 20 September.

83 Government of Malaysia. 2016. First Nationally Determined Contribution of the Government of Malaysia. Kuala Lumpur. 


\section{B. Overarching Climate Change Legal and Policy Framework}

\section{Mitigation and Adaptation Targets}

As part of the Paris Agreement, Malaysia's NDC sets a target for reducing GHG emissions by $45 \%$ by 2030, compared with 2005 emissions intensity of the gross domestic product (GDP) (footnote 83). Although this includes an unconditional reduction by $35 \%$, the remaining $10 \%$ in emissions reduction is conditional upon receiving financing, technology, and capacity building assistance from developed countries (footnote 83). Malaysia also intends to reduce flood risks, prioritize water and food security, protect coastlines, and address climate-related public health issues like increased vector-borne diseases (footnote 83).

\section{Overview of Climate Change Law and Policy}

The Ministry of Natural Resources and Environment (MONRE), along with its subsidiary Department of Environment, is mandated to deal with climate change, including all matters related to the UNFCCC. ${ }^{84}$ The MONRE is responsible for sustainable forest management nationwide, except in Sabah and Sarawak, where separate ministries are responsible for forestry-related policies (footnote 84 ). It also manages the National Water Resources Policy. ${ }^{85}$

The Ministry of Energy, Green Technology and Water (KeTTHA) enacts other climate change-related policies such as renewable energy policies and the feed-in tariff regime (footnote 84). The Malaysian Meteorological Department within the Ministry of Science, Technology and Innovation monitors the climate and creates future climate change projection scenarios (footnote 84).

Malaysia launched the National Policy on Climate Change to mainstream and organize its various activities on climate change. ${ }^{86}$ This policy articulates 5 principles, 10 strategic thrusts or policy goals, and 43 key actions, all centered on climate change mitigation, adaptation, and capacity building. The National Green Technology and Climate Change Council and Malaysian Green Technology Corporation (GreenTech Malaysia) provide institutional support for the policy. (footnote 84). GreenTech Malaysia promotes and coordinates programs that help realize the country's potential for green technology (footnote 84).

Table 5.4 summarizes Malaysia's climate change legal and policy framework.

84 M. Nachmany et al. 2015. Climate Change Legislation in Malaysia: An Excerpt from the 2015 Global Climate Legislation Study: A Review of Climate Change Legislation in 99 Countries. London: Grantham Research Institute on Climate Change and the Environment.

85 Government of Malaysia. 2012. National Water Resources Policy. Kuala Lumpur. More information is available in Government of Malaysia. 2011. Review of the National Water Resources Study (2000-2050) and Formulation of National Water Resources Policy: Final Report. Kuala Lumpur.

86 Government of Malaysia, MONRE. 2009. National Policy on Climate Change of Malaysia. Kuala Lumpur. 


\section{Table 5.4: Climate Change Legal and Policy Framework of Malaysia}

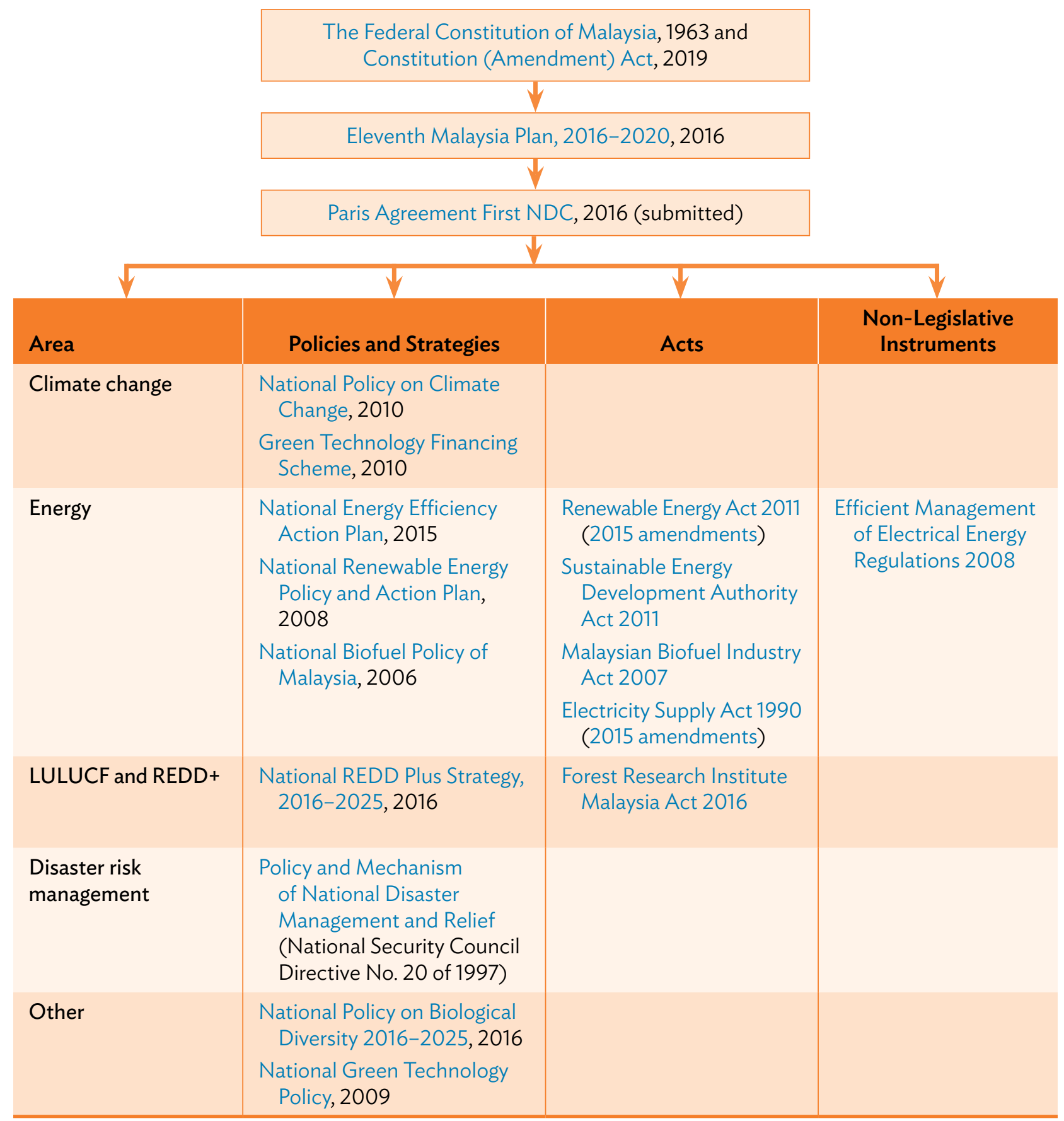

LULUCF = land use, land-use change, and forestry; NDC = nationally determined contribution; REDD + = reducing emissions from deforestation and forest degradation, conservation of existing forest carbon stocks, sustainable forest management, and enhancement of forest carbon stocks.

Source: Authors. 
Malaysia's climate legislation and policies demonstrate a strong focus on the energy sector. Promoting renewable energy development was identified as a priority area in the Eighth Development Plan 2001-2005, Ninth Development Plan 2006-2010, and Tenth Development Plan 2011-2015. ${ }^{87}$ The Eleventh Development Plan 2016-2020 continues the country's focus on renewable energy. It emphasizes reducing Malaysia's carbon footprint, protecting the country from climate change impacts, improving ecological conservation, and strengthening resilience against climate change and associated natural disasters. ${ }^{88}$

In 2016, Malaysia introduced the National Policy on Biological Diversity (2016-2025), which highlights the need for continued conservation, sustainable utilization, and the sharing of benefits from biodiversity fairly and equitably. ${ }^{89}$ The policy calls for improving forest management and rehabilitation to help carbon sequestration, as well as increasing biodiversity conservation.

\section{Energy Supply}

In 2016, Malaysia's total primary energy supply (TPES) was 93.396 million tonnes of oil equivalent (Mtoe), which came from natural gas (40.7\%), crude oil and petroleum (33.5\%), coal and coke (fuel) (20.2\%), hydropower (4.8\%), biodiesel (0.4\%), biomass $(0.2 \%)$, and solar power $(0.1 \%) .{ }^{90}$ Biogas production was negligible (footnote 90 ). Since 1996, increases in the TPES have been primarily driven by natural gas, followed by crude oil and petroleum, as well as coal and coke, and hydropower (footnote 90).

Malaysia's TPES is projected to increase to more than 200 Mtoe by $2040 .{ }^{91}$ The projected energy supply mix is composed of oil (38.3\%), natural gas (35.4\%), coal (24.7\%), and hydropower (1.3\%) (footnote 91). Natural gas is expected to increase to 76.55 Mtoe by 2040 at an average annual growth rate of $4.1 \%$, hydropower to 2.75 Mtoe in 2040 at $4.2 \%$, coal at $4.9 \%$, and oil at 3.5\% (footnote 91 ).

In 2015, KeTTHA released the National Energy Efficiency Action Plan to reduce electricity demand growth by $8 \%$ over 10 years..$^{92}$ The plan forecasts a total reduction of 88 million tons of $\mathrm{CO}_{2}\left(\mathrm{tCO}_{2}\right)$ equivalent over the lifetime of energyefficient technologies adopted (footnote 92). The Electricity Supply Act 1990 provides a legislative foundation for the plan's energy conservation goals.

87 Government of Malaysia. 2001. Eighth Malaysia Plan, 2001-2005. Kuala Lumpur; Government of Malaysia. 2006. Ninth Malaysia Plan, 2006-2010. Kuala Lumpur; and Government of Malaysia. 2010. Tenth Malaysia Plan, 2011-2015. Kuala Lumpur.

88 Government of Malaysia. 2015. Eleventh Malaysia Plan, 2016-2020: Anchoring Growth on People. Kuala Lumpur.

89 Government of Malaysia, MONRE. 2016. National Policy on Biological Diversity (2016-2025). Kuala Lumpur.

90 Suruhanjaya Tenaga (Energy Commission). 2018. Malaysia Energy Statistics Handbook 2018. Putrajaya.

91 Z. Zulkifli. 2016. Malaysia Country Report. In S. Kimura and P. Han, eds. Energy Outlook and Energy Saving Potential in East Asia 2016. ERIA Research Project Report 2015-5. Jakarta: ERIA. pp. 215-236.

92 Government of Malaysia, Kementerian Tenaga Teknologi, Hijau Dan Air (KeTTHA). 2015. National Energy Efficiency Action Plan. Kuala Lumpur. p. 21. 


\section{Renewable Energy Policies}

Beginning with the Eighth Malaysia Plan, 2001-2005, developing the renewable energy sector has been a priority. The Eleventh Development Plan, 2016-2020 includes policy objectives and initiatives aimed at scaling up renewable energy projects by 2020, such as 2,080 megawatts (MW) of renewable energy capacity and net metering (footnote 88). KeTTHA is responsible for promoting the uptake of renewable energy, green technology, and energy efficiency standards under the National Green Technology Strategy in 2009.93

Malaysia created a system of feed-in tariffs under the Renewable Energy Act 2011, which guarantees fixed tariff rates for solar, biomass, biogas, and hydropower for 16-21 years. The government expects the feed-in tariff system to reach a capacity of 2,080 MW by 2020 (approximately $11 \%$ of peak electricity demand), avoiding 42.2 million $\mathrm{tCO}_{2}$ equivalent (footnote 93).

Other initiatives include the Small Renewable Energy Power, Sarawak Corridor of Renewable Energy, and Biomass for Generation and Co-Generation programs (footnote 84). Established in 2001, the Small Renewable Energy Power program aimed to supply small power plants with electricity from renewable resources-biomass, biogas, municipal waste, solar, mini-hydro, and wind-that access the distribution grid system (footnote 84 ). However, the program was mostly unsuccessful. Of the 50 projects approved in 2001-2008 (with a total capacity of $288 \mathrm{MW}$ ), $40 \%$ were canceled and $25 \%$ were issued with licenses, but never started operating. ${ }^{94}$

Sarawak Corridor of Renewable Energy, on the other hand, has attracted about RM79.3 billion (or $\$ 19.1$ billion in late 2020) of investment as of August 2018.95 The 2,400 MW Bakun dam, a major hydro project completed in 2011, will have an additional turbine, expanding its power generation capacity to 2,700 MW. ${ }^{96}$ Ongoing projects include the 1,285 MW Baleh dam and the $944 \mathrm{MW}$ Murum dam (footnote 95). The Biomass for Generation and Co-Generation Project was initiated in 2002 with support from the United Nations Development Programme (UNDP), the Global Environment Facility (GEF), and the private sector.

"It focuses on palm oil industries and the use of waste material in generating" and supplying electricity to the grid. ${ }^{97}$ The $14 \mathrm{MW}$ power plant in Tawau, Sabah, is a major biomass project. In 2004, it used oil palm residues to mitigate up to $50,000 \mathrm{tCO}_{2}{ }^{98}$

93 Footnote 84, p. 3.

94 B. Sovacool and I.M. Drupady. 2016. Energy Access, Poverty, and Development: The Governance of Small-Scale Renewable Energy in Developing Asia. Abingdon-on-Thames: Routledge.

95 J. Wong. 2018. Sarawak Corridor Attracts RM79.3bil in Investments. The Star. 13 August.

96 S. Tawie. 2018. Sarawak to Raise Bakun Dam Power Capacity with New Turbine. Malay Mail. 12 October.

97 UNDP. 2007. Malaysia Generating Renewable Energy from Palm Oil Wastes. Kuala Lumpur. p. iii.

98 World Bank and Australian Agency for International Development. 2013. Green Infrastructure Finance: Green Investment Climate Country Profile-Malaysia. Washington, DC: World Bank. 


\section{Energy Demand}

In 2016, Malaysia's total final energy consumption (TFEC) was 57.218 Mtoe, which came from petroleum products (53.0\%), electricity (21.7\%), natural gas (21.5\%), coal and coke (3.1\%), and biodiesel (0.7\%) (footnote 90). Since 1996, increases in the TFEC have been primarily driven by petroleum products, followed by electricity, natural gas, and coal and coke (footnote 90 ). Energy consumption in 2016 was divided among the following sectors: transportation (42.0\%), industry (28.0\%), non-energy use (15.3\%), residential and commercial (14.1\%), and agriculture $(0.7 \%)$ (footnote 90 ).

Malaysia's TFEC is projected to increase to 157.37 Mtoe by 2040 (footnote 91). The projected energy consumption mix is composed of oil (51.4\%), natural gas (22.5\%), electricity (22.5\%), and coal (3.5\%) (footnote 91 ). Oil demand is expected to increase to 80.83 Mtoe by 2040 at an average annual growth rate of $3.7 \%$ (footnote 91 ). Coal is expected to grow annually at $4.8 \%$ and electricity at $4.4 \%$ (footnote 91 ).

\section{Sector-Wide Strategies}

The Electricity Supply Act 1990, which was amended in 2015, creates the legislative basis for regulating the electricity sector, specifically the electricity supply industry, the supply of electricity at reasonable prices, the licensing and control of any electrical installation, plant and equipment safety, and the efficient use of electricity.

The government has issued two regulations to support the implementation of the Electricity Supply Act. First, the Electricity (Amendment) Regulations 2013 introduce minimum energy performance standards for household appliances and lighting. These regulations create an energy efficiency rating system for electrical appliances and set a required minimum energy efficiency level for certain appliances. Second, the Efficient Management of Electrical Energy Regulations 2008 require all installations with consumption exceeding 3 million kilowatt-hours ( $\mathrm{kWh}$ ) over 6 consecutive months to engage an electrical energy manager. ${ }^{99}$ The manager must assess electrical energy consumption and advise on and monitor energy efficiency measures.

The government has also launched a series of fiscal incentives for energy efficiency, e.g., a 100\% tax exemption of statutory income for 10 years for companies who provide energy conservation services. ${ }^{100}$ An import duty and sales tax exemption is also available for companies that import energyefficient equipment or purchase secondhand or locally produced equipment

99 Government of Malaysia. 2008. Efficient Management of Electrical Energy Regulations 2008. Kuala Lumpur.

100 Kementerian Tenaga, KeTTHA. 2010. Incentives for Renewable Energy, Energy Efficiency \& Green Buildings in Malaysia. 
(footnote 100). Finally, the Green Technology Financing Scheme provides soft loans to companies to develop green technology. ${ }^{101}$

\section{E. LULUCF and REDD+}

Malaysia has one of the highest deforestation rates in the world, which is increasing more rapidly than any other tropical country. ${ }^{102}$ The country lost $14.4 \%$ or 47,278 square kilometers $\left(\mathrm{km}^{2}\right)$ of its forest cover from 2000 to 2012, an area larger than Denmark (footnote 102). The National Forestry Act 1984 is the main law on forest management. The act, amended in 1993, establishes a comprehensive approach to sustainable forestry management and conservation. It also imposes fines for illegal logging.

Malaysia's National REDD Plus Strategy (2016-2025) provides a framework to conserve forests as carbon sinks and their biodiversity in the face of climate change. ${ }^{103}$ It first outlines actions to build synergies and coherence between the federal government-which will lead to implementing the strategy-and state governments. State governments have jurisdiction over land, water, and forests. The strategy then outlines actions to reduce emissions and deforestation, including expanding the terrestrial protected areas network, and identifying and rehabilitating vulnerable ecosystems. It concludes by outlining actions to develop a sustainable financing mechanism by coordinating with the private sector and accessing international REDD+ funding.

The Forest Research Institute Malaysia Act 2016 provides for the continued existence of the Forest Research Institute and dissolves the Malaysian Forestry Research and Development Board. The act delineates the functions of the Forest Research Institute, including the responsibilities to implement policies on research and development programs. The goals are to ensure the growth and sustainability of the forest and forest-based industries and to conduct and promote forestry research.

\section{F. Transportation}

Malaysia launched the National Biofuel Policy in 2006 to promote the production and consumption of biodiesel from palm oil. ${ }^{104}$ The policy aims to reduce the use of and dependency on fossil fuels, decrease imports of petroleum diesel, stimulate new demand for palm oil, lessen GHG emissions, and promote more efficient use of raw materials (footnote 104). In 2004-2006, the government provided $\$ 26.8$ million in subsidies to promote this policy (footnote 84 ). The policy is

101 Malaysian Green Technology Corporation. Key Areas and Projects Criteria.

102 R. Butler. 2013. Malaysia Has the World's Highest Deforestation Rate, Reveals Google Forest Map. Mongabay. 15 November.

103 Government of Malaysia, MONRE. National REDD Plus Strategy. Putrajaya.

104 Government of Malaysia, Ministry of Plantation Industries and Commodities. 2006. The National Biofuel Policy. Kuala Lumpur. 
supplemented by the Malaysian Biofuel Industry Act 2007, which regulates the blending of biofuel as well as its export, import, transport, and storage.

In 2010, the Government Transformation Programme was launched to promote an effective, accountable, advanced, united, and just government. ${ }^{105}$ Improving urban public transport, especially in the Klang Valley, is one of the six pillars of the program.

\section{G. Adaptation}

Malaysia takes part in various initiatives related to climate change adaptation, such as the Coral Triangle Initiative on Coral Reefs, Fisheries and Food Security. Goal 4 of the Malaysia Draft National Plan of Action focuses on climate change adaptation. ${ }^{106}$

Malaysia spent RM51 billion ( $\$ 12.3$ billion in late 2020 ) to build climate change resilience under its Tenth Malaysia Plan (footnote 83). The Second National Physical Plan (2010-2020) identifies measures to deal with climate change. The National Water Resources Policy specifies the need to determine measures to aid the adaptation of water resources to threats and emerging threats. ${ }^{107}$ In addition, in its Second National Communication to the UNFCCC, the government highlights seven sectors where vulnerability assessments have identified "no-regret" actions, which "will prove useful regardless of whether future climate change impacts do indeed occur." 108

\section{H. Disaster Risk Management}

The Policy and Mechanism of National Disaster Management and Relief was implemented in 1997 to respond to the high number of disasters in Malaysia. ${ }^{109}$ It creates a classification system for disasters and establishes the Disaster Management and Relief Committee to coordinate disaster responses.

105 Jabatan Perdana Menteri. 2010. Government Transformation Programme: Annual Report 2010. Putrajaya.

106 Coral Triangle Initiative on Coral Reefs, Fisheries and Food Security. 2009. Malaysia Draft National Plan of Action. Putrajaya: Government of Malaysia, Ministry of Science, Technology and Innovation.

107 Government of Malaysia. 2011. Review of the National Water Resources Study (2000-2050) and Formulation of National Water Resources Policy: Final Report. August.

108 Government of Malaysia, MONRE. 2011. Malaysia Second National Communication to the UNFCCC. Putrajaya. p. xxii.

109 Government of Malaysia, Prime Minister's Department. 1997. National Security Council Directive No. 20: Policy and Mechanism of National Disaster Management and Relief. Putrajaya. 


\section{Myanmar}

\section{A. Country Snapshot: Climate and Environmental Challenges}

The Republic of the Union of Myanmar is a unitary parliamentary republic, which is vulnerable to climate change. The largest city, Yangon, is one of the world's five most vulnerable cities to climate change. ${ }^{110}$ Myanmar has been ranked as the world's second most vulnerable country to extreme weather events. ${ }^{111}$ It faces adverse climate impacts, including flooding and sea level rise, drought, heat waves, and seasonal changes that affect agriculture, water resources, public health, forestry, and biodiversity. ${ }^{112}$

A large proportion of the population lives in low-lying areas that are particularly vulnerable to climate-related risks like flooding (footnote 112). Saltwater intrusion is already compromising freshwater supplies and undermining agriculture and freshwater fisheries (footnote 112). Climate change is also projected to worsen existing development issues like food and water insecurity (footnote 112).

\section{B. Overarching Climate Change Legal and Policy Framework}

\section{Mitigation and Adaptation Targets}

Myanmar's first nationally determined contribution (NDC) establishes mitigation goals, including targets to reach by 2030: (i) producing 9.4 gigawatts (GW) of hydroelectric power, (ii) generating $30 \%$ of rural electricity from renewable energy, and (iii) reducing electricity consumption by $20 \%$ through enhanced energy efficiency. Another goal is to distribute approximately 260,000 energyefficient cookstoves during 2016-2031. ${ }^{113}$ These mitigation actions are conditional on Myanmar receiving international financial support (footnote 113).

The NDC also notes the importance of adaptation and disaster risk reduction. For adaptation, it prioritizes building resilience in the agriculture sector, developing early warning systems, and preserving forests (footnote 113).

\section{Overview of Climate Change Law and Policy}

Myanmar has established an institutional structure for addressing climate-related challenges-i.e., the National Environmental Conservation Committee, which guides all national climate measures and serves as the focal point for various international

110 V. Thomas. 2017. Climate Change and Natural Disasters: Transforming Economies and Policies for a Sustainable Future. New York: Routledge.

111 D. Eckstein et al. 2019. Global Climate Risk Index 2020: Who Suffers Most from Extreme Weather Events? Weather-Related Loss Events in 2018 and 1999 to 2018. Bonn: Germanwatch e.V.

112 R. Horton et al. 2016. Assessing Climate Risk in Myanmar: Technical Report. New York: Center for Climate Systems Research at Columbia University, WWF-US and WWF-Myanmar.

113 Government of Myanmar. 2015. Myanmar's First Nationally Determined Contribution. Nay Pyi Taw. 
environmental conventions, including the UNFCCC in Myanmar. ${ }^{114}$ The committee is responsible for developing climate change policies and action plans. It collaborates with the Environmental Conservation Department to achieve its goals. ${ }^{115}$

The Environmental Conservation Department is a subunit of the Ministry of Environmental Conservation and Forestry (MOECAF) responsible for all national environmental policy. The MOECAF's environmental performance assessment monitors and evaluates the success of environmental policies, including those related to climate change, deforestation, water resource management, and air pollution.

To respond to climate change, Myanmar released its Climate Change Strategy and Action Plan, 2016-2030 in 2017. ${ }^{116}$ It identifies six key social and economic development sectors:

(i) "agriculture, fisheries, and livestock;

(ii) natural resource management;

(iii) energy, transport, and industrial systems;

(iv) towns and cities;

(v) disasters, risks, and health impacts; and

(vi) education, awareness, and technological systems." 117

The principled action plan supports development that is inclusive, resourceefficient, integrated, and results-oriented (footnote 116). The ultimate objectives are to "increase the adaptive capacity of vulnerable communities and sectors so that they are resilient to the adverse impacts of climate change, and create and maximise opportunities for sectors to pursue a low-carbon growth pathway..." "118

Myanmar produced policy guidance briefs with a sectoral action plan. ${ }^{119}$ Each sectoral action plan addresses key objectives and strategies such as (i) integrating climate change considerations into environmental management, (ii) establishing and reinforcing institutional arrangements for climate change responses, (iii) improving resilience and low-carbon initiatives, (iv) establishing financial mechanisms for climate change responses, and (v) promoting multi-stakeholder partnerships.

Myanmar's Sustainable Development Plan, 2018-2030 serves as another guiding climate-related policy with five goals, each with clear strategies with action plans. ${ }^{120}$ Goal 5 (Natural Resources \& the Environment for Posterity of the

114 Government of Myanmar. 2012. Myanmar's National Adaptation Programme of Action (NAPA) to Climate Change. Nay Pyi Taw.

115 REDD+ Myanmar. National Environmental Conservation and Climate Change Central Committee (NECCCCC).

116 Government of Myanmar, Ministry of Natural Resources and Environmental Conservation. 2017. Myanmar Climate Change Strategy and Action Plan (MCCSAP), 2016-2030. Nay Pyi Taw.

117 Footnote 116, p. xix.

118 Footnote 116, p. 49

119 Climate and Disaster Resilience Consulting. 2017. A Series of Briefs Provides Policy Guidance to the Members of the Myanmar Climate Change Strategy \& Action Plan Working Groups.

120 Government of Myanmar, Ministry of Planning and Finance. 2018. Myanmar Sustainable Development Plan (2018-2030). Nay Pyi Taw. 
Nation) calls for (i) ensuring a clean environment with a healthy and functioning ecosystem; (ii) increasing climate change resilience; (iii) enabling safe and equitable access to water and sanitation; (iv) providing affordable and reliable energy through diverse sources of generation; ( $v$ ) promoting sustainable land use; and (vi) managing cities, towns, and historical and cultural centers efficiently and sustainably (footnote 120).

Given that food insecurity is one of Myanmar's key climate-related challenges, the government launched in 2015 the Myanmar Climate-Smart Agriculture Strategy, an agricultural policy that aims to build resilience in response to climaterelated threats to agriculture. ${ }^{121}$ These threats include water scarcity, drought, rising temperatures, floods, land degradation, deforestation, and increased rates of natural disasters (footnote 121).

The Myanmar Climate-Smart Agriculture Strategy seeks to ensure Myanmar's food security by using various measures such as carbon sequestration, increased agricultural productivity and resilience, and proper land management (footnote 121). Adaptation target outcomes identified under the strategy include "(1) new varieties [of] and improved farming systems resilient to drought and water stress, (2) diversified rural income and improved household economic resilience, and (3) increased prevention and protection against disasters." 122

Table 5.5 summarizes Myanmar's climate change legal and policy framework.

\section{Energy Supply}

In 2016, Myanmar's total primary energy supply (TPES) was 14.484 million tonnes of oil equivalent (Mtoe), which came from biomass (49\%), oil (24\%), natural gas (20\%), hydropower (5\%), and coal (2\%). ${ }^{123}$ Other renewable energy production was negligible (footnote 123). Since 2000, Myanmar's TPES has increased by an annual average of $3.7 \%$ (footnote 123). The highest growth rates during this time have been from coal (12.8\%), hydropower (12.3\%), natural gas (6.4\%), and oil (6\%) (footnote 123).

The TPES is projected to increase to 32.7 Mtoe by $2040 .{ }^{124}$ Myanmar's projected energy supply mix is composed of biomass (36.1\%), oil (28.7\%), natural gas (13.5\%), hydropower (11.2\%), and coal (8.8) (footnote 124). Coal is expected to annually grow by an average rate of $7.9 \%$, hydropower by $6.0 \%$, oil by $4.6 \%$, and natural gas by $3.5 \%$ (footnote 124). Biomass is expected to grow more slowly (footnote 124).

121 Government of Myanmar, Ministry of Agriculture and Irrigation. 2015. Myanmar Climate-Smart Agriculture Strategy. Nay Pyi Taw.

122 Footnote 121, p. 28.

123 Government of Myanmar, Ministry of Electricity and Energy, Oil and Gas Planning Department. 2019. Myanmar Energy Statistics 2019. Jakarta: ERIA.

124 T. Myint. 2016. Myanmar Country Report. In S. Kimura and P. Han, eds. Energy Outlook and Energy Saving Potential in East Asia 2016. ERIA Research Project Report 2015-5. Jakarta: ERIA. pp. 237-259. 


\section{Table 5.5: Climate Change Legal and Policy Framework of Myanmar}

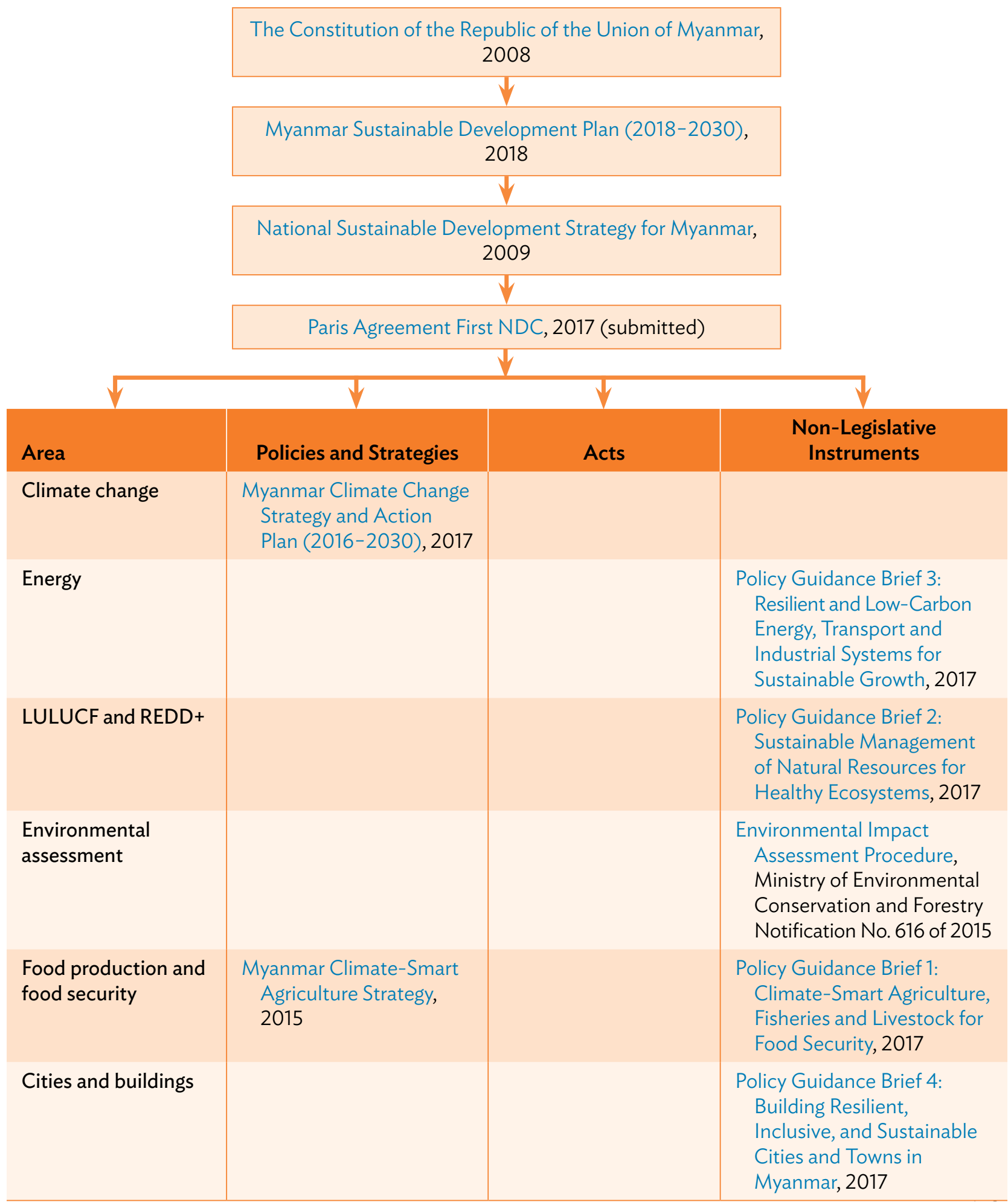


Table 5.5 continued

\begin{tabular}{|c|c|c|c|}
\hline Area & Policies and Strategies & Acts & $\begin{array}{l}\text { Non-Legislative } \\
\text { Instruments }\end{array}$ \\
\hline $\begin{array}{l}\text { Disaster risk } \\
\text { management }\end{array}$ & $\begin{array}{l}\text { Myanmar Action Plan on } \\
\text { Disaster Risk Reduction, } \\
2017 \\
\text { Myanmar National } \\
\text { Framework for } \\
\text { Community Disaster } \\
\text { Resilience, } 2017\end{array}$ & $\begin{array}{l}\text { Law No. } 21 \text { (Natural } \\
\text { Disaster Management } \\
\text { Law), } 2013\end{array}$ & \\
\hline Other & $\begin{array}{l}\text { National Biodiversity } \\
\text { Strategy and Action } \\
\text { Plan (2015-2020), } 2015\end{array}$ & $\begin{array}{l}\text { Law No. 9/2012 } \\
\text { (The Environmental } \\
\text { Conservation Law), } \\
2012\end{array}$ & $\begin{array}{l}\text { Policy Guidance Brief 5: } \\
\text { Managing Climate Risks } \\
\text { for People's Health and } \\
\text { Well-Being, } 2017 \\
\text { Policy Guidance Brief 6: } \\
\text { Building a Resilient } \\
\text { Myanmar Society through } \\
\text { Education, Science and } \\
\text { Technology, } 2017 \\
\text { Environmental Conservation } \\
\text { Rules, } 2014\end{array}$ \\
\hline
\end{tabular}

LULUCF = land use, land-use change, and forestry; NDC = nationally determined contribution; REDD + = reducing emissions from deforestation and forest degradation, conservation of existing forest carbon stocks, sustainable forest management, and enhancement of forest carbon stocks.

Source: Authors.

Relevant agencies within the Ministry of Energy have assumed the responsibilities of the Energy Planning Department, which was abolished in 2015. ${ }^{125}$ These functions include coordinating the activities of the three energy enterprises that are central to the country's economic development strategy: (i) Myanma Oil and Gas Enterprise, which operates oil and gas fields both onshore and offshore; (ii) Myanma Petrochemical Enterprise, which operates liquefied petroleum gas (LPG), methanol, and urea fertilizer plants, and transports crude oil and petroleum products; and (iii) Myanma Petroleum Products Enterprise, which distributes petroleum products (footnote 125).

The oil and gas industry accounts for approximately $85 \%$ of reported revenues from the extractive sector or nearly $25 \%$ of government revenues in $2017 . .^{126}$ Myanmar has also been converting vehicles to natural gas since $1986 .{ }^{127}$

The sectoral action plan for the energy, transportation, and industry sectors addresses Myanmar's inadequate power supply infrastructure, general dependency

125 A. Shin. 2015. Energy Planning Department Gone with Reorganisation. Myanmar Times. 7 April.

126 Natural Resource Governance Institute. 2017 Resource Governance Index: Myanmar (Oil and Gas).

127 Green Car Congress. 2006. Myanmar Converts 4,000 Vehicles to Natural Gas. 2 January. 
on wood fuel in rural areas, and low electrification rates. ${ }^{128}$ The action plan provides policy recommendations - such as increasing renewable energy production and diversifying the country's energy mix - to help Myanmar realize its full energy potential in a climate-resilient and low-carbon fashion (footnote 128).

\section{Energy Demand}

In 2016, Myanmar's total final energy consumption (TFEC) was 15.292 Mtoe, increasing at an average annual growth rate of 3.2\% (footnote 123). Energy consumption came from biomass (58\%), petroleum (27\%), electricity (9\%), natural gas (3\%), and coal (3\%) (footnote 123). Energy consumption in 2016 was divided among the following sectors: industry (37.6\%), residential (28.4\%), service (19.1\%), transportation (14.6\%), and others (0.3\%) (footnote 123).

Myanmar's TFEC is projected to increase to 29.84 Mtoe by 2040 (footnote 124). The largest source of energy consumption by 2040 is expected to be oil (31.1\%) (footnote 124). Natural gas consumption is projected to have an average annual increase of $5.0 \%$ and coal consumption of $4.8 \%$ (footnote 124 ).

In 2013, the National Energy Management Committee and the Energy Development Committee (both ministerial) were established to oversee the energy sector. ${ }^{129}$ The National Energy Management Committee was tasked with (i) formulating the national energy policy, (ii) privatizing state-owned sectors, (iii) developing the electricity sector with short- and long-term plans, and (iv) inviting foreign and domestic investments in energy development (footnote 129).

Myanmar aims to reduce TFEC by $5 \%$ by 2020 and $8 \%$ by 2030 (footnote 124 ). It also intends to improve energy efficiency by $16 \%$ in all sectors by 2030.130 These targets can be achieved by implementing the following strategies by 2020: (i) improving energy efficiency in the industry sector by $10 \%$ against business as usual (BAU) and reducing energy-related GHGs, (ii) replacing at least $8 \%$ of the energy in the transport sector with biofuels, (iii) increasing the proportion of renewable energy to $15 \%$, and (iv) improving energy efficiency in the commercial and residential sectors by $8 \%$ (footnote 124).

\section{E. LULUCF and REDD+}

GHG emissions from the forestry sector (caused by biomass burning following land clearing) were estimated at 40,405 gigagrams $\mathrm{CO}_{2}$ equivalent in 2000. ${ }^{131}$

128 Government of Myanmar, Ministry of Natural Resources and Environmental Conservation. 2017. Resilient and Low-Carbon Energy, Transport and Industrial Systems for Sustainable Growth. Policy Guidance Brief 3. Nay Pyi Taw.

129 World Economic Forum, ADB, and Accenture. 2013. New Energy Architecture: Myanmar.

130 ADB. 2015. Energy Efficiency Developments and Potential Energy Savings in the Greater Mekong Subregion. Manila. p. 7.

131 M. Nachmany et al. 2015. Climate Change Legislation in Myanmar: An Excerpt from the 2015 Global Climate Legislation Study: A Review of Climate Change Legislation in 99 Countries. London: Grantham Research Institute on Climate Change and the Environment. 
Land-use changes, deforestation, shifting cultivation, and land clearance also result in significant GHG emissions (footnote 131).

In 2000, the Ministry of Forestry approved and implemented the National Forest Master Plan, a 30-year plan aiming for 919,000 hectares of community forests by 2030-2031. ${ }^{132}$ In 2011, Myanmar became a partner country of the United Nations Programme on Reducing Emissions from Deforestation and Forest Degradation. In July 2013, it approved the REDD+ Readiness Roadmap outlining the country's activities aimed at reducing emissions due to deforestation and forest degradation. ${ }^{133}$ The inclusive but streamlined REDD+ Task Force, guided by the National Environmental Conservation Committee and chaired by the Forestry Department of MOECAF, is in charge of managing and coordinating the readiness activities (footnote 133).

The sectoral action plan for the natural resources sector addresses Myanmar's deforestation and forest degradation. ${ }^{134}$ It seeks to bolster the resilience of Myanmar's biodiversity and ecosystem services to support social and economic development and preserve the country's forests as a major carbon sink (footnote 134). The plan also includes recommendations such as (i) enforcing laws and regulations against illegal commercial logging, (ii) converting forest to agricultural land, and (iii) strengthening ecosystem-based adaptation and management of biodiversity-rich areas (footnote 134).

\section{F. Transportation}

The transport sector consumed $51.5 \%$ of total final energy in $2010 .{ }^{135}$ By 2035 , the sector's energy demand is expected to increase to $57 \%$ total final consumption (footnote 135). Although the government has yet to promulgate a transport sector strategy, it has expressed concerns about air pollution and air quality management in the Ministerial Statement on Global Environment and Energy in Transport. ${ }^{136}$

\section{G. Adaptation}

In 2012, Myanmar issued its National Adaptation Programme of Action to Climate Change, following Cyclone Nargis in 2008, the most devastating

132 Government of Myanmar, Ministry of Natural Resources and Environmental Conservation and World Bank. Myanmar Country Environmental Analysis 2019.

133 Government of Myanmar. 2013. Myanmar REDD+ Readiness Roadmap. Geneva: UN-REDD Programme.

134 Government of Myanmar, Ministry of Natural Resources and Environmental Conservation. 2017. Sustainable Management of Natural Resources for Healthy Ecosystems. Policy Guidance Brief 2. Nay Pyi Taw.

135 Footnote 131, p. 5.

136 N.H. Aung. n.d. Ministerial Statement on Global Environment and Energy in Transport: Pollution Control and Air Quality Management in Myanmar. Tokyo: Government of Japan, Ministry of Land, Infrastructure, Transport and Tourism. 
cyclone the country had experienced (footnote 114). Based on official figures, Cyclone Nargis killed 84,500 people, left 53,800 missing, and affected at least 2.4 million people. ${ }^{137}$ Identified climate hazards include cyclones, heavy rains, floods, extreme temperatures, drought, and sea level rise (footnote 114). Together with deforestation and diminishing water resources, climate-related hazards and extreme weather events impact agriculture, water resources, energy, public health, and natural resources (footnote 114).

The National Biodiversity Strategy and Action Plan, first issued in 2011, outlines the country's approach to biodiversity conservation. ${ }^{138}$ It notes that existing protected areas, such as the mangrove ecosystem in the Meinmahla Kyun Wildlife Sanctuary, have been subjected to extensive encroachment and overexploitation of biological resources (footnote 138). The updated National Biodiversity Strategy and Action Plan, 2015-2020 takes note of new information and emphasizes the importance of adopting the precautionary approach to protecting biological diversity from the risks posed by living modified organisms and increasing the potential for adaptation..$^{139}$

\section{H. Disaster Risk Management}

In 2013, the Assembly of the Union enacted the Disaster Management Law. One of its principal objectives is to establish the national committee and local bodies on disaster management and risk reduction. The Myanmar Action Plan on Disaster Risk Reduction, implemented in 2017, recognizes the specific risks faced by Myanmar, including sea level rise, extreme heat waves, and changing rainfall patterns. ${ }^{140}$ The plan seeks to increase disaster preparedness through a multi-hazard early warning system, a methodology for risk assessment, and foster community-based disaster preparedness and risk reduction.

The Myanmar National Framework for Community Disaster Resilience (2017) builds on this approach by articulating three objectives: (i) promoting a common understanding among stakeholders of the need to strengthen community disaster resilience, (ii) proposing coherent approaches and lessons for building community-level disaster resilience, and (iii) identifying opportunities to strengthen community disaster resilience through development. ${ }^{141}$

137 International Federation of Red Cross and Red Crescent Societies. 2011. Myanmar: Cyclone Nargis 2008 Facts and Figures. News release. 3 May.

138 Government of Myanmar. 2011. National Biodiversity Strategy and Action Plan. Nay Pyi Taw.

139 Government of Myanmar. 2015. National Biodiversity Strategy and Action Plan 2015-2020. Nay Pyi Taw.

140 Government of Myanmar, National Disaster Management Committee. 2017. Myanmar Action Plan on Disaster Risk Reduction, 2017: Fostering Resilient Development through Integrated Action Plan. Nay Pyi Taw.

141 Government of Myanmar, National Disaster Management Committee. Myanmar National Framework for Community Disaster Resilience: Promoting People-Centered, Inclusive, and Sustainable Local Development. Nay Pyi Taw. 


\section{People's Republic of China}

\section{A. Country Snapshot: Climate and Environmental Challenges}

Rapid economic growth and a population of nearly 1.4 billion people mean significant climate challenges for the People's Republic of China (PRC). ${ }^{142}$ As the world's biggest total emitter of carbon, the PRC will need unprecedented declines in emissions. ${ }^{143}$ Deep emission reductions will also be vital for supporting global efforts to secure a stable climate (footnote 143). Recognizing the need to contribute to global emissions reductions, the PRC has now committed to reach carbon neutrality before 2060 .

The PRC has experienced increasingly frequent extreme weather events in recent years. ${ }^{144}$ Since the 1960 s, the PRC's annual mean surface air temperature has risen by $1.1^{\circ} \mathrm{C}$ (footnote 144 ). The south is a particularly vulnerable region to climate change. Many areas in the south have suffered extremely high temperatures and increased flooding, landslides, and mudslides. ${ }^{145}$ In Yunnan Province, for example, moderate to severe droughts have impacted agriculture and livelihoods. ${ }^{146}$

Adaptation, therefore, forms a key part of the PRC's response to climate change.

\section{B. Overarching Climate Change Legal and Policy Framework}

\section{Mitigation and Adaptation Targets}

The PRC's first nationally determined contribution (NDC) to the Paris Agreement sets ambitious quantified targets for economy-wide emissions reductions in the energy, forestry, transport, building, and agriculture sectors. ${ }^{147}$ The PRC pledges to "lower carbon dioxide $\left[\mathrm{CO}_{2}\right]$ emissions per unit of GDP by $60 \%$ to $65 \%$ from the 2005 level" and to "increase the share of non-fossil-fuels in primary energy consumption to around $20 \%$ " by $2030 .{ }^{148}$ Natural gas consumption will constitute $10 \%$ of primary energy consumption by 2020 (footnote 147).

The NDC commits the PRC to expand renewable energy capacity-100 gigawatts (GW) of solar power and $200 \mathrm{GW}$ of wind power by 2020 (footnote 147). The

142 ADB. 2019. People's Republic of China and ADB; and ADB Data Library. People's Republic of China: By the Numbers (accessed 20 May 2020).

143 The Economist. 2019. Not-so-Cold Comfort: China is Surprisingly Carbon-Efficient-but Still the World's Biggest Emitter. 25 May.

144 ADB. 2014. Developing Indicators and Monitoring Systems for Environmentally Livable Cities in the People's Republic of China. Manila.

145 R. Lu and R. Chen. 2016. A Review of Recent Studies on Extreme Heat in China. Atmospheric and Oceanic Science Letters. 9 (2). pp. 114-121; and Al Jazeera. 2020. Millions in Southern China Face Floods Caused by Heavy Rains. 12 July.

146 F. Yang and J. Zhou. 2013. Why Has Water-Rich Yunnan Become a Drought Hotspot? China Dialogue. 29 April.

147 Government of the PRC. 2016. Enhanced Actions on Climate Change: China's First Nationally Determined Contributions. Beijing.

148 Footnote 147, p. 5. 
PRC sets two quantified goals for the forestry sector: (i) "increase the forested area by 40 million hectares and the forest stock volume by 1.3 billion cubic meters compared to the 2005 levels" by 2020; and (ii) "increase the forest stock volume by around 4.5 billion cubic meters on the 2005 level" by $2030 .{ }^{149}$ Finally, by 2020 , the PRC pledges to achieve a $30 \%$ share of public transport in motorized travel in big- and medium-sized cities, a 50\% share of green buildings in newly built buildings of cities and towns, and zero growth of fertilizer and pesticide use (footnote 147).

\section{Overview of Climate Change Law and Policy}

The PRC considers climate action an integral part of achieving sustainable development and ensuring energy, ecological, and food security. The 13th Five-Year Plan outlines the country's development pathway, including its targets for efficiency and the environment. 150 The plan, published in 2016, aims for peak targets of energy consumption, water use, and carbon emissions. It also contains goals such as increasing renewable energy production, eliminating inefficient production facilities, and implementing green infrastructure.

Specific targets of the plan include (i) an $18 \%$ reduction in $\mathrm{CO}_{2}$ emissions per unit of GDP by 2020 compared with 2015 levels, (ii) a 15\% reduction in energy consumption per unit of GDP by 2020 compared with 2015 levels, (iii) an expansion of the market for electric vehicles, and (iv) an increase to $23 \%$ forest coverage over 5 years (footnote 150).

In addition to integrating climate change into its development planning, the PRC has also created climate policies that focus on energy, forestry, transport, and building sectors. In 2014, the government launched the National Plan for Tackling Climate Change 2014-2020 (Climate Change Plan) to provide a comprehensive strategy on mitigation, adaptation, public awareness, and scientific research. ${ }^{151}$ The Climate Change Plan includes targets, tasks, and safeguarding measures, and sets three main goals: (i) decreasing carbon emissions per unit of GDP by 40\%-45\% from a 2005 baseline, (ii) increasing the share of nonfossil fuels in primary energy consumption up to $15 \%$, and (iii) increasing proportions of stock volume by 1.3 million cubic meters and forest area by 40 million hectares.

The Climate Change Plan also sets some quantified targets across the energy, transportation, and building sectors. In the energy sector, the Climate Change Plan describes measures to limit coal consumption and increase nonfossil-fuel consumption. To this end, the Climate Change Plan describes efforts to increase renewable energy capacity. In 2020, the installed capacity of biomass power

149 Footnote 147, pp. 3 and 5.

150 Government of the PRC, National Development and Reform Commission. 2016. The 13th Five-Year Plan for Economic and Social Development of the People's Republic of China (2016-2020). Beijing.

151 Grantham Research Institute on Climate Change and the Environment and Sabin Center for Climate Change Law. National Plan for Tackling Climate Change 2014-2020. 
generation will reach 30 million kilowatts (footnote 151). Consumption of biomass fuel will reach 50 million tons annually, with biogas use reaching 44 billion cubic meters (footnote 151). The government also plans for biological liquid fuel use to reach 130 billion cubic meters annually in 2020 (footnote 151).

The PRC is also supporting solar energy use. The installed capacity of solar power generation will reach 100 million kilowatts in 2020, with solar farms covering 800 million square meters (footnote 151). The government will also build 80 millionkilowatt-class wind power bases and develop offshore wind power projects to reach an installed grid-connected wind power of 200 million kilowatts by 2020 (footnote 151). According to the Climate Change Plan, the annual generation capacity of hydropower will reach 1.2 trillion kilowatt-hours by 2020, and the government will safely develop nuclear power (footnote 151).

The Climate Change Plan includes two transportation-related goals: (i) reducing carbon emissions from railway transportation by $15 \%$ compared with 2010 , and (ii) achieving a 30\% share of public transportation use in cities by 2020 against a 2014 baseline (footnote 151). Finally, the Climate Change Plan notes that "the percentage of green buildings in new towns will reach $50 \%$ by 2020 against a 2014 baseline" (footnote 151). Although the plan provides a national guiding framework for climate action, provinces and municipalities must also develop their locally informed plans. Many provinces and municipalities have already done so.

The government also launched the comprehensive National Strategy for Climate Change Adaptation in 2013 (Adaptation Strategy) to respond to the PRC's climate change vulnerability. ${ }^{152}$ The Adaptation Strategy, published by the National Development and Reform Commission, aims to minimize soil erosion, protect water resources, strengthen disaster prevention, develop monitoring systems for ocean disasters, develop new farming techniques, and restore the coastline. Additionally, it contains weather-based financing mechanisms, which include weather index-based insurance and catastrophe bonds.

The Adaptation Strategy also sets quantified targets for the forestry and agriculture sectors. "By 2020, the forest coverage will reach 23\%, and the forest reserves will exceed 15 billion cubic meters" (footnote 152). Second, "more than $95 \%$ of the state's key protected wild animals and over $90 \%$ of the minimum wild plant species will be effectively protected against desertification by 2020 " (footnote 152). Third, new farming practices, including controlling plant-eating pests and improving crop adaptability, will be developed to reduce climate impacts on agriculture. Lastly, "the penetration rate of practical adaptive technical training for rural labor will reach 70\% by 2020 against a 2013 baseline" (footnote 152).

Table 5.6 summarizes the PRC's climate change legal and policy framework.

152 Grantham Research Institute on Climate Change and the Environment and Sabin Center for Climate Change Law. National Strategy for Climate Change Adaptation. 


\section{Table 5.6: Climate Change Legal and Policy Framework of the People's Republic of China}

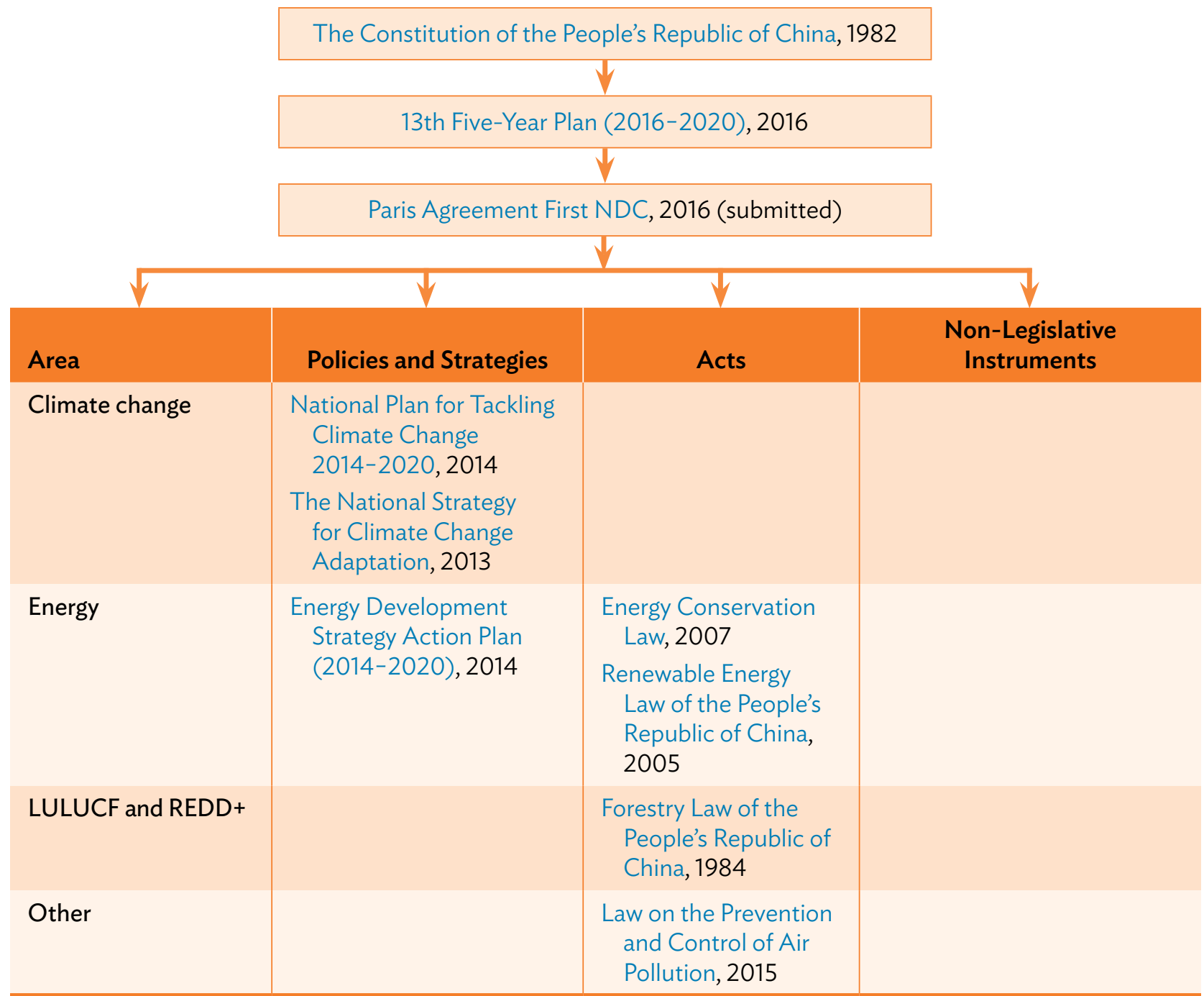

LULUCF = land use, land-use change, and forestry; NDC = nationally determined contribution; REDD + = reducing emissions from deforestation and forest degradation, conservation of existing forest carbon stocks, sustainable forest management, and enhancement of forest carbon stocks.

Source: Authors. 


\section{Energy Supply}

The PRC's rapid industrialization and urbanization have been carbon intensive. ${ }^{153}$ The PRC is endowed with coal, oil, and gas reserves, and has significant hydropower potential..$^{154}$ It is the world's largest coal producer and has the third-largest coal reserves (footnote 154). However, the government has aimed to reduce $\mathrm{GHG}$ emissions even as it continues to pursue economic growth. In September 2020, the government announced its plan to achieve carbon neutrality before $2060 .{ }^{155}$

In 2013, the $\mathrm{CO}_{2}$ emissions per unit of GDP had fallen by $28.5 \%$ since $2005 . .^{156}$ That same year, nonfossil fuels made up $9.8 \%$ of primary energy consumption. ${ }^{157}$ Coal's share in total primary energy supply (TPES) is expected to decrease by $0.1 \%$ a year on average, although it will continue to serve as the largest source of energy in 2040 under a BAU scenario. ${ }^{158}$ In 2015, TPES consisted of coal (66.7\%), oil (18.0\%), natural gas (5.3\%), hydropower (3.2\%), nuclear and other sources (6.8\%) (footnote 158).

The PRC's power is primarily generated from coal-fired power plants, whose electricity generation accounted for $78.2 \%$ in 2015 (footnote 158). The share of hydro was $16.4 \%$ in 2015 , with gas, oil, and nuclear energy generation making up the balance (5.4\%) (footnote 158). The PRC set a goal of carbon emissions peaking by 2030 in its NDC. To reach this ambitious target, the PRC has implemented a range of policies to promote fuel-switching and energy efficiency.

\section{Sector-Wide Energy Strategies}

The PRC plans to reduce $\mathrm{CO}_{2}$ emissions per unit of GDP by $18 \%$ by 2020 compared with 2015 levels (footnote 150). The Energy Development Strategy Action Plan (2014-2020) plays a large role in achieving this target by implementing measures and mandatory targets, and encouraging efficient energy

153 C. Wojcik. 2017. Chinese Industrialization \& Subsequent Environmental Degradation. Dickinson College Honors Theses. Paper 256.

154 Y. Hao and R. Han. 2016. China Country Report. In S. Kimura and P. Han, eds. Energy Outlook and Energy Saving Potential in East Asia 2016. ERIA Research Project Report 2015-5. Jakarta: ERIA. pp. 109-125.

155 L. Myllyvirta and L. Yedan. 2020. Analysis: China's Covid Stimulus Plans for Fossil Fuels Three Times Larger Than Low-Carbon. Carbon Brief. News release. 23 September.

156 L. Zhu et al. 2015. Climate Policy: Steps to China's Carbon Peak. Nature. 522 (7,556). pp. 279-281. 17 June.

157 H. Jian-Kun. 2015. China's INDC and Non-Fossil Energy Development. Advances in Climate Change Research. 6 (3-4). pp. 210-215.

158 H. Yu and Z. Mingyuan. 2019. China Country Report. In S. Kimura and P. Han, eds. Energy Outlook and Energy Saving Potential in East Asia 2019. ERIA. pp. 97-111. 
consumption and production practices. ${ }^{159}$ Critically, the plan aims to cap the annual coal consumption at 4.2 billion tons by 2020 and reduce coal's share in the PRC's TPES to less than $62 \%$ by that year.

Other targets include (i) increasing the share of nonfossil fuel resources in the primary energy mix from $9.8 \%$ in 2013 to $15 \%$ in 2020 and $20 \%$ in 2030; (ii) increasing the natural gas share in the energy mix to over $10 \%$ and decreasing the coal share to below $62 \%$; (iii) installing $58 \mathrm{GW}$ of nuclear capacity by 2020; (iv) reaching $350 \mathrm{GW}$ of hydro capacity, $200 \mathrm{GW}$ of wind capacity, and $100 \mathrm{GW}$ of solar capacity by 2020 ; and ( $v$ ) achieving $85 \%$ energy self-sufficiency through these measures (footnote 159).

The Law on the Prevention and Control of Air Pollution, 2015 seeks to limit air pollutants, including GHGs, authorizing the government to promote clean energy. It requires the efficient and clean use of coal and bans the use of low-quality coal.

\section{Renewable Energy Policies}

In 2005, the PRC passed the Renewable Energy Law, 2005, which requires the government to promote renewable energy and sets a goal of $15 \%$ renewable energy share by 2020 . The law provides descriptions of duties pertaining to renewable energy use and development for businesses, the government, and other users. It stipulates specific goals and measures about regulation, grid connection, tax reliefs and special funds, and differentiated pricing. Additionally, it mandates the establishment of a renewable energy development fund and requires that the government manage renewable energy resources and coordinate national surveys.

Under this law, the Government Offices Administration of the State Council must set and publish targets for national renewable energy volumes. The PRC ranks first in the world in several areas: installed and under-construction renewable energy capacity and generation of hydropower, installed capacity of solar photovoltaic power, and under-construction nuclear power. ${ }^{160}$

\section{Energy Demand}

The PRC can reduce its primary energy supply and consumption by about 734.6 million tons of oil equivalent (Mtoe) or approximately $16 \%$ by 2040 if it implements effective energy efficiency and conservation policies (footnote 154).

159 Government of the PRC, State Council of China. 2014. Energy Development Strategy Action Plan (2014-2020). Beijing. For a summary of the plan, see Grantham Research Institute on Climate Change and the Environment and Sabin Center for Climate Change Law. Energy Development Strategy Action Plan (2014-2020).

160 C. Campbell. 2019. China Is Bankrolling Green Energy Projects around the World. Time. 1 November; D. Roberts. 2019. The Global Transition to Clean Energy, Explained in 12 Charts. Vox. 26 June; and L. Gil. 2017. How China Has Become the World's Fastest Expanding Nuclear Power Producer. International Atomic Energy Agency. 25 October. 
The 13th Five-Year Plan stipulates that energy consumption per unit of GDP will drop by $15 \%$ by 2020 compared with 2015 levels (footnote 150). The government has implemented various administrative, market-based, and legal measures to achieve this goal.

The Energy Conservation Law, 2007 seeks to improve energy conservation by promoting technology and efficient energy use and requires the government to advocate for renewable energy implementation. It specifically includes the importance of renewables such as solar, wind, and biomass in rural areas, and of building energy plants on nonarable land and developing firewood forests. The National People's Congress is mandated to monitor these priorities.

\section{E. Carbon Pricing}

The PRC deploys market-based measures to reduce emissions as part of its development planning. For example, the 12th Five-Year Plan encourages the use of market mechanisms to promote emissions reductions. ${ }^{161}$ Similarly, the 13th Five-Year Plan calls on the government to develop rules and regulations to manage the national carbon trading program. The China Carbon Market program was launched in 2017, after several years of regional pilot projects. ${ }^{162}$ Seven cities and provinces-Beijing, Chongqing, Guangdong, Hubei, Shanghai, Shenzhen, and Tianjin-participated, and their pilot emissions trading systems informed the design of the national carbon trading program. ${ }^{163}$ The PRC's national carbon trading program is being developed by establishing and amending regulations, developing market infrastructure, promoting reporting and verification, and strengthening capacity.

\section{F. LULUCF and REDD+}

The PRC treats forests as a key part of its effort to mitigate $\mathrm{GHG}$ emissions. The PRC's Climate Change Plan, for example, commits the government to cultivate 40 million hectares of forested land to reduce GHG emissions (footnote 151). According to government reports, forest coverage increased from $18.21 \%$ in 2005 to $21.6 \%$ in $2013 .{ }^{164}$ The Forestry Law of the People's Republic of China, 1984 serves as the pillar of forestry legislation in the country. It aims to cultivate, protect, and encourage responsible use of forest resources through afforestation measures, climate regulation, environmental improvement, and the use of forests for soil conservation and water storage.

161 Government of the PRC, National People's Congress. 2011. 12th Five-Year Plan (2011-2015) for National Economic and Social Development. Beijing.

162 H. Harvey and M. Hu. 2017. The China Carbon Market Just Launched, And It's The World's Largest. Here's How It Can Succeed. Forbes. 19 December.

163 D. Stanway. 2012. China Orders 7 Pilot Cities and Provinces to set $\mathrm{CO}_{2}$ Caps. Reuters. 13 January.

164 M. Nachmany et al. 2015. Climate Change Legislation in China: An Excerpt from the 2015 Global Climate Legislation Study: A Review of Climate Change Legislation in 99 Countries. London: Grantham Research Institute on Climate Change and the Environment. 
Chapter IV of the forestry law specifically discusses tree planting efforts and requires that local governments determine appropriate forest coverage levels in consideration of local conditions. From 2012 to the first half of 2013, 10.25 million hectares were afforested in afforestation drives and 4.96 billion trees planted through volunteer tree planting drives. ${ }^{165}$

\section{G. Adaptation}

The Adaptation Strategy serves as the key document in guiding adaptation policy (footnote 152). It seeks to build coastal resilience, minimize soil erosion, ensure water security, and promote resilient agriculture. Some provinces have also developed their regional strategic studies to address climate change.

\section{H. Managing Water Resources}

Water security is a significant issue for the PRC and climate change is aggravating it. Rainfall patterns have changed since the early $1900 \mathrm{~s}$, declining by $20 \mathrm{~mm}-40 \mathrm{~mm}$ per decade in northern provinces of the PRC and rising by $20 \mathrm{~mm}-60 \mathrm{~mm}$ per decade in southern provinces of the PRC. ${ }^{166}$ Water stream flows have also declined in the Hai River, Huang River, Huai River, and Liao River basins. ${ }^{167}$ Rising temperatures will exacerbate water scarcity in the PRC. Current projections suggest that average national temperatures will increase by $1.3^{\circ} \mathrm{C}-2.1^{\circ} \mathrm{C}$ by 2020 , $1.5^{\circ} \mathrm{C}-2.8^{\circ} \mathrm{C}$ by 2030 , and $2.3^{\circ} \mathrm{C}-3.3^{\circ} \mathrm{C}$ by 2050 (footnote 167 ). Increased temperatures will cause higher evaporation rates, compounding water scarcity.

The PRC's water shortage prompted the Ministry of Water Resources to create research programs on water management, which considered the impact of climate change on water resources. The government also stressed the critical nature of strengthening water security in its 13th Five-Year Plan (footnote 150). Chapter 31 of the plan commits to conducting feasibility studies on water resource allocation and strengthening projects on flood control and mitigation systems.

165 Information Office of the State Council. 2016. China's Policies and Actions for Addressing Climate Change. In D. Shambaugh, ed. The China Reader. 6th ed. New York, NY: Oxford University Press.

166 J. Xie et al. 2009. Addressing China's Water Scarcity: Recommendations for Selected Water Resource Management Issues. Washington, DC: World Bank. p. 11; and Government of the PRC, Ministry of Water Resources, Development Research Center. The DRC.

167 J. Xie et al. 2009. Addressing China's Water Scarcity: Recommendations for Selected Water Resource Management Issues. Washington, DC: World Bank. p. 11. 


\section{Philippines}

\section{A. Country Snapshot: Climate and Environmental Challenges}

A unitary state of more than 7,000 islands, the Republic of the Philippines has a population of more than 106 million people. ${ }^{168}$ The Philippines faces some climate-related threats, including coral reef bleaching and flooding due to sea level rise, which will cause extensive damage to infrastructure and heritage structures. ${ }^{169}$ It will also experience an increase in the rate and intensity of natural disasters due to climate change (footnote 169).

The Philippines is already prone to extreme weather events, with 8-9 tropical cyclones crossing the country every year. ${ }^{170}$ Considering that climate change will only aggravate this threat, the Philippines has a strong interest in mitigating and adapting to the effects of climate change. ${ }^{171}$

\section{B. Overarching Climate Change Legal and Policy Framework}

\section{Mitigation and Adaptation Targets}

The Philippines' first nationally determined contribution (NDC) pledges to reduce $\mathrm{GHG}$ emissions by $70 \%$ by 2030 compared with a BAU scenario. ${ }^{172}$ To meet this target, the Philippines will reduce GHG emissions in the energy, transport, waste, forestry, and industry sectors (footnote 172). The commitment is conditional on external financial support, including technology development and transfer, and capacity building (footnote 172). The NDC also identifies the following areas for adaptation action: agriculture; coastal zone; disaster risk management; education; energy; environment; heath; land use, land-use change, and forestry (LULUCF); social development; tourism; transport; and water.

\section{Overview of Climate Change Law and Policy}

The Philippines has a strong legal basis for enacting mitigation and adaptation measures and has been taking climate action since the early 1990s. First, the Philippine Constitution grants a right "to a balanced and healthful ecology in accord with the rhythm and harmony of nature." 173 As early as 1991, the Inter-

\footnotetext{
168 ADB Data Library. Philippines: By the Numbers (accessed 3 January 2020).

169 R.V. Cruz et al. 2017. 2017 Philippine Climate Change Assessment: Impacts, Vulnerabilities and Adaptation. Manila: The Oscar M. Lopez Center for Climate Change Adaptation and Disaster Risk Management Foundation, Inc.

170 Government of the Philippines, Philippine Atmospheric, Geophysical and Astronomical Services Administration. Tropical Cyclone Information (accessed 3 January 2020).

171 See C. Crepin. 2013. Getting a Grip on Climate Change in the Philippines. Public Expenditure Review. Washington, DC: World Bank.

172 Government of the Philippines. 2015. Nationally Determined Contributions. Manila.

173 The Constitution of the Republic of the Philippines, art. II, sec. 16.
} 
Agency Committee on Climate Change was formed. ${ }^{174}$ In 1999, the Clean Air Act (Republic Act [RA] No. 8749) called for the regulation of GHGs. Following the Clean Air Act, the government began tracking its GHG emissions and the loss of its carbon sinks.

More recently, the Climate Change Act, 2009 (RA No. 9279) established a legal framework through which climate change is mainstreamed into all decisionmaking levels, including disaster risk reduction, development planning, and poverty reduction. ${ }^{175}$ The Climate Change Act establishes key principles of climate change policy: the precautionary principle, common but differentiated responsibilities, the Hyogo Framework for Action on disaster risk reduction, and the UNFCCC's ultimate objective of stabilizing "greenhouse gas concentrations in the atmosphere at a level that would prevent dangerous anthropogenic interference with the climate system."176

Additionally, the Climate Change Act establishes the Climate Change Commission, which spearheads climate change policy and prepares the Framework Strategy on Climate Change and the National Climate Change Action Plan. ${ }^{177}$ The act also requires that local governments draft local climate change action plans that align with the national climate change strategy and action plan. ${ }^{178}$

The Climate Change Act is carried out through two key policy documents: the National Framework Strategy on Climate Change 2010-2022 (Climate Strategy) ${ }^{179}$ and the National Climate Change Action Plan 2011-2028. ${ }^{180}$ The Climate Strategy outlines a path toward clean development and aims "to build the adaptive capacity of communities and increase the resilience of natural ecosystems to climate change, and optimize mitigation opportunities towards sustainable development." 181 To this end, the Climate Strategy guides investment, development, and land use on subnational and national levels.

The Climate Strategy also emphasizes energy issues, aiming to double renewable energy capacity to 9,000 megawatts (MW) over 20 years (footnote 179). It further outlines energy efficiency and conservation programs, identifies renewable and low-carbon energy resources, and recommends using low-carbon modes of transportation and energy-saving infrastructure (footnote 179). On the adaptation side, the Climate Strategy seeks to improve ecosystem management (river basins, coastlines, biodiversity), water management, and disaster risk

174 Presidential Administrative Order No. 220 of 1991, Creation of an Inter-Agency Committee on Climate Change.

175 Republic Act No. 9729, Climate Change Act of 2009, sec. 2.

176 United Nations Framework Convention on Climate Change, New York, 9 May 1992, United Nations Treaty Series, Vol. 1,771, No. 30822. Art. 2.

177 Footnote 175, secs. 4, 13-14.

178 Footnote 175, sec. 14.

179 Government of the Philippines, Climate Change Commission. 2010. National Framework Strategy on Climate Change 2010-2022. Manila.

180 Government of the Philippines, Climate Change Commission. 2011. National Climate Change Action Plan 2011-2028. Manila.

181 Footnote 179, p. 5. 
reduction, as well as improve the climate resilience of infrastructure, agriculture, and health (footnote 179). The Climate Strategy treats mitigation and adaptation as synergistic.

In 2011, the National Climate Change Action Plan built on the Climate Strategy by assessing climate change risks in the Philippines. It outlines mitigation and adaptation targets for 2011-2028 in response to these projected impacts. Based on the risk assessment, it identifies the following priorities: food security, water sufficiency, ecological and environmental stability, human security, climatefriendly industries and services, sustainable energy, and knowledge and capacity development (footnote 180).

For food security, the plan seeks to ensure the availability, stability, accessibility, and affordability of safe and healthy food in the wake of climate change. For water sufficiency, the Philippines plans to assess and restructure the water sector to determine the resilience of its infrastructure; manage supply, demand, and quality; and promote conservation. For ecological and environmental stability, the Philippines is focused on protecting vital ecosystems and restoring ecosystem services. Human security involves reducing people's risk of exposure to climate change disasters. Climate-friendly industries and services include the creation of green jobs and sustainable consumption and production. Sustainable energy involves prioritizing the expansion of energy efficiency and conservation, and developing and implementing renewable energy. Knowledge and capacity development involves enhancing knowledge of climate change science, increasing capacity to respond to climate change, and establishing gendered climate change knowledge management accessible to all sectors at the national and local levels (footnote 180).

In 2012, the People's Survival Fund was established via Republic Act No. 10174 (or the People's Survival Fund Act of 2012) to finance climate change measures. The fund supports (i) adaptation actions in land management, water resources management, fisheries and agriculture, infrastructure development, health, and other natural ecosystems; (ii) the monitoring of diseases exacerbated by climate change to improve disease control and prevention; (iii) early warning and forecasting systems for climate-associated hazards; (iv) institutional development for local governments; and ( $v$ ) the establishment of regional centers and information networks for climate change adaptation projects. ${ }^{182}$ The People's Survival Fund Act created the People's Survival Fund Board, a body that oversees strategy and policy on funding. ${ }^{183}$

The Philippines is also integrating climate change into its development planning. The Philippine Development Plan 2017-2022, for example, recognizes climate

182 Republic Act No. 9729, Climate Change Act of 2009, sec. 20, inserted by Republic Act No. 10174, sec. 13.

183 Republic Act No. 9729, Climate Change Act of 2009, sec. 21, inserted by Republic Act No. 10174, sec. 13. 
change as a threat to which the nation must respond. ${ }^{184}$ It is the Philippines' first medium-term plan anchored on a long-term vision, i.e., AmBisyon Natin 2040, that represents the collective aspirations of Filipinos for themselves and the country. The plan highlights that coral bleaching and sea level rise could undermine the Philippines' development, thus seeking to mitigate climate impacts through mapping, improving science and technology, and adaptation measures. It also recognizes the threat that climate change poses to heritage structures.

Table 5.7 summarizes the Philippines' climate change legal and policy framework.

Table 5.7: Climate Change Legal and Policy Framework of the Philippines

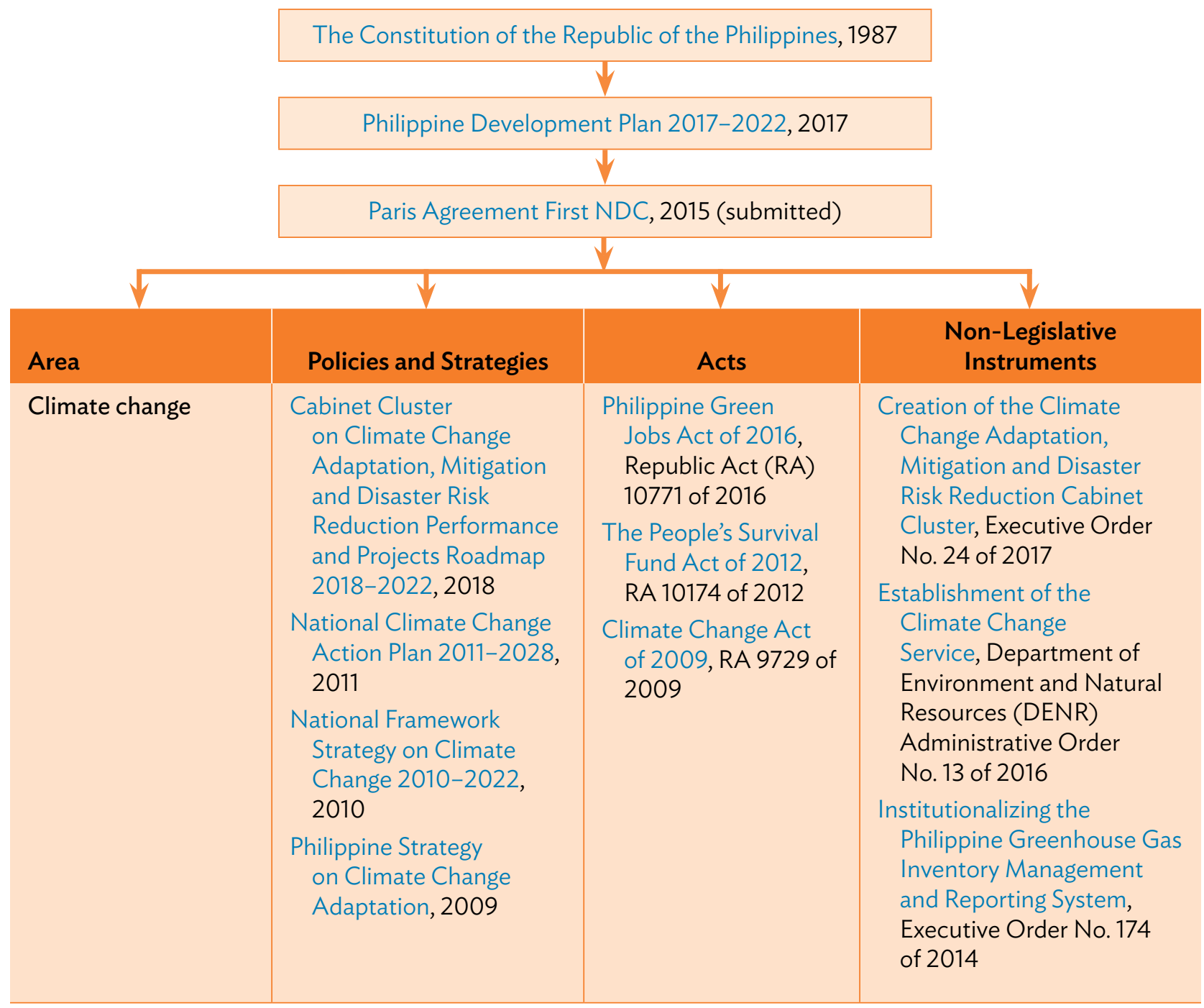

continued on next page

184 Government of the Philippines, National Economic and Development Authority. 2017. Philippine Development Plan 2017-2022. Manila. 
Table 5.7 continued

\begin{tabular}{|c|c|c|c|}
\hline Area & Policies and Strategies & Acts & $\begin{array}{l}\text { Non-Legislative } \\
\text { Instruments }\end{array}$ \\
\hline & & & $\begin{array}{l}\text { Implementing Rules and } \\
\text { Regulations of the Climate } \\
\text { Change Act, Climate Change } \\
\text { Commission Administrative } \\
\text { Order No. } 01 \text { of } 2010 \\
\text { Climate Change Office, } \\
\text { DENR Administrative } \\
\text { Order No. } 04 \text { of } 2009 \\
\text { Mandating the Presidential } \\
\text { Taskforce on Climate } \\
\text { Change to Develop the } \\
\text { National Climate Change } \\
\text { Framework, Executive } \\
\text { Order No. } 785 \text { of } 2009 \\
\text { Reorganizing the Presidential } \\
\text { Task Force on Climate } \\
\text { Change, Executive Order } \\
\text { No. } 774 \text { of } 2008 \\
\text { Rules and Regulations for } \\
\text { the National Authority for } \\
\text { the Clean Development } \\
\text { Mechanism, DENR } \\
\text { Administrative Order } \\
\text { No. } 17 \text { of } 2005 \\
\text { Designating the DENR as } \\
\text { the National Authority for } \\
\text { the Clean Development } \\
\text { Mechanism, Executive } \\
\text { Order No. } 320 \text { of } 2004 \\
\text { Creation of an Inter-Agency } \\
\text { Committee on Climate } \\
\text { Change, Administrative } \\
\text { Order No. } 220 \text { of } 1991 \\
\text { Orang }\end{array}$ \\
\hline Energy & $\begin{array}{l}\text { Philippine Energy Plan } \\
\text { 2016-2030, } 2016 \\
\text { Philippines Energy } \\
\text { Efficiency and } \\
\text { Conservation Action } \\
\text { Plan 2016-2020, } 2015 \\
\text { An Energy Efficiency } \\
\text { Roadmap for } \\
\text { the Philippines } \\
\text { 2014-30, 2013 }\end{array}$ & $\begin{array}{l}\text { Renewable Energy Act } \\
\text { of } 2008 \text {, RA } 9513 \text { of } \\
2008 \\
\text { Biofuels Act of } 2006 \text {, } \\
\text { RA } 9367 \text { of } 2007 \text { and } \\
2015 \text { amendment } \\
\text { to the Biofuels Act, } \\
\text { RA } 10745 \text { of } 2015 \\
\text { Electric Power Industry } \\
\text { Reform Act of } 2001 \text {, } \\
\text { RA } 9136 \text { of } 2001\end{array}$ & $\begin{array}{l}\text { Rules and Guidelines for } \\
\text { the Renewable Portfolio } \\
\text { Standards for On-Grid } \\
\text { Areas, Department of } \\
\text { Energy (DOE) Department } \\
\text { Circular No. DC 2017-12- } \\
0015 \text { of } 2017 \\
\text { Amended Implementing } \\
\text { Rules and Regulations for } \\
\text { the Biofuels Act of } 2006 \text {, } \\
\text { DOE Department Circular } \\
\text { No. DC 2016-07-0012 of } \\
2016\end{array}$ \\
\hline
\end{tabular}


Table 5.7 continued

\begin{tabular}{|c|c|c|c|}
\hline Area & Policies and Strategies & Acts & $\begin{array}{l}\text { Non-Legislative } \\
\text { Instruments }\end{array}$ \\
\hline & & $\begin{array}{l}\text { Mini-Hydroelectric } \\
\text { Power Incentive Act, } \\
\text { RA } 7156 \text { of } 1991\end{array}$ & 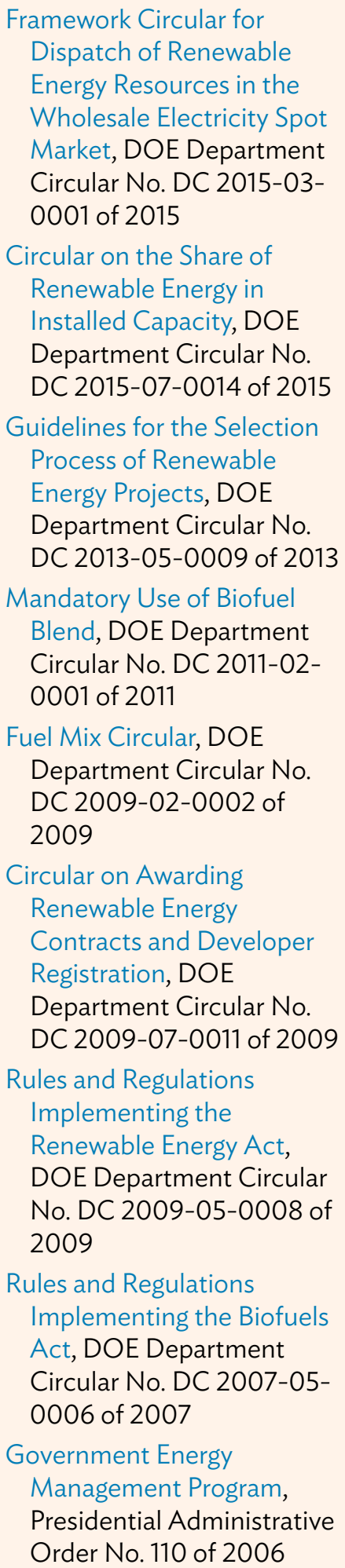 \\
\hline
\end{tabular}


Table 5.7 continued

\begin{tabular}{|c|c|c|c|}
\hline Area & Policies and Strategies & Acts & $\begin{array}{l}\text { Non-Legislative } \\
\text { Instruments }\end{array}$ \\
\hline & & & $\begin{array}{l}\text { Committee on Power } \\
\text { Conservation and Demand } \\
\text { Management, Executive } \\
\text { Order No. } 123 \text { of } 1993 \\
\text { Institutionalizing the } \\
\text { Committee on Power } \\
\text { Conservation and Demand } \\
\text { Management, Executive } \\
\text { Order No. } 123 \text { of } 1993\end{array}$ \\
\hline LULUCF and REDD+ & $\begin{array}{l}\text { Update of the Philippine } \\
\text { National REDD-Plus } \\
\text { Strategy, } 2017 \\
\text { Philippine National } \\
\text { REDD-Plus Strategy, } \\
2010\end{array}$ & & $\begin{array}{l}\text { Authorizing the Climate } \\
\text { Change Commission } \\
\text { to Coordinate REDD+ } \\
\text { Mechanisms, Executive } \\
\text { Order No. } 881 \text { of } 2010\end{array}$ \\
\hline Transportation & $\begin{array}{l}\text { National Environmentally } \\
\text { Sustainable Transport } \\
\text { Strategy for the } \\
\text { Philippines, } 2011\end{array}$ & & $\begin{array}{l}\text { Natural Gas Vehicle Program } \\
\text { for Public Transport, } \\
\text { Executive Order No. } 290 \\
\text { of } 2004 \\
\text { Institutionalizing the } \\
\text { Committee on Fuel } \\
\text { Conservation and } \\
\text { Efficiency in Road } \\
\text { Transport, Executive Order } \\
\text { No. } 472 \text { of } 1998\end{array}$ \\
\hline $\begin{array}{l}\text { Environmental } \\
\text { assessment }\end{array}$ & & $\begin{array}{l}\text { Philippine } \\
\text { Environmental Impact } \\
\text { Statement System, } \\
\text { Presidential Decree } \\
\text { No. } 1586 \text { of } 1978\end{array}$ & \\
\hline Cities and buildings & & $\begin{array}{l}\text { The Philippine Green } \\
\text { Building Code, } 2015\end{array}$ & \\
\hline $\begin{array}{l}\text { Disaster risk } \\
\text { management }\end{array}$ & & $\begin{array}{l}\text { Philippine Disaster } \\
\text { Risk Reduction and } \\
\text { Management Act } \\
\text { of } 2010, \text { RA } 10121 \text { of } \\
2010\end{array}$ & \\
\hline
\end{tabular}


Table 5.7 continued

\begin{tabular}{|c|c|c|c|}
\hline Area & Policies and Strategies & Acts & $\begin{array}{l}\text { Non-Legislative } \\
\text { Instruments }\end{array}$ \\
\hline Other & & $\begin{array}{l}\text { National Environmental } \\
\text { Awareness and } \\
\text { Education Act of } \\
2008 \text {, RA } 9512 \text { of } \\
2008 \\
\text { Philippine Clean Air } \\
\text { Act of } 1999 \text {, RA } \\
8749 \text { of } 1999\end{array}$ & \\
\hline
\end{tabular}

DENR = Department of Natural Resources and Environment; DOE = Department of Energy; LULUCF = land use, land-use change, and forestry; NDC = nationally determined contribution; RA = Republic Act; REDD + = reducing emissions from deforestation and forest degradation, conservation of existing forest carbon stocks, sustainable forest management, and enhancement of forest carbon stocks. Source: Authors.

\section{Energy Supply}

As of 2018 , approximately $40 \%$ of the Philippines' energy supply came from renewable sources, with the other $60 \%$ from fossil fuels. ${ }^{185}$ The country's total primary energy supply (TPES) reached 44.5 Mtoe in 2013. ${ }^{186}$ Oil accounted for the largest share of TPES at 31.6\% in 2013, followed by coal (22.5\%) and geothermal $(18.6 \%) .{ }^{187}$ Coal is projected to account for the largest share of TPES from the next decade onward, reaching $38.6 \%$ share in 2040 (footnote 186). Although fossil fuels contribute significantly to the primary energy supply, the government is trying to promote sustainable energy sources in its long-term strategy.

\section{Sector-Wide Energy Strategies}

The Philippine Energy Plan 2016-2030 was introduced in 2016 to achieve energy security, promote access to energy, and move toward a low-carbon future in the face of climate change. ${ }^{188}$ It resolves to triple the amount of energy generated from renewable sources by 2030 (footnote 188). Specifically, it seeks to increase renewable energy deployment by creating a supportive business environment, building efficient infrastructure, and engaging in research and development. It builds on a strong foundation of energy legislation.

In 2008, Congress enacted the Renewable Energy Act of 2008, which aims to accelerate the development and increase the use of renewable energy. The act

185 M.A.H. Mondal et al. 2018. The Philippines Energy Future and Low-Carbon Development Strategies. Energy. 147. pp. 142-154.

186 D. Vivar. 2016. Philippines Country Report. In S. Kimura and P. Han, eds. Energy Outlook and Energy Saving Potential in East Asia 2016. ERIA Research Project Report 2015-5. Jakarta: ERIA. pp. 273-296.

187 Footnote 186, Annex 4, p. 414.

188 Government of the Philippines, Department of Energy. 2016. Philippine Energy Plan 2016-2030. Manila. 
establishes the Renewable Portfolio Standard for generating electricity from renewable sources, as well as a minimum share of renewable energy supply for all electricity suppliers. ${ }^{189}$ Additionally, the act introduces a feed-in tariff system, including a priority grid connection for all renewable energy sources. ${ }^{190}$

The act also offers incentives to suppliers and manufacturers for developing renewable energy. ${ }^{191}$ For example, the 7 -year income tax holiday and tax exemptions for the carbon credits generated from renewable energy sources reduce the regular $30 \%$ corporate income tax to $10 \%$ once that tax holiday expires and puts a $1.5 \%$ realty tax cap on the original cost of the equipment and facilities needed to produce renewable energy. Other incentives include duty-free equipment import for 10 years, tax caps for renewable energy machinery, an accelerated depreciation scheme, cash-based incentives for electrification projects, and capital equipment tax credits.

The Mini-Hydroelectric Power Incentive Act (RA No. 7156 of 1991) was passed in 1991 to increase energy independence by promoting the use of, and entrepreneurship in, mini-hydroelectric power.

The Biofuels Act of 2006 (RA No. 9367) introduced sales targets for biofuels and biodiesels. By 2009, all oil companies had to ensure that bioethanol comprised at least $5 \%$ of their total sales. ${ }^{192}$ The target increased to $10 \%$ in $2011 .{ }^{193}$ Additionally, $1 \%$ biodiesel must be blended into all diesel engine fuels sold by 2007 and $2 \%$ by 2009. ${ }^{194}$ The Biofuels Act aims to decrease reliance on imported fuels and mitigate GHG emissions. Natural gas-fired power plants were exempted from the Biofuels Act in 2015 in response to reliability and cost issues in the supply of electricity.

\section{Energy Demand}

The energy demand growth outlook for the Philippines points to continued reliance on fossil fuels. According to the Economic Research Institute for ASEAN and East Asia, demand for natural gas is projected to grow at an average annual rate of $3.8 \%$ and oil at 3.9\% largely to meet growth in the transport sector (footnote 186). Demand for coal will show the fastest growth at an annual average of $7.8 \%$, mainly to meet the cement industry's needs (footnote 186). Electricity is projected to see the second-fastest growth rate at $4.8 \%$ (footnote 186).

In 2004, the Department of Energy (DOE) initiated its National Energy Efficiency and Conservation Program to promote energy efficiency and conservation. The DOE has generally taken a more prominent role in the Philippine government in recent years, ensuring access to sustainable, secure, and environmentally friendly

\footnotetext{
189 Republic Act No. 9513, Renewable Energy Act of 2008, sec. 6.

190 Footnote 189 , sec. 7.

191 Footnote 189, sec. 15.

192 Republic Act No. 9367, Biofuels Act of 2006, sec. 5.1.

193 Footnote 192, sec. 5.2.

194 Footnote 192, sec. 5.3.
} 
energy. Its approach includes encouraging private sector participation in energy development and ensuring that relevant stakeholders are aware of energy issues.

In 2004, the DOE launched the Philippines Energy Efficiency and Conservation Action Plan 2016-2020 and the Energy Efficiency Roadmap for the Philippines 2014-2030.195 The Energy Efficiency and Conservation Action Plan provides sector-specific strategies for the transport, industry, commercial, and residential sectors. Developed as part of the action plan, the Energy Efficiency Roadmap outlines efficiency targets by sector, with an economy-wide goal of $1.6 \%$ annual energy savings.

In addition to its renewable energy targets, the Philippine Energy Plan 2016-2030 contains an energy demand-supply outlook for 15 years and sector-specific road maps (footnote 188). These sectors include oil and gas, coal, renewable energy, power, electricity, downstream oil and natural gas, alternative fuels and technology, and energy efficiency and conservation. The energy plan recognizes the global effort to decrease the impacts of climate change and aims to achieve reductions in energy intensity toward a low-carbon future.

\section{E. LULUCF and REDD+}

Deforestation is a major challenge in the Philippines. In 2010, the Philippines had around 6.8 million hectares of total forest cover-around $23 \%$ of the country's total land area. ${ }^{196}$ The country loses around 47,000 hectares of forest cover annually. ${ }^{197}$ In 2009, the Department of Environment and Natural Resources (DENR) drafted the Philippine National REDD-plus Strategy in collaboration with nongovernment organizations. ${ }^{198}$ The government later incorporated the strategy into the National Climate Change Action Plan.

In 2010, the Climate Change Commission of the Philippines took over coordination of REDD+ actions following the issuance of Executive Order No. $881 .{ }^{199}$ The order also requires government agencies to provide necessary resources and information for REDD+ monitoring. It stipulates that the DENR take primary responsibility for REDD+ plan implementation and the management and utilization of international support for REDD+. The REDD+ Strategy was updated in 2017. ${ }^{200}$

195 Government of the Philippines. 2015. Philippines Energy Efficiency and Conservation Action Plan 2016-2020. Manila; and Government of the Philippines. 2013. An Energy Efficiency Roadmap for the Philippines 2014-30. Manila.

196 Government of the Philippines, Senate Economic Planning Office. 2015. Philippine Forests: At A Glance. Manila.

197 G.K. Cabico. 2018. Recovering the Philippines' Forest Cover. PhilStar Global. 4 March.

198 Government of the Philippines, Department of Environment and Natural Resources. 2010. The Philippine National REDD-plus Strategy. Manila.

199 Government of the Philippines. 2010. Executive Order No. 881 s. 2010, Authorizing the Climate Change Commission to Coordinate REDD+ Mechanisms. Manila.

200 Government of the Philippines, Department of Environment and Natural Resources. 2017. Update of the Philippine National REDD-Plus Strategy. Manila. 
The 2017 REDD + Strategy aims to address the drivers of deforestation and forest degradation. It recognizes that a results-based climate change mitigation strategy includes conservation, sustainable management of forests, enhancement of forest carbon stocks, and reduction of emissions from deforestation and forest degradation. The 2017 REDD+ Strategy affirms the following objectives:

(i) ensure sustainable forest management to reduce carbon emissions and conserve biodiversity;

(ii) enhance national carbon stocks to secure social and ecological benefits;

(iii) provide a research-based enabling environment from REDD+ programs;

(iv) leverage REDD+ resources and projects to deliver social benefits and help alleviate poverty;

(v) establish sustainable financing mechanisms to support REDD+ programs;

(vi) enhance the capacity of forest managers to implement REDD+ programs; and

(vii) develop and implement a forest carbon emissions reduction measure, reporting, and verification system. ${ }^{201}$

The Philippines has made progress in reducing deforestation and forest degradation. The Proposed National REDD-plus Safeguards Framework and Guidelines was developed after the Forest Land Boundary Delineation project was carried out in 2017. ${ }^{202}$ Formal and permanent forest boundaries were set-"a total of 89,091.95 kilometers of forest land boundary lines were delineated." 203 The government also developed the National Forest Protection Program (2015-2019) Menu of Options for Effective Forest Protection and Law Enforcement, which protects the country's forests from further destruction and degradation by reducing illegal logging. ${ }^{204}$ The program also assists forest managers in the environmental monitoring of forest health and biodiversity in high conservation areas.

\section{F. Transportation}

The transport sector is the Philippines' most energy-intensive sector and will continue to be until 2023 (footnote 186). However, the government has taken steps to make the transport sector more sustainable. In 1998, the national government created the Committee on Fuel Conservation and Efficiency in Road Transport. ${ }^{205}$ This committee facilitates the fuel conservation campaign that institutes road transport efficiency measures by encouraging the private sector

201 Footnote 200, p. 13.

202 Government of the Philippines. Proposed National REDD-plus Safeguards Framework and Guidelines. Manila.

203 Government of the Philippines, Senate Economic Planning Office. 2018. Policy Brief: Delineating the Philippines'Specific Forest Limits. PB-18-01. p. 5.

${ }^{204}$ Government of the Philippines, Department of Environment and Natural Resources. 2019. ASEAN Agreement on Transboundary Haze Pollution (AATHP). News release. 18 December.

205 Government of the Philippines. 1998. Executive Order No. 472 s. 1998, Institutionalizing the Committee on Fuel Conservation and Efficiency in Road Transport. Manila. 
to conserve fuel, monitor consumption, and follow other measures the new committee may see as appropriate.

In 2004, the DOE initiated the Natural Gas Vehicle Program for Public Transport under Executive Order No. 290. ${ }^{206}$ This program reduced import duties on compressed natural gas vehicles and natural gas vehicle-related equipment, parts, and components. The DOE launched the program to promote vehicles that would be less emissions-intensive than existing vehicles.

\section{G. Adaptation}

On 8 November 2013, Typhoon Haiyan tore through the Visayas, killing more than 6,300 people and injuring another $28,000 .{ }^{207}$ This disaster shocked the nation and spurred some climate change adaptation measures. ${ }^{208}$ Pursuant to Executive Order No. 24, issued in 2017, the Climate Change Adaptation, Mitigation and Disaster Risk Reduction Cabinet Cluster recognized some anti-corruption measures to ensure good governance in the realm of climate change adaptation. ${ }^{209}$ The regulation created a cabinet cluster responsible for implementing climate change resilience and adaptation measures. The cabinet cluster is also tasked with facilitating discussions on disaster risk management, increasing rural resiliency to climate change impacts, strengthening natural resource management, improving emergency response, and promoting adherence to international climate change commitments.

Executive measures build on the Philippine Strategy on Climate Change Adaptation (Adaptation Strategy). ${ }^{210}$ Launched in 2009, the Adaptation Strategy sets up a collaborative framework for adaptation action in the Philippines. It seeks to coordinate action among national agencies, the legislative branch, the academe, business, and civil society in eight major sectors: agriculture, biodiversity, coastal and marine, forestry, water, health, energy, and infrastructure (footnote 210). The Adaptation Strategy sets out the climate change-related risks and challenges these major sectors face. It further identifies a multisector, collaborative working group to lead efforts to deal with those risks and challenges.

206 Government of the Philippines. 2004. Executive Order No. 290, Implementing the Natural Gas Vehicle Program for Public Transport. Manila.

207 Government of the Philippines, National Disaster Risk Reduction and Management Council. 2013. Final Report re Effects of Typhoon "Yolanda" (Haiyan). Manila.

208 V. Thomas. 2013. Typhoon Haiyan Should Spur Climate Change Action. The Guardian. 18 November.

${ }^{209}$ Government of the Philippines. 2017. Executive Order No. 24, Creating the Infrastructure Cluster and Participatory Governance Cluster. Manila.

210 Government of the Philippines, Department of Environment and Natural Resources. 2009. Philippine Strategy on Climate Change Adaptation. Manila. 


\section{H. Disaster Risk Management}

The Philippine Disaster Risk Reduction and Management Act of 2010 (RA No. 10121 of 2010) authorizes the development of the National Disaster Risk Reduction and Management Framework. The act also adopts planning procedures and seeks to improve gender responsiveness of disaster risk reduction. Facilitating discussions on disaster risk management, with emphasis on rural resiliency and improving emergency response, is also within the purview of the Climate Change Adaptation, Mitigation and Disaster Risk Reduction Cabinet Cluster.

\section{VIIII. Singapore}

\section{A. Country Snapshot: Climate and Environmental Challenges}

A parliamentary representative democratic republic, the Republic of Singapore is vulnerable to climate change impacts, including sea level rise, coastal erosion, loss of biodiversity, and greater frequency and intensity of extreme weather events such as heavy rain, floods, and drought. ${ }^{211}$ Sea level rise poses an imminent threat to Singapore because it is a small island city-state with relatively flat land (footnote 211). Most land lies 15 meters above mean sea level, and 30\% of the island is less than 5 meters above mean sea level. ${ }^{212}$

Higher temperatures and more extreme rainfall are also critical climate challenges. During 1972-2014, the annual mean temperature increased from $26.6^{\circ} \mathrm{C}$ to $27.7^{\circ} \mathrm{C}$ (footnote 212 ). Annual average rainfall increased from 2,192 $\mathrm{mm}$ in 1980 to 2,727 mm in 2014 (footnote 212). Higher annual temperatures can lead to heat stress, especially given Singapore's high levels of urban density. Variable rainfall can also place pressure on water resources, overwhelming drainage systems and causing flash floods.

\section{B. Overarching Climate Change Legal and Policy Framework}

\section{Mitigation and Adaptation Targets}

Singapore is a party to all treaties under the UNFCCC. It ratified the Kyoto Protocol in 2006 (as a non-Annex I country), along with the Doha Amendment to the Kyoto Protocol in September 2014. Singapore has submitted three national communications under the UNFCCC, the first in 2000, the second in 2010, and

211 Government of Singapore, National Climate Change Secretariat. 2012. National Climate Change Strategy 2012. Singapore.

212 A.K. Biswas and C. Tortajada. 2016. Water Security, Climate Change and Sustainable Development. Singapore: Springer. 
the third in 2014, along with its first biennial update report. ${ }^{213}$ The country's first nationally determined contribution (NDC) pledges to reduce national emissions intensity by $36 \%$ from 2005 levels by 2030 and to stabilize its emissions to peak around $2030 .{ }^{214}$

\section{Overview of Climate Change Law and Policy}

The government established the Inter-Ministerial Committee on Climate Change in 2007 to facilitate interagency coordination on climate change. Its executive committee oversees working groups for long-term emissions and mitigation, international negotiations, and resilience. These working groups are composed of permanent secretaries and chief executives of ministries and national agencies (footnote 213).

In 2010, Singapore created a dedicated unit within the Prime Minister's Office-the National Climate Change Secretariat-to develop and coordinate climate change policies. The secretariat released the National Climate Change Strategy in 2012, which adopts a whole-of-nation approach to addressing climate change (footnote 213).

The strategy articulates three guiding principles for climate responses: (i) long-term and integrated planning, (ii) pragmatically and economically sound measures, and (iii) developing innovative solutions for Singapore and global markets. ${ }^{215}$ Singapore's main goals in addressing climate change are to (i) reduce carbon emissions in all sectors, (ii) adapt readily to climate change effects, (iii) harness green growth opportunities, and (iv) forge partnerships with both international and regional bodies. ${ }^{216}$

In 2016, Singapore unveiled its Climate Action Plan, which established the climate change-related challenges that the country faces and set some guidelines and quantified goals for various sectors. ${ }^{217}$ To meet Singapore's emissions reduction goals in its first NDC, the action plan sets out four strategies: improve energy efficiency; reduce carbon emissions from power stations; develop and demonstrate cutting-edge low-carbon technologies; and implement action through the collective efforts of government agencies, individuals, businesses, and the community. ${ }^{218}$ The action plan identifies six key areas of concern for resilience:

(i) protecting coasts,

(ii) managing water and minimizing floods,

213 M. Nachmany et al. 2015. Climate Change Legislation in Singapore: An Excerpt from the 2015 Global Climate Legislation Study: A Review of Climate Change Legislation in 99 Countries. London: Grantham Research Institute on Climate Change and the Environment. p. 2.

214 Government of Singapore. 2016. Singapore's First Nationally Determined Contribution. Singapore. p. 7. This part focuses on Singapore's 2016 NDC. However, Singapore submitted an updated NDC in March 2020. See Government of Singapore. 2020. Singapore's Update of Its First Nationally Determined Contribution. Singapore.

215 Footnote 211, pp. 12-13.

216 Footnote 211, pp. 13-14.

217 Government of Singapore, National Climate Change Secretariat. 2016. Singapore's Climate Action Plan: Take Action Today, For a Carbon-Efficient Singapore. Singapore.

218 Footnote 217, p. 2. 
(iii) protecting biodiversity and greenery,

(iv) strengthening resilience in public health and food supply,

(v) keeping essential services running well, and

(vi) keeping buildings and infrastructure safe. ${ }^{219}$

Singapore has also taken action on climate change by instituting a carbon tax. The Carbon Pricing Act, 2018 requires GHG emitters to report and pay tax on their emissions. Emitters that release more than a certain threshold of carbon dioxide $\left(\mathrm{CO}_{2}\right)$ equivalent must register with the National Environment Agency. Singapore's 2018 budget also mandates that facilities emitting 25,000 metric tons or more of GHGs a year must pay a carbon tax of $\$ 5$ per metric ton of emissions from 2019 to 2023.220 The government plans to review the carbon tax rate by 2023 and increase it to $\$ 10-\$ 15$ per metric ton by 2030 (footnote 220 ).

The Sustainable Singapore Blueprint 2015-published by the Ministry of the Environment and Water Resources and the Ministry of National Developmentserves as another key climate document outlining strategies for sustainable development. ${ }^{221}$

Table 5.8 summarizes Singapore's climate change legal and policy framework.

\section{Energy Supply}

In 2017, Singapore imported 189.3 metric tons of oil equivalent (Mtoe) of energy, representing a 7.4\% increase from 2016. ${ }^{222}$ Singapore's energy imports included petroleum products (120.5 Mtoe), crude oil (58.0 Mtoe), natural gas (9.9 Mtoe), coal and peat (0.9 Mtoe), and other energy products (0.1 Mtoe) (footnote 222). Singapore's total energy exports grew by 3.3\% from 99.3 Mtoe in 2016 to 102.6 Mtoe in 2017, primarily petroleum products as well as crude oil and coal and peat (footnote 222).

Singapore's total primary energy supply (TPES) was 28.73 Mtoe in 2013 and is projected to increase to more than 50 Mtoe by $2040 .{ }^{223}$ Singapore's energy supply mix is expected to include oil (69.2\%), natural gas (28.5\%), and other sources (2.3\%) such as solar power (footnote 223 ). Solar power has a projected average annual growth rate of $22.8 \%$ and oil $2.7 \%$, while natural gas is expected to increase depending on the expansion of new gas-fired power plants (footnote 223).

219 Government of Singapore, Ministry of the Environment and Water Resources and Ministry of National Development. 2016. Singapore's Climate Action Plan: A Climate-Resilient Singapore, For a Sustainable Future. Singapore. p. 8.

220 A. Tan. 2018. Singapore Budget 2018: Carbon Tax of \$5 per Tonne of Greenhouse Gas Emissions to Be Levied. The Straits Times. 19 February.

221 Government of Singapore, Ministry of the Environment and Water Resources / Ministry of National Development. 2015. Sustainable Singapore Blueprint 2015. Singapore.

222 Government of Singapore, Energy Market Authority. 2018. Singapore Energy Statistics 2018. Singapore.

223 L. Allan and J. Tao. 2016. Singapore Country Report. In S. Kimura and P. Han, eds. Energy Outlook and Energy Saving Potential in East Asia 2016. ERIA Research Project Report 2015-5. Jakarta: ERIA. pp. 297-322. 


\section{Table 5.8: Climate Change Legal and Policy Framework of Singapore}

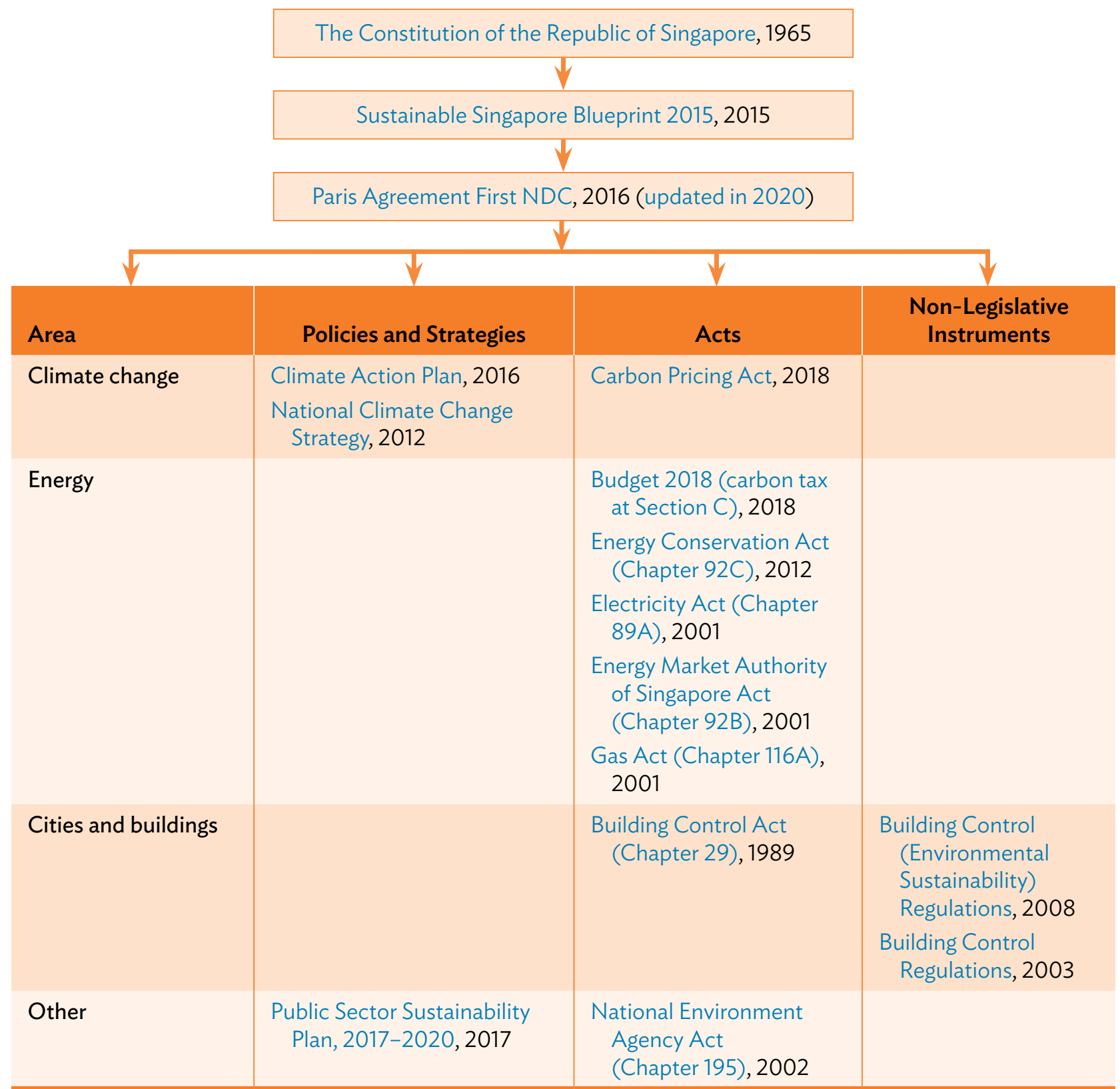

NDC = nationally determined contribution .

Source: Authors. 
Singapore has limited access to alternative energy sources. ${ }^{224}$ Because Singapore is a small island city-state with flat land, low wind speeds, and no geothermal potential, its access to alternative energy options-such as hydroelectric, wind, or geothermal power-is limited (footnote 224). Nuclear power does not present a viable option because of Singapore's small land area and high population density. ${ }^{225}$ Harnessing solar energy is also difficult because of its small size and dense urban landscape. ${ }^{226}$

Nevertheless, Singapore is attempting to promote solar photovoltaic deployment by creating an enabling environment that (i) "facilitates system integration of intermittent sources to ensure grid stability and security"; (ii) "addresses non-market barriers to entry without subsidizing the consumption of any form of energy"; and (iii) "supports continued investment in research, development, and demonstration" to reduce solar costs and increase efficiency. ${ }^{227}$ The government predicts that renewable energy could contribute to $8 \%$ of peak electricity demand by $2030 .{ }^{228}$

In 2001, Singapore enacted the Energy Market Authority of Singapore Act, which created a market framework for the supply of electricity and gas. The framework promotes fair and competitive market conduct and prevents the creation of monopoly powers in the market. The Electricity Act, 2001 stipulates that the Energy Market Authority should establish a competitive marketplace for the electricity industry and promote energy-efficiency practices. The Gas Act, 2001 created a competitive market framework for the gas industry, setting out technical and economic regulations for gas supply for the retail and transport sectors.

\section{Energy Demand}

In 2016, Singapore's total final energy consumption (TFEC) was 15.2464 Mtoe, a decrease of 3.5\% from 2015 (footnote 222). Singapore's energy consumption in 2016 was divided among the following sectors: industry (65.7\%), transportation (17.6\%), commerce and services (11.5\%), and residential (5.0\%) (footnote 222). The industry and transport sectors mostly consumed petroleum products, while the commerce and services and residential sectors mostly consumed electricity (footnote 222).

Singapore's TFEC is projected to increase to more than 45 Mtoe by 2040 (footnote 223). In 2040, Singapore's projected energy consumption mix will include oil (76.9\%), electricity (14.8\%), and natural gas (8.1\%) (footnote 223 ).

224 R. Khasawneh. 2019. Singapore to Stick with Natural Gas Power for Time Being, Expand Solar Use. Reuters. 29 October.

225 J. Zhao. 2015. Singapore's Nuclear Needs. Submitted as coursework for PH241, Stanford University, Winter 2015. California, United States. 17 March.

226 L. Heng. 2017. Why Singapore Needs to Make Nuclear Power Work. The Straits Times. 24 October.

227 Footnote 214, Annex.

228 Government of Singapore, National Climate Change Secretariat. Singapore's Approach To Alternative Energy. 
Singapore's energy consumption by sector is expected to include non-energy consumption (50.7\%), industry (33.3\%), transportation (8.5\%), and others (7.5\%) (footnote 223).

Energy efficiency is a key strategy in reaching Singapore's emissions reduction goals. The government established the Energy Efficiency Programme Office (E2PO) in 2007 to lead energy efficiency initiatives. ${ }^{229}$ The E2PO's Design for Efficiency Scheme provides financial support to "new industrial facility owners who plan to integrate energy and resource efficiency improvements into manufacturing development plans at an early stage." 230 The Energy Efficiency Improvement Assistance Scheme provides grant funding to "owners and operators of existing commercial and industrial facilities undertaking energy assessments" (footnote 230). Finally, the Grant for Energy Efficient Technologies provides financial support to "owners and operators of industrial facilities investing in energy efficient equipment or technologies" (footnote 230).

These energy initiatives are especially important since Singapore is a leading manufacturing hub, with manufacturing contributing about $20 \%$ to its GDP. ${ }^{231}$ Singapore is also the world's 14th-largest export economy. ${ }^{232}$

The Building and Construction Authority serves on the committee of the E2PO and coordinates energy efficiency initiatives. ${ }^{233}$ The authority focuses on promoting green building development to help achieve a national target of granting a Green Mark Certified rating to at least $80 \%$ of buildings by $2030 . .^{234}$ The Building Control (Environmental Sustainability) Regulations, 2008 require a minimum environmental sustainability standard for new buildings and existing ones that have undergone major retrofitting since 2008.

The Energy Conservation Act, 2012 also aims to regulate energy demand by requiring energy-intensive companies in industry and transport to follow energy management practices. The act also imposes energy efficiency requirements. Energy users in the industry and transport sectors consuming at least 54 terajoules of energy per year in at least two of three of the preceding years must appoint at least one energy manager. ${ }^{235}$ The act sets out minimum energy

229 G. Van Calster, W. Vandenberghe, L. Reins, eds. 2015. Research Handbook on Climate Change Mitigation Law. Cheltenham, United Kingdom: Edward Elgar Publishing.

230 M. Nachmany et al. 2015. Climate Change Legislation in Singapore: An Excerpt from the 2015 Global Climate Legislation Study: A Review of Climate Change Legislation in 99 Countries. London: Grantham Research Institute on Climate Change and the Environment. p. 4; Government of Singapore. E2 Singapore. p. 10.

231 Singapore Economic Development Board. 2018. Singapore: A Leading Manufacturing Hub. 21 May.

232 L. Pines. 2019. Singapore Commodities: How Does This "Economic Tiger" Trade in 2020? Commodity. 20 May.

233 Government of Singapore, Energy Market Authority. Energy Efficiency Programmes and Incentives.

234 Government of Singapore, Building and Construction Authority. Green Building Masterplans.

235 D. Ee. 2013. Energy Efficiency Regulations for Industry Users Start from April 22. The Straits Times. 22 April. 
performance standards for household appliances. It also mandates that motor vehicles have their fuel economy evaluated.

Finally, the Public Sector Sustainability Plan (2017-2020) aims to improve energy efficiency in the public sector by reducing electricity consumption by more than $15 \%$ from fiscal year 2013 levels by $2020 .{ }^{236}$

\section{E. Transportation}

Transportation is a significant contributor to Singapore's GHG emissions. Singapore's carbon emissions from transportation represented $15.2 \%$ of the country's total fuel combustion in 2014. ${ }^{237}$ To reduce emissions from the transport sector, the government is promoting public transportation use. ${ }^{238}$ Singapore aims that "75\% of trips during both the morning and evening peak hours will be made by public transport by 2030." 239 It is doubling its rail network by 2030 and increasing its bus fleet by about $20 \%$ (footnote 238). Furthermore, the Walk2Ride program is adding more walkways, and off-road cycling paths are being expanded (footnote 238).

To encourage the purchase of low-emission vehicles and thus curb emissions in the transport sector, the government has implemented various vehicle emission schemes since 2013. ${ }^{240}$ The schemes provide a rebate or impose a surcharge on registration fees according to the emissions levels of the car or taxi (footnote 240).

\section{F. Adaptation}

Singapore has begun the process of adaptation planning. The Climate Action Plan includes adaptation-related goals that focus on key vulnerabilities such as sea level rise and flooding (footnote 217). The plan resolves to do the following:

(i) safeguard public transport stations, airports, seaports, power stations, cellular towers, and other key infrastructure against floods and elevated temperatures;

(ii) build seawalls or use large geobags (sandbags) to harden coastlines against coastal erosion and sea level rise;

(iii) restore and protect mangroves;

(iv) increase connectivity between green areas;

(v) advance scientific understanding of climate change and its impacts on Singapore; and

(vi) promote innovative local farming solutions (footnote 219).

236 Government of Singapore, Ministry of the Environment and Water Resources. 2017. Public Sector Sustainability Plan 2017-2020. Singapore.

237 World Bank. CO2 Emissions from Transport (\% of Total Fuel Combustion) (accessed 29 December 2019).

238 Government of Singapore. Land Transport Master Plan 2013. Singapore.

239 Footnote 238, p. 3.

240 Land Transportation Authority of Singapore. Vehicle Emission Schemes. 
Climate change may also worsen Singapore's urban heat island effect, i.e., the tendency of urban areas to be warmer because natural land cover has been replaced by buildings and infrastructure that retain or produce heat. ${ }^{241}$ The Sustainable Singapore Blueprint outlines efforts to increase urban greenery. These efforts are managed by the Urban Redevelopment Authority, the National Parks Board, and the Housing and Development Board (footnote 221).

\section{Thailland}

\section{A. Country Snapshot: Climate and Environmental Challenges}

Thailand is a unitary parliamentary constitutional monarchy, which, like other Southeast Asian countries, is vulnerable to climate change impacts. It ranked as the 11th most affected by climate change in the world during 1994-2013, and is one of the 16 countries facing "extreme risk" over the next 30 years. ${ }^{242}$ The most significant adverse climate impacts facing the country include higher temperatures, flooding, and drought (footnote 242). During 1955-2005, Thailand saw increases of $0.95^{\circ} \mathrm{C}$ for mean temperature, $0.86^{\circ} \mathrm{C}$ for maximum temperature, and $1.45^{\circ} \mathrm{C}$ for minimum temperature (footnote 242 ).

Heavy rainfall is expected in the southern peninsula, causing flooding, while drought is expected in the arid inland northeastern region (footnote 242). The government reports that severe flooding on par with the 2011 flood in Thailand could cost $\$ 40$ billion to the economy (footnote 242 ). A recent drought cost about $0.52 \%$ of the country's GDP in 2015 , severely impacting the agriculture sector and subsistent farmers (footnote 242).

\section{B. Overarching Climate Change Legal and Policy Framework}

\section{Mitigation and Adaptation Targets}

Thailand pledged to reduce GHG emissions by $20 \%$ from business as usual (BAU) projections by the year 2030 in its NDC to the Paris Agreement (footnote 242). Thailand also committed to increasing national forest cover to $40 \%$ through local community participation (footnote 242 ). The NDC targets a $20 \%$ share of power generation from renewable energy by 2036 , a $30 \%$ share of renewable energy in the total final energy consumption (TFEC) by 2036 , and a 30\% reduction in energy intensity by 2036 compared with a 2010 baseline

241 D. Ng. 2019. Why Singapore Is Heating Up Twice as Fast as the Rest of the World. CNA. 13 January.

242 Government of Thailand. 2016. Thailand's First Nationally Determined Contribution. Bangkok. This part focuses on Thailand's 2016 NDC. However, Thailand submitted an updated NDC in October 2020. See Government of Thailand. 2020. Thailand's Updated Nationally Determined Contribution. Bangkok. 
(footnote 242). The NDC identifies the challenges that Thailand faces in implementing its pledges, including financial barriers and access to technology.

\section{Overview of Climate Change Law and Policy}

Thailand's approach to climate change management hinges on integrating climate change into development planning. Thailand's Twelfth National Economic and Social Development Plan, 2017-2021 acknowledges the burden of the consequences of climate change, and thus sets the nation on a course to mitigate and adapt to climate change. ${ }^{243}$ The plan discusses the importance of good land use practices, improves the nation's capacity to mitigate GHG emissions, and establishes natural resources conservation practices.

Thailand's targeted climate policy also focuses on development. The Climate Change Master Plan 2015-2050 outlines an overall climate change strategy and resolves to integrate climate resilience into national development policy. ${ }^{244}$ The integration will occur across all sectors and at the national and subnational levels to promote climate change adaptation. Furthermore, the Climate Master Plan prioritizes (i) reducing GHG emissions; (ii) pursuing low-carbon sustainable growth; (iii) building stakeholder capacity and awareness to ensure the successful implementation of the plan; and (iv) "developing a database, knowledge, and technology to support climate change adaptation and sustainable low-carbon growth." 245

To manage the nation's GHG emissions, Thailand established the Greenhouse Gas Management Organization through a royal decree issued in 2007. ${ }^{246}$ The organization's central mandate is to serve as the designated authority for Clean Development Mechanism (CDM) projects. It also provides technical assistance on sustainable development practices, administers a GHG database, and provides technical assistance regarding GHG emissions reduction. In 2017, the government designated the Office of Natural Resources and Environmental Policy and Planning as the entity responsible for climate change issues. ${ }^{247}$

Thailand's National Strategic Plan on Climate Change, 2008 sets overarching strategic goals to guide the country's climate change policy. ${ }^{248}$ These strategic

243 Government of Thailand, National Economic and Social Development Board. 2017. The Twelfth National Economic and Social Development Plan (2017-2021). Bangkok.

244 Government of Thailand. 2015. Climate Change Master Plan 2015-2050. Bangkok.

245 PreventionWeb. Thailand: Climate Change Master Plan (CCMP).

246 Government of Thailand. 2007. Royal Decree on Establishment of Thailand Greenhouse Gas Management Organization (Public Organization), BE 2550 (2007). Bangkok.

247 Government of Thailand. 2017. Ministerial Regulation Organizing the Office of Natural Resources and Environmental Policy and Planning, Ministry of Natural Resources and Environment. Bangkok.

248 Government of Thailand. 2008. National Strategic Plan on Climate Change, BE 2551-2555 (2008-2012). Bangkok. See Government of Thailand, Ministry of Natural Resources and Environment, Thailand Greenhouse Gas Management Organization. 2013. Thailand's Policies on Climate Change and Establishment of the Climate Change International Technical and Training Center (CITC). 17 May. 
goals are to (i) build capacity to adapt and reduce vulnerabilities to climate change impacts, (ii) promote GHG mitigation activities, (iii) support research and development to better understand climate change, (iv) raise awareness and public participation in climate change issues, and ( $v$ ) foster international cooperation in climate change mitigation efforts.

Although Thailand has yet to pass concrete climate change legislation, it has demonstrated thorough plans to take aggressive action against climate change. The next step for Thailand is to move past the strategic and target-setting phase and to implement the policies that will realize its climate goals.

Table 5.9 summarizes Thailand's climate change legal and policy framework.

\section{Table 5.9: Climate Change Legal and Policy Framework of Thailand}

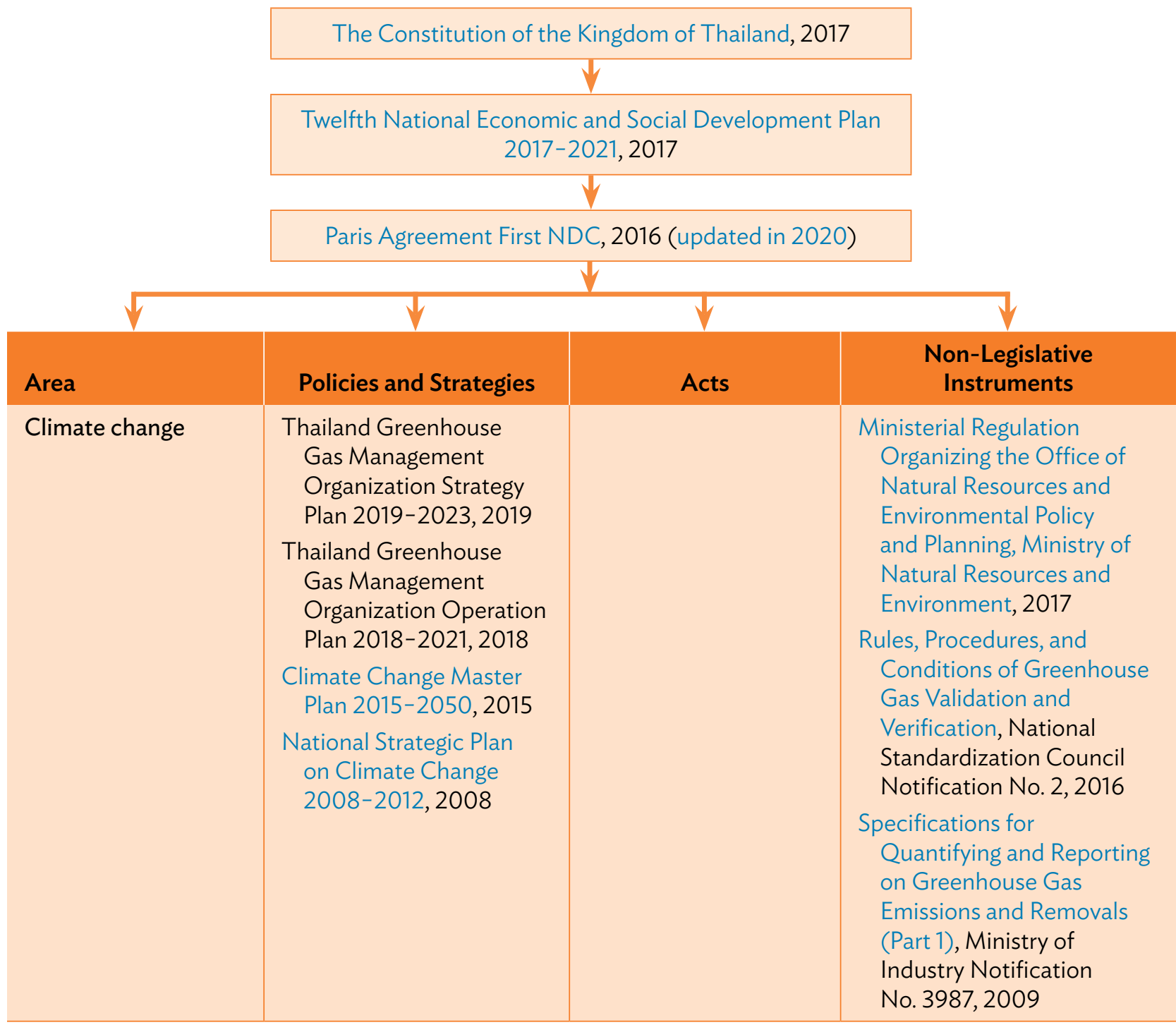

continued on next page 
Table 5.9 continued

\begin{tabular}{|c|c|c|c|}
\hline Area & Policies and Strategies & Acts & $\begin{array}{l}\text { Non-Legislative } \\
\text { Instruments }\end{array}$ \\
\hline & & & $\begin{array}{l}\text { Specifications for } \\
\text { Quantifying, Monitoring, } \\
\text { and Reporting on } \\
\text { Greenhouse Gas Emissions } \\
\text { and Removals (Part 2), } \\
\text { Ministry of Industry } \\
\text { Notification No. 3988, } \\
2009 \\
\text { Specifications for Validation } \\
\text { and Verification of } \\
\text { Greenhouse Gas Emissions } \\
\text { and Removals (Part 3), } \\
\text { Ministry of Industry } \\
\text { Notification No. 3989, } \\
\text { 2009 } \\
\text { Accreditation Requirements } \\
\text { for Greenhouse Gas } \\
\text { Validation and Verification } \\
\text { Bodies, Ministry of Industry } \\
\text { Notification No. 3990, } \\
\text { 2009 } \\
\text { Royal Decree Establishing the } \\
\text { Thailand Greenhouse Gas } \\
\text { Management Organization } \\
\text { (Public Organization), } \\
\text { 2007 } \\
\text { Regulations on Responding } \\
\text { to Climate Change, } \\
\text { Regulations of the Office } \\
\text { of the Prime Minister, 2007 }\end{array}$ \\
\hline Energy & $\begin{array}{l}\text { Alternative Energy } \\
\text { Development Plan } \\
\text { 2015-2036, } 2015 \\
\text { Thailand Energy Efficiency } \\
\text { Development Plan } \\
\text { 2015-2036, } 2015 \\
\text { Oil Plan 2015-2036, } 2015 \\
\text { Thailand Power } \\
\text { Development Plan } \\
\text { 2015-2036, } 2015 \\
\text { Renewable and } \\
\text { Alternative Energy } \\
\text { Development Plan for } \\
\text { 25 Percent in } 10 \text { Years } \\
\text { 2012-2021, } 2012\end{array}$ & $\begin{array}{l}\text { Energy Industry Act BE } \\
\text { 2550, } 2007 \\
\text { Energy Conservation } \\
\text { Promotion Act BE } \\
2535 \text { and BE 2550, } \\
1992 \text { (Part I) and } \\
\text { (Part II) } 2007\end{array}$ & \\
\hline
\end{tabular}


Table 5.9 continued

\begin{tabular}{|c|c|c|c|}
\hline Area & Policies and Strategies & Acts & $\begin{array}{l}\text { Non-Legislative } \\
\text { Instruments }\end{array}$ \\
\hline LULUCF and REDD+ & $\begin{array}{l}\text { Master Plan for } \\
\text { Integrated Biodiversity } \\
\text { Management, } \\
\text { (2015-2021), } 2015 \\
\text { National Forest Policy, } \\
1985\end{array}$ & $\begin{array}{l}\text { Forest Act BE 2484, } \\
\quad 1941\end{array}$ & \\
\hline Transportation & $\begin{array}{l}\text { Climate Change Master } \\
\text { Plan 2015-2050, } 2015 \\
\text { Alternative Energy } \\
\text { Development Plan } \\
\text { 2015-2036, } 2015 \\
\text { Renewable and } \\
\text { Alternative Energy } \\
\text { Development Plan for } \\
\text { 25 Percent in } 10 \text { Years } \\
\text { 2012-2021, } 2012 \\
\text { Thailand National Master } \\
\text { Plan 2011-2020, } 2011\end{array}$ & & \\
\hline $\begin{array}{l}\text { Disaster risk } \\
\text { management }\end{array}$ & $\begin{array}{l}\text { National Disaster Risk } \\
\text { Management Plan, } 2015\end{array}$ & & \\
\hline
\end{tabular}

$\mathrm{BE}=$ Buddhist Era; $\mathrm{LULUCF}=$ land use, land-use change, and forestry; NDC = nationally determined contribution; REDD+ = reducing emissions from deforestation and forest degradation, conservation of existing forest carbon stocks, sustainable forest management, and enhancement of forest carbon stocks.

Source: Authors.

\section{Energy Supply}

Thailand is a rapidly developing nation, resulting in an extreme increase in energy consumption and emissions. ${ }^{249}$ Thailand's total final energy consumption (TFEC) almost tripled from during 1990-2018, and its total carbon dioxide $\left(\mathrm{CO}_{2}\right)$ emissions doubled during that same period (footnote 249). As of 2013, oil accounted for $38.5 \%$ of Thailand's total primary energy supply (TPES), followed by natural gas (28.6\%), and coal (12.9\%). ${ }^{250}$ Thailand has limited indigenous oil resources and has historically relied on imported oil for power generation (footnote 250). Thus energy security is a concern, and the government has designed policies to balance security, climate change, and economic priorities.

249 International Energy Agency. Thailand (accessed 21 January 2020).

250 S. Padprem. 2016. Thailand Country Report. In S. Kimura and P. Han, eds. Energy Outlook and Energy Saving Potential in East Asia 2016. ERIA Research Project Report 2015-5. Jakarta: ERIA. pp. 323-335. 


\section{Sector-Wide Energy Strategies}

In 2013, the National Energy Policy Commission of Thailand implemented feed-in tariffs to support rooftop and ground-mounted solar installations. ${ }^{251}$ Through the tariff system, the government pays producers of solar energy a set price for each unit of energy. Thailand was one of the first Asian countries to adopt such a comprehensive feed-in tariff policy (footnote 251).

In 2015, the Thailand Oil Plan resolved to promote sustainable fuel management. It aims to support fuel conservation measures in the transport sector; encourage the use of fuel types that optimally fit particular energy needs; restructure fuel prices to reflect the costs of pollution, road damage, and other externalities resulting from fuel use; promote ethanol and biodiesel consumption; and encourage investment in fuel infrastructure..$^{252}$

\section{Renewable Energy Policies}

The Alternative Energy Development Plan, 2015-2036, launched in 2015 by the Ministry of Energy, promotes developing alternative energy sources. It focuses on three key areas: (i) energy security-ensuring that supply keeps pace with growing demand; (ii) economy-keeping energy costs reasonable so that they do not hinder economic growth; and (iii) ecology-increasing renewable energy production to reduce the impact on environment and communities. ${ }^{253}$

Table 5.10 highlights the Alternative Energy Development Plan's targets of renewable energy production compared with 2014 levels.

\section{Energy Demand}

Currently, Thailand does not produce as much energy as it consumes. Despite not consuming as much energy per capita as European nations, Thailand relies on energy imports to fully meet demand, of which $76 \%$ is met by fossil fuels. ${ }^{254}$ To cope with this demand for energy while also meeting its climate change commitments, Thailand has strongly promoted energy conservation to reduce the burden of supplying a rapidly developing nation with more energy.

Central to Thailand's energy conservation efforts is the Energy Conservation Promotion Act, 1992 (BE 2535). The act requires factories with high consumption rates or particular energy uses to have their energy usage audited. It also creates

251 R. Pacudan. 2014. Electricity Price Impacts of Feed-in Tariff Policies: The Cases of Malaysia, the Philippines, and Thailand. In F. Kimura and P. Han, eds. Energy Market Integration in East Asia: Energy Trade, Cross Border Electricity, and Price Mechanism. ERIA Research Project Report FY 2013 No. 29. Jakarta: ERIA.

252 Government of Thailand. 2015. Oil Plan 2015-2036. Bangkok.

253 Government of Thailand, Ministry of Energy. 2015. Alternative Energy Development Plan: AEDP2015. Bangkok.

254 World Data. Energy Consumption in Thailand (accessed 21 January 2020). 
Table 5.10: Renewable Energy Production Targets (megawatt)

\begin{tabular}{lrr}
\hline Source of Renewable Energy & 2014 Levels & Target \\
\hline Waste-to-energy & 65.72 & 500.00 \\
\hline Biomass & $2,451.82$ & $5,570.00$ \\
\hline Biogas from waste and wastewater & 311.50 & 600.00 \\
\hline Biogas from plants & 0.00 & 680.00 \\
Wind energy & 224.47 & $3,002.00$ \\
Solar energy & $1,298.51$ & $6,000.00$ \\
Hydropower (small) & 142.01 & 376.00 \\
\hline Hydropower (large) & 0.00 & $2,906.40$ \\
\hline
\end{tabular}

Source: Government of Thailand, Ministry of Energy. 2015. Alternative Energy Development Plan: AEDP2015. Bangkok. p. 9.

a voluntary program for small- to medium-sized companies to undertake energy conservation projects and research via the Energy Fund (ECON) Fund.

The Energy Industry Act, 2007 (BE 2550) further regulates demand for energy by creating the Energy Regulatory Commission, which regulates industrial energy use.

The Thailand Power Development Plan, 2015-2036 was implemented to achieve a 30\% reduction in energy intensity in 2036 compared with a 2010 baseline by (i) imposing fees on factories and buildings that use excessive electricity, and (ii) mandating reports on energy use per area for new buildings. ${ }^{255}$

\section{E. LULUCF and REDD+}

One of Thailand's main sources of regulation in the forestry sector is the Forest Act, BE 2484, 1941, which regulates logging, lumber, and forest clearing to ensure the sustainable harvesting of forest resources. Thailand also created a national committee to develop the National Forest Policy in 1985. ${ }^{256}$ The policy required that $40 \%$ of Thailand's total land area remain forested, of which $25 \%$ was reserved for economic use and 15\% for conservation. The Seventh National Economic and Social Development Plan, 1992-1996 altered these allocations so that 25\% of forests would be for conservation and $15 \%$ for economic use. ${ }^{257}$

In 2011, Thailand began receiving funding from the World Bank's Forest Carbon Partnership Facility to raise its capacity to reduce harmful emissions from forest

255 Government of Thailand, Ministry of Energy. 2015. Thailand Power Development Plan 2015-2036. Bangkok. p. 3-2.

256 Government of Thailand. 1985. National Forest Policy. Bangkok.

257 Government of Thailand, National Economic and Social Development Board. 1992. The Seventh National Economic and Social Development Plan (1992-1996). Bangkok. p. 188. 
degradation and deforestation. ${ }^{258}$ In 2016, Thailand received a $\$ 3.6$ million grant to improve its capabilities for REDD + (reducing emissions from deforestation and forest degradation, conservation of existing forest carbon stocks, sustainable forest management and enhancement of forest carbon stocks) (footnote 258).

In 2015, Thailand passed the Master Plan for Integrated Biodiversity Management to recognize the importance of natural biodiversity to Thailand's economy, as biodiversity fuels the country's production of food, medicine, and tools. ${ }^{259}$ These resources are a major source of Thailand's exports, culture, and customs. To protect Thailand's rich ecosystems, the master plan will increase budget allocations for biodiversity preservation and generally address the sources of stress on the country's natural resources, including forests.

These laws demonstrate that the Government of Thailand is strongly committed to preserving forests and acknowledges that forests and land are vital to the country's economy.

In 2018, to further reduce GHG emissions, Thailand joined the Food and Agriculture Organization of the United Nations (FAO) in its REDD+ program, which helps countries reduce their emissions from the forestry sector. ${ }^{260}$

\section{F. Transportation}

As of 2008, Bangkok emitted 7.1 tons of $\mathrm{CO}_{2}$ per capita, higher than other major cities. ${ }^{261}$ About $84 \%$ of Bangkok's GHG emissions come from energy use and transportation (footnote 261). Although Thailand's government has taken significant steps to reduce emissions from the transport sector, Bangkok remains a significant emitter.

To reduce these emissions, Thailand has promoted greater energy efficiency, including the use of biofuels over traditional fossil fuels. ${ }^{262}$ The Renewable and Alternative Energy Development Plan for 25 Percent in 10 Years (AEDP 2012-2021) resolved to increase ethanol consumption to 9 million liters per day and biodiesel use to 5.97 million liters per day by $2022 .{ }^{263}$ The Alternative Energy Development Plan included gasoline replacement targets for 2036-ethanol production at 11.3 million liters per day and biofuel production at 14 million liters per day (footnote 253). To meet these targets, the government grants subsidies

258 World Bank. 2016. Thailand to Reduce Harmful Emissions from Deforestation with World Bank Support. News. 14 September.

259 Government of Thailand. 2015. Master Plan for Integrated Biodiversity Management, BE 2558-2564 (2015-2021). Bangkok.

260 FAO. 2018. FAO Joins Hands with Thai Government on its REDD+ Program. News. 23 November.

261 C. Kisner. 2008. Climate Change in Thailand: Impacts and Adaptation Strategies. Climate Institute. July.

262 Y. Achawangkul. 2017. Thailand's Alternative Energy Development Plan. Presentation at the National Dialogue on the Urban Nexus in Thailand. 2 March.

263 Government of Thailand. 2012. The Renewable and Alternative Energy Development Plan for 25 Percent in 10 Years (AEDP 2012-2021). Bangkok. 
for biofuels, requiring biodiesel fuel to be blended into other traditional fuels, and provides tax incentives to promote the purchase of low-emission vehicles.

The Ministry of Transport has also developed the Thailand National Transport Master Plan 2011-2020 with the vision "Towards Sustainable Transport." 264 The plan promotes alternative energy use in the transport sector and the use of the public transportation system by improving its quality and increasing multimodal transportation (combined transport). ${ }^{265}$ This plan reduces $\mathrm{GHG}$ emissions by acknowledging that to combat climate change, individuals must begin making greater use of public transportation, which is far more efficient in terms of GHG emissions than individualized transport such as cars. The plan also acknowledges that to minimize the amount of transport needed within a city, that city should aim to consolidate development into a few dense urban centers, rather than allowing the city to sprawl out in all directions.

In addition, the Climate Master Plan includes targets to reduce the GHG emissions coming from the transport sector by $7 \%-20 \%$ by 2021 compared with 2005 , supply at least $25 \%$ of energy demand from renewable sources by 2021 , and reduce energy intensity by $25 \%$ by 2030 (footnote 244 ).

\section{G. Adaptation}

Although Thailand consistently mentions climate change adaptation as one of its central goals in some strategic documents, including its Twelfth National Economic and Social Development Plan, 2017-2021 and its Climate Master Plan, the country has not yet developed a dedicated adaptation strategic document.

\section{H. Disaster Risk Management}

The National Disaster Risk Management Plan was passed in 2015. ${ }^{266}$ It seeks to establish an operational framework to enable effective and efficient responses to disasters, integrate internationally recognized guidelines for disaster risk management, and build the government's capacity to manage disaster risks.

\footnotetext{
264 S. Jaensirisak et al. 2017. Development of National Transport Master Plan in Thailand. Amsterdam: Elsevier B.V.

265 Government of Thailand, Ministry of Transport. Thailand National Transport Master Plan 2011-2020. Bangkok.

266 Government of Thailand. 2015. National Disaster Risk Management Plan. Bangkok.
} 


\section{Viet Nam}

\section{A. Country Snapshot: Climate and Environmental Challenges}

The Socialist Republic of Viet Nam faces some adverse climate change impacts, including sea level rise; increased average temperature; and more frequent and intense extreme events like storms, floods, and droughts. ${ }^{267}$ The government reports that the average temperature in Viet Nam has increased by $0.5^{\circ} \mathrm{C}-0.7^{\circ} \mathrm{C}$, and the sea level has risen by about 20 centimeters $(\mathrm{cm})$ over the past 50 years. ${ }^{268}$ The average temperature in Viet Nam could increase by $3.36^{\circ} \mathrm{C}$ by $2080-2100 .{ }^{269}$ More than 70\% of Viet Nam's population depends on agriculture for their livelihood, making Viet Nam particularly susceptible to food insecurity and other climate-related impacts on the agriculture sector. ${ }^{270}$

Sea level rise is expected to result in the submergence of $39 \%$ of the Mekong River Delta, one of the world's three most vulnerable deltas to sea level rise, and put $20 \%$ of the Ho Chi Minh City area underwater. ${ }^{271}$ Inundation will directly affect $10 \%-12 \%$ of the nation's population and cost the equivalent of $10 \%$ of Viet Nam's gross domestic product (GDP). ${ }^{272}$ Although Viet Nam's GHG emissions only accounted for approximately $0.5 \%$ of the global total and emissions per capita were relatively low at 2.84 metric tons of $\mathrm{CO}_{2}\left(\mathrm{tCO}_{2}\right)$ equivalent in 2010, Viet Nam is nonetheless implementing climate change mitigation and adaptation measures. ${ }^{273}$

\section{B. Overarching Climate Change Legal and Policy Framework}

\section{Mitigation and Adaptation Targets}

Viet Nam's first nationally determined contribution (NDC) pledges an unconditional $8 \%$ reduction in $\mathrm{GHG}$ emissions by 2030 compared with business as usual (BAU) (footnote 273). However, the government aims to reduce $\mathrm{GHG}$ emissions by $25 \%$ by 2030 compared with BAU subject to receiving international support. Reductions in emission intensity per unit of GDP also have unconditional and conditional targets - 20\% by 2030 compared with 2010 levels (unconditional) and 30\% compared with 2010 levels, conditional upon receiving financial support (footnote 273). Viet Nam also intends to increase forest cover to $45 \%$ (footnote 273 ).

267 See World Bank Group. Vietnam: Impacts: Agriculture.

268 Government of Viet Nam, Ministry of Natural Resources and Environment (MONRE). 2009.

Climate Change, Sea Level Rise Scenarios for Viet Nam. Hanoi.

269 World Bank Group. Vietnam: Climate Data: Projections.

270 New Agriculturist. 2008. Country Profile-Vietnam; and Vietnamnet Bridge. 2015. The Challenges of Vietnam Agriculture. 13 October.

271 P. Schmidt-Thomé et al. 2015. Climate Change Adaptation Measures in Vietnam: Development and Implementation. Cham, United Kingdom: Springer International Publishing.

272 Viet Nam Government Portal. National Strategy on Climate Change.

273 Government of Viet Nam. 2016. First Nationally Determined Contribution of Viet Nam. Ha Noi. This part focuses on Viet Nam's 2016 NDC. However, Viet Nam submitted an updated NDC in November 2020. See Government of Viet Nam. 2020. Updated Nationally Determined Contribution. Hanoi. 
The NDC aims to integrate disaster risk management and climate change adaptation into $90 \%$ of socioeconomic development plans by 2030 (footnote 273). The NDC includes a range of targets related to social development: (i) reduce the national poverty rate by $2 \%$ each year, (ii) provide $100 \%$ of the population with access to health care, and (iii) ensure that $90 \%$ of city dwellers and $80 \%$ of rural inhabitants have access to clean water by 2030 (footnote 273).

\section{Overview of Climate Change Law and Policy}

Viet Nam has issued more climate change policies than most other countries in Asia and the Pacific. Most of these policies were formally launched through a prime ministerial decision. The government's climate change efforts focus on developing a low-carbon economy; mitigating emissions in the energy, industry, transport, agriculture, and waste sectors; and adapting the most vulnerable areas, namely agriculture, natural ecosystems, biodiversity, water resources, public health, and infrastructure. Both the Ministry of Natural Resources and Environment and the Ministry of Agriculture and Rural Development handle climate policy.

In 2016, the Prime Minister approved an implementation plan to fulfill Viet Nam's commitments under the Paris Agreement. ${ }^{274}$ The implementation plan outlines key tasks and identifies responsible actors, a timeline, and a budget for carrying out these activities. By creating a work plan to implement the NDC, the government aims to mitigate GHGs, encourage renewable energy development, and promote adaptation. The implementation plan will also allow Viet Nam to establish its institutional climate response and a monitoring, reporting, and verification system for mitigation and adaptation measures.

In 2017, the Government of Viet Nam issued Decision No. 1670/QD-TTg, launching a climate change and green growth program covering 2016-2020.275 The program aims to strengthen Viet Nam's adaptation to the consequences of climate change, mitigate GHG emissions through green growth and a low-carbon economy, restructure economic institutions to encourage efficient energy and resource use, and promote international cooperation and climate change finance. It also builds on Viet Nam's National Green Growth Strategy of 2012. ${ }^{276}$ Since then, the Ministry of Natural Resources and Environment and the Ministry of Transport have issued action plans to implement green growth strategies within their sectors. ${ }^{277}$

274 Government of Viet Nam. 2016. Prime Minister's Decision No. 2053/QD-TTg, the Paris Agreement Implementation Plan. Ha Noi.

275 Open Development Mekong. Decision No. 1670/QD-TTg: Approve the Target Program to Respond to the Climate Change and Green Growth for the Period of 2016-2020.

276 Government of Viet Nam. 2012. Prime Minister's Decision No. 1393/QD-TTg, the National Green Growth Strategy. Ha Noi.

277 Government of Viet Nam, MONRE. 2015. MONRE Decision No. 965/QD-BTNMT, the Natural Resources and Environment Action Program for Implementing the National Green Growth Strategy for 2015-2020, with Vision to 2030. Ha Noi; and Government of Viet Nam, Ministry of Transport and Communications (MOTC). 2016. MOTC Decision No. 1456/QD-BGTVT, MOTC Climate Change and Green Growth Action Plan for 2016-2020. Ha Noi. 
Viet Nam's National Target Program for Responding to Climate Change, first promulgated in 2008, guides the government in mainstreaming climate change across all sectors and fields. ${ }^{278}$ In 2012, the Prime Minister extended the program to the 2012-2015 period to (i) raise awareness of and capacity for climate change adaptation, (ii) reduce GHG emissions, and (iii) strengthen the economy through green growth strategies. ${ }^{279}$ In 2013, the Ministry of Natural Resources and Environment approved three projects under the target program's 2012-2015 period: (i) assessment of climate change and sea level rise; (ii) development and implementation of action plans to respond to climate change; and (iii) capacity building, communication, monitoring, and evaluation of program implementation. ${ }^{280}$

The 2011 National Strategy for Climate Change and the 2012 National Action Plan on Climate Change are two other guiding climate change policies. The 2011 National Strategy for Climate Change aims to (i) mitigate GHG emissions, (ii) enhance adaptation capacity to climate change, (iii) develop a low-carbon economy to improve quality of life, (iv) support national security and sustainable development, and ( $v$ ) protect the climate system. ${ }^{281}$ To achieve these goals, the strategy seeks to increase the government's regulatory and managerial roles. It plans to develop systematic, holistic, multidisciplinary, interregional solutions based on scientific evidence while taking into account the nation's ambition to promote socioeconomic benefits and cope with the risks of climate change.

The 2012 National Action Plan on Climate Change focuses on natural disasters. ${ }^{282}$ It aims to monitor climate, predict and respond to natural disasters, draw maps of areas that will be impacted by floods and rising sea levels, and ensure food and water security. It also aims to develop resilience against natural disasters, mitigate GHG emissions, enhance management and policy capacity to cope with climate change, mobilize the participation of various economic sectors, raise awareness of the threats of climate change, promote international cooperation on climate change, and mobilize economic resources to respond to climate change.

By 2020, Viet Nam intends to launch a national carbon emissions trading scheme. ${ }^{283}$ The scheme aims to reduce GHG emissions (compared with 2005

278 Government of Viet Nam. 2008. Prime Minister's Decision No. 158/2008/QD-TTg, the National Target Program on Response to Climate Change. Ha Noi.

279 Government of Viet Nam. 2012. Prime Minister's Decision No. 1183/QD-TTg, the National Target Program to Respond to Climate Change in 2012-2015. Ha Noi.

280 Government of Viet Nam, MONRE. 2013. MONRE Decision No. 1651/QD-BTNMT approving Initiative Projects Under the National Target Program to Respond to Climate Change in 2012-2015. Ha Noi.

281 Government of Viet Nam. 2011. Prime Minister's Decision No. 2139/QD-TTg approving the National Strategy on Climate Change. Ha Noi.

282 Government of Viet Nam. 2012. Prime Minister's Decision No. 1474/QD-TTg approving the National Action Plan on Climate Change During 2012-2020. Ha Noi.

283 The Climate Group. 2012. Vietnam Plans National Carbon Market from 2020. 26 November. 
levels) in the energy and transport sectors by $8 \%$, in the agriculture sector by $20 \%$, in the forestry sector by $20 \%$, and in waste management by $5 \%{ }^{284}$

The majority of Viet Nam's population depends on agriculture for its livelihood. Thus, the government has focused on reducing climate change risk in the agriculture sector. ${ }^{285}$ The Ministry of Agriculture and Rural Development has issued policies that seek to reduce emissions from the agriculture sector, promote resilience, and ensure food security. The Climate Change Adaptation Framework, for example, was adopted by the ministry in 2008 to ensure stability and safety, maintain food security, and protect the nation's dike system, particularly in the Mekong River Delta, the Red River Delta, the central region, and mountainous areas. ${ }^{286}$

Beyond its policy initiatives, the government passed the Law on Environmental Protection in 2014, which covers environmental protection broadly but contains some climate-related provisions. ${ }^{287}$ The law promotes the development and use of clean energy to reduce $\mathrm{GHG}$ emissions and protect the ozone layer. It also recommends developing an emissions reduction road map in line with Viet Nam's socioeconomic development and in light of its international commitments.

The law also provides for the promulgation of regulations related to climate change response, including the management of GHG emissions and ozonedepleting substances, renewable energy development, eco-friendly production and consumption, waste-to-energy processes, the rights and responsibilities of the human community for the response to climate change, and technological advances for the response to climate change. The law mandates the government to develop a national environmental protection plan to assess the current state of environmental protection and forecast environmental and climate changerelated impacts.

Table 5.11 summarizes Viet Nam's climate change legal and policy framework.

\section{Energy Supply}

Viet Nam's total primary energy supply (TPES) reached 70.1 million tons of oil equivalent (Mtoe) in 2015. ${ }^{288}$ Coal represents the largest share of the country's TPES (35.9\%), followed by oil (22.2\%), natural gas (13.7\%), and hydro (7.8\%), and others (20.3\%) (footnote 288). A net exporter of crude oil and coal,

284 M. Nachmany et al. 2015. Climate Change Legislation in Vietnam: An Excerpt from the 2015 Global Climate Legislation Study: A Review of Climate Change Legislation in 99 Countries. London: Grantham Research Institute on Climate Change and the Environment.

285 See the table below for a listing of the different executive issuances relating to food production and food security.

286 Government of Viet Nam, Ministry of Agriculture and Rural Development (MARD). 2008. MARD Decision No. 2730/QD-BNN-KHCN, the Climate Change Adaptation Framework Action Program for All Bodies Involved in Agriculture and Rural Development in 2008-2020. Ha Noi.

287 Government of Viet Nam. 2014. Law No. 55/2014/QH13, Law on Environmental Protection. Ha Noi.

288 N. Bao. 2019. Viet Nam Country Report. In S. Kimura and P. Han, eds. Energy Outlook and Energy Saving Potential in East Asia 2019. ERIA. Jakarta: ERIA. pp. 316-333. 


\section{Table 5.11: Climate Change Legal and Policy Framework of Viet Nam}

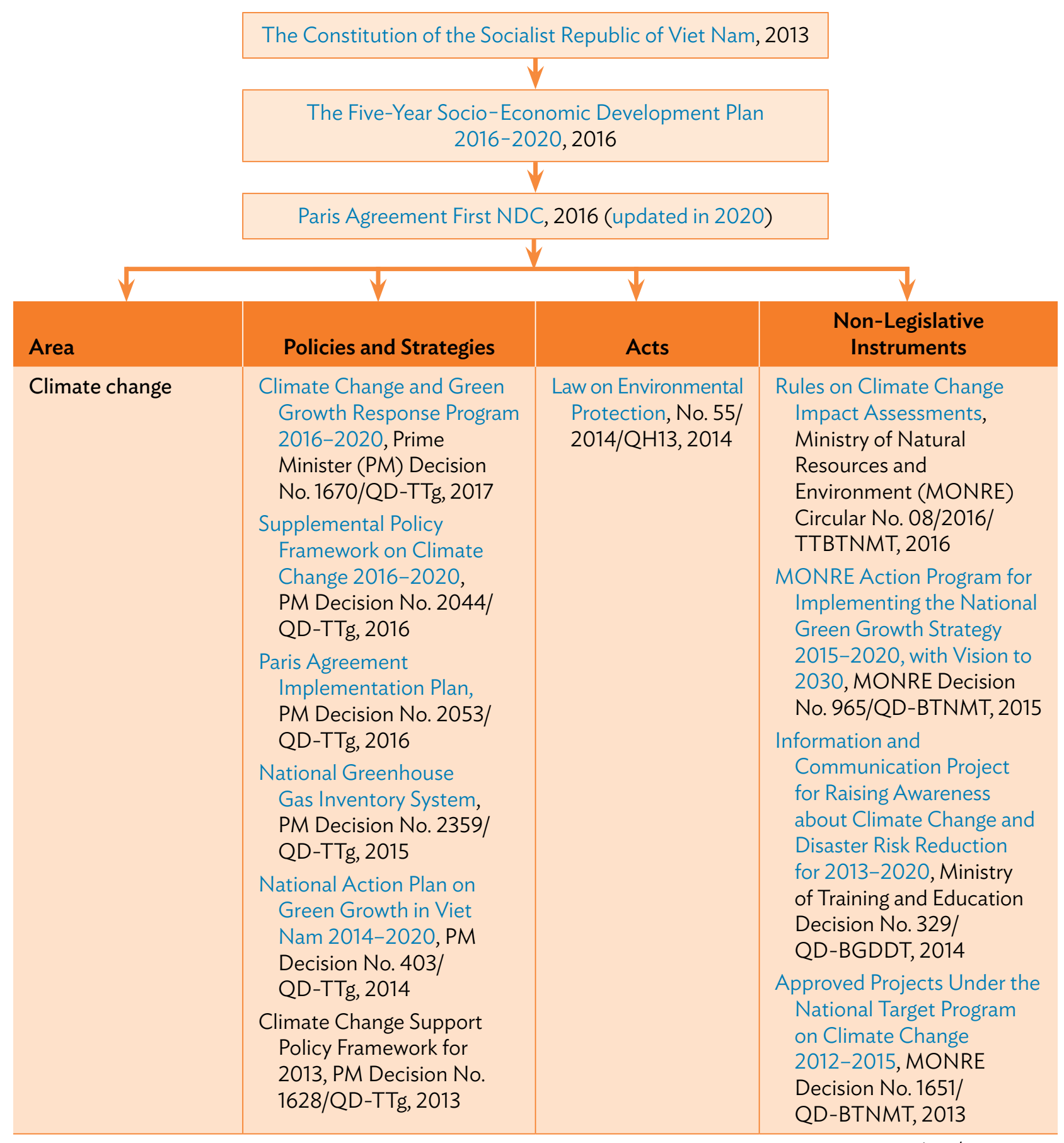


Table 5.11 continued

\begin{tabular}{|c|c|c|c|}
\hline Area & Policies and Strategies & Acts & $\begin{array}{l}\text { Non-Legislative } \\
\text { Instruments }\end{array}$ \\
\hline & 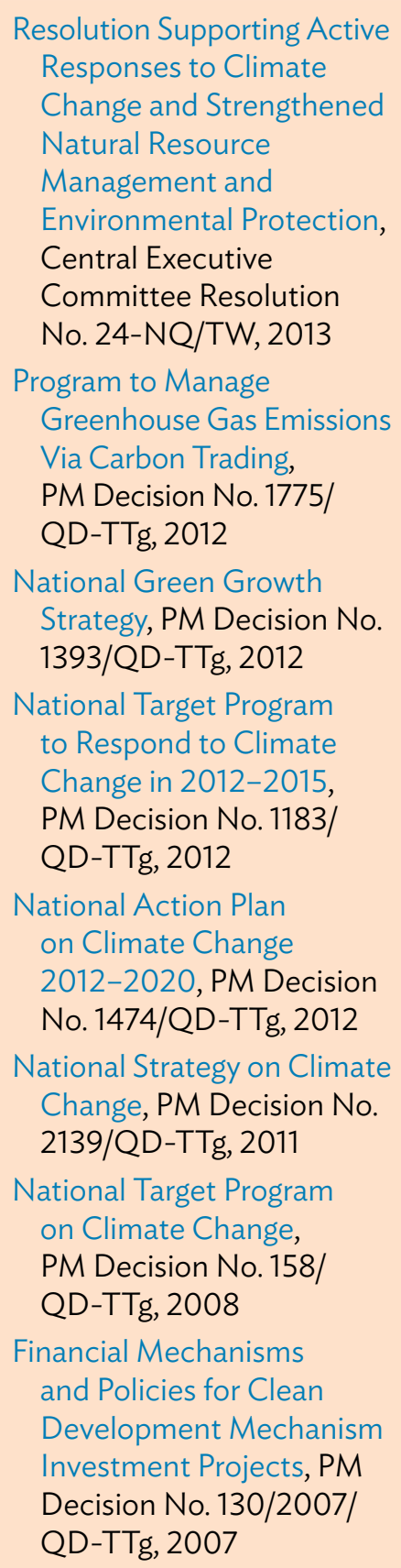 & & $\begin{array}{l}\text { Circular Amending MONRE } \\
\text { Circular No. 12/2010/ } \\
\text { TT-BTNMT, MONRE } \\
\text { Circular No. 12/2011/ } \\
\text { TT-BTNMT, 2011 } \\
\text { MONRE Climate Change } \\
\text { Action Plan 2011-2015, } \\
\text { MONRE Decision No. } \\
\text { 2418/QD-BTNMT, } 2010\end{array}$ \\
\hline Energy & $\begin{array}{l}\text { National Targeted Program } \\
\text { on Energy Efficiency and } \\
\text { Conservation 2012-2015, } \\
\text { PM Decision No. 1427/ } \\
\text { QD-TTg, } 2012\end{array}$ & $\begin{array}{l}\text { Law on Economical } \\
\text { and Efficient Use } \\
\text { of Energy, Part I, } \\
2010 \text { (No. 50/2010/ } \\
\text { QH12) and Part II, } \\
2011 \text { (Decree No. } \\
\text { 21/2011/ND-CP) }\end{array}$ & $\begin{array}{l}\text { Amendments to the } \\
\text { Mechanism Supporting } \\
\text { the Development of } \\
\text { Wind Power Projects, PM } \\
\text { Decision No. 39/2018/ } \\
\text { QD-TTg, } 2018\end{array}$ \\
\hline
\end{tabular}


Table 5.11 continued

\begin{tabular}{|c|c|c|c|}
\hline Area & Policies and Strategies & Acts & $\begin{array}{l}\text { Non-Legislative } \\
\text { Instruments }\end{array}$ \\
\hline & $\begin{array}{l}\text { Biofuels Development } \\
\text { Scheme up to 2015, with } \\
\text { a Vision to 2025, PM } \\
\text { Decision No. 177/2007/ } \\
\text { QDTTg, } 2007 \\
\text { National Energy } \\
\text { Development Strategy } \\
\text { up to 2020, with 2050 } \\
\text { Vision, PM Decision No. } \\
\text { 1855/QDTTg, 2007 } \\
\text { National Strategic Energy } \\
\text { Efficiency 2006-2015, PM } \\
\text { Decision No. 79/2006/ } \\
\text { QD-TTg, 2006 }\end{array}$ & & $\begin{array}{l}\text { Solar Power Development } \\
\text { Program, PM Decision No. } \\
\text { 11/2017/QD-TTg, 2017 } \\
\text { Regulations on Solar Power } \\
\text { Project Development } \\
\text { and Standardized Power } \\
\text { Purchase Agreements } \\
\text { for Solar Power Projects, } \\
\text { Ministry of Industry } \\
\text { and Trade Circular No. } \\
\text { 16/2017/TT-BCT, 2017 } \\
\text { Mechanism Supporting } \\
\text { the Development of } \\
\text { Wind Power Projects, PM } \\
\text { Decision No. 37/2011/ } \\
\text { QD-TTg, } 2011\end{array}$ \\
\hline LULUCF and REDD+ & $\begin{array}{l}\text { National REDD+ Action } \\
\text { Programme to 2030, } 2017 \\
\text { PM Decision No. 419/QD } \\
\text {-TTg, } 2017 \\
\text { National REDD+ Program } \\
\text { 2011-2020, 2012 PM } \\
\text { Decision No. 799/ } \\
\text { QD-TTg, } 2012\end{array}$ & & $\begin{array}{l}\text { Regulations on Forest } \\
\text { Management, } 2006 \text { PM } \\
\text { Decision No. 186/2006/ } \\
\text { QD-TTg, } 2006\end{array}$ \\
\hline Transportation & & & $\begin{array}{l}\text { Ministry of Transport and } \\
\text { Communications (MOTC) } \\
\text { Climate Change and } \\
\text { Green Growth Action } \\
\text { Plan 2016-2020, MOTC } \\
\text { Decision No. 1456/ } \\
\text { QD-BGTVT, 2016 } \\
\text { MOTC Climate Change } \\
\text { Action Plan 2011-2015, } \\
\text { 2011 MOTC Decision No. } \\
\text { 199/QD-BGTVT, } 2011\end{array}$ \\
\hline $\begin{array}{l}\text { Food production and } \\
\text { food security }\end{array}$ & & & $\begin{array}{l}\text { Greenhouse Gas Emissions } \\
\text { Reduction Plan for the } \\
\text { Agriculture and Rural } \\
\text { Development Sector } \\
\text { to 2020, Ministry of } \\
\text { Agriculture and Rural } \\
\text { Development (MARD) } \\
\text { Decision No. 3119/ } \\
\text { QD-BNN-KHCN, } 2011\end{array}$ \\
\hline
\end{tabular}


Table 5.11 continued

\begin{tabular}{|c|c|c|c|}
\hline Area & Policies and Strategies & Acts & $\begin{array}{l}\text { Non-Legislative } \\
\text { Instruments }\end{array}$ \\
\hline & & & $\begin{array}{l}\text { Directive to Integrate } \\
\text { Climate Change into } \\
\text { Agriculture and Rural } \\
\text { Development Sector } \\
\text { Strategies, Plans, Programs, } \\
\text { and Projects 2011-2015, } \\
\text { MARD Directive No. 809/ } \\
\text { CT-BNN-KHCN, } 2011 \\
\text { MARD Climate Change } \\
\text { Action Plan 2011-2015 and } \\
\text { Vision to 2050, MARD } \\
\text { Decision No. 543/QD- } \\
\text { BNN-KHCN, 2011 } \\
\text { Climate Change Adaptation } \\
\text { Framework Action Program } \\
\text { for the Agriculture and } \\
\text { Rural Development Sector } \\
\text { 2008-2020, MARD } \\
\text { Decision No. 2730/QD- } \\
\text { BNN-KHCN, 2008 }\end{array}$ \\
\hline $\begin{array}{l}\text { Water resources } \\
\text { and coastal zone } \\
\text { management }\end{array}$ & $\begin{array}{l}\text { Project to Protect Coastal } \\
\text { Forests and Enhance Their } \\
\text { Resilience to Climate } \\
\text { Change 2014-2020, } \\
\text { PM Decision No. 120/ } \\
\text { QD-TTg, } 2015\end{array}$ & & \\
\hline Cities and buildings & & & $\begin{array}{l}\text { Climate Change Action } \\
\text { Plan for the Construction } \\
\text { Industry 2016-2020, } \\
\text { Ministry of Construction } \\
\text { Decision No. 11/QD-BXD, } \\
2016 \\
\text { Urban Resilience to } \\
\text { Climate Change Project } \\
\text { 2013-2020, PM Decision } \\
\text { No. 2623/QD-TTg, } 2013\end{array}$ \\
\hline Vulnerable groups & & & $\begin{array}{l}\text { Ministry of Labour, Invalids } \\
\text { and Social Affairs Climate } \\
\text { Change Action Plan } \\
\text { 2011-2015, Ministry of } \\
\text { Labour, Invalids and Social } \\
\text { Affairs Decision No. 403/ } \\
\text { QD-LDTBXH, } 2011\end{array}$ \\
\hline
\end{tabular}


Table 5.11 continued

\begin{tabular}{|c|c|c|c|}
\hline Area & Policies and Strategies & Acts & $\begin{array}{l}\text { Non-Legislative } \\
\text { Instruments }\end{array}$ \\
\hline Industry & & & $\begin{array}{l}\text { Ministry of Industry and } \\
\text { Trade Climate Change } \\
\text { Action Plan, Ministry } \\
\text { of Industry and Trade } \\
\text { Decision No. 4103/ } \\
\text { QD-BCT, } 2010\end{array}$ \\
\hline $\begin{array}{l}\text { Disaster risk } \\
\text { reduction }\end{array}$ & $\begin{array}{l}\text { National Strategy for Natural } \\
\text { Disaster Prevention, } \\
\text { Response and Mitigation, } \\
\text { PM Decision No. } \\
\text { 172/2007/QD-TTg, } 2007 \\
\text { Scheme for Improving } \\
\text { Community Awareness } \\
\text { and Community-Based } \\
\text { Management of Natural } \\
\text { Disaster Risks, PM } \\
\text { Decision No. 1002/ } \\
\text { QD-TTG, } 2009\end{array}$ & $\begin{array}{l}\text { Law on Natural } \\
\text { Disaster } \\
\text { Prevention } \\
\text { and Control, } \\
\text { No. 33/2013/ } \\
\text { QH13, 2013 }\end{array}$ & \\
\hline Other & $\begin{array}{l}\text { National Environmental } \\
\text { Protection Strategy } \\
\text { Implementation Plan } \\
\text { to 2020, with Vision to } \\
\text { 2030, PM Decision No. } \\
\text { 166/QD-TTg, } 2014\end{array}$ & $\begin{array}{l}\text { Code of Civil } \\
\text { Procedure, } \\
\text { No. 92/2015/ } \\
\text { QH13, 2015 }\end{array}$ & \\
\hline
\end{tabular}

LULUCF = land use, land-use change, and forestry; MARD = Ministry of Agriculture and Rural Development; MONRE = Ministry of Natural Resources and Environment; MOTC = Ministry of Transport and Communications; NDC = nationally determined contribution; $\mathrm{PM}=$ Prime Minister; REDD+ = reducing emissions from deforestation and forest degradation, conservation of existing forest carbon stocks, sustainable forest management, and enhancement of forest carbon stocks.

Source: Authors.

Viet Nam uses coal domestically for the industry sector and natural gas to generate electricity (footnote 288). The government plans to phase out fossil fuel subsidies by 2020 to make renewable energy sources more competitive. This and other measures will help shift Viet Nam away from its dependence on fossil fuels.

\section{Sector-Wide Energy Strategies}

Viet Nam's National Energy Development Strategy (Energy Strategy) was launched in 2007 to guide energy policy up to 2020 and set an outlook to 2050. ${ }^{289}$ The Energy Strategy articulates a set of qualitative goals, including (i) ensuring national energy security, (ii) supplying adequate high-quality energy in a way that promotes socioeconomic development and supports environmental

289 Government of Viet Nam. 2007. Prime Minister's Decision No. 1855/QD-TTg Approving Vietnam's National Energy Development Strategy up to 2020. Ha Noi. 
protection, (iii) using national energy resources efficiently, and (iv) developing a strong energy market conducive to fair competition. It states that Viet Nam has not adequately assessed its renewable energy potential and mandates further research on renewable energy development and deployment.

\section{Renewable Energy Policies}

Many of Viet Nam's key strategy documents set a goal of increasing renewable energy deployment (footnote 288). The National Green Growth Strategy of 2012, for example, focuses partly on increasing new and renewable energy sources (footnote 276). The 2014 Law on Environmental Protection promotes clean and renewable energy in response to climate change (footnote 287). The Energy Strategy translates these goals into quantitative targets, aiming to increase the proportion of new and renewable energies to approximately $3 \%$ of total commercial primary energy by $2010,5 \%$ by 2020 , and $11 \%$ by 2050.290

The Prime Minister has also approved some renewable energy policies. Prime Minister's Decision No. 11/2017/QD-TTg created regulations to support the development of solar power projects in Viet Nam. ${ }^{291}$ The regulations articulate the requirements for investments in solar power, the connection of solar power projects to existing power grids, the purchase of solar power, and feed-in tariffs. Circular No. 16 for the Implementation of the Prime Minister's Decision also establishes guidelines on national and provincial solar power development and deployment. ${ }^{292}$

Made in 2011, the Decision of the Prime Minister on the Mechanism Supporting the Development of Wind Power Project in Vietnam seeks to increase the use of wind power in the country by establishing a mechanism that includes incentives such as preferential taxing practices for wind power developments and a mandate to buy electricity from wind power projects. ${ }^{293}$ The decision also stipulates that wind power development will be integrated into national and provincial electricity development planning. In September 2018, the government raised the level of feed-in tariffs for wind energy projects. ${ }^{294}$

Finally, the Decision Approving the Scheme on Development of Biofuels up to 2015, with a Vision to 2025 was launched to promote the development and use of biofuels as a renewable energy source. ${ }^{295}$ This decision sets a quantitative

290 Footnote 289, art. 2(b).

291 Government of Viet Nam. 2017. Prime Minister's Decision No. 11/2017/QD-TTg Regulating the Mechanisms for the Development of Solar Power in Viet Nam. Ha Noi.

292 Government of Viet Nam. 2017. Ministry of Industry and Trade Circular No. 16/2017/TT-BCT Regulating Solar Power Project Development and Standardized Power Purchase Agreement for Solar Power Projects. Ha Noi.

293 Government of Viet Nam. 2011. Prime Minister's Decision No. 37/2011/QD-TTg on the Mechanism Supporting the Development of Wind Power Project in Vietnam. Ha Noi.

294 Government of Viet Nam. 2018. Prime Minister's Decision No. 39/2018/QD-TTg Amending Decision No. 37/2011/QD-TTg on Support Mechanism to Develop Wind Power Projects in Vietnam. Ha Noi.

295 Government of Viet Nam. 2007. Prime Minister's Decision No. 177/2007/QD-TTg approving the Scheme on Development of Biofuels up to 2015, With a Vision to 2025. Ha Noi. 
target of increasing the output of ethanol and vegetable oil to 250,000 tons to satisfy $1 \%$ of the nation's gasoline and oil demand by 2015 . By 2025 , ethanol and vegetable output will ideally satisfy $5 \%$ of gasoline and oil demand. The scheme includes financial incentives like tax benefits and concessional loans to create a favorable environment for biofuel investment.

\section{Energy Demand}

Viet Nam's energy demand is expected to grow. As living standards and incomes increase, so will total primary energy consumption per capita. The nation's primary energy per capita increased from 0.27 tons of oil equivalent (toe) per person in 1990 to 0.76 toe per person in 2015 and is expected continue increasing to 2.06 toe per person by $2040 .{ }^{296}$ Given this context, Viet Nam has designed laws and policies to promote energy efficiency and conservation.

In 2006, the Prime Minister approved the National Strategic Program on Energy Saving and Effective Use (Energy Target Program). ${ }^{297}$ The Energy Target Program covers a series of initiatives that promote energy efficiency and conservation, including augmenting state administration of energy efficiency and conservation; raising awareness; developing energy-efficient products; and promoting energy efficiency and conservation in the industry, building, and transport sectors.

The Energy Target Program also strives to implement a 3\%-5\% reduction in the nation's total energy consumption during $2006-2010$ and a 5\%-8\% reduction during 2011-2015 compared with energy use projections. Other major targets include establishing an energy efficiency and conservation model for business enterprises and requiring energy efficiency and conservation standards for $100 \%$ of buildings constructed after 2006.

The National Assembly passed the Law on Economical and Efficient Use of Energy in 2010, which aims to promote economical and efficient use of energy, development of education and consultancy services in the energy sector, and scientific and technological development related to energy efficiency and conservation. ${ }^{298}$ The law is economy-wide and specifically targets the industry, transport, agriculture, and service sectors. It also sets state responsibilities for, and calls for the development of a national target program on, economic and efficient use of energy.

To better reflect the changes resulting from the energy efficiency law, the government updated the 2006 Energy Target Program. In 2012, the Prime Minister approved the National Targeted Program on Energy Efficiency and Conservation Phase 2012-2015, which affirms the energy goal of reducing total energy

296 Footnote 288, p. 324.

297 Government of Viet Nam. 2006. Prime Minister's Decision No. 79/2006/QD-TTg approving the National Strategic Program on Energy Saving and Effective Use. Ha Noi.

298 Government of Viet Nam. 2010. Law No. 50/2010/QH12 on Economical and Efficient Use of Energy. 17 June. Ha Noi. 
consumption by $5 \%-8 \%$ by $2015 .{ }^{299}$ The updated program also implements mandatory energy efficiency management practices and sets a target of increasing public transport use to 10\%-15\% of travel demand in urban areas by 2015 (footnote 299). The total capital required for the program is dong (D) 930 billion (about $\$ 40$ million in late 2020 ).

According to the Energy Target Program, nuclear electricity will account for approximately $15 \%-20 \%$ of total commercial energy consumption by 2050 (footnote 297).

\section{E. LULUCF and REDD+}

Viet Nam treated forest management and climate change as overlapping issues as early as 2006. The Prime Minister's Decision on the Regulation of Forest Management in 2006 clarifies that the government will protect forests to regulate climate. ${ }^{300}$

In 2012, the Prime Minister approved a national action program for REDD+ for 2011-2020. ${ }^{301}$ The program focuses on managing forest resources sustainably and reducing GHG emissions from deforestation and forest degradation. It also seeks to improve the nation's capacity to sequester carbon by conserving forests and preserving biodiversity. The program identifies two actions critical to its successful implementation: (i) improving the legal framework, and (ii) building the technical and human resource capacity of institutions.

In 2017, the government approved the national REDD+ program of action through to $2030 .{ }^{302}$ Deforestation and forest degradation are combatted by conserving and enhancing natural forests, expanding forest areas, and improving plantation forests. Forest protection also aligns closely with Viet Nam's goals to reduce GHG emissions, promote green growth and sustainable development, mobilize international support, and enter the carbon market.

\section{F. Transportation}

Sea level rise poses a significant threat to the transport network. The government reports that 11,000 kilometers $(\mathrm{km})$ of roads could be submerged by 1 meter $(\mathrm{m})$ of sea level rise (footnote 284). However, GHG emissions from the transport

299 Government of Viet Nam. 2012. Prime Minister's Decision No. 1427/QD-TTg approving the National Targeted Program on Energy Efficiency and Conservation Phase 2012-2015. Ha Noi.

300 Government of Viet Nam. 2006. Prime Minister's Decision No. 186/2006/QD-TTg promulgating Forest Management Regulations. Chapter III, sec. 1, art. 25(4)(a).

301 Government of Viet Nam. 2012. Prime Minister's Decision No. 799/QD-TTg approving the National Action Program on Reduction of Green-House Gas Emissions through REDD+ in 2011-2020. Ha Noi. REDD+ means reducing emissions from deforestation and forest degradation, conservation of existing forest carbon stocks, sustainable forest management, and enhancement of forest carbon stocks.

302 Government of Viet Nam. 2017. Prime Minister's Decision No. 419/QD-TTg approving the National REDD+ Programme up to 2030. Ha Noi. 
sector are expected to triple during 2010-2030 (footnote 284). To build resilience in and reduce emissions from the transport sector, the Ministry of Transport launched the Action Plan on Climate Change to cover 2011-2015. ${ }^{303}$

In 2016, the Action Plan on Climate Change was updated to integrate green growth by the Decision of the Minister of Transportation and Communications Promulgating Action Plan on Climate Change and Green Growth of the Ministry of Transportation and Transport in the 2016-2020 Period. ${ }^{304}$ The updated action plan sets out to make Viet Nam's transportation uniformly sustainable and environmentally friendly and to mitigate GHG emissions from transportation. To achieve these goals, the Ministry of Transport, under this updated action plan, will

(i) develop the transport infrastructure system to build climate change resilience and reduce environmental pollution,

(ii) manage low-emission transport operations using energy saving and efficiency,

(iii) promote the application of environmentally friendly technologies and encourage the use of renewable energy sources,

(iv) perform synchronization solutions for emission control traffic,

(v) raise awareness for organizations and individuals of climate change and green growth in transportation, and

(vi) increase international cooperation and diversification of resources to implement activities in response to climate change and green growth in transport.

Transportation targets are also integrated into other climate strategy documents. For example, the 2012 Green Growth Strategy aims to increase the share of public transportation in large and medium cities to 35\%-45\% by 2020 (footnote 276).

\section{G. Adaptation}

While Viet Nam has not developed a national adaptation strategy, adaptation commitments are expressed in other climate documents. For example, the National Action Plan on Climate Change for 2012-2020 identifies specific programs, some of which are adaptation specific (footnote 282). Relevant actions include (i) identifying areas vulnerable to flash flooding, (ii) researching impacts to plants and animals, (iii) creating mechanisms to strengthen agricultural insurance, (iv) conserving coastal mangrove forests, (v) managing water resources, and ( $\mathrm{vi}$ ) reviewing construction regulations and construction techniques in disaster-prone areas. ${ }^{305}$

303 Government of Viet Nam, Ministry of Transport and Communication. 2011. Decision No. 199/ QD-BGTVT, Ministry of Transport and Communications Climate Change Action Plan For 2011-2015. Ha Noi.

304 Government of Viet Nam, Ministry of Transport and Communication. 2016. Decision No. 1456/ QD-BGTVT, Ministry of Transport and Communications Climate Change and Green Growth Action Plan for 2016-2020. Ha Noi.

305 Footnote 282, Part II, Specific Programs, Schemes and Projects. 
Government Resolution No. 24-NQ/TW of 2013 details specific climate responses for adaptation to the year $2020 .{ }^{306}$ It identifies the need to address inundation, flooding, and saline intrusion due to sea level rise, particularly in coastal cities and the Mekong Delta, Red River Delta, and Central Coast. The plan aims to build national capacity for early warning systems and educating the community about climate change risks.

In 2017 the Prime Minister approved the Climate Change and Green Growth Strategy for 2016-2020, which aims to strengthen Viet Nam's adaptation to the consequences of climate change (footnote 275). Similarly, Prime Minister's Decision No. 2053/QD-TTg, outlining the government's Paris Agreement implementation plan, makes adaptation an essential component of Viet Nam's responses to climate change (footnote 274). The National Target Program to Respond to Climate Change in 2012-2015 also aims to enhance adaptive capacity in Viet Nam (footnote 279).

\section{H. Disaster Risk Management}

Over $70 \%$ of Viet Nam's citizens are at risk from natural hazards. ${ }^{307}$ Since 1998, extreme weather events have killed more than 13,000 people and cost the economy more than $\$ 6.4$ billion.

Viet Nam's national strategy for disaster risk reduction runs to $2020 .{ }^{308} \mathrm{~A}$ solution-oriented document, the strategy articulates the need to consolidate the system of laws on disaster risk management and strengthen organizational structures. It identifies programs to enhance disaster risk management and plans for the modernization of early warning systems and improved search and rescue capacities.

In 2009, the Prime Minister approved the National Scheme for Improving Community Awareness and Community-Based Management of Natural Disaster Risks. ${ }^{309}$ The scheme aims to (i) develop central and local mechanisms and policies for community-based management of natural disaster risks, (ii) improve the government's capacity to manage disaster risks and responses, and (iii) implement disaster prevention plans for high-risk communities.

The 2013 Law on Natural Disaster Prevention and Control clarifies institutional responsibilities for disaster prevention and management and establishes

306 Government of Viet Nam. 2013. Resolution No. 24-NQ/TW, Active Responses to Climate Change and Improvement of Natural Resource Management and Environmental Protection. Ha Noi.

307 Global Facility for Disaster Reduction and Recovery. 2018. Mainstreaming Disaster Resilience in Viet Nam: Engaging with Communities to Build Resilience.

308 Government of Viet Nam. 2007. Prime Minister's Decision No. 172/2007/QD-TTg, approving the National Strategy for Natural Disaster Prevention, Response and Mitigation. Ha Noi.

309 Government of Viet Nam. 2009. Prime Minister's Decision No. 1002/QD-TTG, the Scheme for Improving Community Awareness and Community-Based Management of Natural Disaster Risks. Ha Noi. 
guidelines for disaster risk reduction and responses. ${ }^{310}$ It mandates the Ministry of Agriculture and Rural Development to prepare 10-yearly national strategies on natural disaster prevention in consultation with other ministries and provincial officials. Local natural disaster prevention and control plans supplement the national plan. The law, recognizing the importance of community-based approaches to disaster risk management, creates natural disaster prevention and control funds for provincial governments. ${ }^{311}$ Disaster planning should also be integrated into national and local socioeconomic and sector development plans.

The minister of education also established a project to improve national awareness about climate education and disaster risk prevention during 2013-2020.312 The project sets targets for awareness raising. For example, by 2020, $95 \%$ of educators should have enhanced awareness of and capacity to teach about climate change responses and natural disaster prevention and control.

\section{Vulnerable Groups}

Viet Nam is one of the few countries in Asia and the Pacific to adopt a climate change policy with gender-specific considerations. The Climate Change Action Plan 2011-2015 for the Ministry of Labour, Invalids and Social Affairs addresses climate change impacts on vulnerable groups, including women. ${ }^{313}$ The plan seeks to assess the risks that these groups face and create impact forecasting models. These impact forecasts should then be integrated into disaster preparedness plans.

310 Government of Viet Nam. 2013. Law No. 33/2013/QH13 on Natural Disaster Prevention and Control. Ha Noi.

311 Decree No. 94/2014/ND-CP establishes the fund. See Government of Viet Nam. 2014. Decree No. 94/2014/ND-CP Establishing the Natural Disaster Prevention and Control Fund. Ha Noi.

312 Government of Viet Nam, Ministry of Education and Training. 2014. Ministry of Training and Education Decision No. 329/QD-BGDDT approving the Information and Communication Project for Raising Awareness about Climate Change and Disaster Risk Reduction for 2013-2020. Ha Noi.

313 Government of Viet Nam, Ministry of Labour, Invalids and Social Affairs. 2011. Ministry of Labour, Invalids and Social Affairs Decision No. 403/QD-LDTBXH, Climate Change Action Plan 2011-2015. Ha Noi. 


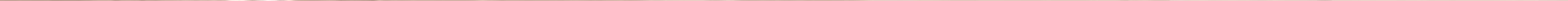




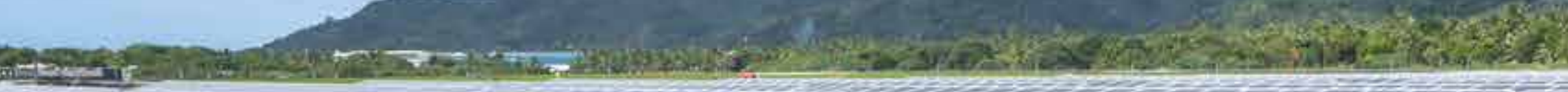

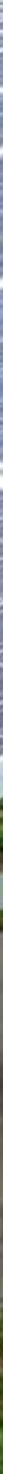

6.

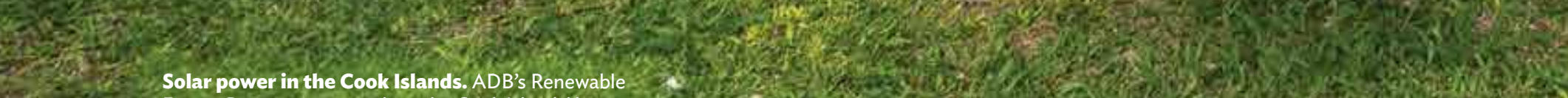
Solar power in the Cook Islands. ADB's Renewable. 20 .

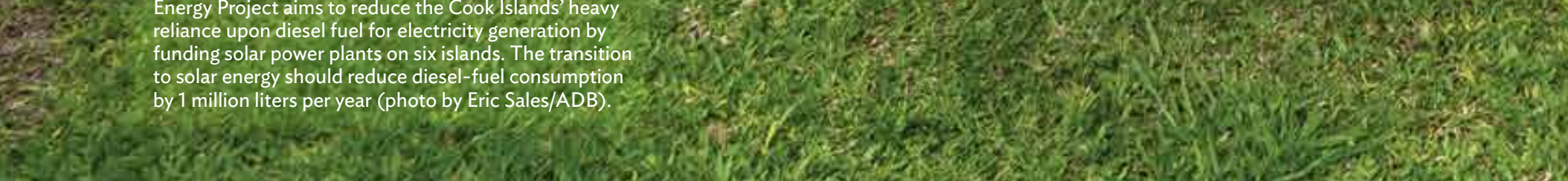

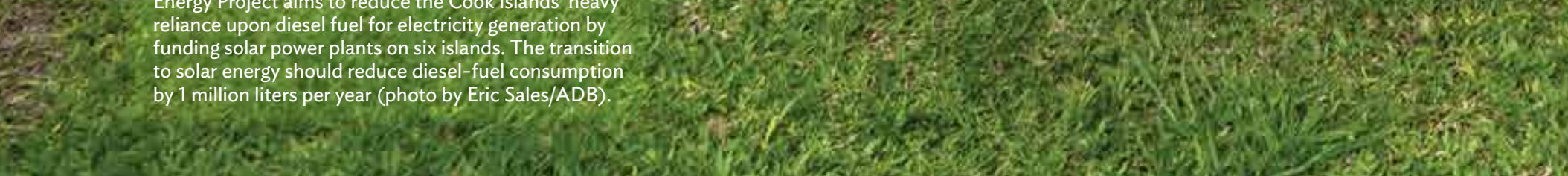

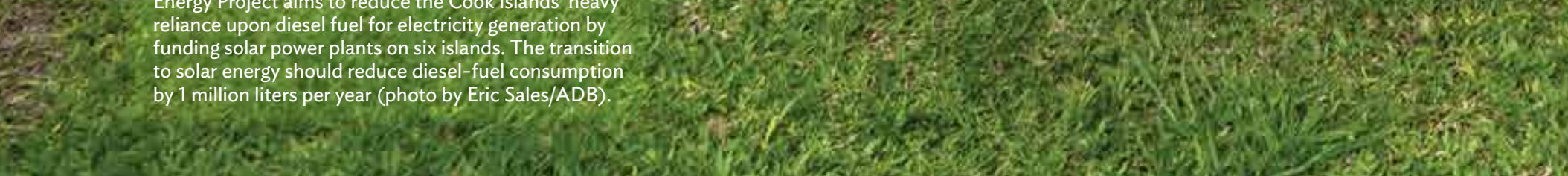

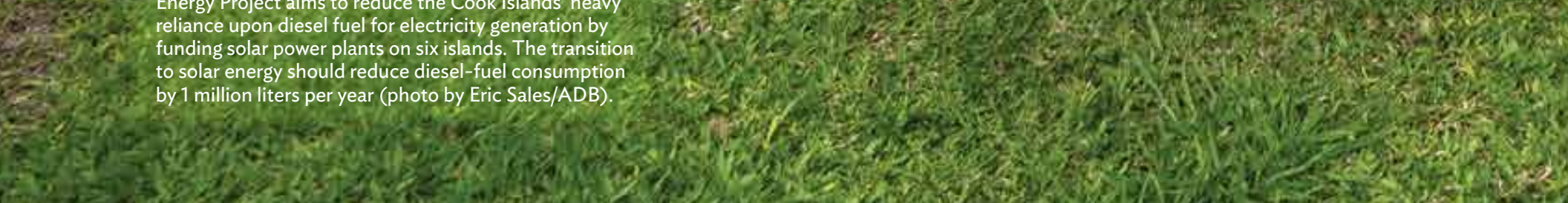

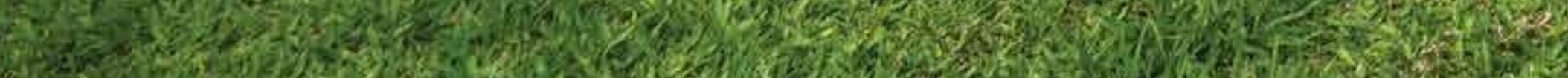




\section{B. Overarching Climate Change Legal and Policy Framework}

\section{Mitigation and Adaptation Targets}

The Government of the Cook Islands submitted its first nationally determined contribution (NDC) on 1 September 2016, committing to transition half of its islands from diesel-based electricity to renewable sources by 2015 , and the other half by 2020. "The Cook Islands has achieved its $50 \%$ target and is on track to achieving the 2020 target. Using 2006 as the base year, emissions from electricity generation will be reduced by $38 \%$ by $2020 . "{ }^{8}$

The Cook Islands also aims to construct additional grid storage, improve energy efficiency, integrate new technologies, promote transfer technology, and strengthen capacities for overall sustainability benefits that are economically and environmentally advantageous (footnote 8 ). This would result in an additional $43 \%$ reduction of emissions from electricity generation, totaling an $81 \%$ emissions reduction by 2030 , compared with the 2006 baseline (footnote 8 ). External support will be needed to achieve the additional $43 \%$ reduction (footnote 8 ). The Cook Islands also intends to embrace low-carbon transportation technologies and various adaptation actions that are conditional on external support.

\section{Overview of Climate Change Law and Policy}

The Cook Islands has embedded climate resilience in Te Kaveinga Nui: National Sustainable Development Plan 2016-2020. ${ }^{9}$ The plan contains a range of sustainable development goals, including Goal 13-to "strengthen resilience to combat the impacts of climate change and natural disasters." 10 This goal includes three areas of focus: (i) promote resilient communities, (ii) enhance protection from cyclones, and (iii) build resilient infrastructure. ${ }^{11}$ Prior to the plan, the Cook Islands issued Kaveinga Tapapa: Climate \& Disaster Compatible Development Policy 2013-2016. ${ }^{12}$

The Cook Islands Second Joint National Action Plan for Climate Change and Disaster Risk Management (JNAP II) lays out a five-year implementation plan for Goal 13 of the National Sustainable Development Plan. ${ }^{13}$ This document records all current and planned activities related to (i) climate change and disaster risk management, and (ii) strengthening the nation's resilience.

Footnote 1, p. 2

9 Government of the Cook Islands, Office of the Prime Minister. 2016. Te Kaveinga Nui: National Sustainable Development Plan 2016-2020. Avarua.

10 Footnote 9, p. 44.

11 Footnote 9, p. 45.

12 Government of the Cook Islands, Office of the Prime Minister. 2013. Kaveinga Tapapa: Climate \& Disaster Compatible Development Policy 2013-2016. Avarua.

13 Government of the Cook Islands. 2016. JNAP II - Are We Resilient? The Cook Islands 2nd Joint National Action Plan: A Sectoral Approach to Climate Change and Disaster Risk Management 2016-2020. Avarua. 
JNAP II seeks to promote a sectoral, collaborative approach that addresses the cross-cutting nature of climate change and disaster risk management. It is organized around nine strategies: (i) good governance; (ii) water and food security; (iii) environmental sustainability; (iv) research, monitoring, and information management; ( $v$ ) Cook Islands' culture and identity; (vi) energy and transport; (vii) infrastructure; (viii) climate and disaster risk; and (ix) health and welfare. ${ }^{14}$

The Cook Islands Environment Act 2003 guides sustainable development. In addition, the renewable energy policy-Te Atamoa o te Uira Natura: Renewable Energy Chart, issued in 2012 and updated in 2016-sets out the nation's plans to develop renewable energy and reduce reliance on fossil fuels. ${ }^{15}$ The chart is accompanied by island-specific implementation plans.

The Environment Act 2003 established the National Environment Service, whose tasks include monitoring the implementation of international instruments signed by the Cook Islands and related to climate change, such as the United Nations Framework Convention on Climate Change (UNFCCC). ${ }^{16}$ The act also provides environmental impact assessments, which can help guide sustainable development and preparations to protect the environment from changing weather conditions and emerging new hazards. ${ }^{17}$

Table 6.1 summarizes the Cook Islands' climate change legal and policy framework.

\section{Energy Supply}

As of 2007, the total primary energy supply (TPES) of the Cook Islands was 21.34 kilotons of oil equivalent (ktoe), with $90 \%$ of the gross energy coming from fossil fuels. ${ }^{18}$ The remaining $10 \%$ came from biomass used primarily for cooking (footnote 18). Historically, the Cook Islands has relied almost entirely on imported fossil fuels, which accounted for over $99 \%$ of the country's energy consumption (footnote 18). All petroleum fuel for land transport, aviation, and electricity continue to be imported (footnote 18).

Since setting a target for 50\% renewable energy by 2015 and 100\% renewable energy by 2020, the Cook Islands has increased its renewable energy supply considerably (footnote 1). As of 2018, the Cook Islands had added 4.2 megawatts (MW) of solar photovoltaic and new high-speed biodiesel engines to the previous 11.75 MW diesel system. ${ }^{19}$ The Northern Group Islands are now powered by

14 Footnote 13, p. 9.

15 Government of the Cook Islands. 2012. Te Atamoa o te Uira Natura no te Pa-Enua Takitai E Tumutevarovaro: Cook Islands Renewable Energy Chart Implementation Plan: Island Specific. Avarua.

16 Environment Act 2003, secs. 5 and 9(m).

17 Footnote 16, sec. 36.

18 Renewable Energy and Energy Efficiency Partnership (REEEP). 2013. Cook Islands (2012). 11 October.

19 ADB. 2018. Pacific Energy Update 2018. Manila. p. 8. 


\section{Table 6.1: Climate Change Legal and Policy Framework of the Cook Islands}

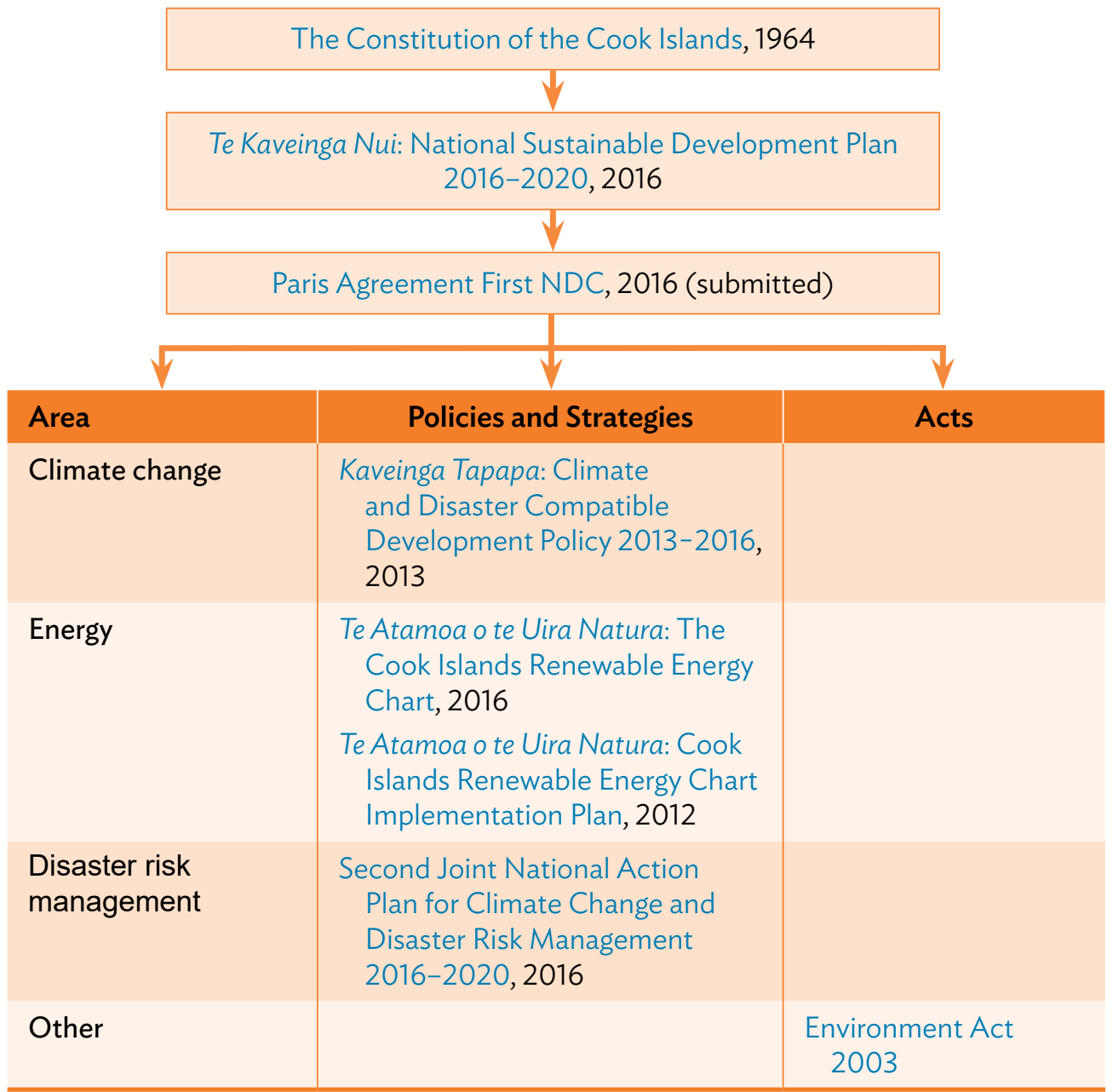

NDC = nationally determined contribution.

Source: Authors.

renewable sources (solar photovoltaic). ${ }^{20}$ As of early 2016, efforts were underway to transition the Southern Group Islands to renewable generation (footnote 20).

The state-owned utility, Te Aponga Uira, provides the power supply for the island of Rarotonga, which constitutes $90 \%$ of the total country demand. ${ }^{21}$ All inhabited islands of the Cook Islands have centralized power supplies, providing electricity "through a distribution grid to most residential[,] commercial and industrial customers." 22 As of 2012, approximately 97\% of households in the Cook Islands were connected to electricity, with $100 \%$ grid connection in Rarotonga (footnote 18).

20 Government of the Cook Islands. 2016. Updated Summary of Te Atamoa o te Uira Natura: The Cook Islands Renewable Energy Chart. Avarua. p. 5.

21 Government of the Cook Islands, Office of the Prime Minister. 2012. Te Atamoa o te Uira Natura: The Cook Islands Renewable Energy Chart Implementation Plan. Avarua. p. 24.

22 Footnote 20, p. 4. 
Affordability has been identified as a concern in increasing the electricity generation to $100 \%$ renewable, but the government intends to address the issue. ${ }^{23}$

\section{Renewable Energy Policy}

The Te Atamoa o te Uira Natura: Renewable Energy Chart is accompanied by implementation plans specific to each island, including costs, technology, time lines, and processes. The 2016 update discusses progress on reaching $100 \%$ renewable energy by 2020 and charts further steps to obtain this goal. It affirms, "The renewable energy policy goal is focused on measuring progress on the accessibility, use and composition of energy and transport." ${ }^{24}$ Energy and transport accessibility, use, and composition are also considered throughout the report, as progress of other Pacific islands toward developing renewable energy and reducing fossil fuel dependence is also discussed.

\section{Energy Demand}

Rarotonga's electricity consumption is about 2,200 kilowatt-hours ( $\mathrm{kWh}$ ) per person; consumption is less on the other islands (footnote 22). The cost of electricity relative to income influences electricity demand (footnote 22). Residents of the outer islands, for example, have lower incomes, resulting in lower per-capita consumption (footnote 22). However, central government subsidies to outer islands have rendered electricity prices comparable across the islands (footnote 22). Currently electricity generation capacity on all islands far exceeds demand (footnote 22).

\section{E. Adaptation}

The Climate \& Disaster Compatible Development Policy 2013-2016 is the leading policy document for both climate change and disaster risk management (footnote 12). In line with this policy, JNAP II identifies various strategies for promoting climate change adaptation, such as (i) strengthening livelihoods and capacity for climate adaptation in agriculture and fisheries, (ii) promoting sustainable land use practices, and (iii) safeguarding the country's sovereignty from climate change impacts (footnote 13).

\section{F. Disaster Risk Management}

JNAP II seeks to increase resilience against natural disasters and ensure sustainable livelihoods (footnote 13). Importantly, it articulates the various responsibilities and roles of government institutions with respect to disaster risk management.

\footnotetext{
Footnote 20, p. 10
}

24 Footnote 20, p. 2. 


\section{Federated States of Micronesia}

\section{A. Country Snapshot: Climate and Environmental Challenges}

A federal republic in free association with the United States, the Federated States of Micronesia (FSM) spans more than 600 islands and islets in the Caroline Islands archipelago in the Pacific Ocean. ${ }^{25}$ Some of the islands are volcanic and support a large variety of plant forms, while others are low-lying coral atolls with poorer soil. ${ }^{26}$ The FSM has four states: Yap, Kosrae, Pohnpei, and Chuuk. The main economic activities are fishing and subsistence farming. ${ }^{27}$ Settlements are predominantly located along the coast. ${ }^{28}$

The FSM is vulnerable to droughts, typhoons, storm waves, flooding, and landslides..$^{29} \mathrm{El}$ Niño events, which are associated with a climate cycle in the Pacific Ocean affecting global weather patterns, can result in drier conditions and consequently fires. ${ }^{30}$ Water and food shortages have happened during extremely dry events (footnote 29). The FSM is at risk from an above-average number of tropical storms during La Niña events, which are associated with cooler than usual ocean surface temperatures in the Pacific Ocean (footnote 29).

The FSM has been experiencing sea level rise at a rate faster than the global average-by over 10 millimeters ( $\mathrm{mm}$ ) per year since 1993 compared with the global average of 2.8-3.6 mm. ${ }^{31}$ Data show a decreasing trend in annual and wet season rainfall since 1950, as well as rising average temperatures and ocean acidification (footnote 31). The FSM also expects higher temperatures, more hot days, changing rainfall patterns, more extreme rainfall days, continued sea level rise, ocean acidification, and less frequent but more intense typhoons. ${ }^{32}$

\section{B. Overarching Climate Change Legal and Policy Framework}

\section{Mitigation and Adaptation Targets}

The Government of the FSM submitted its first nationally determined contribution (NDC) on 15 September $2016 .{ }^{33}$ It pledged to unconditionally reduce its greenhouse

25 BBC. 2018. Micronesia Country Profile. 9 January.

26 D. Lorence. Flora of Micronesia. Smithsonian Institution.

27 Government of the FSM, Department of Resources and Development. 2012. Federated States of Micronesia Agriculture Policy, 2012-2016. Palikir. pp. 11, 43-44.

28 C. Fletcher and B. Richmond. 2010. Climate Change in the Federated States of Micronesia: Food and Water Security, Climate Risk Management, and Adaptive Strategies. Report of Findings 2010. p. 4.

29 Pacific Climate Change Science Program partners. 2011. Current and Future Climate of the Federated States of Micronesia. Palikir. p. 3.

30 Footnote 29, pp. 2-3.

31 Footnote 29, p. 4.

32 Footnote 29, pp. 6-7.

33 Government of the FSM. 2016. First Nationally Determined Contribution. Palikir. 
gas emissions by $28 \%$ from 2000 levels by $2025 .{ }^{34}$ It also set a conditional commitment to increase that reduction to $35 \%$, subject to the availability of financial, technical, and capacity building support from the international community.

In 2000, the FSM's total GHG emissions were only around $0.0004 \%$ of total global GHG emissions. ${ }^{35}$ Electricity generation accounted for $42 \%$ of those emissions. ${ }^{36}$ The FSM plans to achieve its emissions reductions in the energy sector (electricity generation and transport), but has not provided details. It notes its efforts to assess adaptation needs, but its NDC does not discuss adaptation in detail.

\section{Overview of Climate Change Laws and Policy}

The FSM combines sustainable development with climate change plans. For example, its Strategic Development Plan 2004-2023 aims for a 50\% reduction in imported petroleum fuels by 2020 by improving energy efficiency, eliminating energy subsidies, and expanding public transportation. ${ }^{37}$ It also plans to generate $10 \%$ of electricity in urban centers from renewable sources and $50 \%$ in rural areas by 2020 (footnote 37). In 2004, it had aimed to apply the United States (US) standards for energy efficiency to all new public buildings and $50 \%$ of private buildings by 2006 (footnote 37 ). However, there is no publicly available data on whether it was able to meet this target.

In 2013, the Nation Wide Integrated Disaster Risk Management and Climate Change Policy (Climate Change Policy) set out guiding principles to minimize the risk of anthropogenic climate change. ${ }^{38}$ The principles promote sustainable development to bolster the FSM's ability to respond to natural and humaninduced disasters. The policy includes a multi-hazard risk management approach that integrates disaster risk management, climate change adaptation, and GHG emissions reduction. ${ }^{39}$ It also sets climate change adaptation as a strategic objective of the plan. ${ }^{40}$

To implement the Climate Change Policy, Congress passed the Climate Change Act in late 2013. The law set an October 2014 deadline for government agencies to prepare plans and policies consistent with the Climate Change Policy. ${ }^{41}$ It requires the President to issue progress reports to Congress on the

34 Footnote 33, p. 1.

35 In 2000, the FSM's total GHG emissions were 150,000 metric tons of carbon dioxide $\left(\mathrm{tCO}_{2}\right)$ equivalent, while global emissions exceeded 40.6 billion $\mathrm{tCO}_{2}$ equivalent. See footnote 33 and World Bank. Total Greenhouse Gas Emissions (kt of $\mathrm{CO}_{2}$ Equivalent) (accessed 25 March 2020).

36 Footnote 33, p. 2

37 Government of the FSM. 2004. Strategic Development Plan (2004-2023). Palikir. p. 300.

38 Government of the FSM. 2013. Nation Wide Integrated Disaster Risk Management and Climate Change Policy. Palikir. pp. 1-2.

39 Footnote 38, p. 1.

40 Footnote 38, p. 3.

41 Federated States of Micronesia Climate Change Act, sec. 4. 
implementation of the policy and authorizes the President to include in the annual national budget request one or more lines on said implementation. ${ }^{42}$

Table 6.2 summarizes the FSM's climate change legal and policy framework.

\section{Table 6.2: Climate Change Legal and Policy Framework of the Federated States of Micronesia}

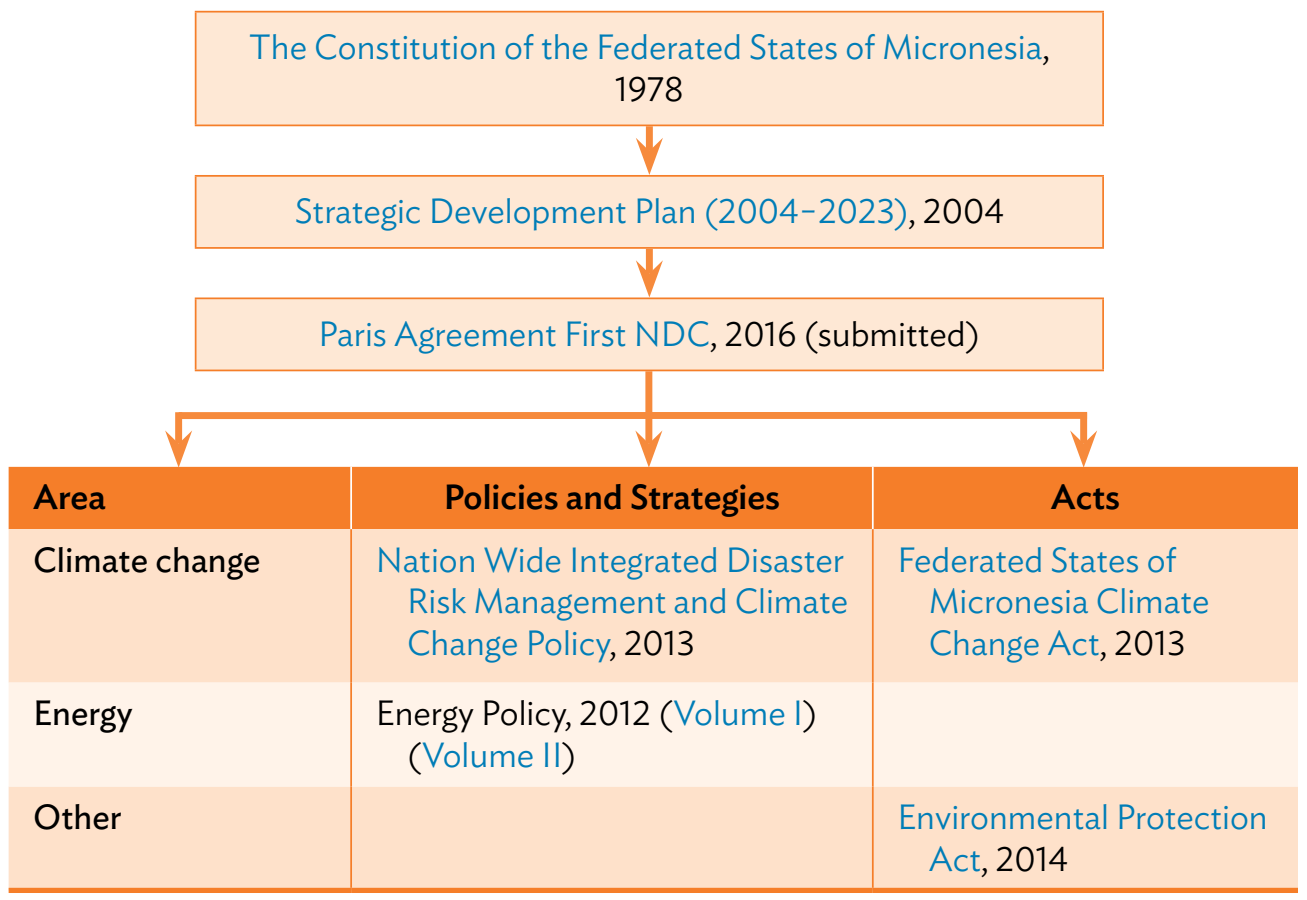

NDC = nationally determined contribution.

Source: Authors.

\section{Energy Supply}

Petroleum is the primary energy source for transportation and electricity generation in the $\mathrm{FSM}^{43}$ In 2009, $95.7 \%$ of energy generation was met by petroleum and only $4.3 \%$ by renewables (small hydro and solar) (footnote 43 ). Electricity rates for residential customers are expensive, exceeding $\$ 0.48$ per kilowatt-hour (kWh). ${ }^{44}$ In 2011, the total installed generation capacity was 6.6 megawatts (MW) in Yap, 4.6 MW in Kosrae, 13.4 MW in Pohnpei, and 5.2 MW in Chuuk (footnote 43).

42 Footnote 41, sec. 5.

43 National Renewable Energy Laboratory. 2015. Energy Transition Initiative: Islands. Energy Snapshot: Federated States of Micronesia. p. 2.

44 Footnote 43, p. 1. 
The national electrification rate in 2018 was around 76\%, with access rates varying sharply across the country. ${ }^{45}$ For example, while electrification rates in Kosrae and Pohnpei were $95 \%$, only $27 \%$ of Chuuk's residents had access to electricity (footnote 45). The FSM's 2018 National Energy Master Plan set to achieve 100\% electrification in Kosrae by 2019, Chuuk by 2023, and Pohnpei and Yap by $2025 .{ }^{46}$

Households without electricity rely on (i) kerosene lamps or solar panels for lighting; and (ii) firewood, kerosene, and biogas for cooking. ${ }^{47}$ In Pohnpei, 400 solar home systems were installed in the $1990 \mathrm{~s} .{ }^{48}$ According to the 2000 census, 300 more were installed on outer islands in Yap and another 402 in Chuuk (footnote 48). The FSM energy master plans anticipate that diesel will remain critical for electricity production, especially to support the introduction of renewable energy sources. ${ }^{49}$

\section{Renewable Energy Policies}

The 2012 Energy Policy seeks to help the FSM become less dependent on imported sources of energy by increasing its share of renewable energy sources. ${ }^{50}$ It aims to have at least $30 \%$ of the FSM's energy production come from renewable sources by 2020 by (i) promoting renewable energy technologies, (ii) effectively managing renewable-based power systems, (iii) fostering partnerships between the private and public sectors, (iv) promoting the availability of renewable energy in remote areas, ( $v$ ) encouraging the creation of markets for clean technologies, and (vi) establishing opportunities for better access to renewable energy. ${ }^{51}$

The FSM's National Energy Master Plan has set more ambitious renewable energy targets: to generate $44 \%$ of electricity from renewable energy by $2020,63 \%$ by 2027 , and $84 \%$ by 2037.52 With reduced diesel use and higher renewable energy generation rates, the FSM intends to reduce electricity emissions to 15,769 metric tons of carbon dioxide $\left(\mathrm{tCO}_{2}\right)$ equivalent by $2037 . .^{53}$

\section{Energy Demand}

Increased rural electrification will increase energy demand, making energy efficiency and conservation critical. The Energy Policy seeks to increase

45 World Bank. 2018. Greener, More Reliable Energy for Micronesia. Press release. 7 December.

46 Castalia Limited. 2018. Energy Master Plans for the Federated States of Micronesia: Final Report to the Department of Resources and Development. Washington, DC. p. 17.

47 Footnote 46, pp. 26, 31, 35, 45, and 57.

48 Renewable Energy and Energy Efficiency Partnership (REEEP). 2013. Federated States of Micronesia (2012). 11 October.

49 Footnote 46, Appendices, p. 33.

50 Government of the FSM, Department of Resources and Development. 2012. Energy Policy. Palikir.

51 Footnote 50, pp. 10 and 34.

52 Footnote 46, p. 16.

53 Footnote 46, pp. 16 and 19. 
energy efficiency by $50 \%$ by $2020 .{ }^{54}$ To achieve this, it anticipates (i) an energy conservation plan applied to government facilities, (ii) building and construction code regulations, (iii) a public awareness campaign, and (iv) a training and capacity building program.

The Energy Policy also aimed to enhance the supply-side energy efficiency of utilities by $20 \%$ by 2015 (footnote 54 ). This objective, however, was not achieved. ${ }^{55}$ As such, the National Energy Master Plan states the importance of securing additional funding and improved policies to meet its targets. ${ }^{56}$

\section{E. Adaptation}

As a nation of 600 islands, the FSM is highly vulnerable to climate change, particularly sea level rise and more frequent, intense, or long-lasting weather events created by El Niño and La Niña (footnote 29). The Climate Change Policy steers the country toward a sustainable development pathway that seeks to minimize natural and human-induced hazards - both slow- and rapid-onsetincluding those associated with climate change (footnote 38 ). As such, the Climate Change Policy sets adaptation as one of its strategic objectives.

\section{F. Disaster Risk Management}

The Climate Change Policy further develops the FSM's commitment to climateresponsive sustainable development through various principles, including the use of multi-hazard risk management. This approach integrates disaster risk management, climate change adaptation, and GHG emissions reduction. The policy also recognizes that the assessment and treatment of existing risks is the starting point for reducing and managing future risks.

\section{Fiji}

\section{A. Country Snapshot: Climate and Environmental Challenges}

The Republic of Fiji is a unitary constitutional democracy with common law jurisdiction. Its islands occupy $18,333 \mathrm{~km}^{2}$ encompassed by an exclusive economic zone of 1.3 million $\mathrm{km}^{2}{ }^{27}$ About one-third of the 332 islands are inhabited (footnote 57). The islands of Viti Levu and Vanua Levu contain about $87 \%$ of Fiji's land area (footnote 57). Fiji has a tropical climate (footnote 57). It is relatively richer in natural resources than its Polynesian and Micronesian neighbors, with vast timber resources, rich soils, mineral deposits, and fish (footnote 57).

54 Footnote 50, p. 10.

55 Footnote 46, p. 19.

56 Footnote 46, p. 20

57 Government of Fiji. 2016. First Nationally Determined Contribution. Suva. p. 2. 
Fiji is vulnerable to earthquakes, landslides, cyclones, flooding, and storm surges (footnote 57). Natural disasters have contributed to the volatility of Fijis growth-for instance, the cyclones in 1985, 1992, 1993, 2009, 2010, and 2012; and the severe flooding in the Western Division and Northern Division in January 2012 and late March 2012 (footnote 57).

Fiji contributes only $0.04 \%$ of global GHG emissions, but it is intensely vulnerable to climate change impacts (footnote 57). These impacts include eroded shorelines and riverbanks, water scarcity, depleted fisheries stock, reduced food production, increased outbreaks of vector-borne diseases, large-scale flooding, and rising sea levels (footnote 57).

Climate change threatens Fiji's marine and coastal resources as well as its economy and primary industries - fisheries, forestry, and agriculture. ${ }^{58}$ For example, on 20-21 February 2016, Tropical Cyclone Winston tore through Fiji, killing 42 people and displacing up to 350,000 people. ${ }^{59}$ Sustained winds of 300 kilometers $(\mathrm{km})$ per hour made Winston the second strongest landfalling cyclone in recorded history. ${ }^{60}$

\section{B. Overarching Climate Change Legal and Policy Framework}

\section{Mitigation and Adaptation Targets}

The Government of Fiji submitted its first nationally determined contribution (NDC) on 22 April 2016. It pledged to reduce GHG emissions from the energy sector by $30 \%$ by 2030 , compared with 2030 emissions under a business as usual (BAU) scenario. ${ }^{61}$ Fiji notes that $10 \%$ of the BAU scenario reduction will be achieved by implementing the Green Growth Framework, the country's unconditional commitment and blueprint for sustainable development. ${ }^{62}$ The remaining $20 \%$ is conditional on the availability of external funding amounting to $\$ 500$ million. ${ }^{63}$ The target is based on increasing renewable energy and energy efficiency in electricity generation. Fiji intends to achieve $20 \%$ of the reductions by increasing the renewable energy share of electricity generation to almost $100 \%$ by 2020 (from around 60\% in 2013) (footnote 61). The other 10\% is expected from energy efficiency (footnote 61).

\footnotetext{
58 Footnote 57, p. 3.

59 United Nations Office for the Coordination of Humanitarian Affairs (OCHA). 2016. Fiji: Severe Tropical Cyclone Winston. Situation Report No. 9. pp. 1, 3, and 9.

60 National Aeronautics and Space Administration (NASA) Earth Observatory. 2016. Tropical Cyclone Winston Slams Fiji.

61 Footnote 57, p. 4.

62 Footnote 57, p. 5; and Government of Fiji, Ministry of Strategic Planning, National Development and Statistics. 2014. A Green Growth Framework for Fiji: Restoring the Balance in Development That Is Sustainable for Our Future. Suva.

63 Footnote 57, p. 5.
} 
The NDC also discusses adaptation challenges and corresponding actions in the short-, medium-, and long-term. ${ }^{64}$ The challenges include the need to (i) further develop an integrated policy and approach to address climate change, (ii) ensure that buildings are cyclone-resistant, (iii) strengthen the role of local governments in building resilience, (iv) gather more information on climate impacts, (v) build partnerships at all government levels, and (vi) ensure that climate change mitigation and adaptation become part of the national and subnational development planning and budgetary process.

Most of the corresponding actions concern (i) issuing new approaches; (ii) reviewing existing laws, regulations, and policies; and (iii) undertaking assessments. ${ }^{65}$ Other actions include developing hazard maps and models for all potential hazards (including sea level rise, storm surge, flood, and tsunami) by 2020 , and building the capacity of communities for which relocation is the long-term adaptation strategy.

\section{Overview of Climate Change Laws and Policy}

Fiji was the first country to ratify the Paris Agreement. It led negotiations at the United Nations (UN) climate talks in 2017, which focused on taking steps to implement the Paris Agreement. In its National Development Plan (NDP), Fiji states its commitment to climate leadership at the local, regional, and global scales, with the plight of small island developing states central to its work. ${ }^{66}$ It seeks to mobilize public and private sector resources for adaptation and mitigation, including community-based adaptation planning (footnote 66).

In 2014, Fiji released the Green Growth Framework, intended to support the (i) [People's] Charter for Change, Peace and Progress, and (ii) Roadmap for Democracy and Sustainable Socio-Economic Development 2010-2014. ${ }^{67}$ The Green Growth Framework builds on three pillars of sustainable developmentenvironment, economic, and social-and includes climate targets. ${ }^{68}$ The framework sets targets for (i) reducing dependence on imported fossil fuel for transportation from $42 \%$ of final energy consumption (a baseline established in 2010 ) to around $32 \%$ by 2020 , and $22 \%$ by 2030 ; (ii) transitioning the tourism and manufacturing industries to $100 \%$ renewable energy by 2030 ; and (iii) generating $99 \%$ of electricity from renewable energy by 2030 (up from 61\%

64 Footnote 57, p. 7 and pp. 9-10.

65 Footnote 57, p. 3 and pp. 9-10.

66 Government of Fiji, Ministry of Economy. 2017. 5-Year \& 20-Year National Development Plan: Transforming Fiji. Suva. p. 16.

67 Government of Fiji, National Council for Building a Better Fiji. 2008. [People's] Charter for Change, Peace \& Progress. Suva; and Government of Fiji, Ministry of National Planning. 2009. Roadmap for Democracy and Sustainable Socio-Economic Development 2010-2014: A Better Fiji for All. Suva.

68 Government of Fiji, Ministry of Strategic Planning, National Development and Statistics. 2014. A Green Growth Framework for Fiji: Restoring the Balance in Development That Is Sustainable for Our Future. Suva. 
in 2013). ${ }^{69}$ These renewable energy targets serve as the basis for Fiji's first NDC. After signing the Paris Agreement, Fiji issued its NDP with a short-term plan (2017-2021) and a long-term plan (2017-2036). ${ }^{70}$ The short-term plan provides a detailed action agenda with specific targets and policies that help advance the long-term plan, which in turn is designed to achieve deeper transformation, including major decarbonization by 2050. The NDP is intended to be consistent with commitments under the Paris Agreement and its goal to achieve climate neutrality and a low-emission world. Strategies to address climate change and impacts are mentioned throughout the report including in sections on the energy sector, food and agriculture, public health, transportation, youth development, and safe and efficient shipping.

The Fiji Low Emission Development Strategy 2018-2050 is a living document compiled in 2018 that defines pathways to achieve low-emission development in Fiji until 2050. ${ }^{71}$ It considers four different emissions scenarios, including one of "very high ambition," which seeks to achieve net-zero emissions in 2041 and net negative emission thereafter. ${ }^{72}$ The greatest emissions reduction would come from shifting Fiji's energy sector to renewable energy generation. The strategy also notes the significance of electrifying land transport using organic waste and recycling programs while avoiding the release of methane due to its decomposition. It aims to achieve net negative emissions due to extensive tree replanting, reduced deforestation, and increased use of sustainable forest plantations.

Supporting the broader climate policy agenda are additional constitutional and legislative measures. Fiji's constitution, for example, establishes the right to a clean and healthy environment. ${ }^{73}$ The Environmental Management Act 2005 requires environmental assessments for significant development projects affecting the environment. ${ }^{74}$ The COP 23 Presidency Trust Fund Act 2017 helped finance Fiji's presidency of the 23rd session of the Conference of the Parties and other climate change activities. ${ }^{75}$ The Environmental Levy Act 2015 (as amended) helps fund environmental and biodiversity conservation projects and climate mitigation and adaptation measures. ${ }^{76}$ In 2019, Fiji passed the Climate Relocation of Communities Trust Fund Act 2019 to support research and assessments of circumstances requiring planned relocation, assessments of communities that might be at risk of being displaced due to climate change

69 Footnote 68, pp. 80, 87, and 99.

70 Footnote 66, pp. 2-10 and 18-132.

71 Government of Fiji, Ministry of Economy. 2018. Fiji Low Emission Development Strategy 2018-2050. Suva.

72 Footnote 71, pp. 5 and 35.

73 The Constitution of the Republic of Fiji, sec. 40(1).

74 Environment Management Act 2005, secs. 28-34.

75 COP 23 Presidency Trust Fund Act 2017 (Act No. 6 of 2017), sec. 4.

76 Environmental Levy Act 2015 (Act No. 20 of 2015); Environmental Levy (Budget Amendment) Act 2017, sec. 13; and Environment and Climate Adaptation Levy (Budget Amendment) Act 2018. The Environment and Climate Adaptation Levy (Budget Amendment) Act 2018 amended the two prior acts. But the purposes of the fund are best enumerated in the 2017 legislation. 
impacts, scouting of viable locations for displaced communities, and provision of needed infrastructure. ${ }^{77}$ In 2019, Fiji introduced the Climate Change Bill 2019, which focuses on establishing the institutional arrangements required to implement Fiji's climate change commitments and activities. ${ }^{78}$

Table 6.3 summarizes Fiji's climate change legal and policy framework.

\section{Energy Supply}

Like other Pacific Islands nations, Fiji relies heavily on imported petroleum-based fuels. ${ }^{79}$ However, it also has significant hydropower resources. As of 2015, over $60 \%$ of Fiji's total petroleum consumption came from the transport sector. ${ }^{80}$ The primary fuels imported by Fiji are diesel (over $50 \%$ of total imports), aviation fuel (30\%), and motor spirit (10\%). ${ }^{81}$

Fiji's total capacity of installed power generation is 269 megawatts (MW).$^{82}$ The Fiji Electricity Authority provided $94 \%$ of that capacity and delivered 857 gigawatt-hours (GWh) in 2013 (footnote 82). Its current power generation mix is approximately $55 \%$ hydro, $40 \%$ diesel and heavy fuel oil, $1 \%$ wind, with the remaining $4 \%$ provided by two co-generators, Tropik Woods Limited and Fiji Sugar Corporation (footnote 82). Additional power comes from a few diesel mini-grids that use a coconut oil and diesel blend (20/80) and over 3,000 solar home systems. ${ }^{83}$

In rural areas, $70 \%$ of households use wood for cooking purposes ${ }^{84}$ It is a challenge for Fiji to provide isolated islands with sustainable access to electricity. As of 2013, approximately $10 \%$ of the population still had no access to electricity (footnote 79 ). In 2017, the total supply of primary energy produced from renewable sources was approximately 5,911 terajoules, of which almost 30\% came from hydropower, $68 \%$ from biofuels, with small contributions from wind, solar, and liquid biofuels. ${ }^{85}$

\section{Sector-Wide Energy Strategies}

The Fiji Low Emission Development Strategy 2018-2050 synthesizes sector-wide targets under existing policies. ${ }^{86}$ While strategies are discussed for various sectors, explicit targets are laid out for the energy, transport, and forestry sectors (Table 6.4).

77 Climate Relocation of Communities Trust Fund Act 2019 (Act No. 21 of 2019), sec. 4(b).

78 Fiji One TV. 2019. Government Introduces Climate Change Bill 2019. 1 October.

79 Economic Consulting Associates and SMEC (New Zealand). 2013. Review of the Fiji National Energy Policy: Draft Energy Policy. London. p. 2.

80 Footnote 79, p. 14.

81 Footnote 79, p. 15.

82 International Renewable Energy Agency (IRENA). 2015. Fiji Renewables Readiness Assessment. Abu Dhabi. p. XI.

83 Footnote 79, p. 13.

84 Footnote 82, pp. 9 and 13.

85 IRENA. Renewable Energy Balances: Overview Tables (accessed 23 March 2020).

86 Footnote 71, pp. 31-32. 
Table 6.3: Climate Change Legal and Policy Framework of Fiji

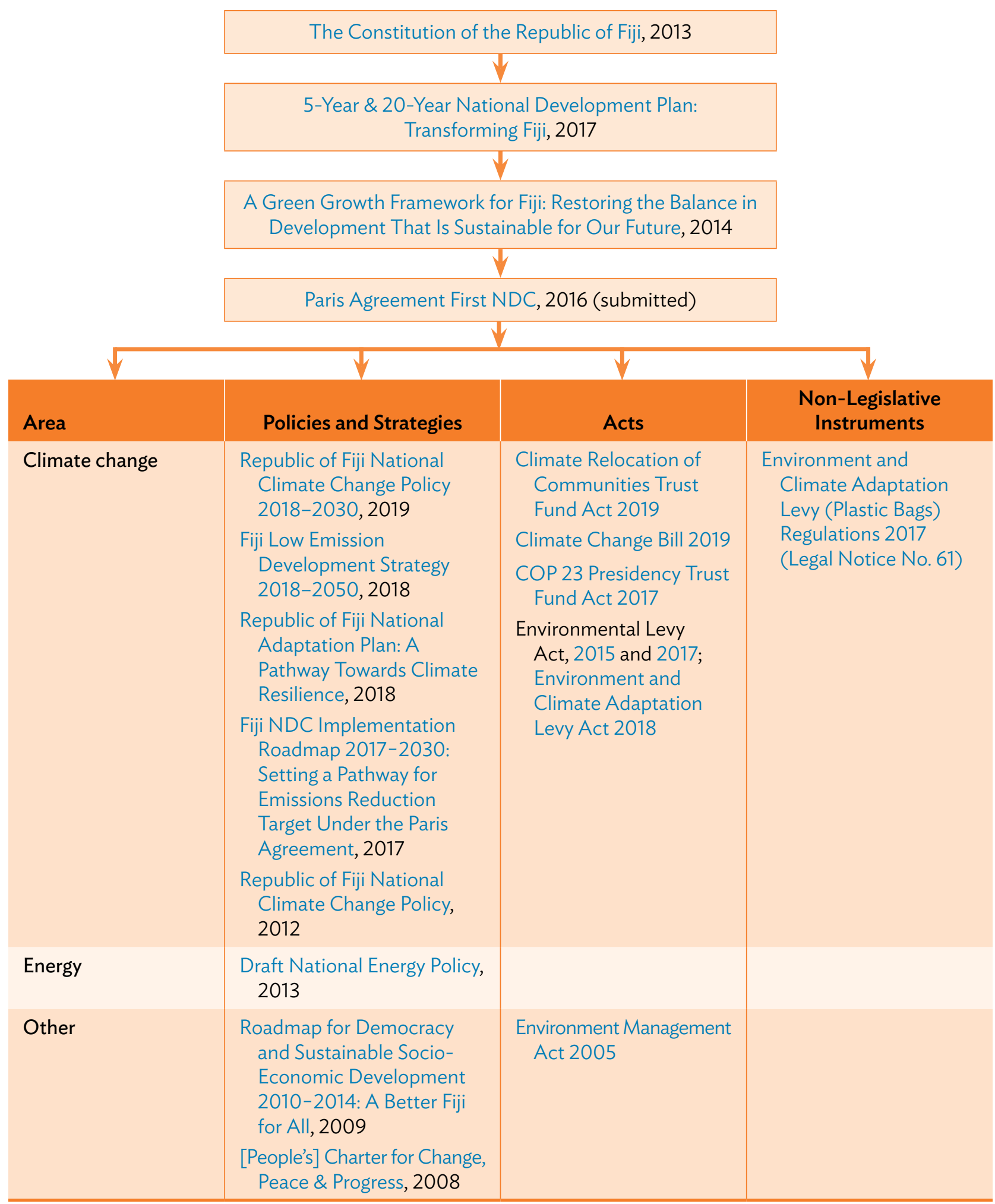

$\mathrm{COP}=$ Conference of the Parties, NDC = nationally determined contribution.

Source: Authors. 
Table 6.4: Emission Targets for Energy, Transport, and Forestry Sectors in Fiji, 2021-2036

\begin{tabular}{|c|c|c|c|}
\hline \multirow[b]{2}{*}{ Sector } & \multicolumn{3}{|c|}{ Targets } \\
\hline & Ву 2021 & Ву 2031 & Вy 2036 \\
\hline Energy & $\begin{array}{l}\text { - Increase household solar } \\
\text { systems to } 1,100 \\
\text { - Increase mini-hydro } \\
\text { systems to } 10\end{array}$ & $\begin{array}{l}\text { - Reduce consumption of } \\
\text { imported fuel per unit of } \\
\text { GDP to } 2.73 \mathrm{MJ} / \mathrm{F} \$ \\
\text { - Reduce power } \\
\text { consumption per unit of } \\
\text { GDP to } 0.209 \mathrm{kWh} / \mathrm{F} \$ \\
\text { - Increase total renewable } \\
\text { energy share in total } \\
\text { energy consumption } \\
\text { to } 25 \%\end{array}$ & $\begin{array}{l}\text { - Eliminate wood-fired } \\
\text { cooking in all households } \\
\text { - Increase renewable } \\
\text { electricity generation } \\
\text { to } 100 \%\end{array}$ \\
\hline Transport & $\begin{array}{l}\text { - Reduce vehicle emission } \\
\text { levels by } 40 \% \\
\text { - Install biogas facilities } \\
\text { and biofuel plants }\end{array}$ & $\begin{array}{l}\text { - Reduce dependence on } \\
\text { imported fossil fuel/km } \\
\text { traveled by } 32 \% \\
\text { - Reduce energy } \\
\text { consumption } \\
\text { dependence on imported } \\
\text { fossil fuel by } 32 \%\end{array}$ & \\
\hline Forestry & $\begin{array}{l}\text { - Put } 5 \% \text { of forest area } \\
\text { under protection } \\
\text { - Reforest } 5,300 \text { hectares } \\
\text { of degraded forest }\end{array}$ & & $\begin{array}{l}\text { - Put } 16 \% \text { of forest area } \\
\text { under protection }\end{array}$ \\
\hline
\end{tabular}

$\mathrm{F} \$=$ Fiji dollar, GDP = gross domestic product, $\mathrm{km}=$ kilometer, $\mathrm{kWh}=$ kilowatt-hour, $\mathrm{MJ}=$ megajoule.

Source: Government of Fiji, Ministry of Economy. 2018. Fiji Low Emission Development Strategy 2018-2050. Suva. pp. $31-32$.

\section{Energy Demand}

Energy demand in Fiji is expected to grow. Under its 5-Year \& 20-Year National Development Plan, 2017, Fiji sets out to achieve a fourfold increase in per capita income, an annual real GDP growth rate of $4 \%-5 \%$, and an unemployment rate of under $4 \%$ over the next 3 decades. ${ }^{87}$

Achieving these development targets will necessitate an increase in available energy, particularly renewable generation. Three important energy objectives in Fiji's NDP, its Low Emission Development Strategy 2018-2050, and its NDC Implementation Roadmap 2017-2030 are (i) ensuring that 100\% of the population has access to electricity by 2021 , (ii) achieving $100 \%$ renewable electricity generation by 2036 , and (iii) eliminating all primary wood-fueled

87 Footnote 66, pp. 2 and 55. 
cooking by $2036 .{ }^{88}$ Household demand for refrigeration and air-conditioning is also projected to grow.

More ambitious development targets include introducing electric vehicles and growing Fiji's mining industry. ${ }^{89}$ Both targets will escalate energy demand. In its Low Emission Development Strategy 2018-2050, Fiji projects the growth of this demand over a range of scenarios and the renewable generation required to meet it. ${ }^{90}$ Fiji has also expressed an interest in adopting smart grid technologies to enable customer demand management. ${ }^{91}$ It has discussed plans to update codes for buildings and industry to require minimum standards for energy use, such as for ventilation, cooling, and lighting. ${ }^{92}$

\section{E. Adaptation}

The National Climate Change Policy 2018-2030 is the central policy document on protecting the country's development priorities from present, future, and intergenerational climate vulnerabilities. ${ }^{93}$ It hinges on eight guiding principles: (i) enabling sustainable well-being, (ii) enhancing social cohesion, (iii) increasing inclusivity, (iv) fostering new partnerships, (v) fostering agility in the face of complex and changing threats, (vi) recognizing urgency given the scale of the climate crisis and the nature of Fiji's climate vulnerability, (vii) improving data transparency and communication, and (viii) promoting integrated learning to boost the efficiency and effectiveness of Fiji's efforts to reduce risk and build national resilience (footnote 93 ).

The National Adaptation Plan identifies 160 priority measures for 2018-2023, which are based on community consensus rather than cost-benefit or least-cost analysis. ${ }^{94}$ They span 10 sector and system categories. The system categories are intended to shift financing streams and create an enabling environment for climate-resilient development. They include goals for climate information services and management, horizontal integration, vertical integration, climate change awareness and knowledge, and resource mobilization (footnote 94).

The sector goals span food and nutrition security, health, human settlements, infrastructure, biodiversity, and natural environment. ${ }^{95}$ These sectors

88 Footnote 66, p. 10; footnote 71, p. 31; and Government of Fiji. 2017. Fiji NDC Implementation Roadmap 2017-2030: Setting a Pathway for Emissions Reduction Target under the Paris Agreement. Suva. pp. 20 and 22. The NDC Implementation Roadmap excludes energy used in non-electric cooking.

89 Footnote 66, pp. 7 and 119.

90 Footnote 71, pp. 51-69.

91 Footnote 71, p. 6.

92 Footnote 71, pp. 72 and 189.

93 Government of Fiji, Ministry of Economy. 2019. Republic of Fiji National Climate Change Policy 2018-2030. Suva. p. 8.

94 Government of Fiji. 2018. Republic of Fiji National Adaptation Plan: A Pathway Towards Climate Resilience. Suva. p. vii.

95 Footnote 94, p. viii. 
correspond with vulnerability to climate hazards as identified in the plan. Other documents will be developed to support the National Adaptation Plan, including financing and communication strategies. The Low-Emission Development Strategy 2018-2050 sets out long-term mitigation actions that are in line with, and complement, the National Adaptation Plan in six sectors: (i) energy infrastructure; (ii) land, maritime, and air transport; (iii) waste infrastructure; (iv) food security; (v) forestry and coastal wetlands; and (vi) tourism. ${ }^{96}$

Recognizing the need for planned relocation as an adaptation measure, the government passed the Climate Relocation of Communities Trust Fund Act 2019, which establishes the Climate Relocation of Communities Trust Fund. Among others, the fund may allocate money to initiatives designed to guarantee an adequate standard of living and safeguard Fijians' constitutional rights and freedoms.

\section{Kiribati}

\section{A. Country Snapshot: Climate and Environmental Challenges}

The Republic of Kiribati comprises 33 atolls and reef islands with a total land area of $810 \mathrm{~km}^{2}$, dispersed over 3.5 million $\mathrm{km}^{2}{ }^{27}$ The geography and size of Kiribati make it one of the most vulnerable countries globally to the adverse impacts of climate change. ${ }^{98}$ The entire population and most infrastructure are clustered along the coast. ${ }^{99}$ Many islands are merely 2 meters - or even less-above sea level. ${ }^{100}$ Climate change is already causing higher temperatures, increased precipitation, extreme rainfall and heat, rising sea levels, and increased ocean acidification. ${ }^{101}$ In addition, Kiribati continues to suffer from loss of biodiversity, increased waste, pollution, and the unsustainable use of natural resources..$^{102}$

Kiribati is categorized by the United Nations (UN) as a small island developing state and least developed country (LDC). About $80 \%$ of the population lives a subsistence lifestyle. ${ }^{103}$ Its parliamentary system is a blend of British and American government systems. ${ }^{104}$

96 Footnote 71, pp. 184 and 186-190.

97 Government of Kiribati. 2014. Kiribati Joint Implementation Plan for Climate Change and Disaster Risk Management (KJIP) 2014-2023. Tarawa. p. 8.

98 Footnote 97, p. 9.

99 Government of Kiribati. 2016. First Nationally Determined Contribution. Tarawa. p. 4.

100 Footnote 99, p. 2.

101 Footnote 97, pp. 9, 24, and 26.

102 Footnote 97, pp. 26 and 28.

103 Government of Kiribati, Ministry of Environment, Lands and Agriculture Development. 2012. Kiribati Integrated Environment Policy. Tarawa. p. 11.

104 House of Assembly (Parliament) of Kiribati. Welcome to the Maneaba ni Maungatabu. 


\section{B. Overarching Climate Change Legal and Policy Framework}

\section{Mitigation and Adaptation Targets}

The Government of Kiribati submitted its first nationally determined contribution (NDC) on 21 September 2016, pledging to reduce its emissions by $13.7 \%$ by 2025 and $12.8 \%$ by 2030 , compared with a business as usual (BAU) projection. ${ }^{105}$ With international assistance, Kiribati believes it could further lower its emissions by $48.8 \%$ by 2025 and $49.0 \%$ by 2030 (footnote 105 ).

Kiribati's contribution to total global carbon emissions is minimal, at $0.0002 \% .^{106}$ Kiribati notes that it is in "no position to make dramatic changes to the global total." 107 Notwithstanding, Kiribati's government is undertaking a whole-of-nation approach, including targets to increase renewable energy and energy efficiency by 2025 (Table 6.5).

\section{Table 6.5: Kiribati's Planned Increase in Renewable Energy and Energy Efficiency by 2025}

$(\%)$

\begin{tabular}{lccc} 
Area & $\begin{array}{c}\text { Renewable } \\
\text { Energy }\end{array}$ & $\begin{array}{c}\text { Energy } \\
\text { Efficiency }\end{array}$ & Total \\
\hline South Tarawa (capital) & 23 & 22 & 45 \\
Kiritimati Island & 40 & 20 & 60 \\
$\begin{array}{l}\text { Outer Islands } \\
\quad \text { (rural public infrastructure) }\end{array}$ & 40 & 20 & 60 \\
$\begin{array}{l}\text { Outer Islands } \\
\quad \text { (rural public and private } \\
\text { institutions) }\end{array}$ & 100 & 100 \\
\hline
\end{tabular}

Source: Government of Kiribati. 2016. First Nationally Determined Contribution. Tarawa. p. 8.

\section{Overview of Climate Change Law and Policy}

Kiribati has launched a number of climate initiatives within the last few years. For example, the 2018 Kiribati Climate Change Policy sets priorities for climate action, based on seven principles:

(i) safeguarding communities and the country as a whole from the adverse impacts of climate change and disasters, and ensuring a safe and resilient Kiribati with a healthy environment for all;

\footnotetext{
105 Footnote 99, p. 6.

106 Footnote 99, p. 7.

107 Government of Kiribati. 2018. Kiribati Climate Change Policy. Tarawa. p. 15
} 
(ii) mainstreaming climate change and disaster risk reduction into development planning, policies, strategies, sector plans, and decisionmaking and budgeting processes at both national and local levels;

(iii) emphasizing that adaptation, mitigation, and disaster risk management are shared responsibilities that require coordinated, integrated, multi-partner, multi-sectoral, and whole-of-government or whole-of-island approaches;

(iv) strengthening key institutions and capacities as a basis for enhanced action, and ensuring measures to secure implementation are conducted efficiently;

(v) focusing on actions that will strengthen the long-term resilience of Kiribati communities through sustainable environmental, social, and economic benefits that combine the use of modern technologies with the preservation of traditional knowledge;

(vi) ensuring that adaptation, mitigation, and disaster risk management are equitable, inclusive, gender-sensitive, community-driven, participatory, and reflect the commitments that Kiribati has agreed to under various multilateral frameworks; and

(vii) strengthening and maintaining strategic partnerships, both internally and externally. ${ }^{108}$

The policy also aims to better manage coastal zones, natural resources, and food and water supply; incentivize renewable energy and energy efficiency; strengthen ecosystem conservation; improve public awareness of the health effects of climate change; implement the government's national disaster risk management plan; and improve climate finance. ${ }^{109}$

In 2013, Kiribati created the National Framework for Climate Change and Climate Change Adaptation (Climate Framework), which requires that climate change and adaptation assume a prominent role in the national development planning process. ${ }^{110}$ The Climate Framework identifies population resettlement and relocation as a priority.

Consistent with the Climate Framework's objectives, the Kiribati Development Plan 2016-19 emphasized integrating climate change into development planning. ${ }^{111} \mathrm{~A}$ key goal is to facilitate sustainable development by protecting biodiversity, reducing environmental degradation, and adapting to and mitigating the effects of climate change.

108 Footnote 107, pp. 3 and 11-22.

109 Footnote 107, pp. 11-18 and 21.

110 Government of Kiribati, Office of Te Beretitenti. 2013. National Framework for Climate Change and Climate Change Adaptation. Tarawa.

111 Government of Kiribati, Ministry of Finance and Economic Development. 2016. Kiribati Development Plan 2016-19. Tarawa. 
In September 2019, the government unveiled its Joint Implementation Plan for Climate Change and Disaster Risk Management 2019-2028. ${ }^{112}$ The plan aligns with the Kiribati Development Plan 2016-19 and the Kiribati 20-Year Vision 2016-2036. ${ }^{13}$ It identifies 12 major strategies to reduce Kiribati's vulnerability to climate change and disasters, such as "strengthening good governance, policies, strategies and legislation." "114 Key priorities include enhancing coordination between climate change adaptation and disaster risk management programs; boosting institutional capacity to ensure sustainable use of natural resources; managing food, water, and health security; building coastal resilience; and fostering climate awareness. ${ }^{115}$

The Kiribati Climate Change and Climate Risk Communications Strategy 2014-2018 sets communications priorities for the country. ${ }^{116}$ The government aims to promote climate literacy by raising awareness; considering appropriate branding; and engaging with stakeholders, communities, and media. The strategy also outlines the specific audiences, messages, and outlets the government intends to target in its climate change communications, as well as the government's plan for implementing the strategy.

Table 6.6 summarizes Kiribati's climate change legal and policy framework.

\section{Energy Supply}

Kiribati depends on a mix of imported fossil fuels and indigenous renewable energy sources to meet its energy needs..$^{117}$ In $2014,63 \%$ of the national energy supply came from imported petroleum products, and $37 \%$ from indigenous renewable energy sources (primarily bioenergy followed by solar). ${ }^{118}$ The government has introduced several initiatives to reduce fossil fuel imports and increase domestic renewable energy use. For example, the Kiribati Solar Energy Company provides solar lighting on rural islands and markets solar appliances. ${ }^{119}$ Coconut oil-based biofuel has been trialed, as has on-grid solar photovoltaic on urban islands. ${ }^{120}$

112 Government of Kiribati, Office of Te Beretitenti. 2019. Kiribati Joint Implementation Plan for Climate Change and Disaster Risk Management (KJIP) 2019-2028. Tarawa.

113 Government of Kiribati. 2016. Kiribati 20-Year Vision 2016-2036. Tarawa.

114 Footnote 112, p. 11.

115 Footnote 112, pp. 69-73.

116 Government of Kiribati, Office of Beretitenti. 2013. Kiribati Climate Change and Climate Risk Communications Strategy 2014-2018. Tarawa.

117 International Renewable Energy Agency (IRENA), Pacific Community (SPC), and Pacific Power Association (PPA). 2017. Kiribati Integrated Energy Roadmap: 2017-2025. Tarawa. p. 8.

118 Footnote 117, pp. 8 and 22.

119 Footnote 117, p. 48.

120 Footnote 117, p. 101. 


\section{Table 6.6: Climate Change Legal and Policy Framework of Kiribati}

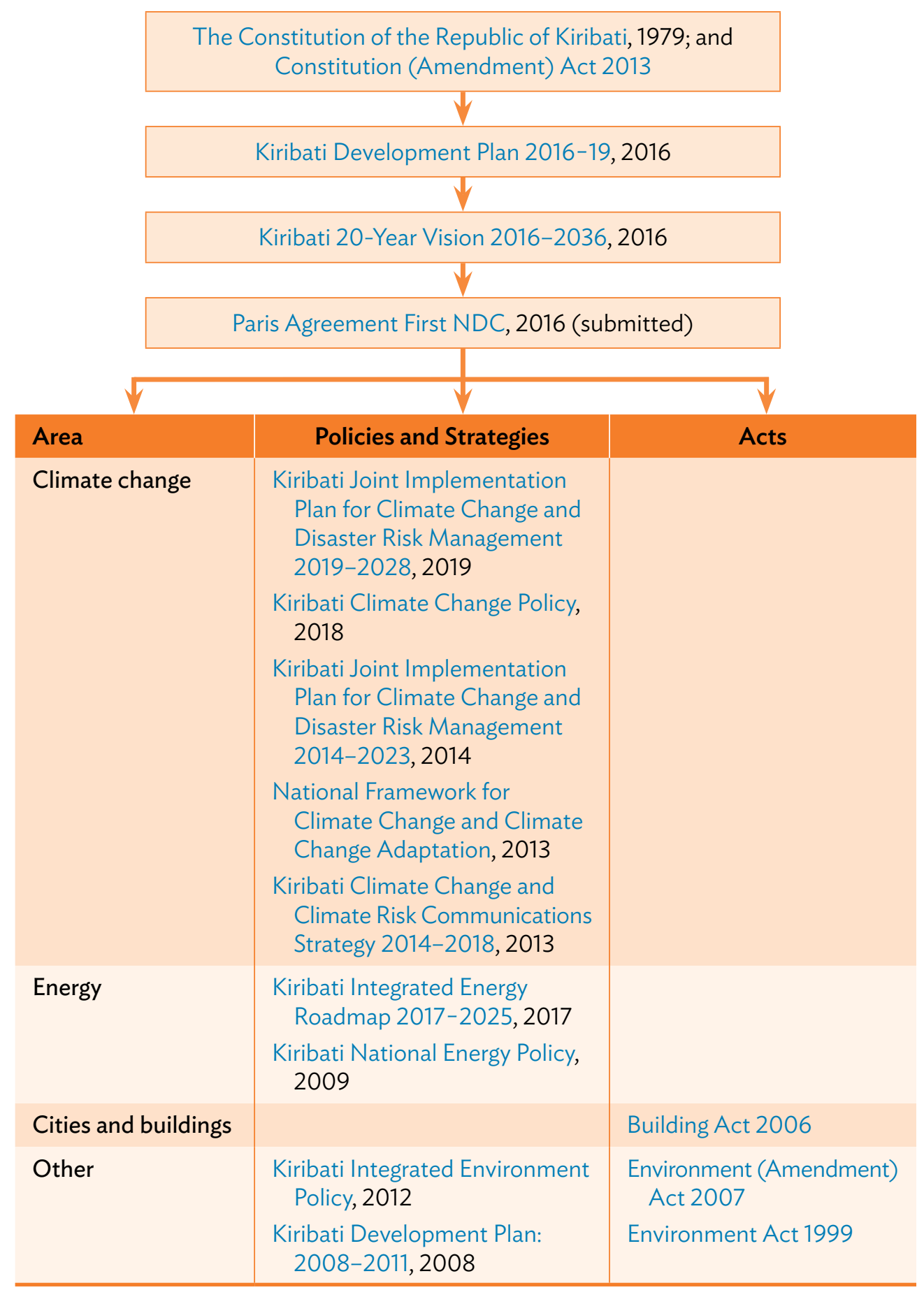

NDC = nationally determined contribution.

Source: Authors. 


\section{Sector-Wide Strategies}

The National Energy Policy of 2009 incorporates measures to mitigate carbon emissions by promoting renewable energy and energy efficiency. ${ }^{121}$ It responds to the call to strengthen Kiribati's energy sector, as outlined in the Kiribati Development Plan of 2008-2011. ${ }^{122}$ The policy provides a framework within which public and private energy sector participants can make informed planning and investment decisions.

\section{Renewable Energy Policies}

To expand the supply of renewable energy and improve energy efficiency, the infrastructure component of Kiribati's Development Plan 2016-19 develops minimum standards and energy labeling regulations. ${ }^{123}$ The development plan is in line with the National Energy Policy, which aims to promote renewable energy.

The Kiribati Joint Implementation Plan for Climate Change and Disaster Risk Management 2014-2023 seeks to increase the share of the grid connected to renewable energy. Against a 2013 baseline of no solar energy, the government aims to increase the share of intermittent solar energy to $60 \%$ by $2025 .{ }^{124}$ The 2019 Joint Implementation Plan for Climate Change and Disaster Risk Management maintains this target. ${ }^{125}$

\section{Energy Demand}

The National Energy Policy, 2009 acknowledges the importance of addressing Kiribati's heavy reliance on imported fuel, increasing energy demand, and inefficient appliances and equipment. ${ }^{126}$ The policy seeks to

(i) introduce and encourage implementation of energy efficiency and conservation programs;

(ii) promote public awareness of energy efficiency and conservation measures;

(iii) introduce and enforce the use of energy-efficient appliances and equipment; and

(iv) introduce appropriate incentives, including taxes, duties, and tariffs, to encourage efficient energy use (footnote 126).

${ }^{121}$ Government of Kiribati, Ministry of Public Works and Utilities. 2009. Kiribati National Energy Policy. Tarawa.

122 Government of Kiribati, Ministry of Finance and Economic Development. 2008. Kiribati Development Plan: 2008-2011. Tarawa.

123 Footnote 111, p. 64.

124 Footnote 97, p. 103

125 Footnote 112, p. 156

126 Footnote 121, p. 24. 


\section{E. Adaptation}

The Joint Implementation Plan for Climate Change and Disaster Risk Management 2019-2028 identifies 12 major strategies and 104 priorities for climate adaptation and disaster risk reduction. ${ }^{127}$ Overall, the plan seeks to coordinate and access the financial and technical support needed to implement the priorities. As such, the plan targets strengthening governance and institutional capacity, and improving public awareness of climate change. The plan identifies the importance of promoting environmentally friendly practices in the private sector; ensuring environmental resilience; and building adaptive capacity for the health, food, and water sectors.

The plan also focuses on maintaining sovereignty and Kiribati's unique identity, and enhancing resilience through community participation. To facilitate a cohesive approach to climate responses, the plan clarifies implementation roles and responsibilities.

\section{Marshall Islands}

\section{A. Country Snapshot: Climate and Environmental Challenges}

With an average elevation of just under 2 meters above sea level, the Republic of the Marshall Islands (RMI) is one of the world's lowest-lying countries and, as a result, is one of the most vulnerable to climate change. ${ }^{128}$ Spread across almost 2 million $\mathrm{km}^{2}$ of the Pacific Ocean, it is a coral atoll nation made up of 1,156 individual islands and 29 different atolls, with a population of approximately 53,000 (footnote 128).

The gross domestic product (GDP) is around $\$ 180$ million, largely supported by remittances and by external assistance from the country's Compact of Free Association relationship with the United States (footnote 128). Industry, agriculture, and fisheries (particularly tuna) are responsible for less than $15 \%$ of economic activity (footnote 128).

The RMI championed the 2013 Majuro Declaration for Climate Leadership, which aimed to show the Pacific's adoption of some of the world's most ambitious greenhouse gas (GHG) emissions reduction targets. ${ }^{129}$ "Adapting to climate impacts is an increasingly pressing national priority," especially for people "in rural communities who have limited access to resources and services, and so are particularly vulnerable" (footnote 128). The RMI "is experiencing increasingly damaging effects from climate change and seeing more frequent and intense events, such as drought, floods and swells, and tropical cyclones and storms" (footnote 128). The RMI declared a state of disaster in 2013 and again in 2016 due to lengthy

127 Footnote 112, pp. 9 and 11.

128 Government of the RMI. 2018. Second Nationally Determined Contribution. Majuro. p. 6.

129 Footnote 128; and Majuro Declaration for Climate Leadership, Majuro, RMI, 5 September 2013. 
and unseasonal droughts (footnote 128). The Post Disaster Needs Assessment created after the 2016 drought estimated the total economic losses to be about $\$ 4.9$ million, with agriculture being the most affected sector. ${ }^{130}$ "In 2015, Typhoon Nangka cost RMI more than 3\% of its GDP in a single night." "131 There remains substantial work to be done to raise support for adaptation efforts (footnote 131).

\section{B. Overarching Climate Change Legal and Policy Framework}

\section{Mitigation and Adaptation Targets}

The Government of the RMI submitted its first nationally determined contribution (NDC) on 22 April 2016. On 22 November 2018, it became the first country to submit its second NDC. The NDC commits to reducing GHG emissions by $32 \%$ below 2010 levels by 2025 and by $45 \%$ by 2030 (footnote 131). The RMI also aims to reduce $\mathrm{GHG}$ emissions by at least $58 \%$ below 2010 levels by 2035, and reaffirms its aspiration to achieve net-zero $\mathrm{GHG}$ emissions by $2050 .{ }^{132}$

The NDC includes commitments to produce a national adaptation plan by the end of 2019, submit an adaptation communication to the United Nations Framework Convention on Climate Change (UNFCCC) by 2020, adopt a gender-responsive and human-rights-based approach in NDC planning, and use the latest guidelines for national GHG inventories from the Intergovernmental Panel on Climate Change (IPCC) (footnote 132).

\section{Overview of Climate Change Law and Policy}

The RMI has developed a range of climate laws and policies, integrating climate considerations into environmental protection law and environmental impact assessment regulations. ${ }^{133}$ In 2018, the RMI issued the Tile Til Eo 2050 Climate Strategy, which outlines the country's goal to achieve net-zero emissions by 2050..$^{134}$ It became the 10th country in the world-and first in Asia and the Pacific-to communicate its long-term, mid-century climate change strategy. The RMI will reach this net-zero target by switching to 100\% renewable energy while adapting to climate change impacts to ensure future protection and prosperity (footnote 134). The strategy makes recommendations to

(i) submit a new NDC under the Paris Agreement by 2020;

(ii) focus on the nation's electricity sector in the short- and medium-term to implement GHG reductions consistent with achieving its NDC targets;

\footnotetext{
130 Footnote 128, pp. 6-7.

131 Footnote 128, p. 7.

132 Footnote 128, p. 8.

133 For example, National Environmental Protection Act 1984 and Environmental Impact Assessment Regulations 1994.

134 Government of the RMI. 2018. Tile Til Eo 2050 Climate Strategy: "Lighting the Way”. Majuro. p. 7.
} 
(iii) reduce the nation's growing waste problem by minimizing organic material in collected waste and consider possibilities to generate energy from waste;

(iv) develop policies to encourage greater use of public transport, cycling and walking, and electric vehicles;

(v) explore options to reduce GHG emissions from domestic ocean-based transport, including improved regulatory control;

(vi) continue efforts to phase out the use of kerosene for lighting and strengthen existing institutional arrangements to reduce GHGs from cooking and lighting;

(vii) establish a long-term financial strategy to implement the 2050 Strategy and its recommendations, and identify and consider options for a more coordinated and centralized approach to applying for and monitoring related overseas aid and investment;

(viii) ensure due diligence is fulfilled before making significant investments to implement the 2050 Climate Strategy and its recommendations;

(ix) prioritize capacity building in all areas relevant to the implementation of the 2050 Climate Strategy and its recommendations;

(x) mainstream gender and human rights, including in relation to developing, adopting, reviewing, and implementing laws, policies, and projects related to climate change, and commission further analysis to design a strategy to improve related data collection, monitoring, and evaluation;

(xi) include health considerations as part of the nation's forthcoming national adaptation plan;

(xii) include education, training, and public awareness considerations as part of the nation's forthcoming national development plan;

(xiii) review and update the 2050 Climate Strategy at least every 5 yearsto recommend targets for inclusion in future NDCs-and at least 1 year before the nation submits future NDCs; and

(xiv) establish a domestic process to oversee reviews and updates to the 2050 Climate Strategy and monitor its implementation. ${ }^{135}$

Launched in 2011, the National Climate Change Policy Framework established five strategic goals-(i) creating an environment conducive to climate change adaptation and mitigation, (ii) working toward a climate-resilient future, (iii) securing energy security, (iv) boosting disaster preparedness, and ( $v$ ) building education and awareness. ${ }^{136}$ The framework is implemented through the Joint National Action Plan for Climate Change Adaptation and Disaster Risk Management 2014-2018, as well as through the Climate Change Roadmap. ${ }^{137}$ The framework created the National Climate Change Committee, which is responsible for monitoring implementation and reporting to the President and the cabinet at least once per year. ${ }^{138}$

135 Footnote 134, pp. 8-9

136 Government of the RMI. 2011. National Climate Change Policy Framework. Majuro. p. 8.

137 Footnote 136, p. 26; Government of the RMI. 2014. Joint National Action Plan for Climate Change Adaptation \& Disaster Risk Management 2014-2018. Majuro; and Government of the RMI. 2010.

National Climate Change Roadmap. Majuro.

138 Footnote 136, p. 25. 
The RMI has also enacted other policies, laws, and regulations with implications for the climate. The National Strategic Plan 2015-2017 covers five sectors, including the environment, climate change, and resiliency sectors. ${ }^{139}$ The plan recognizes climate change and resiliency as two of the most important national issues. It categorizes the country's climate change policy into four implementation clusters: (i) energy security and low-carbon future; (ii) adaptation for a climateresilient future; (iii) disaster preparedness, risk reduction, and response capacity; and (iv) education, awareness, community mobilization, culture, and gender. ${ }^{140}$

In 2003, the RMI established the Office of Environmental Planning and Policy Coordination. As the leading body on biodiversity and climate change projects, the office works "in partnership with other government ministries and agencies, and the international community to prepare strategies to mitigate the negative impacts of climate change and prepare adaptation plans." 141 It advises the executive branch on environmental policy-including adaptation efforts-and implements programs and projects related to the environment.

The Rights of Persons with Disabilities Act 2015 mandates that the government consider the needs and rights of individuals with disabilities when planning for climate change and disasters. It specifically requires barrier-free emergency exits, shelters, and facilities, as well as disability-inclusive training and disaster responses. ${ }^{142}$

Table 6.7 summarizes the RMl's climate change legal and policy framework.

\section{Energy Supply}

Energy supply in the RMI has historically been challenging. Remote islands, limited grid access in rural areas, lack of space and transport, limited access to technicians, and little opportunity for economies of scale have left the RMI reliant upon diesel-fueled energy. ${ }^{143}$ Petroleum fuels around $90 \%$ of energy in the RMI, with biomass-used in cooking-making up the balance. ${ }^{144}$

Efforts to boost electrification meant that around 93\% of the population had access to electricity in 2016. ${ }^{145}$ Off-grid electricity has been the primary source of power in rural areas. ${ }^{146}$ Some outer islands have central power plants, and other remote populations receive electricity services from solar photovoltaic battery

139 Government of the RMI. 2014. National Strategic Plan 2015-2017. Majuro. p. 14.

140 Footnote 139, p. 36.

141 Government of the RMI, Office of Environmental Planning and Policy Coordination. Structure.

142 Rights of Persons with Disabilities Act 2015, sec. 23(4)(b).

143 Government of the RMI. 2018. Navigating our Energy Future: Marshall Islands Electricity Roadmap. Majuro. p. 20.

144 IRENA. 2015. The Republic of Marshall Islands: Renewables Readiness Assessment. Abu Dhabi. p. 3.

145 ADB. Marshall Islands and ADB (accessed 11 April 2020).

146 Government of the RMI, Ministry of Resources and Development. 2016. National Energy Policy and Energy Action Plan. Majuro. p. 16. In 2014, 93\% of households had access to off-grid electricity. 
Table 6.7: Climate Change Legal and Policy Framework of the Republic of the Marshall Islands

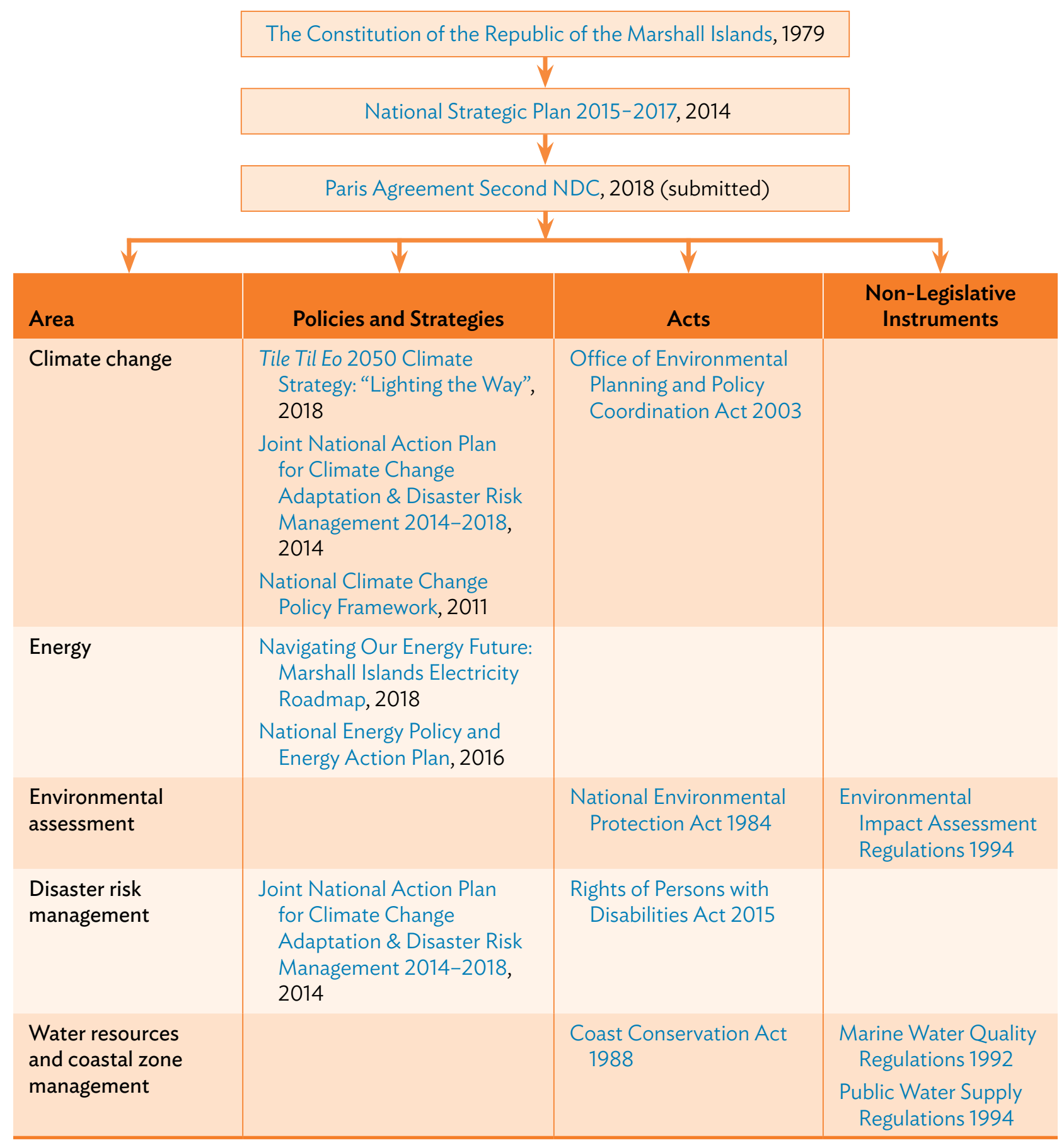

NDC = nationally determined contribution.

Source: Authors. 
systems. In 2018, the RMI electrified almost all households on outer islands, installing at least 3,000 solar home systems. ${ }^{147}$

The RMl's two utility companies-Marshalls Energy Company (MEC) and Kwajalein Atoll Joint Utilities Resources-are state-owned enterprises, functioning with boards appointed by the President's cabinet. ${ }^{148}$ The RMl's challenges with electricity supply have meant high electricity costs. Current tariffs are set at $\$ 0.416 /$ kilowatt-hour ( $\mathrm{kWh}$ ) for government, $\$ 0.406 / \mathrm{kWh}$ for commercial, and $\$ 0.346 / \mathrm{kWh}$ for residential customers. ${ }^{149}$ "Outer-island homes with off-grid solar systems pay a $\$ 5 /$ month lease to MEC for maintenance." 150 Even with full collection, the total of $\$ 5$ monthly maintenance fee and $\$ 7$ government top-up per system is not enough to compensate for MEC's $\$ 19$ estimated cost of maintaining and replacing each system. ${ }^{151}$

Accessing recent data regarding the RMl's energy supply and consumption is difficult. As of 2009, the RMl's total primary energy supply (TPES) was 1.4 petajoules. ${ }^{152}$

In 2016, the RMI put out the National Energy Policy, which emphasizes the need to boost renewable energy. ${ }^{153}$ More specifically, the $\mathrm{RMI}$ aims to provide $20 \%$ of power generation through indigenous renewable resources by 2020 , reducing dependence on imported fossil fuel. ${ }^{154}$

\section{Energy Demand}

The National Energy Policy seeks to make households and businesses 50\% more energy efficient, and government buildings $75 \%$ more efficient, by 2020.155 The policy also sets to achieve a $20 \%$ efficiency improvement in transport sector fuel use by $2020 .{ }^{156}$

\section{E. Adaptation}

In 2014, the RMI issued the Joint National Action Plan for Climate Change Adaptation \& Disaster Risk Management 2014-2018, which outlines a strategy for effectively addressing climate change and disaster risk. ${ }^{157}$ This plan contains six major goals:

147 Footnote 143, p. 49.

148 Government of RMI, National Renewable Energy Laboratory. 2015. Republic of the Marshall Islands Energy Project Development Options and Technical Assessment (2013). Consultant's report. Majuro.

149 Marshalls Energy Company, Inc. Tariffs (accessed 6 October 2020).

150 Footnote 148, p. 8.

151 Footnote 143, p. 50.

152 IRENA. 2012. Renewable Energy Country Profiles: Pacific. Abu Dhabi. p. 13.

153 Footnote 146, pp. 11 and 14.

154 Footnote 146, pp. 22-23.

155 Footnote 146, pp. vi and 20

156 Footnote 146, p. 17.

157 Government of Marshall Islands. 2014. Joint National Action Plan for Climate Change Adaptation \& Disaster Risk Management 2014-2018. Majuro. 
(i) improving disaster risk management coordination and climate change adaptation,

(ii) increasing public awareness and education,

(iii) enhancing emergency preparedness and response,

(iv) improving energy security and aiming for a low-carbon future,

(v) enhancing community resilience and local livelihoods, and

(vi) integrating disaster risks and climate change considerations into development planning. ${ }^{158}$

The implementation strategy for these goals is governed by four major principles: (i) a holistic approach to risk reduction, (ii) building on existing partnerships and mechanisms, (iii) inclusivity and partnership approach, and (iv) clearly defined roles and responsibilities. ${ }^{159}$ The plan also includes a communication strategy and a road map for monitoring and evaluation. ${ }^{160}$

In the Tile Til Eo 2050 Climate Strategy, the government states its intention to develop a national adaptation plan by the end of $2019 .{ }^{161}$ The plan will focus on adaptation and climate resilience milestones to be achieved periodically (e.g., by $2020,2025,2030$, and 2050), gender-responsive actions and investments in 2019-2023, and a plan for adaptation and resilience investments. ${ }^{162}$

The RMI also intends to send an adaptation communication to the UNFCCC that is consistent with the Paris Agreement's enhanced transparency framework. ${ }^{163}$ As explained in the Tile Til Eo 2050 Climate Strategy, the RMI will need predictable financing to implement its adaptation and resilience measures. The adaptation communication and subsequent NDCs will enable the RMI to outline its financing needs.

\section{Naurul}

\section{A. Country Snapshot: Climate and Environmental Challenges}

Nauru is an independent democratic state with a population of approximately $10,000.164$ Its constitution establishes a system of government with a president, parliament, and judicature. ${ }^{165}$ Nauru has historically suffered from environmental

\footnotetext{
158 Footnote 157, p. 7.

159 Footnote 157, p. 28.

160 Footnote 157, pp. 31-32.

161 Footnote 134, pp. 8 and 14.

162 Footnote 134, p. 14.

163 Footnote 134, p. 15. Article 13 of the Paris Agreement provides that all parties should, as appropriate, report on climate change impacts and adaptation. Developing country parties should also report on financial, technology transfer, and capacity-building support needed.

164 Government of Nauru. 2016. First Nationally Determined Contribution. Yaren. pp. 1-2.

165 The Constitution of the Republic of Nauru, Parts III-V.
} 
degradation due to deforestation and intense mining for phosphate. ${ }^{166}$ Achieving sustainable development has been difficult because of Nauru's scarce arable land and freshwater resources, geographic isolation, and subsequent dependence on imports to meet basic food and energy needs (footnote 166). These factors have also made Nauru vulnerable to climate change, as pointed out by the Framework for Climate Change Adaptation and Disaster Risk Reduction. ${ }^{167}$

The small island nation is particularly vulnerable to drought and the risks to marine resources posed by rising temperatures (footnote 166). Sea level rise poses an existential threat. ${ }^{168} \mathrm{Nauru}$ is committed to adapting to climate change and participating in reducing $\mathrm{GHG}$ by tapping into its potential for renewable energy, particularly solar power. ${ }^{169}$

\section{B. Overarching Climate Change Legal and Policy Framework}

\section{Mitigation and Adaptation Targets}

The Government of Nauru submitted its first nationally determined contribution (NDC) on 7 April 2016. While its NDC does not contain numerical GHG targets, Nauru has pledged to replace a substantial portion of its electricity generation with a large-scale grid-connected solar photovoltaic system (footnote 169). This pledge is conditional on receipt of $\$ 50$ million and substantial technical, capacity building, and logistical assistance. ${ }^{170}$ Nauru has unconditionally committed to implementing a 0.6 megawatt (MW) solar photovoltaic system, which will be used as a model project for the larger solar power plant (footnote 170).

\section{Overview of Climate Change Law and Policy}

Nauru has set forth a number of policies addressing energy issues and has prioritized adapting to climate change and improving disaster preparedness. It has also set ambitious renewable energy targets, which will assist it in meeting its GHG reduction goals and reducing reliance on imported fossil fuels.

Nauru's National Sustainable Development Strategy 2005-2025, as revised in 2009, articulates the imperative of building resilience to climate change and the need for a comprehensive law on environmental management. ${ }^{171}$ This imperative would require new projects to be assessed for their environmental impact. The strategy envisions " [a] future where individual, community, business and government partnerships contribute to a sustainable quality of life for all Nauruans." 172 It further states that urgent

166 Footnote 164, p. 3.

167 Government of Nauru, Ministry of Commerce, Industry \& Environment. 2015. Republic of Nauru Framework for Climate Change Adaptation and Disaster Risk Reduction (RONAdapt). Yaren. p. 8.

168 Footnote 164, p. 1.

169 Footnote 164, p. 2.

170 Footnote 164, p. 8.

171 Government of Nauru. 2009. National Sustainable Development Strategy 2005-2025. Yaren.

172 Footnote 171, p. 4. 
measures are needed to improve energy efficiency and increase renewable energy. Nauru has also prioritized developing locally tailored responses to climate change.

Table 6.8 summarizes Nauru's climate change legal and policy framework.

\section{Table 6.8: Climate Change Legal and Policy Framework of Nauru}

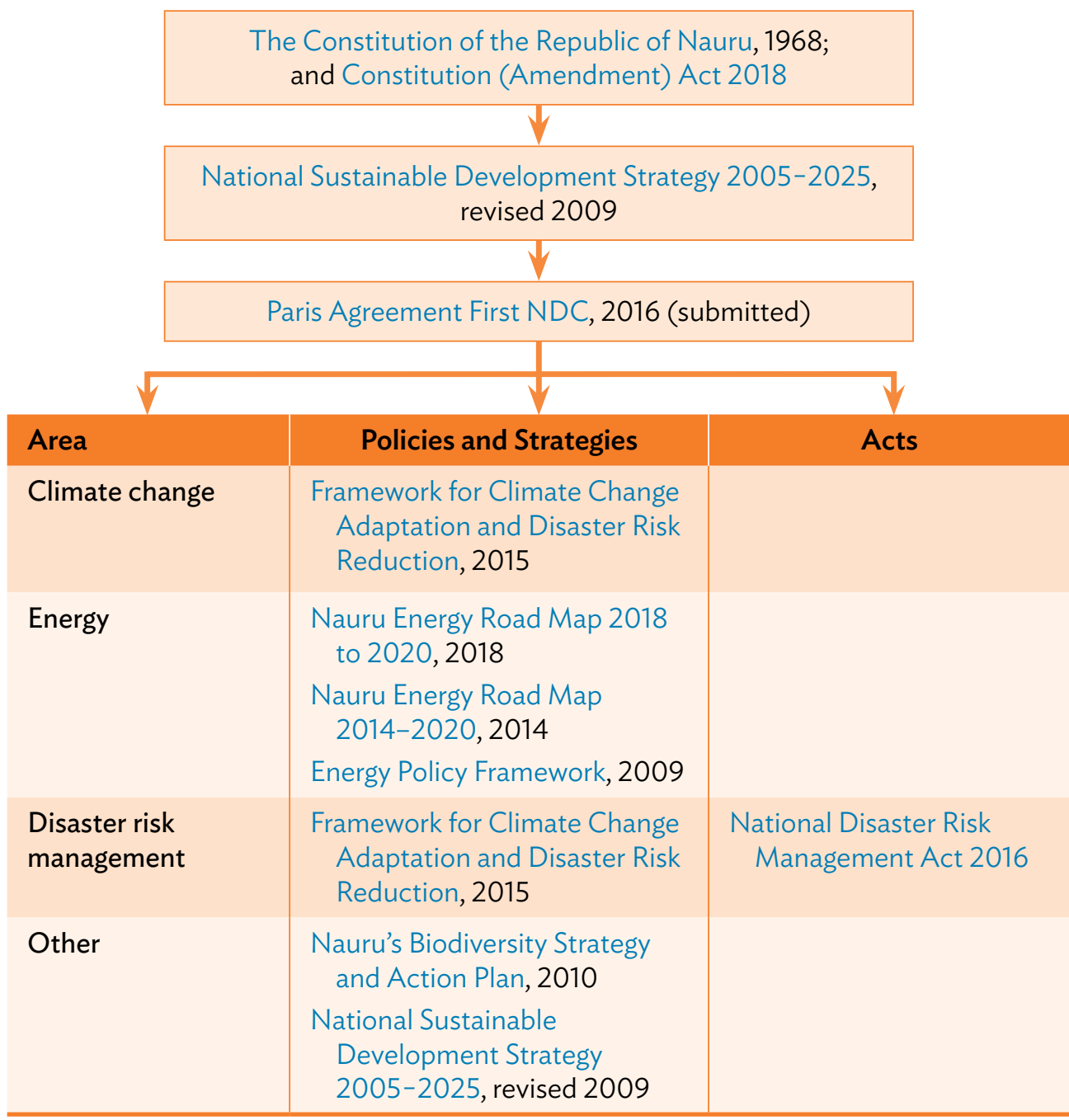

NDC = nationally determined contribution .

Source: Authors.

\section{Energy Supply and Demand}

As indicated in Nauru's Energy Road Map for 2014-2020 (Road Map), with $100 \%$ electrification, Nauru's average electricity tariffs are comparatively low at $\$ 0.14$ per kilowatt-hour ( $\mathrm{kWh}$ ). ${ }^{173}$ Nauru relies mostly on imported petroleum

173 Government of Nauru, Technical Working Group on Energy. 2014. Nauru Energy Road Map 2014-2020: An Implementation Plan for Energy Sector Development. Yaren. p. 22. 
fuels for its energy. Diesel generators provide $99 \%$ of the electricity supply, with renewable energy accounting for only $1 \%$ (footnote 173). There is currently no national energy database or energy balance. With irregular data reporting, energy datasets are fragmented. The Nauru Utilities Corporation supplies electricity with one power station. Maximum demand is approximately 3.3 MW (footnote 173).

The National Sustainable Development Strategy 2005-2025 sets the country's goal for the energy sector: to "provide a reliable, affordable, secure and sustainable energy supply to meet socio-economic development needs." 174 Both the Energy Policy Framework and the Road Map adopted this goal as the country's energy vision. ${ }^{175}$ Both also set a target of meeting $50 \%$ of Nauru's energy needs through renewable energy by 2015 and focused on the potential for solar expansion.

The Road Map further targets a 30\% improvement in energy efficiency in the residential, commercial, and government sectors by $2020 .{ }^{176}$ It states that only solar energy appears to be suitable to replace fossil fuels in the country. ${ }^{177}$ Additionally, it assesses how energy developments will affect the environment and, conversely, how climate change will affect the energy sector. Early planning is needed to manage the impact of sea level rise and increasing salinity and acidity on energy infrastructure.

In 2018, the government released the updated Nauru Energy Road Map 2018-2020.178 The updated Road Map reconfirms a commitment to "improving the sustainability of energy use through renewable energy and energy efficiency." ${ }^{179}$ It acknowledges that building institutional capacity is needed to transition $50 \%$ of grid electricity supply to renewable energy and boost energy efficiency and reliability.

\section{Adaptation}

Nauru recognizes its vulnerability to the impacts of climate change and has thus prioritized adaptation. The 2015 Framework for Climate Change Adaptation and Disaster Risk Reduction identifies immediate priorities for boosting resilience. Improving water, energy, and food security works toward a healthy environment and people, with productive and secure land resources. ${ }^{180}$

The framework encompasses a broad range of socioeconomic and environmental areas, such as water, health, agriculture, fisheries, disaster response, energy, land

\footnotetext{
174 Footnote 171, pp. 11 and 45.

175 Footnote 173, p. 12; and Government of Nauru, Ministry of Commerce, Industry and Environment. 2009. Energy Policy Framework. Yaren. pp. 6 and 14.

176 Footnote 173, pp. 9 and 13.

177 Footnote 173, p. 42.

178 Government of Nauru, Ministry of Commerce, Industry and Environment. 2018. Nauru Energy Road Map 2018 to 2020. Yaren.

179 Footnote 178 , p. 3.

180 Footnote 167, p. 18.
} 
use, infrastructure, biodiversity, as well as community, education, and human development. ${ }^{181}$ It also provides more long-term planning for adaptation and disaster risk reduction activities.

In addition, the framework stresses the need to incorporate gender into these activities. Considering gender would enable "equal and meaningful participation by men, women and youth in planning and decision making." 182 The framework identifies priority actions to facilitate diversity and "empower individuals to be able to plan and respond to different situations" (footnote 182).

Nauru issued its Biodiversity Strategy and Action Plan in 2010 as part of its ecosystem management strategy. ${ }^{183}$ The plan identifies the potentially serious impacts of increased temperatures and sea level rise on the country's biodiversity, committing to protecting and conserving $30 \%$ of Nauru's total land area by $2025 .{ }^{184}$ The adaptation framework acknowledges that implementing Nauru's biodiversity strategy and improving environmental health are critical for climate resilience.

Nauru's National Disaster Risk Management Act 2016 seeks to coordinate disaster response for, among others, natural events induced by climate change.

\section{Palau}

\section{A. Country Snapshot: Climate and Environmental Challenges}

The Republic of Palau comprises an executive branch led by the President, a bicameral legislature called the Olbiil Era Kelulau, and a judiciary. ${ }^{185} \mathrm{As}$ an island nation, Palau is susceptible to the effects of climate change, primarily sea level rise and an increase in extreme weather events such as droughts, flooding, and typhoons. ${ }^{186}$

Sea level rise puts critical infrastructure and facilities that island communities depend on at risk. Water resources and agriculture-both subsistence and commercial—will be adversely affected by climate change. ${ }^{187}$ For example, ocean warming and acidification will impact coral reefs, fisheries, and other marine-based resources that form the backbone of Palau's economy and culture (footnote 187).

181 Footnote 167, pp. 6-7.

182 Footnote 167, p. 51.

183 Government of Nauru, Department of Commerce Industries and Environment. 2010. Nauru's Biodiversity Strategy and Action Plan. Yaren.

184 Footnote 183, p. 23.

185 The Constitution of the Republic of Palau, arts. VIII, IX, and X.

186 Government of Palau. 2016. First Nationally Determined Contribution. Koror. pp. 3-4.

187 Footnote 186, p. 4. 


\section{B. Overarching Climate Change Legal and Policy Framework}

\section{Mitigation and Adaptation Targets}

Palau submitted its first nationally determined contribution (NDC) on 22 April 2016. The NDC provides three unconditional targets by 2025: 22\% emissions reduction from 2005 levels in the energy sector, $45 \%$ renewables share in total energy generated, and 35\% energy efficiency improvement. ${ }^{188}$ The NDC does not include any adaptation commitments.

\section{Overview of Climate Change Law and Policy}

Palau does not have a framework climate change law, but it has enacted various policies and laws addressing environmental and energy issues. It has prioritized adapting to climate change and improving disaster preparedness. It has also set ambitious renewable energy targets, which serve the dual goals of combating climate change and reducing reliance on imported fossil fuels.

Palau's 2015 Climate Change Policy and Action Plan for Climate and Disaster Resilient Low Emissions Development (Climate Policy) is primarily aimed at bolstering the country's resilience to climate change and disasters. ${ }^{189} \mathrm{It}$ forms the basis of Palau's National Adaptation Plan, National Appropriate Mitigation Actions, and its NDC. ${ }^{190}$ It builds on existing efforts to protect carbon sinks, improve energy efficiency, and increase low emission development (footnote 190). This includes commitments to increase renewable energy share in total energy supply to at least $20 \%$ and decrease electrical energy consumption by $30 \%$ by $2020 .^{191}$

By 2020, Palau hopes to establish frameworks to develop climate resilience; build safe, resilient, and disaster-prepared communities; and sustainably manage carbon sinks to reduce GHG emissions by at least $20 \%$ from 2005 levels. ${ }^{192}$ The Climate Policy also sets the goal of creating a framework to make governance more effective, transparent, accountable, responsive, and well-coordinated to build climate resilience and transform Palau to a low-carbon economy. ${ }^{193}$

Climate change and its impacts are addressed directly or indirectly in multiple policies, including those for Palau's energy sectors, and the country's national disaster preparedness framework. Additionally, Palau's Medium-Term Development Strategy for 2009-2014 sets out the Environmental Management

\footnotetext{
188 Footnote 186, p. 1.

189 Government of Palau. 2015. Palau Climate Change Policy: For Climate and Disaster Resilient Low Emissions Development. Koror.

190 Footnote 189, p. 9.

191 Footnote 189, p. 23.

192 Footnote 189, p. 24

193 Footnote 189, p. 27.
} 
Action Plan. ${ }^{194}$ The action plan aims to (i) strengthen environmental legislation by addressing new risks such as climate change, and (ii) develop an energy policy linked with climate policy. ${ }^{195}$

Table 6.9 summarizes Palau's climate change legal and policy framework.

\section{Table 6.9 Climate Change Legal and Policy Framework of Palau}

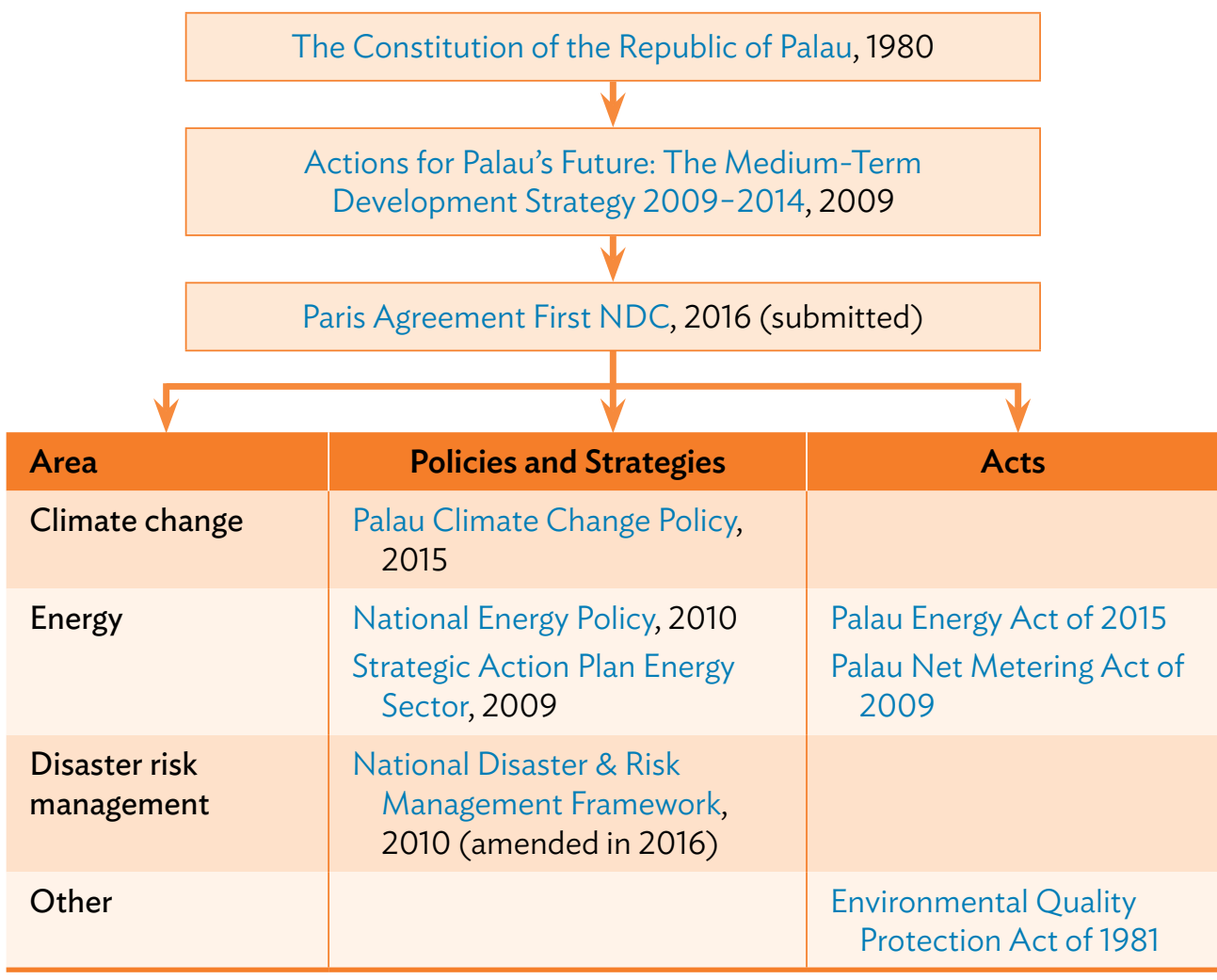

NDC = nationally determined contribution .

Source: Authors.

\section{Energy Supply}

Palau is highly dependent on imported fossil fuels. Of its total energy capacity of 40.1 megawatts (MW), $96.8 \%$ comes from diesel and only $3.2 \%$ from solar photovoltaic. ${ }^{196}$ Its average electricity demand is $8.9 \mathrm{MW}$, and peak demand is 13.5 MW (footnote 196). Palau is investing heavily in renewable energy and hopes

194 Government of Palau. 2009. Actions for Palau's Future: The Medium-Term Development Strategy: 2009 to 2014. Koror.

195 Footnote 194, pp. 132-137.

196 Government of the United States of America, Department of Energy, National Renewable Energy Laboratory. 2015. The Republic of Palau: Pursuing a Sustainable and Resilient Energy Future. Golden, Colorado. 
to generate $20 \%$ of its electrical energy domestically through renewables by the end of 2020 (footnote 191).

\section{Sector-Wide Energy Strategies}

In 2009, Palau put out the Strategic Action Plan Energy Sector, whose goals include (i) conserving energy, and (ii) maximizing cost-effective energy efficiency and renewable resources while safeguarding the environment. ${ }^{197}$ The plan also aims to promote sustainable energy technologies to substitute for imported fossil fuels (footnote 197). Palau also enacted the Palau Net Metering Act of 2009, establishing a net metering system that allows residents to generate their own electricity and encourage renewable energy use.

Palau's National Energy Policy of 2010 (Energy Policy) created the Energy Administration with a mandate to oversee national energy policy implementation. ${ }^{198}$ The Energy Administration was tasked with ensuring Palau's participation in climate change initiatives within the UNFCCC framework. The Energy Policy also promotes energy efficiency and targets "a 30\% reduction in overall national energy consumption by 2020." 199 It advocates for investment in renewable energy, which furthers Palau's climate goals and reduces its reliance on imported energy.

The legislature enacted the Palau Energy Act of 2015 "in order to promote energy security by diversifying the supply of affordable electrical energy within Palau, including renewable energy." 200 The act incorporates the National Energy Policy into law.

\section{Energy Demand}

Palau has made some steps toward promoting energy efficiency. The Energy Administration must set efficiency benchmarks for public utilities such as the Palau Public Utilities Corporation, under the Energy Act of 2015. ${ }^{201}$ The act further instructs the Energy Administration to update Palau's targets for renewable energy and energy efficiency, energy security indicators, and government green fleet efficiency standards, among other metrics. ${ }^{202}$ In part to track progress toward energy efficiency goals, the Energy Administration must prepare the Palau Annual Energy Report for lawmakers. ${ }^{203}$

197 Government of Palau, Palau Energy Office. 2009. Republic of Palau Strategic Action Plan Energy Sector: A Framework for the Implementation of Palau's National Energy Policy. Koror. p. 5.

198 Government of Palau. 2010. Palau National Energy Policy. Koror.

199 Footnote 198, p. 13.

200 Palau Energy Act of 2015, sec. 1.

201 Footnote 200, sec. 2 (amending Title 37 of the Palau National Code by inserting a new Chapter 7), and sec. 704(d) of Chapter 7, which states the Energy Administration's duty to set efficiency benchmarks.

202 Footnote 200, sec. 703(g) of Chapter 7 defines "government green fleet efficiency standards" as "the fuel emissions standards that the Energy Administration establishes for the fleets of relevant government agencies."

203 Footnote 200, secs. 704(b) (1) and 706 of Chapter 7. 


\section{E. Adaptation}

Palau is keenly aware of its vulnerability to climate change and is building resilience to disasters, including through its National Disaster Risk Management Framework. ${ }^{204} \mathrm{~A}$ major goal is improving mechanisms to integrate climate change adaptation and disaster risk management. The Energy Administration is tasked with updating the energy policy to deliver "clean, secure, and affordable energy within Palau, and to respond to the risks of climate change through adaptation and mitigation measures that enhance social and economic resilience and reduce GHG emissions from the energy sector." 205

\section{VIIII. Papua New Guinea}

\section{A. Country Snapshot: Climate and Environmental Challenges}

Located $4^{\circ}$ south of the equator in the West Pacific, Papua New Guinea (PNG) has been described as remote, pristine, and rich in biodiversity. ${ }^{206}$ Shared by PNG and Indonesia, the island of New Guinea is home to the largest tropical rainforest in Asia and the Pacific, the world's third largest after the Amazon and Congo basins. ${ }^{207}$

Despite its rich natural resources, PNG has relatively low per-capita incomes and serious health and social problems. In 2017, 37.5\% of PNG's population lived below the poverty line. ${ }^{208}$ Around $87 \%$ of PNG's 9 million people "live in rural communities, engaging in traditional subsistence and semi-subsistence agriculture in the informal sector." 209

Most Papua New Guineans have traditionally lived a lifestyle with extremely low use of fossil fuels, and thus a low level of GHG emissions. ${ }^{210}$ However, over the last 2 decades, this has begun to change. For instance, earnings from the mining and sale of the country's rich natural resources, such as minerals, oil, and gas, have been used to fund infrastructure development in the main urban areas (footnote 210). Managing these natural resources sustainably to meet the needs of the present without compromising the needs of future generations has been challenging for PNG (footnote 210). Moreover, in the context of climate change, the economy's growth has resulted in a parallel rise in GHG emissions (footnote 210).

\footnotetext{
204 Government of Palau. 2010. National Disaster \& Risk Management Framework 2010 (Amended 2016). Koror.

${ }^{205}$ Footnote 200, sec. 705(a) of Chapter 7.

206 WWF. The Area: Forests of New Guinea.

207 WWF. Biodiversity Hotspot. Rainforest Information. Country Profile: Papua New Guinea.

208 ADB. Poverty Data: Papua New Guinea (accessed 8 October 2020); and ADB. 2019. Basic 2019 Statistics. Manila.

209 World Bank. 2018. Project Information Sheet: Energy Utility Performance and Reliability Improvement Project. Washington, DC. p. 3.

210 Government of PNG. 2016. First Nationally Determined Contribution. Port Moresby. p. 2.
} 
Like other Pacific island countries, PNG sees climate change as an existential threat due to sea level rise, and commits to adapting to climate change and reducing GHG emissions. ${ }^{211}$ PNG's potential to contribute to this effort stems largely from land use, although the country is also striving to tap into renewable energy such as hydroelectric power. ${ }^{212}$

\section{B. Overarching Climate Change Legal and Policy Framework}

\section{Mitigation and Adaptation Targets}

PNG submitted its first nationally determined contribution (NDC) on 24 March 2016. It aims to achieve a carbon-free electricity sector by 2030 , conditional on external funding. Although the NDC does not include any quantitative adaptation commitments, it emphasizes the need for adaptation in PNG.

\section{Overview of Climate Change Law and Policy}

PNG has a number of policies expressly aimed at addressing climate change. Forest management and energy use are governed by numerous other policies, laws, and regulations.

The 2014 National Climate Change Compatible Development Management Policy outlines the national government's guide to building climate resiliency and achieving carbon neutrality through sustainable development. ${ }^{213}$ It aims for "a low carbon growth pathway by 2030 and [to] become climate compatible by 2050." ${ }^{214}$ It names the Climate Change Institutional Authority and the National Climate Fund as key institutions that must be created, and highlights the need for provincial governments and local governments to play a role in implementing climate change activities. ${ }^{215}$

The policy also articulates the need for new legislation to address climate change and calls on the government to enforce current climate change policies (footnote 215). It focuses on reducing emissions in agriculture, and land use, land-use change, and forestry (LULUCF) (footnote 214). The policy further instructs the government to consider climate change in surface transportation programs, promote economic incentives for fuel-efficient vehicles, and take other steps to reform the nation's transportation system to combat and prepare for climate change. ${ }^{216}$ Finally, the policy discusses the need for investment in renewable energy, particularly geothermal and hydropower. ${ }^{217}$

211 Footnote 210, pp. 1 and 7.

212 Footnote 210, pp. 1 and 4.

213 Government of PNG, Office of Climate Change \& Development. 2014. National Climate Compatible Development Management Policy. Port Moresby.

214 Footnote 213, p. 3.

215 Footnote 213, p. 13.

216 Footnote 213, pp. 18-19.

217 Footnote 213, p. 19. 
The Forestry and Climate Change Framework for Action 2009-2015 establishes the medium-term vision for climate change and forestry. ${ }^{218}$ It follows the Fourth National Goal and Directive Principle of the Constitution, seeking to ensure the responsible use of forest resources for present and future generations. ${ }^{219}$ The framework's specific objectives include managing and protecting forests, implementing adaptation measures, and contributing to mitigation efforts. Furthermore, the framework articulates the desire to prioritize benefit sharing in carbon trading schemes as they may arise. ${ }^{220}$

The United Nations Paris Agreement (Implementation) Act 2016 makes the Paris Agreement law in PNG. It clarifies that implementing the Paris Agreement will occur in accordance with it and the Climate Change (Management) Act 2015. Furthermore, it identifies the Climate Change and Development Authority as responsible for implementation by

(i) determining the benefits and levies of the Organic Law on Provincial Governments and Local-level Governments 1998 with respect to GHG emissions and carbon capture and storage;

(ii) determining the rates, management, sharing arrangements, and application of related benefits and levies; and

(iii) establishing and administering trust funds provided by the Organic Law. ${ }^{221}$

The act further

(i) establishes the principles for sharing revenues generated from economic regulatory regimes for emitting and sequestering carbon;

(ii) establishes the consultation process on the consequences of GHG emissions on local development; and

(iii) defines the legal framework necessary to adopt regulations on GHG emissions, as well as organizational and financial implications. ${ }^{222}$

The Climate Change (Management) Act 2015 established the Climate Change and Development Authority. ${ }^{223}$ The authority (i) promotes and manages climate-compatible development through mitigation and adaptation activities;

(ii) implements obligations under international rules and agreements;

(iii) represents PNG at the UNFCCC; and (iv) administers international funding to assist in climate change initiatives. ${ }^{224}$ The law also established the National Climate Change Board, which provides general control over, and guidance to, the Climate Change and Development Authority. ${ }^{225}$

218 Government of PNG, Forest Authority. 2009. Forestry and Climate Change Framework for Action 2009-2015. Port Moresby.

219 Footnote 218, p. 7.

220 Footnote 218, p. 9.

221 United Nations Paris Agreement (Implementation) Act 2016, sec. 7(2) in relation to sec. 2(2).

222 Footnote 221, secs. 2(3), 2(4), and 12.

223 Climate Change (Management) Act 2015, sec. 8(1).

224 Footnote 223 , sec. 10.

225 Footnote 223, secs. 12 and 13(1). 
The act further requires measuring GHG emissions and the removal of targeted GHGs. ${ }^{226}$ The National Climate Change Board recommends the reference level and targets for national net emissions of carbon dioxide $\left(\mathrm{CO}_{2}\right)$ and other $\mathrm{GHGs}$ each year. ${ }^{227}$ Additionally, each person, organization, group, or any other such body participating in an activity in a regulated sector must prepare an annual adaptation plan and a mitigation plan to reduce its $\mathrm{GHG}$ emissions and increase carbon capture in a sink. ${ }^{228}$ Finally, the act provides for the promulgation of regulations on fuel and building standards. ${ }^{229}$

Additionally, PNG's multiple development strategies contain some discussion of climate change and energy. Developed in 2009, Papua New Guinea Vision 2050 includes environmental sustainability and climate change as one of its seven strategic focus areas. ${ }^{230}$ The Medium Term Development Plan 2 2016-2017 articulates the goals of heightening climate resilience, protecting PNG's important rainforests, and reducing fossil fuel use in energy systems. ${ }^{231}$

Under its Medium Term Development Plan III 2018-2022, the government links mitigation and adaptation with its responsible sustainable development goals and strategies. ${ }^{232}$ It plans to improve resilience to climate change and support global efforts to abate GHG emissions. ${ }^{233}$ It specifically targets the need to improve legislative frameworks and negotiate improved funding and "technical, institutional and technology support for climate change mitigation." 234

The National Strategy for Responsible Sustainable Development aims to redirect the socioeconomic growth of PNG away from present unsustainable strategies and toward sustainable and responsible methods of growth. ${ }^{235}$ It encourages investment in, among other things, renewable energy, green agriculture, and sustainable cities.

The Development Strategic Plan 2010-2030 stresses that PNG must understand how and where climate change is likely to impact the country, and that PNG must make a significant contribution to reducing $\mathrm{GHG}$ through forest management and the development of its hydroelectric potential. ${ }^{236}$ Moreover, PNG can "further its interests and those of other Pacific island states by engaging effectively in

226 Footnote 223, sec. 54(1).

227 Footnote 223, sec. 56(1)(I).

228 Footnote 223, secs. 65(1) and 74(1).

229 Footnote 223, secs. 67-68.

230 Government of PNG. 2009. Papua New Guinea Vision 2050. Port Moresby. pp. xiv, 31-32.

231 Government of PNG, Department of National Planning and Monitoring. 2015. Medium Term Development Plan 2 2016-2017. Port Moresby.

232 Government of PNG, Department of National Planning and Monitoring. 2018. Medium Term Development Plan III 2018-2022. Port Moresby.

233 Footnote 232, p. 47.

234 Footnote 232, p. 50.

235 Government of PNG, Department of National Planning and Monitoring. 2014. National Strategy for Responsible Sustainable Development for Papua New Guinea. 2nd ed. Port Moresby.

236 Government of PNG, Department of National Planning and Monitoring. 2010. Development Strategic Plan 2010-2030. Port Moresby. 
global climate change negotiations." 237 The plan recognizes that strategies for the extractive and energy sectors will need to take climate considerations into account. 238

Finally, PNG's constitution establishes five overarching goals and directives, the fourth of which is the conservation of the environment's natural resources. Under this directive, the country strives for PNG's "natural resources and environment...be conserved and used for the collective benefit of us all, and be replenished for the benefit of future generations." 239

Table 6.10 summarizes PNG's climate change legal and policy framework.

\section{Energy Supply}

Although approximately $59 \%$ of the population had access to electricity in 2018 , rates of access to grid electricity are low in PNG ${ }^{240}$ Rural electrification is challenging due to PNG's mountainous terrain and dispersed population. ${ }^{241}$ In 2017, ADB estimated that grid penetration was less than 4\% in rural areas (footnote 241). ADB's Power Sector Development Investment Program aims to boost household electrification to $70 \%$ by $2030 . .^{242}$

PNG has one of the world's lowest consumption of electricity per capita. ${ }^{243}$ In 2014, its total primary energy supply (TPES) was 2.479 million metric tons of oil equivalent (Mtoe). ${ }^{244}$ Oil remained its major energy source, accounting for $44 \%$ of TPES (Figure 1) (footnote 244 ). PNG's TPES is projected to grow at $4.5 \%$ annually in 2010-2035. ${ }^{245}$ The total final energy consumption was 1.194 Mtoe in 2014 (footnote 244).

Low rates of electrification have made PNG reliant on imported fuels. Rural populations use kerosene, biomass, and candles for energy. ${ }^{246}$ Further, $95 \%$ of the rural population use biomass-wood, dung, and burnt agricultural waste-as cooking fuel (footnote 246). PNG has commercial reserves of liquefied natural

237 Footnote 236, p. 120.

238 Footnote 236, p. 5.

239 The Constitution of the Independent State of Papua New Guinea, Preamble, art. 4.

240 World Bank. Access to Electricity (\% of Population) - Papua New Guinea (accessed 8 October 2020).

241 ADB. 2017. Concept Paper: Proposed Multitranche Financing Facility to Papua New Guinea for the Power Sector Development Investment Program. Manila. p. 1.

242 Footnote 241, p. 2.

243 Australia and New Zealand Banking Group Limited (ANZ). 2015. ANZ Insight: Powering PNG into the Asian Century. (6). Sydney. p. 5.

244 Asia-Pacific Economic Cooperation (APEC). 2017. Peer Review on Low Carbon Energy Policies in Papua New Guinea: Final Report. Singapore. p. 3.

245 APEC. 2013. Papua New Guinea. In APEC. APEC Energy Demand and Supply Outlook. 5th ed. Tokyo: Asia Pacific Energy Research Centre. p. 136.

246 Footnote 243, p. 7. 


\section{Table 6.10: Climate Change Legal and Policy Framework of Papua New Guinea}

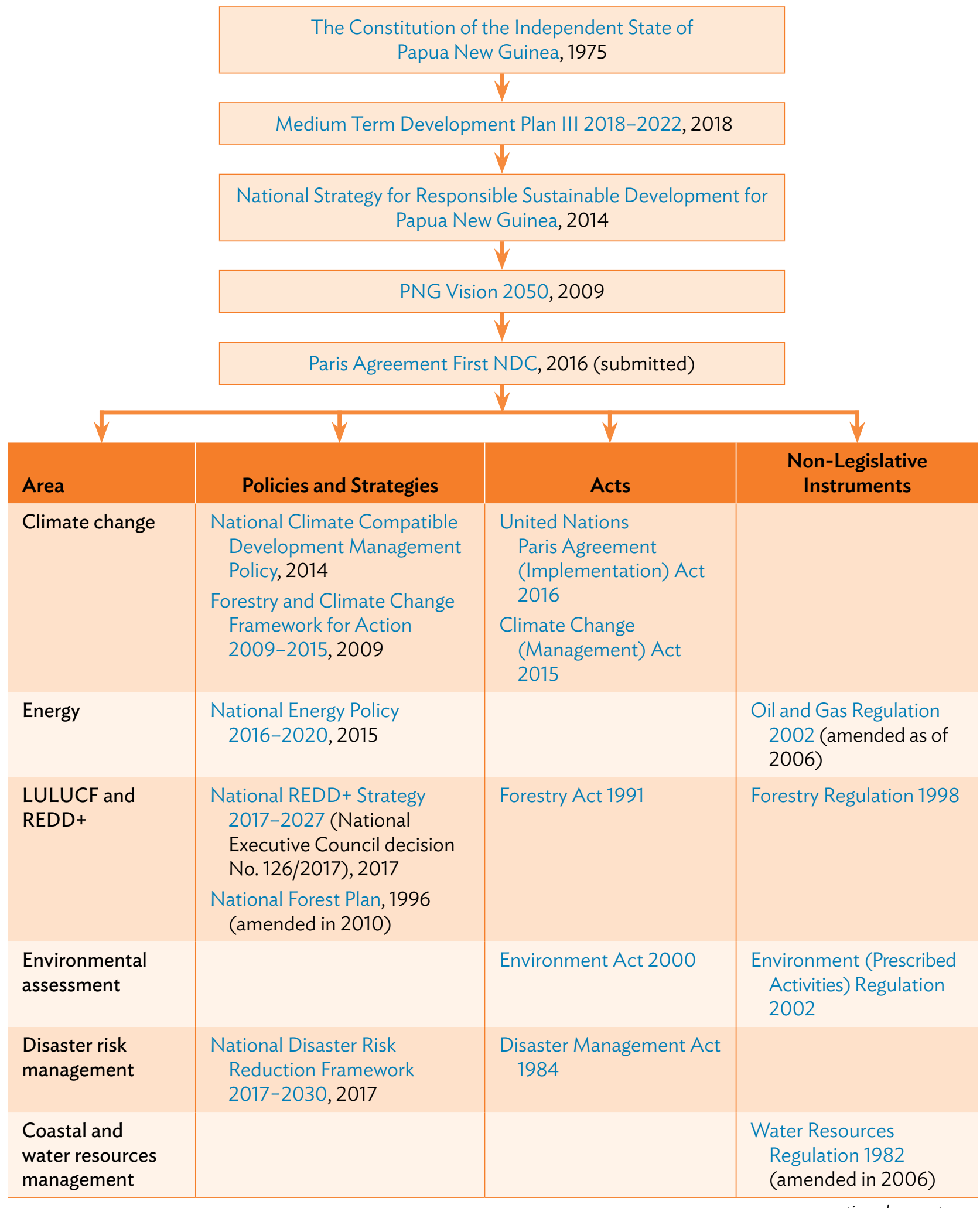


Table 6.10 continued

\begin{tabular}{l|c|c|c|}
\hline \multirow{2}{*}{ Area } & Policies and Strategies & Acts & $\begin{array}{c}\text { Non-Legislative } \\
\text { Instruments }\end{array}$ \\
\hline \multirow{2}{*}{ Other } & $\begin{array}{c}\text { Medium Term Development } \\
\text { Plan 2 2016-2017, 2015 }\end{array}$ & $\begin{array}{c}\text { Conservation and } \\
\text { Environment Protection }\end{array}$ & Authority Act 2014 \\
& $\begin{array}{c}\text { National Strategy for } \\
\text { Responsible Sustainable } \\
\text { Development for PNG, 2014 }\end{array}$ & $\begin{array}{c}\text { Environmental } \\
\text { Contaminants Act 1978 }\end{array}$ \\
& $\begin{array}{l}\text { Development Strategic Plan } \\
\text { 2010-2030, 2010 }\end{array}$ & \\
\hline
\end{tabular}

LULUCF = land use, land-use change, and forestry; NDC = nationally determined contribution; REDD + = reducing emissions from deforestation and forest degradation, conservation of existing forest carbon stocks, sustainable forest management, and enhancement of forest carbon stocks.

Source: Authors.

gas and decreasing reserves of oil. ${ }^{247}$ As of 2013, PNG's proven hydrocarbon reserves consisted "primarily of natural gas ( 440 billion cubic meters), followed by oil ( 0.660 billion barrels) and gas condensates ( 0.262 billion barrels)." 248

The government has ambitious plans for improving electricity supply. The Development Strategic Plan 2010-2030 outlines the government's intention to connect $70 \%$ of the population to electricity by $2030 . .^{249}$ In 2016 , the government released the PNG National Energy Policy 2016-2020, envisioning that 70\% of the population will have access to electricity. ${ }^{250}$ The government intends to power $100 \%$ of its energy supply from renewable and sustainable energy sources by 2050 (footnote 250).

Despite PNG's commitment to transitioning to renewables, the National Energy Policy indicates the government's intention to fast-track the exploration and development of indigenous coal reserves for power generation. ${ }^{251}$ The policy identifies coal's capacity to enable the government to reliably and cheaply meet its electrification targets. ${ }^{252}$

PNG also has significant hydroelectric potential, which the government intends to explore. Total capacity of around 15,000 MW sits across nine large hydrological basins, of which less than $1 \%$ is utilized. ${ }^{253}$

247 Footnote 245; and Government of PNG, Department of Public Enterprises and Department of Petroleum and Energy. 2015. National Energy Policy 2016-2020. Port Moresby. p. xii.

248 Footnote 245; and p. 134.

249 Footnote 236, p. 15.

250 Government of PNG, Department of Public Enterprises and Department of Petroleum and Energy. 2015. National Energy Policy 2016-2020. Port Moresby. p. 2.

251 Footnote 250, p. 26.

252 Footnote 250, p. 38.

253 Footnote 245, p. 134; and footnote 250, p. 43. 


\section{Figure 1: Papua New Guinea's Total Primary Energy Supply, 2014}

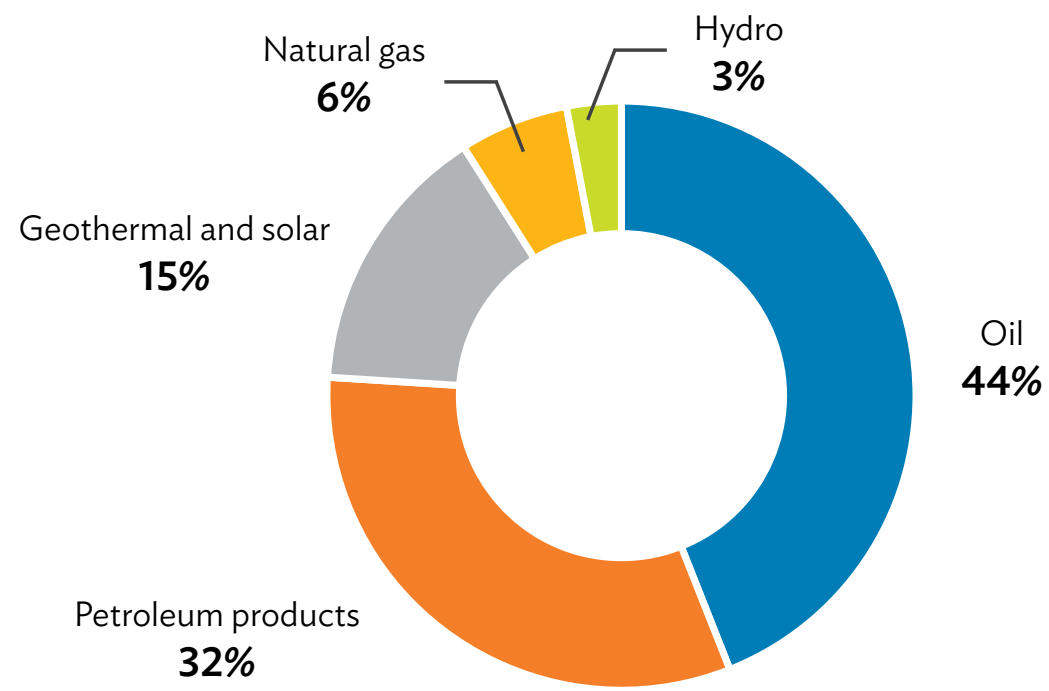

Source: Source: Asia-Pacific Economic Cooperation (APEC). 2017. Peer Review on Low Carbon Energy Policies in Papua New Guinea. Singapore. p. 3.

\section{LULUCF and REDD+}

PNG's pristine rainforests are under threat. During 2002-2014, industrial logging cleared 11,457 square kilometers $\left(\mathrm{km}^{2}\right)$ of pristine forest. ${ }^{254}$ By 2014 , around one-third of PNG's commercial forests had been logged. ${ }^{255}$

PNG has a number of policies governing forest management. The National REDD+ Strategy 2017-2027 aims to address climate change and align with PNG's green growth development agenda. ${ }^{256}$ The strategy seeks to encourage forest sustainability to ultimately decrease emissions of GHGs as well as climate change vulnerability. It has two components: (i) policies and measures and (ii) coordination and reporting. ${ }^{257}$

The 1996 National Forest Plan, amended in 2010, contains several guidelines and plans, including (i) the National Forest Development Programme, (ii) an annual statement of cut volumes, (iii) provincial forest plans, and (iv) the National Forest

\footnotetext{
254 J. Garrett. 2016. Losing Papua New Guinea's Rainforest. ABC. 10 March.

255 J. Gabbatiss. 2018. Alarming Photos Reveal Devastating Scale of Rainforest Destruction in Papua New Guinea. Independent. 21 March.

256 Government of PNG, Climate Change and Development Authority. 2017. Papua New Guinea National REDD+ Strategy 2017-2027. Port Moresby. p. 7.

257 Footnote 256, p. 23.
} 
Development Guidelines. ${ }^{258}$ The guidelines encourage developing a focus on future carbon-based schemes to combat climate change. ${ }^{259}$

The National Forest Plan also sets targets for reforestation and protection, and mentions carbon trading as a means of financial environmental action. ${ }^{260}$ The PNG Forest Authority has established a branch for REDD+ and climate change activities. ${ }^{261}$ According to the plan, the Forest Authority must do the following to address climate change:

(i) continue to be active participants in climate change issues, especially land use, land-use change, and forestry (LULUCF);

(ii) maintain and upgrade an information database on issues related to climate change;

(iii) conduct training and awareness on climate change and REDD+;

(iv) identify geographical areas for initiating REDD+, afforestation and reforestation (or other clean development mechanisms), and watershed management projects;

(v) incentivize landowners and timber industries to undertake afforestation and reforestation activities on grassland and degraded sites;

(vi) continue research and support for other research initiatives into the science of climate change and mitigation;

(vii) help develop and implement a national climate change policy;

(viii) help develop and implement a national REDD + strategy;

(ix) implement the Climate Compatible Development Plan with the Office of Climate Change and Development (now the Climate Change and Development Authority);

(x) implement five REDD+ pilot projects; and

(xi) maintain dialogue on REDD + and climate change issues with all stakeholders at the local, national, regional, and international levels. ${ }^{262}$

Finally, the Forestry Act 1991 authorizes the head of state to declare any government land as a national forest. ${ }^{263}$ The Forestry Regulation 1998 requires permits for burning forests, harvesting timber, and other uses. ${ }^{264}$

\section{E. Adaptation}

As mentioned, the Climate Change and Development Authority is responsible for promoting and managing climate-compatible development through mitigation

258 Government of PNG, PNG Forest Authority. 1996. National Forest Plan (amended in 2010). Port Moresby. p. 1.

259 Footnote 258, p. 3.

260 Footnote 258, p. 8.

261 Footnote 258, p. 17.

262 Footnote 258, pp. 17-18.

263 Forestry Act 1991, sec. 3.

264 Forestry Regulation 1998, secs. 77, 118, 159, 161, 163, 165, and 167. 
and adaptation activities (footnote 224). The Development Strategic Plan 2010-2030 also stresses that PNG must assess how and where climate change is likely to impact the country (footnote 236). PNG has stated that it will need financial support, capacity building, and technical support to face the threats posed by climate change. ${ }^{265}$

\section{F. Disaster Risk Management}

PNG's National Disaster Risk Reduction Framework (NDRRF) 2017-2030 seeks to integrate into domestic policy the international best practices for disaster risk reduction as articulated in the Sendai Framework for Disaster Risk Reduction 2015-2030. ${ }^{266}$ It aims to harmonize PNG's policies with the Framework for Resilient Development in the Pacific 2017-2030 and the Asia-Pacific Economic Cooperation Disaster Risk Reduction Plan (footnote 266). It specifies the functions and relationships between different government departments and agencies with respect to disaster risk management and reduction. ${ }^{267}$

The NDRRF is anchored on the Disaster Management Act 1984. The act established a framework for the efficient and effective response and management of natural disasters in PNG. The act also established the National Disaster Committee and the National Disaster Centre at both the national and provincial levels. ${ }^{268}$

\section{Samoa}

\section{A. Country Snapshot: Climate and Environmental Challenges}

The Independent State of Samoa is a small island developing state in the southern Pacific Ocean with a parliamentary democracy. ${ }^{269}$ It has a population of about 195,000 and consists of nine volcanic islands, only four of which are inhabited (footnote 269).

It is very vulnerable to climate change impacts because at least $70 \%$ of its population and infrastructure are in low-lying coastal areas on two main islands: Savaii and Upolu. ${ }^{270}$ As of 2017, Samoa ranked 124th in the Global Climate

\footnotetext{
265 Footnote 210, p. 7.

266 Government of PNG, National Disaster Centre. 2017. Papua New Guinea National Disaster Risk Reduction Framework 2017-2030. Port Moresby. p. 11.

267 Footnote 266, pp. 17 and 30.

268 Disaster Management Act 1984, secs. 3 and 15.

269 Pacific Trade Invest Australia. Country Profile - Samoa: Treasured Islands of the South Pacific.

270 X. Flores-Palacios. 2015. Samoa: Local Knowledge, Climate Change and Population Movements. In M. Couldrey and M. Herson, eds. Disasters and Displacement in a Changing Climate. Forced Migration Review. (49). p. 59.
} 
Risk Index. ${ }^{271}$ Samoa suffers from increased frequency and intensity in extreme weather and other climate events, such as earthquakes, tsunamis, and cyclones. ${ }^{272}$

\section{B. Overarching Climate Change Legal and Policy Framework}

\section{Mitigation and Adaptation Targets}

Samoa submitted its first nationally determined contribution (NDC) on 22 April 2016, committing to a $100 \%$ renewable energy target by $2025 .{ }^{273}$ The commitment is conditional on receiving international assistance to reach the 100\% target in 2017, and maintain it through to 2025 (footnote 273). Achieving economy-wide emissions reductions is also conditional on international aid (footnote 273).

\section{Overview of Climate Change Law and Policy}

Samoa has adopted two major climate policies-the Strategic Programme for Climate Resilience and the National Policy of Combating Climate Change. The strategic program, launched in 2011, explores ways to increase Samoa's climate resilience through various sectors. ${ }^{274}$ It identifies critical climate change vulnerabilities, including damage caused by high seas, strong winds, droughts, and flooding. ${ }^{275}$ It also identifies highways and roads, agriculture, forestry and fishing, flood protection, and civic engagement as key sectors for climate intervention (footnote 275). It outlines two investment projects: enhancing the West Coast Road's climate resilience and improving the resilience of coastal resources and communities (footnote 275). For financial assistance, the program states an intent to establish a trust fund for adaptation to climate change.

In 2007, the government launched the National Policy of Combating Climate Change. ${ }^{276}$ The policy articulates the overall goal of enhancing "Samoa's response to the impacts of climate change in support of national sustainable development efforts." ${ }^{277}$ It includes the following specific objectives:

(i) raising stakeholder understanding and overall public awareness of climate change causes and impacts,

(ii) bettering climate change information and data management,

(iii) strengthening effective national climate change responses,

(iv) implementing measures toward mitigating GHG emissions,

271 D. Eckstein, M. Hutfils, and M. Winges. 2018. Global Climate Risk Index 2019: Who Suffers Most from Extreme Weather Events? Weather-Related Loss Events in 2017 and 1998 to 2017. Briefing Paper. Bonn: Germanwatch e.V. p. 31.

272 Global Facility for Disaster Reduction and Recovery. Samoa.

273 Government of Samoa. 2016. First Nationally Determined Contribution. Apia. p. 2.

274 Government of Samoa. 2011. Strategic Programme for Climate Resilience (SPCR). Apia.

275 Footnote 274, p. iv.

276 Government of Samoa, Ministry of Natural Resources \& Environment. 2007. National Policy of Combating Climate Change. Apia.

277 Footnote 276, p. 3. 
(v) implementing measures toward climate change adaptation, and

(vi) establishing a regulatory framework to bolster the national climate change response. ${ }^{278}$

In addition to the Strategic Programme for Climate Resilience and the National Policy of Combating Climate Change, the government developed the National Adaptation Programme of Action in 2005. ${ }^{279}$ The program guides the country's response to its most urgent adaptation needs.

Understanding the need to clarify its longer-term aspirations, Samoa is developing Samoa 2040 as part of its national development agenda. ${ }^{280}$ Thematic areas will include ensuring resilient development and aiming for a safe and secure Samoa.

Table 6.11 summarizes Samoa's climate change legal and policy framework.

\section{Energy Supply}

Samoa meets its energy needs primarily by importing fuels and petroleum products. ${ }^{281}$ These fuels include (i) unleaded petrol, widely used for terrestrial and marine transport; and (ii) automotive diesel, used for electricity generation, heavy machinery, and land and marine transport. ${ }^{282}$

As of $2018,100 \%$ of the population had access to electricity. ${ }^{283}$ In 2016 (the latest year for which data is available), electricity consumption by the commercial and industrial sector accounted for $39 \%$ of total consumption, while the residential sector accounted for 31\%. Other sectors accounted for the remaining 30\% (Figure 2).

\section{Sector-Wide Strategies}

Samoa has produced plans to guide the energy sector. The Energy Sector Plan 2012-2016 has an overarching goal of increasing energy self-sufficiency by shifting to renewable energy and reducing "the growth rate in the volume of imported fossil fuels by $10 \%$ by $2016 . " 284$ In the Energy Sector Plan 2017-2022, the government adopted the theme of "Sustainable and Affordable Energy for All." 285 The 2017-2022 plan seeks to align with the Strategy for the Development of Samoa 2016/17-2019/20, which focuses on "Accelerating Sustainable Development and

\footnotetext{
278 Footnote 276, pp. 3-5.

279 Government of Samoa, Ministry of Natural Resources, Environment \& Meteorology. 2005. National Adaptation Programme of Action: Samoa. Apia.

280 Government of Samoa, Public Service Commission. "Samoa 2040" Looks at Transforming Samoa to Higher Growth Path in the Next 20 Years.

281 Government of Samoa, Ministry of Finance. 2007. Samoa National Energy Policy. Apia. p. 11.

282 Footnote 281, p. 20.

283 World Bank. Access to Electricity (\% of Population) (accessed 10 October 2020).

284 Government of Samoa, Ministry of Finance. 2012. Samoa Energy Sector Plan 2012-2016. Apia. p. 18.

285 Government of Samoa, Ministry of Finance. 2017. Samoa Energy Sector Plan 2017-2022. A pia. p. 4.
} 


\section{Table 6.11: Climate Change Legal and Policy Framework of Samoa}

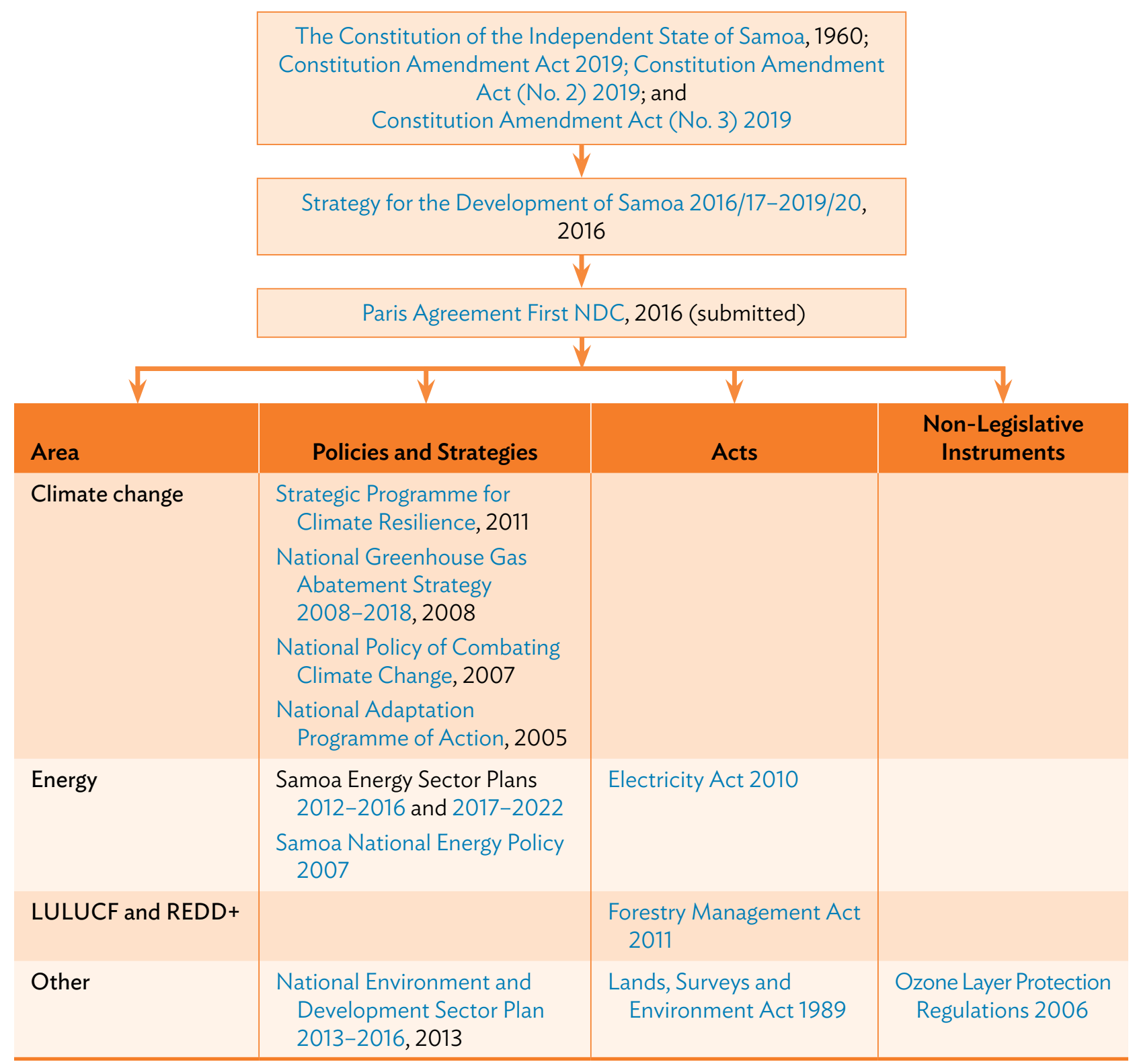

LULUCF = land use, land-use change, and forestry; NDC = nationally determined contribution; REDD+ = reducing emissions from deforestation and forest degradation, conservation of existing forest carbon stocks, sustainable forest management, and enhancement of forest carbon stocks.

Source: Authors. 


\section{Figure 2: Electricity Consumption in Samoa by Sector, 2016}

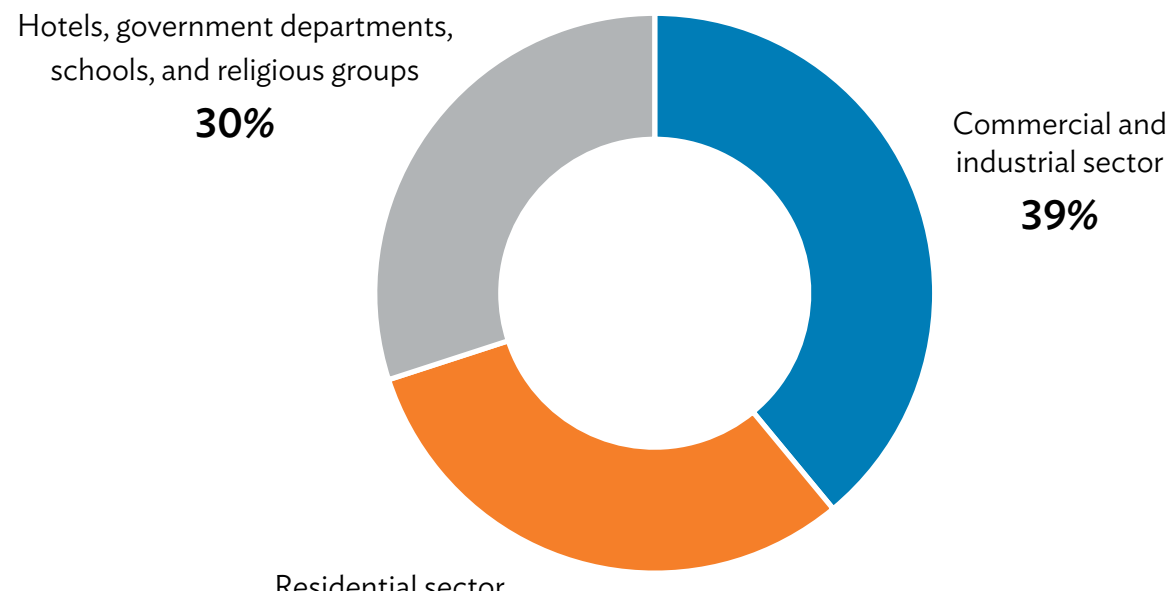

$31 \%$

Source: Government of Samoa, Ministry of Finance. 2017. Samoa Energy Review 2016. Apia. p. 22.

Broadening Opportunities for All." 286 In addition, the government formulated an ambitious target of $100 \%$ renewable energy capacity to further drive its vision for sustainable energy supply in the country. ${ }^{287}$ This target was formalized in Samoa's first NDC (footnote 273).

The NDC further notes electricity sector reforms that improved the country's energy mix. "The Electricity Act 2010 introduces key regulatory changes which have allowed the private sector to be involved in generating electricity and selling it back to the utility. This has allowed independent power producers (IPPs) to build and operate renewable energy power plants and sell electricity to the grid." 288

Other key policy drivers include the National Greenhouse Gas Abatement Strategy 2008-2018 and the National Policy of Combating Climate Change 2007. ${ }^{289}$ The abatement strategy acknowledges the importance of committing to mitigation strategies as a global responsibility. The national policy identifies the

286 Footnote 285; and Government of Samoa, Ministry of Finance. 2016. Strategy for the Development of Samoa 2016/17-2019/20. Apia. p. ii.

287 Government of Samoa, Ministry of Finance. 2016. Strategy for the Development of Samoa 2016/17-2019/20. Apia. p. 13.

288 Footnote 273, p. 7. In 2016, the Samoa Electric Power Corporation had power purchase agreements with six IPPs. UN Economic and Social Commission for Asia and the Pacific. 2016. Asia-Pacific Countries with Special Needs Development Report 2016: Adapting the 2030 Agenda for Sustainable Development at the National Level. Bangkok. p. 28.

289 Samoa Environment Data Portal. National Greenhouse Gas Abatement Strategy 2008-2018 (accessed 10 October 2020); and footnote 276. 
need to develop renewable energy sources - solar, wind, and ocean energy-to reduce GHG emissions. It further recognizes the need for strategies to promote energy efficiency in energy supply, industry, buildings, and transportation. The NDC thus includes the following targets:

(i) achieve a total installed capacity of 6 megawatts (MW) by September 2015 through projects initiated by the public utility or by independent power producers, with total capacity expected to increase over the next 2 years;

(ii) achieve 550 kilowatts ( $\mathrm{kW}$ ) of installed wind power capacity;

(iii) rehabilitate $3.5 \mathrm{MW}$ of hydropower by restoring hydropower plants destroyed by Cyclone Evan in 2012 and through small run-of-river schemes;

(iv) incentivize IPPs to generate $12 \mathrm{MW}$ of bioenergy from various biomass, biogas, or alternative bioenergy sources; and

(v) regulate the importation of energy-inefficient appliances, establish product and labeling standards, replace older and less efficient light bulbs with more efficient alternatives, and implement other demand side management programs. ${ }^{290}$

\section{Renewable Energy Policies}

Under the Energy Sector Plan 2017-2022, Samoa continues its path to energy self-sufficiency by promoting renewable energy, energy efficiency, and energy conservation. ${ }^{291}$ Aiming for $100 \%$ renewable energy share in total energy generation, Samoa plans to (i) develop an overarching energy sector legislation and supporting regulations, (ii) form and strengthen partnerships among stakeholders, (iii) foster private sector investment in renewable energy, (iv) monitor the development and implementation of renewable energy projects, ( $v$ ) integrate renewable energy education into the school curriculum, and (vi) disseminate information on renewable energy. ${ }^{292}$

\section{LULUCF and REDD+}

Approximately $58.3 \%$ of Samoa's land area is covered by what the government has officially designated as forest. ${ }^{293}$ However, the definition of forest excludes small woodlots, small reserves, small patches of mangrove forests, seawall plantings, agroforestry, and other young tree plantings (footnote 293). There has been a decrease of $1.7 \%$ in forest cover due to Cyclone Evan in 2012, agricultural developments, and expansion of residential and industrial areas (footnote 293).

According to the Forestry Management Act 2011, the ministry responsible for forest management must formulate and implement policies and programs in support of international climate change conventions and protocols. ${ }^{294}$ The

290 Footnote 273, p. 7.

291 Footnote 285, p. 9.

292 Footnote 285, pp. 24 and 27-28.

293 Government of Samoa. 2014. Voluntary National Report to the 11th Session of the United Nations Forum on Forests. Apia. p. 9.

294 Forestry Management Act 2011, sec. 32(1). 
act also provides for harvesting licenses and permits for forestry resource management, encourages lands to be declared protected, and authorizes forestry resource inventories in support of carbon trading. ${ }^{295}$

\section{E. Adaptation}

In strategic documents, Samoa consistently identifies climate change adaptation as a central goal. The National Adaptation Programme of Action (NAPA), for example, identifies key sectors with immediate adaptation needs. ${ }^{296}$ It "aims to communicate urgent and immediate adaptation needs and the activities to address these needs to deal with the adverse impacts of climate change; and to develop the strategies for capacity building amongst stakeholders and village communities." 297

NAPA's objectives include implementing project-based actions for climate change adaptation; protecting people, infrastructure, and the environment; incorporating measures for adaptation into policy and development goals; and increasing climate change awareness (footnote 297). NAPA also set out priority actions for a range of areas, such as water security, forest development, climate health, early warning systems, food security and sustainability, zoning and planning, coastal infrastructure management, conservation program establishment, and sustainable tourism. ${ }^{298}$

\section{Solomon Islands}

\section{A. Country Snapshot: Climate and Environmental Challenges}

Covering 28,000 square kilometers $\left(\mathrm{km}^{2}\right)$ of land, Solomon Islands is an archipelago of 994 islands. ${ }^{299}$ Some islands have a mountainous landscape of volcanic origin, while others are coral atolls (footnote 299). There are six main islands-Choiseul, New Georgia, Santa Isabel, Malaita, Guadalcanal, and Makira. The country has almost 670,000 inhabitants as of 2019 , with around $80 \%$ of the national population living in low-lying coastal areas. ${ }^{300}$ Currently considered a least developed country (LDC), Solomon Islands is scheduled to graduate to a developing country in $2024 .{ }^{301}$ It is a parliamentary democracy and follows the English common law system.

\footnotetext{
295 Footnote 294, secs. 37, 32(3), and 58.

296 Footnote 279, p. 7.

297 Footnote 279, p. 16.

298 Footnote 279, pp. 23-24.

299 Government of Solomon Islands. 2016. First Nationally Determined Contribution. Honiara. p. 3.

300 World Bank. Population, Total - Solomon Islands (accessed 10 October 2020); and footnote 299, pp. 4 and 8.

301 United Nations, Department of Economic and Social Affairs. Least Developed Country Category: Solomon Islands Profile.
} 
Solomon Islands is highly vulnerable to the adverse impacts of climate change, including droughts, extreme rainfall, floods, exceptionally high tides, and sea level rise. ${ }^{302} \mathrm{GHG}$ emissions from Solomon Islands are minimal, and per capita emissions are already less than the estimated level required to stay below $1.5^{\circ} \mathrm{C}$ (as compared with $2^{\circ} \mathrm{C}$ ) of warming. ${ }^{303}$

\section{B. Overarching Climate Change Legal and Policy Framework}

\section{Mitigation and Adaptation Targets}

The Government of Solomon Islands submitted its first nationally determined contribution (NDC) on 21 September 2016. While Solomon Islands is an LDC and a small island nation, it commits nonetheless in its first NDC to reduce its emissions by $12 \%$ below the 2015 level by 2025 , and $30 \%$ below by $2030 .{ }^{304} \mathrm{It}$ seeks a $27 \%$ reduction in GHG emissions by 2025 and a $45 \%$ reduction by 2030 , compared with a business as usual (BAU) projection (footnote 304 ). With international assistance, Solomon Islands can reduce its emissions by more than $50 \%$ by 2050 (footnote 304).

\section{Overview of Climate Change Law and Policy}

The Ministry of Environment, Climate Change, Disaster Management and Meteorology is primarily responsible for climate change measures. ${ }^{305}$ It has issued one major climate policy, the National Climate Change Policy 2012-2017, which sets goals for 5 years. These goals include (i) implementing adaptation and mitigation efforts, (ii) integrating climate change into national development, (iii) improving governance structures, (iv) promoting renewable energy and energy efficiency, and ( $v$ ) fortifying citizen resilience. ${ }^{306}$ Furthermore, the policy discusses financing and disaster risk management. ${ }^{307}$

The National Development Strategy 2016-2035 also provides climate-related guidance, setting a long-term target of responding effectively to climate change and natural disasters. ${ }^{308}$

Table 6.12 summarizes Solomon Islands' climate change legal and policy framework.

302 Footnote 299, p. 12.

303 Footnote 299, p. 8.

304 Footnote 299, p. 7.

305 Footnote 299, p. 14; and Government of Solomon Islands. 2011. Assignment of Responsibility to the Minister for Environment [,] Climate Change, Disaster Management and Meteorology. Honiara.

306 Government of Solomon Islands, Ministry of Environment, Climate Change, Disaster Management and Meteorology. 2012. National Climate Change Policy 2012-2017. Honiara. pp. 13-14.

307 Footnote 306, pp. 19-22 and 27-28.

308 Government of Solomon Islands, Ministry of Development Planning and Aid Coordination. 2016. National Development Strategy 2016-2035. Honiara. p. 11. 


\section{Table 6.12: Climate Change Legal and Policy Framework of Solomon Islands}

\begin{tabular}{|c|c|c|c|}
\hline & \multicolumn{2}{|c|}{ The Constitution of the Solomon Islands, 1978} & \\
\hline & \multicolumn{2}{|r|}{$\Downarrow$} & \\
\hline & \multicolumn{2}{|c|}{ National Development Strategy 2016-2035, 2016} & \\
\hline & \multicolumn{2}{|c|}{$\downarrow$} & \\
\hline & \multicolumn{2}{|c|}{ Paris Agreement First NDC, 2016 (submitted) } & \\
\hline & \multicolumn{3}{|c|}{$\downarrow$} \\
\hline$\sqrt{ }$ & 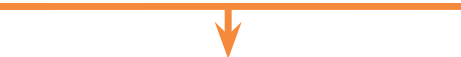 & 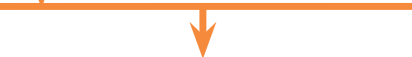 & $\forall$ \\
\hline Area & Policies and Strategies & Acts & $\begin{array}{l}\text { Non-Legislative } \\
\text { Instruments }\end{array}$ \\
\hline Climate change & $\begin{array}{l}\text { National Climate Change } \\
\text { Policy 2012-2017, } 2012 \\
\text { National Adaptation } \\
\text { Programmes of Action, } \\
2008\end{array}$ & & $\begin{array}{l}\text { Assignment of Responsibility } \\
\text { to the Minister for } \\
\text { Environment[,] Climate } \\
\text { Change, Disaster } \\
\text { Management and } \\
\text { Meteorology, } 2011\end{array}$ \\
\hline Energy & $\begin{array}{l}\text { Solomon Islands National } \\
\text { Energy Policy, } 2014 \\
\text { Petroleum and Alternative } \\
\text { Liquid Fuels Strategies } \\
\text { and Investment Plan } \\
\text { 2014-2019, } 2014\end{array}$ & & \\
\hline $\begin{array}{l}\text { Disaster risk } \\
\text { management }\end{array}$ & & $\begin{array}{l}\text { National Disaster Council } \\
\text { Act, } 1990\end{array}$ & \\
\hline Other & $\begin{array}{l}\text { National Development } \\
\text { Strategy 2011-2020, } 2011 \\
\text { National Biodiversity } \\
\text { Strategic Action Plan, } 2009\end{array}$ & $\begin{array}{l}\text { Town and Country } \\
\text { Planning (Amendment) } \\
\text { Act, } 2017 \\
\text { Environment Act, } 1998\end{array}$ & \\
\hline
\end{tabular}

NDC = nationally determined contribution .

Source: Authors.

\section{Energy Supply}

Sustainable energy development is challenging in Solomon Islands due to widely scattered populations on islands separated by substantial expanses of sea, resulting in small communities and isolated population centers. ${ }^{309}$ Approximately $20 \%$ of the population has access to electricity. ${ }^{310}$ Almost all electricity generation, which relies on imported diesel fuel, takes place in Honiara (the capital city) and the provincial centers (footnote 310). Electricity is supplied and regulated by the Solomon Islands Electricity Authority, the country's only power utility (footnote 310).

\footnotetext{
309 Government of Solomon Islands. 2017. Second National Communication. Honiara. pp. 25 and 99.

310 Footnote 309, p. 99.
} 
Only about $5 \%$ of the rural population has access to electricity through a few off-grid and individual household systems (footnote 310). Furthermore, about $85 \%$ of the country's population lives in rural areas and frequently use biomass (fuelwood) for cooking and other activities (footnote 310).

\section{Sector-Wide Strategies}

Solomon Islands National Energy Policy 2014 aims to increase the use of power generated from renewables to $79 \%$ by 2030 , and improve energy efficiency and conservation in all sectors by $10.7 \%$ by 2019 against a 2012 baseline..$^{311}$ In addition, the policy outlines the following goals, as detailed in the Petroleum and Alternative Liquid Fuels Strategies and Investment Plan 2014-2019:

(i) improve capacity for integrated energy sector planning and policy implementation; ensure wider consultations on policy issues, legislation, and regulations; and disseminate energy-related information through school curricula and community training;

(ii) provide reliable and affordable power supply in all urban areas by promoting renewable energy, opening the market to independent power producers, establishing appropriate tariffs, and ensuring Solomon Islands Electricity Authority has sound technical and managerial expertise;

(iii) increase the supply and coverage of electricity in rural areas using renewable energy resources-focusing on hydropower in larger islands and solar power on water-short atolls and outer islands-while evaluating other renewable resources and adopting both appropriate technologies and institutional arrangements, including community management; and

(iv) reduce energy costs by promoting energy conservation and efficiency-e.g., by (a) introducing product standards for appliances (such as appliance labeling) and energy efficiency ratings, and (b) promoting energy-efficient technology-and ensure minimal negative environmental impacts of energy production, distribution, and consumption on the environment. ${ }^{312}$

\section{Energy Demand}

Most rural communities in Solomon Islands have inadequate access to, or cannot afford, basic energy services, including lighting, heating, and transportation, so they are forced to rely on wood and crop residue (biomass). ${ }^{313}$ More people are now using solar power, kerosene, and lanterns, and many low-income earners allocate a large portion of their funds to obtaining energy supplies (footnote 313 ). Over $95 \%$ of rural households and $63 \%$ of urban households use wood for cooking (footnote 313 ).

311 Government of Solomon Islands, Ministry of Mines, Energy and Rural Electrification. 2014. Solomon Islands National Energy Policy. Honiara. p. 2.

312 Government of Solomon Islands, Ministry of Mines, Energy and Rural Electrification. 2014. Petroleum and Alternative Liquid Fuels Strategies and Investment Plan (2014-2019). pp. 10-11.

313 Footnote 308, p. 24. 
Moving to cleaner cooking fuels has two main benefits: (i) it has a positive impact on child and maternal health; and (ii) the availability of electricity extends people's working hours, thereby helping to boost incomes (footnote 313).

The National Development Strategy 2016-2035 aims to reduce the proportion of homes with no electricity supply from $50 \%$ in 2010 to less than $20 \%$ by 2035 (footnote 313). It also seeks to increase the proportion of homes using solar power from $15 \%$ to $50 \%$ by 2035 (footnote 313).

\section{E. LULUCF and REDD+}

The National Climate Change Policy 2012-2017 considers that minimizing the loss of carbon and carbon dioxide $\left(\mathrm{CO}_{2}\right)$ due to land use, land-use change, and forestry (LULUCF) activities is urgent and crucial for both sustainable development and climate action in Solomon Islands. ${ }^{314}$ The policy clarifies that the energy, forestry (logging), and waste management sectors produce the most GHG emissions. ${ }^{315}$

In 2007-2011, logging, fisheries, agriculture, and aid were the main sources of income for Solomon Islands. ${ }^{316}$ However, commercial logging for export exceeds the allowable sustainable cut of 30,000 cubic meters, presenting the biggest threat to terrestrial biodiversity and ecosystem services (footnote 314). The National Climate Change Policy 2012-2017 therefore identifies the need for low-impact logging strategies. ${ }^{317}$

The policy further identifies land clearing for subsistence agriculture as the major cause of deforestation in Solomon Islands (footnote 314). As such, while subsistence agriculture forms the country's foundation of food security, the policy acknowledges the need to adopt more sustainable farming practices (footnote 314 ).

\section{F. Adaptation}

Mindful of its vulnerability to climate change, Solomon Island released in 2008 the National Adaptation Programmes of Action (NAPA), which stresses that climate change threatens the country's capacity for sustainable development. ${ }^{318}$ The NAPA identifies the need to enhance the resilience to climate change of agriculture, water, human settlements, and health. ${ }^{319}$ The NAPA also outlines adaptation priorities for waste management, coastal and fisheries protection, infrastructure development, and tourism resilience. ${ }^{320}$

\footnotetext{
314 Footnote 306, p. 38.

315 Footnote 306, p. 22.

316 Footnote 306, p. 3.

317 Footnote 306, p. 21.

318 Government of Solomon Islands, Ministry of Environment, Conservation and Meteorology. 2008. National Adaptation Programmes of Action. Honiara. p. 5.

319 Footnote 318, pp. 102-103.

320 Footnote 318 , p. 3.
} 
The National Biodiversity Strategic Action Plan identifies climate change as a threat to biodiversity due to warming temperatures, rising sea levels, and changing weather patterns. ${ }^{321}$ It lays out a holistic approach to biodiversity protection and explains the importance of using adaptation planning to address climate change impacts on biodiversity. ${ }^{322}$ The action plan therefore sets goals for climate action, i.e., "to ensure that pressures, impacts and mitigation measures of climate change are adequately supported and addressed to conserve the country's biodiversity." ${ }^{323}$

The first NDC states, "adaptation is not an option-but rather a matter of survival." 324 The total adaptation cost would be around \$126 million, covering agriculture and food security, water and sanitation, human settlements and health, education awareness, waste management, coastal protection, fisheries and marine resources, infrastructure development, and tourism. ${ }^{325}$ The government plans "to build national capacity to facilitate direct access to international climate change financing." 326

\section{G. Disaster Risk Management}

The National Disaster Council Act, passed in 1990, established the National Disaster Council to advise the minister in charge of all disaster-related matters. ${ }^{327}$ The council is also responsible for organizing preparatory actions, responses, and recovery from disaster. ${ }^{328}$ In 2011, the minister for environment, climate change, disaster management and meteorology was legally assigned responsibility for administering and monitoring disaster risk reduction. ${ }^{329}$

\section{Timor-Leste}

\section{A. Country Snapshot: Climate and Environmental Challenges}

The Democratic Republic of Timor-Leste is a small island nation occupying the eastern half of Timor. It gained independence from Portugal in 1975 and from Indonesia in 2002. It has a population of almost 1.4 million people. ${ }^{330}$ Although it faces high climate change risks, Timor-Leste contributes less than $0.003 \%$ to

321 Government of Solomon Islands, Ministry of Environment Conservation and Meteorology. 2009. National Biodiversity Strategic Action Plan. Honiara. p. 24.

322 Footnote 321, p. 9.

323 Footnote 321, p. 36.

324 Footnote 299, p. 11.

325 Footnote 299, p. 13.

326 Footnote 299, p. 14

327 National Disaster Council Act, secs. 2, 3(1), and 5(a).

328 Footnote 327, sec. 5(b).

329 Government of Solomon Islands. 2011. Assignment of Responsibility to the Minister for Environment [,] Climate Change, Disaster Management and Meteorology. Honiara.

330 Central Intelligence Agency (CIA). The World Factbook: Timor-Leste (accessed 13 October 2020). 
global GHG emissions. ${ }^{331}$ Timor-Leste has a low population density, with only $29.5 \%$ of the population living in urban areas. ${ }^{332}$

Timor-Leste struggles with food insecurity in rural regions. ${ }^{333}$ This insecurity is aggravated by climate change impacts such as unpredictable changes in annual seasons and rainfall patterns, which in turn lower crop productivity. ${ }^{334}$ About $30 \%$ of the population lives below the poverty line (footnote 332).

As an island nation, Timor-Leste is vulnerable to sea level rise, increasing temperatures and consequently increasing incidence of vector-borne diseases, and changes in weather patterns. ${ }^{335}$ For example, Timor-Leste depends on the West Pacific monsoon for rainfall and temperature regulation. ${ }^{336}$ Climate change threatens to increase extreme rainfall with risks of flooding. Other climate risks include ocean acidification, intensified tropical cyclones, coastal erosion, and coral reef bleaching. ${ }^{337}$

\section{B. Overarching Climate Change Legal and Policy Framework}

\section{Mitigation and Adaptation Targets}

The Government of Timor-Leste submitted its first nationally determined contribution (NDC) on 16 August 2017, setting out nonquantifiable mitigation and adaptation targets. These targets include (i) managing land sustainably, (ii) reducing the vulnerability of farmland to drought and flood events, (iii) reforesting degraded land to prevent landslides, (iv) establishing early warning systems for natural disasters, ( $v$ ) maintaining mangrove plantations to increase coastal resilience, (vi) including ecosystem management in national planning, and (vii) protecting offshore oil and gas production infrastructure from strong wave damage. ${ }^{338}$ The first NDC also seeks to establish a climate change unit with staffing and budget to support policy development. ${ }^{339}$

Timor-Leste has identified its lack of financial resources as the principal barrier to mitigation and adaptation initiatives. In its first NDC, Timor-Leste requests international financial assistance from the Green Climate Fund, the Global Environment Facility (GEF), and the Least Developed Countries Fund. ${ }^{340}$

\footnotetext{
331 Government of Timor-Leste. 2017. First Nationally Determined Contributions. Dili. p. 7.

332 Footnote 331, p. 4.

333 Footnote 331, p. 5.

334 Footnote 331, pp. 5, 10, and 16.

335 Footnote 331, pp. 16-17.

336 Footnote 331, p. 15.

337 Footnote 331, pp. 15-16.

338 Footnote 331, pp. 13, 17-20.

339 Footnote 331, p. 20.

340 Footnote 331, p. 22.
} 


\section{Overview of Climate Change Law and Policy}

As a least developed country (LDC) with a negligible contribution to global GHG emissions, Timor-Leste focuses its climate policies and framework on adaptation initiatives.

In 2012, Timor-Leste established its legal and policy framework for environmental protection and management, and sustainable resource use. ${ }^{341}$ These laws acknowledge the need to create adaptation and mitigation measures to address climate change. Decree-Law No. 01/2013 established the Ministry of Trade, Industry and Environment, responsible for developing government policies to address climate change.

Due to its status as an LDC and its recent independence from Indonesia in 2002, Timor-Leste has not developed climate change policies or mitigation plans. Rather, the country is primarily focused on economic development and adaptation. Its first NDC to the Paris Climate Agreement does not set forth any quantifiable targets for emission reductions, and emphasizes the national intention to continue developing its offshore oil and gas resources.

The main climate change action taken by Timor-Leste is in the forestry sector. The National Policy and Strategy for the Forestry Sector aims to protect 70\% of national forests by 2020 and stresses the importance of afforestation efforts. ${ }^{342}$

Table 6.13 summarizes Timor-Leste's climate change legal and policy framework.

\section{Energy Supply}

In an attempt to develop economically and improve national infrastructure, Timor-Leste has developed offshore oil and gas extraction to supplement government revenues (footnote 333). National crude petroleum resources are currently processed abroad due to the technologically complex facilities required for the production (footnote 333 ). The oil industry has accounted for approximately $75 \%$ of the gross domestic product (GDP) since $2003 .{ }^{343}$ In the medium term, Timor-Leste expects that the oil and gas industries will have important functions in its economic development. ${ }^{344}$

\section{Renewable Energy Policies}

Timor-Leste received $\$ 1,743,000$ from the GEF to pursue a mitigation project titled "Promoting Sustainable Bio-Energy Production from

341 See Decree-Law No. 26/2012, which established the Environmental Basic Legislation, and Law No. 3/2012, on the legal authorization for Environmental Basic Legislation.

342 Government of Timor-Leste. 2007. Government Resolution No. 9/2007, National Policy and Strategy for the Forestry Sector. Dili.

343 United Nations, Committee for Development Policy, Vulnerability Profile of Timor-Leste, CDP2018/PLEN/6.f (12-16 March 2018).

344 Footnote 331, p. 6. 


\section{Table 6.13: Climate Change Legal and Policy Framework of Timor-Leste}

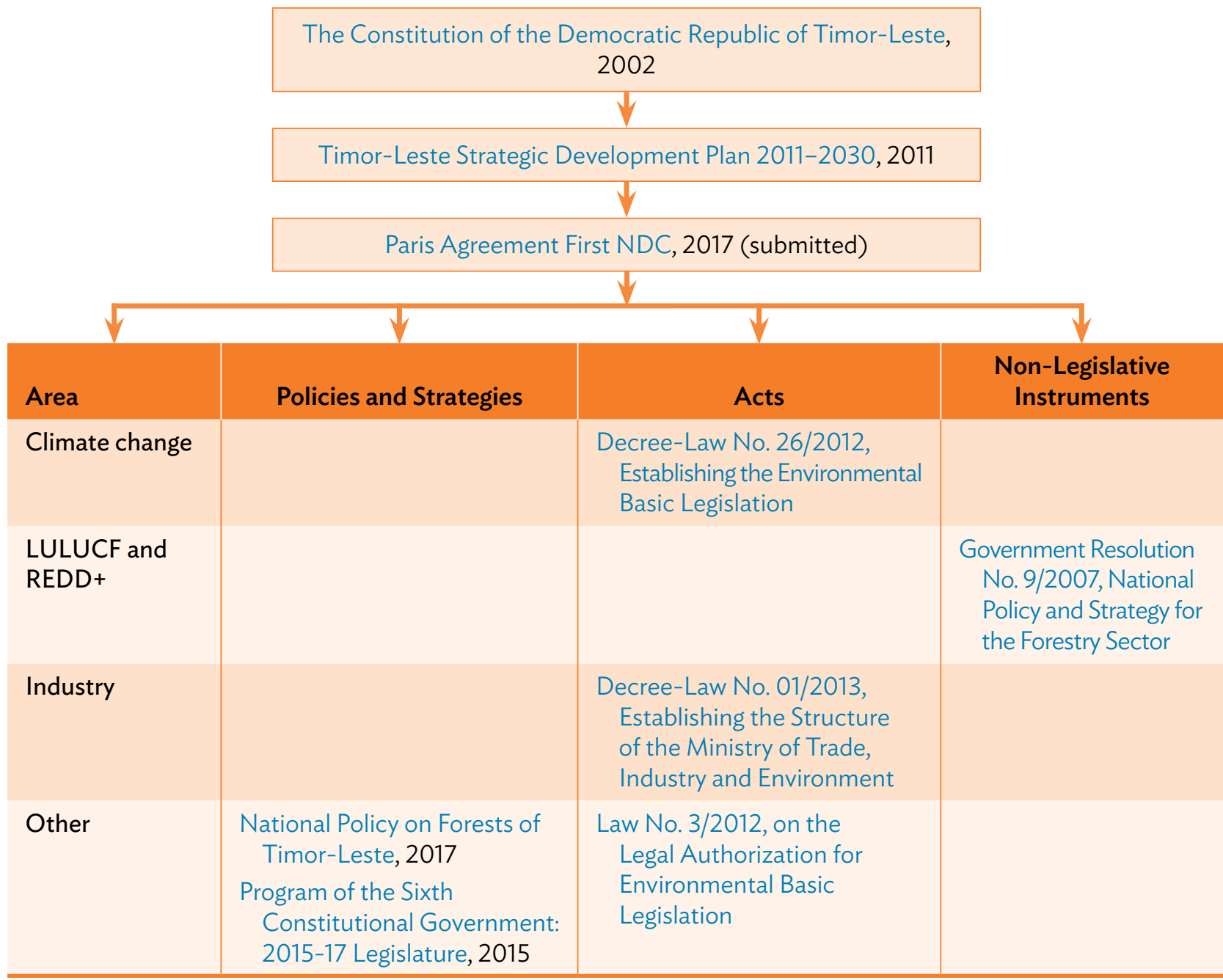

LULUCF = land use, land-use change, and forestry; NDC = nationally determined contribution; REDD + = reducing emissions from deforestation and forest degradation, conservation of existing forest carbon stocks, sustainable forest management, and enhancement of forest carbon stocks.

Source: Authors.

Biomass." 345 The project seeks to make it easier to produce sustainably, use biomass resources, and apply biomass energy technologies. ${ }^{346}$ With respect to other renewable energy sources, Timor-Leste is attempting to promote solar home systems. ${ }^{347}$

345 United Nations Development Programme (UNDP). 2019. Mid-Term Review of UNDP/GEF Project: Promoting Sustainable Bio-Energy Production from Biomass (SBEPB) in Timor-Leste. New York. p. ii.

346 Footnote 345, p. iii.

347 Renewable Energy and Energy Efficiency Partnership (REEEP). 2013. Democratic Republic of Timor-Leste. 11 October. 


\section{LULUCF and REDD+}

About $59 \%$ of the total land area is forest-covered, of which $36 \%$ is primary forest. ${ }^{348}$ Emissions from agriculture, forest, and other land use-comprising the majority of the country's GHG emissions - are caused by (i) forest and grassland conversion; (ii) animal digestion; (iii) agricultural soil emissions; (iv) manure management; ( $v$ ) land use, land-use change, and forestry (LULUCF) and biomass emissions; and (vi) rice cultivation. ${ }^{349}$ Timor-Leste's first NDC expresses interest in (i) exploring REDD+ activities based on national priorities; and (ii) engaging with the Forest Carbon Partnership Facility, a global coalition of governments, businesses, civil society, and indigenous peoples committed to REDD+ activities. ${ }^{350}$ Timor-Leste also seeks to plant 1 million trees annually, and protect at least $70 \%$ of forest areas by $2030 .{ }^{351}$

\section{E. Adaptation}

Timor-Leste is primarily focused on adaptation-especially in its first NDCalthough there are no quantifiable targets or specific policies. However, as a vulnerable small island nation, Timor-Leste recognizes the need to develop infrastructure and resilience mechanisms to mitigate the risks of rising sea levels and increasing extreme weather events.

\section{XIII.Tonga}

\section{A. Country Snapshot: Climate and Environmental Challenges}

The Kingdom of Tonga, a constitutional monarchy, is an archipelago of four island clusters in the South Pacific ocean. As a Pacific island country, Tonga is particularly susceptible to sea level rise, cyclones, ocean acidification, coral bleaching, and changing rainfall patterns. ${ }^{352}$ For example, in 2014, Tropical Cyclone lan resulted in an estimated pa'anga ( $T$ \$) 33 million ( $\$ 14$ million) in damages and an additional T\$5.4 million ( $\$ 2.3$ million) in losses. ${ }^{353}$

Additional climate-related threats include saltwater intrusion affecting groundwater due to sea level rise, droughts that reduce potable water, and

\footnotetext{
348 Footnote 331, p. 10.

349 Footnote 331, p. 9.

350 Footnote 331, p. 11.

351 Government of Timor-Leste. 2017. National Policy on Forests of Timor-Leste. Dili and footnote 331, p. 13.

352 Government of Tonga. 2016. First Nationally Determined Contributions. Nuku'alofa. p. 4.

353 Government of Tonga, Ministry of Meteorology, Energy, Information, Disaster Management, Environment, Climate Change and Communications. 2016. Tonga Climate Change Policy: A Resilient Tonga by 2035. Nuku'alofa. p. 15.
} 
destabilization of climate-sensitive sectors such as agriculture and fisheries. ${ }^{354}$ Coastal developments-including mining of beach sand-sea level rise, and extreme weather events are also accelerating coastal degradation (footnote 354 ).

\section{B. Overarching Climate Change Legal and Policy Framework}

\section{Mitigation and Adaptation Targets}

The Government of Tonga submitted its first NDC on 21 September 2016, pledging to achieve $50 \%$ renewable electricity by 2020 and $70 \%$ by 2030.355 Additionally, it commits to reducing electricity line losses to $9 \%$ by 2020 compared with a baseline of $18 \%$ in 2010 (footnote 355). The first NDC also contains emissions reduction targets by sector and intends to double its number of marine protected areas by 2030 (footnote 355). The NDC further identifies sectors for adaptation, including agriculture, coastal zones, disaster management, tourism, and water.

\section{Overview of Climate Law and Policy}

Tonga's flagship climate change strategy is the Tonga Climate Change Policy (footnote 353). Launched in 2016, the policy provides a 5-year road map for addressing climate change impacts and reducing disaster risk. It serves as a multisector framework, recognizing climate change as "the single biggest issue that will determine the future of Tonga over [the] coming decades." ${ }^{356}$ Ultimately, the policy aims to make Tonga climate-resilient by 2035 . Specific targets in the policy include

(i) reaching $100 \%$ renewable energy by 2035 ;

(ii) securing $30 \%$ of land used in forestry or agroforestry by 2035 ;

(iii) protecting all coastal communities by 2035 ;

(iv) shifting the transportation system away from reliance on fossil fuels;

(v) achieving resilient homes, schools, and community halls; and

(vi) redesigning roads, coastal areas, buildings, and other infrastructure to be more resilient. ${ }^{357}$

Tonga's approach to mitigation and adaptation also focuses on integrating climate change planning into development initiatives. The Tonga Strategic Development Framework 2015-2025, for example, establishes climate change as a national and international development issue. ${ }^{358}$ The framework recognizes the risks posed by climate change and extreme weather, and aims to improve environmental and

\footnotetext{
354 United Nations Development Programme, Climate Change Adaptation. Tonga.

355 Footnote 352, p. 3.

356 Footnote 353, p. 7.

357 Footnote 353, p. 12

358 Government of Tonga, Ministry of Finance and National Planning. 2015. Tonga Strategic Development Framework 2015-2025. Nuku'alofa.
} 
land management to bolster resilience. Both the strategic framework and the Tonga Climate Change Policy build on an earlier climate policy: the Joint National Action Plan on Climate Change Adaptation and Disaster Risk Management 2010-2015 (Joint National Action Plan). ${ }^{359}$

Tongan climate change policies focus on marine and forest conservation, combined with quantifiable targets for transitioning electricity production to renewable energy.

Table 6.14 summarizes Tonga's climate change legal and policy framework.

Table 6.14: Climate Change Legal and Policy Framework of Tonga

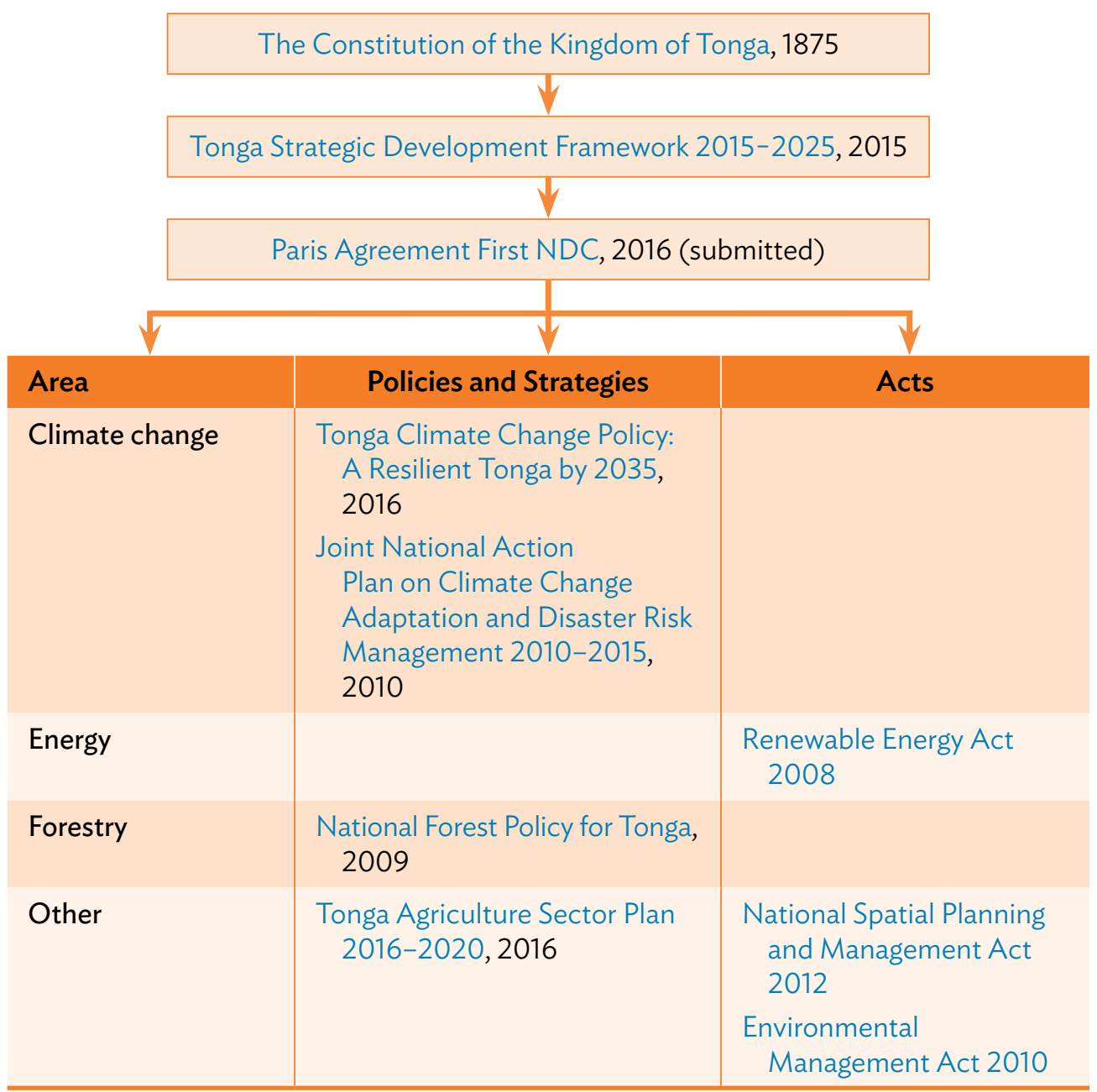

NDC = nationally determined contribution.

Source: Authors.

359 Government of Tonga. 2010. Joint National Action Plan on Climate Change Adaptation and Disaster Risk Management 2010-2015. Nuku'alofa. 


\section{Energy Supply}

Tonga currently meets the vast majority of its energy needs by importing fossil fuels. ${ }^{360}$ In 2016, about $74 \%$ of the total electricity generated came from burning fossil fuels, while $26 \%$ was renewable. ${ }^{361}$ Tonga ranks 205 th in the world for carbon dioxide $\left(\mathrm{CO}_{2}\right)$ emissions from energy consumption (footnote 361). Nevertheless, increasing renewable energy is a principal focus for Tonga in its climate change laws and policies.

\section{Renewable Energy Policies}

The Renewable Energy Act 2008 seeks to increase renewable energy use throughout the country by establishing an authority to regulate all renewable energy projects, and to promote renewable energy electrification services, especially in remote areas. ${ }^{362}$ Further, it encourages investment in renewable energy and recommends research and development initiatives through partnerships with the private sector. ${ }^{363}$ This act reflects the larger initiative to transition to primarily renewable sources.

The Joint National Action Plan sets quantifiable targets, including 50\% renewable energy by 2013 and 10\% GHG emissions reductions by 2015, compared with a 2000 baseline. ${ }^{364}$ Further, the Climate Change Policy aims for $100 \%$ renewable energy by 2035 (footnote 357).

\section{LULUCF and REDD+}

Tonga's efforts in forest management are concentrated in the National Spatial Planning and Management Act 2012, along with the National Forest Policy for Tonga 2009.365 The act establishes a framework for planning land use and management, focusing on preserving biodiversity and conserving ecosystems.

The forest policy seeks to support sustainable forest management, specifically of exotic and indigenous forests, agroforests, and urban trees. ${ }^{366}$ Like the act, the forest policy aims to preserve biodiversity, soil, water, and ecosystem integrity (footnote 366). It additionally integrates mitigation goals by referring to carbon sequestration and its intent to participate in carbon trading mechanisms. ${ }^{367}$

In addition, the Climate Change Policy sets a target that $30 \%$ of land be used in forestry and agroforestry by 2035 (footnote 357).

\footnotetext{
360 Tonga Power Limited. Outer Islands Renewable Project.

361 Central Intelligence Agency (CIA). The World Factbook: Tonga (accessed 16 October 2020).

362 Renewable Energy Act 2008, secs. 3(b), 3(c), and 3(e).

363 Footnote 362, sec. 3(a).

364 Footnote 359, pp. 25 and 42.

365 Government of Tonga, Ministry of Agriculture, Food, Forestry and Fisheries. 2009. National Forest Policy for Tonga. Nuku'alofa.

366 Footnote 365, p. 3.

367 Footnote 365, p. 5.
} 


\section{E. Transportation}

Tonga does not have a large transportation industry, especially given its small territorial size and population. It has one airport with paved runways and 184 kilometers $(\mathrm{km})$ of paved roadways (footnote 361 ). Nuku'alofa, Neiafu, and Pangai are the three major seaports.

The Climate Change Policy sets out a broad goal of creating a transportation system not reliant on fossil fuels. However, there are no quantifiable targets or specific implementation plans (footnote 357 ).

\section{F. Adaptation}

Adaptation is a central focus of Tonga's climate change laws and policies. Like most other low-lying Pacific island countries, Tonga faces the risk of complete inundation due to sea level rise. Many of the national climate change policies and laws reference the need to protect coastal communities and create mechanisms for disaster management in preparation for increased and extreme weather events. Nevertheless, the existing legal and policy frameworks implemented by Tonga lack quantifiable adaptation targets.

The Tonga Agriculture Sector Plan 2016-2020 describes climate change as the single biggest factor that shapes Tonga's agriculture and ability to be selfreliant. ${ }^{368}$ The plan therefore stresses the need to incorporate climate change adaptation and disaster risk reduction into agriculture sector planning. It also provides for an updated hydrogeological study to assess water availability.

\section{G. Disaster Risk Management}

The Joint National Action Plan on Climate Change Adaptation and Disaster Risk Management 2010-2015 articulates six priority goals:

(i) improving governance for climate change adaptation and disaster risk management;

(ii) enhancing technical knowledge, information, education, and understanding of climate change adaptation and disaster risk management;

(iii) analyzing and assessing vulnerability to climate change impacts and disaster risks;

(iv) enhancing community preparedness and resilience to impacts of disasters;

(v) providing reliable, affordable, and sustainable energy; and

(vi) cultivating collaboration with civil societies, government agencies, nongovernment organizations, and the private sector. ${ }^{369}$

368 Government of Tonga, Ministry of Agriculture, Food, Forestry and Fisheries. 2016. Tonga Agriculture Sector Plan 2016-2020. Nuku'alofa. p. 16.

369 Footnote 359, pp. 40-42. 


\section{XIII.Tuvalu}

\section{A. Country Snapshot: Climate and Environmental Challenges}

Tuvalu, a parliamentary democracy under a constitutional monarchy, is a group of nine small, low-lying islands facing a range of severe climate impacts. Climate threats include sea level rise, flooding, unpredictable rainfall, ocean acidification, coral bleaching, and more intense cyclones. ${ }^{370}$ Saltwater intrusion is decreasing fruit tree yields and destroying crops, thus reducing agricultural productivity. ${ }^{371}$ Extreme weather events are increasingly damaging productive land and property. ${ }^{372}$

Tuvalu has had to import fresh water and create emergency desalination plants to increase water security in the face of drought. ${ }^{373}$ The sea level has increased by 5 millimeters ( $\mathrm{mm}$ ) annually since 1993. ${ }^{374}$ All nine islands in Tuvalu are less than 5 meters $(\mathrm{m})$ above mean sea level, with an average elevation of only $1.83 \mathrm{~m} .{ }^{375}$ Tuvalu therefore faces extreme risk from tropical cyclones, tsunamis, and sea level rise and related impacts such as flooding.

The fact that Tuvalu is the fourth-smallest nation in the world-and extremely reliant on foreign aid-exacerbates its climate vulnerability (footnote 374).

\section{B. Overarching Climate Change Legal and Policy Framework}

\section{Mitigation and Adaptation Targets}

The Government of Tuvalu submitted its first nationally determined contribution (NDC) on 22 April 2016. It pledges a 100\% GHG emissions reduction in the electricity sector by 2025 , and a $60 \%$ reduction in emissions from the entire energy sector by 2025 compared with 2010 levels. ${ }^{376}$ Further GHG emissions reductions from the agriculture and waste sectors are conditional on technological and financial support (footnote 376).

Tuvalu's NDC also sets energy-related targets, such as (i) increasing energy efficiency by $30 \%$ on Funafuti, an atoll and the capital; and (ii) generating $100 \%$ of electricity from renewable sources by $2020 .{ }^{377}$

370 Pacific-Australia Climate Change Science and Adaptation Planning Program partners. 2015.

Current and Future Climate of Tuvalu. p. 2, 5-6.

371 United Nations Development Programme (UNDP), Climate Change Adaptation. Tuvalu.

372 Footnote 370, p. 2.

373 BBC. 2011. Tuvalu Declares Emergency over Water Shortage. 3 October.

374 UNDP, Climate Change Adaptation. 2017. Government of Tuvalu Launches New Coastal Protection Project to Bolster Resilience to Climate Change. News release. 8 July.

375 Footnote 374; and Government of Tuvalu. 2016. First Nationally Determined Contributions. Funafuti. p. 4.

376 Government of Tuvalu. 2016. First Nationally Determined Contributions. Funafuti. p. 1.

377 Footnote 376, p. 6. 


\section{Overview of Climate Change Law and Policy}

Tuvalu's climate change laws and policies set some of the most ambitious targets and commitments in the Pacific. The Ministry of Natural Resources, Energy and Environment is the main government entity responsible for climate change. Under the ministry is the Department of Environment, which directs the Climate Change Unit. The Prime Minister also launched the National Advisory Council on Climate Change in 2014 to create a coordinated climate response. ${ }^{378}$

The two main documents that drive climate change policy in Tuvalu are (i) Te Kaniva: Tuvalu Climate Change Policy 2012 (Climate Change Policy), and (ii) Tuvalu National Strategic Action Plan for Climate Change and Disaster Risk Management 2012-2016. The Climate Change Policy provides a 10-year plan for climate and disaster risk response and sets seven thematic goals. ${ }^{379}$ These thematic goals include increasing renewable energy opportunities, enhancing Tuvalu's institutional climate framework, and strengthening adaptation responses (e.g., by conducting crop studies and managing marine areas). ${ }^{380}$ The Climate Change Policy also discusses long-term security given the threat posed by territorial loss, and recommends establishing a special visa category for climate migrants. ${ }^{381}$

Tuvalu National Strategic Action Plan for Climate Change and Disaster Risk Management 2012-2016 also addresses the country's security in the context of the existential threat climate change poses. ${ }^{382}$ The plan aims to predict where forced migration may occur, conduct a feasibility study on relocation costs, and develop a climate change migration and resettlement plan for Tuvalu's nine islands. ${ }^{383}$ The plan also sets the same seven goals as the Climate Change Policy:

(i) strengthening adaptation actions to address current and future vulnerabilities;

(ii) improving the understanding and application of climate change data, information and site-specific impacts assessment to inform adaptation and disaster risk reduction programs;

(iii) enhancing Tuvalu's governance arrangements and capacity to access and manage climate change and disaster risk management finances;

(iv) developing and maintaining Tuvalu's infrastructure to withstand climate change impacts, climate variability, disaster risks and climate change projection;

378 M. Nachmany et al. 2015. Climate Change Legislation in Tuvalu: An Excerpt from The 2015 Global Climate Legislation Study (A Review of Climate Change Legislation in 99 Countries). London: Grantham Research Institute on Climate Change and the Environment. p. 3.

379 Government of Tuvalu, Ministry of Foreign Affairs, Trade, Tourism, Environment and Labour. 2012. Te Kaniva: Tuvalu Climate Change Policy 2012. Funafuti. p. 6.

380 Footnote 379, pp. 4, 13-14, 17-18, and 21-22.

381 Footnote 379, pp. 25-26.

382 Government of Tuvalu, Ministry of Foreign Affairs, Trade, Tourism, Environment and Labour. 2012. Tuvalu National Strategic Action Plan for Climate Change and Disaster Risk Management 2012-2016. Funafuti. p. 33.

383 Footnote 382, p. 53. 
(v) ensuring energy security and a low carbon future for Tuvalu;

(vi) planning for effective disaster preparedness, response, and recovery; and

(vii) guaranteeing the security of the people of Tuvalu from the impacts of climate change, as well as the maintenance of national sovereignty. ${ }^{384}$

In 2015, the government passed the Climate Change and Disaster Survival Fund Act to finance recovery and rehabilitation. The act sets two major objectives: (i) to provide immediate vital services to citizens in combating the devastating impacts of climate change and natural disasters; and (ii) to enable the government and citizens to respond to climate change impacts and disasters in a coordinated, effective, and timely manner. ${ }^{385}$ The government committed $\$ 2$ million out of its 2017 national budget for the fund, primarily for the development of the fund's investment policy, operational framework, and payout policy. ${ }^{386}$

Tuvalu has also integrated climate concerns into its sustainable development strategy. Te Kakeega III: National Strategy for Sustainable Development 2016 to 2020 dedicates its first chapter to climate change. ${ }^{387}$ The strategy recognizes climate risk and adaptation costs.

Table 6.15 summarizes Tuvalu's climate change legal and policy framework.

\section{Energy Supply}

Tuvalu is heavily reliant on fossil fuels to meet its electricity and transport needs. ${ }^{388}$ It has eight power stations, all powered by diesel-based generations. ${ }^{389}$ However, the government is committed to increasing renewable energy use and sourcing $100 \%$ of its electricity from renewable energy by 2020 (footnote 377). Ninety-five percent of the renewable energy will come from solar and the remaining $5 \%$ from biodiesel (footnote 378 ).

\section{Sector-Wide Energy Strategies}

The Tuvalu National Energy Policy sets the country's energy strategy. The policy, launched in 2009, is governed by the vision of attaining "a prosperous living standard that is fostered through an energy policy that promotes the provision of socially, financially, economically, technically, politically and environmentally sustainable energy systems." 390

\footnotetext{
384 Footnote 382, p. 9.

385 Climate Change and Disaster Survival Fund Act 2015, sec. 7.

386 Government of Tuvalu. 2016. Government of Tuvalu 2017 National Budget. Funafuti. pp. 3, 5, 7, 14, 47 and 50-51. An initial \$5 million was set aside in 2016 for the establishment of the fund.

387 Government of Tuvalu. 2016. Te Kakeega III: National Strategy for Sustainable Development 2016 to 2020. Funafuti.

388 Footnote 376, p. 5.

389 Footnote 376, p. 8.

390 Government of Tuvalu, Ministry of Public Utilities and Industries. 2009. Tuvalu National Energy Policy. Funafuti. p. 6.
} 


\section{Table 6.15: Climate Change Legal and Policy Framework of Tuvalu}

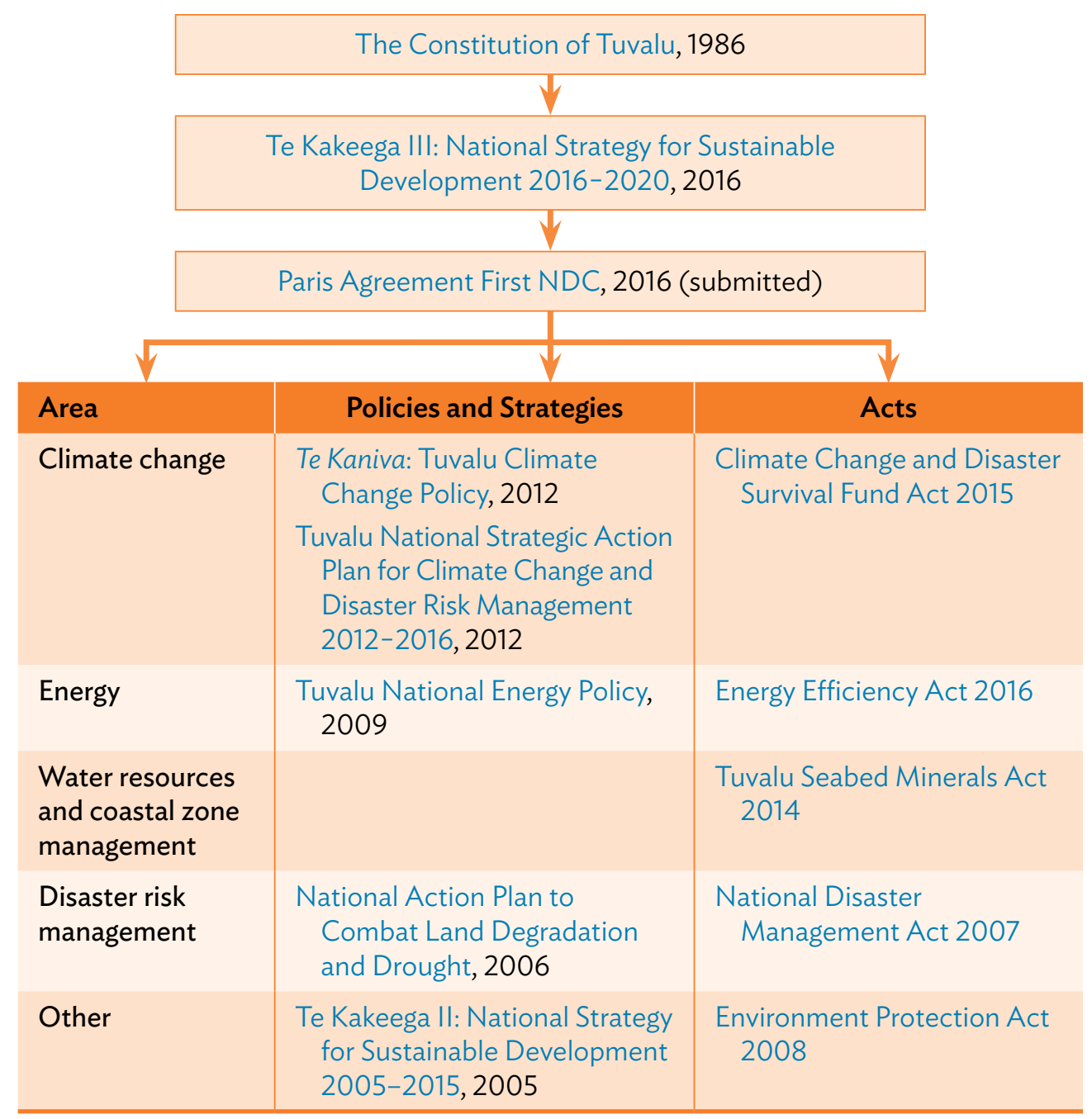

$\mathrm{NDC}=$ nationally determined contribution.

Source: Authors.

The energy policy's three principal considerations are supply, utilization, and the environment. ${ }^{391}$ Its seven major areas are (i) energy sector planning, coordination, and management; (ii) petroleum; (iii) transport; (iv) electricity; (v) renewable energy; (vi) energy conservation and efficiency; and (vii) environment. ${ }^{392}$ The policy seeks to establish climate change mitigation projects, including renewable energy development.

Besides the $100 \%$ renewable electricity commitment by 2020 , the policy's other renewable energy targets include

(i) implementing affordable technology in urban and rural areas;

(ii) developing knowledge on renewable sources;

391 Footnote 390, p. 9.

392 Footnote 390, pp. 14-16. 
(iii) maintaining efficient use of renewable energy resources;

(iv) developing expertise in renewable energy installation and management;

(v) building partnerships with those in renewable energy fields; and

(vi) preparing an implementation plan for developing renewable energy technologies by 2020.393

\section{Energy Demand}

Tuvalu is expected to experience increasing energy demand-likely 3\%-4\% over the next 10 years - from growth in the transport and electricity sectors. ${ }^{394}$ The government has made efforts to increase energy efficiency. The Energy Efficiency Act 2016 was passed to promote energy efficiency and conservation, and support Tuvalu in meeting its first NDC energy efficiency target.

The act authorizes the government to set minimum energy performance and labeling standards for electrical appliances and other energy-related products. ${ }^{395}$ Any electrical appliance or product that does not comply with the standards is prohibited from being imported. ${ }^{396}$ It also establishes a registry of inefficient electrical appliances to regulate their importation, use, and sale. ${ }^{397}$ The act further provides that noncompliance may result in fines or imprisonment. ${ }^{398}$

In 1990, the Tuvalu Electricity Corporation was transformed from a government division into a $100 \%$ state-owned corporation with exclusive rights to supply electricity throughout the country (footnote 394). In 2013, the Renewable Energy and Energy Efficiency Unit was established within the Tuvalu Electricity Corporation to (i) help Tuvalu reduce dependence on imported diesel, (ii) reduce carbon emissions, (iii) improve the efficiency of power generation and supply, and (iv) support the development of infrastructure for solar and wind power (footnote 394).

\section{E. Disaster Risk Management}

The National Disaster Management Act 2007 establishes the National Disaster Committee to (i) advise the minister responsible for disaster management on disaster mitigation, preparedness, response, and recovery; and (ii) coordinate all government and nongovernment responses to disasters. ${ }^{399}$

In 2012, Tuvalu implemented the National Strategic Action Plan for Climate Change and Disaster Risk Management 2012-2016, which recommends establishing the National Strategic Action Plan Coordinating Committee. ${ }^{400}$

393 Footnote 390, p. 23.

394 Renewable Energy and Energy Efficiency Partnership (REEEP). 2013. Tuvalu (2012). 11 October.

395 Energy Efficiency Act, secs. 10-11.

396 Footnote 395, sec. 11(1).

397 Footnote 395, secs. 17-29.

398 Footnote 395, sec. 35.

399 National Disaster Management Act 2017, secs. 7, 8(a), and 8(b).

400 Footnote 382, p. 10. 
The government passed the Climate Change and Disaster Survival Fund Act in 2015 to establish a fund to finance recovery and rehabilitation. International funds and grants channel through the fund. The government may use the fund to provide emergency relief and enhance climate change resilience.

\section{Vanuatu}

\section{A. Country Snapshot: Climate and Environmental Challenges}

The Republic of Vanuatu, a unitary parliamentary republic, is a small island nation in the western Pacific Ocean. With a population of about 298,000 , it is an archipelago of over 80 islands. ${ }^{401}$ It is extremely vulnerable to the effects of climate change, specifically the increasing frequency of cyclones and flash floods as well as sea level rise. ${ }^{402}$ For example, in 2015 , Cyclone Pam destroyed $96 \%$ of food crops, affected $64.1 \%$ of the national economy, and caused a loss of $\$ 449.4$ million. ${ }^{403}$

Climate change will increase the severity and frequency of these weather events, threatening human lives, societies, food security, livelihoods, biodiversity, and infrastructure. ${ }^{404}$ In addition, the country's major food stocks-marine fisheriesare threatened by ocean warming and acidification. ${ }^{405}$

\section{B. Overarching Climate Change Legal and Policy Framework}

\section{Mitigation and Adaptation Targets}

The Government of Vanuatu submitted its first NDC on 21 September 2016, committing to reduce its $\mathrm{GHG}$ emissions by $30 \%$ below business as usual (BAU) emissions from its entire energy sector. ${ }^{406}$ Vanuatu also endeavors to generate $100 \%$ of its electricity from renewable sources by 2030 , depending on receipt of financial and technical support (footnote 406). Although the NDC does not set out quantifiable or specific adaptation requirements, it notes that adaptation is a top priority in its national response to climate change. It also establishes the National Advisory Board for Climate Change and Disaster Risk Reduction and indicates the government's intention to pursue REDD+ projects to reduce deforestation. ${ }^{407}$

401 Central Intelligence Agency (CIA). The World Factbook: Vanuatu (accessed 16 October 2020).

402 Government of Vanuatu, National Advisory Committee on Climate Change. 2007. National Adaptation Programme for Action (NAPA). Port Vila. pp. 16-17.

403 United States Agency for International Development (USAID). 2015. South Pacific-Tropical Cyclone Pam. Fact Sheet \#3, Fiscal Year (FY) 2015; and Government of Vanuatu. 2015. Vanuatu Post-Disaster Needs Assessment: Tropical Cyclone Pam. p. ix.

404 Footnote 402, pp. 3, 7, 14, 16-17, 23, and 33.

405 United Nations. The Permanent Mission of the Republic of Vanuatu to the United Nations: Climate Change.

406 Government of Vanuatu. 2016. First Nationally Determined Contribution. Port Vila. p. 4.

407 Footnote 406, pp. 3-4. 


\section{Overview of Climate Change Law and Policy}

Vanuatu ratified the Paris Agreement with the Paris Agreement (Ratification) Act in 2016. It has demonstrated a commitment to climate action by promulgating two major climate policies: (i) the Vanuatu Framework for Climate Services, and (ii) the National Policy on Climate Change and Disaster-Induced Displacement (National Climate Change Policy).

The Vanuatu Framework for Climate Services serves as a basis for developing climate change adaptation strategies based on sustainable and accessible climate services. ${ }^{408}$ The term "climate services" refers to the "provision of climate information in a way that assists end-user decision-making," requiring ongoing stakeholder engagement, access to information, and responsiveness to user needs. ${ }^{409}$ The framework aims to make climate information more accessible and useful by developing (i) mobile phone applications for a climate early warning system, and (ii) a climate communications strategy and action plan. ${ }^{410}$

The framework is consistent with the Vanuatu National Adaptation Programme for Action, the Vanuatu Climate Change and Disaster Risk Reduction Policy 2016-2030, Vanuatu 2030 (the national sustainable development plan), and the Pacific Islands Meteorology Strategy. ${ }^{411}$ It also includes a climate services road map, which offers prioritization, time frames, and indicative costs associated with the recommendations. ${ }^{412}$

In 2018, the government launched the National Climate Change Policy, which specifically manages displacement. ${ }^{413}$ Displacement occurs when "individuals and communities are obliged to move, either temporarily or permanently, because they are no longer able to reside on the land on which they live or lose access to land and natural resources upon which their livelihoods depend." 414 The policy aims to minimize the drivers of displacement, better understand and consider the population's needs and wishes, and promote access to disaster-resilient housing. The policy promotes (i) sustainable return and reintegration at the place of origin, (ii) sustainable local integration in areas where displaced persons have taken

\footnotetext{
408 Secretariat of the Pacific Regional Environment Programme. 2016. Vanuatu Framework for Climate Services. The framework was prepared in consultation with the Government of Vanuatu, Vanuatu Meteorology and Geo-Hazard Department.

409 Footnote 408, p. 12.

410 Footnote 408, p. 8.

411 Footnote 402; footnote 408, p. 9; Government of Vanuatu. 2015. Vanuatu Climate Change and Disaster Risk Reduction Policy 2016-2030. Port Vila; Government of Vanuatu, Department of Strategic Policy, Planning and Aid Coordination. 2016. Vanuatu 2030: The People's Plan (National Sustainable Development Plan 2016 to 2030). Port Vila; and Secretariat of the Pacific Regional Environment Programme et al. 2017. Pacific Islands Meteorology Strategy (PIMS) 2017-2026. Apia.

412 Footnote 408, p. 44-46.

413 Government of Vanuatu. 2018. National Policy on Climate Change and Disaster-Induced Displacement. Port Vila.

414 Footnote 413, p. 9.
} 
refuge, and (iii) sustainable integration in another part of the country. ${ }^{415}$ The government will identify a lead ministry to implement the policy. ${ }^{416}$

Vanuatu's other climate change-related legal and policy frameworks focus principally on adaptation and transitioning to renewable energy. For example, Vanuatu promulgated the National Green Energy Fund Act (No. 10 of 2018), which aims to create a fund to support the Updated National Energy Road Map 2016-2030 and the development of renewable energy sources. ${ }^{417}$

With respect to adaptation, Vanuatu passed the Meteorology, Geological Hazards and Climate Change Act (No. 25 of 2016), which aims to provide high-quality forecasting of weather, flood, and climate to improve information dissemination and increase capacity to respond to extreme weather events. ${ }^{418}$ The act also established the National Advisory Board on Climate Change and Disaster Risk Reduction to oversee this initiative. ${ }^{419}$

Table 6.16 summarizes Vanuatu's climate change legal and policy framework.

\section{Energy Supply}

Like other Pacific island countries, Vanuatu faces significant hurdles in providing electricity to a small population dispersed across 83 islands. ${ }^{420}$ In 2018, only a third of Vanuatu's population had access to electricity. ${ }^{421}$ Electrification rates vary significantly between urban (80\%) and rural households (17\%). ${ }^{422}$ Vanuatu plans to increase electrification to $75 \%$ by 2020 , with renewables supplying $65 \%$ of the total energy share (footnote 421).

Low electrification rates have made Vanuatu highly dependent on imported fossil fuels. ${ }^{423}$ Fossil fuels mainly support urban electricity and transport needs, while biomass is used mainly for rural cooking. In 2012, diesel oil accounted for $63.3 \%$ of all imported fuel, and generated over $80 \%$ of all electricity (footnote 423 ). In 2015, nearly all poor households in Port Vila used wood and coconut shells as their primary fuel for cooking, while higher-income households used gas and electricity. ${ }^{424}$

415 Footnote 413, p. 16.

416 Footnote 413, p. 22

417 National Green Energy Fund Act (No. 10 of 2018), secs. 2 and 3(1); and Government of Vanuatu, Department of Energy. 2016. Updated Vanuatu National Energy Road Map 2016-2030. Port Vila.

418 Meteorology, Geological Hazards and Climate Change Act (No. 25 of 2016), sec. 2.

419 Footnote 418, sec. 7.

420 World Bank. 2017. Vanuatu Rural Electrification Program Benefits Remote Communities. News release. 22 May.

421 ADB. 2018. Pacific Energy Update 2018. Manila. p. 15.

422 International Renewable Energy Agency (IRENA). 2015. Vanuatu Renewables Readiness Assessment. Abu Dhabi. p. xi.

423 United Nations Development Programme (UNDP). 2015. Rural Electrification in Vanuatu. p. 22.

${ }^{424}$ Assessment Capacities Project (ACAPS). 2015. Vanuatu Tropical Cyclone. Briefing Note. 15 March. pp. 3-4. 


\section{Table 6.16: Climate Change Legal and Policy Framework of Vanuatu}

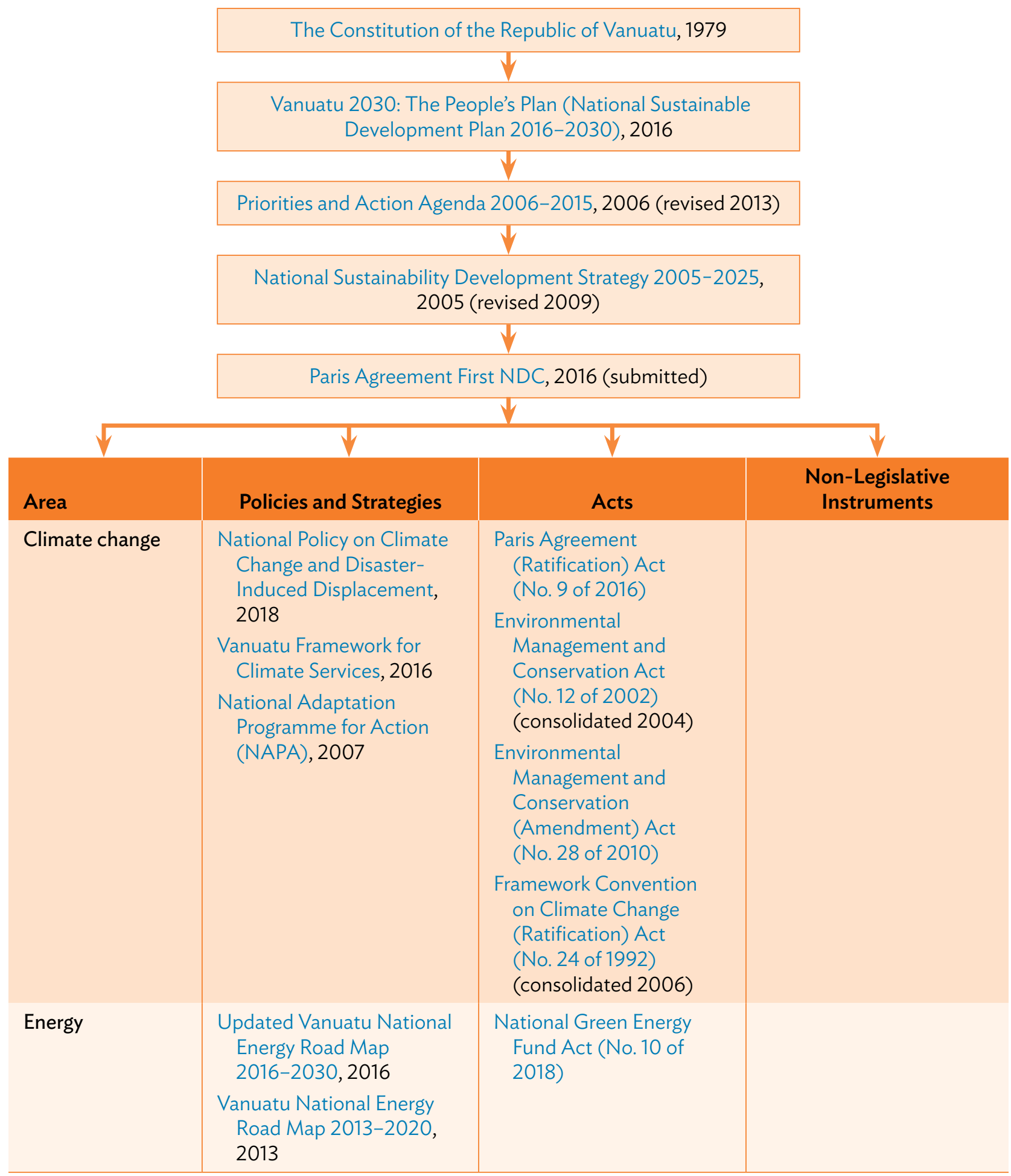


Table 6.16 continued

\begin{tabular}{|c|c|c|c|}
\hline Area & Policies and Strategies & Acts & $\begin{array}{l}\text { Non-Legislative } \\
\text { Instruments }\end{array}$ \\
\hline $\begin{array}{l}\text { LULUCF and } \\
\text { REDD+ }\end{array}$ & & $\begin{array}{l}\text { Forestry Act (No. } 26 \text { of 2001) } \\
\text { (consolidated 2006) } \\
\text { Forestry Rights Registration } \\
\text { and Timber Harvest } \\
\text { Guarantee Act (No. } 28 \\
\text { of } 2000 \text { ) }\end{array}$ & $\begin{array}{l}\text { Forestry Regulations, } \\
\text { (Order No. } 46 \text { of } 2003 \\
\text { and Order No. } 41 \text { of } \\
\text { 2004) }\end{array}$ \\
\hline $\begin{array}{l}\text { Disaster risk } \\
\text { management }\end{array}$ & $\begin{array}{l}\text { Vanuatu Climate Change } \\
\text { and Disaster Risk } \\
\text { Reduction Policy } \\
\text { 2016-2030, } 2015\end{array}$ & $\begin{array}{l}\text { Meteorology, Geological } \\
\text { Hazards and Climate } \\
\text { Change Act (No. } 25 \text { of } \\
\text { 2016), } 2017\end{array}$ & \\
\hline $\begin{array}{l}\text { Environmental } \\
\text { impact } \\
\text { assessment }\end{array}$ & & & $\begin{array}{l}\text { Environmental Impact } \\
\text { Assessment Regulations, } \\
\text { (Order No. } 175 \text { of 2011) } \\
\text { Environmental Impact } \\
\text { Assessment Regulations } \\
\text { (Amendment), } \\
\text { (Order No. } 102 \text { of 2012) }\end{array}$ \\
\hline Other & & $\begin{array}{l}\text { Ozone Layer Protection } \\
\text { Act (No. } 27 \text { of 2010) } \\
\text { Ozone Layer Protection } \\
\text { (Amendment) Act } \\
\text { (No. } 4 \text { of 2014) } \\
\text { Pollution (Control) Act } \\
\text { (No. } 10 \text { of 2013) } \\
\text { Statute of the International } \\
\text { Renewable Energy } \\
\text { Agency (IRENA) } \\
\text { (Ratification) Act } \\
\text { (No. } 15 \text { of } 2012 \text { ) } \\
\text { Convention on Biological } \\
\text { Diversity (Ratification) } \\
\text { Act (No. } 23 \text { of 1992) }\end{array}$ & $\begin{array}{l}\text { Ozone Layer Protection } \\
\text { (Fees and Penalty } \\
\text { Notice) Regulations, } \\
\text { (Order No. } 100 \text { of } 2011 \text { ) }\end{array}$ \\
\hline
\end{tabular}

LULUCF = land use, land-use change, and forestry; NDC = nationally determined contribution; REDD+ = reducing emissions from deforestation and forest degradation, conservation of existing forest carbon stocks, sustainable forest management, and enhancement of forest carbon stocks.

Source: Authors. 
High costs of imported fuel have undermined government efforts to meet its sustainable development goals. ${ }^{425}$ Since some urban and rural households remain without electricity, improving electricity access is a government priority (footnote 425). Vanuatu has national renewable energy sources such as hydro, solar, biomass, wave, wind, coconut biofuel, and geothermal (footnote 425). Tapping into these renewable energy sources could help Vanuatu transition from its dependence on imported fossil fuels.

\section{Renewable Energy Policies}

In the electricity sector, Vanuatu's first NDC has set a target of generating $100 \%$ of electricity using renewable sources by 2030, subject to receipt of financial and technical support (footnote 406). The NDC also aims to reduce emissions for the entire energy sector by $30 \%$, compared with a BAU projection, by 2030 (footnote 406). These mitigation goals are to be achieved by doubling installed wind capacity by 2025 , establishing a solar-connected grid by 2025 , and substituting fossil fuels with coconut oil-based electricity generation (footnote 406). However, these targets are contingent on Vanuatu receiving significant external funding of $\$ 180$ million (footnote 406 ).

Beyond its NDC commitments, Vanuatu set out its National Energy Road Map 2013-2020 (Energy Road Map) in 2013. ${ }^{426}$ Published by the Department of Energy with assistance from the Australian government and the World Bank, the Energy Road Map offers a long-term development plan to reduce reliance on imported petroleum fuel in the energy sector and promote renewable energy. The following five energy sector priorities have quantitative targets and associated strategic directions for action:

(i) access to secure and affordable electricity for all citizens by 2030;

(ii) reliable and affordable petroleum supply throughout Vanuatu;

(iii) more affordable energy services in Vanuatu;

(iv) an energy secure Vanuatu; and

(v) climate change mitigation through renewable energy and energy efficiency. ${ }^{427}$

The Energy Road Map directly responds to the energy sector's highest priority objectives from a national development perspective. It seeks to work through the challenges Vanuatu has faced, including price volatility in the fossil fuel market and limited government capacity to develop an energy management framework.

Developments in 2015-2016 prompted the government to prepare the Updated Vanuatu National Energy Road Map 2016-2030. ${ }^{428}$ Cyclone Pam demonstrated

425 Renewable Energy and Energy Efficiency Partnership (REEEP). 2013. Vanuatu (2012). 11 October.

426 Government of Vanuatu. 2013. Vanuatu National Energy Road Map 2013-2020. Port Vila.

427 Footnote 426, pp. 5-6.

428 Government of Vanuatu, Department of Energy. 2016. Updated Vanuatu National Energy Road Map 2016-2030. Port Vila. 
the importance of having a resilient and reliable energy infrastructure.

The government believed it important that the Energy Road Map reflect commitments contained in its first NDC, the Vanuatu Infrastructure Strategic Investment Plan 2015-2024, the Vanuatu Climate Change and Disaster Risk Reduction Strategy 2016-2030, and Vanuatu's national sustainable development plan (Vanuatu 2030: The People's Plan). ${ }^{429}$ The Updated Vanuatu National Energy Road Map 2016-2030 focuses on five revised priorities: "accessible energy, affordable energy, secure and reliable energy, sustainable energy, and green growth." 430

In 2018, the National Green Energy Fund Act (No. 10 of 2018) was passed to finance the road map's implementation.

\section{LULUCF and REDD+}

In 2000, Vanuatu passed the Forestry Rights Registration and Timber Harvest Guarantee Act (No. 28 of 2000) to oversee the leasing of forestry rights, including carbon sequestration rights.

The first NDC advances Vanuatu's forest management efforts by prioritizing REDD+ projects to reduce deforestation and implement sustainable land management practices as part of the country's mitigation strategy.

\section{E. Adaptation}

As a small island nation vulnerable to sea level rise, Vanuatu recognizes adaptation as its top climate change priority. Vanuatu's five main adaptation priorities are (i) agriculture and food security, (ii) sustainable tourism development, (iii) community-based marine resources management, (iv) sustainable forest management, and (v) integrated water resource management. ${ }^{431}$ Adequate adaptation would cost $1.5 \%$ of Vanuatu's gross domestic product annually. ${ }^{432}$ The government has requested assistance from the Least Developed Countries Fund to finance adaptation measures aimed at supporting agriculture and food security as well as integrated water resource management (footnote 432).

429 Footnote 428, pp. 12-13; Government of Vanuatu, Department of Strategic Policy, Planning and Aid Coordination. 2015. Vanuatu Infrastructure Strategic Investment Plan 2015-2024. Port Vila; Government of Vanuatu. 2015. Vanuatu Climate Change and Disaster Risk Reduction Policy 2016-2030. Port Vila; and Government of Vanuatu, Department of Strategic Policy, Planning and Aid Coordination. 2016. Vanuatu 2030: The People's Plan (National Sustainable Development Plan 2016 to 2030). Port Vila.

430 Footnote 428, p. 3.

431 Footnote 406, p. 2.

432 Footnote 406, p. 6. 
The draft National Climate Change Adaptation Strategy for Land-Based Resources 2012-2022 identifies more than 500 adaptation measures across the water, livestock, forestry, agriculture, and environment sectors. ${ }^{433}$

\section{F. Disaster Risk Management}

In 2012, the government established the National Advisory Board on Climate Change and Disaster Risk Reduction. ${ }^{434}$ The government also conducted a risk assessment of the national capacity for climate change and disaster governance, and incorporated the results of the assessment into the Climate Change and Disaster Risk Reduction Policy 2016-2030 (footnote 434).

The policy, focusing on strategic development, aims to make Vanuatu "a resilient community, environment and economy." ${ }^{435}$ The policy identifies six strategic priorities, categorized into themes that "include climate change adaptation and disaster risk reduction, low carbon development, and response and recovery." ${ }^{436}$ Six principles underpin policy implementation: accountability, sustainability, equity, community focus, collaboration, and innovation (footnote 434).

In 2016, the government passed the Meteorology, Geological Hazards and Climate Change Act, which focuses on ensuring high-quality forecasting services for weather, climate, floods, and geological hazards (footnote 418). It also requires any person mandated to implement the act to apply the precautionary principle when fulfilling their responsibilities or exercising their powers. ${ }^{437}$ Thus, lack of scientific certainty about impacts should not prevent parties from making decisions to respond or take action to minimize potential adverse risks or effects. ${ }^{438}$ Under this law, the National Advisory Board on Climate Change and Disaster Risk Reduction is charged with providing advice for all disaster risk reduction and climate change projects in Vanuatu, and establishing climate change or disaster risk management financing mechanisms. ${ }^{439}$

The 2018 National Climate Change Policy outlines durable solutions for ensuring that displaced people in Vanuatu are resilient and have equal opportunities in Vanuatu's security, wealth, and prosperity. The policy also envisions "an inclusive and equitable nation in which no one is left behind." 440

\footnotetext{
433 Government of Vanuatu. 2011. National Climate Change Adaptation Strategy for Land-Based Resources (2012-2022): Second Draft. Port Vila.

434 Government of Vanuatu. 2015. Vanuatu Climate Change and Disaster Risk Reduction Policy 2016-2030. Port Vila. p. 1.

435 Footnote 434, p. 2.

436 Footnote 434, p. 8.

437 Footnote 418, sec. 3(1).

438 Footnote 418, sec. 3(2).

439 Footnote 418, secs. 9(1)(a) and 10(2)(d).

440 Footnote 413, p. 17.
} 
Various principles guide the implementation of the climate change policy, including respect for customs, human rights and dignity, voluntary and informed choices, gender equity and responsiveness, environmental and ecological sustainability, freedom of movement, and protection of traditional knowledge (footnote 440). The policy identifies the need for community consultation when working toward durable solutions, including with displaced and host communities-"guided by principles specific to the displacement context in Vanuatu, identified through consultation with communities, government and nongovernment stakeholders." ${ }^{441}$

441 Footnote 413, p. 17-18. 

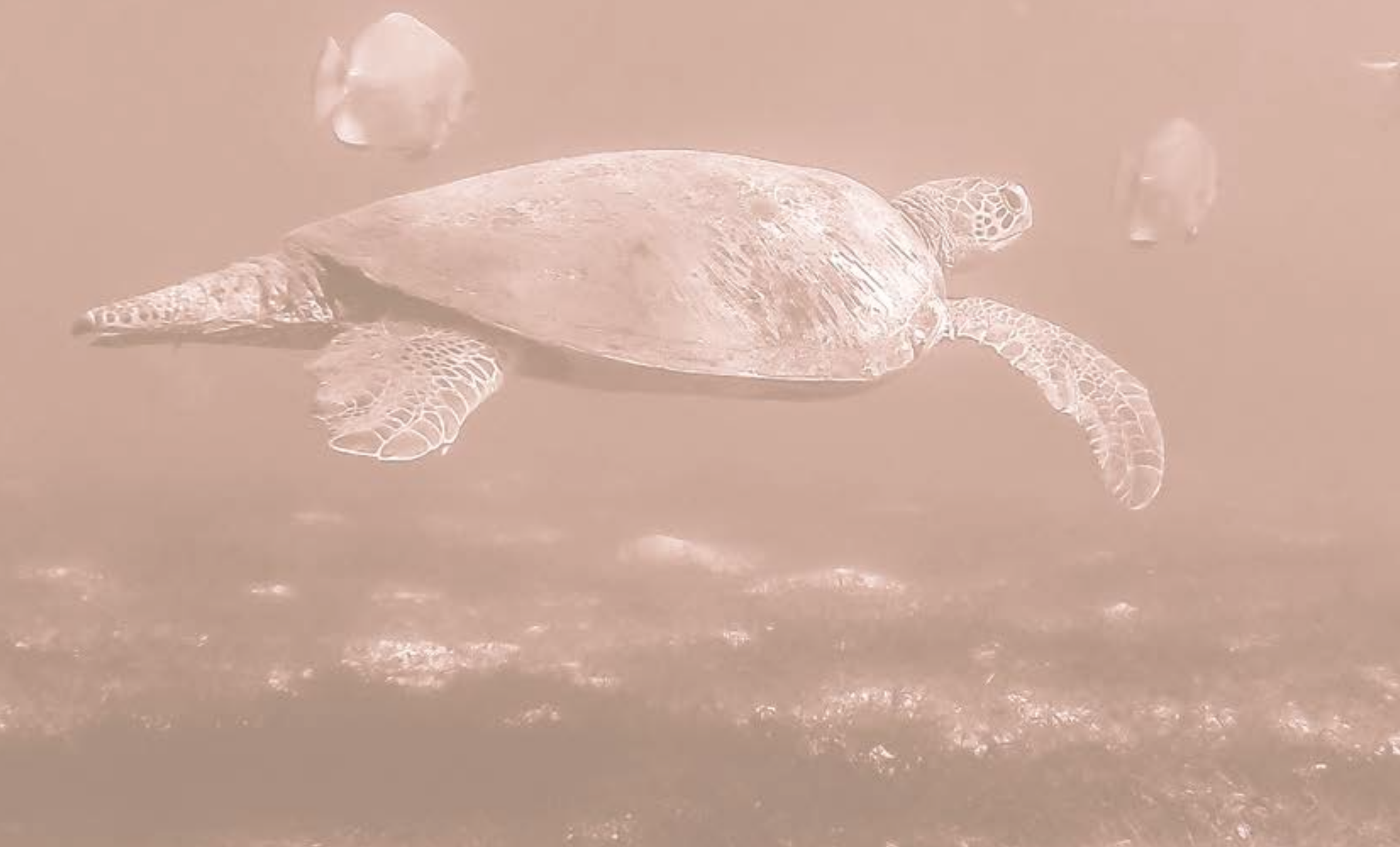

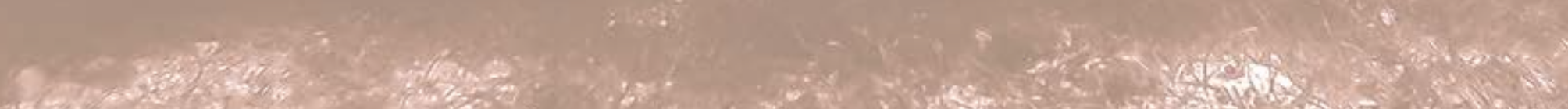

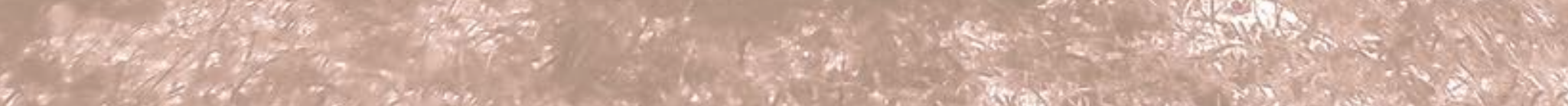
Se.t.

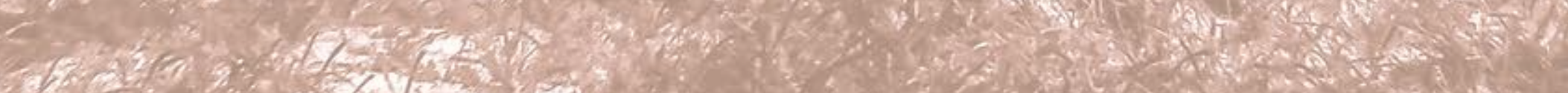

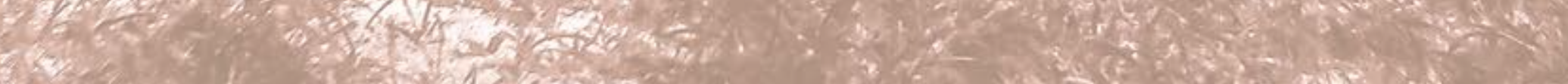

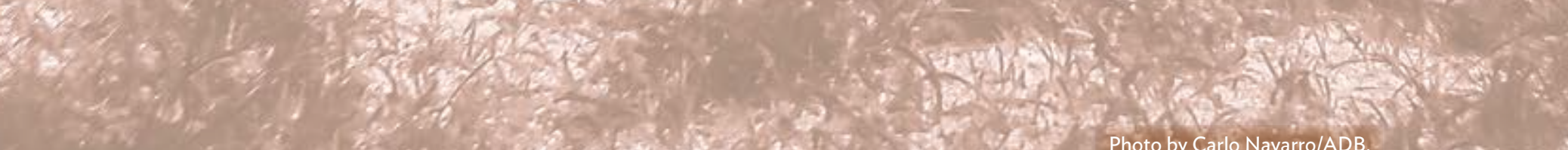

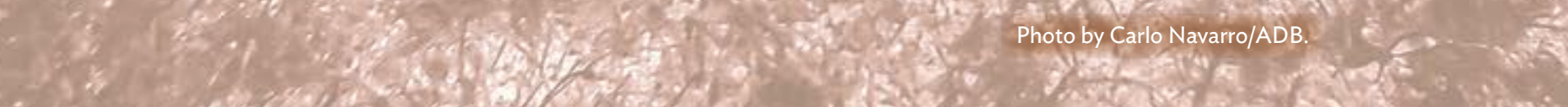

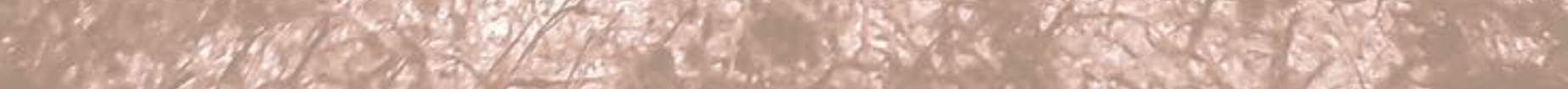

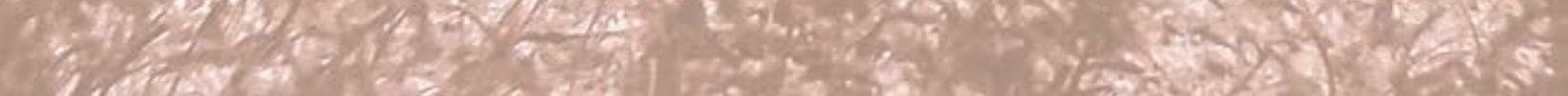


Neighbors working together to pull in

a fishing net in Gentuma Raya, Indonesia.

Climate action will take a village, a people, and

a global community (photo by Eric Sales/ADB)

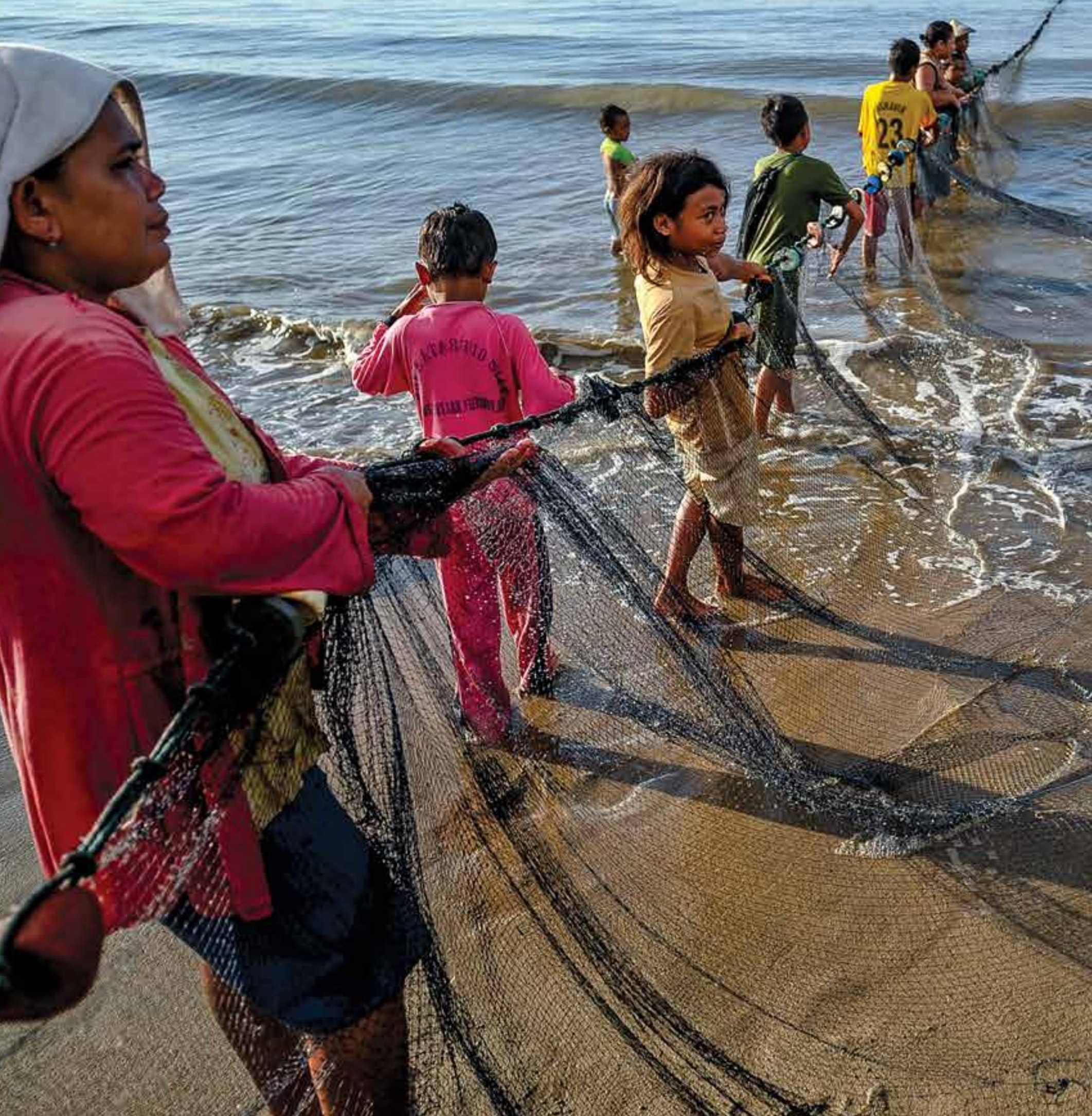


Citizens are suing their governments over slow or weak climate action, and private entities over climate risk. The growing trend of climate litigation in Asia and the Pacific inspired the theme of this report series-Climate Change, Coming Soon to a Court Near You. ADB is working with judges in the region to support them in the face of inevitable climate litigation. ${ }^{5}$ Given the growing number of climate cases, judges need good quality information about regional legal and policy frameworks - the purpose of this report.

Judges are central to interpreting laws, moderating executive action, and safeguarding rights. Their focus on the rule of law and legal ethics and principles helps bridge the gap between international and national legal frameworks. In many jurisdictions across Asia and the Pacific, judiciaries are institutions that can help shape, craft, and improve law and policy, and influence reforms where needed. Such powers, therefore, make courts an essential component of domestic climate governance in the region.

\section{Key Takeaways}

\section{A. National Climate Change Laws and Policies Reveal Likely Future Litigation Trends}

Part Two of this report outlines some key trends observed during the review of climate laws and policies across Asia and the Pacific. The discussion does not assess the sufficiency of any particular legal and policy framework. Instead, it identifies general trends and limitations in laws and policies across the region. Minding these characteristics and gaps is relevant. Litigants will exploit available laws and policies or vulnerabilities in future climate lawsuits.

National laws and policies are pivotal for driving and supporting the objectives of international climate change law. But national legal frameworks are also responding to global shifts and the pressure of climate litigation. Hence, climate change legal and policy responses - global and national - and climate litigation are mutually reinforcing.

The cross-cutting nature of climate change presents new challenges for law and policy makers. Effective responses require sector implementation guided by national goals. Of the 32 countries surveyed for this report, 24 (75\%) typically use climate policies, action plans, and existing laws to drive national action. ${ }^{6}$ They

5 Report One in this series covers climate science, Report Two looks at climate litigation trends in Asia and the Pacific and beyond, and Report Four details the international climate change legal regime.

6 Afghanistan, Bangladesh, Bhutan, Cambodia, the Cook Islands, Fiji, India, Kiribati, Malaysia, Maldives, the Marshall Islands, Myanmar, Nauru, Nepal, Palau, the People's Republic of China (PRC), Samoa, Singapore, Solomon Islands, Sri Lanka, Thailand, Timor-Leste, Tonga, and Viet Nam do not yet have a framework climate change law, but regulate national climate responses with a combination of national policies and plans and updates to existing legislation. 
do not have a dedicated, economy-wide climate law-framework legislation-to guide and ground the national legal and policy structure.

Framework legislation is useful for building a cohesive, whole-of-government approach to climate regulation. Overarching framework legislation can identify national institutional arrangements for sectoral action, climate finance, data sharing, and reporting. Unified climate responses are particularly important over the next 5-10 years because countries must intensify their climate action. The Paris Agreement's Enhanced Transparency Framework also has additional reporting requirements for low- to middle-income countries. ${ }^{7}$ As of August 2020, eight of 32 countries (25\%) surveyed for this report have adopted a dedicated framework law. ${ }^{8}$

\section{B. Constitutional Rights Litigation Is Growing-Information about Constitutional Rights Is Valuable}

Claimants across Asia have built climate cases on constitutional rights, especially the rights to life and environment. The trend in rights-based litigation reflects a growing global trend for claimants to sue over infringements of their constitutional or human rights. ${ }^{9}$

Given the growing popularity of rights-based litigation, it is beneficial for judges to have access to information about relevant constitutional rights embedded in their national and equivalent constitutions in the region. Part Three contains summary tables showing constitutional rights across Asia and the Pacific.

\section{Climate Change Legal and Policy Frameworks Can Be Fragmented}

Sector regulation of climate change-a national and cross-cutting issue-can make it tough to understand how climate change legal and policy frameworks fit together and function. Meaning is lost in a maze of frequently updated statutes and policies.

Resource constraints in some jurisdictions in Asia and the Pacific can result in ad hoc printing of statutes and policies and restrict online publishing. Such occurrences mean that judges, legal practitioners, and international donors

7 For more information about the Paris Agreement's Enhanced Transparency Framework, see S. Barakat et al. 2017. A Guide to Transparency under the UNFCCC and the Paris Agreement. London: International Institute for Environment and Development.

8 The Federated States of Micronesia, Indonesia, the Lao People's Democratic Republic (Lao PDR), Pakistan, Papua New Guinea, the Philippines, Tuvalu, and Vanuatu have a framework climate change law. Fiji and Nepal have drafted framework climate change laws, which are sitting as bills in their parliaments. Bangladesh has legislatively created a climate change trust fund. Singapore has a carbon pricing law.

9 Outside the United States, rights-based lawsuits constitute around 35\% of all climate litigation against governments. See "The Rights Turn in Climate Litigation," YouTube video, 43:47, from a presentation given by César Rodríguez-Garavito at the World Commission on Environmental Law Webinar 4: Climate Change in the Courts on 5 June 2020. 
cannot access a complete or current picture of a country's climate change legal and policy framework. Therefore, Parts Four, Five, and Six of this report summarize the legal and policy frameworks regulating climate change in 32 countries in South Asia, Southeast Asia, and the Pacific, including the PRC.

\section{Looking Forward}

\section{A. ADB and Judiciaries}

ADB has been working with judiciaries in Asia and the Pacific since 2010. Climate change regulation is evolving fast, making it increasingly challenging for judges to access current and comprehensive material on climate change.

This report seeks to support judiciaries in dealing with climate change and advancing sustainable development by providing much-needed information for deciding climate change cases. However, climate laws and policies evolve, so ADB encourages judges, decision-makers, and lawyers to access current information on national climate laws and policies from the following databases:

- Climate Change Laws of the World, see https://climate-laws.org/.

- ECOLEX, see https://www.ecolex.org/.

- FAOLEX Database, see http://www.fao.org/faolex/country-profiles/en/.

- Pacific Islands Legal Information Institute (PacLii) Databases, see http://www.paclii.org/.

- Asian Judges Network on Environment, see http://www.ajne.org/.

- Global Judicial Portal on Environmental Law, see https:/judicial-portal.edw.ro/.

- United Nations Information Portal on Multilateral Environmental Agreements (InforMEA), see https://www.informea.org/.

\section{B. COVID-19 Is Slowing International and National Climate Commitments}

The year 2020 will be remembered for the health and financial crisis launched by the novel coronavirus disease (COVID-19) pandemic. As of 26 November 2020, infections in Asia and the Pacific had reached almost 11.4 million, with around 177,600 deaths. ${ }^{10}$ COVID-19 had killed around 1,405,000 people globally (footnote 10).

The COVID-19 crisis is slowing global climate action at a time when it is most critical. The 26th Conference of the Parties to the United Nations Framework Convention on Climate Change (COP 26) was postponed to 2021. COP 26 is

10 World Health Organization (WHO). WHO Coronavirus Disease (COVID-19) Dashboard (accessed 26 November 2020). Countries from Asia and the Pacific fall within the WHO Southeast Asia and Western Pacific regions. 
critical because countries must still agree on standardized reporting requirements and time frames, increasing the ambition of country pledges, and mechanisms for cooperating on climate goals (market-based and non-trade). ${ }^{11}$

The UN climate change conferences are vital because they bring people together and scrutinize climate action globally. No COP 26 in 2020 makes it easier for countries to deprioritize climate in their post-COVID economic recovery plans or to delay submitting their second NDCs. ${ }^{12}$ As of 26 November 2020, two states had submitted their second NDCs to the UNFCCC, while 15 states had submitted their updated NDCs. ${ }^{13}$

The COVID-19 crisis has slowed the passage of climate laws and policies. As of 26 November 2020, 17 laws and 44 executive instruments (including policies) had been passed, a slowdown compared with previous years. ${ }^{14}$ This downturn is unsurprising, given that lawmakers around the world have refocused their legislative priorities on COVID-19. Legislators have, understandably, shifted their focus to health and economic crisis management. Additionally, the practical impacts of COVID-19 include restricted parliamentary processes and increased use of online portals to deliver various executive functions. ${ }^{15}$ Across Asia and the Pacific, this meant that many government employees worked remotely, where possible, including those central to climate action.

\section{But We Have a Choice to Build New Social Contracts}

Throughout 2020, many governments shut down economies and imposed curfews to flatten the curve of COVID-19 infections and deaths. The new normal paradigm created by COVID-19 restricted social mobility and changed how we interact. As road and air traffic lessened, emission and pollution levels dropped, prompting some to announce the potential climate benefits of 2020 .

But global warming has not abated amid the COVID-19 shutdowns. ${ }^{16}$ Atmospheric $\mathrm{CO}_{2}$ averaged 409.50 parts per million (ppm) in August 2020 compared with 407.43 ppm in August 2019, and scientists have not yet detected a significant drop in atmospheric $\mathrm{CO}_{2}{ }^{17}$

11 For a discussion of the key COP 25 outcomes, see CarbonBrief. 2019. COP 25: Key Outcomes Agreed at the UN Climate Talks in Madrid. 15 December.

12 R. Cho. 2020. COVID-19's Long-Term Effects on Climate Change-For Better or Worse. State of the Planet. 25 June.

13 UNFCCC Secretariat. NDC Registry (Interim) (accessed 26 November 2020). The Republic of the Marshall Islands and Suriname had submitted their second NDCs. Singapore, Thailand, and Viet Nam had submitted updated first NDCs.

14 Grantham Research Institute on Climate Change and the Environment. Climate Change Laws of the World-Laws and Policies (accessed 26 November 2020).

15 Inter-Parliamentary Union. Country Compilation of Parliamentary Responses to the Pandemic (accessed 7 August 2020).

16 L.M. Lombrana and H. Warren. 2020. A Pandemic That Cleared Skies and Halted Cities Isn't Slowing Global Warming. Bloomberg Green. 8 May.

17 National Oceanic and Atmospheric Administration (NOAA), Earth System Research Laboratories (ESRL). Trends in Atmospheric Carbon Dioxide: Global Monthly Mean $\mathrm{CO}_{2}$ (accessed 26 November 2020); and NOAA, ESRL. Can We See a Change in the $\mathrm{CO}_{2}$ Record Because of COVID-19? 
Historically, recoveries from global economic crises have too frequently spurred greenhouse gas emissions spikes, with governments falling back on fossil fuel and high emission sectors to reboot economies. ${ }^{18}$ So, although the COVID-19 crisis, and its associated lockdowns, temporarily reduced emissions, robust legal and policy frameworks are still needed to build sustainable and resilient economies. Promising COVID-19 vaccines emerged at the end of 2020, sparking hope of a return to normal life. ${ }^{19}$ When economies spring back, it will be critical for governments and society to prioritize low-carbon and resilient options to avoid an emissions spike (footnote 18). Such approaches are possible. If there is a silver lining amid the COVID-19 pandemic, it is that governments and citizens are willing to go to extraordinary lengths when faced with an extreme crisis, and climate change has the potential to dwarf the impacts of COVID-19.

In June 2020, the World Economic Forum launched the Great Reset initiative, aimed at supporting sustainable economic recovery from the COVID-19 crisis. Klaus Schwab, Executive Chairman of the World Economic Forum, observed:

The COVID-19 crisis has shown us that our old systems are not fit anymore for the 21st century. It has laid bare the fundamental lack of social cohesion, fairness, inclusion, and equality. Now is the historical moment - the time-not only to fight the virus but to shape the system, possibly for the post-corona era. We have a choice to remain passive...

But we have another choice. We can build a new social contract, particularly integrating the next generation. We can change our behavior to be in harmony with nature again. And, we can make sure that the technologies of the fourth industrial revolution are best utilized to provide us with better lives. In short, we need a great reset. We have to mobilize all constituents of our global society to work together. We must not miss this unique window of opportunity. ${ }^{20}$

\section{Climate Justice and Legal and Policy Frameworks in the Time of COVID-19 and Beyond}

The COVID-19 crisis has also affected courts and climate litigation. Courtrooms and court registries experienced closures, delaying new filings, especially in regions without online registries. Trials usually require personal appearance in the courtroom. Courts are, therefore, trying to find new ways of adjudicating in an age of face masks, social distancing, and online conferencing.

18 The Economist. 2020. The Epidemic Provides a Chance to Do Good by the Climate. 26 March.

19 J. Gallagher. 2020. Covid Vaccine Update: When Will One Be Ready? BBC News. 23 November.

20 "The World Economic Forum: The Great Reset." Soundcloud podcast, 2:41, speech given by Mr. Klaus Schwab, Executive Chairman of the World Economic Forum, at The Great Reset launch on 4 June 2020, posted by World Economic Forum. 
Climate activists are unlikely to defer litigation indefinitely, especially if emissions continue to grow and adaptation programs stall. Social media allows activists to keep the pressure on the governments and coordinate climate lawsuits. Climate activists will continue to identify weaknesses in national climate action and within national legal and policy frameworks. ${ }^{21}$ As discussed in Part Two of this report, climate litigation is shaping national legal and policy frameworks, meaning that judges have an important role in holding governments accountable for meeting their commitments.

Although it is a global fight, climate change can only ever be fought in our own backyard, making national legal and policy frameworks foundational to international climate action. The next 5-10 years are critical for reducing global emissions, so the climate cannot wait for the world to sit out the pandemic before taking action.

What humanity must do now is figure out how to continue meeting its climate goals in the 21st century in the "new normal" and during post-COVID-19 economic recovery. The Paris Agreement is built on science and "points the world in the right direction." 22 Because it aims to achieve carbon neutrality by 2050 , which requires significant emissions within the next 10 years, the agreement also requires its members to improve on their actions and commitments continually. Countries must now discern how to build climate-resilient, carbon-neutral economies and maintain momentum with their NDCs. Setting transparent commitments within well-defined legal and policy frameworks is a good start.

Judiciaries in Asia and the Pacific might be of real use to safeguarding momentum on domestic climate responses. They are the very institution that can clarify legal and policy frameworks and hold governments accountable for their climate commitments - a significant contribution to climate justice. Climate litigation is asking - and will continue to ask-judges to decide whether these national climate pledges are scientifically plausible and morally sound. To make these assessments intelligently and effectively, judges require clear information about their climate change law and policy frameworks, which is why ADB wrote this report series.

It is time for us to remember that climate change is not something that any of us can fix in isolation. But we must each play our part and remember:

It's not about what it is, it's about what it can become...

Unless someone like you cares a whole awful lot, Nothing is going to get better. It's not. ${ }^{23}$

21 Part Two of this report examines the trends within the national climate change legal and policy frameworks in the region.

22 A. Doyle et al. 2015. Factbox: World Reacts to New Climate Accord. Reuters. 13 December.

23 Dr. Seuss. 1971. The Lorax. New York: Penguin Random House. 


\section{| GLOSSARY}

The terms presented in the glossary table have been adapted or taken from a number of sources listed under the Glossary References at the end of this section.

\begin{abstract}
Adaptation
the process of adjustment to actual or expected climate and its effects, in order to moderate harm or exploit beneficial opportunities in human or natural systems (Intergovernmental Panel on Climate Change 2018)
\end{abstract}

Adaptive capacity

Anthropogenic

Biomass

Carbon capture and storage

Carbon credit

Carbon sequestration

Climate change litigation

Climate justice the ability of systems, institutions humans, and other organisms to adjust to potential damage, to take advantage of opportunities, or to respond to consequences (Intergovernmental Panel on Climate Change 2018). See also adaptation

of, relating to, or resulting from the influence of human beings on nature (Merriam-Webster anthropogenic)

living or recently dead organic material (Intergovernmental Panel on Climate Change 2018)

(or carbon dioxide capture and storage) a process in which a relatively pure stream of carbon dioxide $\left(\mathrm{CO}_{2}\right)$ from industrial and energy-related sources is separated (captured), conditioned, compressed and transported to a storage location for long-term isolation from the atmosphere (Intergovernmental Panel on Climate Change 2018)

a tradable credit granted to a country, company, etc., for reducing emissions of $\mathrm{CO}_{2}$ or other greenhouse gases by one metric ton below a specified quota (Merriam-Webster carbon credit)

the process of storing carbon in a carbon pool (Intergovernmental Panel on Climate Change 2018)

(or climate change case) any case that: (i) raises climate change as a central issue; (ii) raises climate change as a peripheral issue; or (iii) does not explicitly raise climate change but has ramifications for climate change mitigation or adaptation efforts (definition our own)

Climate justice links human rights and development to achieve a human-centered approach, safeguarding the rights of the most vulnerable people and sharing the burdens and benefits of climate change and its impacts equitably and fairly. Climate justice is informed by science, responds to science and acknowledges the need for equitable stewardship of the world's resources. (Mary Robinson Foundation-Climate Justice Principles of Climate Justice) 
Climate migration

$$
\begin{aligned}
& \text { Compressed } \\
& \text { natural gas (CNG) }
\end{aligned}
$$

Ecosystem services

\section{Environmental constitutionalism}

\section{Environmental impact assessment}

\section{Environmental impact statement}

\section{Fossil fuels}

Greenhouse gases

\section{Intergenerational equity}
Intergenerational responsibility

human settlement patterns in response to changes in the climate (International Organization for Migration 2008)

a natural gas mainly comprised of methane stored under high pressures (while remaining in its gaseous form), mainly as a means to transport it, or as storage for later use as vehicle fuel (Stenhouse et al. 2018)

ecological processes or functions having monetary or nonmonetary value to individuals or society at large. These are frequently classified as (1) supporting services such as productivity or biodiversity maintenance, (2) provisioning services such as food or fibre, (3) regulating services such as climate regulation or carbon sequestration, and (4) cultural services such as tourism or spiritual and aesthetic appreciation (Intergovernmental Panel on Climate Change 2018)

a relatively recent phenomenon at the confluence of constitutional law, international law, human rights, and environmental law; embodies the recognition that the environment is a proper subject for protection in constitutional texts and for vindication by constitutional courts worldwide (May and Daly 2017)

an examination, analysis and assessment of planned activities with a view to ensuring environmentally sound and sustainable development (United Nations Environment Programme [UNEP] 1987)

a government document that outlines the impact of a proposed project on its surrounding environment; meant to inform the work and decisions of policy makers and community leaders (Middleton 2018)

carbon-based fuels from fossil hydrocarbon deposits, including coal, oil, and natural gas (Intergovernmental Panel on Climate Change 2018)

those gaseous constituents of the atmosphere, both natural and anthropogenic, that absorb and emit radiation at specific wavelengths within the spectrum of terrestrial radiation emitted by the Earth's surface, the atmosphere itself and by clouds (Intergovernmental Panel on Climate Change 2018)

the principle that states that every generation holds the Earth in common with members of the present generation and with other generations, past and future (Weiss 2013)

a legal concept which says that every generation has a responsibility to the next to preserve the rhythm and harmony of nature for the full enjoyment of a balanced and healthful ecology (Oposa v. Factoran, G.R. No. 101083, 30 July 1993) 


\section{Intergovernmental Panel on Climate Change (IPCC)}

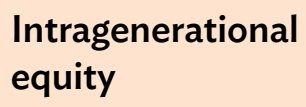

Kyoto Protocol

\section{Mitigation (of climate change)}

Paris Agreement

Particulate matter (PM)

Precautionary
principle

\section{Public trust doctrine}

Renewable energy the United Nations body for assessing the science related to climate change (Intergovernmental Panel on Climate Change. About the IPCC)

relates to fairness among the present generation; primarily concerns the relationship between developed and developing countries (Shelton 2008)

entered into force on 16 February 2005, this international treaty operationalizes the United Nations Framework Convention on Climate Change by committing industrialized countries to limit and reduce greenhouse gases (GHG) emissions in accordance with agreed individual targets (United Nations Framework Convention on Climate Change. 2020. What is the Kyoto Protocol?)

a human intervention to reduce emissions or enhance the sinks of greenhouse gases (Intergovernmental Panel on Climate Change 2018)

entered into force on 4 November 2016, this agreement builds upon the United Nations Framework Convention on Climate Change to strengthen the global response to the threat of climate change by keeping a global temperature rise this century well below $2^{\circ} \mathrm{C}$ above preindustrial levels and to pursue efforts to limit the temperature increase even further to $1.5^{\circ} \mathrm{C}$ (United Nations Framework Convention on Climate Change. 2020. The Paris Agreement)

very small solid particles emitted during the combustion of biomass and fossil fuels. PM may consist of a wide variety of substances. Of greatest concern for health are particulates of diameter less than or equal to 10 nanometers, usually designated as PM10 (Intergovernmental Panel on Climate Change Definition of Terms Used Within the DDC Pages)

where there are threats of serious or irreversible damage, lack of full scientific certainty shall not be used as a reason for postponing cost-effective measures to prevent environmental degradation (United Nations 1992)

a doctrine asserting that the state holds land lying beneath navigable waters as trustee of a public trust for the benefit of its citizens (Merriam-Webster public trust doctrine)

energy from a source that is naturally replenishing but flow-limited, and is virtually inexhaustible in duration but limited in the amount of energy that is available per unit of time (US Energy Information Administration 2019) 
Right to a healthy environment

\section{United Nations \\ Framework \\ Convention on \\ Climate Change}

Vulnerable groups or people

Waste-to-energy the interaction between human rights and the environment; encompasses the environmental dimensions of the rights to life, health, food, water, sanitation, property, private life, culture, and non-discrimination, among others (Human Rights Watch 2018)

a reservoir (natural or human, in soil, ocean, and plants) where a greenhouse gas, an aerosol or a precursor of a greenhouse gas is stored (Intergovernmental Panel on Climate Change 2018) entered into force on 21 March 1994, this international treaty ultimately aims to prevent "dangerous" human interference with the climate system (United Nations Framework Convention on Climate Change. 2020. What is the United Nations Framework Convention on Climate Change?)

(or vulnerable persons) minors, unaccompanied minors, disabled people, elderly people, pregnant women, single parents with minor children, victims of trafficking in human beings, persons with serious illnesses, persons with mental disorders, persons who have been subjected to torture, rape or other serious forms of psychological, physical or sexual violence, and indigenous peoples (See European Commission vulnerable person)

the conversion of waste into energy in the form of steam, electricity or hot water; a hygienic method of treating waste that reduces its volume by about $90 \%$ (Confederation of European Waste-to-Energy Plants What is Waste-to-Energy)

\section{GLOSSARY REFERENCES}

Confederation of European Waste-to-Energy Plants. What is Waste-to-Energy.

European Commission. Vulnerable Person.

Human Rights Watch. 2018. The Case for a Right to a Healthy Environment. 1 March.

International Organization for Migration. 2008. Migration and Climate Change. IOM Migration Research Series No. 31. Geneva: International Organization for Migration. p. 21.

Intergovernmental Panel on Climate Change. 2018. Annex I: Glossary. In V. Masson-Delmotte et al., eds. Global Warming of 1.5.C. An IPCC Special Report. In press.

Intergovernmental Panel on Climate Change. About the IPCC.

Intergovernmental Panel on Climate Change. Definition of Terms Used Within the DDC Pages.

Mary Robinson Foundation. Principles of Climate Justice.

May, J. and E. Daly. 2017. Judicial Handbook on Environmental Constitutionalism. Nairobi: United Nations Environment Programme. p. 1.

Merriam-Webster. anthropogenic.

Merriam-Webster. carbon credit.

Merriam-Webster. public trust doctrine.

Middleton, T. 2018. What is an Environmental Impact Statement? American Bar Association.

17 December. 
Oposa v. Factoran, G.R. No. 101083, 30 July 1993.

Shelton, D. 2008. Equity. In Bodansky, D., J. Brunnée, and E. Hey, eds. The Oxford Handbook of International Environmental Law. Oxford: Oxford University Press. pp. 32, 53.

Stenhouse, K. et al. 2018. Compressed Natural Gas. 25 June.

UN Doc. A/CONF.151/26 (vol. I), 31 ILM 874. 1992. Principle 15.

United Nations Environment Programme. 1987. UNEP - United Nations Environment Programme Goals and Principles of Environment Impact Assessment: Preliminary Note. 16 January.

United Nations Framework Convention on Climate Change. 2020. The Paris Agreement.

United Nations Framework Convention on Climate Change. 2020. What is the Kyoto Protocol?

United Nations Framework Convention on Climate Change. 2020. What is the United Nations Framework Convention on Climate Change?

United States Energy Information Administration. 2019. Renewable Energy Explained. 27 June.

Weiss, E. 2013. Intergenerational Equity. Oxford Public International Law. February. 



\section{National Climate Change Legal Frameworks in Asia and the Pacific Climate Change, Coming Soon to A Court Near You-Report Three}

National legal and policy frameworks underpin international climate action because they are the backbone of domestic responses to the climate emergency. Unless they support global objectives, local climate action stalls. Concerned by sluggish national responses to climate change or injured by its impacts, citizens are filing lawsuits, making courts central to national climate governance. To adjudicate these lawsuits, courts require current information about their climate change legal and policy frameworks. This report provides holistic syntheses of the climate legal and policy frameworks of 32 countries in Asia and the Pacific and discusses key legislative trends and climate-relevant constitutional rights.

\section{About the Asian Development Bank}

ADB is committed to achieving a prosperous, inclusive, resilient, and sustainable Asia and the Pacific, while sustaining its efforts to eradicate extreme poverty. Established in 1966, it is owned by 68 members -49 from the region. Its main instruments for helping its developing member countries are policy dialogue, loans, equity investments, guarantees, grants, and technical assistance.
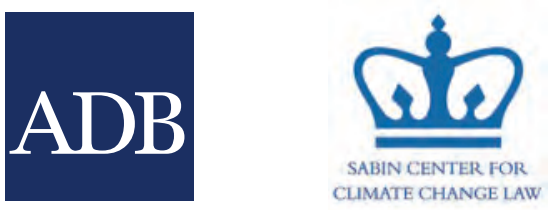